\title{
Metáfora de la crueldad: \\ la pena capital de Cesare Beccaria al tiempo presente
}

\section{Editores:}

Luis Arroyo Zapatero, Rafael Estrada Michel y Adán Nieto Martín Coordinadora:

\section{Agustina Alvarado}

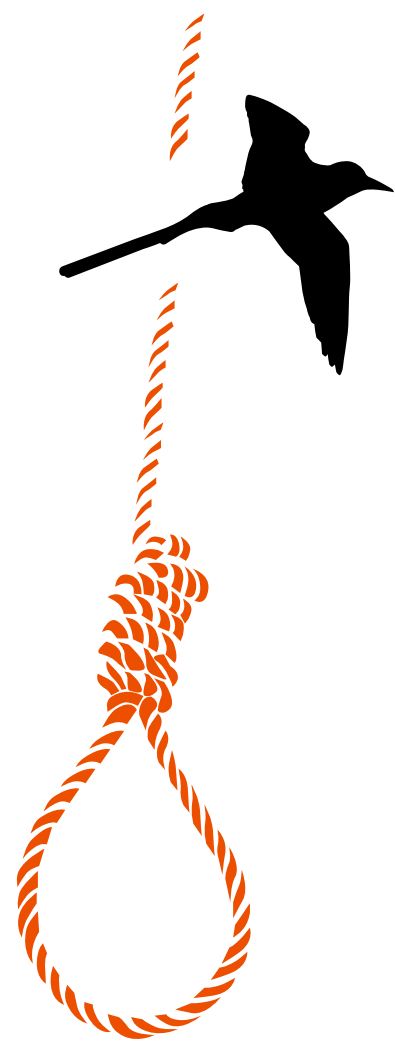





\section{METÁFORA DE LA CRUELDAD. LA PENA CAPITAL DEL TIEMPO DE CESARE BECCARIA AL TIEMPO ACTUAL}



Editores:

Luis Arroyo Zapatero, Rafael Estrada Michel, Adán Nieto Martín

\author{
METÁFORA DE LA CRUELDAD. \\ LA PENA CAPITAL DEL TIEMPO DE \\ CESARE BECCARIA AL TIEMPO ACTUAL
}

Coordinadora:

Agustina Alvarado Urízar

(§) $\frac{\text { Ediciones de la Universidad }}{\text { de Castilla-La Mancha }}$

Cuenca, 2016 
METÁFORA de la crueldad: la pena capital, de Cesare Beccaria al tiempo actual / Luis Arroyo Zapatero, Rafael Estrada Michel, Adán Nieto Martín (Edit.) ; Agustina Alvarado Urízar (Coord.). - Cuenca : Ediciones de la Universidad de Castilla-La Mancha, 2016

359 p.- (Marino Barbero Santos; 17)

ISBN 978-84-9044-278-4

1. Derecho penal 2. Pena de muerte 3. Derechos Humanos I. Arroyo Zapatero, Luis ed. II. Estrada Michel, Rafael, ed. III. Nieto Martín, Adán ed. IV Alvarado Urízar, Agustina, coord. V. Universidad de Castilla-La Mancha, ed. VI Serie

343.25

342.7

LNF

LNDC

Este libro ha sido financiado por el Ministerio de Ciencia e Innovación del Gobierno de España a través del proyecto «La abolición de la pena de muerte en el Derecho» (Ref. DER2012-31859 MINECO2012)

Cualquier forma de reproducción, distribución, comunicación pública o transformación solo puede ser realizada con la autorización de EDICIONES DE LA UNIVERSIDAD DE CASTILLA-LA MANCHA, salvo excepción prevista por la ley.

Diríjase a CEDRO (Centro Español de Derechos Reprográficos - www.cedro.org), si necesita fotocopiar o escanear algún fragmento de esta obra.

(C) de los textos e imágenes: sus autores.

(C) de la edición: Universidad de Castilla-La Mancha.

Edita: Servicio de Publicaciones de la Universidad de Castilla-La Mancha.

Colección MARINO BARBERO SANTOS n 17

Dirigida por Luis A. Arroyo Zapatero

$1^{a}$ edición: 300 ejemplares

Diseño de la colección y de la cubierta:

CIDI (Universidad de Castilla-La Mancha)

Ue Esta editorial es miembro de la UNE, lo que garantiza la difusión y comercialización de sus publicaciones a nivel nacional e internacional.

I.S.B.N.: 978-84-9044-278-4 (UCLM)

D.O.I.: http://doi.org/10.18239/mbs.17.2016

D.L.: CU 266-2016

Fotocomposición e impresión: Gráficas Izquierdo, S.L. Impreso en España (U.E.) - Printed in Spain (U.E.) 


\section{ÍNDICE}

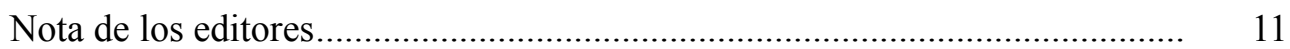

\section{CESARE BECCARIA 250 AÑOS DESPUÉS DEL TRATADO}

La metáfora de la crueldad en la cultura y en el Derecho Internacional

Luis Arroyo Zapatero

Beccaria en nuestra América

Sergio García Ramírez.

Beccaria y el Iluminismo italiano en la cultura jurídica hispana

Gonzalo Quintero Olivares

La crueldad razonada. La pena de muerte en el pensamiento punitivo reaccionario español

Gregorio María Callejo Hernanz

Contrato social y pena capital. Beccaria vs. Rousseau

Dario Ippolito

Cesare Beccaria y la pena de muerte. Del De los delitos y de las penas al debate actual sobre la sanción capital

Stefano Canestrari y Mattia Celva 
Beccaria y el nacimiento del garantismo constitucional en el Derecho penal y procesal

Javier Llobet Rodrigues

Eugenio María de Hostos en España y Puerto Rico contra la pena capital

\section{HACIA UNA TEORÍA DE LA CRUELDAD HUMANA}

La crueldad en el mundo clásico

César Chaparro Gómez.

La crueldad: sus modalidades

Mario Pisani.

Los tratos inhumanos en el derecho penal. De la prohibición del tormento y el castigo de la crueldad de los individuos a la llamada tortura de necesidad Gonzalo Quintero Olivares

La crueldad humana en la literatura

Gabrio Forti.

La pena de muerte: moratoria universal medio siglo después de El Verdugo

Miguel Abel Souto

\section{PENA DE MUERTE EN EL DERECHO INTERNACIONAL}

Actores, factores y procesos en el camino de la Abolición Universal de la pena de muerte

Luis Arroyo Zapatero

La pena de muerte y el derecho consuetudinario internacional

Ana Manero Salvador.

Las salvaguardias para proteger los derechos de las personas condenadas a muerte y su relación con el Ius Cogens

Florabel Quispe Remón 
El incierto camino de la pena de muerte en Asia.

La necesidad de diseñar nuevas estrategias para su abolición

Antonio Muñoz Aunión

Perspectivas de abolición internacional de la pena de muerte

Agustina Alvarado Urízar 



\section{PRESENTACIÓN DE LOS EDITORES}

La cuestión de la abolición de la pena de muerte no ha perdido actualidad. El impulso de la Acción Complementaria del Ministerio de Educación de 2010 y la continuación con el proyecto de investigación La abolición de la pena de muerte en el Derecho penal Internacional, ha permitido continuar los trabajos hasta 2016 y acompañar con publicaciones y ponencias, congresos y reuniones la elaboración científica de los problemas y servir de apoyo a quien mejor puede aprovechar estos trabajos que es la Comisión Internacional contra la Pena de Muerte, que preside Federico Mayor Zaragoza.

Tres seminarios hemos organizado. El primero sobre Beccaria en su Centenario, en el Centro de Estudios Políticos y Constitucionales en 2014. El segundo, en el mismo año, sobre el problema del concepto de la crueldad de las penas, en la Fundación Ortega y Gasset. Por último, sobre perspectivas de abolición internacional en la Universidad de Castilla-La Mancha en Toledo en 2015 y la jornada sobre ello en 2016 en la UCLM en Ciudad Real.

Ha sido también el proyecto una plataforma de presentación e instrumento para encontrar grupos y especialistas en cuyos seminarios hemos podido participar, lo que nos ha permitido recopilar y contrastar los trabajos, así como incrementar la actividad general. Muy especialmente a destacar es la participación en el Seminario de la École Normale Supérieure de Paris para la elaboración de una cartografia digital de la pena de muerte, en 2013, en el gran Congreso de Milán conmemorativo de Beccaria, en 2014, en Naciones Unidas en el Congreso Mundial celebrado en Qatar por la Comisión de Prevención del delito y la Justicia penal, en 2015, y en conferencias en Croacia, Buenos Aires, Bogotá, y México, especialmente aquí en el 
Congreso conmemorativo en 2016 de los 40 años de la creación por Sergio García Ramírez del Instituto Nacional de Ciencias Penales, (INACIPE) dirigido por Rafael Estrada Michel, quien ha colaborado decididamente en el impulso a estos trabajos así como en la elaboración del MOOC sobre Pena de muerte y Derechos Humanos: hacia la abolición universal, que ha tenido 2000 alumnos en la primera edición y 4000 en la segunda, preparándose ahora la tercera para 2017.

Los trabajos realizados que se presentan aquí se agrupan en tres bloques: En primer lugar, los relativos a Cesare Beccaria en su centenario y la pervivencia en nuestra cultura jurídica del rechazo de las penas crueles y de la pena de muerte. En segundo lugar, las contribuciones a la construcción de una teoría de la crueldad. En tercer y último lugar, las relativas al Derecho Internacional, a los procesos de abolición y a la construcción jurídica de la proscripción de la pena de muerte en las normas internacionales.

Merece destacarse que se ha dado comienzo a abordar la cuestión del carácter más teórico de la abolición, que es la vinculada a la prohibición de la crueldad de las penas del artículo 7 del Pacto Internacional de Derecho Civiles y Políticos, con una primeras aproximaciones a la que sería una teoría general de la crueldad humana que, a su vez, sería el fundamento de la más sólida interpretación como ius cogens de la prohibición de las penas crueles que hace el Pacto. Se incluyen al respecto varios trabajos sobre la crueldad y dos que marcan el futuro de la investigación, tanto sobre la proscripción de la penas crueles del artículo 7 como de la infracción y consecuencias jurídicas de las llamadas "salvaguardias" de los derechos de los que afrontan el riesgo de la pena de muerte allí donde no ha sido todavía abolida, que se encuentran previstas en el artículo 6 y en disposiciones complementarias.

Son todavía graves los obstáculos que hacen retener la pena de muerte y los fenómenos criminales contemporáneos como el terrorismo y el estrago de las drogas no ayudan a la racionalización de los castigos. Pero es sin duda el peso de los argumentos que caracterizan a la pena de muerte como pena cruel lo que impulsa tanto el proceso de abolición como la reducción de las ejecuciones capitales. Baste advertir que los factores y procesos de lo que se llama el declinar de la pena de muerte en EE.UU., así como de la abolición o moratoria en numerosos estados en los últimos diez años es la visualización por la opinión pública de la crueldad de las ejecuciones capitales. La denuncia de la crueldad de la pena de muerte y su proscripción por el Derecho Internacional sigue siendo una buena causa académica y humanitaria.

Luis Arroyo Zapatero

Rafael Estrada Michel Adán Nieto Martín 
CESARE BECCARIA 250 AÑOS DESPUÉS DEL TRATADO 



\title{
LA METÁFORA DE LA CRUELDAD EN LA CULTURA Y EN EL DERECHO INTERNACIONAL
}

\author{
LUIS ARROYO ZAPATERO \\ Presidente de la SIDS. Universidad de Castilla-La Mancha
}

El Marqués de Beccaria es metáfora de la denuncia de la crueldad. Y no solo de la crueldad propia de las lóbregas prisiones de ayer y de hoy, si no de la tortura e, incluso, de la pena de muerte. Todo nuestro mundo cultural desde California hasta Vladivostok pasando por Lisboa está conformado en su pensamiento por la obra en denuncia del sistema penal del Antiguo Régimen por Cesare Bonesana, nuestro Marqués de Beccaria. Se han cumplido en 2014 los doscientos cincuenta años de la publicación del Tratado. La conmemoración se celebró en Milán su ciudad natal y en la que junto a los hermanos Verri formó su criterio y las líneas maestras de su libro.

Es bien conocido que despertó adhesiones en los intelectuales de la época, en aquellos tiempos en que las Españas incluían no solo las Américas sino a las Filipinas, fracasó el Fiscal del Consejo el Conde de Campomanes en su propósito de difundir su obra en lengua española y a pique estuvo de que la Inquisición, tras prohibir como blasfemia el texto del milanés, precisamente por su crítica a la pena de muerte, llevara al traductor y al impresor al fuego de leña verde.

En vísperas del Centenario se ha publicado un excelente libro que evidencia la influencia del pensamiento de Beccaria en los padres fundadores de los Estados Unidos de América, magnífico libro de John D. Bessler, The birth of American Law. Au italian philosopher and de American Revolution ${ }^{1}$.

En Carolina Academic Press, Durham 2014. 
El valor y la valentía de Beccaria se muestra en el hecho que hizo frente a la Inquisición con todas sus críticas y propuestas, pero la más arriesgada y solitaria de las causas que abrazó fue la denuncia de la pena de muerte.

\section{EL MARQUÉS DE BECCARIA CONTRA LA PENA DE MUERTE}

Si tuviéramos que elegir entre nosotros que crítica o que propuesta fue la más relevante de todas cuantas Beccaria formuló en su genial libro es bien probable que no llegáramos a un acuerdo unánime. Pero en la experiencia de Beccaria en España tenemos un indicador que es el más seguro: el dictamen de la Santa Inquisición por el que la traducción ya impresa se prohíbe severamente, incluye en el Índice y su difusión se conmina con la máxima pena. Lo expuso con brillantez hace 50 años Giovanna Calabró en un magnífico estudio titulado Beccaria e la Spagna que estudio el dossier completo conservado en el Archivo Nacional de Simancas, que más tarde elaboró Ángel Torío y quien suscribe².

La traducción, inspirada por el propio Gobierno reformista de nuestro Rey napolitano Carlos III choca con la firme decisión de la Inquisición que no admite la edición ni siquiera expurgada, es decir, tras de suprimir párrafos o capítulos. Manifiesta el Inquisidor que en esta obra capciosa, dura e inductiva de una impunidad casi absoluta y que promueve el tolerantismo, las proposiciones merecedoras de censura están esparcidas por todo el libro y, en segundo término - y esto es hoy aquí para nosotros lo esencial- el gran inquisidor proclama que "reprobar toda pena de muerte y propagar que sirven más para el escarmiento las otras penas es calumniar la conducta de Dios, que el mismo Dios estableció la pena capital en el Antiguo Testamento". Es decir, la crítica de Beccaria a la pena de muerte es una blasfemia y la pena que merece su autor y su traductor es -ayer como entre los radicales religiosos de hoy- la de muerte en el fuego. Esa crítica de Beccaria a la pena capital era para el Inquisidor más grave que todo lo demás, que en definitiva solo limitaba el poder de los Reyes.

Dedica Beccaria el capítulo 28 de Los delitos y las penas a la pena de muerte. Un asunto sobre el que vuelve en escritos posteriores menores. Cuatro son las ideas fundamentales en que fundamenta su tesis abolicionista:

En primer lugar, la idea de que el contrato social no puede incorporar al formularse la renuncia a la propia vida. Éste argumento fundamentó agrias críticas de Rousseau, Kant y Hegel, pero no tenían razón. Lo que el Marqués quería proclamar era que los individuos tenían un derecho inalienable a la vida, no disponible por terceros ni por sí mismo, pero en aquel tiempo aún no se había descubierto la

2 L. Arroyo y J. Bordes, Francisco de Goya. Contra la crueldad de la pena de muerte/ Against the cruelty of capital punishment, Universidad de Castilla-La Mancha y Real Academia de Bellas Artes, Madrid 2013. 
tecnología de las palabras y de los conceptos del "derecho fundamental" que todos empleamos hoy, faltaba entonces la "palabra" para la "cosa".

En segundo lugar, Beccaria proclama que la pena capital carece de efectos preventivos o disuasorios mayores a los que proporcionan las largas penas de prisión. Es más, indica que en ocasiones tiene la ejecución pública efectos criminógenos, como denunciaría el Dr. Ángel Pulido hasta conseguir en el Senado la prohibición de la ejecución pública y resguardar así la ejecución en el interior de las cárceles ${ }^{3}$.

Proclama Beccaria, además, que la justicia es falible y comporta el riesgo de condenar y ejecutar a quienes no son verdaderamente culpables al ser la pena de muerte irreversible. Recordemos que en aquel tiempo la tortura era práctica legal y no se disponía, naturalmente, de la tecnología del ADN.

Por último, denunciaba el efecto socialmente pernicioso de una pena que aleja a los ciudadanos de la conciencia de pertenencia al orden jurídico por ser, además, practicada sobre los pobres, que habrían de verla necesariamente como una pena que sólo protegía los ricos, con los consiguientes efectos degradatorios de la vigencia real de las normas. Era la denuncia de la pena capital como pena arbitraria en la que reconocemos la denuncia contemporánea, especialmente en EE.UU. de la sobre-proporcionalidad de condenas capitales sobre negros, hispanos y otros grupos minoritarios expuestos.

Poco evolucionó el estatuto legal de la pena de muerte en el mundo salvo los episodios de la abolición en la Toscana, Austria, y de modo definitivo en Michigan y Portugal.

\section{EL CARÁCTER DE IUS COGENS DE LAS SALVAGUARDIAS QUE ACOMPAÑAN EL ARTÍCULO 6 Y 7 DEL PIDCP}

La pena de muerte no está frontalmente prohibida en el PIDCP, pero está severamente restringida por el artículo 6, que establece limitaciones para los países que todavía no la han abolido. Tanto el artículo 6 como el 7 del Pacto deben aplicarse conforme a su texto literal y a su interpretación generalmente aceptada que es la que incorporan las Salvaguardias.

Recientemente recurría John Tasioulas al enfado de Kant por el "escándalo filosófico" ante la falta de prueba convincente de la existencia del mundo exterior, para aplicarlo a lo que él llama el "escándalo de los internacionalistas" de no disponer todavía de un sistema de identificación preciso de lo que sea derecho consuetudinario o ius cogens y reclama un papel capital de los principios y de la opino iuris frente a la mera práctica de los Estados. Será necesario precisar esta cuestión en relación con los artículos 6 y 7 de Pacto Internacional de Derechos Civiles y Políti-

Vid. Pulido Fernández Ángel, La pena capital en España. Enrique Teodoro, Madrid, 1897; Oliver Olmo, Pedro, La pena de muerte en España, Síntesis, Madrid 2008, p. 72 y sigs. 
cos. Tal y como se ha comenzado a hacer por nuestro grupo de investigación y Mads Andenaes, en The prohibition of the death penalty: an emerging ius cogens norm ${ }^{4}$.

Las salvaguardias aprobadas por el ECOSOC son la interpretación más auténtica del artículo 6 y deben ser consideradas verdadero ius cogens internacional, en especial baste referirnos aquí a la primera y principal, en virtud de la cual la pena de muerte no se puede imponer salvo por los delitos más graves, por los que se entienden como mínimo los homicidios intencionales y asesinatos. Por recordar en esencia los términos de la cuestión, el artículo 6.2. del Pacto dice: "En los países en que no hayan abolido la pena capital sólo podrá imponerse la pena de muerte por los más graves delitos" mientras que en la salvaguardia $\mathrm{n}^{\circ} 1$ dice: "En los países que no la hayan abolido, la pena de muerte sólo podrá imponerse como sanción para los delitos más graves, entendiéndose que su alcance se limitará a los delitos intencionales que tengan consecuencias fatales u otras consecuencias extremadamente graves", en la versión de 1984, lo que se interpreta como al menos homicidios voluntarios o asesinatos. Lo que excluye cualquiera otros delitos menores, como los relacionados con las drogas, el adulterio, la homosexualidad, etc 5 .

El fundamento de por qué esas salvaguardias son ius cogens se encuentra en las siguientes razones:

a) Porque en cuanto a plasmación de derecho a la vida y de la dignidad de las personas pertenece al núcleo duro de los derechos fundamentales, a lo que el artículo 53 de la convención de Viena de 1969 llama garantías básicas y esenciales inherentes al respeto de la dignidad humana.

b) Porque la generalidad de los países ha ratificado el PIDCP y son aplicadas por los diversos órganos de Derechos Humanos de las Naciones Unidas, por los rapporteurs del Alto Comisionado, por el Consejo en los informes periódicos nacionales y su validez se reconoce en las respuestas generalizadas de los países a las preguntas para la confección de los informes quinquenales del Secretario General.

c) Porque incluso países que como China no han firmado el protocolo manifiestan su disposición a hacerlo y acomodan progresivamente sus prácticas jurídicas hacia su cumplimiento, lo que se manifiesta en las decisiones legislativas de reducción de los delitos capitales previstos en el código penal, las reformas institucionales en su Tribunal Supremo, etc. A su vez, el principal país de occidente, Estado Unidos de América, que mantiene la pena capital,

4 The prohibition of the death penalty: an emerging ius cogens norm, Universidad de Oslo, como ancillary meeting al Congreso Mundial contra la pena de muerte, junio 2016, v. https://www.jus. uio.no/ifp/english/research/news-and-events/events/2016/death-penalty-seminar.html; http://www. worldcoalition.org/Coordinator-for-the-6th-World-Congress-against-the-Death-Penalty.html

5 Véase Arroyo Zapatero L., Pena de muerte y tráfico de drogas, en Tiempo de Paz: la abolición universal de la pena de muerte, $\mathrm{n}^{\circ} 108$, primavera 2013, p. 20-28. 
experimenta un proceso de intenso debate en los últimos 6 años y ha comportado la abolición o la moratoria en 7 Estados en los últimos 5 años.

d) La generalidad de los países manifiestan su aceptación de las Salvaguardias al responder de modo sistemático a los informes y encuestas que se realizan para la composición de los informes quinquenales del Secretario General. En los que se advierte que en el paso de los últimos 20 años se ha llegado a cumplir la primera y principal de las salvaguardias en la generalidad de los países, incluidos no pocos que se pensaban que formaban parte del núcleo duro de los ejecutores "hard executioners", en expresión de Hood y Schabas". Debe advertirse que el consenso de los Estados en el cumplimiento estricto de las salvaguardias para llegar a ser consideradas ius cogens debe ser general, pero no unánime. El que varios países incumplan las salvaguardias no merma su validez general.

e) Por su parte, el art. 4.2 del Pacto Internacional de Derechos Civiles y Políticos señala entre otros que las salvaguardias $1,2,3$ y 7 son inderogables. La 4 y la 9 han sido reconocidas como inderogables por el Comité de DDHH en la Observación General 29, y la 5 y 6 también por el Comité en la Observación General 32, conclusión 8: las salvaguardias son inderogables.

\section{LA PENA DE MUERTE COMO ES COMO TAL UNA PENA CRUEL E INHUMANA}

Resulta contraria en su aplicación ordinaria al art. 7 PIDCP: "Nadie será sometido a

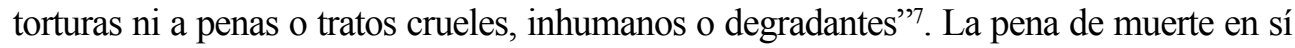
misma puede constituir un trato inhumano o degradante, más aun cuando no existe un consenso internacional total en negar esta posibilidad y el derecho internacional vive una trasformación y evolución constante. En este sentido, los relatores especiales sobre tortura y otros tratos o castigos crueles, inhumanos o degradantes calificó de forma explícita la pena capital como una forma de pena cruel, inhumana o degradante. Por su parte, tanto la Corte Interamericana de Derechos Humanos (CIDH), como la Corte Constitucional de Sudáfrica declaran que la pena de muerte constituye un trato cruel e inhumano ${ }^{8}$.

6 En Arroyo/Nieto y Schabas, Pena de muerte, Una pena cruel e inhumana y no especialmente disuasoria, Coord. Beatriz Garcia-Moreno, UCLM y Tirant lo Blanch, Cuenca y Valencia 2014,p. 23 y sigs.

7 J.Jones, “U.S. Death Penalty Support Lowest in More than 40 Years," Gallup, October 29, 2013, en http://www. deathpenaltyinfo.org/public-opinion-support-death-penalty-its-lowest-40-years (Consultado 1.11.2016) ; Seth Miller, Misty Thomas, A Forty-Year Retrospective of the Death Penalty, en Human Rights Magazine, 2016-17, Vol. 42, vol. 2 Resulta prometedor el próximo libro de Bessler, John D., The Death Penalty as Torture. From the Dark Ages to Abolition que se publicara en 2017 por la Carolina Academic Press,

8 Me remito para las referencias a mí La pena de muerte como trato cruel, inhumano y degradante, en "Revista Brasilera de Direito Penal", vol. 100, 2013; También a L. Arroyo y J. Bordes, Francisco de Goya. Contra la crueldad de la pena de muerte/ Against the cruelty of capital punishment, Universidad de Castilla-La Mancha y Real Academia de Bellas Artes, Madrid 2013. On line http://www.inacipe.gob.mx/publicaciones/Goya.php ) 
La salvaguardia $\mathrm{n}^{\circ} 9$ dispone que: Cuando se aplique la pena capital, su ejecución se hará de forma que se cause el menor sufrimiento posible. Pero la experiencia histórica muestra que la innovación en los medios de ejecución de la pena de muerte está inspirada por la permanente búsqueda del medio de ejecución menos inhumano. El fracaso reciente de la inyección letal en los Estados Unidos pone a los estados en la terrible disyuntiva de regresar a la silla eléctrica o al pelotón de fusilamiento, o bien camina rápidamente a la abolición. Son bien conocidos también los informes de los relatores tanto sobre la tortura como sobre ejecuciones extrajudiciales acerca de que las condiciones del tiempo de espera para la ejecución, el callejón de la muerte, que pueden llevar muchos años, el modo y manera concreta de la ejecución, etc., convierten a la pena de muerte en la práctica en una pena cruel e inhumana9.

\section{SANCIONES POR VIOLACIÓN DE LAS NORMAS FUNDAMENTALES DE DERECHOS HUMANOS POR LOS ESTADOS}

La responsabilidad de los Estados por la vulneración de normas básicas de la comunidad internacional es un asunto que tras el proyecto elaborado por James Crawford ${ }^{10}$ y presentado a los gobiernos y examinado por la Asamblea General en 2001 es asunto que requiere más esfuerzo político que jurídico. Sin embargo, a la espera de que una norma internacional disponga qué sanciones o consecuencias jurídicas procede imponer al Estado que vulnere una norma esencial de Derechos Humanos como las contenidas en los artículos 6 y 7 del PIDCP, cabe imaginar la adopción por organismos de Naciones Unidas así como por otras organizaciones regionales, algunas como las siguientes ${ }^{11}$ :

a) En virtud del principio de coherencia con las disposiciones internacionales vinculantes en materia de derechos humanos debería excluirse como elegibles para los órganos y cuerpos de Naciones Unidas competentes en esa materia a los efectos conformar las pertinentes comisiones. Podría ser un criterio a adoptar por las mayorías abolicionistas en cada instancia.

b) En los casos de países que no respetan el artículo 6 del PIDCP se debería suspender la cooperación policial y judicial internacional, incluida la extradición respecto de los delitos que se castiguen de modo ilegitimo con la pena de muerte ${ }^{12}$.

9 Vers l'interdiction absolue de la peine de mort. Perspectives philosophiques et juridiques", Editado por Marc Crépon, Jean Luis Halpérin y Stefano Manacorda del Collége de France

10 Los artículos de la Comisión de Derecho Internacional sobre la responsabilidad internacional del Estado: introducción, texto y comentarios, Dykinson, Madrid 2004, y del mismo autor: State Responsibility. The General Part, Cambridge University Press 2014.

11 Véase Special Rapporteur para ejecuciones extrajudiciales, sumarias y arbitrarias A/70304, 7.8.2015, conclusiones, párrafo 116-120.

12 Kendal, Wesley, The Death Penalty and U.S. Diplomacy: How Foreign Nations and International Organizations Influence U.S. Policy, Rowman \& Littlefield Publishers, 2013. 
c) En los casos de países que aplican la pena de muerte a delitos que no son los más graves, como por ejemplo por los delitos relacionados con las drogas, podría suspenderse la ayuda o asistencia técnica internacional o regional en dicha materia, tanto la de orden financiero como el policial y judicial.

\section{PERSPECTIVAS DE LA ABOLICIÓN A LA ALTURA DE 2016}

La evolución del proceso internacional de la abolición a la altura de 2016 debe considerarse favorable, muy especialmente en África. Es cierto como señala Amistía Internacional ${ }^{13}$ que en el año 2015 se han incrementado el número de penas de muerte ejecutadas en algunos de los países más "Hard excusioner" cómo Irán, 977, Pakistán, 326, Arabia Saudita, 158. Pero lo es también que han abolido la pena de muerte países como la República del Congo, Madagascar, Surinam, Guinea ecuatorial $^{14}$.

Sin duda el obstáculo más formidable a la generalización de la abolición es la persistencia de la pena de muerte en los Estados Unidos de América, un mal ejemplo en el que se apoyan países como China y otros para justificar su retencionismo. Que el país más importante de occidente mantenga la pena de muerte debilita el mensaje abolicionista de los países que consideran que dicha abolición pertenece al concepto de civilización. Sin embargo los datos de Norteamérica son muy positivos, tanto por los numerosos estados que han adoptado la abolición o la moratoria los últimos años, como por la sistemática reducción de las penas de muerte ejecutadas que han pasado de un elevado número que alcanzó en 1999 los 100 ejecutados en el año a los 36 y 27 respectivamente de 2015 y 2016 lo que se corresponde plenamente con el declinar de la opinión pública en su favor ${ }^{15}$. No obstante, las novedades políticas que comporta impulsa la nueva presidencia de los Estados Unidos podría ofrecer algunos resultados negativos tanto en la cuestión penal como en ésta en particular.

En cualquier caso, parece que el proceso más preocupante es el de las Filipinas, país que tras sucesivos casos escandalosos de errores judiciales y de ejecuciones arbitrarias había llegado con la presidenta Gloria Marcapagal Arroyo adoptar la abolición. El nuevo presidente ya en campaña electoral se manifestó no sólo par-

13 Amnistía Internacional, Informe 2016 sobre pena de muerte, https://www.es.amnesty.org/en-que-estamos/temas/pena-de-muerte/ Amnistía Internacional, Informe 2016 sobre pena de muerte, https:// www.es.amnesty.org/en-que-estamos/temas/pena-de-muerte/

14 Vers l'interdiction absolue de la peine de mort. Perspectives philosophiques et juridiques",Editado por Marc Crépon, Jean Luis Halpérin y Stefano Manacorda del Collége de France.

15 J. Jones, "U.S. Death Penalty Support Lowest in More than 40 Years," Gallup, October 29, 2013, en http://www.deathpenaltyinfo.org/public-opinion-support-death-penalty-its-lowest-40-years (Consultado 1.11.2016) Seth Miller, Misty Thomas, A Forty-Year Retrospective of the Death Penalty, en Human Rights Magazine, 2016-17, Vol. 42, vol. 2. 
tidario de la pena de muerte sino incluso de las ejecuciones extrajudiciales y, al parecer, desde que tomo posesión sus fuerzas de seguridad han dado muerte a más de 15.000 personas $^{16}$. Un auténtico reto para la comunidad política y académica internacional.

16 Manuel Quezon III, Democracy Post Opinion President Duterte's honeymoon may be ending, Washington Post, 28 de febrero; Associated Press March 7<, Philippine House OKs restoring death penalty for drug cases. Philippines Moves Closer to Reinstating Death Penalty, 1 march 2017. Duterte May Be Guilty of Crimes Against Humanity, Rights Group Says. By FELIPE VILLAMOR and MIKE IVESMARCH 2, 2017. 


\title{
BECCARIA EN NUESTRA AMÉRICA
}

\author{
SERGIO GARCÍA RAMÍREZ \\ Vicepresidente de la Société Internationale de Défense Sociale. \\ Catedrático de Derecho penal. Universidad Nacional Autónoma de México.
}

Miraré mi tema con ojos americanos, de lo que José Martí llamó "nuestra América": territorio, población y cultura que se extienden entre el río Bravo y la Patagonia. Es la América desplegada en el escudo de mi Universidad, la Nacional Autónoma de México, con la estampa y el lema que estableció el rector José Vasconcelos $^{2}$. También aquí se recibió la buena nueva beccariana. Arribó cautelosa-como la primera edición de Liorna-, con los vientos de la Ilustración y la Revolución. Desembarcó sorteando baluartes, mejor dispuestos para disuadir la cultura que para detener a los piratas. Y se abrió camino en la formación de repúblicas inciertas, acostumbradas al cadalso y al tormento.

Un antiguo maestro en la Universidad de México -Raúl Carrancá y Trujillo, discípulo de Jiménez de Asúa y autor del primer tratado de Derecho penal moderno en Iberoamérica ${ }^{3}$, según la modernidad de su tiempo- me atrajo a las andanzas

1 Cfr. Martí, J. «Nuestra América». En La Revista Ilustrada, Nueva York, 10 de enero de 1891, y El Partido Liberal, México, 30 de enero de 1891. Para una revisión de este tema en la producción martiana, cfr. Martí, J. Nuestra América. Caracas, Venezuela, Fundación Biblioteca Ayacucho, 2005.

2 Cfr. «El nuevo escudo de la Universidad Nacional». En Vasconcelos, J. Discursos 1920-1950, México, Ed. Botas, 1950, p. 13.

3 "Tiene - cito a Jiménez de Asúa- el insuperable mérito de haber sido el primer Tratado en Iberoamérica que, con sistema moderno, expone la Dogmática Penal". Se refería al Derecho penal mexicano. Parte general, México, Ed. Porrúa, 11ª ed., 1976, p. 766 -de donde tomo la cita (que se halla en La Ley, Buenos Aires, diciembre 11, 1946)-, cuya primera edición apareció en 1937. 
del marqués, que llevaba un siglo y medio entre nosotros. Me hice del librito en la traducción que vio la luz en Puebla, elaborada por un devoto beccariano: Constancio Bernaldo de Quirós, español transterrado 4 . Así llamaba José Gaos, ex rector de la Universidad Central de Madrid, a los migrantes republicanos ${ }^{5}$. Don Constancio agregó a su traducción un estudio fervoroso ${ }^{6}$.

Conservo ese libro, con las notas que alojaron mis hallazgos. Andando el tiempo, conté con un ejemplar de la edición príncipe, que horrorizó a los Facchinei que se le opusieron ${ }^{7}$, e irritó al Índice que la proscribió ${ }^{8}$. A la edición facsimilar preparada por el Fondo de Cultura Económica agregué un estudio sobre el autor, su obra y su circunstancia - como recomienda Ortega en la meditación del Quijote 9 . En una publicación de este 2014 milita al lado de John Howard, el country gentleman inglés metido a insigne penitenciarista ${ }^{10}$.

He ahí dos insólitos personajes, antípodas en el temperamento y el comportamiento, pero coincidentes en el destino. Poseyeron -resume Elías Neuman- "el mismo acento de vehemente sinceridad (...) y el mismo empeño de abrir paso a las razones del futuro"11. Uno, aristócrata, se formó en el coloquio de los iracundos, que hacen la revolución sin prescindir de la tertulia; colega de Pedro Verri alterado por el espectáculo de la tortura, y de Alejandro Verri, prottetore dei carcerati, ombudsman de los presos en espera de la horca. Beccaria concluyó su rebelión en el mezzo giorno de su existencia, la hora marcada en la Comedia para otras correrías. Había alcanzado su cenit, enarbolando una doble bandera: la piedad y la razón.

$4 \quad$ Tratado de los delitos y de las penas. Trad. Constancio Bernaldo de Quirós, Puebla. Cajica, 1957.

5 Cfr. Varios, El exilio español en México. 1939-1962. México, Fondo de Cultura Económica, 1982, p. 776.

6 «César Beccaria y su libro». En Tratado..., cit., pp. 7 y ss.

7 Fachinei impugnó el libro de Beccaria, en Note ed osservazioni sul libro intitulato 'Dei delitti e delle pene', publicado en 1764: "obra horrible, envenenada, de una licencia dañosa, infame, é impía". Véase la contestación en "Respuesta a las notas y observaciones de un fraile dominico, sobre el libro De los delitos y de las penas", que se reproduce parcialmente en Beccaria, Tratado de los delitos y de las penas, México, ed. facsimilar de la española de 1822, Porrúa, 1982, p. 337.

8 Cfr. Del Val, J. A. «Introducción» a Beccaria, De los delitos y de las penas. Trad. Juan Antonio de las Casas. Alianza Editorial, Madrid, 1968, p. 14.

9 García Ramírez, S. «Estudio introductorio. Beccaria: el hombre, la circunstancia, la obra». En Beccaria, César, De los delitos y de las penas, facsimilar de la edición príncipe en italiano de 1764, seguida de la traducción de Juan Antonio de las Casas de 1774, México, 1a. ed., 2a . reimp. Fondo de Cultura Económica, pp. 7 y ss. Este estudio, junto con el correspondiente a John Howard, que se menciona en la n. 10, quedaron integrados en mi libro Los reformadores. Beccaria, Howard y el Derecho penal ilustrado. México, Instituto de Investigaciones Jurídicas, UNAM/Instituto Nacional de Ciencias Penales (INACIPE)/Tirant lo Blanch, 2014.

10 Cfr. Howard, J. El estado de las prisiones en Inglaterra y Gales, trad. Esteban Baca Calderón, con estudio introductorio de Sergio García Ramírez, "John Howard: la obra y la enseñanza". México, Fondo de Cultura Económica, 2003.

11 Neuman, E. Prisión abierta. Una nueva experiencia penológica. Buenos Aires, Depalma, 1962, p. 46. 
El otro personaje, con su covenant sobre el pecho ${ }^{12}$, consumó un recorrido de cuarenta mil millas en Europa ${ }^{13}$. Caminante sin reposo -la continua estancia en un lugar "abate mi espíritu", advertía ${ }^{14}$-, visitó y denunció prisiones y lazaretos, de Portugal a Crimea. El high sheriff de Bedforshire, que polemiza con monarcas -José II, de Austria ${ }^{15}$ - y arriesga el encierro en la Bastilla, admiró la obra de Beccaria. Lo llamó el "bondadoso marqués" y lo citó sobre la prevención de los delitos, el rigor de las cárceles, el tormento, la pena de muerte y el infortunio de los deudores sometidos a prisión ${ }^{16}$.

Dei delitti e delle pene -sostiene Badinter- figura en la "pléyade de las obras esenciales", al lado de El espiritu de las leyes, El contrato social, ¿Qué es el Tercer Estado? y El capital $^{17}$. Sin duda, ha sido una guía puntual para viajeros de la justicia. Es la encarnación literaria de Jano. Mira hacia el pasado y observa hacia el porvenir, que es nuestro presente y acaso nuestro futuro.

En su tiempo clareaba la revolución en las ideas y las prácticas de la justicia penal. En los cahiers de doléances para los Estados Generales ${ }^{18}$ fluyeron las quejas contra el sistema penal del absolutismo. Ortolan refiere que los cuadernos de las tres órdenes "pedían unánimes (la) reforma de las leyes penales é indicaban las bases: la revolución social y política vino a operarla y á abrir la era del nuevo derecho penal moderno" 19 .

Esas quejas discurrieron en nuestra América, en documentos de otro género pero con estirpe semejante: apremios insurgentes, planes y proyectos, esbozos constitu-

12 En el covenant, que portó hasta su muerte, manifestaba sumisión a la voluntad de Dios. Cfr. Bernaldo de Quirós, Criminología. Puebla, Ed. Cajica, 1948, p. 279.

13 Cfr. id.

$14 \quad I d$.

15 Cfr. Brown, James Baldwin. Memoirs of the public and private life of John Howard, the Philantropist; compiled from his own Diary, in the posession of his family; his confidential letters; the communications of his surviving relatives and friends; and other authentic sources of information. London, Printed for Thomas and John Underwood, $2^{\text {nd }}$. ed., 1823, p. 465 y ss. Igualmente, cfr. Howard (D.L.). John Howard: prison reformer. New York City, Archer House Inc., 1963, pp. 148-149; y Ramos y Paz Anchorena, J. M. Curso de Derecho penal. Penología. Buenos Aires, Biblioteca Jurídica Argentina, 1929, t. III, p. 64 n. 6.

16 Cfr. El estado de las prisiones..., cit., pp. 183, 213 n. 40, 249 n. 35, 262 n. 53 y 298 n. 97.

17 «Beccaria, l'abolition de la peine de mort et la Révolution française». En Varios, Cesare Beccaria and Modern Criminal Policy. Milan (Italy), Castello Sforzesco, December 15th-17th, 1988, Centro Nazionale di Prevenzione e Difesa Sociale/Giuffre editore, Milano, 1990, p. 36 (citaré con frecuenta esta fuente como Cesare Beccaria and Modern...). Este artículo figura, igualmente, en Revue de Science criminelle et de Droit pénal comparé, no. 2, avril-juin 1989, pp. 235 y ss.

18 Cfr. Badinter, R. «L'abolition de la peine de mort...». En Varios, Cesare Beccaria and Modern..., cit., p. 47.

19 Ortolan, M. Tratado de Derecho penal. Trad. Melquiades Pérez Rivas, Madrid, Lib. De Leocadio López, 1878, t. I, p. 8. 
cionales, declaraciones de independencia, en los que las reclamaciones políticas aparecían junto a las exigencias de justicia: legalidad, igualdad, humanidad.

En esa circunstancia europea se informó el modelo del Estado de Derecho, dice Ferrajoli: "En los siglos XVII y XVIII el derecho penal constituyó el terreno en el que principalmente fue delineándose el modelo del Estado de Derecho" ${ }^{20}$. La idea del Estado de Derecho cruza - con otras expresiones- la obra de Beccaria, en oposición al estado de arbitrio, subraya Mario Pisani al invocar las reflexiones de Mondolfo $^{21}$. Sebastián Soler señala: "Las obras de Montesquieu y de Rousseau cambiaron la constitución de los Estados; la de César Beccaria dio una nueva concepción de la actividad represiva"22. El siglo XVIII proclama "una necesidad general: la de destruirlo todo -escribe Ortolan-. Poco importa lo que haya de sustituirlo: abajo lo existente será el grito y la misión" de ese $\operatorname{siglo}^{23}$. Las propuestas de Beccaria se convertirían en $l e{ }^{24}$, y ésta en vida.

Es en el ámbito penal donde mejor se miran los pasos adelante y pueden temerse los pasos atrás- Ahí, Leviatán entra en la más dramática contienda con el ser humano, cada quien bajo sus pendones. Y en la circunstancia americana hizo su propio trayecto la justicia penal; nuestro Continente se caracterizaba por la penalidad, no por la justicia.

El opúsculo de Beccaria ha recibido numerosas traducciones al español, lisas y llanas o provistas de extensos comentarios. Es un clásico a la mano. En cambio, la obra de Howard fue vertida al castellano en $2003^{25}$, aunque el autor y sus ideas fueran conocidos y elogiados a través de alusiones y citas fragmentarias.

De los delitos y de las penas -a veces titulado como "tratado"26 - inició el itinerario de los Apeninos a los Andes, merced a Juan Antonio de Las Casas -Madrid, 1774-. Esta edición, inicialmente anónima, incluyó las adiciones a la primera y

20 Cfr. Derecho y razón. Teoría del garantismo penal. Trad. Perfecto Andrés Ibáñez, Alfonso Ruíz Miguel, Juan Carlos Bayón Mohino, Juan Terradillas Basoco y Rocío Cantarero Bandrés, Madrid, Trotta, $3^{\text {a }}$. ed., 1998, p. 24.

21 Cfr. Pisani, M. «Asterischi argentine su Cesare Beccaria». En Materiali per una Storia della Cultura Giuridica, a. XXXI, n. 1, giugno 2001, pp. 27-28.

22 Derecho penal argentino. Buenos Aires, Tipográfica Editora Argentina, 10ª. reimp. total, 1992, t. I, p. 86.

23. Curso de legislación penal comparada. Madrid, Imprenta de la Sociedad Literaria y Tipográfica, 1845, p. 145.

24 José Antón Oneca cita la afirmación de Ellero: "setenta de las ochenta proposiciones contenidas en aquel (libro) han sido llevadas a la práctica, y muchas perduran en la actualidad". Derecho penal, Madrid, AKAL, 1986, p. 60.

25 La primera traducción se hizo en México, para el Fondo de Cultura Económica, en 2006, por Esteban Baca Calderón. Cfr. n. 10, supra.

26 Que es el caso de la difundida edición española de 1822, con el comentario de Voltaire y otros documentos valiosos e ilustrativos, cit. n. 7, e igualmente el de la edición poblana de Cajica, con traducción de Bernaldo de Quirós, ya mencionada. 
adoptó la reordenación propuesta por Morellet ${ }^{27}$. Agregáronse otras traducciones ${ }^{28}$ : una anónima, madrileña, de 1820; otra, de Juan Rivera, de 1821; una más, igualmente madrileña, cuyo editor firma "C.Y." -, de $1822^{29}$; otra de semejantes características, de 1851; una de Pascual Vincent, de 1879; otra, de Buenos Aires, de 1945; y las de Bernaldo de Quirós, que ya mencioné, Santiago Sentís Melendo y Marino Ayerra Redín ${ }^{30}$ y, finalmente, "al amparo de una efímera fase de apertura política" -dice Luis Arroyo Zapatero ${ }^{31}$-Francisco Tomás y Valiente, de $1974^{32}$. Confío en la benevolencia de quienes me escuchan por las omisiones que probablemente cometo.

Beccaria recogió elogios y sufragios de sus lectores en idioma español, que secundaron los que iniciaran Voltaire, Diderot y D'Alembert. Sus méritos han dominado el paisaje y favorecido la adopción paulatina de sus propuestas. Fue premonitorio el epígrafe que Beccaria tomó de Bacon para el pórtico de su opúsculo ${ }^{33}$ : los frutos llegan después de la siembra y la maduración. Así debía ocurrir, tratándose de una obra llamada a producir un "entusiasmo ardiente" y una "oposición violenta" ${ }^{4}$.

La obra de Beccaria es producto de una circunstancia europea, que de alguna manera sería también americana, con las variantes que imponen el tiempo y el espacio. Pensemos en círculos concéntricos que se desenvuelven en un proceso de creación continua. Primero, el estado que guardaban la libertad y la tiranía, resumido en la rotunda fórmula de Rousseau: "El hombre ha nacido libre, y sin embargo, vive dondequiera encadenado" 35 . La justicia penal era el eslabón más poderoso de esa cadena.

Luego un segundo círculo, excitado por aquél: una nueva insurgencia pretendía atar las manos del poderoso y desanudar las del desvalido: quería demoler, en cada litigio, una Bastilla. Después, la circunstancia precipitante, que pone en marcha un proceso a partir de un suceso: el caso Calas, en 1762, que irguió a Voltaire, y los

27 Cfr. Tomás y Valiente, F. «Introducción». En Beccaria, De los delitos..., cit., p. 50, y «Carta primera a M. Beccaria». En Tratado de los delitos..., ed. de 1822, facsimilar de Porrúa, cit. n. 7, supra, p. 390.

$28 \mathrm{Al}$ respecto, cfr. Jiménez de Asúa, L. Tratado de Derecho penal. Buenos Aires, Ed. Losada, $3^{\mathrm{a}}$. ed., 1964.

29 Citada en la n. 7 supra.

30 De los delitos y de las penas. Temis, Bogotá, 1994, pp. 856-857, y Zaffaroni, E. R., Alagia, A., y Slokar, A. Derecho penal. Parte general. Buenos Aires, EDIAR, 2 ${ }^{\mathrm{a}}$. ed., $2^{\mathrm{a}}$. reimp., p. 287, n. 86.

31 «La moderna política criminal en España y el pensamiento de Cesare Beccaria». En Varios, Cesare Beccaria and Modern..., cit., p. 189.

32 Beccaria, C. De los delitos y de las penas. Trad. Francisco Tomás y Valiente. Madrid, Aguilar, 1a . ed., 1974.

33 "En las cosas difíciles, no hay que esperar sembrar y coger todo á la vez; es menester trabajar para hacer madurar, á fin de poder recoger un día los frutos que se han de sacar".

34 Sodi, D. Nuestra ley penal. Estudios prácticos y comentarios sobre el Código del Distrito Federal de $1^{\circ}$ de abril de 1872. México, Librería de la Vda. de Ch. Bouret, $2^{\text {a }}$. ed., 1917, t. I, p. 17.

35 El contrato social o principios de derecho político. México, Ed. Porrúa, 1969, p. 3. 
de Sirven y el caballero de La Barre, después de Beccaria ${ }^{36}$. "El edificio del viejo derecho penal ardía lentamente - diría Von Liszt- (...) cuando un motivo externo sopló sobre él, levantando llamas" 37 .

Algo semejante se podría decir de nuestra América. Despertaba de su sueño, en muchas repúblicas en ciernes, cada una con sus patíbulos, sus picotas, sus inquisiciones, sus cárceles perpetuas, como las que flanqueaban la gran plaza de Santo Domingo en el corazón de México. Agréguese la heterogeneidad de las sociedades americanas, donde coexistían -porque no convivían- grupos estancos, pequeños mundos de extraños en recelo y en conflicto, reunidos por la geografia y enemistados por la sangre.

Añádase el pensamiento de la Ilustración y todo lo que pudo aportar, en este marco, el agregado beccariano que ingresaba por cada ventana abierta y cada palabra liberada, aunque lo hiciera de manera indirecta, sin acta de nacimiento. Operaron la Revolución, cuyas proclamas llegaron a lectores en la sombra, y el impulso de las Cortes de Cádiz, foro de una España imposible, tendida en los flancos del océano.

En Cádiz actuaron hombres de América ${ }^{38}$. Algunos provenían de las posesiones cuya representación ostentaban; otros residían en la península. Los hubo conservadores, moderados y liberales de gran vuelo, como Miguel Ramos Arizpe y Miguel Guridi y Alcocer, que se alzaron con las inquietudes del nuevo Continente y luego llevaron a éste, a sus congresos y a sus batallas, ideas sostenidas en Cádiz. Ots y Capdequi destaca que las disposiciones sobre justicia penal son muy representativas "de la mentalidad imperante en los diputados de las Cortes de Cádiz" ${ }^{39}$. A la vieja normativa española "vinieron a agregarse los principios de libertad y de emancipación política" que figuraban en la Constitución y los decretos de las Cortes ${ }^{40}$.

En la porción americana, los flamantes ciudadanos que estrenaban libertades cifraron su primer empeño en la formación de instituciones políticas, más que en la revisión de instituciones judiciales. Aquello no podía aguardar; esto debía esperar su hora, aunque angustiara a los justiciables ${ }^{41}$. Ocurrió en ambos extremos de América $^{42}$.

En nuestra América decimonónica hubo entusiastas del pensamiento reformador y del propio Beccaria, presente con su nombre o por sus ideas. Resistieron el asedio de los impugnadores, cada vez menos vigoroso en la medida en que avanzaban

36 Cfr. Badinter. «L'abolition...». En Varios, Cesare Beccaria and Modern..., cit., p. 38.

37 Tratado de Derecho penal. Trad. Quintiliano Saldaña, Madrid, Instituto Editorial Reus, $3^{\mathrm{a}}$. ed., t. I., p 389.

38 Cfr. Hernández Mota, J. I. Visiones del México independiente. ¿Génesis y topos del liberalismo mexicano?. México, DGE/Equilibrista, 2012, pp. 145 y ss.

39 Historia del Derecho español en América y del Derecho indiano. Madrid, Aguilar, 1968, p. 321.

40 Cfr. Macedo, M. Apuntes para la historia del Derecho penal mexicano. México, Ed. Cultura, 1931, p. 198.

41 Ibidem, pp. 209-210.

42 Sobre Argentina, cfr. Soler, S. Derecho penal argentino..., cit., t. I, p. 112. 
las ideas liberales, de diversa fragua. Las refutaciones llegaron muy tarde, si acaso acudieron, aunque no faltarían transitorias arremetidas en defensa del trono y las creencias.

La obra del marqués sobrevivió a todos los embates. No la mellaron ni el desdén con que se trató a sus restos, depositados en una fosa común ${ }^{43}$, ni los estudios de personalidad - por llamarles de alguna manera- que circularon en su perjuicio, ni los cotejos desfavorables con otros reformadores, como Lardizábal -autor que merece el mayor aprecio-, de los que es ejemplo el ensayo de Francisco Blasco y Fernández de Moreda ${ }^{44}$. Alguna vez se dijo que los beccarianos, poseedores de magros argumentos, coronaron a Beccaria con laureles arrancados a la frente del eximio fraile zamorano Alfonso de Castro $^{45}$.

Al hablar de América y desde ella, es necesario tributar a la obra de Manuel de Lardizábal, eminente nativo de Tlaxcala, que vivió veinte años en su tierra de origen y a quien México y España reclaman como suyo, cuando puede ser de ambos. Se aproxima en varios extremos Beccaria, pero también se aparta en puntos fundamentales, como la interpretación judicial, la pena capital -en la misma línea de Alfonso de Castro-y la medida de los delitos.

A los trabajos preparatorios de los primeros códigos penales llegó el pensamiento de Beccaria, directa o indirectamente; así, el Código de Bolivia, llamado Santa Cruz, que se inspiró en el español de 1822, y el Codigo Criminal do Imperio, de Brasil, influido por Pascalis Joseph Mello Freire, autor de un avanzado proyecto para Portugal y receptor, en éste, de la influencia del marqués ${ }^{46}$.

En Cádiz se previó una legislación penal única ${ }^{47}$, que pondría orden y daría sentido al mundo hispánico reconcebido en 1812. Crear una legislación implicaría -en la línea beccariana-suprimir el arbitrio. La idea no prosperó; no hubo unidad, ni política, ni legislativa. Con todo, el código de 1822, fruto del "Trienio Liberal", sembró una semilla para España y una parte de América. Entre nosotros, la codificación -que es línea de defensa, organizada, de la ideología penal- anduvo un buen trecho en el siglo XIX y consolidó su paso en la primera mitad del XX.

Los redactores del Derecho emergente miraron hacia el ordenamiento de Francia y la doctrina derivada de éste, con el ímpetu de la gran Declaración de 1789. Ahí se

43 Cfr. Pilliteri, P. «Opening Adress». En Varios, Cesare Beccaria and Modern..., cit., p. 4.

44 Lardizábal. El primer penalista de América española. México, Universidad Nacional Autónoma de México, Imprenta Universitaria, 1957.

45 Cfr. Ambriz Q., J. T. La teoría penal en Alfonso de Castro. Toluca, Cuadernos del Estado de México, 1967, p. 9.

46 Cfr. Zaffaroni, E.R. Derecho penal..., cit., pp. 288-289.

47 Artículo 258: "El código civil y criminal y el de comercio serán unos mismos para toda la Monarquía, sin perjuicio de las variaciones que por particulares circunstancias podrán hacer las Cortes". 
halló Beccaria, en cuerpo y alma: díganlo los artículos 5 , legalidad, donde engarza el dogma nullum crimen sine lege; 6 , igualdad; 7 , debido proceso, identificado con las palabras de su momento; 8 , sentido y contenido de la pena, y 9 , presunción de inocencia y prisión preventiva. Todo esto sería parte de la herencia que asumió el Derecho constitucional americano, a punto de nacer, el internacional de los Derechos humanos, alumbrado muchos años después, y particularmente la sección que ahora me interesa: el interamericano.

Estas fórmulas, que deshicieron - al menos en la animosa letra- el derecho "atroz, desigual e injusto" que hallaron los revolucionarios, dice Esmein ${ }^{48}$, fueron legado para el mundo en proceso de renovación, y también, por supuesto, herencia para la fracción que construían los americanos. En Europa llegaban a su término -invoco la elocuente expresión que Beccaria incorporó a su opúsculo- aquellos "restos de la legislación de un antiguo pueblo conquistador (...) que componen la tradición de opiniones que una gran parte de Europa honra todavía con el nombre de leyes" ${ }^{\text {"9 }}$.

En América, marchando de la colonia a la insurgencia, ocurriría un fenómeno similar. También habrían de llegar a su término -paso a paso- las disposiciones del antiguo régimen, que perseveró profundamente en el siglo XIX. En el Derecho americano de alborada está la honda huella de la reforma europea y de la obra de Beccaria.

El artículo 23 de la primera Constitución de México, antes de la consumación de la Independencia -Decreto dictado en Apatzingán, en 1814- resolvió con una expresión cuyo origen es perfectamente reconocible: "La ley sólo debe decretar penas muy necesarias, proporcionales a los delitos y útiles a la sociedad". El mismo país expidió en 1857 una luminosa Constitución federal. Sin embargo, en 1860 se hallaban vigentes - previene el manual de práctica criminal de Rafael Roa Bárcena ${ }^{50}$, el Fuero Juzgo, las Partidas, las Leyes de Indias, la Nueva y la Novísima Recopilaciones, esta última muchos años posterior a las determinaciones liberales y muy distanciada de ellas.

Era lenta la andanza de la reforma penal. Sin embargo, la luz en el fondo del túnel anunciaba el feliz advenimiento. En diversos viajes y por hondas razones acudían -como refiere Zaffaroni- "las legislaciones penales importadas de Europa

48 Précis élémentaire de histoire du Droit francais de 1789 a 1814. Révolution, Consulat \& Empire, Paris, Rec. Sirey, 1911, pp. 249-250.

49 «Al lector», p. 207. A partir de aquí citaré fragmentos de la obra de Beccaria. Al hacerlo invocaré entre comillas los epígrafes que figuran en la edición del Fondo de Cultura Económica, trad. de Juan Antonio de las Casas, cit. n. 9 supra, con la adición del preámbulo incorporado por Beccaria en ediciones posteriores a la primera, que menciono en la n. 4, supra. Cito entre comillas el epígrafe bajo el que figura el texto citado y las páginas correspondientes en aquella edición.

50 Cfr. Manual razonado de práctica criminal y médico-legal forense mexicana. México, Imp. de Andrade y Escalante, 1860, pp. 5-8. 
para reemplazar la vieja legislación colonial" ${ }^{\prime 2}$. El Derecho penal de nuestros países -con esfuerzos por constituir, en ocasiones, corrientes nacionales- provino de la codificación y la doctrina europeas, no del intercambio o la influencia recíproca de los propios Estados americanos ${ }^{52}$.

La energía del poder, llevada a su máxima expresión, desencadenó una contrafuerza irresistible que finalmente se impondría: insumisión y reivindicación; energía humanitaria, y en todo caso liberal, que acabaría por ser también democrática. Era el prolongado final de una época y el difícil inicio de otra, un desgarramiento con frontera reticente; ni se muere ni se nace de pronto en las ideas, el orden social, la conciencia colectiva. En términos de justicia penal, esto se traduciría en aboliciones, sustituciones y devoluciones.

Miguel Macedo, caudillo del penalismo mexicano en el tránsito entre los siglos XIX y XX, refirió los datos dominantes en la formación de la nueva sociedad, que concurren a la gestación del orden penal: humanitarismo filantrópico del siglo XVIII; "necesidad de reprimir el notable aumento en la criminalidad que habían producido los cambios políticos" y "exaltación de los odios y pasiones" 53 .

Había disposición para recibir derechos y libertades, pero también violencia criminal, que tenía en vilo al gobierno débil y a su justicia incipiente. "Desenfreno de las costumbres" y "exceso de criminalidad", resume el cronista José María Marroqui ${ }^{4}$. Y todo ello mientras las fuerzas sociales liberadas disputaban el poder y la gloria, utilizando a menudo los métodos penales que habían repudiado en el discurso y disimulado en la conducta.

En el siglo XIX y el primer tercio del XX, la cátedra y los motivos de la normativa americana invocaron a los juristas franceses, y ocasionalmente al propio Beccaria; y luego a los tratadistas españoles e italianos. La corriente beccariana ingresó en todos los casos -o diré, con cautela: en casi todos- de esa era de formación y convicción. Así lo refieren quienes se han ocupado del desarrollo penal en el cono sur, especialmente en Argentina, siempre poderosa en estas disciplinas, y en el extremo norte, México, que también se hizo cargo de las corrientes liberales.

Nos corresponde mirar de nuevo hacia el marqués, salvando un cuarto de milenio. Mirarlo en puntos específicos que pudieran tender el puente hasta los americanos de esta hora. Traer a Beccaria a nuestros días y a nuestra tierra, negándole reposo. $\mathrm{Si}$ el autor y su tratado figuran en la galería de los clásicos, esto no significa que su tema, sus protestas, sus exigencias pertenezcan a la arqueología de los delitos y las

51 «La influencia del pensamiento...». En Varios, Cesare Beccaria and Modern..., cit., p. 527.

52 Cfr. Bustos Ramírez, J. y Valenzuela Bejas, M. Derecho penal latinoamericano comparado. Buenos Aires, Depalma, 1981, t. I, p. 9.

53 Apuntes para la historia..., cit., p. 212.

54 La ciudad de México. México, Jesús Medina Editor, 1969, t. I, pp. 104-105. 
penas, o que se haya confinado en su Continente. Su pensamiento es internacional e intemporal, reitera Mireille Delmas-Marty ${ }^{55}$.

Puedo valerme de la reflexión de Bernaldo de Quirós, que a su traducción agregó un epílogo bajo el rubro "Si volviera Beccaria..." 56 . En los países de América Latina sigue siendo obligada la referencia al marqués, como lo acreditan los estudiosos de su influencia y recepción ${ }^{57}$ : por ejemplo, Nódier Agudelo Betancur ${ }^{58}$, de Colombia; Lolita Aniyar de Castro, de Venezuela; Bernardo Beiderman, de Argentina (quien precisa con acierto: el "ideario de César Beccaria palpita con vibrante actualidad en la política criminal de las naciones latinoamericanas y también (...) en sede internacional latinoamericana" 59 ), aunque a menudo las buenas leyes sean "catálogos de ilusiones" "60; Paulo José da Costa, de Brasil; Eugenio Raúl Zaffaroni, de Argentina, y no pocos mexicanos. Ciertamente, el nombre y las ideas de Beccaria se hallan también, extensamente, en leyes, jurisprudencia y doctrina de otros países ${ }^{61}$.

La lectura de Beccaria, "consoladora y edificante", como la halló Piero Calamandrei ${ }^{62}$, deriva de lo que se ha podido y de lo que aún no se ha conseguido en doscientos cincuenta años; y también de lo que pudiera perderse. En este sentido el tratado reviste actualidad y resulta incitante. Coincide con los trazos radicales de la Declaración Universal de los Derechos Humanos ${ }^{63}$. Por ello, el best seller del marqués está más vivo que nunca, dice Cavanna ${ }^{64}$, y ha sido bastión del garantismo, mucho antes de que se difundiera este concepto, como señala Adela Asúa ${ }^{65}$.

55 Cfr. «Le rayonnement international de la pensée de Cesare Beccaria». En Varios, Cesare Beccaria and Modern..., cit., p. 136.

56 Cfr. «Epílogo». En Beccaria, Tratado de los delitos..., cit., pp. 187 y ss.

57 Cfr. los artículos de autores latinoamericanos en Varios, Cesare Beccaria and Modern..., cit., pp. 401 y ss.

58 Cfr., de este autor, «Estudio preliminar. La actualidad del pensamiento de Beccaria. Qué nos dice Beccaria, hoy, a los juristas de Colombia y de Latinoamérica». En Beccaria, De los delitos y de las penas (edición latinoamericana), Santafé de Bogotá, 1992. Agreguemos: Guzmán Mora, F. y Pradilla Giraldo, A. Cesare Beccaria. Su influencia en el Derecho penal y en la criminología. Medellín (Colombia), Universidad Militar Nueva Granada/Biblioteca Jurídica Dike, 2006.

59 «Vigencia del ideario de Beccaria en la política criminal latinoamericana». En Varios, Cesare Beccaria and Modern..., cit., p. 414.

$60 \quad$ Ibidem, p. 415.

${ }^{61}$ Cfr. en lo que respecta a países europeos, africanos y asiáticos, Varios, Cesare Beccaria and Modern..., cit., pp. 153 y ss.

62 «Prefazione». En Beccaria, C. Dei delitti e delle pene. Firenze, Felice Le Monnier, pp. 19 y 23.

${ }_{63}$ Cfr. Anstee, Margaret J. «Opening Adress». En Varios, Cesare Beccaria and Modern..., cit. p. 10.

${ }^{64}$ Cavanna. «Giudici e leggi nella Milano di Cesare Beccaria». En Jus. Rivista di Scienze Giuridiche, anno XXV, 1, gennaio-aprile 1989.

65 Cfr. «Reivindicación o superación del programa de Beccaria». En Estudios de Deusto, 2a . época, vol. 38/2, fasc. 85, julio-diciembre, 1990, pp. 543-544. 
Para ponderar la actualidad de Beccaria baste con formular algunas preguntas: ¿se retrajo el orden penal a su dimensión inevitable? ¿fue abolida la pena de muerte? ¿desapareció la tortura? ¿corre con fortuna la prevención del delito? ¿los procesos penales son modelo de civilización y justicia? ¿sirve la pena a los fines que pretende? ¿prevalece la igualdad? ¿cesó o aminoró siquiera la impunidad? Cien años después de Beccaria, Francesco Carrara -al refutar el jubiloso optimismo de algún colega, que creía concluida la tarea del marqués- no pudo "reprimir una irónica sonrisa de escepticismo ante esa supuesta terminación de la lucha"; no es posible "deponer las armas" ${ }^{66}$. Tampoco ahora.

Veamos ciertas resonancias beccarianas en nuestra América. Aquí nos abastecemos de dos fuentes, que reciben y esparcen la mejor doctrina. Una fuente, la interna, recogida en el orden constitucional, cada vez más abierto a los derechos y las libertades, al paso que avanza la democracia, como dijo Giovanni Spadolini en un homenaje a Beccaria ${ }^{67}$ : constitucionalismo real, no apenas nominal. Otra fuente, la externa, últimamente internalizada: el Derecho internacional de los derechos humanos, que asciende al bloque de constitucionalidad -a partir de la doctrina francesa- en varios Estados de América Latina.

La normativa interamericana se integra con varios instrumentos y actos derivados: Declaración Americana de Derechos y Deberes del Hombre -la primera en el mundo, en 1948, seis meses antes de la universal-, la Convención o Pacto de San José, algunos protocolos, varias convenciones especializadas y un sinnúmero de actos con el mismo signo: estatutos, reglamentos, opiniones, sentencias, recomendaciones, relatorías.

El impulso democrático latinoamericano tiene, a su turno, doble vena: la democrática formal y la democrática sustantiva. En esta segunda orientación -la más característica en este Continente, pese a incontables avatares, o quizás por ellostambién enlaza nuestra América con el hombre que propone consultar "el corazón humano" para encontrar los principios fundamentales del verdadero derecho" de castigar $^{68}$; y que enjuicia el origen de leyes hechas por "hombres ricos y poderosos, que no se han dignado ni aun visitar las miserables chozas de los pobres" ${ }^{\prime 69}$. Algunos tratadistas latinoamericanos ponen énfasis en la conexión entre las ideas de Beccaria y una avanzada concepción democrática social ${ }^{70}$.

66 «Conveniencia de una revista científica independiente de la jurisprudencia penal». En Opúsculos de Derecho criminal. Trad. José J. Ortega Torres y Jorge Guerrero, Bogotá, Ed., Temis, 1976, vol. IV, p. 272.

67 «Opening Adress». En Varios, Cesare Beccaria and Modern..., cit., p. 20.

68 «Origen de las penas», cit, p. 216.

69 «De la pena de muerte», cit., p. 279.

70 Cfr. Aniyar de Castro, L. «Rasgando el velo de la política criminal en América Latina, o el rescate de Cesare Beccaria para la nueva criminología». En Varios, Cesare Beccaria and Modern..., cit., pp. 404 y ss. 
Las resonancias de las que pretendo ocuparme tienen que ver con las piezas maestras del alegato beccariano, que hizo luz sobre las decisiones políticas fundamentales de la justicia penal, sus selecciones básicas: ¿qué son los delitos? ¿quién es delincuente? ¿cuáles son las consecuencias del delito? ¿cómo se investiga, juzga y sentencia? ¿cómo se ejecuta? ${ }^{71}$ Hubo respuesta para cada cuestión en De los delitos y las penas, como la hubo, paulatina, en el universo americano que desanudaba el lazo con la metrópoli y ensayaba sus pasos republicanos.

En ese catálogo de cuestiones hay un asunto de previo y especial pronunciamiento: ¿hasta dónde debe llegar el sistema penal? ¿cuáles son sus fronteras, cuyo traspaso conduce al abismo? ¿dónde deposita sus mandamientos: en la voluntad general o en el "inmenso arbitrio", signo rector del antiguo régimen, en palabras de Boitard $^{72}$ ? Todo esto discurrió en el opúsculo del marqués y se localiza en el orden constitucional de América.

El carácter de ese sistema como último recurso pugna con el redoble de la justicia penal. Aquel designio custodia el lindero entre la tiranía y la libertad. Recordemos palabras de Beccaria: "en caso de haber una exacta y universal escala de las penas y de los delitos, tendríamos una común y probable medida de los grados de tiranía y de libertad y del fondo de humanidad, y de malicia, de todas las naciones"73; el desbordamiento del pacto social "es abuso, y no justicia; es hecho, no derecho"74; en la escala de los desórdenes "están comprendidas todas las acciones opuestas al bien público, que se llaman delitos"75. El marqués se atiene el marqués a los delitos "que provienen de la naturaleza humana y del pacto social"76; su medida es el "daño hecho a la sociedad" "77; "cada ciudadano debe saber cuándo es reo y cuándo es inocente" "78; la ley es "el estable monumento del pacto social"79.

El principio crucial nullum crimen nulla poena sine lege aparece en las constituciones y en las leyes de los Estados americanos. En torno gira el aparato punitivo, aunque esto no es garantía de que los tipos y las sanciones legales sean también legítimos. La formulación de tipos debe atenerse a la tutela de bienes jurídicos acogidos por la ley fundamental de la sociedad democrática, dice la doctrina mayo-

71 Cfr. García Ramírez, S. «Panorama de la justicia penal». En Varios, La ciencia del Derecho durante el siglo $X X$, México, Instituto de Investigaciones Jurídicas, Universidad Nacional Autónoma de México, 1998, pp. 718 y ss.

72 Lecons de Droit criminel contenant l'explication compléte des Codes pénal et d'Instruction criminelle, rev. par Faustin Hélie, Paris, A. Cotillon et Cie., Libraires du Conseil d' 'Etat, 1880, p. 2.

73 «Proporción entre los delitos y las penas», p. 226.

74 «Derecho de castigar», p. 218.

75 «Proporción entre los delitos y las penas», p. 226.

76 «De un género particular de delitos», p. 311.

77 «División de los delitos», p. 230.

78 «De la tranquilidad pública», p. 237.

79 «Oscuridad de las leyes», p. 224. 
ritaria de América Latina, que acoge un principio establecido: no utilizar "la afilada espada del Derecho penal cuando otras medidas de política social puedan proteger igualmente o incluso con más eficacia un determinado bien jurídico"80.

El legalismo beccariano obliga a revisar la función del juzgador -fuente del viejo Derecho punitivo ${ }^{81}$ - y el alcance de la interpretación judicial. Compete al magistrado declarar que un ciudadano ha violado el pacto. Pero debe hacerlo a través de "meras aserciones o negativas de hechos particulares" un hecho" 83 . En efecto, ¿quién debe interpretar la ley: "el depositario de las actuales voluntades de todos, o el juez, cuyo oficio es sólo examinar si tal hombre ha hecho o no una acción contraria a las leyes" ${ }^{4}$ ? No puede -sería "peligroso" - "consultar el espíritu de la ley" ${ }^{\prime 85}$.

En estos años decayó el apotegma que hacía del juez, en expresión de Montesquieu, "boca que pronuncia las palabras de la ley" ${ }^{\prime 6}$. El juzgador ha "destronado" al legislador, dice Francisco Rubio Llorente ${ }^{87}$. Pero es preciso destacar que el juez es "garante" de los derechos del enjuiciado ${ }^{88}$ y para ello ejerce la interpretación "pro persona", que suele ser "pro reo". Así se desprende del nuevo constitucionalismo latinoamericano y, por supuesto, de la jurisprudencia interamericana ${ }^{89}$.

Esa jurisprudencia acoge al derecho penal mínimo, un orden "condicionado y limitado (que) corresponde no sólo al máximo grado de tutela de las libertades de los ciudadanos respecto del arbitrio punitivo, sino también a un ideal de racionalidad y de certeza" 90 . En el tribunal interamericano se le invoca por su nombre y con su figura $^{91}$. Asimismo, la Corte se ocupa en establecer el sentido material y formal de

80 Ferrajoli, L. Derecho y razón..., p. 104.

81 "La antigua Francia -refiere René Garraud- tuvo un código de procedimiento civil y un código de procedimiento penal, pero nunca contó con un código penal ni con nada que se le asemejara". Traité Théorique et Pratique du Droit Pénal Francais. Paris, Librairie de la Société du Recueil Sirey, 1913, t. I, p. 138.

82 «Consecuencias», p. 219.

83 «Indicios y formas de juicios», p. 242.

84 «Interpretación de las leyes», p. 220.

85 Ibidem., p. 221.

86 Del espiritu de las leyes. Trad. Nicolás Estévanez. México, Ed. Porrúa, 4ª ed., 1980, p. 108.

87 «Seis tesis sobre la jurisdicción constitucional en Europa». En La forma del poder (Estudios sobre la Constitución). Madrid, Centro de Estudios Constitucionales, 1993, p. 606.

88 Cfr. Varios, La justicia como garante de los derechos humanos: la independencia del juez. San José, Costa Rica, Unión Europea/Instituto Latinoamericano de Naciones Unidas para la Prevención del Delito y el Tratamiento del Delincuente (ILANUD), 1996.

89 Cfr. Caso Bayarri vs. Argentina. Excepción preliminar, fondo, reparaciones y costas. Sentencia del 30 de octubre de 2008, párr. 67.

$90 \quad$ Ferrajoli, L. Derecho y razón..., cit., p. 104.

91 Cfr. mis votos particulares en los casos De la Cruz Flores vs. Perú, sentencia del 18 de noviembre de 2004, párr. 4, y Kimel vs. Argentina, sentencia del 2 de mayo de 2008, párr. 17. En este último 
la ley, para asegurar su título de legitimidad. E insiste en la acuciosa formulación de tipos penales. Así se declara en opiniones consultivas y sentencias de la Corte Interamericana ${ }^{92}$, que además ordenan la tipificación de violaciones graves ${ }^{93}$, rechazan la de conductas justificadas ${ }^{94}$ y disponen la proporcionalidad de las penas ${ }^{95}$.

Beccaria repudió ciertas incriminaciones en boga: casos de lesa majestad ${ }^{96}$, pecado ${ }^{97}$, brujería -"un género de delitos que ha cubierto la Europa de sangre humana" ${ }^{98}$-, suicidio ${ }^{99}$, adulterio ${ }^{100}$, entre otras, y su acompañante del camino: deudas civiles ${ }^{101}$. Ayudó a despejar el campo. Y pugnó contra la incriminación del pensamiento, flagelo de su tiempo, con prolongaciones en el nuestro: a la intención, "parte (...) libre del hombre, no alcanza el imperio de las leyes humanas"102.

Estos límites a la tipificación penal han sido observados generalmente $-\mathrm{y}$ lo siguen siendo- por la legislación americana, que en ocasiones, sin embargo, anticipa la punición: así ocurre cuando ésta se adelanta a través de la conspiracy desplegada en la batalla contra el crimen organizado. El péndulo americano no ha dejado de moverse: ora criminalizando, ora desincriminando. Los vientos encontrados recogen, a menudo, el pánico social.

caso señalé: "la Corte ha destacado la compatibilidad entre el llamado derecho penal mínimo y los valores y principios de la democracia, contemplados desde la perspectiva penal. El empleo del sistema de delitos - por incriminación de las conductas- y los castigos - por penalización de sus autores- contribuye a establecer la distancia entre la democracia y la tiranía, que siempre acecha. La desmesura penal vulnera el código jurídico y el sustento político de la sociedad democrática".

92 "En la elaboración de los tipos penales se debe tener presente el principio de legalidad penal, es decir, una clara definición de la conducta incriminada, que fije sus elementos y permita deslindarla de comportamientos no punibles o conductas ilícitas sancionables con medidas no penales. La ambigüedad en la formulación de los tipos penales genera dudas y abre el campo al arbitrio de la autoridad, particularmente indeseable cuando se trata de establecer la responsabilidad penal de los individuos y sancionarla con penas que afectan severamente bienes fundamentales, como la vida o la libertad". Caso Cantoral Benavides vs. Perú. Fondo. Sentencia del 18 de agosto de 2000, párr.157.

93 Cfr. Caso Goiburú y otros vs. Paraguay. Fondo, reparaciones y costas. Sentencia del 22 de septiembre de 2006, párr. 92.

94 Cfr. Caso de la Cruz Flores vs. Perú. Fondo, reparaciones y costas. Sentencia del 18 de noviembre de 2004, párr. 94.

95 Sobre proporcionalidad de las penas, cfr., por ejemplo, Caso Manuel Cepeda Vargas vs. Colombia. Excepciones preliminares, Fondo, reparaciones y costas. Sentencia del 26 de mayo de 2010, párr. 150; y Caso Vargas Areco vs. Paraguay. Fondo, reparaciones y costas. Sentencia del 26 de septiembre de 2006, párr. 108.

96 «División de los delitos», p. 231.

97 «Errores en la graduación de las penas», p. 229.

98 «De un género particular de delitos», p. 310.

99 «Suicidio», pp. 294-299.

100 «Delitos de prueba difícil», pp. 291-293.

101 «De los deudores», pp. 301-303.

102 «Suicidio», p. 296. 
El marqués examina la razón, el sentido y el alcance de la pena, clave de la potestad penal y de la sujeción del ciudadano. Legalidad y utilidad son sus hilos conductores. ¿Cuál es el fin de las penas? "Impedir al reo causar nuevos daños (...) y retraer a los demás de la comisión de otros iguales" ${ }^{\prime 103}$. Esta orientación no constituye, por supuesto, salvoconducto de la desmesura. Se detiene y establece linderos inamovibles: los del derecho penal mínimo: la atrocidad es "contraria a aquellas virtudes benéficas que son efecto de una razón iluminada" 104 .

Al imponer las penas debe guardarse la proporción que logra "una impresión más eficaz y más durable sobre los ánimos de los hombres, y la menos dolorosa sobre el cuerpo del reo" ${ }^{105}$. Basta que el mal de la pena exceda al bien que nace del delito; "todo lo demás es superfluo y, por tanto, tiránico"106. En fin de cuentas, la medida beccariana de la pena queda bien establecida en el "teorema general" que cierra su obra: "para que toda pena no sea violencia de uno o de muchos contra un particular ciudadano, debe esencialmente ser (...) necesaria, la más pequeña de las posibles en las circunstancias actuales, proporcionada a los delitos"107. Son palabras que acogería el artículo 15 de la Constitución francesa de $1793^{108}$.

La igualdad ante la ley tiene expresiones propias cuando se trata de la norma penal, la que mayormente utiliza el monopolio weberiano de la violencia, ante hombres que comparecen en pie de absoluta desigualdad. Beccaria se pregunta: “¿Cuáles serán, pues, las penas de los nobles, cuyos privilegios forman gran parte de las leyes de las naciones?" 109 No se aventura en el examen de la injusticia social; se limita a la legal y resuelve, invocando la doctrina del contrato, que las penas deben "ser las mismas para el primero que para el último ciudadano" ${ }^{110}$.

En América Latina la desigualdad es un patrón social inveterado. La denunció Humboldt ${ }^{111}$, al paso que Tocqueville exaltó el espíritu igualitario en el origen de

103 «Fin de las penas», p. 238

104 «Consecuencias», p. 219.

105 «Fin de las penas», p. 238.

106 «Dulzura de las penas», p. 272.

107 «Conclusión», p. 323. Bentham reconoce que Montesquieu y Beccaria se refirieron a esta cuestión y que el segundo "ha insistido sobre la importancia de ella; pero ambos la han más bien recomendado que explicado". En seguida, el tratadista inglés se explaya en un capítulo acerca «De la proporción entre los delitos y las penas». Tratados de legislación civil y penal, obra extractada por Esteban Dumont, trad. Ramón Salas, Madrid, Editora Nacional, 1981, pp. 297 y ss.

108 "La ley sólo debe aplicar penas estrictas y evidentemente necesarias; éstas deben ser además proporcionales al delito y útiles a la sociedad".

109 «Penas de los nobles», p. 260.

110 Ibidem., p. 261.

111 Cfr. Ensayo político sobre el Reino de la Nueva España. México, Ed. Porrúa, 3ª ed., 1978, pp. 83 y ss. 
la sociedad norteamericana ${ }^{112}$. Si la justicia penal es desigualitaria, lo es en mayor medida donde existen abismos tan profundos entre la pobreza y la riqueza. Las 100 Reglas de Brasilia, sobre el acceso de los vulnerables a la justicia, reservan un capítulo a los pobres; para ellos el acceso debe remontar montañas ${ }^{113}$. Y la pobreza es una condición transversal que cruza todas las formas de vulnerabilidad.

La jurisprudencia interamericana pretende aliviar las distancias con medidas de alivio y moderación de exigencias procesales, que evocan la enseñanza de Couture acerca de la igualdad por compensación y las reflexiones de Roberto Berizonce sobre las tutelas procesales diferenciadas ${ }^{114}$. He aquí un problema lacerante que no se ha resuelto en nuestra América - $i$ y dónde sí? - y que se proyecta sobre el régimen de las penas.

El discurso de moderación punitiva, sujeto a un finalismo controvertido, prevalece en las constituciones de estos países americanos y en su acompañamiento secundario. Consagran el proyecto recuperador -que no debiera confundirse con un designio invasor- cuando hablan de readaptación o reinserción. Pero hay disposiciones iracundas, o peor aún, desesperadas, que extreman la privación penal de la libertad: si nos desembarazamos de la prisión perpetua, es a cambio de elevar desmesuradamente la punibilidad: por ejemplo, 140 años de prisión ${ }^{115}$, privación vitalicia de la libertad.

Más allá del debate sobre aquellos conceptos, esto ha servido para que aquella jurisprudencia cuestione la extrema severidad de los castigos y recuerde a los Estados -a través de estándares empeñosamente procurados- el contenido y el alcance de su misión.

En el corazón del pensamiento beccariano está la pena de muerte, asunto radical del orden penal, sostuvo Antonio Beristáin ${ }^{116}$. En América el Estado solía -y no ha perdido la costumbre- aplicar la muerte por doble cuerda: ejecución extrajudicial y privación penal de la vida, solemnemente ejecutada. En suma: pena formal y pena informal. Su crónica se halla en todas las historias americanas. Se ha dicho, inclusive - expresión de Marino Barbero Santos-, que la vergüenza de los Estados que se niegan a admitir la pena formal de muerte, conduce a esta forma criminal de aplicarla ${ }^{117}$.

112 Cfr. La democracia en América. Trad. Luis R. Cuéllar. México, Fondo de Cultura Económica, 2a . ed., 1963 , pp. 67 y ss.

113 Cfr. 100 Reglas de Brasilia sobre acceso a la justicia de las personas en condiciones de vulnerabilidad. XIV Cumbre Judicial Iberoamericana, Brasilia, 2007, reglas 15-16.

114 Cfr. Tutelas procesales diferenciadas. Buenos Aires, 2009, pp. 15 y ss.

115 Así, en supuestos agravados de secuestro, conforme al artículo 11 de la Ley General para Prevenir y Sancionar Delitos en Materia de Secuestro, reglamentaria de la fracción XXI del artículo 73 constitucional, según reforma publicada en el Diario Oficial de la Federación, de México, el 28 de julio de 2014.

116 «Pro y contra la pena de muerte en la política criminal contemporánea». En Cuestiones penales y criminológicas. Reus, S. A., Madrid, 1979, p. 579.

117 «Cesare Beccaria, la pena de muerte...». En Varios, Cesare Beccaria and Modern..., cit., p. 73. 
Beccaria, en medio del "silencio de las conciencias" - escribe Badinter- tuvo la audacia de proponer, con temeridad que se debe ponderar en su circunstancia, la abolición de la pena de muerte ${ }^{118}$. Se ha dicho que fue abolicionista o sólo minimalista ${ }^{119}$, es decir, cauteloso retencionista. Me parece lo primero, y en ello descansa la fortuna que tuvo su discurso. Elevó la voz contra toda pena capital, no sólo contra la muerte exacerbada -que era un dato de ese tiempo, narra Barbero Santos ${ }^{120}$ - y multiplicada en una feria de conminaciones -que alarmó a Montesquieu, asombrado de que en Inglaterra hubiese "ciento sesenta (acciones) que un acto del Parlamento ha declarado crímenes (...) que deben ser castigados con la pena de muerte" 121 . Lector atento de Beccaria, el inglés Bentham proclamó: "Cuanto más se examina la pena de muerte, tanto más justa y racional parece la opinión de Beccaria"122.

Calamandrei asegura que el marqués es el "primer negador absoluto de la legitimidad de la pena de muerte" 123 ; y Badinter lo considera "padre fundador de la moderna doctrina de la abolición" ${ }^{24}$. En esto se esforzó Beccaria: "si demostrase que la pena de muerte no es útil ni es necesaria, habré vencido la causa a favor de la humanidad" "25. Pero no sólo acreditó su inutilidad, sino estableció su ilegitimidad bajo el manto contractualista: "¿quién es aquel que ha dejado a los otros hombres el arbitrio de hacerlo morir?" 126.

En los países americanos, escenario de encono y violencia, el abolicionismo se instaló trabajosamente en el siglo XIX y ganó la batalla en el XX. Los abolicionistas citaron a Montesquieu y a Beccaria, o por lo menos recogieron su sentimiento y su proyecto. Los siguieron, expresa o implícitamente, en medio de las turbulencias de una vida civil erizada de problemas y acosada por el crimen. Los reformadores de la hora temprana -e incluso del tiempo reciente- debían sacar de raíz el prejuicio favorable a la muerte punitiva y revertir el arraigo que había conseguido como herramienta de paz, en manos de tribunales implacables y al cabo de procesos fulminantes, como los seguidos por la Santa Hermandad.

118 Cfr. «L'abolition de la peine de mort...». En Varios, Cesare Beccaria and Modern..., cit., p. 42.

119 Bernaldo de Quirós. «Prólogo» a Beccaria. En Tratado..., cit., p. 41.

120 «Cesare Beccaria, la pena de muerte y la tortura». En Varios, Cesare Beccaria and Modern..., cit., p. 64.

121 Observations de un voyageur anglais su Bicêtre, 1788, cit. en la edición de De los delitos y de las penas, trad. Juan Antonio de las Casas, anotada por Juan Antonio Delval, Alianza Editorial, Madrid, 1982.

122 Tratados de legislación..., op. cit., p. 320. El propio Bentham censuró la forma en que Inglaterra prodigaba la muerte punitiva: "Yo asombraría a los lectores si les expusiera el código penal de una nación célebre por su humanidad y sus luces", que, sin embargo, prodiga "la pena de muerte por los delitos menos graves". Id.

123 En notas a Beccaria, Dei delitti..., cit., p. 251, n. 1.

124 «Beccaria: 1'abolition de la peine...». En Varios, Cesare Beccaria and Modern..., cit., pp. 36-37.

125 «De la pena de muerte», p. 274.

126 Id. 
En México se intentó abolir la muerte punitiva en la Constitución liberal de 1857, adoptada por una asamblea de hombres adelantados. Las condiciones del país se rebelaron y la asamblea retuvo la pena capital de mala gana, a reserva de sustituirla por el sistema penitenciario. En el horizonte se hallaba la opción beccariana por la prisión, relevo de la muerte. No faltó quien dijera -Guillermo Prieto-: ¿por qué hacemos "recaer sobre los reos el descuido de los gobiernos en la mejora de las cárceles"?; "no te doy trabajo ni educación, pero te doy cadenas"127. El sistema penitenciario, que no llegaba, tuvo aquí la misma eficacia dilatoria que la "paz general", condición para que se aboliese la pena capital, anunciada en la Convención revolucionaria de Francia el 14 de Brumario del año IV (5 de septiembre de 1795).

Brasil estuvo a punto de abolir esa pena en el Código Criminal do Imperio, publicado en 1831. A favor del retencionismo gravitó "la existencia de la esclavitud", considera Zaffaroni ${ }^{128}$. Pasaría más de un siglo para que la pena capital desapareciera de la Constitución mexicana, que acompasó su paso al que siguieron otras leyes del Continente. El Código penal de Veracruz, de 1869, obra del magistrado Fernando J. Corona, excluyó la pena de muerte: primera gran exclusión adoptada en el Estado mexicano. En 1871, el Código penal retuvo la pena capital, a despecho de la mayoría de sus redactores: pesaron más la opinión del gobierno y el parecer del presidente de la comisión, que se plegó al "realismo" 129 . México dispuso la exclusión definitiva en $2005^{130}$ : ciento treinta y cinco años después del código de Corona.

Cuando se aprobó la Convención Americana sobre Derechos Humanos -San José, 1969- catorce delegaciones, de las diecinueve que representaban a sus gobiernos, se pronunciaron en favor de la abolición. Sin embargo, no se atrevieron a dar el paso. El mérito quedaría -dijeron en un documento colmado de razones- a un

127 Sobre la deliberación del Congreso Constituyente acerca de la abolición o la retención de la pena de muerte, cfr. García Ramírez, S. El artículo 18 constitucional: prisión preventive, sistema penitenciario, menores infractores. México, Universidad Nacional Autónoma de México, Coordinación de Humanidades, 1967, pp. 45 y ss.

128 «La influencia del pensamiento...». En Varios, Cesare Beccaria and Modern..., cit., p. 442.

129 Cfr. Martínez de Castro, A. «Exposición de motivos» del Código Penal para el Distrito Federal y el Territorio de Baja California y para toda la República para delitos contra la Federación, de 1871. En Leyes penales mexicanas. México, Instituto Nacional de Ciencias Penales, 1979, t. I, pp. 341 y ss. Estimó que podría ser abolida la pena capital y sustituida por la prisión "cuando estén ya en práctica todas las prevenciones que tienen por objeto la corrección moral de los criminales; cuando por su trabajo honesto en la prisión puedan salir de ella instruidos en algún arte u oficio y con un fondo bastante á proporcionarse después los recursos necesarios para subsistir; cuando en las prisiones se los instruya en su religión, en la moral y en las primeras letras; y, por último, cuando nuestras cárceles se conviertan en verdaderas penitenciarías de donde los presos no puedan fugarse, entonces podrá abolirse sin peligro la pena capital. Hacerlo antes sería, á mi juicio, comprometer la seguridad pública, y tal vez reducir á nuestra sociedad al extremo peligroso de hacerse justicia por sí misma, adoptando la bárbara ley de Lynch", pp. 341-342.

130 México abolió la pena de muerte mediante reforma de los artículos 14 y 22 de la Constitución, el 9 de diciembre de 2005 . 
protocolo posterior ${ }^{131}$. Así ocurrió, aquí como en Europa y en el orden mundial. En 1990 llegó el protocolo interamericano.

La Convención Americana de 1969 no suprime de plano la pena capital, pero tiene una orientación marcadamente abolicionista. William Schabas considera -a la luz del tratado y de la práctica- que en América Latina se ha instalado un jus cogens regional contra la pena de muerte ${ }^{132}$. La tendencia de la Convención ha cimentado una sólida jurisprudencia constante de la Corte Interamericana, depositada en una opinión consultiva ${ }^{133}$ y en diversas sentencias ${ }^{134}$. Siembra de restricciones la implantación y la ejecución de la pena capital. A ella se deben, en diversa medida, el retraimiento de Guatemala en este ámbito y la moderación de los países caribeños.

En el Segundo Protocolo Facultativo del Pacto Internacional de Derechos Civiles y Políticos -1989-, destinado a abolir la pena de muerte, de 1989, aparecen quince Estados de América ${ }^{135}$. El protocolo americano, de 1990, tiene en su favor trece Estados, entre ellos un solo caribeño: República Dominicana ${ }^{136}$. Este instrumento sólo autoriza la pena capital por delitos graves de orden militar cometidos en tiempo de guerra. Únicamente dos países han adoptado esta reserva: Chile y Brasil. Otros dos, que retienen la pena de muerte en la ley, se comportan como abolicionistas de facto: Cuba y Guatemala. Ha de tomarse en cuenta, en todo caso, que ni siquiera en el supuesto de persecución de los más graves delitos -como es el terrorismo, frecuentemente perseguido en países americanos- cede el respeto a los derechos humanos: así lo dispone la Convención Interamericana contra el Terrorismo, suscrita en Barbados en $2002^{137}$.

131 Cfr. Conferencia Especializada Interamericana sobre Derechos Humanos, San José, Costa Rica, 7-22 de noviembre de 1969, Actas y documentos, OEA/Ser.K/XVI/1.2, Washington, D.C., 1973, p. 467.

132 Cfr. The Abolition of the Death Penalty in International Law. 3a. ed., Cambridge University Press, 2004, p. 367.

133 Cfr. Restricciones a la pena de muerte (artículos 4.2 y 4.4 Convención Americana sobre Derechos Humanos). Opinión Consultiva OC-3/83 del 8 de septiembre de 1983.

134 Así, las correspondientes a los casos Hilaire, Constantine y Benjamin y otros vs. Trinidad y Tobago. Fondo, reparaciones y costas. Sentencia del 21 de junio de 2002; Raxcacó Reyes vs. Guatemala. Fondo, reparaciones y costas. Sentencia del 15 de septiembre de 2005; Fermín Ramírez vs. Guatemala. Fondo, reparaciones y costas. Sentencia del 20 de junio de 2005; Boyce y otros vs. Barbados. Excepción preliminar, fondo, reparaciones y costas. Sentencia del 20 de noviembre de 2007, y DaCosta Cadogan vs. Barbados. Excepciones preliminares, fondo, reparaciones y costas. Sentencia del 24 de septiembre de 2009.

135 Son (al día último de junio de 2014): Argentina, Bolivia, Brasil, Chile, Colombia, Costa Rica, Ecuador, El Salvador, Honduras, México, Nicaragua, Panamá, Paraguay, Uruguay y Venezuela.

136 Figuran como partes (al día último de junio de 2014): Argentina, Brasil, Chile, Costa Rica, Ecuador, Honduras, México, Nicaragua, Panamá, Paraguay, República Dominicana, Uruguay y Venezuela.

137 Cfr. García Ramírez, S. «The Inter-American Court of Human Rights Perspective on Terrorism». En Varios, Counter-Terrorism. International Law and Practice. Ana María Salinas de Frías, Katja LH Samuel and Nigel D. White (eds.), Oxford University Press, 2012, pp. 789 y ss. 
Los Estados del Caribe con raíz política en la Gran Bretaña estipulan la pena capital; empero, las ejecuciones son infrecuentes. La muerte ha decaído a golpes de presión internacional, corrientes de opinión interna y sentencias de los tres tribunales que ejercen diversa jurisdicción en el área: el Privy Council, la Corte Suprema del Caribe Oriental y la Corte Caribeña de Justicia ${ }^{138}$.

La Organización de las Naciones Unidas ha buscado alternativas prácticas para avanzar en la abolición sin romper lanzas con la retención. Se ha hecho a base de moratorias, que tampoco cuentan con unanimidad de los países americanos. La moratoria de 2010 tiene en su haber veinte votos americanos ${ }^{139}$; doce en contra: nuevamente Estados Unidos y once caribeños ${ }^{140}$, y dos abstenciones ${ }^{141}$. La de 2012 recabó el voto favorable de veinte Estados del área ${ }^{142}$; el desfavorable de nueve Estados Unidos y ocho caribeños ${ }^{143}$ y la abstención de dos ${ }^{144}$.

Plantado contra la muerte, Beccaria optó por la privación de libertad-Aquélla no es el "freno más fuerte contra los delitos (...) sino el largo y dilatado ejemplo de un hombre que, convertido en bestia de servicio y privado de libertad, recompensa con sus fatigas a la sociedad que ha ofendido"145. El marqués pensaba en la prisión punitiva, invención del Derecho canónico -dijo Ruíz Funes ${ }^{146}$ - en la frontera entre el Medievo y el Renacimiento. Los americanos, como todos, la promovieron con demasiado optimismo. Sucedió y sucede en América, escenario de los excesos y las frustraciones de la prisión, ya señalados en el tiempo en que aparece la obra del marqués, tanto por Howard como por otros observadores y tratadistas: Bentham -autor del famoso "Panóptico" - hizo notar que "las prisiones, si se exceptúan algunas poquísimas, encierran todo lo más eficaz que podría hallarse para infestar el cuerpo y el alma"147.

138 Sobre la situación de la pena de muerte en el Caribe, cfr. García Ramírez, S. «Consideraciones sobre la pena de muerte en la jurisprudencia de la Corte Interamericana y en países del Caribe», 2014 (en prensa).

139 Argentina, Bolivia, Brasil, Canadá, Chile, Colombia, Costa Rica, República Dominicana, Ecuador, El Salvador, Guatemala, Haití, Honduras, México, Nicaragua, Panamá. Paraguay, Perú, Uruguay y Venezuela.

140 Antigua y Barbuda, Bahamas, Barbados, Belice, Estados Unidos, Granada, Guyana, Jamaica, Saint Kitts y Nevis, Santa Lucía, San Vicente y Las Granadinas, y Trinidad y Tobago.

141 Cuba y Dominica.

142 Argentina, Bolivia, Brasil, Canadá, Chile, Colombia, Costa Rica, República Dominicana, Ecuador, El Salvador, Guatemala, Haití, Honduras, México, Nicaragua, Panamá, Paraguay, Perú, Uruguay y Venezuela.

143 Barbados, Belice, Estados Unidos, Granada, Guyana, Jamaica, Santa Lucía, San Vicente, y las Granadinas y Trinidad y Tobago.

144 Cuba y Surinam.

145 «De la pena de muerte», p. 276.

146 Cfr. La crisis de la prisión. La Habana, Jesús Montero editor, 1949, p. 76.

147 Tratados de legislación..., cit., p. 318. 
La jurisprudencia de la Corte Interamericana ha insistido, con escaso éxito, en la necesidad de moderar la privación de libertad y mejorar, de veras, el estado de las prisiones. En varias sentencias describe el desastre carcelario que campea en buena parte del Continente: los juicios sobre el Retén de Catia ${ }^{148}$ y el Penal Castro y Castro $^{149}$ son ejemplos de esta realidad abismal, que jamás quiso Beccaria, contra la que Howard pugnó, que se aparta de la exigencia interamericana a propósito del fin esencial de la privación de libertad: "reforma y readaptación social" 150 , y se aleja, mediando un abismo, del discurso constitucional y político del mundo americano, pero no de su experiencia arraigada y cotidiana. La Comisión Interamericana ha expedido un documento de principios y buenas prácticas ${ }^{151}$, y la jurisprudencia invoca los estándares internacionales, entre ellos los europeos, y fija sus propias reglas pertinentes ${ }^{152}$, yendo más allá del principio de subsidiariedad.

Otra cuestión fue el encarcelamiento preventivo, pena que se anticipa a la condena y que en esta paradoja aclimata su injusticia. No habría mayor agravio para la presunción de inocencia. De ahí la petición beccariana de emplearla con infinita cautela. Beccaria dedica pasajes del opúsculo a la prisión cautelar: "La prisión es una pena que por necesidad debe, a diferencia de las demás, preceder a la declaración del delito"153, pero sólo "en cuanto la necesidad obliga"; "esta custodia, siendo por naturaleza penosa debe durar el menos tiempo posible y debe ser lo menos dura que se pueda"154.

El sistema procesal tradicionalmente adoptado en América Latina -que hoy se retrae ante una reforma que podría alcanzar buenos resultados- favoreció el empleo de la preventiva. Lo ha investigado el Instituto Latinoamericano para la Prevención del Delito y el Tratamiento del Delincuente ${ }^{155}$. A ese uso exuberante se debe el número excesivo de presos sin condena que colma las prisiones y maltrata

148 CorteIDH, Caso Montero Aranguren y otros (Retén de Catia) vs. Venezuela. Fondo, reparaciones y costas. Sentencia del 5 de julio de 2006.

149 CorteIDH, Caso del Penal Miguel Castro Castro vs. Perú, Fondo, reparaciones y costas. Sentencia del 25 de noviembre de 2006.

150 Ibidem, párr. 314.

151 Principios y Buenas Prácticas sobre la Protección de las Personas Privadas de Libertad en las Américas, Res. 1/108 de la Comisión Interamericana de Derechos Humanos, de 13 de marzo de 2008.

152 Cfr. Caso Pacheco Teruel y otros vs Honduras. Fondo, reparaciones y costas. Sentencia del $27 \mathrm{de}$ abril de 2012, párr.. 67.

153 «De la prisión», p. 284.

154 «Prontitud de la pena», p. 257.

155 Cfr. Carranza, E., Houed, M., Mora, L. P., y Zaffaroni, E. R. El preso sin condena en América Latina y el Caribe. San José, Costa Rica, Instituto Latinoamericano de las Naciones Unidas para la Prevención del Delito y Tratamiento del Delincuente, 1983, donde se indica que en América Latina los presos sin condena constituyen en promedio ponderado el $68.47 \%$ tomando en cuenta el total de los presos de cada país, p. 25. 
a los cautivos. La jurisprudencia interamericana marcha en la línea beccariana, con las aportaciones de nuestro tiempo: limita su aplicabilidad, exactamente como lo hizo Beccaria: "para impedir la fuga o para que no se oculten las pruebas de los delitos" 156 . Por ello Carrara subrayó: la preventiva "resulta intolerable y es un acto de verdadera tiranía cuando no existen las razones expuestas"157.

Y la misma jurisprudencia de la Corte de San José reduce la aplicación de la medida cautelar a través de garantías judiciales y principios exigentes: legalidad, presunción de inocencia, pertinencia, necesidad, proporcionalidad, revocabilidad, brevedad $^{158}$. Buena parte de la doctrina interamericana sobre las restricciones a los derechos humanos se eleva sobre el examen crítico de la restricción cautelar de la libertad. Pero la limitación no siempre ha sido seguida por todas las leyes americanas.

El marqués revisa otras penas. Rechaza la confiscación ${ }^{159}$-un "resto de barbarie (que) subsiste todavía en la jurisprudencia de casi todas las naciones de Europa", denuncia Bentham ${ }^{160}$, , la infamia ${ }^{161}$, el destierro ${ }^{162}$, actualmente proscritos por la legislación penal americana, inclusive desde el peldaño constitucional.

Beccaria dedicó a la tortura uno de los capítulos más celebrados y certeros de su opúsculo evangelizador. Arremetió contra el tormento recogido en las ideas y en la práctica judicial, que actuaba, como la pena, sobre el cuerpo del inculpado en procuración de la verdad o anticipación del castigo. Fue parte del ritual político en el que se manifiesta ceremoniosamente el poder, sostiene Foucault ${ }^{163}$. La tortura giudiziaria se formalizó en un Tractatus de tormentis, del siglo XIII ${ }^{164}$.

Beccaria asumió la tendencia que florecía en su tiempo, e impugnó frontalmente la tortura, alentado por Pedro Verri. "Una crueldad consagrada por el uso entre la mayor parte de las naciones es la tortura del reo mientras se forma el proceso"165; "medio seguro de absolver a los robustos malvados y condenar los flacos inocentes" "166; "las

156 «Prontitud de la pena», p. 258.

157 «Inmoralidad del encarcelamiento preventivo». En Opúsculos..., cit., vol. IV, p. 226.

158 Cfr. Caso López Álvarez vs. Honduras. Fondo, reparaciones y costas, Sentencia del 1 de febrero de 2006, párrs. 67. Cfr., asimismo, Bigliani, Paola, y Bovino, Alberto, Encarcelamiento preventivo y estándares del sistema interamericano, Presentación de Stella Maris Martínez. Buenos Aires, Defensoría Federal de la Nación/Ed. del Puerto, 2008, esp. pp. 31-37. «Destierros y confiscaciones», p. 267.

160 Tratados de legislación..., cit., p. 303.

161 «Infamia», pp. 263-264.

162 «Destierros y confiscaciones», p. 267.

163 Cfr. Vigilar y castigar. Trad. Aurelio Garzón del Camino. México, Siglo XXI Editores, 1976, p. 52.

164 Cfr. Tomás y Valiente, F. La tortura en España. Estudios históricos. Barcelona, Ed. Ariel, 1973, pp. 106 y ss. y 212 y ss.

165 «Del tormento», p. 246.

166 Ibidem, p. 247. 
leyes te atormentan -acusó, delatando el oscuro prejuicio que latía en el tormentoporque eres reo, porque puedes ser reo, porque yo quiero que tú seas reo"167.

En este caso la discusión, que la hubo, no llegó muy lejos; los motivos del pragmatismo naufragaron frente a las razones de la ley. La formal supresión de la tortura progresó en América, donde proliferaba para intimidar a los "enemigos", indagar los delitos o purgar las culpas. En el alba americana, cuando se vieron frente a frente el pasado que se retraía y el futuro que despuntaba, persistió el tormento, por una parte, y se pugnó por suprimirlo, por la otra. De ahí que fuera tema de planes y disposiciones de alborada en los países insurgentes.

La supresión de la tortura figuró junto a los requerimientos de libertad política. El punto 32 de un documento prócer, los "Elementos constitucionales de Rayón", de 1811, declaran: "Queda proscrita como bárbara la tortura, sin que pueda lo contrario aún admitirse a discusión". He ahí una cláusula pétrea. Tuvo su correspondencia en el Decreto LXI del 22 de abril de 1811, expedido por las Cortes de Cádiz.

Los "Sentimientos de la Nación", proclama del insurgente Morelos, sostuvo "que en la nueva legislación no se admitirá la tortura". Y lo mismo dijeron la Constitución española de 1812 ("No se usará nunca del tormento ni de los apremios": artículo 303); y la mexicana de 1824 ("Ninguna autoridad aplicará clase alguna de tormentos, sea cual fuere la naturaleza y estado del proceso": artículo 149).

Viejos tratadistas americanos del siglo XIX se limitan a citar, con absoluta adhesión, párrafos de Beccaria y Voltaire para repudiar el tormento ${ }^{168}$. Ha llovido copiosamente: ahora el tormento se halla proscrito en todo tiempo y lugar, aunque las referencias de los observadores advierten sobre una práctica persistente en el ámbito americano, con distinta intensidad.

En el Derecho interamericano de los derechos humanos hay que mencionar la Convención de 1969, la mundial contra la tortura y otros tratos crueles, inhumanos o degradantes, de 1984, y la Interamericana para prevenir y sancionar la tortura, de 1985. Veintitrés Estados americanos, inclusive los Estados Unidos y Canadá1 ${ }^{169}$, son partes en la segunda; y veinte en la tercera ${ }^{170}$, entre los que no figuran estos países septentrionales, pudiendo aparecer, porque se trata de un tratado independiente del Pacto de San José, no de un protocolo.

167 Ibidem, p. 253.

168 Cfr. Valdés, R. F. Diccionario de jurisprudencia criminal mexicana; común, militar y naval; mercantil y canónica. México, Tipografía de V. G. Torres, 1850, pp. 307-308.

169 Hasta el final de junio de 2014: Argentina, Belice, Bolivia, Brasil, Canadá, Chile, Colombia, Costa Rica, Cuba, República Dominicana, Ecuador, El Salvador, Guatemala, Haití, Honduras, México, Nicaragua, Panamá, Paraguay, Perú, Estados Unidos, Uruguay y Venezuela.

170 Al final de junio de 2014: Argentina, Bolivia, Brasil, Chile, Colombia, Costa Rica, Ecuador, El Salvador, Guatemala, Haití, Honduras, México, Nicaragua, Panamá, Paraguay, Perú, República Dominicana, Suriname, Uruguay y Venezuela. 
La jurisprudencia interamericana se ha ocupado de la tortura en un buen número de sentencias, que la condenan en su doble versión de física y psicológica. Contraviene el jus $\operatorname{cogens}{ }^{171}$. Es tema reiterado, junto con la desaparición forzada y la ejecución extrajudicial. Triple manifestación de la violencia extrema, que no ceja.

Para combatir la impunidad, la Corte de San José ha extraído del tratado interamericano sobre la tortura los lineamientos para la investigación de las violaciones graves de los derechos humanos: estándares que llegan a ser vinculantes en la medida en que ese Tribunal los incluye en sus sentencias. Por ello el Protocolo de Estambul es mucho más que una recomendación incorporada en el soft-law, como guía para médicos y criminalistas ${ }^{172}$.

Beccaria denuncia la demora que enrarece la justicia. "La prontitud de la pena (...) es uno de los principales frenos de los delitos"173. La pena debe ser "pronta", señala en el teorema final de su opúsculo. En el catálogo constitucional americano figura la justicia pronta y expedita. También se localiza en la Convención Americana, a título de garantía judicial en relación con el "plazo razonable", concepto al que ha hecho buenas aportaciones la jurisprudencia de San José ${ }^{174}$.

Nuestro autor, que impugna la criminalización frondosa y las penas desorbitadas, se pronuncia por la certeza del castigo y combate la impunidad, cuya eficacia criminógena había denunciado. Retoma, también por esta vía, la racionalidad de las penas. "La certidumbre del castigo, aunque moderado, hará siempre mayor impresión que el temor de otro más terrible, unido con la esperanza de la impunidad" 175 ; "la persuasión de no encontrar un palmo de tierra que perdonase a los verdaderos delitos sería un medio eficacísimo de evitarlos" ${ }^{\text {176 }}$. De ahí que vea con malos ojos el asilo ${ }^{177}$-pero no el político, bienhechor en América-, el perdón y el indulto ${ }^{178}$. En esto le secunda Bentham: "Haced buenas leyes y no creéis una varita de virtudes que tenga el poder de anularlas. Si la pena es necesaria no se debe perdonar; si no es necesaria no debe pronunciarse" 179 .

Estos asuntos también gravitan sobre la práctica penal en América Latina. En algunos Estados las cifras de impunidad son dominantes: cifra negra y crímenes sin

171 Cfr. Caso de los Hermanos Gómez Paquiyauri vs. Perú. Fondo, reparaciones y costas. Sentencia de 8 de julio de 2004, párrs. 100 y 103.

172 Cfr., por ejemplo, Caso Gutiérrez Soler vs. Colombia. Fondo, reparaciones y costas. Sentencia del 12 de septiembre de 2005, párr. 100.

173 «Procesos y prescripciones», p. 287.

174 Cfr. García Ramírez, S. El debido proceso. Criterios de la jurisprudencia interamericana. México, Ed. Porrúa, $1^{\text {a }}$. ed., $1^{\text {a }}$ reimp., 2014, pp. 65 y ss.

175 «Dulzura de las penas», p. 271.

176 «Asilos», p. 304.

177 Id.

178 «Del perdón», pp. 321-322.

179 Tratados de legislación..., cit., p. 322. 
castigo. El combate a la impunidad es un tema tradicional de la Corte Interamericana, que la define como "la falta en su conjunto de investigación, persecución, captura, enjuiciamiento y condena de los responsables de las violaciones de los derechos protegidos por la Convención Americana"180.

Hay una expresión de impunidad especialmente reprobada por la legislación y la normativa internacional: las violaciones graves de los derechos humanos. La jurisprudencia reclama justicia en esta materia, y para ello cuestiona instituciones y figuras que la alejan en el marco de procesos de pacificación, sentencias internas que la evitan so capa de cosa juzgada y decisiones populares que la enrarecen. Hay muestras rotundas de la reclamación de justicia: son elocuentes los casos Barrios Altos ${ }^{181}$, de Perú, que desechó las autoamnistías a modo, Gomes Lund (Guerrilha do Araguaia) ${ }^{182}$, de Brasil, y Gelman, de Uruguay, con sus implicaciones a propósito de los límites que detienen la voluntad popular ante la frontera de los derechos humanos ${ }^{183}$.

Otra victoria del combate frontal a la impunidad que postula Beccaria, asociado al reproche dirigido al asilo que guarece al criminal, se halla en el nuevo Derecho internacional penal finalmente concretado en el Estatuto de Roma, del que forman parte veintiocho Estados americanos ${ }^{184}$.

Hoy se carga el acento sobre la garantía colectiva de los derechos humanos y el deber de colaboración entre los Estados. Ejemplo: las condenas interamericanas sobre la operación Cóndor ${ }^{185}$, en las que se invoca la garantía colectiva que obliga a los países del área.

Si son relevantes los capítulos beccarianos sobre la pena capital y la tortura, no lo son menos - dice Mario Pisani- las páginas que dedica al proceso: "el arco que se interpone

180 Cfr. Caso de la "Panel Blanca" (Paniagua Morales y otros) vs. Guatemala. Fondo. Sentencia del 8 de marzo de 1998, párr. 173. Entre sentencias recientes, que acogen esta jurisprudencia constante, cfr. por ejemplo Caso Almonacid Arellano y otros vs. Chile. Excepciones preliminares, fondo, reparaciones y costas. Sentencia del 26 de septiembre de 2006, párr. 111.

181 "Son inadmisibles las disposiciones de amnistía, las disposiciones de prescripción y el establecimiento de excluyentes de responsabilidad que pretendan impedir la investigación y sanción de los responsables de las violaciones graves de los derechos humanos, tales como la tortura, las ejecuciones sumarias, extralegales o arbitrarias y las desapariciones forzadas, todas ellas prohibidas por contravenir derechos inderogables reconocidos por el Derecho internacional de los derechos humanos". Caso Barrios Altos vs. Perú. Fondo. Sentencia del 14 de marzo de 2001, párr. 41.

182 Cfr. Caso Gomes Lund y otros (Guerrilha do Araguaia) vs. Brasil. Excepciones preliminares, fondo, reparaciones y costas. Sentencia del 24 de noviembre de 2010, párr. 171.

183 Cfr. Caso Gelman vs. Uruguay. Fondo y reparaciones. Sentencia del 24 de febrero de 2011, párr. 239.

184 Al final de julio de 2014: Antigua y Barbuda, Argentina, Barbados, Belice, Bolivia, Brasil, Canadá, Chile, Colombia, Costa Rica, Dominica, Ecuador, Granada, Guatemala, Guyana, Honduras, México, Panamá, Paraguay, Perú, St. Kitts y Nevis, Sta. Lucía, St. Vicente y Granadinas, Surinam, República Dominicana, Trinidad y Tobago, Uruguay y Venezuela.

185 Cfr., por ejemplo, Caso Goiburú vs. Paraguay. Fondo, reparaciones y costas. Sentencia del 22 de septiembre de 2006, párrs. 72-73 y 128-132. 
entre el delito y la pena"186. Este es un "terreno central de la batalla liberadora de Beccaria", sostiene Giuliano Vassalli ${ }^{187}$. Combate el enjuiciamiento "ofensivo", dominante en "la iluminada Europa del siglo XVIII" - son las palabras del marqués-, y se pronuncia por el "informativo": "indagación indiferente del hecho, según manda la razón"188.

En el marco procesal beccariano domina una idea que se tornaría central desde que surge la sospecha de responsabilidad de un individuo hasta que la condena firme resuelve su suerte, con fuerza de verdad legal y cosa juzgada: presunción de inocencia: "Un hombre no puede ser llamado reo antes de la sentencia del juez, ni la sociedad puede quitarle la pública protección sino cuando esté decidido que ha violado los pactos bajo los que le fue concedida" 189 .

Las constituciones y las leyes procesales de los Estados americanos detallan los caracteres de lo que hoy denominamos debido proceso, proceso justo, tutela judicial efectiva, plena defensa ${ }^{190}$. Esos ordenamientos - vinculados con el Derecho convencional interamericano de los derechos humanos y con la interpretación de la Corte Interamericana- invocan con firmeza la presunción de inocencia, a la que ese Tribunal ha considerado "fundamento de las garantías judiciales"191; dicho en otros términos: idea rectora, principio conductor, cimiento natural en la construcción del proceso penal garantista.

La jurisprudencia de la Corte Interamericana ampara las garantías mínimas en el desarrollo del proceso -sin mengua de otras garantías adicionales-, y bajo ese título abarca "investigación, acusación, juzgamiento y condena"192.

En el estudio del proceso, Beccaria rechaza la delación ${ }^{193}$, favorece la publicidad $^{194}$, pondera la seriedad de la prueba ${ }^{195}$, repudia la costumbre de poner precio a la cabeza del reo ${ }^{196}$, temas socorridos en la reflexión americana del presente.

186 «Cesare Beccaria et le proces pénal». En Varios, Cesare Beccaria and Modern..., cit., p. 110. Asimismo, cfr. Pisani, M. Attualita di Cesare Beccaria. Milano, Giuffre Editore, pp. 7 y ss.

187 «Spunti di politica criminale in Cesare Beccaria». En Varios, Cesare Beccaria and Modern..., cit., p. 25.

188 «Del espíritu de fisco», pp. 255-256.

189 «Del tormento», p. 246.

190 Cfr. García Ramírez, S. Panorama del proceso penal. México, Ed. Porrúa, 2004, pp. 31 y ss., y El debido proceso..., cit., esp., pp. 3 y ss. y 22.

191 "Esta Corte ha señalado que el principio de presunción de inocencia constituye un fundamento de las garantías judiciales". Caso Acosta Calderón vs. Ecuador. Fondo, reparaciones y costas. Sentencia del 24 de junio de 2005, párr. 111, que invoca precedentes: Caso Tibi vs. Ecuador. Excepciones preliminares, fondo, reparaciones y costas. Sentencia del 7 de septiembre de 2004, párr. 180; y Caso Suárez Rosero vs. Ecuador. Fondo,. Sentencia del 12 de noviembre de 1997, párr. 77.

192 Cfr., por ejemplo, Caso Lori Berenson Mejía vs. Perú. Fondo, reparaciones y costas. Sentencia del 25 de noviembre de 2004, párr.. 176, y Caso Mohamed vs. Argentina. Excepción preliminar, fondo, reparaciones y costas. Sentencia del 23 de noviembre de 2012, párr. 91.

193 «Acusaciones secretas», pp. 243-246.

194 Ibidem, p. 245.

195 «Indicios y formas de justicia», pp. 241-243.

196 «De la talla», pp. 304-306. 
El proceso aspira a la verdad y debe viajar asido a la prueba. Es la ruta hacia la sentencia. En el fondo, procesar es probar. Su cauce era tortuoso en la época de Beccaria. Había que demoler -recuerda Pisani- los conceptos prevalecientes asociados a la tortura, al juramento y a otras figuras deleznables ${ }^{197}$. En pos de Europa, se hizo en América. Comenzamos por demoler instituciones: cayó el Santo Oficio y se inició el largo camino de la abolición de los fueros, labor de un siglo y muchas contiendas. Las ideas nucleares sembradas al término del siglo XVIII, animaron un sector de la reforma procesal al cabo del XX y en el inicio del XXI, con las figuras que sugieren las circunstancias.

Esa reorientación se halla en la legislación de varios países americanos, cada vez más, ampliamente reconsiderada en los últimos años, y no menos en las guías procesales que imprime el Derecho interamericano, acuñadas por la jurisprudencia del Tribunal de San José.

Sin embargo, también hay resistencias y alegatos que abrigan verdades y falacias. Transformaciones plausibles y deformaciones inquietantes. Algunas soluciones cuestionables se localizan, a mi juicio, en el régimen de entendimientos procesales que elude la verdad de los hechos y sacrifica la justicia a la economía. Se encumbra el market system, señala Fairén Guillén ${ }^{198}$, quien advierte acerca del bargain: "la pena pasa a ser contractual"199. Muy severa es la apreciación de Alcalá-Zamora: "bochornoso chalaneo con apariencias de allanamiento y realidades de transacción penal" "Todas las garantías penales y procesales (...) resultan efectivamente alteradas con la negociación entre las partes", advierte Ferrajoli ${ }^{201}$. Reaparece -aunque lo haga sin violencia- la ocurrencia de que el fin justifica los medios, cuando sólo la legitimidad de éstos -como se desprende de la corriente beccariana-justifica el fin que se alcanza con el proceso: la sentencia justa. En suma, la piedad y la razón se complementan.

La obra de Beccaria tiene un punto final que es también, visto desde otro ángulo, punto inicial: la prevención de los delitos; evitar, más que sancionar, exactamente como en la medicina del cuerpo individual y del cuerpo colectivo. Si comenzamos

197 Cfr, «Beccaria e il proceso...». En Varios, Cesare Beccaria and the Modern..., cit., pp. 114 y ss. Igualmente, cfr. Pisani, M. Attualità..., cit., pp. 17 y ss.

198 Cfr. «Los equivalentes jurisdiccionales». En Estudios de Derecho procesal civil, penal y constitucional. La reforma procesal penal (1998-1992). Madrid, Ed. Revista de Derecho Privado/ Editoriales de Derecho Reunidas, 1992, t. III, p. 83.

199 «Examen crítico de los principios rectores del proceso penal». En Varios, Memoria del $X V$ Congreso Mexicano de Derecho procesal. México, Instituto de Investigaciones Jurídicas, UNAM/ Instituto Mexicano de Derecho procesal, 1998, p. 431.

200 Proceso, autocomposición y autodefensa (Contribución al estudio de los fines del proceso. México, Universidad Nacional Autónoma de México, Instituto de Investigaciones Jurídicas, $3^{\text {a }}$. ed., 1991, p. 431.

201 Derecho y razón..., cit., p. 609. 
aquí, con el éxito posible, no será necesario llegar allá, sin perjuicio de las cuotas mínimas que siempre se hallarán entre nosotros.

¿Qué hacer? La respuesta beccariana conserva frescura; "Haced que acompañen las luces a la libertad" ${ }^{202}$. Contiene propuestas impecables: cultura de la legalidad -o de la juridicidad-, función de policía -que es mucho más que el desempeño de la policía $-{ }^{203}$, perfeccionamiento de la educación ${ }^{204}$. En suma, poner el cimiento de la libertad y la justicia antes de que la delincuencia ocupe el edificio social. Así se resume el mensaje beccariano "siempre vivo y actual, por una política criminal racional y humana", en palabras de Vassalli ${ }^{205}$.En América, como en otros lugares, los instrumentos de control por la convicción y la solidaridad se han retraído; la desesperación y la exasperación sugieren mano dura a los oídos del Parlamento: gobernar con el código penal en la mano.

Hoy día abundan las expresiones de preocupación por el rumbo y destino de la justicia penal. Las manifestaciones de algunos juristas, observadores de ese rumbo -al menos en determinados ámbitos, con la concurrencia de ciertos movimientos mundializadores- no dejarían en paz a los reformadores del siglo XVIII, como Beccaria, que vieran resurgir, con otra fachada, a sus viejos adversarios.

Mireille Delmas-Marty señala que muchos penalistas temen un derecho penal regresivo, bajo la bandera de la eficacia, y previene sobre la tensión que se presenta entre el derecho penal y los derechos humanos ${ }^{206}$. Moisés Moreno analiza la vigencia de la alternativa entre un Derecho penal liberal y democrático y un Derecho penal autoritario, que se expande al amparo de la globalización y la internacionalización del delito ${ }^{207}$. Zaffaroni recuerda la tentación perenne del Estado de policía ${ }^{208}$. Miguel Polaino Navarrete apunta que el Derecho penal mínimo es una utopía, más que una realidad ${ }^{209}$. Ulrich Sieber hace notar que los nuevos riesgos mundiales alientan

202 «De las ciencias», p. 316

203 «De la tranquilidad pública», p. 237.

204 «Educación», pp. 320-321.

205 «Spunti de politica...». En Varios, Cesare Beccaria and Modern..., cit., p. 25.

206 «Discurso». En Varios, Panorama internacional sobre justicia penal. Proceso penal y justicia penal internacional. Culturas y sistemas jurídicos comparados. Séptimas Jornadas sobre Justicia Penal. México, Universidad Nacional Autónoma de México, Instituto de Investigaciones Jurídicas, 2007, p. XXIII, y «Final Remarks». En Varios, Cesare Beccaria and Modern..., cit., p. 449.

207 «Última ratio o expansión del Derecho penal». En Varios, Hacia la unificación del Derecho penal. Logros $y$ desafios de la armonización y homologación en México y en el mundo. México, Instituto Nacional de Ciencias Penales/Max-Planck-Institut für ausländisches und internationales Strafrecht, 2006, cit., p. 351.

208 Cfr. «La justicia como garante de los derechos humanos en México y América Central: la independencia del juez». En Varios, La justicia como garante..., cit., p. 15.

209 Cfr. «La controvertida legitimación del Derecho penal en las sociedades modernas». En Jakobs, G. y Polaino Navarrete, M. El Derecho penal en las sociedades modernas (Dos estudios de dogmática penal y política criminal). México, Flores Editor y Distribuidor, 2006, p. 76. 
la actuación del Estado fuerte, por medio del Derecho penal ${ }^{210}$. Y Daniel Erbetta observa una "crisis derivada de la tensión expansiva a que se está sometiendo al derecho penal" "211. Con otro rostro, vuelve a la escena en el siglo XXI la crisis del siglo XVIII, que reapareció, con diverso formato, en sucesos de otras centurias, especialmente el siglo XX.

El vacío que dejan los instrumentos no punitivos del control social se ocupa de la expectativa del control represivo. Pero sabemos, con Talleyrand, que se puede hacer cualquier cosa con las bayonetas, salvo sentarse en ellas. Habrá que observar con cautela los pasos del Estado opresivo, que vela. La democracia, armada con las ideas beccarianas de piedad y razón, podría menguar bajo el asedio de la criminalidad y la seducción del arsenal punitivo. Es el riesgo que corremos.

Es verdad que la argumentación de Beccaria lo identifica como un hombre de su tiempo, como señala Mireille Delmas-Marty ${ }^{212}$. Ahora bien, la racionalidad de sus planteamientos, por fortuna, y las sombras que han poblado otras horas después de la suya y hasta la nuestra, por desgracia, le han conferido una vitalidad que le permite viajar por encima de los años -lo muestra esta celebración, a un cuarto de milenio de la edición del opúsculo- y ejercer donde quiera y cuando sea su magisterio. Por eso Beccaria se halla en vigilia en el suelo americano.

210 Cfr. «Unificación, armonización y cooperación: a la búsqueda de soluciones para los sistemas penales federales y supranacionales». En Varios, Hacia la unificación.., cit., p. 10.

211 «Postmodernidad y globalización: ¿hacia dónde va el Derecho penal». En Varios, El Derecho privado ante la internacionalidad, la integración y la globalización. Homenaje al profesor Miguel Ángel Ciuro Caldani. Buenos Aires, La Ley, 2005, p. 79.

212 «Le rayonnement international...». En Varios, Cesare Beccaria and Modern..., cit., p. 141. 



\title{
BECCARIA Y EL ILUMINISMO ITALIANO EN LA CULTURA JURÍDICA HISPANA ${ }^{1}$
}

\author{
GONZALO QUINTERO OLIVARES
}

Catedrático de Derecho Penal, Universidad Rovira i Virgili, España.

\section{BECCARIA Y EL INICIO DE UN NUEVO TIEMPO EN LA HISTORIA DEL DERECHO PENAL}

En las páginas que siguen he de dar noticia de cuál fue la influencia de la obra del Marqués de Beccaria en la cultura jurídica ibérica, o, lo que es lo mismo, cuál fue la transcendencia de su obra en la evolución de las ideas penales en España, con independencia del grado de influencia efectiva en la práctica criminal y en la legislación de la época ${ }^{2}$ (reinado de Carlos III), pues la distancia entre intelectualidad y realidad, siempre grande en todos los países, ha sido especialmente significativa en España, por razones que sería demasiado largo referir.

Al dirigir la mirada hacia aquella época es inevitable contemplar lo que fue el problema penal para la Ilustración española, pues el Siglo de las Luces fue en

1 Una parte de este trabajo fue presentada como "Relazione" al Convegno della Unione Camere Penali per il $250^{\circ}$ anniversario della pubblicazione di "Dei delitti e delle Pene" di Cesare Beccaria (Livorno maggio 2014).

2 Ninguna reforma legal se acometió en aquellos tiempos, pues la abolición de la los azotes y otras penas infamantes, por ejemplo -tortura-cuestión que era una de las exigencias centrales en la obra de Becaria-no produciría hasta las Cortes de Cádiz. Vid.: Tomás y Valiente, F. La tortura judicial en España. Madrid, Crítica, 2000, p.123 y 124; Antón Mellón, J. «Las reformas penales durante el reinado de Carlos III. Repercusiones en España de la difusión de la obra de Cesare Becaria De los delitos y las penas». En Revista de Historia moderna, Pedralbes, No 4, 1984, p.158. 
Europa determinante en la evolución de las ideas penales, pero eso no oculta que la difusión de nuevas ideas tropezó con obstáculos fuera y, especialmente, dentro de España. Las ideas del Marqués topaban con demasiados muros religiosos e ideológicos, y lo mismo habría de suceder en España poco después, con las de Gaetano Filangieri, que no tenía relación directa con Becaria, pero que fue autor de una obra esencial en la evolución del pensamiento penal. La visión de la inmovilista reacción hispánica frente a las nuevas ideas es más completa incluyendo a ambos fundamentales pensadores ${ }^{3}$.

Partimos de que en la exposición de la historia del derecho penal existen algunas tradiciones, que tal vez se conservan sin especiales discusiones porque han logrado un suficiente consenso, lo que no por ello las hace indiscutibles. La primera tradición es que la historia moderna de nuestra disciplina comienza con la obra de Cesare Beccaria, y que toda la literatura penal anterior a Dei delitti e delle pene pertenece al "Antiguo Régimen", lo cual no deja de ser relativamente arbitrario; pero esa ha sido una decisión de historiadores del derecho penal tan reputados como Enrico Pessina, que además entendieron que era preciso diferenciar entre desarrollo de la legislación y desarrollo de la ciencia, pero en todo caso con una frontera situada en torno a la obra de Beccaria y, también, de la Revolución Francesa ${ }^{4}$.

La costumbre de situar la evolución del derecho penal con un antes y un después de la Revolución francesa es también discutible. En primer lugar, la obra de Beccaria -que fue comentada por Voltaire- es anterior a la Revolución francesa, aunque sea cierto que el ideario ideológico pre-revolucionario fuera, en buena parte, común. Pero cuesta aceptar que la Revolución francesa tuviera como objetivos claros y principales imponer la racionalidad en la represión penal, acabar con

3 La obra de Beccaria se traduce al español en 1774 y la de Filangieri en 1787. Tanto uno como otro fueron severamente censurados y prohibidos, y, a su vez, la difusión de sus obras fue impulsada por las mismas personas, concretamente, y en especial, por Pedro Rodríguez de Campomanes, personaje de gran importancia en la España de Carlos III, y uno de los máximos exponentes del pensamiento ilustrado, y como muestra basta recordar que fue el impulsor de la Real Sociedad Económica de Madrid, creada en 1775, y que dio lugar a la proliferación por toda España de y América de las Sociedades Económicas de Amigos del País, entidades de inequívocamente orientadas a propiciar el salto cultural que promovía el Siglo de las Luces, a pesar de que en sí misma no dejaron de ser círculos elitistas, lo cual no se puede valorar con los criterios de nuestro tiempo (Vid.: Enciso Recio, L-M. «Campomanes y las Sociedades Económicas». En Torre de los Lujanes, Boletín de la Real Sociedad Económica Matritense de Amigos del País, no23, 1993, p. 27 y ss.)

4 En la cultura anglosajona son visibles otras ideas, comenzando por la prioridad de la propia Revolución Inglesa y de la Revolución norteamericana y la Declaración de Independencia y la subsiguiente Constitución de 1788. Es comprensible que ese mundo tuvieran más impacto que Beccaria y su obra, otras, como la de John Howard "El estado de las prisiones en Inglaterra y Gales" aparecida en 1777. 
el terror punitivo, abolir la pena de muerte ${ }^{5}$, y tantas otras ideas presentes en el libro de Beccaria.

Es cierto que en los inicios de la Revolución francesa se sentaron las bases de lo que debía de ser un Estado de Derecho, así como principios esenciales del derecho y el proceso penal, y eso sería sin duda el punto de partida del derecho constitucional y del derecho administrativo hasta entonces desconocidos, aunque la propia Revolución se encargó de ahogar sus principios ${ }^{6}$. Los cambios efectivos en el derecho penal tardarán todavía muchos años en ser visibles, aunque ya a fines del s. XVIII e inicios del siglo XIX se puedan ver importantes muestras de evolución, especialmente en temas como la proscripción del uso del tormento o los primeros intentos de racionalizar la ejecución de las penas.

Con ello no discuto la importancia fundamental de conquistas revolucionarias, como la función de bóveda del principio de legalidad, en todas sus dimensiones, pero eso no es motivo bastante como para sostener que el inicio de la moderna ciencia del derecho penal sea fruto, ni siquiera parcial del ideario revolucionario francés. Otra cosa es que el modelo de Estado que aparecería en la Europa del s. XIX (el Estado liberal de Derecho) generará las condiciones precisas para la construcción del derecho penal que irá evolucionando hasta nuestro tiempo, y ese proceso pasará también por la codificación, que con criterios dispares se extiende por Europa a lo largo del s. XIX.

En ese proceso, en lo que respecta a España, se verá la influencia de Beccaria, tanto a través de las muy numerosas ediciones de su obra ${ }^{7}$, cuanto, como es normal,

5 Ese era uno de los puntos centrales del ideario de Beccaria, y tuvo una cierta influencia. Así sucedió con Leopoldo I de Toscana, que promulgó en 1786 un Código penal que eliminaba totalmente la pena de muerte. En 1787 la pena de muerte se eliminó del Código penal austriaco, aunque luego sería restablecida. El Código penal francés revolucionario de 1791 incluyó la pena de muerte que Luis XVI había abolido pocos años antes.

6 Es indiscutible la importancia de la Revolución en cuestiones nucleares como fue la separación de poderes y la configuración de un poder judicial independiente, y eso fue obra de la Ley Fundamental de agosto de 1790, que además distinguió entre justicia civil y justicia penal. El procedimiento penal, regulado por las Ordenanzas de Colbert, fue reformado por leyes de julio y septiembre de 1791, pasando de un proceso inquisitorial y secreto a otro modelo, basado en el principio acusatorio, pero orientado a garantizar la aplicación de los principios consagrados en la Declaración de Derechos del Hombre y del Ciudadano. En esa misma época se elaboró el Código penal de 1791. La Declaración es una relación de principios con vocación universal, que contiene ideas esenciales (legalidad, irretroactividad, exclusión del castigo arbitrario, presunción de inocencia, libertad de opinión y de conciencia. Pero el período del Terror relegó la obra de los Constituyentes al rango de meros principios ideales no vinculantes. Los tribunales revolucionarios creados por la Ley de 10 de marzo de 1793 desplazan a las jurisdicciones ordinarias, que además son vigiladas por el Estado, y se arrumban todos los supuestos derechos de los acusados, comenzando por la presunción de inocencia. Todos aquellos principios no serán realidad hasta mucho tiempo después.

7 Es de destacar que desde la primera y temprana traducción de 1774, la hecha por J.A. de las Casas, la obra del Marqués ha estado siempre presente en la literatura penal española, al punto de que la última, y excelente, edición es "Cesare Beccaria: De los delitos y de las penas", con prefacio de 
a través de su influencia en personajes que fueron determinantes de la orientación de los primeros Códigos.

Es cierto, en todo caso, que el Antiguo Régimen y sus leyes quedan fuera de esa perspectiva histórica que quiere situar el "momento inicial" de la ciencia del derecho penal. Mayoritariamente se entiende que antes de la Revolución francesa no tiene sentido hablar de derecho penal en el modo en que se pudiera entender esa expresión en el siglo XIX y a partir de los primeros Códigos que se promulgan en Europa.

Pese a ello, en la historia del derecho penal español no faltan quienes defienden la tesis de que es injusto dar la condición de padre de la ciencia penal a Beccaria, y en defensa de su tesis aportan, con cierta razón, ejemplos de pensadores -la mayoría teólogos o canonistas- que mucho tiempo antes ya habían escrito profundos análisis de las leyes criminales ${ }^{8}$ pues según esa opinión fue el fraile franciscano ( $\mathrm{y}$ padre conciliar en Trento $^{9}$ ) Alfonso de Castro, el fundador de la ciencia del derecho penal. Castro fue autor del "De iusta haereticorum punitione" y de "De potestate legis poenalis".

Pero esa tesis es equivocada por dos motivos: en primer lugar, porque la obra de Castro es coherente con su tiempo, su condición de franciscano, teólogo de Trento, y consejero real, y lo que era el Poder en su época, tanto del Rey como de la Iglesia, a quienes respetaba y consideraba que había que respetar como poderes naturales, mientras que la de Beccaria comienza por negar esos poderes supuestamente naturales ${ }^{10}$.

En segundo lugar, porque nadie estima que Beccaria fundara la "ciencia" del derecho penal, sino que fue un revolucionario de las ideas, mientras que la "ciencia del derecho penal", si se quiere hablar de eso, ha de buscar sus padres en Filangieri y Romagnosi (en Italia) y en Feuerbach y Mittermaier (en el mundo germánico ${ }^{11}$ ).

Piero Calamandrei, texto italiano establecido por Gianni Francioni, edición bilingüe al cuidado de P. Andrés Ibáñez, Ed.Trotta, Madrid 2011.

8 Así lo sostenía el Padre Jerónimo Montes. En Precursores de la Ciencia Penal en España y las causas y remedios del delito. Madrid, V.Suárez, 1911, y es algo que asume también Tomás y Valiente, F. en la "Introducción" de la traducción española de Dei delitti e delle pene, Madrid, 1969, pág. 17.

9 Al igual que otro de los considerados precursores de la ciencia penal en España: Domingo de Soto, autor de De iustitia et iure, aparecido en Salamanca en 1556.

10 Sobre esa absurda "reivindicación" hispana vid.: Bullón y Fernández, E. Alfonso de Castro y la ciencia penal. Madrid, Hijos de G. Hernández, 1900, y, Rodríguez Molinero, M. Origen español de la ciencia del Derecho penal, Alfonso de Castro y su sistema penal. Madrid, 1959.

11 También en el mundo germánico se produjo la influencia de Beccaria: Weis, E. Cesare Beccaria (1738-1794), Mailänder Aufklärer und Anreger der Strafrechtsreform in Europa. C.H.Beck, München, 1992; y se señala su influencia en Feuerbach, para muchos padre de la ciencia penal alemana (Th. Würtenberger. Th. «Cesare Beccaria und die Strafrechtsreform». En Erinnerungsgabe für Max Grünhut, 1965, N. G. Elwert, Marburg, 1965, p.208. 
En la historia del derecho penal español aparecen, sin duda eminentes juristas, cuyas obras alcanzaron una gran difusión en su tiempo, ayudada a veces por la condición de teólogos de prestigio de los autores, en unión de la nada desdeñable circunstancia del poder del Imperio hispano-germánico bajo Carlos V y Felipe II $^{12}$.

Frente a la tradicional prioridad otorgada a Beccaria, ha habido también, por otros motivos, grandes críticos en la misma Italia, como, por ejemplo, Italo Mereu ${ }^{13}$, que consideraba injusto suponer que antes de ese tiempo «nadie» fue capaz de pensar científicamente en los problemas penales; y que todos los elementos del concepto técnico jurídico de delito estaban sobradamente estudiados por los criminalistas del siglo XVI, y en esa línea se cita, especialmente a Tiberio Deciano y su "Tractatus Criminalis $^{14}$.

Los pensadores anteriores a Beccaria no tuvieron, en modo alguno, la influencia que tuvo la obra del Marqués. Puede decirse que el espíritu del Iluminismo propició la divulgación, y puede añadirse que obras coetáneas o anteriores, como las de Montesquieu o Voltaire, habían circulado entre la intelectualidad europea, y que todo ello propició el fenómeno. Seguramente es cierto, pero no puede ponerse en duda el carácter revolucionario del libro de Beccaria, y no solo porque se enfrentaba a lo que hasta entonces era intocable: el poder real y la Iglesia, cosa que ciertamente no habían hecho los considerados precursores de la ciencia penal, sin cuestionar sus valiosas construcciones sobre conceptos centrales del derecho penal (como la imputabilidad, el dolo, el estado de necesidad, el error, etc.).

Pero nada de eso causó una revolución. Aunque en el siglo XVI o XVII se hubiesen llegado a utilizar conceptos similares a los que se empleaban en la penalística del s. XIX su significado profundo no era ni podía ser el mismo que tuvo en su momento para los Carrara, Pessina, etc., pues lo que explica el modo de entenderse y aplicarse el derecho penal no es el pensamiento de un autor, sino el marco político, legislativo y judicial en que se aplica. Esa vinculación del pensamiento penal a las fluctuaciones políticas de cada época no se da tal vez en otras ramas del Ordenamiento, que

12 Vid.: Pérez Marcos, R. «Notas sobre la génesis de la ciencia penal en España». En Estudios de Historia de las Ciencias Criminales en España. Madrid, Dykinson 2007, ofrece una detallada relación de personajes cuyas obras fueron de indiscutible importancia.

13 Mereu, I. Storia del diritto penale del '500. Napoli, 1961; Id. La pena di morte a Milano nel secolo di Beccaria. Milano, Neri Pozza Editore, 1988.

14 Sobre la importancia de Deciano, "Tiberio Deciani 1509-1582.. Alle origini del pensiero giuridico moderno", Atti del Convegno internazionale di studi storici e giuridici, 2002, a cura de M. Cavina, Udine 2004. Su repercusión fuera de Italia puede verse en Schaffstein, F. «Tiberius Decianus und seine Bedeutung für die Entstehung des Allgemeinen Teils im Gemeinen deutschen Strafrecht». En Deutsche Rechtwissenschaft, ed.. K.A. Eckhardt, Hamburg 193; lo mismo en Abhandlungen zur Strafrechtsgeschichte und zur Wissenschaftsgeschichte, Aalen, 1986. 
por ello mismo han propiciado un mejor desarrollo y aplicación del pensamiento metodológico historicista, como ocurre por ejemplo en el Derecho civil.

Antes de que en 1764 apareciera en Livorno su libro, se había publicado (1748) el libro de Montesquieu «L'ésprit des lois». La obra del señor de La Brède recogía ya principios que estaban destinados a ser considerados posteriormente como sillares del Derecho penal moderno: la separación e independencia del poder judicial, la estructuración y pureza del proceso, la inutilidad de las penas largas, la proporción entre pena y delito, lo absurdo del tormento. Todo lo cual habría de recibir nuevo y, según algunos, más democrático impulso a través de la obra de J.J. Rousseau.

Sea como fuere, lo cierto y aceptado es que el primer pensador italiano cuyas ideas penales transcienden a su país es Beccaria, cuyo famoso "Dei delitti e delle pene", se divulgó por toda Europa, y, por supuesto, por España, y marcó, sin duda, un antes y un después en la historia de la cuestión penal, fenómeno que, en menor medida, se repetiría muchos años después cuando en 1876, otro Cesare, Lombroso, publicó L'uomo delinquente.

Mucho se ha hablado de las influencias presentes en la obra de Beccaria. Es común afirmar que Montesquieu influyó en él, lo cual es perfectamente lógico en el ámbito cultural de la Ilustración, al igual que puede decirse que también influyeron en él John Locke, Helvétius o Bonnot de Condillac.

En realidad lo más razonable es ver un ambiente común en la intelectualidad europea del siglo XVIII, y ese ambiente lo marca el Iluminismo, en su denominación italiana, Siécle des Lumières, en la cultura francesa, Enlightenment, para los ingleses, y Aufklärung, para los alemanes, y que, en España, será la Ilustración, que a su vez se presenta y desarrolla de maneras muy diferentes dependiendo de los Estados europeos, teniendo además en cuenta que en 1776 se produce la Revolución americana y en 1789 la francesa, sucesos que marcaron decisivamente la Historia, tanto por lo que supusieron como golpes al Antiguo Régimen como por el alcance de sus documentos máximos (la Declaración de Independencia de Estados Unidos, seguida de la Constitución de Estados Unidos de América (1787) y la Carta de Derechos (1791) y la Declaración de los Derechos del Hombre y del Ciudadano aprobada por la Asamblea Nacional Constituyente francesa).

En estas pocas páginas no pretendo abordar el tema de las influencias que hubieran podido afectar al propio Beccaria, sino de lo que supuso su obra en la cultura hispánica ${ }^{15}$.

15 Tema que siempre ha interesado en la penalística en lengua española, en especial: Saldaña, Q. El Derecho Penal, Estudio preliminar a De los delitos y de las penas, de Cesare Beccaria. Hernando, Madrid 1936. Bernaldo de Quirós, C. Traducción, estudio preliminar y notas al Tratado de los Delitos y Las Penas de C. Beccaria. Puebla, México, 1956. Torío López, A. «Beccaria y la Inquisición española». En Anuario de Derecho Penal, 1971; Zaffaroni, R.E. «La influencia 


\section{LA ILUSTRACIÓN Y LA INFLUENCIA DE BECCARIA EN ESPAÑA}

\section{II.1. La Ilustración en España}

He dicho antes que el significado y transcendencia del Iluminismo no es igual en todos los Estados europeos. Se acepta que sus orígenes se sitúan en la Inglaterra, de donde pasaría a Francia a través de la figura capital de Voltaire y, con él, los enciclopedistas (Montesquieu, Diderot, Bouffon). Partiendo de esos dos focos (Inglaterra y Francia) el movimiento se extendería a otros países, como Italia o España. Es cierto, no obstante, que el Siglo de las Luces no fue especialmente significativo, comparativamente, en España, al punto de que está muy extendida la opinión de que en nuestro país el siglo XVIII no supuso culturalmente nada.

Tal vez esa es una opinión excesivamente dura, aunque la hayan sostenido eminentes intelectuales españoles como Ortega y Gasset. Es injusto minusvalorar los esfuerzos de los ilustrados ${ }^{16}$, defendiendo sus ideas en un ambiente especialmente hostil, y también es injusto dar a entender que en los Estados europeos en el s. XVIII no había contradicciones y fuertes subsistencias de los horrores penales del Antiguo Régimen ${ }^{17}$. Pero en cualquier caso es cierto que en España, y en concreta referencia a la justicia penal, las ideas ilustradas no pasaron de ser consejos y ruegos elevados a S.M. Carlos III, sin consecuencia alguna, lo cual no tiene nada que ver con la formación de una nueva ideología.

Los que serían los "ilustrados españoles" reciben el nuevo modo de pensar viviendo en un país que está entrando en clara decadencia, a pesar de algunas importantes mejoras producidas durante el reinado de Carlos III, y en el que el poder de la Iglesia era todavía muy importante. Una férrea Monarquía absoluta, que nadie osaba discutir era el eje de la vida pública en todos los territorios, europeos y americanos -a pesar de que el propio Carlos III respetó a contó con importantes ilustrados en su acción de gobierno-.

del pensamiento de Cesare Beccaria sobre la política criminal en el mundo». En Anuario de Derecho Penal, 1989; Quintero Olivares, G. «La influencia de la penalística italiana en la penalística española». En Revista de Derecho Penal, mayo-junio, 2010; Rico Lara, M. Cesare Beccaria, Historia 16, 230, 1995; Arroyo Zapatero, L. «Cesare Beccaria y la moderna política criminal en España». En Revista jurídica de Castilla - La Mancha, 10, 1990; Tomás y Valiente, F. La tortura judicial en España. Barcelona, Crítica, 2000; Antón Oneca, J. «Los fines de la pena según los penalistas de la Ilustración». En Revista de Estudios Penitenciarios, nº 166, 1964; González Guitián, L. «La más alta preocupación del Príncipe: una introducción a Dei delitti e delle pene». En Estudios Penales y Criminológicos, XXX, Universidad de Santiago de Compostela, 2011.

16 Esa injusticia fue denunciada hace muchos años por un historiador francés: Sarrailh, J. L'Espagne éclairée de la seconde moitié du XVIIIe siècle”. Paris, C. Klincksieck, 2ª ed, 1964.

17 En este sentido, Rodríguez Ennes L. y Allegue, P. «Reflexiones sobre a1 gunas ideas punitivas del P. Sarmiento». En Anuario de Derecho penal y Ciencias penales, t. 45, Fasc. 3, 1992, p.856. 
Las leyes penales eran de extrema dureza, a pesar de que la paulatina influencia de los ilustrados entre los jurisconsultos llevó a suavizar de facto muchas de las terribles penas que se preveían para delitos de poca importancia (por ejemplo, muerte para el delito de hurto, porque así lo disponía una Pragmática de Felipe II cuya vigencia se aceptaba), a lo que se debe añadir la abundancia del tormento, los azotes, la vergüenza pública, y el desconocimiento de nada que se pareciera a la certeza del derecho.

Por su parte, la nobleza, en sus propiedades, podía ejercer funciones judiciales y administrativas, privilegio que duraría hasta la Constitución de 1812. Eso pone de manifiesto un problema que realmente fue determinante de la suerte del pensamiento ilustrado y, posteriormente, del pensamiento liberal en el primer tercio del siglo XIX: la falta de una clase media potente y reconocible, esto es, de una auténtica burguesía, que hubiera sido el soporte natural del movimiento, como sucedería en Francia.

Pese a todo, la relativa simpatía que Carlos III profesaba al movimiento, propició la aparición de un importante elenco de ilustrados, así como la fundación de instituciones culturales de primer orden, como fueron las Reales Academias. Ese grupo de personajes no cesó de proponer reformas de las leyes penales presentando al Rey diferentes documentos sobre la situación de la Justicia penal, entre los que destacan el "Discurso" de Lardizábal, del que me ocuparé después, y los diferentes textos de Jovellanos ${ }^{18}$.

Mucho peor sería la situación a partir de la muerte de Carlos III. Su sucesor, Carlos IV (1788-1808), era hombre débil y sin personalidad, aunque en un principio quiso seguir la línea reformista de su padre, y para ello contó con los mismos importantes primeros ministros (Floridablanca y Aranda), pero esos buenos propósitos duraron hasta que la Revolución francesa decidió la ejecución de Luis XVI y su esposa, sucesos que produjeron terror en muchas Cortes europeas, y especialmente en la española, y no solo por el parentesco entre los reyes de la familia Borbón, sino por la propia debilidad del Estado.

La consecuencia fue el abandono de cualquier intento "ilustrado" de modernizar España y la entrega del poder ministros que en modo alguno se pueden comparar a los anteriores. A eso se ha de añadir lo poco que costó a los movimientos con-

18 Sobre ello vid.: Coronas González, S.M. Jovellanos, justicia, estado y constitución en la España del antiguo régimen. Gijón, Foro Jovellanos, 2000. Una buena muestra del progresivo empeoramiento de las condiciones de desarrollo del pensamiento ilustrado lo ofrece la propia vida de Jovellanos. El 10 de noviembre de 1797 fue nombrado ministro de Gracia y Justicia, cargo desde el que intentó reformar la justicia y acabar con la influencia de la Inquisición. Duró en el cargo nueve meses. En diciembre de 1800, Godoy, todopoderoso Ministro de Carlos IV, vuelve al poder del que se había alejado por poco tiempo, y ordena la detención de Jovellanos el 13 de marzo de 1801 y su destierro a Mallorca, primero a una Cartuja y luego a la prisión del castillo de Bellver. 
servadores encabezados por la siempre poderosa Iglesia, aristocracia y grandes propietarios imputar a las ideas ilustradas la responsabilidad de toda la violencia revolucionaria francesa, cuya entrada en España a toda costa había que impedir, lo cual daría lugar a que en 1793 se declarara la Guerra entre España y la Convención Republicana francesa, conflicto que resultó catastrófico para España.

En un panorama de esas características es fácil comprender las crecientes dificultades con que iba a topar la difusión del pensamiento de Beccaria, pues nada de extraño tiene el que las fuerzas conservadoras se alzaran contra las ideas del Marqués, como lo hicieron, y durante muchas décadas, contra todo lo que cuestionara la distribución del poder en el Antiguo Régimen, pues ni siquiera el liberalismo se libró de una persecución brutal, incluyendo fusilamientos y encarcelamientos ordenados por el siniestro rey Fernando VII.

Estas últimas ideas hay que retenerlas, pues el antiliberalismo no solo estaba presente en la España metropolitana, sino también, y con fuerza, en muchos sectores de la sociedad colonial latinoamericana, lo que explica la abundancia de regímenes autoritarios a lo largo del siglo XIX (sin entrar en las dictaduras del siglo XX).

\section{II.2. La llegada del libro y la influencia de Beccaria}

Según Mollfulleda ${ }^{19}$, aunque es algo discutible, “...el primer autor español que se refiere a la obra de Beccaria, aunque sin citar a su autor, es Alfonso María de Acevedo, a quien... puede considerarse como el adelantado de los autores españoles opuestos al tormento. Con el fin de desterrarlo de los tribunales escribió, en 1770, su obra De reorum absolutione... "20, en la que defendía la necesidad de suprimir el tormento, texto que provocó un auténtico revuelo en su época ${ }^{21}$. Aquella obra fue contestada por Pedro de Castro - Catedrático de Teología en Bolonia y Canónigo de Sevilla - con su "Defensa de la tortura y leyes patrias que la establecieron: e impugnación del tratado que escribió contra ella el doctor d. Alfonso María de Acevedo".

Efectivamente, en España, y ese es un hecho indiscutible, la tortura no era considerada ni siquiera una práctica "inevitable", sino legítima y adecuada a derecho,

19 Mollfulleda, S. Estudio preliminar, "Discurso sobre la tortura", de Juan Pablo Forner, Barcelona, Crítica, 1990.

20 La obra estaba escrita originariamente en latín, y su título en español era "Ensayo acerca de la tortura o cuestión del tormento; de la absolución de los reos que niegan en el potro los delitos que se les imputan, y de la abolición del uso de la tortura principalmente en los tribunales eclesiásticos". Fue traducida en 1817. La tortura "legal" fue abolida por Real Cédula de 25 de julio de 1814. Sobre la influencia de Beccaria en Acevedo vid.: Guerrero Latorre, A. «La reforma judicial bajo Carlos III: La tortura». En Cuadernos de Historia Moderna y Contemporánea, VI-1985, Ed.Univ. Complutense.

21 A favor de las opiniones de Acevedo se manifestaron personajes de la importancia de Jovellanos, Forner, Sempere y Lardizábal, quien expresamente, en el Discurso sobre las penas, rechazó la obra de Castro. 
y, por eso mismo, y ya antes de la llegada de la obra de Beccaria, las críticas de los primeros ilustrados eran vistas como críticas a la esencia del orden jurídico ${ }^{22}$. Por aquel mismo tiempo, y eso era admirado por Beccaria, y por los ilustrados, en la justicia inglesa se había proscrito el tormento (no la abundancia de la pena de muerte) por ser indigno de la condición humana ${ }^{23}$.

Respetando ese dato histórico, hay que dar la justa prioridad a un hecho cierto cual es el que el libro de Beccaria fue traducido tempranamente al español en $1774^{24}$, supuestamente por Juan Antonio de las $\operatorname{Casas}^{25}$ y además debe advertirse que se trataba de una traducción directa, procedente de la $5^{\text {a }}$ edición italiana, que respeta esencialmente. Eso aporta un dato significativo, pues la mayor difusión europea de la obra de Beccaria la alcanzaría la traducción francesa que hizo el abate Morellet, con significativas entradas correctoras en el texto original.

Antes de la aparición de la traducción, la influencia de Beccaria había alcanzado a Jovellanos ${ }^{26}$, Meléndez Valdés, Valentín de Foronda ${ }^{27}$, Juan Sempere y Guarinos $^{28}$. Está comprobado, pues, que era una obra conocida por los ilustrados

22 Esa era una específica característica del problema en España. Vid. Risco, A. «Présence de Beccaria dans l'Espagne des Lumiéres». En Beccaria et la culture juridique des Lumières, Actes du colloque européen de Genève, 25-26 novembre 1995, ed. por M. Porret, Librairie Droz, Geneve, 1997, p.149 y ss. También, Scandellari, S. «La polemica sull'abolizione della tortura nella Spagna della seconda metà del secolo XVIII». En Archivio Storico e Giuridico sardo di Sassari, vol. 1, 1994, p. 103 y ss.

23 Blamires, C. «Beccaria et l'Angleterre». En Beccaria et la culture juridique des Lumières, cit., p. 69.

${ }^{24}$ "Tratado de los delitos y las penas", sin incluir el nombre del autor, traducido del italiano por D. Juan Antonio de las Casas, por D. Joachim Ibarra, Impresor de Cámara de S.M., Madrid, MDCCLXXIV. Hay reedición de Alianza Editorial, Madrid, 2004.

25 De quien fue Juan Antonio de las Casas, su profesión o sus actividades, no hay datos de ninguna clase, aunque en algún texto se refieren a él como "abate", lo cual es un tanto equívoco pues es un tratamiento eclesiástico usual en Francia, pero no en España. Por ese motivo se ha especulado con la posibilidad de que se tratara de un seudónimo de alguien que, por razones de prudencia, prefirió no aparecer como traductor. Algunos atribuyen la traducción a un supuesto abate Juan Alves o Álvarez, al que menciona Alejandro Verri, como el verdadero traductor de Beccaria. En todo caso hay que recordar que durante muchos años las traducciones de la obra de Beccaria aparecían sin mencionar el nombre del traductor o bajo un nombre supuesto. La edición de la obra que más se difundió en América fue la de 1828, en la que no consta el nombre del autor, y la razón última era la inclusión de la obra en el Índice de libros prohibidos (cfr. Zaffaroni, R. E. «La influencia del pensamiento de Cesare Beccaria sobre la política criminal en el mundo», cit., p.521).

26 Es sabido que Jovellanos usó palabras de Dei delitti e delle pene para concluir su obra teatral " $E l$ delincuente honrado”, obra compuesta, según Calvo, hacía 1773 (Calvo Gonzáles, J. «Lacrimae \& Luminos: el delincuente honrado de Gaspar Melchor de Jovellanos». En Revista Jurídica de Investigación e Innovación Educativa, nº 7, 2013, p.18 y 25.

27 Sobre este fantástico personaje, vid. "Valentín de Foronda, Los sueños de la razón", Biblioteca de visionarios heterodoxos y marginados, edición de M. Benavides y C. Rollán, Madrid, Editora Nacional, 1984.

28 Vid.: Prieto Sanchís, L. «La filosofía penal de la ilustración española». En Libro Homenaje al Dr. Marino Barbero Santos, Ediciones de la Universidad de Castilla-La Mancha, Ediciones de la Universidad de Salamanca, Cuenca, 2001. 
españoles antes de la traducción ${ }^{29}$. Pero, lógicamente, el gran impacto se producirá con la traducción de Juan Antonio de las Casas que hizo posible el acceso a la obra a círculos mucho más amplios de personas. Sería injusto y equivocado, en cambio, que los alegatos contra la tortura no se produjeron hasta entonces (1774) pues ya se habían escrito en España importantes alegatos contra ella, especialmente a raíz de la aparición de la obra de Acevedo $^{30}$ a la que me he referido, y aun antes, y por plumas de la talla del P. Jerónimo Feijoo ${ }^{31}$ o, con mucha mayor fuerza, del P.Sarmiento ${ }^{32}$.

La publicación del libro, en un principio, no fue especialmente difícil. La impresión fue autorizada tras un dictamen crítico de la Academia de la Historia, en donde el eje central era que en ningún caso se podía poner en cuestión la obediencia a las leyes. Tan fue así que el traductor, el abate Juan Antonio de las Casas tuvo que añadir un prologo advirtiendo que "...el autor ha protestado en muchas partes de la obra y su apología, la sumisión y respeto que tiene y predica que los demás deben tener a las leyes dominantes del País en que cada uno reside;...el parecer de un filosofo con esta clase de materia podrá acaso servir e ilustrar a los príncipes y magistrados a cuyo cargo está el gobierno de los hombres pero nunca fomentar la vana confianza de los que sin discurrir, deben obedecer..." Con excusa y crítica se consiguió la autorización.

Pero tan pronto como comenzó la circulación de la obra empezaron los tremendos ataques que culminarían con la decisión de prohibirla tomada por el Santo Oficio (la Inquisición) en 1777. La prohibición, en sí misma era solo el último de los avatares por los que pasó la obra en aquellos años ${ }^{33}$ en los que sufrió ataques demoledores hasta que lograron que se prohibiera su difusión.

Se ha llegado a decir, y creo que no es acertado, que en la causa profunda de rechazo a la obra de Beccaria hay que situar la extensión y "normalidad" del tor-

29 Cfr. Torío López, A. «Beccaria y la Inquisición española», cit., p.392. Sobre ese período, vid.: Herrero, C. La justicia penal española en la crisis del poder absoluto (1750-1845). Madrid, ed. Ministerio de Justicia, 1989.

30 Luis Bermejo, J.L. «Una disertación académica de fines del Antiguo Régimen sobre tortura judicial». En Anuario de Historia del Derecho español, no 72, 2002, p. 325 y ss.

31 Así, la "Paradoja Décima", dentro de las "Paradojas políticas y morales" que el P. Feijoo incluye en el Tomo VI de su "Teatro crítico universal", en donde trata de la injusta inutilidad de la tortura. La obra había aparecido en 1734 (hay edición elect. de la Biblioteca Feijoniana).

32 Rodríguez Ennes, L. y Allegue, P. «Reflexiones sobre algunas ideas punitivas del P. Sarmiento», cit., p.871. Según Santos Puerto, el P. Sarmiento pudo ser el autor de la "Sinapia", obra considerada como la expresión máxima del pensamiento español de la primera mitad del s. XVIII. Vid.: Santos Puerto, J. La Sinapia: luces para buscar la utopía de la Ilustración. Bulletin Hispanique, Año 2001, Volumen 103 n , pp. 481 y ss. Sobre esta obra, también Avilés Fernández, M. Sinapia. Una utopía española del Siglo de las Luces. Editora Nacional, Madrid, 1976.

33 Sobre las vicisitudes por las que la obra de Beccaria pasó en aquellos años, vid. Antón Mellón, J. «Las reformas penales durante el reinado de Carlos III...», cit. pp. 152 y s. 
mento y la pena de muerte en la sociedad española, especialmente por la tradición inquisitorial ${ }^{34}$.

El protagonismo mayor de los ataques a Beccaria no vino tanto del mundo de los juristas -que incluso fue sensible a las ideas del Marqués- como del clero. Hay que recordar que la Iglesia ya en 1766 -sobre todo a la vista de que el libro, había tenido una rápida difusión en Francia, logrando seis ediciones en dieciocho meses y que había recibido la valoración positiva de Voltaire- decidió incluir en el Índice ${ }^{35}$ a Dei delitti e delle pene, lo cual no impidió la divulgación de la obra, e incluso la fomentó, como sucedería años más tarde con la prohibición de la obra de Gaetano Filangieri ${ }^{36}$.

Especialmente brutal contra la obra de Beccaria fue el ataque que le dirigió un fraile jerónimo fanático, pero muy respetado en su tiempo, Fray Fernando de Cevallos, autor de "La falsa filosofía o El ateísmo, deísmo, materialismo, y de más nuevas sectas convencidas de crimen de Estado" Madrid, 1774-1776. La "Falsa filosofía...", se componía de siete tomos dedicados íntegramente a combatir a la Ilustración y a los enciclopedistas, y tan desaforados y excesivos fueros los insultos que Cevallos lanzó a diestro y siniestro, junto con su encendida defensa de la bondad

34 En ese sentido, Jacobs, H. «Die Beccaria-Rezeption in Spanien». En Gegen Folter und Todesstrafe: aufklärerischer Diskurs und europäische Literatur vom 18. Jahrhundert bis zur Gegenwart, coord. por Jacobs, Lang, Frankfurt am Main, 2007, p.75 a 77. Esa normalidad de la pena de muerte la relaciona, incluso, con las ejecuciones populares que aparecen en el teatro de Calderón y de Lope de Vega.

35 Por estar escrito por un penalista sacerdote, tiene interés las palabras de A. Beristain: “... considero oportuno censurar que muchos (la mayoría de los) canonistas y teólogos anteriores a Beccaria no auscultasen v no criticasen la lamentable situación de la política criminal de entonces, violadora de elementales derechos de los hombres y de los pueblos; que los teólogos coetáneos no aplaudiesen - desarrollasen - su obra, sino al contrario algunos la criticasen (como el Padre Zevallos), e incluso, el 20 de junio de 1776, el Tribunal del Santo Oficio la incluyese por edicto inquisitorial en el Índice de libros prohibidos. Condena que ha perdurado hasta la desaparición del Índice, por obra y gracia del Concilio Vaticano 11. Con relativo rubor y dolor escribo esta nota, en la línea que Sehillebeecks denomina "la hoy deseable y provechosa «eclesiología negativa» que corrige el prurito de superioridad de muchos siglos" (Beristain, A. «Derechos humanos en perspectiva metarracional: Observaciones criminológicas sobre Beccaria». En Protección de los derechos humanos en derecho penal internacional y español, VVAA, coord. por Beristain y Cuesta Arzamendi, Publicaciones de la Universidad del País Vasco, 1989, p.144).

36 Como no podía ser menos, en atención a sus ideas sobre el origen de las leyes, la necesidad de reformar la justicia, y la de abolir los privilegios de la nobleza y del clero, la Iglesia Católica prohibió la difusión y lectura de la obra de Filangieri incluyéndola en el "Índice de libros prohibidos", para lo cual se tomó en cuenta un "informe" sobre los errores de Filangieri redactado por un canónigo de Tarragona, Félix Amat, que andando el tiempo sería premiado con un ascenso a Arzobispo, y que estaba considerado como "ilustrado y jansenista". Como han destacado los estudiosos de la época, la inclusión en el Index sirvió para aumentar la difusión de la obra, especialmente durante el Trienio liberal (1820-1823). 
del tormento y de los poderes de la Inquisición, que provocó que también su obra acabara siendo prohibida, pues en la Corte de Carlos III abundaban ilustrados que no podían soportar la lluvia de insultos retrógrados ${ }^{37}$.

Pero antes de que eso sucediera se explayó en ataques a todos los ilustrados y, entre ellos, a Beccaria y a su traductor al español (De las Casas), insultos que incluían descalificaciones personales y agresiones a la dignidad y probidad de los insultados. El Santo Oficio, que a buen seguro fue sensible a la feroz crítica del fraile, prohibió la difusión de la traducción del "Dei delitti...", pero el Consejo de Castilla toleró la circulación de la obra.

Esta discrepancia de criterios entre la Iglesia y el poder civil era expresiva de un problema que iba más allá de la obra de Beccaria, aunque ésta provocara uno de los más conocidos choques. En el reinado de Carlos III se produjo un claro distanciamiento entre Iglesia y Monarquía a causa precisamente de la "eficacia civil" que deseaba la Iglesia para sus prohibiciones y anatemas.

En 1762 ya se había advertido que la publicación de decisiones eclesiásticas tenía que ser autorizada por la Corona, y buena muestra de la profundidad de esa divergencia de criterios fue la exposición que Campomanes ${ }^{38}$ y Floridablanca, Ministros de Carlos III, le hicieran señalando que el abuso de las prohibiciones de libros ordenadas por el Santo Oficio es una de las fuentes de ignorancia que reina en gran parte de la nación y en su virtud, en 1768 se ordenaba a la Inquisicion que antes de efectuar cualquier prohibición, sometiera el proyecto correspondiente a la autorización del Rey ${ }^{39}$.

Pero a pesar de todo ese ambiente aparentemente favorable a tolerar la circulación de la obra de Beccaria, la prohibición acabó produciéndose. Hay que tener en cuenta que, dejando de lado al clero, la posibilidad de que las ideas de Beccaria cuajaran en la sociedad española de aquellos tiempos ${ }^{40}$ eran muy pocas. Cuestionar la pena de muerte o el poder omnímodo del soberano para dictar las leyes penales que le vinieran en gana, era intolerable. En el entorno de Carlos III hubo claros

37 Sobre este personaje, vid. el interesante texto de Robledo Hernández, R. «El Padre Cevallos, ¿"humilde capellán" de Godoy? El Plan de Universidades de 1796». En Trienio. Ilustración y liberalismo. Revista de Historia, 59, 2012. Vid., también, Calabrò, G. «Beccaria e la Spagna» Atti del Congreso Internazionale su Cesare Beccaria, Torino, 1966.

38 Aunque no está demostrado, según algunos Pedro Rodríguez de Campomanes, ministro de Carlos III podría ser el autor de la primera traducción de Dei delitti e delle pene, ocultándose bajo el seudónimo de Juan Antonio de las Casas.

39 Torío López, A., op. cit., p. 393.

40 Sin duda que serían permeables a ellas los liberales reunidos en Cádiz (1810), pero con la breve excepción del Trienio Liberal (1820-1823), era imposible que nadie osara defender ideológica políticamente aquellas ideas sin pagar un alto precio por ello. 
defensores de la necesidad de reformar la justicia y las leyes penales ${ }^{41}$, pero más allá de los buenos deseos, muy pocas fueron las reformas reales, y, además, se produciría una progresiva involución a partir del reinado de Carlos IV.

Sobre las razones por las que la primitiva tolerancia hacia la obra dejó paso a la prohibición mucho se ha especulado. Para unos, la Corona no quería tener problemas con la Inquisición y la Iglesia. Para otros, más severos en su juicio, el Poder civil y la Monarquía llegaron a la conclusión de que las ideas del Marqués podían poner en peligro la propia autoridad real.

En opinión de Torío ${ }^{42}$, el dictamen del Santo Oficio apuntaba precisamente en esa dirección: la obra ponía en cuestión no la ley divina, sino el Poder civil, y seguramente eso causó en los gobernantes el efecto deseado por la Iglesia. Las ideas contractualistas podían fácilmente presentarse como un ataque revolucionario a la monarquía absoluta, a la que además -según el Santo Oficio- se presentaba como Poder apoyado en leyes atávicas y crueles, y a los jueces que aplicaban las leyes del Reino al solo servicio de los poderosos. La mera crítica a la pena de muerte era presentada como una crítica y negación de los propios poderes del Rey.

Los reformadores ilustrados españoles, que sinceramente deseaban cambiar las durísimas leyes penales de la época, se encontraron solos en la defensa de sus ideas, impotentes ante la estrategia de ataque organizada desde el clero, que además prodigaba las acusaciones de blasfemia, tolerancia con el pecado, negación de la inspiración divina de las leyes y, en suma, todo el ideario iusnaturalista que venía acumulándose desde la Escolástica del siglo XVI.

Incluso en un problema tan crucial como el de la legitimidad de la pena de muerte, el Santo Oficio encontró argumentos extraídos del Antiguo Testamento para justificarlo como realización de la justicia divina ${ }^{43}$, y, de paso, legitimar sus propias condenas a muerte que todavía estaban presentes en el s. XVIII. A eso ha de sumarse otro factor, que era la tibieza de los que eran contrarios a la pena de muerte, con muy pocas excepciones. La aplicación de la pena máxima estaba tan arraigada en la sociedad española de la época (y en todas las europeas) que los detractores corrían el riesgo de ser insultados bajo la acusación de amigos de los criminales. Por esa razón, a lo más que se atrevían era a reclamar que no se castigara a muerte a personas que solamente habían cometido pequeños robos, pero poco más.

\footnotetext{
41 Entre otros, Jovellanos y sus muchos escritos jurídicos. Es cierto que a finales del reinado de Carlos III apareció un esbozo de un Código Criminal (considerando la de codificar como una idea ilustrada), pero que no llego a fructificar. Sobre ese intento vid.: J. R. Casabó, "Los orígenes de la codificación penal en España: el plan de Código criminal de 1787”, ADP, 22, 1969.

42 Torío López, A., op. cit., p.397 y ss.

43 Cfr. Torío López, A., op. cit., p.400.
} 
La prohibición de la obra de Beccaria duró, formalmente, bastante tiempo. La Inquisición continuó obsesivamente persiguiendo ejemplares de la obra, que circulaba de modo clandestino con una gran profusión (como habría de suceder con la obra de Filangieri).

Pero la macabra vida de la Inquisición tocaba a su fin. Las Cortes de Cádiz declararon que era incompatible con la Constitución de 1812. El siniestro Rey Fernando VII la restauró formalmente en 1814, pero pronto fue de nuevo disuelta durante el llamado Trienio Liberal. Finalmente, un Decreto firmado por la Regenta María Cristina el 15 de julio de 1834 supuso la abolición definitiva, aunque la obra de Beccaria continuaría en el Índice de libros prohibidos por la Iglesia hasta la $32^{\mathrm{a}}$ edición del mismo, que fue la de 1948.

\section{LARDIZÁBAL, COMO "BECCARIA ESPAÑOL"}

Existe unanimidad en sostener que el personaje más influido por la obra de Beccaria fue Manuel de Lardizábal, hasta el punto de tenerlo, en palabras de Q. Saldaña, como el "Beccaria español" (y especialmente lo sienten así en México, pues había nacido en San Juan del Molino, Tlaxcala, el 22 de diciembre de 1739). Es además importante recordar que la obra de Lardizábal se difundió por América Latina, siendo así una vía indirecta de divulgación de parte de las ideas de Beccaria, aunque solo sea porque Lardizábal, en muchas de sus tomas de postura, comienza por exponer la opinión de Beccaria para luego desarrollar su propia opinión, acorde o desacorde con la de Beccaria.

Pero sobre esa idea hay que hacer algunas precisiones, sin poner en duda que la obra capital de Lardizábal, el Discurso sobre las penas: contraído a las leyes criminales de España para facilitar su reforma, tuvo una enorme influencia en la cultura hispánica de la época, y que para muchos hacen del personaje el máximo ilustrado en la evolución de las ideas penales en España, idea que otros no compartimos plenamente.

El año 1776 Lardizábal recibió un encargo del Consejo Real, para que sistematizara y recopilara las distintas leyes penales entonces existentes. De ese encargo nació su «Discurso sobre las penas... " La obra apareció en 1782. Por aquel entonces la literatura enciclopedista se había difundido ampliamente. A buen seguro Lardizábal tuvo un "espíritu reformador" pero, por razones fácilmente suponibles, también tuvo que conocer la persecución y prohibición de la obra de Beccaria y la virulenta actitud de la Iglesia a través de la Inquisición, y sabía cuántos autores habían sido ya condenados (no solo Beccaria).

Situado en ese escenario, Lardizábal escribe su obra procurando "no molestar" ni a la Iglesia ni al Poder Real. Por lo tanto, no pondrá en duda los componentes católicos-iusnaturalistas del pensamiento jurídico dominante en la época y no osará 
referirse abiertamente al contrato social como explicación de las relaciones entre gobernantes y gobernados.

La obra de Beccaria tuvo un sesgo revolucionario, la de Lardizábal mucho menos. El iluminismo de Lardizábal se manifiesta netamente cuando dice que «... el conocimiento exacto de la justicia esencial y primitiva escrita en el código de la naturaleza...es fuente y origen de toda legislación y de las relaciones entre la sociedad y sus individuos. A ese conocimiento contribuirá la filosofía, toda vez que las leyes vigentes no constituyen tal fuente de razón y deben ser reformadas..." Reclama que las penas sólo puedan imponerse al hombre «por el acto propio y moralmente imputable...» y se acerca al contractualismo de Beccaria de dos maneras. La primera cuando admite que las penas se explican porque los hombres cedieron parte de su libertad para constituirse en sociedad; la segunda cuando afirma que a partir de dicho pacto social, el derecho a establecer leyes y penas corresponde exclusivamente al Príncipe, cuya figura y función es imprescindible para el funcionamiento de la sociedad. Ahí, en su idea del Príncipe, es donde se aleja abiertamente de los iluministas, pues Lardizábal estimaba fuera de discusión que la potestad suprema del Príncipe de dictar y aplicar leyes, necesaria para la conservación de la sociedad, es de origen divino, lo cual no era muy revolucionario, sino lo propio de un sumiso súbdito de Carlos III.

Hay que añadir que Lardizábal, por tantos considerado el máximo penalista ilustrado, discrepaba de Beccaria en un punto esencial: el derecho a discrepar y criticar la voluntad del Soberano. Es cierto que coincidía con Beccaria cuando reclama la necesidad de que las penas se proporcionen a los delitos, no sean innecesariamente duras, y estén claramente expresadas en la ley, así como que los procesos sean prontos y públicos. El fin de prevención general que asigna a la pena requiere que ésta sea pública e irremisible, pero no cree claramente en el principio de legalidad, pues, en contra de Beccaria, y de todos los que propugnaban el imperio de la ley (Montesquieu, Rousseau) Lardizábal propugna un cierto arbitrio judicial para que el juez pueda resolver aquellos casos no descritos acudiendo al espíritu de la ley o a la «voluntad del legislador», que puede ser la del propio Príncipe.

En cambio, y es justo reconocerlo, en ciertas materias Lardizábal hace alarde de una profundidad jurídica que no se aprecia en Beccaria. Expone principios sobre la autoría y la participación, sobre los grados de ejecución del delito, sobre las circunstancias que han de influir en la determinación de la pena, sobre la diversa gravedad de pena que conviene al hecho intencional y al culposo. Se refiere a la conveniencia de arbitrar en las leyes escalas de penas, y de contar con una organización penitenciaria que cuente con varias especies de establecimientos de cumplimiento, en virtud de las diferencias de edad, sexo, y condición de los presos. Igualmente aborda cuestiones como el error, la ignorancia, la enfermedad 
mental, etc. Esboza, pues, un sistema penal completo, inexistente en la obra de Beccaria. El juicio global que merece la obra del español es que supone, políticamente, una actitud conservadora respecto a Beccaria y otros ilustrados, aunque constituyese ya un progreso para España.

En suma, Lardizábal era un personaje con criterio jurídico profundo, pero con vocación de obediente. En cambio, Jovellanos, que para muchos fue el máximo representante de la Ilustración en España, sintió tanta admiración por Beccaria que en su drama teatral "El delincuente honrado" concluye el texto poniendo en boca del protagonista una frase de Beccaria ${ }^{44}$.

\section{LAS SUCESIVAS TRADUCCIONES DE LA OBRA DE BECCARIA Y SU INFLUENCIA EN LOS JURISTAS ESPAÑOLES}

Tras las dificultades con que topó la primera edición se fueron sucediendo otras muchas, y cabe señalar dos características: la primera es que una buena parte de ellas, tal como dije antes, no indican el nombre del traductor, o incluyen un nombre que posteriormente se ha comprobado que no correspondía a persona concreta alguna.

La segunda característica es que la mayoría de las traducciones lo son de la versión francesa, la que en su día hiciera el abate Morellet, que como es sabido se trataba de un texto en el que el traductor introdujo alteraciones que no se limitaban al estilo, sino que afectaban a la estructura de la obra y la ordenación del pensamiento del Marqués, con independencia de que, como también es sabido, el propio Beccaria acabara dando su conformidad a las modificaciones de Morellet. Se puede asegurar que la traducción al español de la versión francesa tuvo posiblemente mayor difusión que la del original en italiano.

La influencia de Beccaria en los juristas españoles, como he dicho antes, se percibe en obras de Ilustrados famosos. Pero esa es una influencia intelectual que lentamente se plasmaría en concretas reformas. La visibilidad de la influencia de Beccaria (y también de Bentham) se habría de ver en los debates que precedieron a la promulgación del Código penal de 1822, que fue el primer Código español.

El Código de 1822 era consecuencia de la Constitución de Cádiz de 1812, que introducía por vez primera la idea de "codificar" el derecho ${ }^{45}$. El Discurso Preliminar a la Constitución fue elaborado por Agustín de Arguelles, y recogía las opiniones penales de Montesquieu y Beccaria, pese a lo cual la Constitución misma no

44 Cfr. Fernández Fernández, L.L. Jovellanos: antropología y teoría de la sociedad. Madrid, UP Comillas, 1991.

45 El artículo 258 de la Constitución de 1812 disponía: "El Código civil y criminal y el de comercio serán unos mismos para toda la Monarquía, sin perjuicio de las variaciones que por particulares circunstancias podrán hacer las Cortes". 
tenía una afirmación tan expresa como la del artículo 8 de la Declaración francesa de 1789 , esto es una enunciación inequívoca del carácter de legalidad previa que debiera tener toda figura delictiva y toda pena.

En el debate sobre previo a la promulgación del Código, conservados en los Diarios de Sesiones, es comprobable que los autores más citados son Bentham en primer término, seguido de Beccaria, Montesquieu y, alguna vez, pocas, a Lardizábal.

\section{LA INFLUENCIA TARDÍA DE BECCARIA EN AMÉRICA LATINA}

\section{V.1. La ilustración en América hispana y lusa}

Al hablar del Iluminismo o la Ilustración en América Latina hay que comenzar con algunas puntualizaciones:

La primera pasa por distinguir entre dos cuestiones distintas: saber si el libro Dei delitti e delle pene llegó a América latina y se difundió, y, como problema bien distinto, si las ideas de Beccaria encontraron en eco en la intelectualidad de la época con independencia de que el libro se editara en alguno de aquellos países.

En segundo lugar hay que recordar que el libro aparece en 1764, momento en que en España reina Carlos III y en que toda Latinoamérica forma parte de la Corona española, pues los movimientos independentistas no se producirán hasta la segunda década del siglo XIX. Siendo así resulta algo forzado establecer diferencias entre el impacto de Beccaria en el territorio de la Península y en las tierras americanas.

En la América latina portuguesa la situación es parecida: al tiempo de la publicación del libro reina en Portugal José I y Brasil es un territorio colonial que no será independiente hasta el 7 de septiembre de 1822, siendo proclamado el 12 de octubre el Príncipe Pedro, hijo de Juan VI, emperador de Brasil con el nombre de Pedro I.

La realidad de la situación colonial, unida al nivel de las comunicaciones propio de la época, explica la tardanza en la llegada de un pensamiento jurídico que cuestiona de raíz incluso el modelo de Estado, pero esa llegada se produjo gracias a la obra de los penalistas ilustrados de España y de Portugal, especialmente Lardizábal, de quien ya he tratado, y Mello Freire dos Reis ${ }^{46}$, al que me referiré después.

La traducción (anónima) española de $1822^{47}$, reeditada en 1828 fue la que más se difundió en América hispana. En cuanto al portugués, se conoce la edición de Rio de Janeiro de 1837. El tiempo de las traducciones no significa que la obra no fuera previamente conocida por la intelectualidad hispana y portuguesa de la época que pudo disponer de la versión italiana y de la versión francesa.

46 Sobre este punto, Zaffaroni, R.E. «La influencia del pensamiento de Cesare Beccaria sobre la política criminal en el mundo», cit., p.525 a 528.

47 Aparece fechada en 1822, Madrid, Imprenta de Albán, añadiendo que: "hállase también en casa de Rosa, en Paris, gran Patio del Palacio Real". 
En todo caso: no hay duda de que el pensamiento ilustrado o iluminista estaba presente en la América latina del último tercio del siglo XVIII. Precisamente por eso es posible plantear la realidad de la influencia de Beccaria.

\section{V.2. En la América hispana}

Lógicamente, las obras de los ilustrados españoles llegaban a los territorios americanos. El más conocido fue Lardizábal -de quien se ha tratado antes. Pero la influencia más visible fue la indirecta, esto es, la que tuvo el CP español de 1822 en los procesos legislativos de las nuevas Repúblicas independientes. El caso más significativo sería el de Bolivia, que con pocas variaciones adoptó el Código español de 1822 como propio.

\section{V.3. En el mundo luso-brasileño}

Parece aceptado por los historiadores portugueses que los juristas formados en Coímbra fueron los introductores del racionalismo jurídico en Brasil, en tanto que fueron a su vez los que constituyeron las élites pensantes en la Administración pública. Aquel fenómeno fue consecuencia de las reformas educativas impulsadas por el Marqués de Rombal ${ }^{48}$, todopoderoso Primer Ministro, que determinaron el declive de la influencia de la formación jesuítica en los estudios jurídicos. Gracias a ello Portugal recibió la influencia del Iluminismo y eso llevaría, con el paso del tiempo, a la búsqueda de la racionalización del derecho a través de la Codificación, que muy pronto se llevó a cabo en Portugal (el Código de 1837, aunque no llegó a entrar en vigor) y también en Brasil. La reforma de los contenidos en la enseñanza del derecho fue decididamente el factor que determinó la extensión del iluminismo en los juristas luso-brasileños ${ }^{49}$, y, con mayor fuerza incluso, el ideario jurídico que -con todas las contradicciones propias de la época- domina el Brasil, independiente a partir de $1827^{50}$.

El Iluminismo tuvo en Mello Freire ${ }^{51}$ el que tal vez sería el más importante jurista de su época. Fue el impulsor de la revisión de las viejas Ordenadores Filipinas, trabajo del que surgieron dos proyectos: el Código de Derecho Público y el Código de Derecho Criminal. Este proyecto no superó la censura, pero en él se plasmaban las ideas que Mello Freire expondría en sus Instituciones de Derecho Criminal Portugues, obra que abiertamente se adscribe al contractualismo y declara como principal influencia la obra del Marqués de Beccaria, sin perjuicio de citar también a Montesquieu, Grocio, Pufendorf y Locke y Filangieri.

48 Concretamente la Lei da Boa Razão, de 18 de agosto de 1769.

49 De Carvalho, S. Pena e garantías. Rio de Janeiro, 3a ed. Lumen Juris, 2008, p. 51.

50 Vid.: Rodrigues Maciel, J.F. A Lei da Boa Razão e a formação do direito brasileiro. Carta Forense, 2008.

$51 \quad$ Pascoal José de Melo Freire dos Reis, 1738-1798. 
La importancia de la obra de Mello Freire se apreciará después, cuando se discute en Brasil el que habría de ser Código penal de 1830, pues en aquellos debates era constante la referencia a su obra, y, a través de ella, a las ideas iluministas con Beccaria en cabeza.

De la importancia que tuvo el Código penal del Brasil solo quisiera hacer una última observación, por lo que supone indirectamente para la historia de la codificación española. El Código penal español de 1848 fue redactado por una Comisión que dejó constancia de que se inspiraban en las virtudes del Código del Brasil y también del Código del Reino de Nápoles, aunque en menor medida. La influencia de Beccaria en Mello Freire, y la de éste en el Código del Brasil, permite trazar una línea de continuidad que a través de los años hace pervivir la sombre del Marqués.

\section{LA CONTINUACIÓN DE LA INFLUENCIA: GAETANO FILANGIERI}

La obra de Beccaria fue objeto de continua persecución por parte de la Iglesia española. Ese especial "privilegio" le habría de ser dispensado solo a otra obra fundamental en la historia del derecho penal: la de Gaetano Filangieri (1753-1788), concretamente su Scienza della Legislazione ${ }^{52}$, obra de carácter político, económico y jurídico-penal, que también fue duramente denostada. Ambas obras son, sin duda, los textos capitales del Iluminismo penal. Pero vayamos por partes:

A comienzos del siglo XIX, el influjo reformista de Beccaria se percibía en la obra de legisladores y científicos del Derecho penal, propiciando la aparición y difusión en España de las obras de otros reformadores como eran Bentham, Filangieri, y Romagnosi, cuyas obras son menos revolucionarias, pero sin duda de superior categoría técnico-jurídica que la de Beccaria, pues suponen construcciones más o menos completas de un sistema de Derecho penal, si bien sus planteamientos no pueden inscribirse directamente en el Derecho penal «moderno», hecho que, según opinión dominante no se producirá hasta la publicación en 1801 de la obra de Feuerbach "Lehrbuch des gemeinen in Deutschland geltenden peinlichen Rechts,"; pero esa es otra cuestión que nos alejaría del tema de la influencia italiana.

Veamos que sucede con Romagnosi y Filangieri, este último tenido en Italia como padre de la ciencia penal ${ }^{53}$. La obra de Romagnosi, que tuvo gran impacto en Italia, no tuvo prácticamente eco en la España de aquel tiempo, tal vez porque su obra "Genesi del diritto penale" no había sido traducida al español (no lo sería hasta $1956^{54}$ ), o tal vez porque sus ideas "defensistas" lo colocaban más cerca de lo que mucho tiempo

52 La "Scienza della legislazione", aparece en Napoli, Stampa, Raimondiana. La primera edición es de 1780, y le habrían de seguir nuevas ediciones en Nápoles y en diferentes ciudades de Italia (cfr. Sánchez Osés, J. «Gaetano Filangieri». En Anuario de Derecho Penal, 1966, III p.417).

53 Cfr. Spirito, U. Storia del diritto penale italiano. Roma, 1925.

54 Romagnosi, G.D. Génesis del Derecho penal. Trad. de González Cortina y J. Guerrero, Editorial Temis, Bogotá, 1956. 
después serían los positivistas naturalistas (que, por cierto, lo tuvieron como precursor). Pero lo cierto es que no se encuentra en la literatura de la época reflejo de sus ideas, a pesar de que hoy no se cuestione en modo alguno su importancia histórica, pues se ha llegado a decir ${ }^{55}$ que comparte con Feuerbach el título de fundador del derecho penal científico. En todo caso, su prestigio, en su tiempo, fue enorme, y trabajó intensamente en el Progetto di Codice Penale per il Regno d'Italia, inspirado por Napoleón, en tanto que invasor dispuesto a unificar la península en una sola corona, que no llegó a entrar en vigor, pero que fue considerado "perfecto" por los juristas de la época, y que sin duda influyó en Carmignani y Carrara.

La significación de Filangieri para España fue bien otra. Su obra máxima fue la colosal "Ciencia de la legislación", que estaba llamada a influir poderosamente en los economistas y en los penalistas españoles, portugueses y latinoamericanos. Nada se descubre diciendo que en el siglo XVIII español las ideas de los ilustrados no gozaron de comprensión y apoyo, antes al contrario. La fuerza de la ya citada obra de Cevallos no puede entenderse sin ese difuso consenso en contra del progreso, y la ortodoxia católica fue consiguiendo frenar la difusión de ideas nuevas incluso contra la propia voluntad real en algunos casos. Esa gran cantidad de fuerzas reaccionarias se puso, como señala Astigarraga, “.... la defensiva ante la llegada a España de los primeros ecos de la publicación en Nápoles de la Scienza della legislazione y que, después, emprendieran una dura batalla de oposición a esa obra..." ${ }^{56}$, razón por la cual la entrada de la obra en España fue trabajosa ${ }^{57}$.

No ha de extrañar, pues, que un edicto de la Inquisición de 1790, prohibiera su lectura, y ese edicto estaba pensando tal vez en la edición italiana, pues la versión española, realizada por Jaime Rubio entre 1787 y 1789 había sufrido la censura del propio traductor que había suprimido pasajes que no le parecieron adecuados además de añadir estudios críticos en cada parte ${ }^{58}$, y así se mantuvo en sucesivas ediciones $^{59}$. Posteriormente se publicarían otras traducciones ${ }^{60}$.

55 Así, Sainz Cantero, J.A. «El informe de la Universidad de Granada sobre el proyecto que dio tugar al Código Penal de 1822». En Anuario de Derecho Penal, F.I, 1967.

56 Astigarraga, J. «La Ilustración napolitana imputada. Críticas y censuras a la Scienza della legislazione de G. Filangieri en la España de finales del siglo XVIII». En Nuevo Mundo, 18/6/2007, texto PDF, 5.

57 Lalinde Abadía, J. «El eco de Filangieri en España». En Anuario de Historia del Derecho español, $\mathrm{n}^{\circ} 54,1984$, p. 478.

58 No solo la Iglesia cargó contra la Scienza, sino también importantes sectores intelectuales (Astigarraga, J. op. cit., 6).

59 Ciencia de la Legislación. Escrita en italiano por el Caballero Cayetano Filangieri. Traducida al castellano por Don Jaime Rubio, Abogado de los Reales Consejos. Madrid, Manuel González, 1787-1789. Del mismo, Ciencia de la Legislación escrita en italiano por el Caballero Cayetano Filangieri, y traducida al castellano por Don Jaime Rubio, abogado de los Reales Consejos. $3^{\mathrm{a}}$ ed. corregida y añadida con discursos analíticos en cada libro, Madrid, Imprenta de Núñez, 1822.

60 Ciencia de la Legislación. Obra escrita en italiano por el Caballero Cayetano Filangieri. Nuevamente traducida por Don Juan Ribera. Madrid, Fermín Villalpando, 1821-1822; Ciencia de la Legislación, 
De Filangieri se dice que fue quien tradujo en conceptos técnico-jurídicos los principios del iluminismo y, partiendo de ello, construyó un completo sistema de derecho penal. Hay que añadir que Filangieri no solo se ocupaba de problemas penales ${ }^{61}$ sino también mercantiles y económicos ${ }^{62}$ (por cierto, al igual que Jeremy Bentham), lo cual le concede un puesto fundador también en la historia del pensamiento económico, y hasta se considera por algunos que las primeras traducciones parciales de la obra de Filangieri no fueron una iniciativa de penalistas, sino de Victorian de Villava ${ }^{63}$; pero en todo caso su importancia como economista, y su conocimiento de la situación de Europa y de España eran muy notables, y dieron lugar a críticas tanto o más duras que las que recibió en su dimensión de penalista ${ }^{64}$.

Como no podía ser menos, en atención a sus ideas sobre el origen de las leyes, la necesidad de reformar la justicia, y la de abolir los privilegios de la nobleza y del clero, la educación, la Iglesia Católica prohibió su difusión y lectura incluyéndola en el "Índice de libros prohibidos", para lo cual se tomó en cuenta un "informe" sobre los errores de Filangieri redactado por un canónigo de Tarragona, Félix Amat, que andando el tiempo sería premiado con un ascenso a Arzobispo.

Hay que añadir que, como han destacado los estudiosos de la época, la inclusión en el Index sirvió para aumentar la difusión de la obra, especialmente durante el Trienio liberal. Pero al igual que sucedió con la obra de Beccaria, la difusión tam-

Por el Caballero Cayetano Filangieri, nuevamente traducida por don Juan Ribera, Imprenta de don Pedro Beaume, Bordeaux 1823; “Compendio de la ciencia de la legislación. Compendio de la obra que escribió el caballero Filangieri, titulada Ciencia de la Legislación, con notas de los autores más clásicos, redactado en el año 1834", por Bernaldo Latorre, Madrid, Imprenta de I. Boix, 1839.

${ }_{61}$ La obra de Filangieri fue también traducida al inglés, al francés, y al alemán. Se dice que fue uno de los pensadores que estudió Benjamin Franklin, y por él influiría en las ideas plasmadas en la redacción de la Constitución Americana.

62 La concurrencia en unos mismos pensadores de las inquietudes por el derecho penal y por la economía no debe atribuirse al azar o a la excentricidad. Al contrario: encierra una plena coherencia. Desde que en el s. XVI se iniciara en Salamanca lo que luego se llamaría "liberalismo", una preocupación central fueron los temas relativos al precio justo, la honestidad en el trabajo, el salario, la legitimidad de la esclavitud, las reglas del comercio, etc. La base ética que daba sustento a los argumentos sobre esas materias será la misma que se invocará, por los liberales de fin del s. XVIII y principios del XIX para proponer orientaciones para las leyes criminales (sobre el origen del pensamiento liberal y su primitiva relación con la Escolástica, vid.: Vergés, J.C. «Corruptors i corruptes». En Cuaderns Crema, Barcelona, 1999.

63 Astigarraga, J. «Victorián de Villava, traductor de Gaetano Filangieri». En Cuadernos aragoneses de economía, Vol. 7, $\mathrm{N}^{\mathrm{o}}$ 1, 1997.

${ }^{64}$ Una excelente exposición de las ideas mercantiles y económicas de Filangieri, incluyendo sus críticas a la situación económica española, puede verse en Astigarraga, J. «La Ilustración napolitana imputada: críticas y censuras a la Scienza della legislazione de G. Filangieri en la España de finales del siglo XVIII». En Revista Electrónica Nuevo mundo, Mundos nuevos, №. 7, 2007; y del mismo autor, «The great success of Filangieri's Scienza della legislazione in Spain (1780-1839)». En Revista Nuevo Mundo, id., nº 6, 2006. 
bién contó con el apoyo de personajes importantes, concretamente, y como ya dije al principio, Campomanes, pero también Jovellanos, a lo que se sumaba la entonces visible simpatía por lo que se decía en el Reino de las Dos Sicilias, de donde provenía la obra de Filangieri ${ }^{65}$.

De Filangieri se ha dicho que fue un autor plenamente impregnado por el pensamiento contractualista, por lo tanto convencido de que el derecho de punir corresponde a la sociedad, que lo hace por su seguridad y tranquilidad; su contractualismo es más sincero que el de Beccaria lo cual explica que siguiendo a Locke sostuviera que el derecho de punir, que a cada uno corresponde en el estado de naturaleza, ha sido heredado por la comunidad gracias al contrato social, apareciendo así un verdadero derecho a castigar. El delito es contrario a la ley; pero porque esta es fruto de un consenso: el pacto social. Por eso el delito es contrario a la sociedad y a sus derechos (lo que era totalmente diferente de las ideas imperantes sobre el delito como desobediencia al soberano creador natural de la ley).

Si queremos contemplar sus ideas sobre el fundamento de la responsabilidad penal habrá que destacar que para Filangieri el delito no era tanto la violación de la ley, cuanto que era una acción que iba acompañada de la voluntad de violarla, lo que en lenguaje de nuestro tiempo supondría el rechazo de la responsabilidad objetiva $^{66}$. Pero no acaba ahí la gran construcción jurídica de Filangieri (dedica los volúmenes III y IV de su "Ciencia", a las leyes penales), pues formuló un sistema completo, exponiendo tanto los principios de lo que corresponde a la teoría del delito y de la pena como la relación de las acciones que debían ser delictivas y la razón que lo aconsejaba ${ }^{67}$, así como los posibles modelos de organización judicial, con expresa observancia de las diferencias entre el sistema inglés frente a los de otras naciones europeas. Filangieri no criticaba especialmente las leyes vigentes en su tiempo, ya fuera en el Reino de Nápoles (su país) o en España, sino cómo debieran ser esas leyes; por lo tanto se trata de un sistema de estricta creación intelectual que expresa una ideología sobre el fundamento y el fin del derecho de penar, que, por cierto, no residencia en la omnímoda voluntad del Soberano.

65 Astigarraga, J. «Political Economy and Legislation. The great success of Filangieri's Scienza della legislazione in Spain (1780-1839)». En Revista Nuevo Mundo, Mundos Nuevos, Colloques, mis en ligne le 18 mars 2006, 52 y 53.

66 La exclusión de la responsabilidad objetiva, al menos en teoría, se propugna en el derecho inglés desde la famosa decisión de Enrique II (s. XII) a propósito de las condiciones subjetivas para apreciar delito de perjurio: "actus non facit reum nisi mens sit rea". Por lo tanto se incorporó a la cultura jurídica básica de los anglosajones, y eso se ve también en Locke, a quien sin duda estudió Filangieri. No olvidemos que en la Europa continental la regla imperante era la del versari in re illicita, tan cara a la tradición penal española.

67 Una exposición resumida pero interesante de las propuestas de Filangieri, puede verse en Sánchez Osés, J. "Gaetano Filangieri», cit., p.413 y ss. 
Adviértase que, a diferencia de lo que pocos años después sostendrá Carrara, para Filangieri la única finalidad admisible de la pena es la prevención. La cárcel tiene que ser una "pena di correzione" y nada más. El retribucionismo iusnaturalista, que tanto habría de calar en España, no cabía en su propuesta.

$\mathrm{Su}$ carácter de creación intelectual de un ilustrado hace comprensible que su obra, en aquella España, no pudiera tener más que acogida intelectual ${ }^{68}$, que no en la legislación, a pesar de que se aprecia su influencia en el Código penal de $1822 \mathrm{o}$ al menos en los protagonistas de su creación, y también gozó de significativa difusión en la América hispana ${ }^{69}$. Entre los personajes influidos claramente por Filangieri creo que se puede destacar a Valentín de Foronda ${ }^{70}$, que fuera además traductor de la obra de Rousseau, y que, significativamente, compartía con el napolitano la dedicación intelectual a la economía y a las leyes criminales. Sus escritos varios los recogió en las "Cartas sobre los asuntos más exquisitos de la Economía-política, y sobre las leyes criminales", Madrid 1789 y 1794. En ellas Foronda se considera continuador del camino emprendido por Beccaria y Filangieri, aunque compartía también las ideas sobre las penas y su ejecución de Bentham ${ }^{71}$, pero en muchos puntos esenciales sobre la función y límites de las leyes criminales su coincidencia con Filangieri era cuasi literal.

Todo aquel ambiente alcanzó claramente a los redactores de nuestro primer y efímero Código penal de 1822. Al respecto escribió Antón Oneca ${ }^{72}$ : “...En cuanto a legislaciones extranjeras, la Comisión, por labios de -Calatrava, su principal animador y alma de los debates parlamentarios- confesaba ingenuamente «haber tomado muchas cosas del Código francés, pero no haberlo tomado por modelo...”. De fuentes doctrinales cita (las obras de Bentham, Filangieri, Beon) y de los demás que han tenido a mano...". Pero lo cierto es que la resistencia a las ideas de los ilus-

68 Pero entre los ilustrados fue de lectura obligada e influyó decisivamente en la formación de sus ideas penales. Cfr.: Scandellari, S. «La difusión del pensamiento criminal de Gaetano Filangieri en España». En Revista Nuevo Mundo, Mundos Nuevos, [En ligne], Colloques, 28 enero 2007.

${ }_{69}$ Al respecto, vid. el interesante artículo de Morelli, F. «Tras las huellas perdidas de Filangieri: nuevas perspectivas sobre la cultura política constitucional en el Atlántico hispánico». En Historia Contemporánea, 33, 2006, p. 435 y 436. También, Escobar Villegas, J.C. y León Maya, A. «Ilustrados, leyes penales, control social y administración de justicia durante la época de las revoluciones modernas en nueva Granada: una mirada desde la obra de Gaetano Filangieri». En Revista Historia de la Educación Latinoamericana, no 9 2007, págs. 141 y ss.

70 Para conocer al personaje vid.: De Foronda, V. Escritos Políticos y Constitucionales. Ed. de Ignacio Fernández Sarasola, Ediciones de la Universidad del País Vasco, Clásicos del Pensamiento político y social en el País Vasco, Bilbao, 2002.

71 Vid.: De Rivacoba, M. «Últimos escritos penales de Foronda». En Libro Homenaje a Marino Barbero Santos, Ed. de Arroyo y Berdugo. Vol. I, Ediciones de la Universidad de Castilla-La Mancha, Ediciones Universidad Salamanca, Cuenca, 2001.

72 Antón Oneca, J. «Historia del Código penal de 1822». En Anuario de Derecho Penal, II, 1965. 
trados fue muy efectiva, y cuando hablamos de influencias solo nos podemos referir a la presencia de las ideas de Beccaria o de Filangieri en determinados ambientes intelectuales, pero en modo alguno en una legislación ${ }^{73}$ que se resistió a cambiar, y que en materia penal llegaría prácticamente así hasta 1848 .

73 Sobre este punto, Lorente Sariñena, L. «De la suerte normativa de la ciencia de la legislación: Filangieri y la codificación en la España decimonónica». En Revista Nuevo Mundo, Mundos Nuevos, 2007. 



\title{
LA CRUELDAD RAZONADA. LA PENA DE MUERTE EN EL PENSAMIENTO PUNITIVO REACCIONARIO ESPAÑOL
}

\author{
GREGORIO MARÍA CALLEJO \\ Magistrado
}

\section{INTRODUCCIÓN}

Si hay algo en lo que tenía razón (de forma incontestable) el llamado pensamiento reaccionario era en la esencial universalidad y atemporalidad de la pena de muerte. Desde los albores de la humanidad hasta la actualidad se ha matado para castigar. Corresponde al movimiento ilustrado el mérito del cuestionamiento de la imposición de dicha pena, como acto de respeto a nosotros mismos, como conquista propia de los seres que nos llamamos humanos, como limitación razonable y necesaria a la posibilidad de castigo impuesta por el poder público. Desdichadamente, la propuesta que hizo Beccaria no ha sido aún asumida por decenas de Estados. Desdichadamente, aun en los países en los que la pena de muerte está prohibida no deja de haber voces que claman por su restablecimiento ${ }^{1}$.

1 Textualmente, del programa de Justicia de la página web del Frente Nacional francés recojo una referencia a declaraciones de Marie Le Pen: «la peine de mort existe encore en France pour une seule catégorie de personnes : les victimes de fous furieux» y se la cita para decir que "Elle renouvelle sa proposition d'organiser un référendum auprès du peuple français pour lui proposer le choix entre le rétablissement de la peine de mort et la mise en place de la réclusion criminelle à perpétuité réelle, sans possibilité de sortir un jour de prison ». (http://www.frontnational. com $/ 2011 / 11 /$ meurtre-d $\%$ e $\% 80 \% 99$ oceane-la-peine-de-mort-existe-encore-en-france-mais- 
El objeto de este trabajo es exponer los argumentos que los pensadores reaccionarios y los neoescolásticos del XIX y de la primera mitad del XX dieron en favor de la pena de muerte. Por la naturaleza de sus argumentos entendí en su momento que bien puede considerarse dicho conjunto de argumentos como integrista en el sentido de que la razón ciencia aportada se basa en una verdad revelada, en lo sobrenatural $^{2}$. En esos anteriores trabajos traté de argumentar como las insuficiencias del movimiento ilustrado español habían permitido la pervivencia de un discurso sobre el derecho penal metodológicamente integrista y que permitía un concepto de lo punitivo esencialista, en cuanto derecho penal que protege una esencia, el concepto de España formulado históricamente por el pensamiento reaccionario español, basado en la idea de nuestro país como comunidad católica con una Constitución Histórica. Por lo tanto, muchas de las páginas que ahí redacté se encuentran aquí recogidas, si bien centrándome ahora de manera más específica en la posición relativa a la pena de muerte.

Conforme a esa visión esencialista y a esa metodología integrista, el que daña, el que pone en peligro esa esencia antes definida, se convierte en enemigo susceptible de represión penal. Dañar esas características supone dañar a la misma España, supone un riesgo de que España deje de ser tal. La formulación de Menéndez Pelayo creo que contiene las notas básicas de esa esencialidad española que debe protegerse: «España, evangelizadora de la mitad del orbe; España martillo de herejes, luz de Trento, espada de Roma, cuna de San Ignacio...; ésa es nuestra grandeza y nuestra unidad; no tenemos otra. El día que acabe de perderse, España volverá al cantonalismo de los arévacos y de los vetones o de los reyes de taifas $\rangle^{3}$. España vista como una nación configurada por una raza de espíritus indómitos, sólo unida por un catolicismo intolerante con sentido misional. Lo que perturba esa estructura

seulement-pour-les-victimes/). De su programa en materia de seguridad recojo bajo la rúbrica «Rétablissement de la peine de mort ou instauration de la réclusion criminelle à perpétuité réelle » que «L'alternative entre ces deux possibilités pour renforcer notre arsenal pénal, sera proposée aux Français par référendum. La réclusion à perpétuité aurait un caractère définitif et irréversible, le criminel se trouverait sans possibilité de sortir un jour de prison ». El padre de Marine Le Pen (el histórico líder del Frente Nacional, Jean Marie Le Pen) fue bastante más preciso, reclamando que la ejecución para los terroristas se verificase por decapitación, como se recogió en toda la prensa los días 20 y 21 de noviembre de 2015.

2 La base de este trabajo se encontraba ya en dos investigaciones, que publiqué dentro de la obra colectiva «El derecho penal de la posguerra», y que titulé «El pensamiento punitivo reaccionario español: pervivencia en el siglo XIX y principios del XX y su influencia en el primer franquismo» (38 a 87). Tirant lo Blanc, 2016. Con anterioridad «Jaime Balmes, Jerónimo Montes e Isaías Sánchez Tejerina: la continuidad de una propuesta de derecho penal integrista y esencialista en España», en Revista de derecho y proceso penal, $n^{\circ} 26,2011$ pags. 41-66.

3 Menéndez Pelayo, M. «Historia de los heterodoxos españoles», Madrid, 2007, Ed. Homo Legens, vol. II, pag. 907. 
debe ser penalmente relevante, más aún en una situación de grave peligro para esa esencia: la que se dio con la II República y en la Guerra Civil ${ }^{4}$.

Y hablaba también de derecho penal integrista, en el sentido, en primer lugar, de corresponderse con la ideología del sector católico español que en el siglo XIX se calificó como tal y que confluyó en el partido político fundado a fines del siglo XIX. El Partido Católico Nacional, oficiosamente llamado Partido Integrista, cuyo ideario estaba basado en el mantenimiento de la integridad de la tradición española y que fue creado por Ramón Nocedal, fundador también del influyente periódico El Siglo Futuro, y que aquí citaré con alguna frecuencia. Partido de pequeño tamaño pero con mucha influencia en círculos radicales. En segundo lugar, integrista metodológicamente, desde la perspectiva de que la reflexión sobre lo punitivo debe estar imbuida de la doctrina que emana de una instancia trascendente y de una fuente revelada (Dios mismo y la Sagrada Biblia). Es decir, una metodología no conforme con las exigencias del iusracionalismo moderno. Veamos pues como ese método y esa concepción de España inciden en la posición sobre la pena de muerte. Ahora bien, el éxito de tales posiciones (éxito práctico, en cuanto asumidas por la praxis del primer franquismo) y su pervivencia entendí que se debieron también a las insuficiencias del difícil proceso ilustrado español. Que Lardizábal o el Padre Feijoo defendieran (entre otras cosas propias del Antiguo Régimen) la pena de muerte, resultó un cómodo anclaje para que los teóricos del franquismo pudieran defender el proceso de ilustración punitiva en España como algo razonable y alejado del radicalismo de Beccaria.

\footnotetext{
Apuntando los motivos por los cuales España era un país en el que la revolución fascista podría tener éxito y que guardan relación con la pérdida de esa sustancia hispánica, decía José Antonio que «...la pérdida de la unidad (territorial, espiritual, histórica) ¿Es menos patente aquí que en otras partes?» (Primo de Rivera, J.A, «Carta a Julián Pemartín» en «Obras Completas», Madrid. 1945, Ediciones de la Vicesecretaría de Educación Popular de F.E.T y de las J.O.N.S.). En cualquier caso, fuera de esa esencia comunitaria no se concibe la existencia. Refiriéndose elogiosamente al nacionalsocialismo, decía Juan del Rosal que «Conceptualmente, la comunidad es una unidad sustancial, y de esta manera no se deduce la existencia del particular». (Del Rosal, J. «Una realización del nacionalsocialismo. El servicio de trabajo alemán», en Revista de Trabajo, n⿳01 Julio-agosto de 1939, pgs. 61 a 78. La frase es de la pág. 71). Es precisamente la guerra un excelente envite para calibrar la fuerza de esa raza de espíritus con vocación imperial, así un penalista como del Rosal dejó escrito que: «Todos los pueblos desgajan sus símbolos de las máximas tensiones de sus heroicidades; nuestra España tiene, en la gesta que ha transpuesto victoriosamente, símbolos en que el heroísmo se hermanaba con la santidad. El espiritu heroico y desprendido de la guerra es el que marca el nuevo signo de nuestro tiempo. Como arremetida contra un mundo de mercaderes, se yergue, con majestad de imperio, la entereza guerrera de servicio y abnegación para raer de las conciencias el mundo material de la mercancía y el dinero». Del Rosal, J. «Una realización del nacionalsocialismo...», pág. 65 .
} 
Desde la publicación de la obra de Beccaria, se generó un efecto reactivo casi inmediato, cuyo primer hito lo constituyen las soflamas del Padre Ceballos contra la obra del milanés.

Ceballos es un fanático ultramontano. La exageración de sus planteamientos ${ }^{5}$ hace que hasta Menéndez Pelayo lo encuentre excesivamente radical. Sin embargo, el juicio sobre su monumental La falsa filosofia es muy positivo en cuanto a su carácter «profético», que luego fue de nuevo reivindicado desde las páginas de Acción Española. Según Menéndez Pelayo escribió un Examen del libro de Beccaria sobre los delitos y las penas, que quedó inédito. Sobre Beccaría nos dejó escrito Ceballos que «entre los poco que se puede entender de su lenguaje, se ve transportado el ánimo del autor a un afecto de humanidad que le dicta mil discursos contra la pena de muerte, a favor de los parricidas, sodomitas, ladrones y otros malvados» y con fundamentación legitimista «Dios no debe a ninguna criatura la vida que le ha dado y puede quitársela con tanta alabanza y gloria cuanta merece porque se la dio» y «lo mismo se debe decir de cualquier otro que en nombre de Dios y por sus órdenes quitase la vida a ciertos hombres aun cuando por parte de esto son hubiera culpa», a todo lo anterior se unen sus famosos pasajes a favor del tormento, que se ordena «para que en ella se quebrante la contumacia del acusado y quede más dócil y fácil a entregar el secreto que guarda injustamente» ${ }^{6}$. En tono jocoso (y con su tosquedad habitual), también el Filosofo rancio criticaba el libro de Beccaria en un texto de $1816^{7}$

5 « Algo flaquea el P. Ceballos en las disertaciones subsiguientes así por el método como por la sustancia, y hubiera acertado en suprimirlas, a lo menos la que trata de la cuestión de tortura en juicios criminales», siendo así que «son siempre odiosas tales disquisiciones, y en una apología de la religión, odiosísimas amén de impertinentes. Para rebatir las teorías penales del abuelo de Manzoni, para defender el derecho de castigar y la pena de muerte, no era preciso extremar tanto el intento contrario». (Heterodoxos, Libro VI, Capítulo III, apartado VII) Vid también, Luis Prieto Sánchis, la filosofía penal de la ilustración, en Homenaje a Marino Barbero Santos, Ediciones de la Universidad de Salamanca y Castilla la Mancha, coordinadores Luis Arroyo Zapatero y Berdugo de la Torre, 2001 Volumen 1, pgs 489-510.

6 Tomo las citas del clásico trabajo de Herrero.J. «Los Orígenes del Pensamiento Reaccionario Español». Madrid, Cuadernos para el Diálogo, 1971, pags. 181 y ss.

7 «Constitución Filosófica que un filósofo rancio transformado en filósofo liberal escribió antes que las llamadas Cortes Extraordinarias sancionasen su constitución politica de la Monarquía Española». Sevilla, 1816. Se trata de una especie de comentario sobre un texto constitucional liberal, en el cual Alvarado (el Filósofo Rancio) hace escolástica satírica. «La ley es la expresión de la voluntad general, «item passim los filósofos de dentro y fuera del congreso; y antes que estos nuestro padre y patriarca Juan Jacobo Rousseau. Escolio 1: Todos quieren justicia y ninguno por su casa, decían nuestros viejos, y decimos nosotros aunque seamos mozos. Si pues la ley es la expresión de la voluntad general, quedando la ley haya de regular la justicia, deberá expresar una justicia que no vaya por la casa de nadie. Nota: No será nueva esta filosofí. Un tal Beccaria la deduxo de este principio, y de los otros del pacto social en el tratadito de delitos y penas, que hizo traducir ...» 
Guerra, pena de muerte y tortura aparecen como insustituibles pilares del orden social, el humanitarismo intenta cortar ese canal de Dios con las autoridades temporales. Y así exclamaba Ceballos que «Cuando en una Corte o en una gran ciudad veo la cárcel pública la venero por una obra tan acepta a -Dios y no menos necesaria que muchísimas obras sagradas».

\section{PENA DE MUERTE, CASTIGO Y CRUELDAD EN LA NOVELA ESPAÑOLA DEL SIGLO DE ORO}

Pero además, el marco de la presente investigación, tal y como se deduce del programa, se refiere también a la crueldad, a la crueldad institucionalizada, con manifestaciones tan ajenas al principio de humanidad de las penas como la cadena perpetua y la propia pena capital. En nuestro país, antes de la Ilustración no hay discusión en la esencial justificación de la aplicación de la pena capital, como de hecho no la hay en referencia a los castigos corporales o al tormento. Es decir, no había discusión sobre su necesidad y su universal aplicación. La literatura del Siglo de Oro nos ofrece magníficas críticas a la corrupción generalizada y necesidad de reforma de una justicia cruel, pero me parece advertir que no cuestiona en modo alguno ni la legitimidad de origen divino del Rey para aplicarla, ni la pena de muerte en sí, ni su esencial justicia. Existe efectivamente la percepción social de que estamos ante un sistema penal injusto y sujeto a la arbitrariedad. A los estudios y relatos de Chávez y Bobadilla, se une el acervo de una extensa literatura, especialmente en las llamadas novelas picarescas. En muchos casos esa literatura implica una crítica muy incisiva al sistema de justicia y a los excesos de la respuesta punitiva, realmente un alegato contra la crueldad: «A tan mísero estado como éste me han traído las experiencias de tan grave desdicha, la tiranía y maldad con que dominan los ministros de prisiones y cárceles sus infelices súbditos, la desvergüenza de un portero, la soberbia e imperio de un alcaide, y finalmente el tropel con que es atropellada la justicia del digno». Así se dice en la introducción de la Varia fortuna del soldado Píndaro de González de Céspedes. Pero en otras ocasiones, simplemente se expone un cuadro de atrocidades con el fin de moralizar al lector, de hacerle saber las consecuencias de la vida del maleante. Me interesa dar una relación de ejemplos, porque la literatura, la novela, no deja de ser un indicador muy sugestivo del estado de pensamiento de una sociedad en un momento concreto. La sociedad barroca española, a un siglo vista del comienzo de la Ilustración tenía unas ideas sobre el castigo penal y su necesidad, sobre la legitimidad para su imposición, pero también un hartazgo de los abusos, corrupciones y miserias del proceso penal. Y Ese es el cuadro punitivo que se encontraron nuestros penalistas en los albores del siglo, incluso empezado el mismo, cuando la ordenación de la legislación penal se llevó a cabo en un texto tan propio del Antiguo Régimen como lo era la Novísima Recopilación. 
¿Qué se desprende del variopinto cuadro sobre la represión punitiva que nos da la literatura clásica española?. Creo que hay un primer sustantivo que nos asalta al cotejar la colección de atrocidades que aparecen en el Guzmán de Alfarache, en el Estebanillo González, en el Buscón, o en la Fortuna Varia del Soldado Píndaro: crueldad. Una violencia desmedida, que supera al objeto propio del castigo. El condenado a galeras o a prisión sufre una infinidad de penalidades desproporcionadas, exorbitantes a la pena misma. La novela barroca española nos habla de cárceles, galeras, tormentos y cadalsos con notable crudeza.

Por ejemplo, el caos carcelario está magníficamente estampado en el Guzmán de Alfarache $^{8}$, obra que añade también una tenebrosa descripción de la pena de galeras $^{9}$. Es cierto que parte de esa literatura no cuestiona el modelo, lo describe y con

8 En la segunda parte, III, cap 7 se describe que algunos presos consiguen escapar de prisión vestidos de mujer, y Guzmán lo intenta provisto incluso de una espada. Además de reconocer las tropelías y abusos que él mismo cometía con otros presos, culmina su descripción la tremenda frase «allí (en prisión) aunque se conoce a Dios, no se teme» (parte 2, III, cap. 8). En el mismo capítulo se narra el acceso por soborno que podían tener los presos al vino y como, cuando son llevados veintiséis galeotes a las galeras, quedan entristecidas las prostitutas por la suerte de sus rufianes. En el traslado a galeras, los condenados roban a un ganadero sus lechones iy el comisario que los acompaña no sólo no intenta evitar el robo, sino que les pide que compartan el botín!. Aunque ya no referida a España (pues los episodios narrados versan sobre la cárcel de Sevilla, con respecto de una en Bolonia, nos dice Guzmán que era «un vivo retrato del infierno» (Guzmán, segunda parte, II, cap. 3). También como «infierno» describe la cárcel Carlos García en su «Desordenada codicia de los bienes ajenos» (cap 1). En «Fortuna varia...», la situación carcelaria se presenta como caótica y, como luego se verá, la buena disposición del Alcaide, determina una fuga masiva.

9 Guzman...parte segunda, III, cap. 8, donde además de la descripción de la lastimosa vida que llevan los galeotes, se explicitan las formas de tormento aplicadas, incluso dadas por los propios penados a sus compañeros (como el pase de banco), o como azotan a algunos por robar hasta que «les hicieron levantar los verdugos», es decir, las ronchas que levantan los azotes, «y después de bien azotados los lavaban con sal y vinagre fuerte, fregándoles las heridas, dejándolos tan torcidos y quebrantados como si no fueran hombres». El cómitre acaba azotando incluso al mozo de varas porque no le parece que pegue con bastante intensidad, y el galeote después de una prolongada tortura confiesa su culpa creyendo que lo iban a «matar a palos». Los azotes aparecen en el Guzmán con frecuencia, bien como medio punitivo bien para confesar (como en el episodio de los eslabones robados de la cadena del capitán de las galeras, o el tormento que le dan a Guzmán cuando desaparece el cinto del sombrero del capitán, donde la descripción de la tortura es aterradora, con Guzmán colgado de las muñecas y azotándole los mozos en la barriga). Cuando se descubre el motín de un amigo de Guzmán llamado Soto en las costas de Berbería, condenan a los cabecillas a morir «despedazados de cuatro galeras», y a otros a morir ahorcados o a galeras perpetuas, y «cortando las narices y orejas a muchos moros». Como ya traté en su momento, la cuestión de los azotes no deja de aparecer cíclicamente en el debate sobre lo penal en España, defendiéndose su necesidad incluso por autores del siglo XX como Sánchez Tejerina. En otra obra, El Lazarillo del Manzanares, el padre del Lazarillo es azotado y van proclamando los pregoneros que «Esta es la justicia que manda hacer el Rey nuestro señor a estos hombres por ladrones» (Lazarillo de Manzanares, cap. 1), sin olvidar las consecuencias sociales que el azote tenía «Heme aquí vuesa merced, hijo del azotado y sin honra para con muchos», dice Lazarillo. 
intención moralista adorna a sus personajes de cualidades que los hacen acreedores al castigo ${ }^{10}$, pero no es menos cierto que el estado que se presenta de la administración de justicia es deplorable y que existe ciertamente esa crítica a la que antes nos referíamos. Los jueces se presentan como corruptos, hasta el punto de poderse librar uno de la pena capital si son debidamente sobornados ${ }^{11}$, los escribanos son vistos como reincidentes en el cohecho ${ }^{12}$ los abogados meros intrigantes dispuestos

10 «Más que todo aquello y castigos mayores merecian mis culpas, por otras ofensas contra su Majestad cometidas» nos dice Guzmán de Alfarache, sin poner en cuestión por lo tanto que la ofensa por el delito lo es al Rey, cosa indiscutida en la época. (Segunda parte, III, cap. 7). En «Fortuna Varia...» se dice también de un ajusticiado que «fue condenado aun antes de dos meses a tormento y ejecutado con rigor: castigo merecido ... a lo menos de la ingratitud y villanía que usó con su dama». (cap. XXII), por cierto que luego se dice de otro ajusticiado «ya sentenciado a degollar» que fue perdonado por su padre «y salió de la cárcel con destierro al Peñón», en esa extraña mezcla de rigorismo punitivo y autocomposición que presenta el derecho penal del antiguo régimen. Las críticas de Cervantes, a las que luego haremos mención y de obras más antiguas como el Crotalón, se cuidan también de destacar la importancia que para la República tiene el sistema de justicia y se critica sobre todo la corrupción de los funcionarios.

11 «Fueron condenadas a muerte, y aún se quiso dezir que alguna de aquellas ranas que fueron presas, por ser hijas de personas señaladas fueron secretamente sueltas y ausentadas, porque untaron las manos a los juezes, y aún más los escribanos en cuya mano dizen que está más çierto poderse hazer, y ansí escaparon las vidas del morir». (Crotalón, Octavo canto del gallo). La percepción sobre jueces, letrados y personal de la Administración no puede ser más lamentable en «Fortuna Varia». Incluso el alcaide de la prisión de Córdoba, «no tan cruel y rígido como siempre lo son lo de su oficio», paga su bondad de organizar una fiesta en la prisión (cosa no infrecuente en las cárceles según no dice el libro) con la fuga de veintiún presos. El juez que instruye la causa contra Píndaro en Córdoba aparece presentado como un monstruoso prevaricador que inventa indicios y pruebas, condena a tormento sin escrúpulo alguno y se presta descaradamente al cohecho. «Son estos hombres un género de gente, miembros bastardos de la jurisprudencia. Llamánlos en la corte Bártulos en docena, Baldos de toda broza, $y$ en general catarriberas y como alli se portan de ordinario en continua miseria, hambre canina y hechos quitapelillos, pantublos y albañares de relatores y escribanos» .

Los episodios carcelarios suelen presentar a los presos dedicados a la molicie, peleándose con frecuencia, y mofándose de sus compañeros, como en el episodio del mulato.

Profusamente, en Guzmán, segunda parte, II, cap 2 y 3, donde además se pone de manifiesto una mayor arbitrariedad judicial en el campo criminal que en otros y la imposibilidad de que le hagan justicia siendo pobre. La crítica más severa y el paroxismo de la liberación de las iniquidades la ofrece Quevedo en «La hora de todos» cuando se truecan los papeles y los alguaciles pasan a estar cargados de cadenas y los azotados se convierten en azotadores (sueceso 13 y 3). La visión como la que descarnadamente nos da de lo penal Estebanillo González es la característica del esperpento, con un cuadro de una sociedad insensible y egoísta ante el sufrimiento del ajusticiado. En «Hora de todos» $\mathrm{y}$ ante la visión de dos ahorcados con fiebre maligna que se exterioriza en unas manchas, Quevedo nos pinta a dos médicos que rompen a llorar desconsoladamente «...por ver morir dos hombres sin pagar nada a la facultad», (Suceso 25).

12 Desde obras además del siglo XV, y así gran descuido es el que passa en el mundo el día de hoy, que siendo un offiçio tan prinçipal y caudaloso el del escribano, y tan neçesario que esté en hombre de fidelidad para que todos vivan en paz y quietud, consienten y permiten los prínçipes criar notarios y escribanos hombres viles y de ruines castas y suelo, los cuales por pequeño interés pervierten el 
a saquear a los inocentes y a intrincar el procedimiento, la figura del verdugo se percibe como corruptible y despreciable ${ }^{13}$, el tormento se utiliza de manera regular ${ }^{14}$, los agentes de la justicia son vistos como partícipes del saqueo al justiciable y se les atribuyen las peores cualidades morales ${ }^{15}$, el soborno es utilizado masivamente ${ }^{16}$, el condenado es en ocasiones una figura ridícula y despreciable ${ }^{17}$.

derecho y justiçia del que la ha de haber; y sobre todo los proveen de los offiçios más principales y de más peligro en su reino: como es de escribanías de chançellerías, y consejos y regimientos y gobiernos de su hazienda y república, lo cual no se habia de hazer por ninguna manera, pues en ello va tan gran interés y peligro». Crotalón, octavo canto del gallo. El tema es frecuentísimo y especialmente recalcado en Quevedo. Con sentido crítico también Cervantes, «Pues si este oficio tantas buenas partes requiere, ¿por qué se ha de pensar que de más de veinte mil escribanos que hay en España se lleve el diablo la cosecha, como si fuesen cepas de su majuelo? No lo quiero creer, ni es bien que ninguno lo crea; porque, finalmente, digo que es la gente más necesaria que había en las repúblicas bien ordenadas, y que si llevaban demasiados derechos, también hacian demasiados tuertos» (Cervantes, el Licenciado Vidriera), si bien que decir mal de uno no es decirlo de todos; sí, que muchos y muy muchos escribanos hay buenos, fieles y legales, y amigos de hacer placer sin daño de tercero; sí, que no todos entretienen los pleitos, ni avisan a las partes, ni todos llevan más de sus derechos, ni todos van buscando e inquiriendo las vidas ajenas para ponerlas en tela de juicio, ni todos se aúnan con el juez para «háceme la barba y hacerte he el copete», ni todos los alguaciles se conciertan con los vagamundos y fulleros, ni tienen todos las amigas de tu amo para sus embustes. Muchos y muy muchos hay hidalgos por naturaleza y de hidalgas condiciones; muchos no son arrojados, insolentes, ni mal criados, ni rateros, como los que andan por los mesones midiendo las espadas a los estranjeros, y, hallándolas un pelo más de la marca, destruyen a sus dueños. Sí, que no todos como prenden sueltan, y son jueces y abogados cuando quieren. (El Coloquio de los perros)

13 En El Buscón, el padre de Pablos azota con mayor o menor rigor a los ajusticiados en función del soborno que antes haya recibido de ellos. El oficio de verdugo se vive por el protagonista como un estigma que le hace imposible progresar socialmente.

14 «...esta malo de lo mucho que se burló el verdugo con él hasta hacerlo músico» se dice de un amigo de Guzmán, es decir, de lo mucho que lo atormentaron hasta que «cantó», (Guzmán parte 2a , III, cap. 7). En el mismo capítulo se especifica que lo descomponen «en el ansia» (tormento del agua, consistente en tapar la nariz con un paño y echar agua a chorro en la boca). Al mismo preso, cuando se le traslada a galeras y para que confiese sobre un hurto, se le aplican cordeles en los testículos (parte 2, III, cap. 8)

15 El juego de palabras de Quevedo en el «Alguacil endemoniado» es muy significativo, cuando el diablo posee a un alguacil, aquel se acaba sintiendo «demonio alguacilado».

16 Como «racimo seco, en las cáscaras» refiere Guzmán que quedo tras sobornar a los empleados de la prisión de Sevilla (Guzmán de Alfarache, parte $2^{\mathrm{a}}$, III, cap. 7), en el mismo capítulo dice que su pleito quedó parado por no tener nada para «cohechar al escribano». La percepción de una justicia cara, inútil y cohechada aparece también en La Pícara Justina : «Dios nos libre de pleitear en pueblos chicos, donde hace la cabeza del proceso la envidia; el proceso, el soborno; los autos, la afición; la apelación, la del alcalde; la revista, solturas y, sobre todo, el dinero (Libro III, cap. 1).

17 En la «Vida de Estebanillo González» (quizás la novela más descarnada de toda la literatura del XVII) Estebanillo, cuando es condenado a muerte y le conmina el sacerdote a que se encomiende a Dios, contesta que «aún no se ha encomendado a Baco», en el episodio del rufían condenado a la horca que narra el Guzman de Alfarache, aquel dice que «ya tengo rezado cuanto se» y conmina a sus guardianes a que se emborrachen con él. 
Llama la atención la diferente percepción que parece tiene el pueblo de los tribunales reales con respecto del de la inquisición. Con otro ejemplo de la literatura, una novela como Varia Fortuna que ya hemos visto tan crítica con el sistema de justicia (parece ser que no es ajeno a ello el encarcelamiento que padeció el propio González de Céspedes), contiene un capítulo altamente elogioso sobre el tribunal inquisitorial, y los propios protagonistas corren a dar parte al inquisidor de haber encontrado una hechicera, no por miedo, sino como clara interiorización de un deber moral ${ }^{18}$. En cualquier caso, y con toda certeza, hay una crítica patente y con un componente criminológico que en algunos casos llama la atención por su crudeza. Por supuesto, como en tantas cosas, es Quevedo de los que más profundizan en esa cuestión. En La hora de todos y en su suceso 13, se critica la ejecución de la pena de muerte tras la aplicación de un periodo de prisión de tres años,. «este ladrón que después de tres años queréis ahorcar, echaréis a galeras, porque hoy ...sería injusticia muy cruel».

Así pues, nos encontramos en la literatura una visión de un derecho penal cruel y una administración de justicia que practica esa crueldad concienzudamente ${ }^{19}$. La

18 «Fortuna varia...» tomo I, cap. XVIII, que concluye diciendo que «...gracias al a la incansable diligencia con la que la venerable y santa Inquisición ...extingue y desvanece semejante semilla».

19 «y es de considerar que aqueste bárbaro y cruel tratamiento no lo padecen los facinerosos delincuentes, los homicidas y ladrones. Porque éstos siempre tienen alli sus ángeles de guarda, digo, su cierta inteligencia, con que pasan holgados. El alcaide, de quien son tributarios, los favorece. Los alguaciles, con quien parten y viven, les dan la mano; los porteros y guardas, que comen con sus hurtos, les regalan y ayudan; y así las órdenes terribles, las asperezas y rigores que justamente se dispusieron para el castigo y enfrentamiento destos, sólo se ejecutan y cumplen con el pobre inocente y con el hombre honrado y de vergüenza, que su desdicha, más que no sus pecados ...les trajo a semejante desventura...y asi , hacendé golpe sobre sus tristes cuerpos las cadenas y grillos, las injurias y afrentas, las clausuras y encierros, y todas las inhumanidades de tan fieros verdugos» (Fortuna varia cap. X).

Y concretamente en el mismo capítulo se da cuenta de la situación de los presos en la cárcel de Córdoba. Píndaro pasa la noche tratando que no le devoren ratas y comadrejas, para despertar diciendo que «...llegó el día, conocido de mí más por el gran calor que empezaba a abrasarme que por la escasa luz que entraba por las junturas de la puerta; la cual no se abrió en más de mil horas, o al menos tantas se me antojaron las que hubo hasta la de comer», comida por cierto bien lamentable, una suerte de potaje en el que flotan bofes de oveja, pan negro y «un jarro de agua, él desbocado y sucio , y ella ardiendo y no limpia».

La percepción sobre jueces, letrados y personal de la Administración no puede ser más lamentable, incluso el alcaide de la prisión de Córdoba, «no tan cruel y rígido como siempre lo son lo de su oficio», paga su bondad de organizar una fiesta en la prisión (cosa no infrecuente en las cárceles según no dice el libro) con la fuga de veintiún presos. El juez que instruye la causa contra Píndaro en Córdoba aparece presentado como un monstruoso prevaricador que inventa indicios y pruebas, condena a tormento sin escrúpulo alguno y se presta descaradamente al cohecho. «Son estos hombres un género de gente, miembros bastardos de la jurisprudencia. Llamánlos en la corte Bártulos en docena, Baldos de toda broza, y en general catarriberas y como alli se portan de ordinario en continua miseria, hambre canina y hechos quitapelillos, pantublos y albañares de relatores y escribanos». . En el episodio del Letrado de Valencia, el sacerdote que debe oficiar el 
crítica al sistema del Antiguo Régimen no era, pues un espontáneo descubrimiento de unos hombres más o menos ilustrados que leen el libro de Beccaria: es casi un clamor durante el antiguo régimen. Cuando en las Cortes de Cádiz se afronte una cierta racionalización del sistema penal apenas hubo debate ni criterios enfrenta$\operatorname{dos}^{20}$. Hay una convicción de que la justicia es corrupta, y de que el sistema de penas es excesivamente cruel. Esa crítica lo es, pues, en cuanto al contenido de ese modelo de derecho penal y más en concreto sobre determinadas aberraciones del sistema estatal de castigo. Lo que jamás se pone en cuestión es la propia legitimación de la potestad penal, los textos de esa literatura entienden unívocamente ese caos como una afrenta al Rey. Es decir, no hubo propiamente una revolución jurídico penal en la España del XIX y finales del XVIII, sino la plasmación de una petición que era casi unánime y contra la cual sólo estaban unos cuantos elementos casi marginales. Cuestión mucho más delicada es la aceptación de unas bases sobre la legitimidad del derecho a castigar que son correlativas a la polémica sobre el ostentador de la propia soberanía.

Ni siquiera el proceso ilustrado fue determinante en España. Intenté ya en su momento dar cuenta de la enorme carga que la obra de Lardizábal tenía de elementos del Antiguo Régimen. El uso de la teoría de las divinas potestades, la desigualdad en los castigos, la defensa de la pena de muerte hicieron a Lardizabal un autor de cómodo uso por los penalistas más afectos al franquismo. Frente al vilipendio constante que sufrió Beccaría ${ }^{21}$, Lardizabal podía ser usado sin violencia como un defensor del derecho penal que sostenían los Sánchez Tejerina, del Rosal o Serrano Rodríguez.

\section{EL SENTIDO DE LA PENA Y LA PENA DE MUERTE EN LOS PENSADORES REACCIONARIOS ESPAÑOLES}

Así pues, en esa mezcolanza de rechazo a un derecho penal de violencia desmedida y de falta de ataque a las raíces profundas de su legitimación, ¿Con base en qué se defendió la pena de muerte por parte de ese grupo de juristas, filósofos, teólogos y moralistas del XIX y el XX ?. El Padre Jerónimo Montes nos indicaba en 1912 cuáles eran los fines de la pena: «En el orden moral, que también se per-

funeral tiene una revelación la noche anterior en la que se le obliga a proclamar en esa misa que el finado letrado está condenado al infierno.

20 Instrucción de la Comisión de Cortes de 4 de octubre de 1809 «La legislación criminal y el orden de los juicios debe ocupar muy particularmente la atención de la junta, considerando que la menor imperfección en esta materia puede destruir la libertad civil y politica de los ciudadanos», el texto es significativo de la transformación del derecho penal como derecho de garantías y límites a un poder arbitrario, pero la formulación sugiere que no era una cuestión sobre la que hubiera un enfrentamiento significativo.

21 Callejo Hernánz, G.M, «El pensamiento punitivo...», pag.50 y especialmente nota 28. 
turba por el delito, la pena es expiación; en el orden jurídico, restauración; en el orden social, defensa ó tutela; en el orden privado ó de relaciones con la víctima, reparación y satisfacción" ${ }^{\prime 22}$. Y en cuanto al propio penado, la pena, en la tesitura de si debe ser «correctora» o mero escarmiento, tiene un carácter mixto. Los que «por su carencia absoluta de sentimientos religiosos y morales, por sus precedentes ó por las experiencias realizadas en ellos, no ofrecen esperanza alguna de redención con medios suaves y educativos, ni la pena produce efecto alguno en sus almas si no va acompañada de sufrimiento y castigo. Con éstos debe emplearse un sistema de rigor, único eficaz para escarmentarlos y refrenar sus instintos criminales» ${ }^{23}$.

Orden moral que debe restablecerse, orden jurídico verificado en su vigencia, satisfacción a la víctima y, desde luego, expiación. La pena era concebida cómo «dolor que purifica» ${ }^{24}$. El penado, nos dice Valdés Rubio, precisa de oración y trabajo. Debe procurarse que la pena «suscite en el reo la conciencia de la falta, la necesidad de la reconciliación con Dios». La expiación es «...purificación por medio del sufrimiento moral, la pena provoca la reacción, causa del arrepentimiento y la hace más eficaz».

Y otra definición de otro autor: «El fin fundamental y esencial de la pena, el único que la legitima y la hace verdadera pena jurídica es la expiación. Expiación es la compensación del delito con un hecho contrario: el sufrimiento» ${ }^{25}$.

Asi pues, veremos que los principios fundamentales que pueden extraerse de los textos de los apologetas de la pena capital desde el siglo XIX para la defensa de ésta son su necesidad para el sostenimiento del orden moral creado por Dios (cosa que se vincula con la clásica teoría legitimista de las potestades), la relación directa de esta pena con la necesaria expiación del delito, y además como base para su defensa su establecimiento directo por Dios en la Biblia, su sentido «corrector-trascendente» (defensa de la misma en cuanto ayuda a salvar el alma del reo), y, por último su

22 Montes Luengo, J. «¿La pena debe ser corrección o escarmiento?», Revista Ciudad de Dios, n99, año 1912, pag. 434

23 Montes Luengo, J. «¿La pena debe ser corrección...?» Pág. 444. Este sistema de «rigor», a los mismos fines expiatorios, parece poder incluir los castigos corporales, puesto que «son las más eficaces para escarmentar al que no quiere corregirse, sin que dejen de tener también un carácter correccional, sobre todo, aplicadas á delincuentes jóvenes...». Los azotes deben ser vistos sin «prejuicios filosóficos y políticos». Y como al fin y al cabo la pena implica sufrimiento físico y moral, y uno y otro se conjugan con las penas corporales, «mejor que con ninguna otra», esas penas «cumplen sin duda alguna el fin expiatorio». Montes Luengo, J., «El problema del castigo corporal», en Ciudad de Dios, nº91, año 1913, pgs.12-25.

24 Valdés Rubio J.M, «¿Existen realmente criminales incorregibles? En caso negativo ¿qué medios son adecuados para conseguir la reforma moral de los delincuentes contumaces?». En Revista Ciudad de Dios, nº8 (1909) pág. 450 y ss.

25 Amor y Neveiro, C. «Examen crítico de las nuevas escuelas de Derecho Penal». Madrid, Imprenta del Asilo de huérfanos del Sagrado Corazón de Jesús, 1899. Pgs. 17 y 18. 
esencial historicidad. La pena de muerte ha existido siempre, desde los albores de la humanidad. Su presencia en todo momento y toda cultura supone un argumento imprescindible para su defensa.

La visión expiatoria de la pena con una importante carga de sufrimiento formó parte más tarde de los slogans penológicos estrella del franquismo. La concepción de la pena como sufrimiento compensador del daño hecho, sirvió para justificar las terribles condiciones de los presos en la Guerra y en la postguerra.

Obviamente, y desde la base de esa concepción expiatoria, el pensamiento punitivo conservador español siempre fue favorable a la existencia de la pena capital, que justificó con los argumentos antes expuestos. Muy significativa es la posición del Padre Feijoo en el punto, el relativo a la orientación de la pena de muerte como salvadora de almas. El padre Feijoo, sostiene que es muy conveniente la pena de horca porque permite que el alma del ajusticiado vaya al purgatorio, evitando su perdición si muriera por causas propias de su condición de malhechor ${ }^{26}$. La clemencia judicial es injusta y pierde almas. Lo cierto es que no destacaba precisamente el padre Feijoó por su humanidad: «con los crímenes de herejía y de lesa majestad, en que se apartan los jueces del modo de proceder ordinario... en que se tiene por conveniente, por lograr ese bien público, dispensarse en algunas circunstancias del modo de proceder ordinario, aunque más seguro éste para la investigación de la verdad: de suerte que se juzga menor inconveniente permitir con ese menos exacto juicio el riesgo de que sea condenado un inocente, que aventurarse al peligro de que queden sin la debida pena delitos tan perjudiciales a la República $»^{27}$. Por tanto, una especie del «in dubio pro republica» que propugnó Maggiore en el fascismo italiano. Nos sigue diciendo Feijoo que «el terror de las primeras ejecuciones reprime todos los genios aviesos, y con cincuenta o cien ahorcados en el primer año de un reinado esta hecho casi todo el gasto para mientras viva el Príncipe» ${ }^{28}$, añadiendo que «Destiérrense, pues, de toda república esos peligrosos melindres de la piedad». Para Feijoo, en algo tan conectado a la crueldad, el suplicio no es tan cruel como parece y sólo causa un dolor instantáneo, «porque perdiendo el sentido desde el momento mismo que reciben el golpe fatal, todo el tiempo que resta hasta la separación del alma, son troncos más que hombres $\rangle^{29}$, lo que incluso argumenta para la muerte en la hoguera. La muerte conviene no sólo a la república, sino también al propio reo,

26 Feijoo B.J. Teatro Crítico Universal.Tomo III, discurso undécimo, parágrafo 37.

27 Feijoo, B.J. Cartas eruditas y curiosas, Tomo III, carta 22 «Sobre la importancia de abreviar las causas judiciales», parágrafo 18. He hecho uso de la edición digital de la Fundación Gustavo Bueno http://www.filosofía.org /bjf/bjfc y que se corresponde con la edición de 1774 de la Imprenta Real de la Gaceta.

28 Feijoo B.J «Teatro...», Tomo Sexto, Discurso Segundo «Apología de algunos personajes famosos de la historia», parágrafo XI, epígrafe 119.

29 Feijoo B.J «Teatro...», Tomo Sexto, Discurso Primero, Paradoja 11, epígrafe 111 
pues, muriendo en la horca, «de allí tomaría el camino para el Purgatorio, para pasar después al Cielo, y muriendo en alguno de los encuentros a que es arriesgada su profesión, mucho más probablemente perdería para siempre el alma con la vida $\rangle^{30}$. De hecho no duda de que en los infiernos una larga lista de malhechores perdonados están maldiciendo contra los jueces clementes.

La salvación del alma justifica y hace necesario matar al reo. El argumento fue reiterado en la década de los cuarenta del siglo XX por Isaías Sánchez Tejerina. sí que es «correctiva» (correccional), y lo es desde el punto de vista religioso y para aquellos que mueren arrepentidos, siendo así que muchos de los condenados «de no morir ejecutados morirían impenitentes». Se colige que «Para nosotros es este un hecho que tiene un valor extraordinario». Es decir, la función de la pena de muerte es salvar almas. Es uno de los ejemplos más evidentes de esa concepción integrista a la que estamos haciendo referencia. Es, por lo tanto, una pena correctivo-trascendente o, mejor aún, tiene un sentido preventivo especial trascendental. La argumentación a la que Tejerina responde es una de las clásicas, especialmente en el XIX, para criticar a la pena capital. Sencillamente formulada por los abolicionistas: no corrige al reo porque nada puede ya enmendar el que fallece ${ }^{31}$.

Tejerina, además de indicar que esa corrección no es el único fin de la pena, ofrece esta peculiar argumentación. Bien leído, la pena de muerte es un bien para muchos condenados.

Por supuesto, la concepción de la pena como sufrimiento purificador amparaba también la posibilidad de penas corporales, concebidas como medicina para el alma. En otros autores se hace uso del argumento de las potestades divinas. Dados por Dios a los Príncipes los medios para la correcta ordenación de la sociedad, suprimir la pena de muerte es suprimir un instrumento esencial para que la sociedad cumpla sus fines ${ }^{32}$.

Ahora bien, admitir la pena de muerte suponía tener que entrar en muchas disquisiciones sobre su ejecución, sus formas, su carácter público o secreto etc. Códigos indiscutiblemente duros como el de 1850 y su «fotocopia» de 1875 (Código de D. Carlos VII) mantenían la publicidad de la ejecución, pero habían reducido drásticamente la regulación del ceremonial a apenas cuatro artículos ${ }^{33}$. Este adel-

$30 \quad$ Feijoo, B, J. «Teatro...», Tomo III, Discurso Undécimo, epígrafe 37.

31 Sánchez Tejerina, I., «Derecho Penal Español», Tomo I. 5a Edición. Madrid. 1950, págs. 372 y ss

32 Mendive,J. «Elementos de Derecho Natural». Valladolid, imprenta de la Viuda de Cuesta e Hijos, 1884.Pags. 272 y ss.

33 Arts. 85 a 89 en el Código Carlista y 89 a 93 del de 1850. Mantenían la conducción con hopa negra (o amarilla en el caso de delitos como el regicidio y el parricidio), la exposición del cadáver hasta un tiempo después de la ejecución, el garrote sobre tablado como forma de ejecución, y la prohibición de enterrar con pompa al ejecutado, así como la prohibición (también clásica) de ejecutar la pena sobre mujer embarazada. Se mantenía la pena infamante de argolla, y así el artículo 109 del 
gazamiento de preceptos con respecto de la ampulosa redacción de la ejecución en el Código Penal de 1822, no se debía sólo a los resabios que tenía éste Código de «compilación» y de heredero en tantas cosas del modo de redacción de las leyes del Antiguo Régimen. Se estaba procediendo a ocultar el suplicio por toda una serie de cuestiones morales. En el Código de 1928 la ocultación legislativa era ya absoluta, remitiendo los detalles de la ejecución «a lo que dispusieran las leyes y reglamentos especiales» ${ }^{34}$. El Anteproyecto de Código Penal de FET y de las JONS ${ }^{35}$, por el contrario, establecía en su art. 75 que «se ejecutará en garrote, de día, en sitio adecuado de la prisión en que se hallare el reo y a las 18 horas de notificarle la señalada para la ejecución, que no se verificará en días de fiesta, religiosa o nacional». El Preámbulo definía la pena de muerte como algo esencial para la defensa social. Se establecía la incomunicación del sentenciado (con ciertas excepciones) y se regulaba qué personas estaban autorizadas para acudir a la ceremonia. El art. 77.2 establecía que «En el momento de la ejecución se izará en parte visible desde el exterior de la prisión, una bandera negra, que se mantendrá ondeada todo el día». En esta evolución legislativa van apareciendo todas las preocupaciones del pensamiento ultraconservador con respecto de la pena capita ${ }^{36}$. No es sorprendente que

Código de D. Carlos y el 113 del de 1850 establecían que precederían los sentenciados a tal pena a los reos de pena capital y que serían conducidos al cadalso, lugar en el que verían la ejecución con la argolla al cuello.

34 Si bien el mismo artículo 170 en su segundo párrafo mantenía las tradicionales prohibiciones de ejecutar la condena sobre la mujer encinta y siquiera de notificarle la sentencia hasta pasados 40 días del alumbramiento. Pero esto no incidía en el ocultamiento del espectáculo punitivo.

35 Debo agradecer al catedrático D. Gerardo Landrove Díaz su amabilidad (y celeridad) al proporcionarme el texto de dicho Anteproyecto y remitírmelo desde la Universidad de Murcia.

36 Que ya había recogido Concepción Arenal en una obrita clásica «El reo, el pueblo y el verdugo, o la ejecución pública de la pena de muerte». (he utilizado la versión digital de la Biblioteca Virtual Miguel de Cervantes de la Universidad de Alicante, basada en la editada en Madrid, Librería de Victoriano Suárez, en 1896, Obras Completas, vol. 12). Aquí se exponen los motivos de la necesidad de ocultar el suplicio. Sin pronunciarse sobre la abolición de la pena de muerte (así lo dice expresamente, dando la existencia de la misma como un hecho común en la mayoría de las naciones), Arenal pone de relieve la contradicción del Estado que ayuda a bien morir al condenado enviándole un ministro de culto que le asista, y que por otro lado fomenta el mal morir, permitiendo que el condenado pueda dejarse llevar por su vanidad en el modo de afrontar la muerte ante un público nutrido. La multitud es un «obstáculo al recogimiento». El reo entra en una relación perversa con el público, en el que éste pide que el criminal asuma un determinado rol y el condenado desea satisfacer esa expectativa de admiración. El propio carácter del criminal hace que suela auto absolverse cuando percibe las faltas ajenas. «Si queréis que el culpable llore sus culpas, que vea alguno compadecer sus dolores», nos dice Arenal. Ocultar el suplicio se reivindica por la nula eficacia represiva de la publicidad. Para Arenal tiene un efecto preventivo general más saludable la idea de una muerte tras una especie de hora oscura: «¿Quién sabe si aquella muerte en la obscuridad, si aquella última hora sin testigos, llevaría al ánimo ese terror que infunde en él lo desconocido, lo misterioso?». Por lo demás, la familiarización con la visión de la muerte resulta nociva para el pueblo, que pierde un instintivo respeto a la vida de los demás. El riesgo de imitación 
desde algunos sectores, y ya en el siglo XX, se reclamase que la ejecución tuviera una puesta en escena esencialmente religiosa. Realmente era perfectamente coherente con esa visión dada antes de la pena de muerte como instrumento para salvar almas perdidas: «La guillotina laica, despojada de todo aparato religioso, produce la repulsiva impresión de una maquinaria brutalmente vengadora. Para darle el aspecto de lo que es, o debiera ser, ese instrumento de justicia, habría que permitir a la Religión purificarlo, y santificarlo, o idealizarlo con su augusta presencia, y con sus preces, de tal suerte que penetrase bien por los sentidos de todos los presentes que en el castigo no había odio, sino amor, y no crueldad, sino misericordia, y que la misma sociedad que hacía rodar en el cesto fatal aquella cabeza, se elevaba al Padre común pidiéndole por su alma» ${ }^{37}$.

Desde luego, en el pensamiento ultraconservador, la pena de muerte se percibe como una institución tan necesaria como avalada por la historia. Posteriormente veremos las referencias de Balmes y Donoso sobre este particular, por ahora dejamos una cita que extracta perfectamente este principio básico para la defensa de la pena capital:

«La historia ha reconocido siempre esta pena, y dejando aparte aquellos trastornos revolucionarios, en los que las persecuciones han causado no pocas víctimas, examinando la vida de los pueblos en su progreso de paz y de orden, en ella encontramos sancionada esta penalidad, lo que viene a afirmar la razón que nos asiste a los que creemos necesaria dicha pena. Habrase impuesto de forma más o menos bárbara; se habrá ejecutado guiada muchas veces con ánimo de venganza; su aplicación habrá sido desproporcionada en relación al delito cometido; no se habrá tenido en cuenta las circunstancias del delito: todo esto lo reconocemos; pero no pueden menos de concedernos los abolicionistas que todos los pueblos conservaron como principio fundamental e indestructible de su derecho, la legitimidad de la última pena."¿ Cómo se explica, dice un penalista, que pueblos de costumbres, de carácter, de legislación tan diversos, tuviesen y conservasen, sin excepción, el derecho de imponer la pena capital?, ¿Cómo se explica que, al ser descubierta América, se

en la infancia da otro motivo para esconder los suplicios. Concepción Arenal propone el valor moralizante de una muerte recogida y el efecto lúgubre que genera la muerte con un ceremonial austero y con personas solemnemente vestidas. «A fin de evitar estos inconvenientes proponemos que las ejecuciones no se hagan en público, y que sustituya la electricidad a los medios de destrucción que hoy se emplean». Pero Arenal no despoja totalmente de simbolismo a la pena capital, y como garantía de su cumplimiento tolera la exposición del cadáver: «A la exposición del cadáver puede darse toda la solemnidad, toda la publicidad que se quiera. Puede llevarse por los parajes más públicos y dejarse expuesto en un tablado. Si ha de haber escarmiento, vendrá de la muerte del culpable, y no de ver cómo muere. La vista del cadáver puede tener como ejemplar la eficacia que no tuvo la del reo. Éste excitaba mil afectos diversos, como hemos observado, y que sus restos mortales no pueden excitar»».

37 . Melgar. M., «Crónica Social e Internacional», en Revista Católica de las Cuestiones Sociales, Año XIII., núm. 155, noviembre de 1907». 
encontrase establecida en todos aquellos países, sin comunicación con el resto del mundo, y sin que pudieran haber tomado esta penalidad por imitación de otros pueblos? ¿Cómo se explica que dondequiera que se ha encontrado una sociedad, más o menos perfecta, o de cualquier modo que se halle organizada, allí se ha encontrado el derecho de imponer la pena de muerte? $\rangle^{38}$.

Desde la filosofía neoescolástica se vertieron también argumentos en favor de la absoluta necesidad de la pena capital. Dentro de dicho movimiento destaca, lógicamente, la figura de Jaime Balmes, pero no debemos dejar de prestar atención a otros pensadores como Ortí y Lara (habitual del periódico reaccionario El Siglo Futuro). Ortí y Lara es uno de los pensadores más intransigentes del movimiento neoescolático español. Incluso la literatura apologética de este movimiento destaca su rigidez intelectual ${ }^{39}$. Catedrático de metafísica en la universidad de Madrid dirigió diversas revistas apologéticas como El Universo, La Ciudad de Dios o La Ciencia Cristiana. Ortí y Lara es el ejemplo más extremo de la violencia penal propugnada por los reaccionarios del XIX. Por ejemplo polemizó en 1888 (por tanto 60 años después de desaparecido el tribunal de la Inquisición), en el periódico El Siglo Futuro ${ }^{40}$ con la línea editorial del periódico carlista $L a F e$, sobre si los herejes contumaces debían ser condenados a muerte por la autoridad civil (posición de Ortí) o si, como sostenía ese diario Carlista, bastaba con la pena de excomunión. Nótese además que éste periódico no defendía la pena exclusivamente canónica en atención a ninguna idea sobre la separación del hecho moral con respecto del hecho punible, sino porque siendo el delito de herejía de mucha mayor gravedad que el asesinato, la pena también debía ser más grave. Argumento que Ortí i Lara considera absolutamente falaz. En el artículo del moralista citado, se hace expresa mención a una teoría de la pena de carácter tomista, necesidad de la pena para la defensa de la sociedad y apartamiento del «miembro corrupto» por medio de la pena de muerte.

Se sostiene la diferencia entre «pena medicinal», que no es propiamente pena y pena vindicativa, orientadas a la expiación y «a la tutela y defensa del bien común», frente a la orientación de las «medicinas» a la corrección y enmienda del delincuente. Al hereje contumaz conviene aplicarle, concluye, tanto la medicina como la pena, «proveyéndose a su salud espiritual por medio de la excomunión y al bien de toda la grey, a quien puede pegarle la roña que él padece, quitándole de este mundo». Es además potestad de la Iglesia exigir al Estado leyes que repriman la herejía con pena capital.

38 Cossío y Gómez Acebo, M.: Sustitutivo legal de la pena de muerte y régimen penitenciario, Madrid, 1914. Pag.21

39 Un filósofo tan afín al ultraconservadurismo como Guillermo Fraile, se refería a sus obras apologéticas como llenas de «cerrazón» y con uso de un tono excesivamente «agresivo», Historia de la Filosofia Española II. Biblioteca de Autores Cristianos, Madrid 1964.

$40 \quad$ El Siglo Futuro, 14 de agosto de 1888. 


\section{LA POSICIÓN DE JAIME BALMES Y OTROS NEOESCOLÁSTICOS}

Balmes, en su Ética, describe una teoría de la pena y del derecho a castigar que está manifiestamente influenciada por San Isidoro y que se corresponde con esas ideas de necesidad para mantenimiento del orden moral creado por Dios. El capítulo XXVII de dicha obra tiene la rúbrica "penas y premios», en la que Balmes ${ }^{41}$ establece la ratio de su sistema penológico y que tiene su base en esa misma sustentación del orden cósmico. El orden universal, subjetivizado, debe llevar a cabo una serie de actos para conseguir los fines que se propone. Si yo quiero dibujar una línea en un papel, necesito proveerme de dicho papel y de un objeto apto para dibujar. Para mantener su propio estado de cosas, el orden universal también precisa de medios. Las leyes necesarias son suficientes para operar como medios aptos para mantener ese orden cósmico cuando nos referimos a seres sin libertad. Un mundo en el que la ley de la gravedad rigiese de forma aleatoria, o en el que la velocidad no fuese la resultante de dividir, siempre y en cada caso, el espacio entre el tiempo sería un mundo caótico.

Tales leyes, por el contrario, no son suficientes en lo que al hombre se refiere en su calidad de ser moral. Debe existir un medio que, «respetando la libertad del agente, garantice la ejecución y conservación del orden». Ese medio debe garantizar la ejecución y conservación del «orden moral» (orden que ha procurado definir en los veinticinco capítulos anteriores). Y ese medio no es más que la influencia en el sujeto del temor o la esperanza por los resultados que puedan deparar sus conductas

${ }^{41}$. Balmes, J., «Curso de Filosofía Elemental. Ética», Imprenta Barcelonesa, Barcelona, 1909 (décima edición). Especialmente capítulo XXVII, págs. 169 a 172, del cual extraemos las citas salvo que se haga otra referencia.

Balmes cuestiona algunas consecuencias y contradicciones de una hipotética superioridad de la idea correctora en la teoría de la pena:»...y es que la pena debería ser tanto menos aplicable cuanto menos esperanza hubiese de enmienda». La doctrina que se deriva es, a juicio de Balmes, «horrible», pues implica que a mayor «proporción de maldad», en vez de aumentarse la pena, se disminuye.

La pena como corrección implica que la ejecución queda más en manos de la medicina que de la propia justicia, contradiciendo además la voluntad del penado, al que se le somete a esa «curación» sin su consentimiento; ( «se me quieren hacer favores y a la fuerza se me obliga a aceptarlos», dice un penado en un ficticio diálogo juez-condenado). La idea, pues, de expiación es absolutamente intrínseca a la idea de justicia. El «castigo envuelve la idea de expiación», si ésta falta, la pena es una mera medida de utilidad y no un efecto de la justicia. El sentimiento de indignación e ira ante lo injusto y la idea de merecimiento de castigo ante lo malo están fijos en la conciencia de toda persona. Es el carácter público del derecho de castigar el que evita que ese sentimiento de legítima ira ante el delito convierta el mundo en un lugar ingobernable pero, por lo mismo, es necesario que el Estado lleve a efecto el castigo que es merecido. El exceso de filantropía en las ideas sobre la pena no constituye sino una "crueldad refinada» y una «injusticia que indigna», en tanto que con ese exceso supone que el orden moral, la justicia, la amistad y la humanidad no requieren reparación. 
(binomio pena-premio). De nuevo aquí, ese orden por el que los sujetos libres deben regir su conducta bajo la esperanza del premio o la amenaza de la pena, no es sino el que «Dios ha prescrito a sus criaturas», definido, pues, por la ley divina. En esa lógica, es plenamente consecuente que el Creador no pueda admitir que sus mandatos queden al albur del sujeto receptor de los mismos. En tal contexto, se respeta la libertad del individuo pero con un mecanismo que permite conservar ese orden moral. Si el individuo, ante el mandato de Dios, dice «no quiero», ese orden moral que no se ha podido «....conservar en la esfera de la libertad, se restablece en la de la necesidad». Hay una «compensación» del desorden (el castigo), en palabras de «una satisfacción tributada al orden moral».

Bajo este esquema, justificativo de la necesidad del establecimiento de penas y premios para nuestras conductas como algo establecido por Dios mismo, define qué sea la pena: «mal aflictivo aplicado al sujeto culpable a consecuencia de su culpa». La pena tiene por objeto: prevenir las faltas (y en consecuencia, realizar y conservar así ese orden moral), reparar el desorden moral (si la conducta contraria a la regla se ha llevado a cabo), «restablecer el equilibrio perdido»y, por último, prevenir nuevas acciones contrarias a la norma por parte del culpable y, a su vez, servir de lección a terceros que presencien el castigo.

El carácter preventivo de la pena «no es absolutamente necesario». Por lo demás, mirar a la pena como exclusivamente correccional es «desconocer su naturaleza». La supresión de la nota de expiación a la pena y la colocación del eje de ésta en la corrección es «altamente cruel» y contraria a la noción de justicia, tal y como viene sellada en cada corazón humano. Si la pena es exclusivamente correccional, eso presupone que «el orden moral no exige ninguna reparación». El orden moral, en esas condiciones de exclusiva corrección como fundamento de la pena, no recibe la reparación que supone el carácter expiatorio esencial a la pena conforme al esquema moral antes formulado y, como consecuencia, lo que ocurre es que prevalece la voluntad de la criatura sobre la de Dios.

Es decir, el fundamento expiatorio de la pena es de impronta teológica y se basa en un esquema de compensación de penas y premios que rige en el orden moral.

Todo lo interesante que en la tierra hay (justicia, moral, víctima) quedan apartados en favor de la compasión por lo más repugnante, el crimen ${ }^{42}$. La tradición y la propia antropología demuestran que la pena es y ha sido siempre expiación, en todas las culturas y en todos los pueblos. Está lo anterior tan grabado en el corazón de todo hombre, que en toda cultura también se han ofrecido sacrificios a los dioses para aplacar su ira. De nuevo y, tal y como ocurre con Donoso Cortés, la teoría de

42 En el mismo sentido: La pena de muerte no es «...venganza como suponen torpemente ciertos observadores miopes, sino por satisfacer los fueros de la justicia violados y reprimir atentados de igual especie (La Censura, número 24, de junio de 1846). 
los sacrificios envuelve una justificación del carácter necesario del castigo como castigo expiatorio. La crítica al correccionalismo no implica, en cualquier caso, un rechazo absoluto por la idea correctora de las penas, y nos dice que "¿Qué más puede desear el legislador que reparar el desorden en sí mismo, y restituir al orden al que lo había infringido?». Este objeto, en cuanto pueda ser compatible con la justicia, es exigible a la pena, y de nuevo lo es a imitación de la disposición del orden moral llevada a cabo por Dios y por la ley divina «que no castiga sino para mejorar, excepto el caso en que, llenada la medida, cierra el Juez Supremo los tesoros de su misericordia y descarga sobre el culpable el formidable peso de la justicia». Su preocupación por las cuestiones atinentes al fundamento y fin del castigo penal las expresó también en ocasiones en forma de diálogos, en un estilo muy característico de Balmes.

Lo interesante de este pequeño diálogo que se recoge en Criterio es la pluralidad de tópicos sobre la pena y el castigo que incorpora, uno de ellos, repetido hasta nuestros días: la cuestión del cómo se percibe por el criminal el castigo y el agobio que causa socialmente el que lo viva como un descanso, como un premio o, al menos, con indiferencia.

Dice el texto ${ }^{43}$ :

Anselmo, joven aficionado al estudio de las altas cuestiones de legislación, acaba de leer un elocuente discurso en contra de la pena de muerte. Lo irreparable de la condenación del inocente, lo repugnante y horroroso del suplicio, aun cuando lo sufra el verdadero culpable; la inutilidad de tal castigo para extirpar ni disminuir el crimen, todo está pintado con vivos colores, con pinceladas magníficas; todo realzado con descripciones patéticas, con anécdotas que hacen estremecer. El joven se halla profundamente conmovido, imaginase que medita, y no hace más que sentir; cree ser un filósofo que juzga, cuando no es más que un hombre que se compadece. En su concepto, la pena de muerte es inútil, y aun cuando no fuera injusta es bastante la inutilidad para hacer su aplicación altamente criminal. Este es un punto en que la sociedad debe reflexionar seriamente para libertarse de esa costumbre cruel que le han legado generaciones menos ilustradas. Las convicciones del nuevo adepto nada dejan que desear; en ellas se combinan razones sociales y humanitarias; al parecer, nada fuera capaz de conmoverlas.

El joven filósofo habla sobre el particular con un magistrado de profundo saber y dilatada experiencia, quien opina que la abolición de la pena de muerte es una ilusión irrealizable. Desenvuelve, en primer lugar, los principios de justicia en que se funda, pinta con vivos colores las fatales consecuencias que resultarían de semejante paso, retrata a los hombres desalmados, burlándose de toda otra pena que no

43 Balmes, J. Criterio cap. XIX, parágrafo V, Anselmo: sus variaciones sobre la pena de muerte, págs. 158-159 
sea el último suplicio, recuerda las obligaciones de la sociedad en la protección del débil y del inocente, refiere algunos casos desastrosos en que resaltan la crueldad del malvado y los padecimientos de la víctima; el corazón del joven ya experimenta impresiones nuevas; una santa indignación levanta su pecho, el celo de la justicia le inflama; su alma sensible se identifica y eleva con la del magistrado; se enorgullece de saber dominarlos sentimientos de injusta compasión, de sacrificarlos en las aras de los grandes intereses de la humanidad, e imaginándose ya sentado en un tribunal, revestido con la toga de un magistrado, parece que el corazón le dice: «Sí, también sabrías ser justo, también sabrías vencerte a ti mismo; también sabrías, si necesario fuese, obedecer a los impulsos de tu conciencia, y con la mano en el corazón y la vista en Dios pronunciar la sentencia fatal en obsequio de la justicia.

Otro sacerdote neoescolástico del XIX, el Padre Mendive, defendió también con profusión de argumentos la pena de muerte. La defensa de la pena capital está en relación con la propia finalidad de las penas. «...la enmienda del delincuente no es el fin primario de la pena sino el secundario; el cual por lo mismo no se debe procurar sino de una manera secundaria. El fin primario y principal de toda pena es la restauración del orden, violado con el delito» ${ }^{44}$ En su lógica consecuencia, el indulto debe ser excepcional, puesto que la no aplicación de la pena de muerte genera el riesgo de actuar como disolvente del orden social, así pues la excepción «...debe ser rara, para que no cobren ánimo los malhechores con la esperanza de que serán indultados».

La definición de los derechos corresponde al gobernante, con el fin de que la república atienda a su fin que no es sino la prosperidad pública. Esa autoridad tiene «el derecho de castigar con penas sensibles». Los fines de la pena son la prevención general «....sin este castigo las leyes civiles estarían destituídas de conveniente sanción; y por lo tanto quedarían inutilizadas por completo...», además del argumento (ya visto en Ortí y Lara y en Balmes) de pena como reacción del propio orden social contra el que altera el mismo.

Si reside en la autoridad pública el deber de imponer penas sensibles proporcionadas a la falta cometida, los delitos especialmente graves es lógico que lleven aparejada la pena capital. De nuevo se nos vierte un argumento meramente teológico: Dios ha dado a cada ser aquellos medios que le son necesarios para poder alcanzar sus fines y «Es así que, sin el derecho de castigar con la pena de muerte ciertos delitos gravísimos, no puede alcanzar la sociedad su propio fin. Pues este fin consiste principalmente en la paz, seguridad, y tranquilidad». Esa tranquilidad queda perturbada si les consta a los criminales que sea cual sea el delito cometido y su atrocidad, no conllevará la pena de muerte.

$44 \quad$ Mendive.J «Elementos ...». Pag.272. 
Otro argumento «integrista» en favor de la pena capital y vinculado con los anteriores: la sociedad ha recibido de Dios «Suficiente Virtud» para poder proteger y guardar sus bienes de toda agresión injusta. «porque de lo contrario no estaría bien ordenada y este desorden debería atribuirse al mismo Dios», es decir, sin pena de muerte, estaríamos ante la imposibilidad teológica de que Dios hubiera generado desorden social. Los otros argumentos son los ya clásicos de Santo Tomás ${ }^{45}$.

Un reaccionario militante como Ortí y Lara decía que «El derecho a la existencia...nace con el cumplimiento y se pierde por la infracción del deber ${ }^{46}$. Desde la base de que el derecho es «...un beneficio que otorga la ley moral a los seres que la obedecen y que niega a los que la quebrantan», se desprende que «el autor de la muerte de uno de sus semejantes pierde el derecho a vivir a los ojos de la justicia absoluta». Igual que en o en Donoso, se apela a lo histórico, a lo irracional, a que en el corazón de los seres humanos está grabado "satisfacer el mal con el mal», de donde se concluye que «aquel que ha derramado voluntariamente la sangre de alguno de sus semejantes, merece que sea derramada la suya». La pena de muerte, propiamente, ni es un instrumento de defensa social, ni un medio de venganza, es más bien «la expresión de la justicia, el cumplimiento de aquella gran ley de la espiación que el poder social tiene la misión de realizar respondiendo al grito universal de la conciencia, que pide la muerte para el homicida».

Pero además, y como ya dijimos, la pena de muerte se trata profusamente en el pensamiento ultraconservador desde el punto de vista de los fines de la pena, como una pena correccional, pero de manera trascendente, tal y como veíamos antes; lo anterior guarda relación con dos aspectos muy llamativos del pensamiento reaccionario español, la reivindicación del Tribunal de la Inquisición y el uso de esa metodología basada en la verdad revelada ${ }^{47}$. Las condenas de la Inquisición consiguieron salvar almas, ese es uno de sus méritos. Veamos el texto de un pequeño artículo

45 Mendive. J. »Elementos...» pág. 273.

46 Ortí y Lara J.M «Ética o principios de filosofía moral». Madrid. Establecimiento Tipográfíco de Nicolás Castro Palomino, 1853, págs. 195 y ss.

47 El Tribunal de la Inquisición fue sistemáticamente reivindicado como algo propio y consustancial al verdadero carácter español, así Menéndez Pelayo «¿hubiera podido existir la Inquisición si el principio que dio vida a aquel popularísimo tribunal no hubiese encarnado desde muy antiguo en el pensamiento y en la conciencia del pueblo español?», (Menéndez Pelayo M, «Historia de los Heterodoxos...» pág. 44). Acabada la guerra, Sánchez Tejerina decía que España precisaba de un nuevo Tribunal de la Inquisición y que bien se conformaba con que fuera como la de la España Imperial. Jerónimo Montes también había dicho que siendo la imperial «la época más gloriosa de nuestra Patria en la justicia penal», la Inquisición (frente a los corruptibles jueces de principios del XX, y recogiendo una frase tópica) era un Tribunal «ante el cual tanto significaba el último labriego, como el Arzobispo de Toledo y Primado de España», como ejemplo de trato igual ante los tribunales. (Montes Luengo, J. «Causas jurídicas y políticas de la criminalidad» Revista Ciudad de Dios, número 1047, Madrid, 1917, pg.15). 
publicado en El Siglo Futuro el 15 de enero de 1880 llamado «El justo medio en derecho penal»: Para la corrección individual del reo, ninguna pena más eficaz que la de muerte. Pocos son los reos de muerte tan empedernidos y feroces que resistan impenitentes las cuarenta y ocho horas de capilla; pocos los delincuentes para quien la capilla no sea camino de arrepentimiento y salvación eterna, qu, a muchas criminales reincidentes en vano les procuró la ley en cárceles y presidios.

La legitimidad de la pena de muerte la da, efectivamente, la historia y la verdad revelada. Si se ha aplicado en todo tiempo y en toda sociedad, ¿Quién se atreve modernamente a cuestionarla? Jerónimo Montes hace uso de este argumento e impugna las tesis de Beccaria que relaciona contrato social con proscripción de la pena de muerte y, en realidad, acaba sus argumentos a favor de la pena capital donde frecuentemente lo hacía, colocando la democracia y la ilustración como criminógenas y volviendo a la teoría de las potestades ${ }^{48}$ : «El poder de la sociedad no se deriva de los asociados, sino de la naturaleza moral del hombre, mejor dicho, de Dios, que lo hizo sociable». La Palabra Revelada da el argumento irrefutable a favor de la pena capital: «REVELACIÓN. - He aqui una palabra vacía de sentido para una gran parte del género humano, mientras que es fuente de verdad eterna para los que, iluminados por la luz de la fe, estamos persuadidos de que Dios ha hablado al hombre, y creemos en la infalibilidad de cuanto ha dicho y cuanto han consignado en las Escrituras los Profetas y los Apóstoles. Prescindiría de este argumento si sólo para espiritus racionalistas me hubiese propuesto escribir; pero como la mayor parte de mis lectores, acaso todos, creen en la revelación, y están persuadidos de la infalibilidad de sus doctrinas, no dudo presentarla en apoyo de la proposición que defendemos, y como una de las pruebas más convincentes que podemos aducir en defensa de la pena capital». La pena de muerte la instaura Dios mismo para su cumplimiento por el pueblo de Israel en el libro del Éxodo (Éxodo 21.11 y ss.). Si Dios hubiera prescrito la pena de muerte de manera meramente excepcional, lo hubiera dicho expresamente. Por otra parte, el Nuevo Testamento no la reprueba, y así y con toda lógica, «cuestionar la legitimidad de la pena de muerte no es sino arrojar el borrón de la infamia sobre la conducta del supremo Jerarca» ${ }^{49}$, es decir, cuestionar la pena de muerte viene a ser algo así como blasfemar. El autor, en fin, remite a «la Historia, a la Revelación y al testimonio de su propia conciencia».

Aceptada así como irrefutable la legitimidad y necesidad de la pena capital, y como referí anteriormente, toca argumentar sobre extremos más escabrosos. ¿Mere-

48 Montes Luengo J. «La pena de muerte y el derecho de indulto» en Revista Ciudad de Dios. En su publicación original (que es la que he manejado) aparece diseminada en varios números, el 27 (año 1892) págs. 425-435 y 495 a 507. El 28, (año 1892) págs.170-184 y 357 a 368, y 29 (1892) págs.168-182.

49 Montes Luengo J. «La pena de muerte...» pág. 362. 
ce la misma ejecución el que ha matado diez veces que el que sólo lo ha hecho una vez? Montes nos dice que la pena de muerte es «indivisible», pero que no parece justo que deba padecer lo mismo en el cadalso el autor de diez muertes que el autor de una sola, si bien acaba repugnando la posibilidad de que se infiera mayor sufrimiento a unos reos que a otros. Toda esta lógica horrenda conlleva también a preguntarse sobre el modo más cristiano, menos doloroso y más digno de administrar la muerte: «Los medios que a nosotros nos parecen más sencillos, más suaves para el reo y menos odiosos para el público, son los últimos que hemos indicado, es decir, los que causan la muerte por asfixia. Puede emplearse, por ejemplo, el óxido de carbono, que, según consta por experiencia, produce la muerte en pocos momentos, se siente poco un levísimo dolor, y el hombre sometido á sus efectos termina su existencia del modo menos repulsivo que es posible en casos de este género. Esta clase de muerte aparecería ante el público con todos los caracteres de un sueño; la aplicación del gas asfixiante al reo podría hacerse sumamente sencilla con la invención de un aparato a propósito, y no dejaría huella alguna en el cadáver» ${ }^{50}$.

\section{LA JUSTIFICACIÓN MÁS RADICAL. DONOSO CORTÉS.}

Y como decía, la pena capital se justifica desde diversos puntos de vista y con diversas teorías. Cabe destacar, por su virulencia y su carácter extremadamente reaccionario, la posición sobre esta cuestión Donoso Cortés, uno de los pensadores más relevantes del ultraconservadurismo europeo del XIX. Las escasas páginas que Donoso Cortés dedica al derecho penal están escritas, como toda su obra final y correspondiente al periodo que él mismo denominó de conversión, desde un sólido integrismo. Su Ensayo sobre el catolicismo, el liberalismo y el socialismo ${ }^{51}$, comienza, de hecho, con el siguiente pórtico: «La teología, por lo mismo que es la ciencia de Dios, es el océano que contiene y abarca todas las ciencias, así como Dios es el océano que contiene y abarca todas las $\cos a s\rangle^{52}$. Sus escritos políticos de esta etapa tienen una buscada base teológica. Sus ideas sobre el derecho penal (dedicadas casi exclusivamente a la cuestión de la pena de muerte) se sustentan enteramente en esa base teológica.

50 Montes Luengo, J. «La pena de muerte...».pág. 364. Montes escribió otra obrita sobre el mismo particular: «¿Debe ser pública la ejecución de la pena capital?», y que publico Ciudad de Dios en su $\mathrm{n}^{\circ} 40$ (año 1896) pgs. 161 a 175. Este tipo de disquisiciones son la lógica consecuencia de regular instituciones tan aberrantes. Por eso resulta estremecedora la exposición que Tomás y Valiente lleva a cabo sobre las opiniones de los autores de la Edad Moderna sobre cuándo, cómo, a quién, con qué intensidad etc. debían ser torturados los acusados (Tomás y Valiente. F, «La Tortura ...», especialmente, su Cap. III pgs. 93 y ss.).

51 Donoso Cortés, J. «Ensayo sobre el catolicismo, el liberalismo y el socialismo», publicada en 1851, he manejado la edición de la Biblioteca de Autores Cristianos, Obras Completas, 1946. Vol. II, 348-551.

52 Donoso Cortés, J. «Ensayo...», pág. 348. 
Desde ese entendimiento, la única fuente posible de verdad es la doctrina de la Iglesia Católica. Fuera de ella, y en su contraste, los gobiernos humanos han generado con sus errores otros nuevos, pudiendo asegurar que en puridad «La intolerancia doctrinal de la Iglesia ha salvado el mundo del caos» ${ }^{53}$. La explicación para todas las cosas desde Dios y la fuente de legitimación en el derecho divino constituyen un punto de partida de las construcciones de Donoso en su Ensayo. Lógicamente, también la formulación y la fundamentación de los castigos públicos. El Ensayo contiene en su libro segundo un revelador capítulo sexto titulado «Dogmas correlativos al de la solidaridad: los sacrificios sangrientos. Teorías de las Escuelas Racionalistas acerca de la pena de muerte». La universalidad de la efusión de sangre humana en la historia a través de los sacrificios, sirve al Donoso Cortés más radical para abordar la cuestión de la pena de muerte: «El género humano, en el que no ha dejado de soplar de todo punto el viento de las tradiciones bíblicas, ha creído siempre, con una fe invencible, estas tres cosas: que es fuerza que la sangre sea derramada; que, derramada de un modo, purifica, y de otro, enloquece ${ }^{54}$, y ejemplo de todo esto es la universal aplicación de la pena capital: «la legislación de todos los pueblos, por la que el que quita la vida ajena está excomulgado y pierde la suya, saliendo de la comunión de los vivientes» ${ }^{55}$. La primera nota que tiene la pena de muerte, es pues, su universalidad histórica. Es una institución contemplada en todos los pueblos. El que quita la vida, pierde la suya. Posteriormente, da otra nota de principio, la pena de muerte es una institución necesaria para la paz social. «En dondequiera que la pena de muerte ha sido abolida, la sociedad ha destilado sangre por todos sus poros $\rangle^{56}$. La efusión de sangre cumple un fin de equilibrio social. Pero el Ensayo contiene, a través de la teoría sobre la pena de muerte, una construcción sobre el fundamento del castigo en las sociedades que parte de una teoría sobre los sacrificios humanos en relación con determinados principios católicos. Donoso, partiendo de la desviación de Adán con respecto de lo mandado por Dios, refiere una serie de principios de la especie humana en su relación con Dios y en su relación con la culpa. Expone así los principios de solidaridad y unidad. La solidaridad y la unidad de todos los hombres conlleva la existencia de una especie de responsabilidad en común, $\mathrm{y}$ «esta responsabilidad supone a su vez que los méritos y los crímenes de los unos pueden dañar y aprovechar a $\operatorname{los}$ otros $\rangle^{57}$. Y añade que: «Cuando el daño es el que se comunica, el dogma conserva su nombre genérico de solidaridad, y le cambia por el de reversibilidad cuando lo que se comunica es

$\begin{array}{ll}53 & \text { Donoso Cortés, J. «Ensayo...», pág. } 367 . \\ 54 & \text { Donoso Cortés, J. «Ensayo...», pág. } 519 . \\ 55 & \text { Donoso Cortés, J. «Ensayo...» pág., } 519 . \\ 56 & \text { Donoso Cortés, J. «Ensayo...», pág. } 522 . \\ 57 & \text { Donoso Cortés, J. «Ensayo...», pág. } 516 .\end{array}$ 
el provecho. Así se dice que todos pecamos en Adán, porque todos somos con él solidarios, y que todos fuimos hechos salvos por Jesucristo, porque sus méritos nos son reversibles». Somos solidarios (participamos en la culpabilidad) con el daño que causan otros, y nos aprovechamos también de la expiación que llevan a cabo terceros (reversibilidad).

Estos dos principios se complementan con los de imputación y sustitución; Por la imputación «padecemos todos la pena de Adán, y por el de la sustitución padeció el Señor por todos nosotros».

En Donoso, el delito mancha y la sangre vertida purifica, expía. Sobre esos principios y sobre la teoría de los sacrificios, Donoso explica el fundamento del ius puniendi, con un momento fundacional, la prevaricación de Adán y el posterior sacrificio de Abel. La efusión de sangre no puede expiar el pecado original, y ahí ha residido la confusión del ser humano en la aplicación de los sacrificios. Sin embargo, esa efusión de sangre puede ser «expiatoria de ciertos pecados individuales, de donde se sigue no sólo la legitimidad, sino también la necesidad y la conveniencia de la pena de muerte» ${ }^{58}$. La pena de muerte por lo tanto tiene una función expiatoria, al menos de ciertos pecados, y parece que se encuentra en una vía intermedia entre el sacrificio perfecto (el de Jesucristo) y el parcialmente erróneo sacrificio de los inocentes que ha sido tan común a toda cultura. Y así, la universalidad de la pena capital es prueba de esa convicción de todos los pueblos en la eficacia purificante del derramamiento de sangre ${ }^{59}$. El Ensayo contiene, en fin, la formulación sobre la

58 Donoso Cortés, J. «Ensayo...», pág. 522.

59 Donoso aparece invocado por una tradición que apela los principios de teología católica de solidaridad, reversibilidad e imputación para solicitar, de lege ferendae, el castigo penal del suicidio. Por supuesto se puede seguir su rastro en las páginas del Siglo Futuro. En su edición de 14 de agosto de 1907 leemos los siguientes fragmentos: «...castigar al suicida con algún género de pena es posible y es justo , puesto que la Iglesia de Dios castiga el suicidio y no exclusivamente con pena espirituales y en los códigos de todos los pueblos civilizados se castigó con penas de orden temporal. Pero no sólo es posible y justo, sino también útil y eficaz por cuanto pueda probarse con las estadísticas que el número de suicidios ha aumentado desde que este delito no tiene pena señalada en las leyes humanas». El texto está acompañado, de nuevo, de las habituales disertaciones contra Beccaria: «En este punto la influencia del sentimentalismo que predicó Beccaria no ha podido ser más desastrosa para la salud de las almas...», puesto que «Desde que es el suicidio, dijo el famoso marqués, un delito que no puede ser castigado sin hacer recaer la pena sobre un cadáver o sobre inocentes que no pueden ser responsables de un crimen que no han cometido... son legión los penalistas que lo han repetido y repiten como dogma de fe, para pronunciarse contra las penas de infamia con que de antiguo se castigaba a los suicidas, y la confiscación cuando no dejaban descendientes». Y sin embargo, pese a esta impunidad, la «voz del pueblo» ve como por el dogma de solidaridad donosiano «que vuelve a los de una misma sangre los reflejos de gloria o los estigmas del demérito», que «queda algo» que desmerece la estimación de las colectividades domésticas. (el artículo lo firma Manuel S Asensio). En su edición de 30 de noviembre de 1914 y en un editorial titulado «El suicidio y la política liberal» se advertía con la habitual inflexibilidad de que el suicidio era un crimen. El fundamento, como es lógico, está en la indisponibilidad de la vida 
legitimación del ius puniendi más radical del pensamiento reaccionario español: «... en esta materia de la penalidad todos los gobiernos son incompetentes, porque todos son falibles. Sólo puede acusar de delito el que puede acusar de pecado, y sólo puede imponer penas por el uno el que puede imponerlas por el otro. Los gobiernos no son competentes para imponer una pena al hombre sino en calidad de delegados de Dios, ni la ley humana tiene fuerza sino cuando es el comentario de la ley divina. La negación de Dios y de su ley por parte de los gobiernos viene a ser la negación de sí propios. Negar la ley divina y afirmar la humana, afirmar el delito y negar el pecado, negar a Dios y afirmar un gobierno cualquiera, es afirmar aquello mismo que se niega y negar aquello mismo que se afirma, es caer en una contradicción palpable y evidente» ${ }^{60}$. El despegue de los Gobiernos con respecto de Dios ha traído monstruosas consecuencias en materia penal. Cuando los Gobiernos «comienzan a secularizarse o apartarse de Dios, luego al punto aflojan en la penalidad, como si sintieran que se les disminuye su derecho». «Las teorías laxas de los criminalistas modernos son contemporáneas de la decadencia religiosa, y su predominio en los códigos es contemporáneo de la secularización completa de las potestades políticas. Desde entonces acá el criminal se ha ido transformando a nuestros ojos lentamente, hasta el punto de parecer a los hijos objeto de lástima el mismo que era asunto de horror para sus padres. El que ayer era llamado criminal, hoy pierde su nombre en el de excéntrico o en el de loco. Los racionalistas modernos llaman al crimen desventura. ¡Día vendrá en que el gobierno pase a los desventurados, y entonces no habrá otro crimen sino la inocencia! A las teorías sobre la penalidad de las monarquías absolutas en sus tiempos decadentes se siguieron las de las escuelas liberales, que trajeron las cosas al punto y trance en que hoy las vemos; tras las escuelas liberales vienen las socialistas con su teoría de las insurrecciones santas y de los delitos heroicos; ni serán éstas las últimas, porque allá en los lejanos horizontes comienzan a despuntar nuevas y más sangrientas auroras. El nuevo evangelio del mundo se está escribiendo quizá en un presidio. El mundo no tendrá sino lo que merece cuando sea evangelizado por los nuevos apóstoles $\rangle^{61}$.

de la que uno no es dueño. «El suicida dispone de lo que no es suyo, hace injuria a Dios y viola el dominio de Dios». Si el argumento teológico está claro, el argumento dogmático es al menos curioso. «¿No es un crimen el homicidio? Pues el homicidio es tanto más grave cuando más se allega la persona que lo sufre a la que lo comete. Por eso en todos los códigos el parricidio cualifica y agrava la culpa y la pena. Pero el suicida quita la vida a la persona más próxima suya, que es el mismo suicida. Luego el suicidio es el homicidio más grave». Por supuesto la argumentación se hace dialécticamente contra un liberalismo que «lejos de condenar y de castigar el suicidio lo ensalza, lo glorifica» (en referencia a los suicidios «por honor»).

60 Donoso Cortés, J. «Ensayo...», pág.523.

${ }^{61}$ Donoso Cortés, J. «Ensayo...», págs. 523-524. 
Un reaccionario militante como Ortí y Lara decía que «El derecho a la existencia...nace con el cumplimiento y se pierde por la infracción del deber». Desde la base de que el derecho es «....un beneficio que otorga la ley moral a los seres que la obedecen y que niega a los que la quebrantan», se desprende que «el autor de la muerte de uno de sus semejantes pierde el derecho a vivir a los ojos de la justicia absoluta». Igual que en o en Donoso, se apela a lo histórico, a lo irracional, a que en el corazón de los seres humanos está grabado "satisfacer el mal con el mal», de donde se concluye que «aquel que ha derramado voluntariamente la sangre de alguno de sus semejantes, merece que sea derramada la suya». La pena de muerte, propiamente, ni es un instrumento de defensa social, ni un medio de venganza, es más bien «la expresión de la justicia, el cumplimiento de aquella gran ley de la espiación que el poder social tiene la misión de realizar respondiendo al grito universal de la conciencia, que pide la muerte para el homicida» ${ }^{62}$.

\section{LA JUSTIFICACIÓN DESDE LA PSIQUIATRÍA EN EL SIGLO XX: VALLEJO NÁJERA}

Dentro del pensamiento reaccionario y sobre los fines de la pena y sobre la misma pena de muerte conectan los argumentos anteriores con una teoría de nuevo cuño formulada en los años treinta del siglo XX: los trabajos de Vallejo Nájera, que le llevan a la conclusión de la necesidad de una fuerte violencia punitiva desde un enfoque basado en la psiquiatría ${ }^{63}$. Ofrece una nueva vertiente a la justificación ultraconservadora de la respuesta penal desde la psiquiatría. Sostiene Vallejo Nájera que la conducta no es sólo un simple reflejo de la personalidad biosíquica, sino que existen importantes intercalaciones de la afectividad y la inteligencia. En opinión de Vallejo la tendencia a buscar motivos de inculpabildad en la deficiencia mental es correlativa al descuido con inculcar a las «clases desheredadas intelectualmente...sentimientos éticos que contrarresten las reacciones producto de no interponer inhibiciones inteligentes $\rangle^{64}$.

Desde luego, si el orden moral no inhibe la conducta antisocial es preciso que la inhibición se produzca por miedo al castigo. Y aquí entra en juego otro factor muy de uso en los años treinta por la prensa conservadora: la queja contra la impunidad. La experiencia de impunidad es un incentivo para los criminales. Existe por lo demás, y así lo habría venido a demostrar el psicoanálisis, un sentimiento innato al

62 Ortí y Lara J.M «Ética o principios de filosofía moral». Madrid. Establecimiento Tipográfico de Nicolás Castro Palomino, 1853, págs. 195 y ss.

63 Vallejo Nájera, A. «Psicopatología de la conducta antisocial», Acción Española nº 1 de 1936, págs. 168-194. El texto completo se publicó en tres números, el segundo de ellos éste que ahora citamos. La primera entrega apareció en el Tomo XV, nº82 de diciembre de 1935 (págs. 495-521) y el tercero en el número 84 (febrero de 1936) págs. 286 a 306.

64 Vallejo Nájera, A. «Psicopatología...» pág. 172 
hombre de justicia y de venganza, sentimiento que algunos relacionan con el llamado principio de consistencia. Un sujeto es consistente cuando hay una concordancia entre su modo de obrar conforme a una idea de justicia y cuando refrena su comportamiento ante lo que es injusto, y además, dicha consistencia exige que se obre con él conforme al mismo patrón. El amoral, el psicópata, el delincuente (pues de todas estas categorías predica Vallejo Nájera el mismo fenómeno) se caracterizan por el principio contrario, la inconsistencia: se cree injustamente tratado cuando obran con él del mismo modo que él obra con los demás. La moderna penología, en opinión de Vallejo, «concede demasiada importancia a las tenencias instintivas y menosprecia la importancia de las leyes de inhibición y consistencia en la formación del carácter». Del principio de consistencia brota necesariamente una tendencia de venganza, que se traduce en el Talión. La idea de que el daño que recibimos precisa de una reparación está en nuestro inconsciente, del mismo modo que la idea de escarmiento al criminal. El talión «está en la base del derecho penal». Si se tiene en cuenta el principio de consistencia como básico en la formación del carácter «es de todo punto necesario que el delincuente sufra un daño igual en cuantía al causado» ${ }^{65}$. En Vallejo además, esa lucha contra la criminalidad no sólo cumple con funciones meramente preventivo general, sino de «regeneración racial», extrañándole que se haya propuesto la segregación de los enfermos y, sin embargo, se abran las puertas de las cárceles a los psicópatas ${ }^{66}$. Si la sanción que se reserva al delito no tiene esta proporción, se revienta la consistencia del sujeto, se pueden liberar todas las inhibiciones que en condiciones normales están operativas y se puede llegar a aplicar la justicia privada. La previa experiencia de impunidad y la falta de proporción del castigo con la pena dan una seguridad a los criminales sobre el éxito de seguir obrando como lo vienen haciendo, así que el pistolerismo sólo desaparecerá «en cuanto la pena de muerte se aplique inflexiblemente, con crueldad si así se quiere, a pistoleros y cómplices» ${ }^{67}$.

La relajación de la educación del pueblo y el relajamiento de los principios morales (religiosos), confluyen en el desequilibrio social. Educación laica, democracia, sufragio popular son pues culpables de que no se corrijan las tendencias psicopáticas sociales. Como suele ser frecuente, delincuencia y democracia acaban entremezclándose en el pensamiento punitivo de la ultraderecha.

Pues bien, en este contexto de férrea defensa de la pena capital, compendia de modo enteramente coherente estos criterios, la Exposición de Motivos de la Ley de 5 de mayo de 1938 por la cual se venía a restablecer la pena de muerte en el

65 Vallejo Nájera, A. «Psicopatología...» pág. 191.

66 Vallejo Nájera, A. «Eugenesia de la hispanidad y regeneración de la raza», Burgos 1937, parágrafo XXXIII.

67 Vallejo Nájera, A. «Psicopatología...», pág. 192. 
Código Penal, (incluyéndola en la escala del Código Penal y estableciéndola como sanción para las figuras de homicidio, asesinato y robo con homicidio, BOE de 7 de julio de 1938). De nuevo hace una apelación a la historia y a la universalidad de la institución: «La Ley que a continuación se promulga es de las que no requieren explicación ni justificación, porque es la propia realidad la que la impone y la dicta. De ello dan testimonio bien expresivo las leyes penales de la casi totalidad de las Naciones...». Esa apelación a la universalidad de la institución y a la historia permite que en realidad la restauración de la pena de muerte no requiera ni justificación ni explicación ${ }^{68}$.

No es necesario profundizar en que su uso fue masivo durante la Guerra Civil y la primera postguerra, pero para ilustrar ese recurso constante a la pena capital y sus estremecedoras consecuencias, creo que resulta muy significativa la escalofriante nota que el Director de Prisiones, Máximo Cuervo, envió la víspera del aniversario del Alzamiento a los encargados de la asistencia religiosa a los que iban a ser ejecutados, y de la que da cuenta Gutmaro Gómez Bravo ${ }^{69}$ : «Siendo una de las principales obligaciones de los capellanes la asistencia a los reclusos que están en capilla y concurriendo en este servicio las circunstancias de grandísimo mérito delante de Dios, pero también de grande dificultad y trabajo por el número de penados y frecuencia de las ejecuciones es forzoso establecer un turno riguroso para que no quede desatendido».

\section{EPÍLOGO. EL RIESGO DE LA REGRESIÓN.}

Creo que no nos podemos sentir enteramente desprendidos de esta forma de argumentar. Quizás podemos caer en la tentación de sentirnos satisfechos ante la nula repercusión dogmática de teorías favorables a la pena de muerte y a su retorno. Tampoco las ciencias penales modernas contemplaban nada parecido a esta forma de argumentar, y sin embargo las teorías expuestas tuvieron una realización práctica durante el franquismo. Ya hemos visto como fuerzas políticas emergentes en Europa y claramente ultraderechistas (por más que eviten ese término y prefieran refugiarse en otros conceptos como el de «partidos identitarios») apuestan por la pena capital como forma de lucha contra la delincuencia más grave y especialmente contra el terrorismo.

68 También en el Preámbulo del Anteproyecto de Código Penal de 1938 de FET y de las JONS podemos leer «La trágica experiencia del escaso tiempo en que ha estado suprimida de la Ley la pena de muerte...ha culminado en el asesinato más gigantesco que registra la Historia», cosa que «...excusa de mayor justificación para el restablecimiento de este arma indispensable para la defensa social». La supresión de la pena de muerte sólo conduce a la violencia más extrema, retomando así el argumento de Donoso Cortés.

69 Gómez Bravo, G. «La política penitenciaria del franquismo y la consolidación del Nuevo Estado». ADPCP, Vol .LXI, 2008, pgs. 165-197. La nota de Máximo Cuervo aparece en pgs. 180-181. 
La traslación de estos argumentos expuestos sobre la pena de muerte se ha venido combinando con otros nuevos. A mero título de ejemplo, desde la Fundación Gustavo Bueno, diversos acólitos del filósofo asturiano han venido defendiendo la pena de muerte. Leamos este pequeño artículo de la revista digital El Catobeplas ( $\mathrm{n}^{\circ}$ 52, junio de 2006, pag. 20) bajo el título «Eutanasia procesal para los narcotraficantes». Bajo el subtítulo «China celebra el Día internacional contra las drogas, proclamado por la ONU, ejecutando a cinco narcotraficantes», se dice que:

«La Asamblea General de la Organización de las Naciones Unidas decidió en 1987 (resolución 42/112 de 7 de diciembre) establecer el día 26 de junio de cada año como Día Internacional de la lucha contra el uso indebido y el tráfico ilícito de drogas. La ONU decidió que este 2006 el tema de ese día internacional sea «Las drogas no son un juego de niños». Las autoridades de la República Popular China saben bien que las drogas no son un juego de niños, y que los traficantes de drogas, hombres que desprecian a sus semejantes hasta el punto de estar dispuestos a enriquecerse a costa de anular la personalidad de sus víctimas drogadictas, no deben ser considerados personas, teniendo la sociedad necesariamente que eliminar el peligro objetivo que supone la criminal actividad de alimañas tan peligrosas. La lucha contra las drogas en China es desde hace tiempo uno de los objetivos prioritarios del Pueblo, pues conoce de sobra que las drogas han sido y son una de las armas utilizadas por los enemigos interiores y exteriores para hacer peligrar la eutaxia nacional. Sin duda la mejor celebración que se puede reseñar de las celebraciones en 2006 del Día Internacional de la lucha contra el uso indebido y el tráfico ilícito de drogas ha sido la eutanasia procesal aplicada por la República Popular China a esos cinco narcotraficantes».

En las diferentes publicaciones relacionadas con la fundación y en los textos de Gustavo Bueno se sustituye el término pena de muerte por el de «eutanasia procesal», que se defiende vivamente. En el libro de Gustavo Bueno y el Secretario General de Vox, Santiago Abascal, se defendían entre otras extravagantes medidas de reforma de la Justicia la «eutanasia procesal para crímenes horrendos» $»^{70}$. Otro ejemplo, en una entrevista publicada el 3 de noviembre de 2013 en el diario ultraderechista Alerta Digital al abogado y profesor asociado de la Universidad de Valencia Luis Zapater Espín ${ }^{71}$ se apreciaban los resabios de la tradición ultra española en materia de derecho penal unida a nuevas influencias que permiten la estructuración de un discurso ultraconservador sobre el derecho penal. Es patente la influencia de Jakobs,

70 Defensa de España: Razones para el patriotismo español, de Gustavo Bueno Sánchez y Santiago Abascal Conde (Fundación para la Defensa de la Nación Española, Ediciones Encuentro, Madrid 2008).

71 Se presentó en principio por el partido ultra «Soluciona» a las elecciones al Parlamento Europeo de mayo de 2014, rompiendo finalmente con esa formación. 
Se defendía la pena de muerte y la cadena perpetua, con referencia a las excelencias penales del régimen franquista:

«...existían dos instituciones muy saludables para la Justicia y la defensa de la sociedad frente al crimen, que eran la cadena perpetua y la pena de muerte». Y «la pena de muerte es un gran instrumento de eugenesia procesal, que permite salvar a la sociedad de la amenaza de sus peores enemigos que la quieren destruir, además de ser instrumento de justicia (no de venganza como dicen los abolicionistas, porque se practica sobre el autor de los peores crímenes, no sobre otros). Es justicia porque es proporcional al daño causado, e incluso podemos encontrar casos como los de los etarras que han matado decenas de personas que ni con la pena de muerte pagarán bastante el daño, pero al menos equipara el daño producido al que se recibe como respuesta del orden penal. Ha probado ser instrumento eficaz con poder de tremenda disuasión en todas las épocas de la historia. Pensemos en el ejemplo de los reyes Católicos, que con el recurso a la misma acabaron con un siglo de desmanes, tropelías y crímenes patrocinados por los nobles que se lucraban de participar en organizaciones criminales»

$\mathrm{y}$

«Aquel que voluntariamente se aparta de la sociedad para poder atentar contra ella y usa los instrumentos que la sociedad le permite, en particular la falsa teología de los derechos humanos, para beneficiarse de un orden penal benigno y continuar atentado contra la sociedad debe perder la condición de ciudadano y exponerse a ser privado de todos sus derechos incluida la vida. No me gusta Rousseau, pero si los liberales fueran coherentes le darían la razón cuando dice que el que atenta contra la voluntad popular lo hace no como ciudadano sino como enemigo, y al ser enemigo de la verdadera libertad, debe ser eliminado para que la sociedad prevalezca. Lo curioso es que los progres aceptan de Rousseau lo que dice para destruir el orden de valores tradicional, pero no para defender la sociedad y el Estado».

Otros discursos no son sino meros arcaicismos, continuidad (cada vez más extinguida) del derecho penal propuesto por los integristas del XIX, sin esa riqueza nueva que suman populismo identitario y funcionalismo. Se ha dicho que

«Hay mucha basura social, y por eso se ha quitado la pena capital desgraciadamente, que es doctrina Católica, y habría que eliminar a mucha gentuza que está haciendo la vida imposible a los inocentes, entonces, pues con justicia... y comprobada la peligrosidad de un sabotaje por ejemplo aunque fuera infecundo, todo eso merece una pena capital...». Estas frases son de un sacerdote leonés llamado Jesús Calvo y están dichas después de relacionar la enfermedad de cáncer del dirigente socialista Pedro Zerolo con la providencia divina, vista la condición de homosexual de éste ${ }^{72}$. Obviamente es una grosera extravagancia, pero desdichadamente

72 Entrevista en el programa «La Ratonera» de Alerta Digital el 9 de enero de 2014 
la historia nos advierte del riesgo de regresiones en estas materias, especialmente en tiempos de fragilidad económica y de debilitamiento de lo que hasta ahora eran bases incontestables del Estado de Derecho.

He hecho referencia a la literatura clásica, y acabo, después de esta exposición lúgubre de argumentos que justifican la crueldad, con la reflexión, llena de sarcasmo, que da no un teórico, no un ser humano sabio, sino un pícaro como lo era Estebanillo González cuando se narra su condena a morir en la horca: «Como quien no quiere la cosa, me sentenciaron a oir sermoncito de escalera... y a bambolearme con todos vientos, como si tuviera otra vida al cabo de un arca».

Efectivamente, no tenemos ninguna otra vida en esta tierra escondida en un arca. Exponer los argumentos de aquellos que defendieron y defienden la supresión de este derecho y combatirlos, como hizo hace doscientos cincuenta años Beccaria, creo que es un deber moral e intelectual que debemos cumplir mientras se vierta un solo argumento en defensa de esta execrable atrocidad. 


\title{
CONTRATO SOCIAL Y PENA CAPITAL BECCARIA VS. ROUSSEAU ${ }^{1}$
}

\author{
DARIO IPPOLITO \\ Profesor Asociado de Filosofía del Derecho. \\ Universidad Roma Tre
}

El presente artículo pretende afrontar la vexata quaestio de la influencia de Rousseau sobre Beccaria, con el objetivo de superar, a través de un análisis conceptual, algunos equívocos interpretativos pasados y recientes. El contraste entre el pensamiento político del filósofo ginebrino y la tesis de Beccaria está impostada sobre la base de dos planos relacionados: por una parte, la doctrina del contrato social y, por otra, aquel relativo al juicio sobre la pena de muerte. Examinadas las nociones de «soberanía» y «voluntad general» en los textos de ambos autores, la investigación se mueve sobre el problema de la justificación del poder soberano de matar para castigar. Dei delitti e delle pene revela su alteridad respecto al Contrat social bajo cada uno de los perfiles considerados.

\section{BECCARIA SEGUIDOR DE ROUSSEAU}

I.1. A pocos meses de la publicación de Dei delitti e delle pene-impreso anónimo en Livorno en julio de $1764^{2}-$, la «Gazette littéraire de l'Europe», dirigida por

1 Traducción del italiano de Agustina Alvarado Urízar, Doctoranda en Ciencias Jurídicas, Università degli Studi di Milano (Italia) y Universidad de Girona (España).

2 Cfr. Firpo, L. «Le edizioni italiane del «Dei delitti e delle pene». En Beccaria, C. Dei delitti e delle pene, a cura de G. Francioni, en Edizione nazionale delle opere di Cesare Beccaria, dirigida por L. Firpo, Mediobanca, Milano 1984, vol. I, pp. 382-394 (en adelante, Dei delitti, 1984). 
François Arnaud e Jean-Baptiste-Antoine Suard, anunciaba a sus lectores que «les études philosophiques commenc[aient] à germer dans un Pays où depuis longtemps les gens de Lettres semblaient se borner presque à l'érudition» ${ }^{3}$. Sobre el autor («qui a montré du talent» ${ }^{4}$ ) y sobre el contenido del libro, el periódico francés reportaba la apreciación de sus corresponsales en Italia:

L'Auteur de cet ouvrage traite de la cruauté des supplices et de l'irrégularité des procédures criminelles. Persuadé que Montesquieu, sur cet article, n'a fait que laisser entrevoir son opinion, il s'est chargé du soin de la développer et ne craint pas d'affirmer que son Traité n'est autre chose qu'une explication claire et précise des sentimens de l'immortel Auteur de l'Esprit des lois. On assure cependant qu'il marche bien moins sur les traces de ce grand homme que sur celles du fameux Citoyen de Genève. Son ouvrage, dit-on, n'est qu'un Recueil des principales maximes du Contrat social, appliquées par l'Auteur à son sujet et dirigées à sa manière ${ }^{5}$.

Que Beccaria se haya auto presentado como un fiel discípulo de Montesquieu es falso ${ }^{6}$. Que hubiese sido un seguidor de la huella del escandaloso filósofo de Ginebra fue lo que pensó la mayor parte de sus contemporáneos. «Ambiciona ser considerado el Rousseau de los italianos» ${ }^{7}$, sentenció, a vituperio del autor, el primero y más feroz de los críticos de los Delitti: el agudo, culto e inquieto Mónaco Facchinei. Desde las primeras páginas de su muy dura diatriba, indicaba que la matriz de las sediciosas y sacrílegas tesis trasmitidas por el pamphlet $^{8}$ se encontraba en el Contrat social, y que detrás del homenaje de Beccaria a «aquel filósofo que había tenido el coraje de sacar de su oscuro y despreciado gabinete y lanzar a la multitud las primeras semillas largamente infructuosas de útiles verdades $\rangle^{9}$, no dudaba en reconocer el perfil de Rousseau. Reconocimiento (en realidad poco convincente ${ }^{10}$ ) que se acompaña de una pesada acusación de blasfemia (insinuada

3 «Gazette littéraire de l'Europe», 13 febrero 1765, pp. 302-303.

4 Ivi, p. 302.

5 Ivi, p. 301-302.

6 «El inmortal Presidente de Montesquieu - escribe Beccaria en la "Introducción" de Dei delitti- ha pasado rápidamente por esta materia. La indivisible verdad me ha forzado a seguir las huellas luminosas es este gran hombre, pero los hombres pensadores sabrán distinguir mis pasos de los suyos» (cursiva agregada) (Beccaria, C. Dei delitti e delle pene, a cura de F. Venturi, Einaudi, Torino, 1965, p. 10).

7 Facchinei, F. Note ed osservazioni sul libro intitolato Dei delitti e delle pene, s.e., s.l. [ma Venezia] 1765 , p. 188.

8 «Io mi pongo a notar quest'Operetta, -escribe Facchinei- tanto più volentieri ch'ella mi sembra una vera figliuola dirò così del Contratto sociale di Rousseau (ivi, p. 4).

9 Beccaria, C. Dei delitti cit., «Introduzione», p. 10.

10 Cfr. Francioni, G. Beccaria filosofo utilitarista, en Cesare Beccaria tra Milano e l'Europa. CariploLaterza, Milano-Bari 1990, pp. 72-73; y la nota 31 del comentario de Philippe Audegean a C. Beccaria, Des délits et des peines. Dei delitti e delle pene, Texte italien établi par G. Francioni, introduction, traduction et notes de Ph. Audegean, ENS Éditions, Lyon 2009, p. 308. 
bajo la forma retórica de preterición) que se desenvuelve en un polémico asalto en contra de la cultura iluminista:

Dado que lamentablemente incluso yo sé, por la deplorable ceguera de algunos literatos, con cuánto desprecio son recibidas las razones extraídas del Evangelio de Jesucristo, dejaré de dar a conocer cuán grande e impía blasfemia escribe aquí N.A., limitándome a afirmar por ahora que un Misántropo fanático ha venido a traer a la humanidad los primeros principios de verdades útiles y sólo advertiré, que aquí se felicita a Gio. Giaccomo Rousseau, [...] del cual aunque reconozca, y esté convencido, de la reputación que la que goza como un hombre de letras, igualmente protesto, que pronto vendrá un día en el que nos avergonzaremos de haber elogiado con tanto entusiasmo sus máximas, y sus principios, y que esta será una muy vergonzosa prueba de la extravagancia del pensamiento $y$, del modo de juzgar de nuestro tan alabado siglo ${ }^{11}$.

Del (presunto) rousseaunismo de Beccaria también se dolían algunos de sus admiradores. El $1^{\circ}$ de enero de 1765 Gianrinaldo Carli escribió a Paolo Frisi contándole haber leído Dei delitti y de haber apreciado «la fuerza, el talento y el coraje de la vivacidad del autor» ${ }^{12}$. A diferencia de Facchinei (y de casi todos los lectores de primera hora), él sabía bien que detrás del velo del anonimato se escondía el joven amigo de los hermanos Verri; y sabía también - no de oídas - que «el Conde Pietro, el Conde Alessandro [...], el marqués Longo, y otros de la denominada Academia dei pugni» le habían dado una «mano» ${ }^{13}$. En sus palabras de elogio resuena el entusiasmo con que Dei delitti fue escuchado en la République des Lumières ${ }^{14}$ : el mismo es celebrado como «el primer libro escrito en Italia en favor de la humanidad, con energía y con independencia» ${ }^{15}$. Ello no quita que Carli nutriera importantes reservas de fondo sobre el discurso de Beccaria. Así, luego de haber pronosticado el éxito entre los «Enciclopedistas» de París, invitaba a su interlocutor a ponderar sus defectos: «Contentémonos de alabar el trabajo, tirando un velo sobre los principios de la misma; porque éstos son desconocidos por la naturaleza, por no decir contrarios a ella. Rousseau, del que luego deriva Gravina, no tenía bajo sus ojos más que Ginebra» ${ }^{16}$.

Sería fácil multiplicar los ejemplos de textos del setecientos en que el pensamiento de Beccaria es conectado al de Rousseau. Fácil, pero inútil: el dato es conocido. Más interesante resulta intentar comprender el por qué de tales juicios (que pueden

11 Facchinei, F. Note cit., p. 15.

12 «Lettera di Gianrinaldo Carli a Paolo Frisi». En Beccaria, C. Dei delitti, cit., p. 186.

13 Ibidem.

14 Cfr. Venturi, F. «Introduzione». En Beccaria, C. Dei delitti, cit., pp. VII-XXXVI; y Porret, M. Beccaria (2003). Il Mulino, Bologna, 2014, pp. 25-28.

15 «Lettera di Gianrinaldo Carli a Paolo Frisi». En Beccaria, C. Dei delitti, cit., p. 186.

16 Ivi, p. 187. 
diferir, obviamente, en el signo de valor asociado a la constatación). El máximo estudioso italiano de Beccaria, Gianni Francioni, ha propuesto una explicación basada en elementos culturales, estilísticos y de contenido: «en general, con muy pocas excepciones, para los contemporáneos de Beccaria hablar de contractualismo y hablar de Rousseau era todo uno. Ellos fueron los más afectados por el pathos de la página, por la carga emocional y humanitaria que las recorren, desde el uso de imágenes eficaces hasta el uso de un fraseo corto e incisivo: en síntesis por el tono marcadamente rousseauniano que Beccaria había querido dar a su libro» ${ }^{17}$.

Efectivamente, si volvemos a considerar los comentarios de Facchinei y de Carli, nos damos cuenta que la principal razón por la que ambos reconocen en Dei delitti la influencia de Rousseau está precisamente en el hecho que Beccaria centre toda su reflexión iusfilosófica en el postulado del contrato social: o bien en una visión de Estado como entidad artificial creada por el libre acuerdo de las voluntades individuales. Carli rechaza expresamente esta doctrina política, junto a la antropología igualitaria que la sostiene: «si se considera su naturaleza en el padre de familia y en los hijos, nos encontramos con que ella, en lugar del frío sentimiento de convención, de contrato o de pacto, teje en su mano los vínculos del amor, de la ternura, de la gratitud, de la estima, de respeto y de subordinación con los cuales la sociedad natural se mantiene en modo de conformar el tipo y modelo de la sociedad artificial $\rangle^{18}$.

El Estado como familia en grande; la autoridad paterna como paradigma del poder político: es remontándose a estas consolidadas representaciones de la civitas que el economista capodistriano remarca su radical disenso respecto a las «conclusiones de Rousseau y de Beccaria» ${ }^{19}$. En cuanto a Ferdinando Facchinei, en sus Note ed osservazioni la premisa contractualista del discurso beccariano es liquidada como «hipótesis [...] falsa y absurda»: una «verdadera quimera», ya que «los hombres jamás han estado $\sin$ Patrón $»^{20}$. Es la ley del más fuerte, no el consenso, lo que determina los asuntos políticos de los hombres ${ }^{21}$; las relaciones de sujeción y dominio se basan en principios normativos del ius naturae, no sobre convenciones pactadas: «Por ley natural - afirma el Mónaco vallombrosano - todos los hombres, desde jóvenes son súbditos de sus parientes, porque han recibido de ellos su vida, y su educación; luego, de adultos, se convierten en súbditos de aquellos que señoreen en el estado en que han sido criados, y deban por la misma ley natural obedecer, y conformarse a las leyes recibidas en aquella Sociedad; y quien niegue estos principios, destruye el fundamento de todas las Sociedades ${ }^{22}$.

\footnotetext{
17 Francioni, G. Beccaria, cit., p. 74.

18 «Lettera di Gianrinaldo Carli», cit., p. 187.

19 Ibidem.

20 Facchinei, F. Note, cit., p. 13.

21 Cfr. ivi, p. 9.

22 Ivi, p. 14.
} 
II.2. Dos siglos y medio después de la tremenda acusación de Facchinei, la asimilación del contractualismo de Dei delitti a la doctrina del Estado de Rousseau es considerado por muchos como un viejo cliché, desgastado por décadas de estudios historiográficos, filológicos y hermenéuticos ${ }^{23}$. Sin embargo, no faltan excepciones que no son para nada despreciables. Adriano Cavanna, por ejemplo, en una muy lúcida ilustración de las tesis filosófico-jurídicas que informan Dei delitti, ha escrito que «siguiendo los pasos de Rousseau, Beccaria postula un acto formal de abandono del estado de naturaleza como origen de la sociedad regida por leyes» ${ }^{24}$. Antes que él, Giovanni Tarello, cuya Storia della cultura giuridica moderna continúa destacando en el panorama de los estudios sobre iluminismo iuspolítico, ya había observado, en Dei delitti, «la sincrética yuxtaposición de la idea contractualista de Rousseau a la aceptación del magisterio de Montesquieu» ${ }^{25}$. Más recientemente, Philippe Audegean, autor de la más importante monografía sobre La philosophie de Beccaria ${ }^{26}$ así como de la magistral edición comentada de la obra maestra del $64^{27}$, ha sintetizado los débitos teóricos del iluminista milanés en los siguientes términos: «Beccaria quedó particularmente impresionado por las obras de Montesquieu, Helvétius y Rousseau. Él conecta estas fuentes con los principales elementos de un discurso filosófico coherente e innovador: una teoría de la historia como proceso civilizador de las costumbres y una concepción de la libertad política como seguridad individual, derivada de la certeza subjetiva de estar al reparo de injerencias ilegítimas (Montesquieu); una visión de la felicidad como bienestar puramente terrenal y una teoría de la utilidad pública como máxima compatibilidad y convergencia de los intereses particulares (Helvétius); una doctrina igualitaria y republicana del contrato social (Rousseau) $»^{28}$.

En realidad, el original análisis conducido por Audegean sobre el contractualismo de Beccaria, es mucho más complejo, articulado y problemático ${ }^{29}$. Sin embargo,

23 «Tranne qualche sporadico commentatore, -ha escrito Francioni- nessuno crede più che il contrattualismo beccariano derivi da quello di Rousseau» (G. Francioni, Beccaria cit., p. 69). La edición crítica de Dei delitti a cura de Francioni, acompañada de un rico Apéndice y de una preciosa Nota al texto, ha aportado una contribución fundamental al progreso de los estudios sobre Beccaria (cfr. Dei delitti 1984, pp. 15-129; pp. 131-214; 215-327).

24 Cavanna, A. Storia del diritto moderno in Europa. Milano, Giuffrè, 2005, vol. II, p 197.

25 Tarello, G. Storia della cultura giuridica moderna (1976). Bologna, Il Mulino, 1997, p. 465.

26 Audegean, Ph. La philosophie de Beccaria. Savoir punir, savoir écrire, savoir produire. París, Vrin, 2010 (publicado traducido en italiano con el título Beccaria filosofo europeo, Carocci, Roma 2014).

27 Beccaria, C. Des délits et des peines. Dei delitti e delle pene, cit. (véase, supra, nota 9).

28 Audegean, Ph. «Dei delitti e delle pene»: significato e genesi di un pamphlet giuspolitico». En La libertà attraverso il diritto. Illuminismo giuridico e questione penale, a cura de D. Ippolito, Editoriale scientifica, Napoli, 2014, pp. 86-87 (cursiva agregada).

29 Cfr. Audegean, Ph. La philosophie de Beccaria, pp. 39-170. 
un pasaje como el apenas citado (en un ensayo firmado por uno de los estudiosos más autorizados de Dei delitti) es suficiente para advertir la necesidad de liquidar la imagen del joven italiano seguidor del «Citoyen de Genève» ${ }^{30}$. Por otra parte, también un especialista de Rousseau del calibre de Bruno Bernardi ha sostenido la citada convicción, según la cual Dei delitti es un libro «tout entier écrit en aval du Contrat social $\rangle^{31}$; y ha expresado esta opinión al interior de un ensayo relativo a Le droit de vie et de mort selon Rousseau, en el cual ha sostenido que Beccaria, deslegitimando la pena capital, no habrá hecho otra cosa «que prolonger la voie ouverte par Rousseau lui-même» ${ }^{32}$; el cual, al contrario, al reiterar su fundamento jurídico, no habría sido coherente con sus axiomas ético-políticos. En síntesis, frente al dilema de la pena de muerte, Beccaria habría sido más rousseniano que Rousseau ${ }^{33}$.

El hecho de que la influencia de este último sobre Beccaria pueda ser identificada incluso ahí donde las opiniones de ambos autores divergen diametralmente - como ciertamente ocurre frente al derecho soberano de castigar matando (a pesar de cuanto afirmado por Italo $\mathrm{Mereu}^{34}$ ) - insta a reanudar el examen de la relación entre la filosofía del Contrat social y el contractualismo de Beccaria. Ello es cuanto precisamente me propongo efectuar en las páginas que siguen, a través de una serie de muestras que apuntan al ámbito conceptual de Dei delitti.

\section{SOBERANÍA Y VOLUNTAD GENERAL EN LA TEORÍA DEL CONTRATO SOCIAL}

II.1. Como punto de partida literal podemos tomar tanto el $\S$ I del afortunado «libriccino» ${ }^{35}$ («Origen de las penas») como el primer párrafo del § XXVIII («De la pena de muerte»). Elijo este último debido a que resume en pocas palabras la teoría de la soberanía de Beccaria, o en otras palabras, su concepción del contrato social:

¿Cuál puede ser el derecho que los hombres se atribuyen para matar a sus semejantes? Ciertamente, no puede ser aquél del cual resulta la soberanía y las leyes.

30 Véase también la importante Introduzione de Alberto Burgio a su bella edición de C. Beccaria, Dei delitti e delle pene, a cura de A. Burgio, con una prefación de S. Rodotà, Feltrinelli, Milano 1990 (en adelante, Dei delitti, 1990), donde Rousseau es enumerado entre las «fuentes esenciales» (ivi, p. 17) del pensamiento beccariano.

31 Bernardi, B. «Le droit de vie et de mort selon Rousseau: une question mal posée». En Revue de Méthaphysique et de Morale, XXXVII (2003), p. 13 (de la edición on line).

32 Ibidem.

33 Ha retomado la lectura de Bernardi, enmendándola con inteligencia crítica, Coqui, G. «Le «droit de vie et de mort» est-il un droit de punir? (Sur Rousseau, Du Contrat Social, II, V)». En Corpus. Revue de philosophie, LXII (2012), La peine de mort, mis en œuvre e par L. Delia et F. Hoarau, pp. 157-176.

34 Cfr. Mereu, I. La morte come pena (1982). Roma, Donzelli, 2007, pp. 97-110.

35 Así Alessandro Manzoni designa Dei delitti en su Storia della Colonna Infame (1842), BUR, Milano 1961, p. 56. 
Ellos no son más que una suma de mínimas porciones de la libertad privada de cada uno; ellos representan la voluntad general, que es la suma de las particulares. ¿Quién ha querido jamás dejar entregado en otros hombres el arbitrio de matarlo? ¿Cómo es posible que en el mínimo sacrificio de la libertad de cada uno pueda estar comprendida la vida como máximo sacrificio entre todos los bienes? Y si ello fuese así, ¿cómo se concilia este principio con otro, consistente en que el hombre no sea dueño de matarse, si para delegar este poder en otros o en la sociedad entera debiera poder serlo? ${ }^{36}$

En el fondo de esta serie de preguntas retóricas, Beccaria formula una tesis disruptiva, susceptible de ser subsumida en la hipótesis del crimen lesae maiestatis: el Estado no tiene el derecho de castigar con la muerte. Que la conclusión beccariana pueda ser revista como el desarrollo de los principios contractuales de Rousseau es realmente sorprendente, si se considera el tenor de la argumentación que la sostiene. Es verdad que a primera vista se podría reconocer una impronta rousseniana en la conexión entre soberanía, ley y voluntad general. Sin embargo, se trata de una impronta superficial: una envoltura lingüística que encierra un pensamiento irreductible a aquel del filósofo ginebrino.

En efecto, con una mirada más de cerca, resulta que ni el concepto de voluntad general que se traza en Dei delitti, ni la configuración beccariana de la relación entre autoridad soberana, leyes y voluntad general pueden ser asimilables a las tesis de Rousseau.

La soberanía -en la doctrina del Contrat social- es el poder legibus solutus, indivisible e inalienable, perteneciente al cuerpo político ${ }^{37}$. El cuerpo político -o sea «el Estado»- es «la persona moral» constituida por la totalidad de las personas físicas involucradas en el pacto social («sus miembros» ${ }^{38}$ ). En cuanto persona, en cuanto «yo común $»^{39}$, el cuerpo político tiene una voluntad propia, dirigida a la realización del interés general ${ }^{40}$. Esta voluntad general, trasciende por sobre las voluntades particulares de cada uno de los componentes del cuerpo político, se manifiesta en el ejercicio del poder soberano, a través del establecimiento de reglas generales y abstractas: las leyes ${ }^{41}$. El poder soberano del cuerpo político es por tanto, el poder legislativo y sus actos son expresión directa de la voluntad general.

El nudo conceptual atado por Rousseau entre ley, soberanía y voluntad general se disuelve en el contractualismo beccariano. Si bien la ley permanece enganchada a la

36 Beccaria, C. Dei delitti, cit., § XXVIII, p. 62.

37 Rousseau, J.J. «Del contratto sociale o Principi del diritto politico (1762)». En Id., Scritti politici, a cura de M. Garin, Laterza, Roma-Bari 1994, vol. 2, lib. II, capp. I-II e IV, pp. 101-109.

38 Ivi, cap. IV, p. 105.

39 Ivi, lib. I, cap. VI, p. 94.

40 Cfr. ivi, lib. II, cap. I, pp. 101-102; cap. III, pp. 104-105.

${ }^{41}$ Cfr. ivi, lib. II, cap. VI, pp. 112-114. 
soberanía; el poder supremo es ciertamente identificado en el legislativo (de acuerdo con un asunto doctrinal largamente compartido en la filosofía política moderna) ${ }^{42}$. Sin embargo, la centralidad de la voluntad general viene a menos. Su carga directiva está debilitada por la delegación de facultades legislativas. Su liderazgo político es puramente virtual, ya que su expresión directa es reemplazada por su representación institucional. Mientras Rousseau niega que la voluntad general pueda ser representada -porque la voluntad de una parte del cuerpo político es constitutivamente «diferente» respecto a la voluntad que se expresa «cuando todo el pueblo delibera sobre todo el pueblo» ${ }^{43}$-, Beccaria afirma que la soberanía y las leyes representan la voluntad general: es decir, esta última está representada por el soberano-legislador en las expresiones típicas de su voluntad imperativa ${ }^{44}$.

A la pregunta «¿quién es el titular del poder legislativo?» Beccaria responde como Rousseau: el soberano. Sin embargo, a la interrogante «¿quién es el soberano?», su respuesta diverge netamente de la doctrina democrática del Contrat social. Para Beccaria, el soberano no es el pueblo, sino que el sujeto institucional que administra la soberanía como representante de la sociedad toda ${ }^{45}$. En el horizonte político del iluminista lombardo, no hay huella del pueblo rousseniano, concebido como ente soberano, compuesto por todos los miembros del consorcio civil: la palabra 'pueblo', en Dei delitti, no vale para designar a la totalidad de los ciudadanos colectivamente investidos del poder de legislar, sino sólo a una parte de la sociedad: la masa de individuos de condición económica y cultural modestas; la clase social numéricamente más consistente, pero políticamente menos influyente ${ }^{46}$.

Así, despejado el espacio político del agorà, el ejercicio de las funciones soberanas se traslada a sedes institucionales menos concurridas. La autodeterminación popular abre la puerta a la heteronomía de las reglas establecidas por el depositario de la soberanía. Los asociados tienen la obligación de obedecer a este último: ellos son los súbditos y él es el soberano ${ }^{47}$. Lejos de debilitar la legitimidad de la estructura monárquica del poder político, el contractualismo de Beccaria consolida sus bases, resaltando el carácter representativo de la autoridad real. No es que excluya la posibilidad de que la administración de la soberanía pueda ser confiada a una diputación nacional, a un parlamento ${ }^{48}$; sin embargo, el soberano que se perfila en las páginas de Dei delitti no tiene la fisionomía de una asamblea elegida, sino aque-

42 Beccaria, C. Dei delitti, cit., §§ 1-3, pp. 11-17.

43 Rousseau, J.J. Del contratto, cit., lib. II, cap. VI, p. 112.

44 Cfr. Beccaria, C. Dei delitti, cit., § III, p. 14; § XXVIII, p. 62.

45 Véase el comentario de Burgio en Dei delitti, 1990, p. 127, nota 15.

46 Cfr. Beccaria, C. Dei delitti, § V, p. 18; § 10, p. 28; § XIV, p. 36; § XXI, p. 52; §XXIII, p. 54; § XXVIII, p. 69; § XXIX, p. 71; §XXXVII, p. 90; § XXXVIII, p. 92; § XLII, p. 98 у p. 100.

47 Cfr. ivi, § II, p. 12; § IV, p. 15; §XV, p. 37; § XLIII, p. 101.

48 Cfr. ivi, § 11, p. 30. 
lla de un jefe de Estado que se sienta en un trono y sostiene un cetro ${ }^{49}$. En cuanto legislador, «representa a toda la sociedad unida por [...] el contrato» ${ }^{50}$. En cuanto, «representante de ella» $\rangle^{51}$, las leyes que quiera «representan la voluntad general $»^{52}$. Por tanto, la representación legitimadora de la soberanía real pasa a través de su legitimación representativa. En este pasaje ideológico, la voluntad general pierde, respecto del paradigma rousseniano, su relación inmediata con el ejercicio del poder legislativo.

II.2. Beccaria también se aleja de la filosofía del Contrat social, en el diverso modo de concebir la voluntad general en cuanto tal (es decir, más allá de las relaciones entre ella y la soberanía y las leyes). En la reflexión de Rousseau, sus «principios de derecho político» ${ }^{53}$, los contornos de la categoría de la voluntad general son lanzados en contraste a la categoría de la voluntad particular. La primera emana de la «persona pública» ${ }^{54}$ y persigue el «interés común» ${ }^{55}$. La segunda tiene por objeto intereses particulares y por sujeto los individuos singulares. Por tanto, la voluntad general, no es el resultado de la suma de las voluntades particulares. La diferencia entre las dos grandezas es cualitativa, no cuantitativa. De esta fundamental alteridad deriva la dicotomía rousseniana entre la voluntad general y la «voluntad de todos», siendo esta última configurada como «una suma de voluntades particulares» ${ }^{56}$. El marco conceptual de Dei delitti, en cambio, no contempla estas distinciones. Cuando Beccaria trata la fuente de legitimación de la soberanía y las leyes, habla indiferentemente de «voluntad general $»^{57}$ y de $\langle\text { voluntad de todos }\rangle^{58}$. En el léxico de Dei delitti, estos dos sintagmas resultan semánticamente equivalentes. En efecto, a diferencia de Rousseau, Beccaria define la voluntad general como la «suma de las [voluntades] particulares» ${ }^{59}$.

\footnotetext{
49 Cfr. ivi, § III, p. 14; § XV, p. 36; § XXIX, p. 71; §XXXV, p. 87; § XLII, p. 98; § XLVI, p. 103.

$50 \quad$ Ivi, $\S$ III, p. 14.

$51 \quad$ Ivi, § IV, p. 14.

52 Ivi, § XXVIII, p. 62.

53 La fórmula, empleada en el título de la obra, es retomada en la «Conclusión» (cfr. Rousseau, J.J. Del contratto, cit., lib. IV, cap. IX, p. 204).

54 Ivi, lib. I, cap. VI, p. 94.

55 Ivi, lib. I, cap. VII, p. 96.

56 Ivi, lib. II, cap. III, p. 104.

57 Cfr. Beccaria, C. Dei delitti, cit., § V, p. 18.

58 Cfr. ivi, § IV, p. 15. Cfr. el comentario de Francioni en Dei delitti, 1984, p. 86, nota 3.

59 Cfr. Beccaria, C. Dei delitti, cit., § XXVIII, p. 62. Destacan oportunamente esta oposición Salvatorelli, L. Il pensiero politico italiano dal 1700 al 1870. Torino, Einaudi, 1935, p. 41; Francioni, G. Beccaria, cit., p. 74; y Tabet, X. «Beccaria, la peine de mort et la Révolution française». En Laboratoire italien, IX (2009), p. 3 (de la edición on line).
} 
La diversa formulación de estas categorías es indicadora de una muy profunda discordancia filosófico-política. Al contraponer la voluntad general a la voluntad de los individuos en particular, al sacralizarla como axiológicamente superior a la voluntad de todos (en cuanto considerada sobre su utilidad pública), al hipostasiarla como voluntad de un ente colectivo, personificado como «yo común», Rousseau abandona las premisas individualistas de la doctrina del contrato social arribando a una concepción organicista del Estado, sostenida en la metáfora cosificada del «cuerpo político» ${ }^{60}$. Viceversa, Beccaria concibe al Estado exclusivamente como una asociación política y sólo reconoce la dignidad de persona a los individuos de carne y hueso. Su versión «secularizada» de la noción de voluntad general, corresponde al rechazo de la concepción holística de la sociedad y al reconocimiento de la centralidad del hombre en el orden político ${ }^{61}$. Es esta impostación esencialmente individualista la que abre el espacio a la deslegitimación de la pena de muerte. Un espacio que permanece cerrado en la perspectiva del organicismo (sui generis) de Rousseau: según el cual, una vez que los contrayentes son incorporados a la totalidad comunitaria, la vida individual deja de ser un «beneficio de la naturaleza» y se convierte en «un don condicionado por el Estado» ${ }^{62}$.

El análisis efectuado hasta ahora nos conduce a reiterar la constatación de la prueba tantas veces reiterada (a partir del siglo pasado) por los intérpretes de Beccaria ${ }^{63}$ : la divergencia entre su doctrina iuspolítica y aquélla de Rousseau se evidencia con nitidez desde la determinación de la hipótesis contractualista. Tras la tesis rousseniana, según la cual la vida del individuo, después de la formación del cuerpo político, se trasmuta en un don prodigado sub condicione por la persona pública a los sujetos concretos, se encuentra el paradigma filosófico de un contrato social que prescribe «la alienación total de cada asociado con todos sus derechos a la comunidad» $\rangle^{64}$, que, «como cuerpo», acoge a «cada miembro como parte indivisible del todo» ${ }^{65}$. Una cláusula clave de este tenor es la concepción que menos puede ser aceptada desde el punto de vista del individuo beccariano: el cual, al constituir la asociación política, consiente en

60 «Como la naturaleza a cada hombre un poder absoluto sobre todos sus miembros, el pacto social da al cuerpo político un poder absoluto sobre los suyos, y es este poder el que, dirigido por la voluntad general, porta [...] el nombre de soberanía» (Rousseau, J.J. Del contratto, cit., lib. II, cap. IV, p. 105).

${ }_{61}$ «Beccaria [...] -ha escrito Luigi Salvatorelli- niega todo concepto de un interés, de un valor estatal distinto y superior al interés y al valor de los individuos. Se trata de una negación explícita, resuelta. Él afirma la existencia de un "bien público" abstracto que se contrapone y se ubica sobre los intereses privados» (Salvatorelli, L. Il pensiero político, cit., p. 40).

62 Rousseau, J.J. Del contratto, lib. II, cap. V, p. 109.

${ }_{63}$ Cfr., por ejemplo, Salvatorelli, L. Il pensiero politico, cit., p. 41; Mondolfo, R. Cesare Beccaria. Milano, Nuova accademia editrice, 1960, pp. 41-42 e pp. 53-54.

64 Rousseau, J.J. Del contratto, cit., lib. I, cap. VI, p. 93.

65 Ivi, p. 94. Véase el comentario de Francioni en Dei delitti, 1984, pp. 26-28, nota 1. 
renunciar sólo a una porción mínima de su propia libertad natural, a cambio de la garantía jurídica de la máxima libertad civil compatible con la seguridad colectiva ${ }^{66}$.

\section{CONTRACTUALISMO Y PENA DE MUERTE}

III.1. Casi todos los estudiosos que han destacado la alteridad del contractualismo beccariano respecto del paradigma del Contrat social están de acuerdo en individuar en John Locke como verdadero inspirador de Beccaria en cuanto concierne a la doctrina del origen contractual del consorcio civil ${ }^{67}$. Según Rodolfo Mondolfo, el iluminista milanés, rechazando la idea rousseniana de un contrato basado sobre la «alienación total de cada asociado», «adhiere a la doctrina anterior de Locke», dirigida a establecer «los límites de los poderes legítimos de la sociedad y del Estado» ${ }^{68}$. Por su parte, Giuseppe Zarone, aun cuando no avala la cercanía con el filósofo inglés sobre el plano ideológico-político, afirma que Beccaria acoge «los principios del contractualismo lockiano ${ }^{69}$. Análogo, pero mucho más nítido y cargado de consecuencias, es el juicio de Gianni Francioni, según el cual las tesis contractualistas, en nombre de las cuales se abre el pamphlet de Beccaria, deben «ser reconducidas a la teoría del contrato social de Locke» ${ }^{70}$.

Una verificación puntual de tales propuestas interpretativas, me conduciría demasiado lejos de la pista temática sobre la que he encaminado mi análisis. Sin embargo, considero útil tomar en consideración al menos un elemento del pensamiento de Locke, que puede ayudarnos a profundizar la comparación entre la tesis de Beccaria y de Rousseau: me refiero a la legitimación del poder de matar para castigar. Se trata de una legitimación que el pensamiento filosófico occidental tradicional ha corroborado por milenios y que el contractualismo moderno ha insistentemente reiterado (hasta Dei delitti, e incluso después) ${ }^{71}$.

66 «Beccaria vuelca las conclusiones del ginebrino oponiendo sus mismas premisas», ha escrito Vincenzo Ferrone comparando las tesis de ambos autores sobre la (i)legitimidad de la pena capital (Ferrone, V. Storia dei diritti dell'uomo. Roma-Bari, Laterza, 2014, p. 238).

67 Diferente es la opinión de Audegean, Ph. La philosophie, cit.; y de Costa, P. «Beccaria e la filosofia della pena». En Un fortunato libriccino. L'attualità di Cesare Beccaria, a cura de R. Davis y P. Tincani, Edizioni L'Ornitorinco, Milano, 2014, pp. 33-50.

68 Mondolfo, R. Cesare Beccaria, cit., p. 54.

69 Zarone, G. Etica e politica nell'utilitarismo di Cesare Beccaria. Napoli, Istituto italiano per gli studi storici, 1971, p. 198.

70 Francioni, G. Beccaria, cit., p. 74. Sobre la misma posición se da fe, en una penetrante lectura sintética de Dei delitti, Birocchi, I. Alla ricerca dell'ordine. Toriono, Giappichelli, 2002, p. 449.

71 Cfr. Bobbio, N. Contro la pena di morte (1981); e «Il dibattito attuale sulla pena di morte (1983)». En Id., L'età dei diritti, Einaudi, Torino 1990, pp. 189-234; Cantarella, E. «Uccidere per punire. Come e perché, ieri e oggi». En Ead., Supplizi capitali, Rizzoli, Milano 2005, pp. V-XL. Antes que Beccaria, había recurrido a la doctrina del contrato social para deslegitimar la pena capital el florentino Giuseppe Pelli. Sobre su reflexión abolicionista véase el excelente ensayo de Audegean, Ph. 
Por lo demás, en el ámbito de la «filosofía patibularia» ${ }^{72}$, encontramos al fundador mismo de la lignée contractualista que impronta la reflexión sobre la autoridad política en edad moderna: Thomas Hobbes. Por cuanto pueda parecer paradojal, en su concepción del Estado, el poder punitivo no tiene un origen convencional, sino que totalmente natural. El soberano no lo detenta porque lo haya adquirido a través del pacto social, sino porque, a diferencia de todos los individuos ingresados en la sociedad política, él no ha renunciado a aquel ius in omnia que en el estado de naturaleza permitía a cada uno «hacer uso de aquello que consideraba fuese necesario para su conservación: someter a cualquier hombre, herirlo o matarlo» ${ }^{73}$. Mientras los contrayentes, entrando en el estado civil, han alienado todos sus derechos pre-políticos (salvo el derecho a la vida); el soberano, que no es parte del contrato, permanece en la plenitud de su derecho original. Tal condición jurídica legitima el uso de la fuerza y le consiente infligir las penas que estime más oportunas a efectos de inducir a los hombres a la obediencia. Dar muerte a quien escapa del orden legal es, por tanto, un acto de ejercicio del derecho natural del que el soberano es titular exclusivo ${ }^{74}$.

El discurso de John Locke en torno al castigo capital, no obstante su diverso marco teórico, arriba a la misma conclusión justificativa. En el segundo de sus Two Treatises of Government, define «al poder político como la autoridad de formular leyes que contemplan la pena de muerte y, en consecuencia, todas las penas menores, en conformidad con una reglamentación y conservación de la propiedad» ${ }^{75}$. «Propiedad», en el léxico lockiano, designa el suum de cada individuo, o bien un conjunto de derechos naturales comprensivo del derecho a la vida, a la integridad física, a la libertad y a las posesiones $^{76}$. El poder político, en cambio, es concebido por él como un ente artificial, creado por una convención intersubjetiva, cuyas cláusulas se basan en normas de derecho natural. De acuerdo con esta visión, la potestad soberana de matar a quien infringe las leyes que regulan «la conservación de la propiedad», ciertamente no deriva de un acto de alienación del derecho a la vida, efectuado por los sujetos involucrados en el contrato.

«Una battaglia segreta di Pelli: «abolire la morte per pena a’ delitti». En Pelli, G. Contro la pena di morte, a cura de Ph. Audegean, Padova, Cleup, 2014, pp. 14-60.

72 Ferrajoli, L. Il fondamento del rifiuto della pena di morte, en Il diritto di uccidere. L'enigma della pena di morte, a cura de P. Costa, Milano, Feltrinelli, 2010, p. 57 (ahora también en Id., Il paradigma garantista. Filosofia e critica del diritto penale, a cura de D. Ippolito y S. Spina, Napoli, Editoriale scientifica, 2014, pp. 188-198).

73 Hobbes, Th. Leviatano (1651). Milano, Rizzoli, 2011, cap. XXVIII, pp. 329-330).

74 Ivi, pp. 329-339. Cfr. Huning, D. «The Basis for the Right to Punish in Hobbes's Leviathan». En The Cambridge Companion to Hobbes's Leviathan, ed. por P. Springborg, Cambridge University Press, Cambridge, 2007, pp. 217-240; Yates, A. «The Right to Punish in Hobbes's Leviathan». En Journal of the History of Philosophy, 2 (2014), pp. 233-254.

75 Locke, J. Trattato sul governo (1690), a cura de L. Formigari, Editori Riuniti, Roma, 1997, cap. I, $\S 3$, p. 4.

76 Cfr. ivi, cap. IX, § 123, p. 90. 
$\mathrm{Su}$ fundamento de legitimidad se encuentra en la ley natural misma, que asigna a cada individuo, en el estado de naturaleza, el poder de castigar a los autores de las acciones contrarias a sus prescripciones ${ }^{77}$. Tal «poder ejecutivo de la ley natural $»^{78}$ se encuentra disciplinado en su ejercicio por el principio de proporcionalidad, según el cual la entidad de la pena debe ser determinada de acuerdo con la gravedad de la ofensa ${ }^{79}$. Ello significa que la justicia natural exige que «quienquiera que derrame la sangre de un hombre, haya visto su propia sangre derramada por tal hombre» ${ }^{80}$. En el poder natural de punir, por ende, queda incluido el poder de castigar con la muerte. Es precisamente este poder sobre la vida ajena, y no ya el derecho a la (o sobre la) vida propia, el que los individuos transfieren al Estado a través del pacto que engendra a este último ${ }^{81}$.

En consecuencia, tanto para Locke como para Hobbes, las raíces de la penalidad estatal se encuentran en la ley natural. En particular, para Locke, existe un conjunto de prohibiciones de lesionar, de reglas sancionatorias y de normas de competencia que conforman el derecho penal natural. Ni Beccaria ni Rousseau comparten tal visión iusnaturalista del poder punitivo. En la representación rousseniana del estado de naturaleza, la legalidad penal no está contemplada ${ }^{82}$. La potestad de castigar se perfila solamente en su dimensión política, post-contractual, de instrumento de regulación social instituido a efectos de asegurar la observancia del derecho positivo, o bien la efectividad de las normas sancionadas por la voluntad general ${ }^{83}$. El contrato social no produce un cuerpo inerme. A la soberanía pertenece el monopolio

77 «Para que todos se abstengan de usurpar derechos ajenos y de hacerse recíprocamente el mal [...], la ejecución de la ley natural en dicho estado es confiada a cada uno, donde cada uno tiene el derecho de castigar a quien traicione aquella ley» (ivi, cap. II, $\S 7$, p. 7).

78 Ivi, cap. II, § 12, p. 11.

79 «En el estado de naturaleza, un hombre ejercita el poder sobre otro; pero no se trata de un poder absoluto y arbitrario de disponer de un culpable, caído entre manos, según el furor apasionado y capricho desregulado de la propia voluntad; sino sólo de retribuirlo según los dictámenes de una serena razón, según la medida de su transgresión» (ivi, cap. II, § 8, p. 8).

80 Tal precepto bíblico (extraído del Genesi, 9, 6) es considerado por Locke como una «gran ley natural [...] impresa en el corazón de los hombres» (ivi, cap. II, § 11, p. 10.)

81 Cfr. Silvestrini, G. «Diritti naturali e diritto di uccidere. Teorie moderne della guerra fra modelli teorici e tradizioni di pensiero». En Filosofia politica, XXI (2007), pp. 425-452.

82 El pasaje del Discours sur l'origine et les fondements de l'inegalité parmi les hommes, en que Rousseau menciona el tema de los «castigos», trata de la fenomenología de las relaciones humanas, y no sobre las leyes del orden natural, observando que en la sociedad pre-estatal las ofensas intersubjetivas eran frenadas por el «terror a la venganza» (Rousseau, J.J. «Discorso sull'origine e i fondamenti della disuguaglianza fra gli uomini (1755)». En Id., Scritti politici cit., vol. I, Parte II, p. 180). Por lo demás, en el Contrat, afirma claramente que las normas de la «justicia universal» son vanas entre los hombres en cuanto desprovistas de «sanción natural» (Rousseau, J.J. Del contratto, cit., lib. II, cap. VI, p. 111).

83 Sobre el derecho natural en Rousseau véase, además del clásico Derathé, R. Jean-Jacques Rousseau et la science politique de son temps. Paris, Vrin, 1974; Silvestrini, G. Diritto naturale e volontà generale. Il contrattualismo repubblicano di Jean-Jacques Rousseau. Torino, Claudiana, 2010, pp. 121-174. 
del uso legítimo de la fuerza: «el pacto social, para no ser reducido a un conjunto de fórmulas vanas, incluye tácitamente solo el empleo capaz de dar fuerza a todos los otros, que significa que cualquiera que se niegue a obedecer la voluntad general será forzado por el entero cuerpo ${ }^{84}$. Las órdenes del soberano son prescripciones vinculantes sostenidas por el poder coactivo. En la «relación entre el hombre y la ley», a la «desobediencia» sigue «la pena $\rangle^{85}$. El poder estatal, por ende, es constitutivamente poder penal. Más que una «especie particular» de normas jurídicas, observa Rousseau, las «leyes penales» son la «sanción de todas las otras leyes» ${ }^{86}$.

El despojo de la potestad soberana de castigar del terreno de la ley natural, no es una peculiaridad del contractualismo rousseniano. En esta relevante operación conceptual, el ginebrino es precedido por Pufendorf y seguido por Beccaria ${ }^{87}$. Sin embargo, mientras en la obra pufendorfiana la cuestión es afrontada directamente - en polémica con Grozio e Hobbes - ; en Dei delitti, así como en el Contrat social, ella permanece en el fondo del discurso. Por otra parte, a Beccaria no le interesa elaborar una completa doctrina del pacto social. Se limita a esbozar un borrador al inicio de la obra. La ubicación es reveladora: el contractualismo es el punto de partida, no el baricentro filosófico de la reflexión beccariana. Este último, como ha sido autorizadamente destacado, está «constituido por la teoría utilitarista de Helvétius» ${ }^{88}$, aplicada a la cuestión criminal. Sin embargo, es precisamente la fictio mentis del contrato, lo que abre el camino que conecta la antropología de lo útil con la reforma de la justicia penal. En cuanto doctrina de la artificialidad y de la convencionalidad del orden estatal, de hecho, el contractualismo consiente que Beccaria pueda desvincular al discurso jurídico de toda axiología metafísico-religiosa, emancipar la civitas terrena de la civitas coelestis, proyectar la política del derecho moviéndose desde la experiencia humana antes que desde los preceptos de la voluntad divina. Dentro de los confines de esta dimensión completamente mundana de la existencia, el criterio de utilidad puede desplegar libremente su inmanente actitud normativa y convertirse en la regla para la construcción de un nuevo sistema penal refundado sobre el parámetro de legitimidad del pacto social.

III.2. Beccaria ilustra sumariamente la génesis, objetivos y contenido de este pacto: cansados de vivir en un continuo estado de guerra y de gozar de una libertad vuelta inútil por la incerteza de conservarla, [los hombres] sacrificaron una parte de ella para gozar de la restante con seguridad y tranquilidad. La suma de todas estas

84 Rousseau, J.J. Del contratto, cit., lib. I, cap. VII, p. 96.

85 Ivi, lib. II, cap. XII, p. 128.

86 Ibidem.

87 Sobre el poder de castigar en Pufendorf, véase Fiorillo, V. «Salus populi suprema lex esto»: il potere punitivo, come 'officium regis', nel giusnaturalismo di Pufendorf». En Samuel Pufendorf filosofo del diritto e della politica, a cura de V. Fiorillo, La Città del Sole, Napoli, 1996, pp. 139-169.

88 Francioni, G. Beccaria, cit., p. 69. 
porciones de libertad sacrificadas en beneficio de cada uno, forma la soberanía de una nación, y el soberano es el legítimo depositario y administrador de aquellas; sin embargo, no bastaba con formar este depósito, sino que se requería defenderlo de las usurpaciones privadas de cada hombre en particular, que no sólo busca quitar del depósito su propia porción de libertad, sino incluso usurpar aquella de los demás. Las leyes de la sociedad necesitaban motivos sensibles que bastasen para distraer el ánimo déspota de cada hombre de resumergirse en el antiguo caos. Estos motivos sensibles son las penas establecidas contra los infractores de las leyes [...] Por tanto, aquello sobre lo que está fundado el derecho del soberano para castigar los delitos es: la necesidad de defender el depósito de la salud pública de las usurpaciones particulares ${ }^{89}$.

Ni la claridad conceptual, ni la arquitectura lineal de las grandes teorías de la moderna política contractualista se encuentran en este pasaje. A diferencia de Hobbes, Locke e Rousseau, Beccaria deja en la indeterminación el contenido del pacto: los contrayentes renuncian a una parte de su libertad a efectos de asegurarse la defensa de la parte remanente. Para poder atribuir un significado definitivo a esta Grundklausel, sería necesario saber en qué consiste aquella parte de libertad cedida, y en qué consiste aquella parte de la libertad que el contrato deja consolidada. Sin embargo, Beccaria, no lo esclarece. La interpretación de su contractualismo en clave lockiana colma este déficit semántico proyectando la distinción entre derechos innatos y poderes pre-políticos presente en el Second Treatise, en la página de Dei delitti: «Es evidente - escribe Francioni - el objetivo del exordio contractual de Dei delitti: remarcar que la libertad de los individuos reunidos en sociedad, aun con la limitación que deriva de la cesión de aquella "mínima porción posible" que corresponde al poder individual de vengar las ofensas, queda garantizada por las leyes de la naturaleza, y que todos los derechos que el individuo naturalmente posee deben ser conservados - con la excepción, precisamente, del derecho a castigar - en el estado social $»^{90}$.

Encontrar evidenza en el exordio beccariano de conceptos tales como-«ley natural», «derechos que el individuo naturalmente posee», «poder individual de vengar las ofensas» entendido como «derecho de castigar»- parece cualquier cosa menos fácil. Una lectura de este tipo es proponible solo como conjetura. Sin embargo, una conjetura no es otra cosa que una invitación a practicar el arte de la duda. Por ello, desde el momento en que en Dei delitti falta la explícita identificación de aquella parte de libertad alienada de los individuos por el poder de castigar que (según la visión de Locke) tenían en el estado de naturaleza, corresponde preguntarse si tal identificación está implícita en su razonamiento. En caso que lo estuviese, el

89 Beccaria, C. Dei delitti, cit., § I, p. 11; § II, p. 12.

90 Francioni, G. Beccaria, cit., p. 75. 
derecho estatal de infligir castigos debería ser representado como una derivación directa de las libertades cedidas por los contrayentes. Sin embargo, esta no es la representación de Beccaria. Como se ha apenas visto, él escribe que «la suma de todas [...] las porciones de libertad sacrificadas en beneficio de cada uno forma la soberanía de una nación»; luego de lo cual agrega que «no bastaba formar este depósito», ya que «se requería de motivos» aptos para «distraer el ánimo despótico de cada hombre de» violar «las leyes de la sociedad»: tales motivos son «las penas establecidas contra los infractores de las leyes $\rangle^{91}$. Así, aquello que no bastaba luego de la alienación parcial de las libertades individuales y que se requería adicionalmente -es decir, las penas- demuestra lo diverso del contractualismo de Beccaria respecto del paradigma lockiano: la parte de libertad cedida, evidentemente, no consiste en el poder natural de castigar. Una sorprendente confirmación es extraíble de la concepción beccariana del «fundamento» del «derecho del soberano de castigar los delitos $\rangle^{92}$. A diferencia de cuanto sucede en la construcción contractualista del Second Treatise, el mismo no se individua en la alienación del «poder individual de vengar las ofensas», sino que en la «necesidad»: una necesidad que nace con la sociedad política: la «necesidad de defender el depósito de la salud pública de las usurpaciones particulares $\rangle^{93}$.

En este punto, se evidencia el neto clivage que separa la reflexión filosófico-jurídica de Beccaria de aquélla de Locke. En virtud de esto último es que el derecho penal es parte de la ley natural: con anterioridad a la constitución del Estado, antes del establecimiento de las leyes positivas, ya existe el poder de castigar y existen ya las reglas que lo disciplinan. Para Beccaria, en cambio, el derecho penal es solamente una dimensión de la soberanía: deriva de la decisión humana de abandonar el estado de naturaleza siendo la consecuencia necesaria del artificio civil. Subestimar el alcance político de esta concepción «positivista» de la sanción penal sería un error. Emancipándose de los esquemas mentales del iusnaturalismo, Beccaria pudo confutar las justificaciones retributivas de la pena y repensar las formas del castigo legal más allá del dogma de la correspondencia entre el mal cometido y mal sufrido $^{94}$. Si las normas del derecho penal no están inscritas en el orden natural, entonces

91 Beccaria, C. Dei delitti, cit., § I, p. 11 (cursiva agregada).

92 Ivi, § II, p. 12.

93 Ivi, § I, p. 11.

94 «El abolicionismo -ha justamente observado Gabriella Silvestrini- [...] emerge ahí donde hayan sido debilitados o abandonados dos presupuestos iusnaturalistas centrales en el pensamiento político moderno: el nexo entre derechos naturales y derecho de matar y una concepción iusnaturalista o naturalista-racionalista de la pena» (Silvestrini, G. «Fra diritto di guerra e potere di punire: il «diritto di vita e di morte» nel Contratto sociale». En Rivista di storia della filosofia, 1 (2015), p. 139). «La position abolitionniste de Beccaria implique de faire justice de tout raisonnement "déontologique" portant sur les peines et leur mesure» (K. Ladd, Penser la peine dans la souveraineté 
la legitimidad de la pena de muerte deja de ser evidente y los hombres son libres de elegir racionalmente cómo castigar. Bien, la institución de la pena de muerte, según Beccaria, no podría jamás ser la opción racional de los hombres libres ${ }^{95}$.

III.3. A esta interpretación del contractualismo de Beccaria en clave no iusnaturalista ${ }^{96}$, se podría objetar que precisamente ahí donde él niega la juridicidad de la pena capital se sirve de la lógica del derecho natural ¿La evocación del principio según el cual «el hombre no es dueño de matarse» puede ser una clara señal de fe iusnaturalista? Creo que puede replicarse distinguiendo el valor argumentativo de una evocación del valor de una afirmación. Ciertamente, la pregunta con la que se concluye el primer párrafo del célebre capítulo XXVIII pone el índice sobre la contradicción entre la previsión legal de la muerte como pena y la prohibición del suicidio, sufragando la deslegitimación de la primera mediante la invocación de un principio iusnaturalista de matriz teológica, transpuesto - junto con gran parte de los preceptos religiosos - en el ordenamiento penal positivo. Sin embargo, sería un error concebir tal principio como la piedra angular de la argumentación contractualista beccariana ${ }^{97}$. Para ello, el iluminista lombardo

et dans l'époque. Situation de l'argumentation abolitionniste dans Des délits et des peines de Cesare Beccaria, en Penser la peine à lâge des Lumières, a cura de L. Delia e G. Radica, [fascículo monográfico de] «Lumières», 20 (2012), pp. 105-106). Sobre las relaciones conceptuales entre iusnaturalismo, retribucionismo y legitimación de la pena de muerte, véase también Ippolito, D. «La philosophie pénale des Lumières entre utilitarisme e retributivisme». En ivi, pp. 21-34.

95 Sobre la pena de muerte en Beccaria son imprescindibles los aportes de Francioni, G. Beccaria. cit.; Costa, P. Beccaria, cit.; Audegean, Ph. La philosophie, cit., pp. 152-167.

96 «La versión de Beccaria es una versión anti-iusnaturalista del pacto», ha escrito Ph. Audegean, «Beccaria, Cesare». En Enciclopedia italiana. VIII Appendice. Filosofia. Il contributo italiano alla storia del pensiero, a cura de M. Ciliberto, Istituto dell'Enciclopedia Italiana «Giovanni Treccani», Roma 2012, p. 3 (de la edición on line). Sobre el tema véase el convincente y refinado análisis de Costa, P. Beccaria, cit., pp. 34-38.

97 Así, en realidad, ha sido entendido por muchos lectores de Dei delitti. Véase, por ejemplo, Mondolfo, R. Cesare Beccaria, cit., pp. 60-61; y -casi dos siglos antes- Filangieri, G. La scienza della legislazione (1780-1791). Ed. crítica dirigida por V. Ferrone, lib. III (1783), a cura de G. Tocchini y A. Trampus, Centro di Studi sull'Illuminismo europeo «Giovanni Stiffoni», Venezia 2004, tomo IV, cap. XXIX, el que ha criticado el «sofisma» de Beccaria, reconstruyéndolo bajo la forma del siguiente silogismo: «nadie puede dar aquello que no tiene; como el hombre no tiene el derecho de matarse; entonces el soberano, que no es más que el depositario de los derechos trasferidos por los individuos al entero cuerpo de la sociedad, no puede siquiera tener el derecho de castigar a alguien con la muerte » (ivi, p. 20). Sobre la pena de muerte en Filangieri véase el lúcido ensayo de Tuccillo, A. «Droit de punir et légitimation de la peine de mort dans la Science de la législation de Filangieri». En Corpus. Revue de philosophie, LXII (2012), pp. 231-243. Para una completa reconstrucción de la doctrina penal filangieriana, véanse los excelentes trabajos de Berti, F. «Droit de punir et construction d'une citoyenneté vertueuse dans la philosophie de la peine de Filangieri». En Penser la peine cit., pp. 73-86; Id., «Diritto penale e 
recurre sólo por exigencias retórico-persuasivas: instrumentaliza a sus fines un axioma del derecho natural cristiano que, a la luz de la distinción delito/pecado y de la polémica contra la prohibición-castigo del suicidio ${ }^{98}$, no parece inherente al sistema filosófico de su reformismo penal ${ }^{99}$. Cuando leemos Dei delitti no debemos jamás olvidar que fue escrito con el propósito de incidir sobre la opinión pública. Beccaria apuntaba a convencer a sus lectores, a moverse de sus propias posiciones heterodoxas: y era perfectamente consciente que, para una parte de sus lectores, el principio de utilidad y la teoría del contrato valían infinitamente menos que los mandamientos del Éxodo ${ }^{100}$ y de las verdades reveladas en el Deuteronomio ${ }^{101}$.

La pregunta sobre la indisponibilidad de la vida humana se encuentra dirigida a quienes creen que el hacer morir a los hombres sólo corresponde a Dios: que ciertamente no son los seguidores de Locke o Rousseau. Ello porque estos últimos, además, ya habían formulado claramente su respuesta. Ya hemos visto la respuesta de Locke. Ahora debemos tomar en consideración aquella de Rousseau.

III.4. Se pregunta cómo es posible que los privados, no teniendo el derecho de disponer de su propia vida, puedan transmitir un derecho que no tienen al Soberano. El problema parece difícil debido a que está mal enfocado. Todo hombre tiene el derecho de arriesgar su propia vida para conservarla [...] El tratado social tiene como finalidad la conservación de los contrayentes. Quien pretende un fin también quiere los medios y estos medios son inescindibles de tal riesgo, e incluso de otra

diritti dell'uomo: il garantismo di Gaetano Filangieri». En La libertà attraverso il diritto, cit., pp. 115-147.

98 Cfr. Beccaria, C. Dei delitti, cit., § XXXII, pp. 79-82. Sobre el tema de la «secularización del derecho a castigar» véanse las bellas páginas de Porret, M. Beccaria, cit., pp. 47-55.

99 He avanzado esta hipótesis interpretativa en Ippolito, D. «Beccaria, la pena di morte e la tentazione dell'abolizionismo (2007)». En Id., Diritti e potere. Indagini sull'Illuminismo penale. Roma, Aracne, 2012, pp. 77-102. La repropongo en esta sede confortado por la autorizada opinión de Pietro Costa: «Cierto, no faltan referencias, en los textos beccarianos, al derecho natural. Sin embargo, mi impresión es que la referencia a la condición de criaturas del ser humano y su dependencia de las leyes naturales obligatorias en cuanto queridas por Dios, quede sustancialmente fuera de la visión antropológica y ética de Beccaria. Por el contrario, profundamente coherente con esta visión es el principal argumento utilizado por Beccaria contra la pena de muerte: el sujeto no puede adherir a un contrato que ponga en riesgo su vida, no porque no sea dueño de su vida, sino porque pone la vida al vértice de sus opciones utilitarias. Si ello es cierto, podremos llegar a ver que la invocación de la prohibición del suicidio como un cuerpo extraño a la estructura discursiva de Dei delitti, introducido por motivos exquisitamente retóricos, teniendo en cuenta la parte de su auditorio contrario a la lógica utilitarista, pero sensible a las sirenas iusnaturalistas» (Costa, P. Beccaria, cit., pp. 37-38). Sobre el significado de la evocación de la prohibición de suicidio véase también Audegean, Ph. La philosophie, cit., pp. 127-130.

100 Éxodo, 20, 13: «No matar».

101 Deuteronomio, 32, 39: «Ahora ved que yo solo soy Dios [...]. Hago morir y hago vivir». 
pérdida. Quien pretende conservar su propia vida a costa de los demás, también debe darla para los demás, cuando corresponda. Pues bien, el ciudadano ya no es juez del peligro al que la ley decide que se exponga, y cuando el príncipe le ha dicho: «el Estado requiere que tu mueras» debe morir; porque solo bajo esta condición es que ha vivido seguro hasta ahora, y su vida ya no es solo un beneficio de la naturaleza, sino un don condicionado por el Estado. Más o menos bajo el mismo ángulo visual puede considerarse la pena de muerte infligida a los criminales: para no ser víctima de un asesinato, se acepta morir en caso que nos transformemos en asesinos. Con este pacto, lejos de disponer de la propia vida, se piensa en garantizarla, y entonces no se debe suponer que alguno de los contrayentes premedite hacerse ahorcar ${ }^{102}$.

Con este pasaje se abre el capítulo V del libro II del Contrat social, titulado «Del derecho a la vida y a la muerte», temáticamente ligado al capítulo precedente sobre «límites del poder soberano». Cruz de los intérpretes y admiradores de Rousseau, este capítulo ha sido recientemente iluminado por un hermoso ensayo de Gabriella Silvestrini, quien ha esclarecido el «objeto», la «estrategia argumentativa» y la «red discursiva, en apariencia tan anómala» ${ }^{103}$, situándolo dentro del «debate entre los autores contractualistas sobre el derecho de guerra y el derecho a castigar: dos derechos marcados por un entrelazamiento constitutivo y fundante en el pensamiento político moderno» ${ }^{104}$. En particular, trabajando desde un impecable análisis filológico, Silvestrini ha mostrado cómo «el texto de Rousseau» refleja y reelabora la discusión que Pufendorf -seguido de Burlamaqui- había consagrado al ius vitae ac necis, como prerrogativa soberana relevante en el ámbito del castigo de los crímenes y en el ámbito de la defensa del Estado ${ }^{105}$. ¿Por qué el soberano puede pretender que los ciudadanos combatan en guerra como soldados y sacrifiquen su vida por la patria? ¿Por qué puede matar a los ciudadanos que infrinjan el orden legal? Estas son las interrogantes -que integran la cuestión del «derecho a la vida y a la muerte»-afrontadas por Pufendorf en el De iure naturae et gentium y retomadas por Rousseau en la unión entre los capítulos mencionados anteriormente.

Habiendo representado el poder penal como un poder generado por el contrato social, Rousseau -al igual que Pufendorf- no puede deducir el derecho de castigar con la muerte de un derecho natural preexistente. Por tanto, la justificación la pena capital, debe basarse en la lógica contractual y explicar por cuál razón los individuos, con el objeto de tutelar su propia vida, habrían formado un cuerpo político dotado del poder de quitarles su vida. La explicación rousseaniana se encuentra en en el pasaje poco antes citado: el objetivo primario de la auto conservación,

102 Rousseau, J.J. Del contratto, cit., lib. II, cap. V, pp. 109-110.

103 Silvestrini, G. «Fra diritto di guerra e potere di punire», cit., p. 127.

104 Ivi, p. 126.

105 Cfr. ivi, pp. 126-129. 
perseguido a través de la fundación del Estado, impone la aceptación de los medios correspondientes y de los consiguientes riesgos. En particular, para no ser víctima de un asesino, cada contrayente debe aceptar la posibilidad de ser ejecutado en el momento en que cometa un homicidio. Por tanto, consintiendo atribuir al soberano el poder de decretar «tú debes morir», el individuo actúa legítimamente en defensa de su propia vida. No dispone abusivamente de ella: asume los riesgos necesarios para conservarla.

Comentando tal justificación del castigo extremo, Silvestrini ha destacado que Rousseau, «aun considerando el derecho a la vida y a la muerte como un derecho político y no natural, de todos modos abraza -más o menos implícitamente- una forma de iusnaturalismo penal, y no una concepción puramente convencional y política de la pena» ${ }^{106}$. Sobre la base de este acento se observa que «la frase "c'est pour n'être pas victime d'un assassin que l'on consent à mourir si on le devient" traiciona algo no dicho, un presupuesto implícito, que emerge en modo explícito en otros pasajes de la obra de Rousseau: la adhesión a una concepción naturalista de la pena» ${ }^{107}$, según la cual el tipo de castigo debe corresponder con el tipo de delito ${ }^{108}$.

Me parece que esta lectura no puede ser compartida. Es cierto que en el pasaje en examen, la pena capital se asocia con el delito de homicidio, pero no debe olvidarse que en el Contrat también existe otro ámbito en que la muerte es invocada como justa sanción legal. Se trata del capítulo VIII del libro IV: donde, frente a la afirmación de la exigencia de «una profesión de fe puramente civil de la que corresponde al soberano fijar los artículos», sigue la terrible advertencia de que «si alguien, después de haber reconocido públicamente estos [...] dogmas, se comporta como si no los creyese» debe ser «castigado con la muerte», porque «ha cometido el más grave de los delitos»: «ha mentido delante a las leyes ${ }^{109}$. Ahora bien, teniendo en cuenta que los «dogmas» de la religión civil preconizados por Rousseau pertenecen a la esfera de aquellos «sentimientos de sociabilidad, sin los cuales resulta imposible ser buenos ciudadanos o súbditos fieles» ${ }^{110}$ parece suficientemente claro que los comportamientos que considera deban ser forzosamente castigados con la muerte no sean reconducibles a la hipótesis de homicidio. En consecuencia no convence la idea que tras su justificación de la pena capital esté «la adhesión [...] al principio de proporcionalidad de las penas a la naturaleza de los crímenes» ${ }^{111}$.

106 Ivi, p. 137.

107 Ibidem.

108 Para confirmar su observación, Silvestrini cita un pasaje de las Lettres écrites de la Montagne, en que Rousseau parafrasea las opiniones expresadas por Montesquieu en el capítulo IV del libro XII del Esprit des lois.

109 J.-J. Rousseau, Del contratto cit., lib. IV, cap. VIII, p. 203.

110 Ibidem.

111 Silvestrini, G. «Fra diritto di guerra e potere di punire», cit., p. 137. 
Sin embargo, yo también considero que la argumentación contractualista sobre la que Rousseau funda el poder del Estado de matar para castigar contiene una premisa implícita. La misma premisa que permanece implícita en un obiter dictum de Montesquieu que podría haber inspirado la reflexión rousseniana: «El motivo por el cual la muerte de un criminal es algo lícito - se lee en un capítulo del Esprit des lois dedicado a la cuestión de la esclavitud - es que la ley que lo sanciona había sido establecida en su favor. Un asesino, por ejemplo, ha gozado de la ley que lo condena; ella ha conservado su vida en todo momento; por ende, él no puede reclamar en contra de ella» ${ }^{112}$.

Pues bien, ¿cuál es la premisa detrás de gran parte de este razonamiento montesquesiano como la de Rousseau? En mi opinión, es el convencimiento -casi universalmente compartido a la época en que escribían- de que la pena de muerte sea un dispositivo de seguridad imprescindible, o que sin ella la vida humana no pueda ser adecuadamente protegida. Si los contrayentes roussenianos no creyesen ciegamente en este dogma político no habrían tenido ningún motivo para instituir el patíbulo. Si no pensasen que el único modo de protegerse de los asesinos fuese ser ejecutados por el Estado en caso de transformarse en asesinos, no estarían obligados a consentir que la ley sancionase el homicidio con la muerte. La cadena lógica «persecución de los fines seleccionados-aceptación de los medios necesarios-asunción de los riesgos inevitables», de hecho, conduce a la legitimación de la pena capital solo presuponiendo que ella sea el medio sine quo non se puede alcanzar el fin de la auto conservación (por el cual cada uno debe asumir el riesgo «de se faire pendre»). Admitiendo la existencia de otras modalidades punitivas idóneas para garantizar la seguridad personal, el esquema contractualista de Rousseau se vuelve inservible como doctrina de justificación del ius vitae ac necis en materia penal.

Por tanto, me parece que la razón de fondo por la que el Contrat social se inscribe en la tradición de la filosofía del patíbulo no sea la participación de Rousseau en una ideología de la pena de tipo iusnaturalista anclada al canon de la homogeneidad entre la acción ofensiva y la respuesta punitiva, sino que sea su aceptación acrítica de la idée reçue según la cual el orden social no puede prescindir de la pena capital. Una vez más, Beccaria está en otra parte y viaja solo. Desafiando a la aparente evidencia, al sentido común, a la opinión de los juristas y la opinión autorizada de los filósofos, enfrenta a la pena de muerte incluso desde la perspectiva de su aptitud

112 De Montesquieu, Ch.L. Lo Spirito delle leggi (1748), a cura de R. Derathé, Rizzoli, Milano, 1996, cit., lib. XV, cap. II, p. 403. Sobre la doctrina penalista de Montesquieu, véase Carrithers, D.W. «La philosophie pénale de Montesquieu». En Revue Montesquieu, 1 (1997), pp. 39-63; Cattaneo, M.A. Il liberalismo penale di Montesquieu. Napoli, Edizioni Scientifiche Italiane, 2000; Ippolito, D. «La dimensione politica della questione penale: l'eredità di Montesquieu». En La libertà attraverso il diritto cit., pp. 33-70. 
para producir seguridad. Si Rousseau da por descontada su necesidad; él pone en discusión incluso su utilidad. Es más, llega a denunciar su nocividad: el Estado, derramando la sangre de los ciudadanos, da un ejemplo de crueldad institucionalizada que degrada el valor de la persona y eleva el nivel de violencia en la sociedad ${ }^{113}$.

III.5. A estas alturas del análisis, la pregunta es inevitable: ¿en qué consistiría la influencia rousseniana sobre el pensamiento de Beccaria respecto de la pena capital, del que ha hablado Bruno Bernardi en el ensayo precedentemente citado? Para comprender la tesis del estudioso francés corresponde tener presente su perspectiva de lectura del capítulo V, libro II, del Contrat social, que -bajo el perfil que nos interesa- está perfectamente sintetizada en el siguiente pasaje: «La peine de mort n'est dans ce chapitre examinée que comme acte de défense. Rousseau entend y démontrer non qu'il y a un droit de punir de la mort, mais que si et seulement si sa défense l'exige, le Souverain est en droit d'ôter la vie à celui qui menace la conservation particulière et commune. Le peine de mort ne relève pas du registre pénal mais de celui de la défense» ${ }^{114}$. De este modo, al rubricar la pena de muerte bajo la voz «guerra»y al justificarla como recurso exclusivamente en los casos de amenaza de la seguridad de la nación, Beccaria no hace más que construir sobre las lecciones de Rousseau.

Para verificar esta tesis, se requiere ante todo delinear los contornos de la cualificación beccariana de la pena de muerte como un acto de guerra y luego medirlo sobre el parámetro de su presunta fuente. Ahora, en Dei delitti, el poder de quitar la vida se encuentra efectivamente excluido del ámbito del derecho penal; incluso del ámbito de la legalidad y de la latitud potestativa de la soberanía: dado que la legalidad y la soberanía son construcciones humanas, modeladas por el acuerdo de las voluntades individuales, vinculadas y limitadas por los objetivos por los cuales son producidas. Salir de la precariedad del estado de naturaleza; asegurarse el goce de la propia libertad fijando los confines más allá de los cuales no puede empujarse el ejercicio de las facultades de cada uno; regular las acciones para impedir los abusos: a esto es que apuntan los hombres al concordar someterse a la heteronomía del poder político. Lo hacen mirándose a sí mismos, calculando su propia utilidad, buscando obtener el máximo provecho con el mínimo gasto. Saben que deben renunciar a una porción de su libertad natural, pero no están dispuestos a sacrificar

113 «El cálculo utilitario de Beccaria -ha escrito Michel Porret- desacredita así la filosofía de la intimidación social del patíbulo [...]. La pena capital falla en la prevención del crimen, porque la misma es socialmente nociva con el ejemplo de crueldad que inflige. Motivado por intimidar a los seguidores de la delincuencia, el espectáculo del patíbulo en vez de hacer que la represión sea ejemplar, muestra la "ferocidad" de la misma» (Porret, M. Beccaria, cit., p. 85).

114 Bernardi, B. Le droit de vie, cit., p. 13 (de la edición on line). 
más que una pequeña parte de ella: aquella (polemógena) cuya conservación impediría el acercamiento a la sociedad civil y el alcance de la seguridad individual. Por tanto, aceptan establecer solamente las prohibiciones encaminadas a hacer que la libertad de cada uno sea compatible con la de los demás, reconociendo la necesidad de garantizar la observancia de tales prohibiciones a través de sanciones penales.

Sin embargo, este reconocimiento realista no legitima cualquier forma de castigo. Si el poder prohibitivo se encuentra tendencialmente regulado por el principio de la máxima libertad posible; el poder punitivo está rigurosamente limitado por el principio del mínimo sufrimiento necesario. Toda aflicción penal superflua respecto del fin de prevención (general y especial) de delitos, exorbita los confines del derecho y degenera en violencia tiránica. Por otra parte, en la fenomenología de los castigos, existe una modalidad punitiva que de por sí recae más allá del espacio de la legalidad: la pena de muerte. Su antijuridicidad, incluso antes que su crueldad innecesaria, deriva de la configuración del pacto social que determina la fisionomía potestativa del Estado. La parte de libertad cedida por los contrayentes, siendo mínima, no puede ciertamente comprender el máximo bienestar individual: la vida. En ruptura clara y definitiva con la condición de vulnerabilidad que le afligía en el estado de naturaleza, ella se coloca a salvo de cualquier acción ofensiva: inmunizada, mediante el derecho, tanto por la violencia social como por la violencia institucional; sustraída, por tanto, incluso de la amenaza penal.

Por ende, matando a quien viola el orden legal, el Estado actúa fuera del orden legal (perimetrado por el contrato social). Ello significa que la pena de muerte no es un acto de ejercicio del poder legítimo de castigar a los criminales. Entonces, ¿qué cosa es? La respuesta de Beccaria es perentoria: es «una guerra de la nación con un ciudadano, porque estima necesaria o útil la destrucción de su ser» ${ }^{115}$. A partir de esta definición, que sella la deslegitimación de la pena capital desde un perfil jurídico, el discurso de Beccaria se mueve en el terreno de la eventual justificación de tal guerra asimétrica en base a los criterios de utilidad y necesariedad. El objetivo de este nuevo examen es declarado desde el inicio: ganar «la causa de la humanidad», probando que la muerte de un ciudadano por parte de la pública autoridad no es «ni útil ni necesaria» ${ }^{116}$.

Del todo diversa es la lógica del razonamiento de Rousseau entorno a la pena de muerte. Inmediatamente después de haber afirmado el fundamento convencional, escribe que:

Por otra parte, todo criminal que lesione el derecho social, con sus fechorías deviene en un rebelde y traidor de la patria, violando sus leyes deja de ser miembro, e incluso le hace la guerra. Entonces, la conservación del Estado se vuelve incom-

115 Cfr. Beccaria, C. Dei delitti, cit., § XXVIII, p. 62.

116 Ibidem. 
patible con la suya, requiere que éste perezca, y cuando se da muerte al culpable no se hace en cuanto ciudadano sino en cuanto enemigo. Los procedimientos, el juicio, son las pruebas y la declaración que él ha roto el tratado social, y que por ende ya no es miembro del Estado. Pues bien, dado que se ha reconocido como tal, al menos como residente, debe ser eliminado a través del exilio, en cuanto ha violado el pacto, o con la muerte en cuanto enemigo público; porque un tal enemigo no es una persona moral, es un hombre, y en este caso es un derecho de guerra matar al vencido ${ }^{117}$.

Prescindiendo del problema de la coherencia de este pasaje con las tesis afirmadas por Rousseau en el capítulo IV del primer libro del Contrat ${ }^{118}$, intentemos tomarlo en consideración como posible matriz ideológica del discurso de Beccaria. Me parece que la distonía resulta estridente y que de la comparación surge distancia y no proximidad. Ante todo, es preciso notar que, no obstante que la referencia a la guerra esté presente en ambos textos, su función argumentativa resulta antitética. La palabra 'guerra', en el capítulo XXVIII de Dei delitti, aparece en oposición a la palabra 'derecho': la pena de muerte «no es [...] un derecho [...] sino que es una guerra ${ }^{119}$ : así, Beccaria niega la juridicidad del homicidio de Estado. Al contrario, Rousseau evoca la guerra precisamente para afirmar la plena legitimidad de la pena capital. Luego de haberla justificado ex contractu, de hecho, reitera su fundamento jurídico desde otro perfil: esto es, desde el ius belli, que le permite confirmar la pena de muerte como «un derecho» del vencedor sobre el vencido. En este contexto, una segunda diferencia macroscópica salta a la vista. En el Contrat lo que es calificado como «guerra» es la violación de la ley: el crimen. En Dei delitti, en cambio, la perspectiva es completamente volcada: es la pena de muerte la que figura como «guerra». De este modo, mientras que para Rousseau es el «malhechor» el que hace guerra a la «patria»; para Beccaria es la «nación» la que hace la guerra al «ciudadano». Las consecuencias de esta divergencia no pueden escapar: concebida la pena capital como una guerra de la nación, Beccaria puede interrogarse si existen circunstancias en que la «destrucción» de un ciudadano sea, por decirlo de algún modo, una guerra justa, circunscribiendo únicamente a estos casos su eventual admisibilidad política. Contrariamente, en la óptica de Rousseau, siendo la guerra del malhechor una guerra injusta por definición (en cuanto guerra de agresión), la reacción bélica por parte del agredido está siempre justificada. Ello nos conduce a una última observación: mientras con la asociación pena capital-guerra Beccaria marca el fin y el límite al poder de castigar en virtud de la protección de la vida humana y de su intangibilidad; a través de la asociación rousseniana delito-guerra la esfera del derecho penal se abre

117 Rousseau, J.J. Del contratto, cit., lib. II, cap. V, p. 110.

118 Cfr. Con cuanto observado por Robert Derathé en Rousseau, J.J. EEuvres complètes. Paris, Gallimard, 1964, vol. III, p. 1460.

119 Beccaria, C. Dei delitti, cit., § XXVIII, p. 62 (la cursiva es de texto). 
a la lógica del ius in bello y la muerte del criminal se vuelve -en línea de principiouna pena jurídicamente admisible para cualquier crimen.

Ahora bien, si nos detuviésemos en este punto del análisis, correríamos el riesgo de confundir a Rousseau con un intelectual orgánico a los intereses del ejecutante. Siguiendo en la página del Contrat, en cambio, nos encontramos inmediatamente con un pasaje textual que rectifica el aberrante resultado de la identificación entre «malhechor» $\mathrm{y}$ «enemigo». Un pasaje rápido, formado por tres frases lapidarias que espantan al fantasma de la guerra del proscenio de la vida civil: «la frecuencia de los suplicios es siempre una señal de debilidad o de pereza del gobierno. No hay mal que no pueda volverse bueno para algo. No se tiene derecho a matar, ni siquiera a título de ejemplo, de lo contrario no hay nadie que se pueda mantener vivo sin peligro» ${ }^{120}$. Pena de muerte sí, pero como extrema ratio, por ende: esta es la tímida conclusión con que el filósofo republicano amansa las pretensiones de represalia del vencedor sobre el vencido.

¿Podemos advertir, al menos frente a este precepto de moderación penal, un eco del discurso rousseniano del capítulo XXVIII de Dei delitti ${ }^{121}$ ? Más precisamente, en el controvertido pasaje en que Beccaria afirma que la muerte de un ciudadano puede estimarse necesaria «cuando incluso privado de libertad tenga todavía relaciones tales y tal potencia que afecte a la seguridad de la nación; cuando su existencia pueda producir una revolución peligrosa en la forma de gobierno establecida» ${ }^{122}$ ¿está tal vez haciendo eco de las tesis de Rousseau? Una vez más, sería partidario de una negativa. El discurso beccariano no se refiere en absoluto a las condiciones de ejercicio del «derecho a matar» ${ }^{123}$, sino que alude a los «motivos» que justifican como necesaria la «guerra de la nación contra un ciudadano»: motivos que no existen sino en los momentos en que «la nación recupera o pierde su libertad, o en tiempos de anarquía, cuando los desordenes ocupan el lugar de las leyes» ${ }^{124}$ : o bien, en situaciones del todo excepcionales, fuera de las cuales justiciar no es jamás hacer justicia ${ }^{125}$.

120 Rousseau, J.J. Del contratto, cit., lib. II, cap. V, p. 110.

121 «El autor de Delit -ha escrito Pietro Verri (luego de la ruptura con Beccaria)- no hace otra cosa que desarrollar aquello que dice R[ousseau]. En el § Au reste» (cit. por Francioni en Dei delitti 1984, p. 88, nota 2). Con la locución adverbial «Au reste» se abre el párrafo compuesto por las tres frases apenas citadas.

122 Beccaria, C. Dei delitti cit., § XXVIII, p. 62.

123 Rousseau, J.J. Del contratto, cit., lib. II, cap. V, p. 110.

124 Beccaria, C. Dei delitti, cit., § XXVIII, p. 62.

125 Sobre el significado del tercer párrafo del $\S$ XXVIII Dei Delitti (de aquí son extraidas las últimas dos citas), véase Cattaneo, M.A. «Morale e politica nel dibattito dell'illuminismo». En AaVv. La pena di morte nel mondo. Casale Monferrato, Marietti, 1983, pp. 116-118; Francioni, G. Beccaria, cit., pp. 79-80; Costa, P. Beccaria, cit., pp. 46-49; Ippolito, D. «Filosofia e diritto penale in Cesare Beccaria. Intervista a Philippe Audegean». En Politeia, 116 (2014), pp. 57-58 (en que Audegean argumenta la interpretación propuesta por él en Beccaria, C. Des délits et des peines, préfation, tradution et note de Ph. Audegean, Payot \& Rivage, Paris, 2014, pp. 130-131). 
La independencia de la reflexión de Beccaria de las posiciones expresadas por Rousseau al término de su razonamiento sobre la pena de muerte se puede advertir incluso desde otro punto de vista. Distinguiendo las figuras del malo a convertirse en bueno "para algo» y del criminal irremediablemente peligroso, Rousseau se muestra favorable a una modulación de las sanciones basada en la identidad de los sujetos, más que en la entidad de los delitos. Sin embargo, el paradigma garantista elaborado por Beccaria reposa en torno a la legalidad de la pena y a la igualdad frente a la ley penal: dos principios incompatibles con la individualización del tratamiento punitivo ${ }^{126}$.

Concluyendo estos apuntes, quisiera prevenir un posible mal entendido. No he pretendido negar la influencia de Rousseau sobre Beccaria: solamente he intentado demostrar que dicha influencia no se encuentra donde con frecuencia es buscada.

126 Sobre los principios del garantismo de Beccaria véase Calamandrei, P. «Prefazione». En Beccaria, C. Dei delitti e delle pene. Firenze, Le Monnier, 1945, pp. 7-129; Andrés Ibáñez, P. «Introducción». En Beccaria, C. De los delitos y de las penas. Madrid, Trotta, 2011, pp. 9-29; Ferrajoli, L. «La actualidad del pensamiento de Cesare Beccaria». Trad. de T. Effer. En Jueces para la democracia, 79 (2014), 51-63. 


\title{
CESARE BECCARIA Y LA PENA DE MUERTE. DEL DE LOS DELITOS Y DE LAS PENAS AL DEBATE ACTUAL SOBRE LA SANCIÓN CAPITAL ${ }^{1}$
}

\author{
STEFANO CANESTRARI \\ Catedrático de Derecho Penal. Universidad de Boloña. \\ MATTIA CELVA \\ Doctorando en Ciencias Jurídicas. \\ Universidad de Parma y Universidad de Módena y Reggio Emilia.
}

\section{INTRODUCCIÓN}

Bien se adopte una perspectiva diacrónica -observando el curso de la Historia-, o se prefiera adoptar, más bien, una aproximación sincrónica -centrada en el análisis de las diferentes experiencias jurídicas contemporáneas-, la pena de muerte aflora en una constante actualidad. No existe periodo histórico en el que la pena capital no se haya infligido, ni contexto cultural que no haya debatido acerca del fundamento de dicha sanción, para justificarlo o bien refutarlo; todo eso, notoriamente, sigue produciéndose.

Los Autores desean agradecer a Andrea Fabrizi, doctorando de la Université Paris 1 PanthéonSorbonne, Ecole Doctorale de Droit Comparé, por la traducción al español. La edición en lengua española del De los delitos y de las penas empleada en esta contribución, es la de F. Tomás y Valiente (Madrid, 1969): nótese que en ésta edición el capítulo sobre la pena de muerte es el XVI (ivi, 114 ss.). Todos los extractos del De los delitos y de las penas en esa lengua se refieren a la edición indicada. Las traducciones que aparecerán en las siguientes páginas, referidas a otros Autores, han sido preparadas por el traductor, a falta de una versión en español. 
Las próximas páginas se ocuparán, en particular, del pensamiento de Cesare Beccaria. Hablar de Beccaria implica tratar de las luces del derecho penal y por ende, de las penas, de su proporcionalidad en relación a los delitos, de su finalidad, de la necesidad de contenerlas. En este contexto se coloca, naturalmente, el tema central de las presentes reflexiones, es decir la posición del Marqués sobre la pena capital; posición que no ha recibido, en la literatura especializada, una interpretación unívoca.

El análisis de las páginas del De los delitos y de las penas inherentes al problema de la sanción capital ofrece igualmente la oportunidad de hablar del debate reciente sobre ese tema y de efectuar algunas observaciones sobre el rol actual del penalista en dicho ámbito. En consecuencia, la segunda parte de esta contribución abarcará, dentro de esos límites, además de sendas cuestiones.

\section{LA PENA DE MUERTE EN LA ÉPOCA DE BECCARIA}

A fin de proporcionarle un análisis exhaustivo y para que se le pueda entender completamente, todo pensamiento necesita preliminarmente una contextualización. Cesare Beccaria y su "libriccino fortunato" ${ }^{2}$ (según la definición de Manzoni) aparecieron a la escena de la Historia en el siglo XVIII: el Marqués nació en Milán en 1738, el célebre ensayo se dio a la estampa en el verano de 1764. Si se quiere investigar sobre las páginas del De los delitos y de las penas que versan sobre el tema de la pena de muerte, resulta pues necesario preguntarse cómo ésta fue concebida en aquella época.

La literatura pertinente es, lógicamente, conspicua. De hecho, el argumento permite la elaboración de numerosas reflexiones que, sin embargo, no podrán llevarse a cabo por razones de economía y coherencia del discurso.

Para esbozar un marco de referencias funcional a los objetivos propios de esta contribución, puede ser útil remitirse a la preciada obra de Michel Porret -intitulada Beccaria. Le droit de punir-, donde el Autor ofrece una visión bien documentada de la realidad de la época ${ }^{3}$.

Tras la abolición de la pena de la hoguera por crímenes de brujería, ocurrida alrededor del año 1670 -afirma el estudioso-, «[i]1 rigore penale è espresso sul corpo del condannato ${ }^{4}$ y varía en función de dos diferentes parámetros: el «statuto

2 Entiéndase "breve libro afortunado". Esta definición proviene de Alessandro Manzoni, literato italiano contemporáneo de Beccaria y su familiar, casado con la hija del Marqués (N. del T.).

3 El excursus histórico que se leerá a continuación se basa en la obra de Porret, M. Beccaria. Il diritto di punire. Bologna, 2013, 80 ss. (orig.: Beccaria. Le droit de punir. Paris, 2003): a ella pueden igualmente referirse las citas contenidas en el presente párrafo, de él como de otros Autores que Porret menciona (v. ivi para la indicación de las respectivas fuentes).

4 «...[1]a severidad penal se expresa sobre el cuerpo del condenado». 
giuridico del condannato ${ }^{5} \mathrm{y}$, por supuesto, la «atrocità del suo crimine» ${ }^{6}$ cometido. De esta manera, relacionadas al primer aspecto se encuentran el suplicio de la rueda para bandoleros o envenenadores y el ahorcamiento para el ladrón o el asesino, siempre que fueran plebeyos. Si para ellos la ejecución de la condena pasaba por manos del verdugo, tal infamia no recaía sobre el aristocrático, cuya punición consistía en el degollamiento. En relación al segundo aspecto, cabe señalar que el regicidio -crimen insólito en la época moderna- estaba penado de manera más aflictiva: el suplicio implicaba el descuartizamiento propiciado por cuatro caballos, cada uno ligado por una cuerda a los miembros del condenado. Así, en 1757, fue ejecutado Robert-François Damiens, que «aveva ferito con un colpo di temperino il corpo reale di Luigi $\mathrm{XV} \gg{ }^{7}$.

Entonces, destaca Porret, «[a]ll'epoca di Beccaria, la pena capitale esprime l'alta giustizia legata alla sovranità assoluta dello Stato moderno ${ }^{8}$, revistiendo un «ruolo politico ${ }^{9}$, pero además representa un $«$ strumento drastico di terapia sociale» ${ }^{10}$.

El Autor prosigue su análisis recordando las tres corrientes de pensamiento más influyentes de la época que intentaron legitimar la pena capital. Antes de todo, se menciona la escuela de derecho natural fruto del legado de Jean Bodin, la cual considera que el suplicio supremo tendría su propia justificación en la necesidad de proteger la sociedad del crimen; Montesquieu sugiere que la pena de muerte es necesaria para reprimir los delitos de sangre; Rousseau, por otra parte, reconoce en esta sanción no tanto un acto en contra de un ciudadano sino contra un "enemigo" $\mathrm{y}$, precisamente, quien es tal en cuanto que amenaza la estabilidad del contrato social (es interesante notar cómo en este fragmento se pueda hallar, incluso bajo un perfil lexical, algo parecido a una conceptualización in nuce del derecho penal del enemigo $\left.{ }^{11}\right)$.

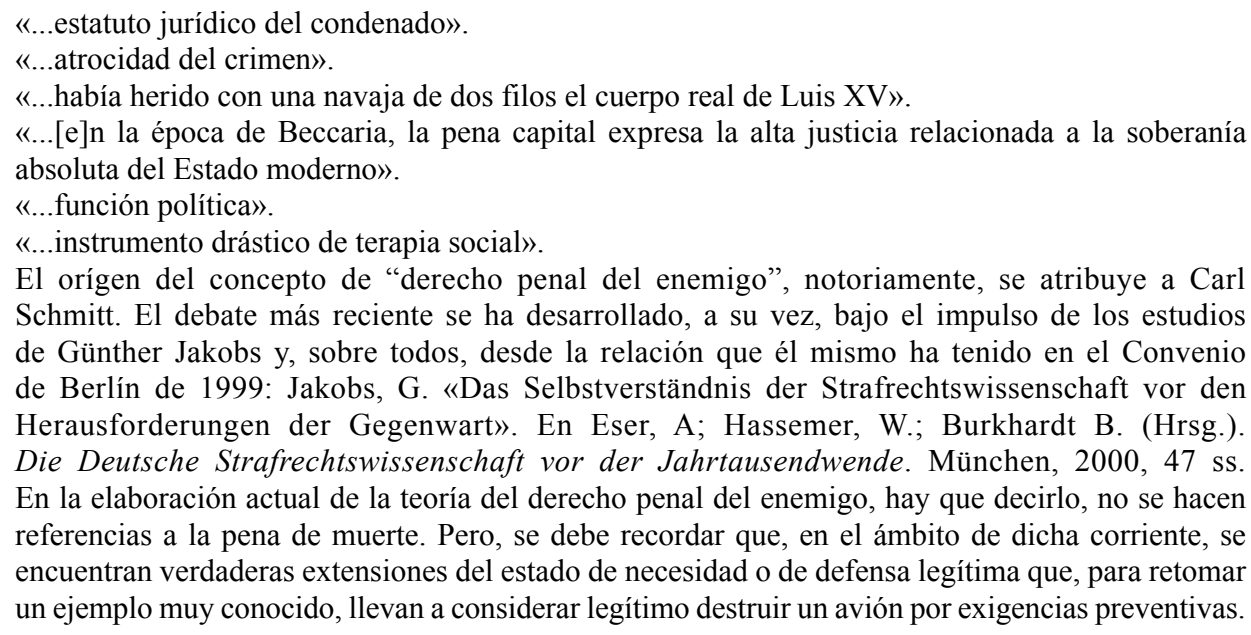
encuentran verdaderas extensiones del estado de necesidad o de defensa legítima que, para retomar un ejemplo muy conocido, llevan a considerar legítimo destruir un avión por exigencias preventivas. 
En fin, es oportuno recordar que pese a la existencia de estudiosos del derecho penal que ya se habían mostrado decididamente contrarios a la pena capital, pudiendo ser definidos como abolicionistas, los penalistas contemporáneos de Beccaria justificaron la pena de muerte fundándose en tres principios de prevención general. Porret los enumera eficazmente, a través de la pluma de Pierre-François Muyart de Vouglans: el primero, resalta la necesidad de «sterminare il cattivo, affinché non faccia più male» ${ }^{12}$; el segundo destaca que la pena capital puede «fungere da esempio e deviare gli altri dal male che potrebbero fare ${ }^{13}$; el tercero, enfatiza la pretendida exigencia de «purgare la società e preservarla dal contagio che il miscuglio con $\mathrm{i}$ cattivi non mancherebbe di spargere» ${ }^{14}$.

Este es, en resumen, el contexto donde intervino el De los delitos y de las penas $\mathrm{y}$, por lo que interesa esta contribución, su $\S$ XXVIII, intitulado De la pena de muerte.

Beccaria suele ser considerado un símbolo de la lucha contra la pena capital. En realidad, como se verá enseguida tal vez él no expresó ideas tan radicales ni absolutas: conviene anticipar que su postura fue, más bien, políticamente prudente; probablemente fue elaborada con el intento precipuo de garantizarle eficacia en la práctica.

\section{LA PENA DE MUERTE EN EL § XVIII DEL DE LOS DELITOS Y DE LAS PENAS}

Como se indicó, el tema de la pena de muerte es analizado en el $\S$ XXVIII del De los delitos y de las penas ${ }^{15}$. Es la sección más larga del ensayo y Beccaria la consagra a la refutación y oposición al uso de la pena capital, cuya abolición, se deduce de su pensamiento, estaría estrechamente ligada al desarrollo del espíritu humano.

$\mathrm{Su}$ esfuerzo no está orientado a propugnar simplemente la tesis de la inutilidad de la pena de muerte, es más, él aspira a demostrar su ilegitimidad, al menos en lo que concierne a crímenes de derecho común. Beccaria entiende, entre otras cosas,

Para una visión general de la configuración actual del derecho penal del enemigo en la literatura italiana señalamos, entre otros: Donini, M.; Papa, M. (a cura de). Diritto penale del nemico. Un dibattito internazionale. Milano, 2007; Gamberini, A.; Orlandi R. (a cura de). Delitto politico e diritto penale del nemico, Atti di convegno (Trento, 10-11 marzo 2006), Bologna, 2007. A esas fuentes se remite para referencias ulteriores, inclusive literatura extranjera.

13 «...servir de ejemplo y desviar a los demás del mal que podrían cometer».

14 «...purgar la sociedad y resguardarla del contagio que la mezcla con los malvados no dejaría de difundir».

15 Entre las ediciones italianas disponibles del "libriccino", se hace referencia, aquí y a continuación (excepto referencias particulares), a Beccaria, C. Dei delitti e delle pene, a cura de G. Francioni. En Firpo L. (dirigida por), Edizione nazionale delle opere di Cesare Beccaria. Milano, I, 1984, precisamente 86 ss., donde se pueden encontrar -a excepción de las variaciones advertidas de las páginas de referencia- todas las citas del ensayo. 
favorables a su opinión las experiencias de algunas pocas sociedades que se han abstenido de establecer la pena de muerte. Afirma que ninguna autoridad puede legitimar la pena de muerte hacia esos crímenes, cuando encuentre aprobación en la ideología de la seguridad propia de algunos sectores de la magistratura, ni cuando sea invocada por reivindicación popular ${ }^{16}$.

Aquí Beccaria es perentorio y en sus razonamientos la "causa abolicionista" se manifiesta con contundencia: la pena de muerte en relación a los crímenes de derecho común debe suprimirse definitivamente porque, sostiene el Marqués, el patíbulo no representa un instrumento útil, ni necesario ni justo para proteger la sociedad y el orden público.

Cesare Beccaria, al igual que Voltaire ${ }^{17}$, rechaza ante todo el postulado no demostrable de la funcionalidad de la pena capital para conseguir fines de prevención general. Tanto la razón como la experiencia histórica acumulada a lo largo de los siglos, y aún, los sistemas legislativos vigentes, demuestran cómo dicha pena no cumple mínimamente con una función de intimidación dirigida a los que cometen o resuelven a cometer un crimen.

El Autor del De los delitos y de las penas además se opone a la concepción rousseauniana del "enemigo público", precisamente cuando apunta que el contrato social (rectius, su ruptura) no legitima la pena capital frente a crímenes de derecho común. Aunque el Marqués reconozca que la soberanía y las leyes expresan la voluntad general como unión de las voluntades particulares, esto no autorizaría a los hombres matar a sus semejantes:

«[c]hi è mai colui che abbia voluto lasciare ad altri uomini l'arbitrio di ucciderlo? Come mai nel minimo sacrificio della libertà di ciascuno vi può essere quello del massimo tra tutti i beni, la vita? E se ciò fu fatto, come si accorda un tal principio coll'altro, che l'uomo non è padrone di uccidersi, e doveva esserlo se ha potuto dare altrui questo diritto $\mathrm{o}$ alla società intera? $\rangle^{18}$.

16 Sería oportuno retomar, sobre este argumento, las posiciones de los Autores norteamericanos que, de manera neutral, hablan de "voluntad popular" en favor de la pena de muerte y, pese a que aceptan la oposición entre populismo y democracia liberal, de alguna manera consideran que dicha voluntad popular puede mantenerse dentro de los límites ( $\mathrm{y}$, al contrario, fecundar) una democracia liberal. Es suficiente subrayar como, en la materia, nuestra impostación cultural asume -incluso históricamente- un punto de vista diferente con respeto al excepcionalismo estadounidense.

17 Cfr. Voltaire. «Commentario sopra il libro Dei delitti e delle pene del Sig. di Voltaire». En Beccaria, C. Dei delitti e delle pene, Edizione rivista, corretta e disposta secondo l'ordine della traduzione francese. Approvato dall'Autore coll'aggiunta del Commentario alla detta opera di Mr. de Voltaire tradotto dal celebre Autore, Londra (ma Livorno), 1774, § X (Della pena di morte), 131 s. (orig.: Commentaire sur le livre Des délits et des peines, par un Avocat de Province, 1766).

18 «QQuién ha querido jamás dejar a otros hombres el arbitrio de matarlo? ¿Cómo en el mínimo sacrificio de la libertad de cada uno puede incluirse el del máximo entre todos los bienes, la vida? Y si así fuese, ¿cómo conciliar tal principio con el otro, según el cual el hombre no es dueño de matarse? Debería serlo, para que hubiera podido conceder a otros, o a la sociedad entera, este derecho». 
El extracto expuesto contiene, francamente, un argumento que no se puede aceptar in toto, por lo menos hoy en día. Tal vez lo era en el tiempo del Marqués y éste utiliza el ejemplo del quitarse la vida con el fin de probar la falacia de la concepción rousseauniana del enemigo público, empleada por el eminente filósofo suizo -como se recordó- como base justificante de la pena capital.

De todas maneras, la posición del Marqués sobre la pena capital puede resumirse, al menos en el ámbito de crímenes de derecho común, por la célebre frase que afirma que la pena de muerte «no es $[\ldots]$ un derecho, [...] sino una guerra de la nación en contra de un ciudadano».

Dicho esto, se debe tener asimismo en cuenta otro extracto del § XXVIII del De los delitos y de las penas, que dice:

«[1]a morte di un cittadino non può credersi necessaria che per due motivi. Il primo, quando anche privo di libertà egli abbia ancora tali relazioni e tal potenza che interessi la sicurezza della nazione; quando la sua esistenza possa produrre una rivoluzione pericolosa nella forma di governo stabilita. La morte di qualche cittadino divien dunque necessaria quando la nazione ricupera o perde la sua libertà, o nel tempo dell'anarchia, quando i disordini stessi tengon luogo di leggi; ma durante il tranquillo regno delle leggi, in una forma di governo per la quale i voti della nazione siano riuniti, ben munita al di fuori e al di dentro, dalla forza e dalla opinione, forse più efficace della forza medesima, dove il comando non è che presso il vero sovrano, dove le ricchezze comprano piaceri e non autorità, io non veggo necessità alcuna di distruggere un cittadino, se non quando la di lui morte fosse il vero ed unico freno per distogliere gli altri dal commettere delitti, secondo motivo per cui può credersi giusta e necessaria la pena di morte» ${ }^{19}$.

Pues entonces, en las páginas del "libriccino" no se niega totalmente el recurso a la pena capital: el rechazo, como ya se ha visto, es pleno exclusivamente para los crímenes de derecho común, permaneciendo algunas situaciones que darían el paso a su aplicación.

19 «No puede considerarse necesaria la muerte de un ciudadano más que por dos motivos. El primero, cuando aun privado de la libertad tenga todavía tales relaciones y tal poder, que interese a la seguridad de la nación; cuando su existencia pueda producir una revolución peligrosa en la forma de gobierno establecida. La muerte de un ciudadano viene a ser, pues, necesaria cuando la nación recobra o pierde su libertad, o en el tiempo de la anarquía, cuando los desórdenes mismos hacen el papel de leyes; pero durante el tranquilo reinado de las leyes, en una forma de gobierno en pro de la cual están reunidos los votos de la nación, bien provista hacia el exterior y hacia adentro de la fuerza y de la opinión - quizá más eficaz que la fuerza misma -, donde el mando no reside sino en el verdadero soberano, donde las riquezas compran placeres y no autoridad, no veo yo necesidad alguna de destruir a un ciudadano, sino cuando su muerte fuese el verdadero y único freno para disuadir a los demás de cometer delitos; lo que constituye el segundo motivo por el que puede considerarse justa y necesaria la pena de muerte». 
El hecho de que Beccaria, en el $\S$ XXVIII del De los deitos y de las penas, haya concebido la posibilidad de aplicar la sanción capital - aunque en hipótesis limitadas - ha, por cierto, fomentado un debate sobre la mera posibilidad de contar al Marqués entre los abolicionistas de la pena de muerte.

Esta cuestión merece, ahora, tratamiento.

\section{III.1. (Sigue). Beccaria, la pena de muerte, la pena perpetua}

«Cesare Beccaria è passato alla storia, e non soltanto alla storia del diritto penale, soprattutto per la sua fervida battaglia contro la pena di morte: tanto che non v'è abolizionista che non invochi il suo nome come uno squillo di guerra contro la pena capitale $\rangle^{20}$.

Con estas palabras, Gian Domenico Pisapia abre, en 1973, su presentación a la edición del De los delitos y de las penas que él mismo realizó. En efecto, la cultura occidental ha encontrado tradicionalmente en la figura del Marqués milanés una especie de abolicionista par excellence, como lo testimonian las palabras de Giuseppe Garibaldi y las ilustradas plumas de Pietro Ellero, Enrico Pessina y Piero Calamandrei ${ }^{21}$.

Sin embargo, una parte de la literatura ha adoptado una actitud diferente sobre ese argumento.

G.D. Pisapia, en su presentación, sigue afirmando que:

«[q]uesto giudizio, pur sostanzialmente esatto, va però $[\ldots]$ in parte rettificato. Va rettificato, perché l'avversione del Beccaria contro la pena di morte, malgrado le eloquenti ed infuocate parole da lui scritte contro il supplizio supremo, non fu assoluta né esclusiva» ${ }^{22}$.

20 «Cesare Beccaria ha pasado a la historia, no solamente del derecho penal, sobre todo por su rotunda batalla en contra de la pena de muerte: no hay abolicionista que no invoque su nombre como señal de trompeta contra la pena capital». G.D. Pisapia, Presentazione a C. Beccaria, Dei delitti e delle pene, a cura di G.D. Pisapia, Milano, 1973, V; enteramente en cursiva en el original. La cita sucesiva de G.D. Pisapia se refiere a la misma obra.

21 Garibaldi, G. «Lettera al direttore». En Giornale per l'abolizione della pena di morte. Bologna, 1863, II, 6, 139 ss.; Ellero, P. «Programma». En Giornale per l'abolizione della pena di morte. Milano, 1861, I, 1, 3 ss.; Pessina, E. «Il diritto penale in Italia da Cesare Beccaria sino alla promulgazione del Codice Penale vigente (1764-1890)». En Enciclopedia del diritto penale italiano. Milano, 1905, 541 ss.; Calamandrei, P. Prefazione a C. Beccaria, Dei delitti e delle pene, a cura de P. Calamandrei, $2^{\mathrm{a}}$ ed., Firenze, 1992, 17 ss. (la figura del Marqués està descrita positivamente a lo largo de la obra; sobre la cuestión de la pena de muerte, v. precisamente ivi, 70 ss., 98 ss., 110 ss. y, en particular, 126 ss.).

22 «La opinión sobre Beccaria, como abolicionista, aunque sea substancialmente exacta, necesita una rectificación parcial, porque su adversión a la pena de muerte, a pesar de las palabras elocuentes y acaloradas que él escribió en contra del suplicio supremo, no fue ni absoluta ni exclusiva». 
Aún más interesante es mencionar las críticas dirigidas al Marqués por Italo $\mathrm{Mereu}^{23}$. El historiador del derecho italiano rebate con fuerza la idea que el Autor del De los delitos y de las penas haya sido un innovador autentico en la lucha contra la pena de muerte. Efectivamente, un pasaje citado en el precedente párrafo - donde Beccaria justifica, en algunos casos, la aplicación de la pena capital - confirmaría la crítica de Mereu, dado que éste parece sugerir que no es posible ser abolicionista de manera intermedia.

Mereu evidencia cómo el Marqués, cuando considera necesario renunciar a la sanción suprema, propone substituirla con la pena perpetua y lo hace en términos aparentemente contradictorios con la «suavidad de las penas» que él mismo sostenía - pocas páginas atrás - propugnando la necesidad que ellas sean "dulces"24. Mereu cita, en la ocasión, algunos pasajes del § XXVIII del "libriccino":

«[n]on è il terribile ma passeggiero spettacolo della morte di uno scellerato, ma il lungo e stentato esempio di un uomo privo di libertà, che, divenuto bestia di servigio, ricompensa colle sue fatiche quella società che ha offesa, che è il freno più forte contro i delitti. Quell'efficace, perché spessissimo ripetuto ritorno sopra di noi medesimi, io stesso sarò ridotto a così lunga e misera condizione se commetterò simili misfatti, è assai più possente che non l'idea della morte, che gli uomini veggon sempre in una oscura lontananza. [...] [M]oltissimi risguardano la morte con viso tranquillo e fermo, chi per fanatismo, chi per vanità, che quasi sempre accompagna l'uomo al di là dalla tomba, chi per un ultimo e disperato tentativo o di non vivere o di sortir miseria; ma né il fanatismo né la vanità stanno fra i ceppi o le catene, sotto il bastone, sotto il giogo, in una gabbia di ferro, e il disperato non finisce i suoi mali, ma gli comincia. [...] Chi dicesse che la schiavitù perpetua è dolorosa quanto la morte, e perciò egualmente crudele, io risponderò che sommando tutti i momenti infelici della schiavitù lo sarà forse anche di più, ma questi sono stesi sopra tutta la vita, e quella esercita tutta la sua forza in un momento; ed è questo il vantaggio della pena di schiavitù, che spaventa più chi la vede che chi la soffre. [...] [C]olui che si vede avanti agli occhi un gran numero d'anni, o anche tutto il corso della vita che passerebbe nella schiavitù e nel dolore in faccia a' suoi concittadini, co' quali vive libero e sociabile, schiavo di quelle leggi dalle quali era protetto, fa un utile paragone di tutto ciò coll'incertezza dell'esito de' suoi delitti, colla brevità del tempo di cui ne goderebbe i frutti. L'esempio continuo di quelli che attualmente vede vittime della propria inavvedutezza, gli fa una impressione

23 Salvo indicación diferente, se hace referencia a Mereu, I. La morte come pena. Milano, 1982, p. 93 ss., también para las citas relativas a este Autor.

24 El § XXVII del De los delitos y de las penas està, en efecto, dedicado a la Suavidad de las penas: C. Beccaria, Dei delitti e delle pene, cit., 83 ss. 
assai più forte che non lo spettacolo di un supplicio che lo indurisce più che non lo corregge ${ }^{25}$.

Palabras como esas inducen al estudioso a considerar que en realidad Beccaria no haya sido de manera absoluta el promotor de un cambio de perspectiva profundo, ni siquiera un partidario de la pena perpetua cuyo pensamiento puede interpretarse en sentido "humanitario":

«[q]uelle che abbiamo esposto sono le idee di Beccaria sulla pena di morte e sull'ergastolo. E non sono idee rivoluzionarie. Uno scrittore che riconosce al principe o alla società il diritto di eliminare qualunque oppositore gli possa dar fastidio, non è poi un grande innovatore. Altri scrittori prima di lui avevano assunto posizioni molto più "radicali" $\rangle^{26}$.

La voz revolucionaria restaría, en suma, un "mito", que se debe distinguir de la figura histórica efectiva.

El retrato de Beccaria podría ser entonces el de un defensor de la «primato assoluto dell'autorità giustificato in chiave utilitaristica ${ }^{27}$ dirigida a la defensa de la «forma di governo stabilita ${ }^{28}$ y cuyo pensamiento se debe poner en la estela de las tesis rousseaunianas:

25 «No es el terrible pero pasajero espectáculo de la muerte de un criminal, sino el largo y penoso ejemplo de un hombre privado de libertad, que convertido en bestia de servicio recompensa con sus fatigas a la sociedad que ha ofendido, lo que constituye el freno más fuerte contra los delitos. Aquel estribillo frecuentísimamente repetido dentro de nosotros mismos, y por ello eficaz, que dice: Yo mismo seré reducido a tan larga y mísera condición si cometo semejantes delitos, es mucho más poderoso que la idea de la muerte, que los hombres ven siempre en una oscura lontananza. [...] Muchísimos miran la muerte con rostro tranquilo y firme; algunos por fanatismo, otros por vanidad, que casi siempre acompaña al hombre más allá de la tumba, otros por un último y desesperado intento de o no vivir más o salir de la miseria; pero ni el fanatismo ni la vanidad permanecen entre los grillos o las cadenas, bajo el palo, bajo el yugo, en una jaula de hierro; el desesperado no termina sus males, sino que los empieza. [...] A quien dijese que la esclavitud perpetua es tan dolorosa como la muerte y, por tanto, igualmente cruel, le respondería que quizá incluso lo sea más sumando todos los momentos infelices de la esclavitud; pero estos están repartidos durante toda la vida y aquella ejerce toda su fuerza en un momento: y esta es la ventaja de la pena de esclavitud, que atemoriza más a quien la ve que a quién la sufre. [...] Pero quien ve ante sus ojos un gran número de años o incluso todo el transcurso de la vida que pasaría en la esclavitud y en el dolor en presencia de sus conciudadanos con los cuales vive libre y sociable, esclavo de aquellas leyes por las cuales era protegido, hace una útil comparación de todo eso con la incertidumbre del éxito de sus delitos y con la brevedad del tiempo en que gozaría de sus frutos. El ejemplo continuo de los que actualmente ve víctimas de la propia irreflexión, le produce una impresión mucho más fuerte que el espectáculo de un suplicio que lo endurece más que lo corrige».

«Las que acabamos de exponer son las ideas de Beccaria sobre la pena de muerte y la pena perpetua. Y no son ideas tan revolucionarias. Todo escritor que reconozca al Príncipe o a la sociedad el derecho de eliminar cada opositor que le pueda fastidiar no es, en fin, un gran inovador. Otros escritores antes de él habían tenido posiciones mucho más radicales».

27 «...primacía absoluta de la Autoridad justificada en clave utilitarista».

28 «...forma de gobierno establecida». 
«[i]l principio sul quale è intessuta la trama del Dei delitti e delle pene è quello del Contratto Sociale di Rousseau, che viene interpretato dando la prevalenza alla volontà generale piuttosto che ai diritti individuali. [...] Quali sono, dunque, il diritto o i diritti della società e quali il diritto o i diritti dei singoli individui? A una domanda di questo genere, Beccaria risponde con un sofisma. Nessun individuo ha posto nelle mani della società il diritto di punirlo con la morte; ma la società, quando lo ritenga "utile e necessario" ha questa "podestà" [....] Quando, cioè, gli interessi della società esigeranno la pena di morte perché "utile e necessaria" (e sarebbe più giusto dire necessaria perché utile, in quanto è solo l'utilità la molla dei consociati), Beccaria non ha nessuna difficoltà teorica ad ammetterla. [...] Non esiste nessun diritto individuale imprescrittibile, non esiste nemmeno il valore assoluto della persona umana. Unici criteri di giudizio sono gli interessi del grande Moloch di cui si viene teorizzando (la società), e di fronte a questo il valore della persona perde d'importanza. È proprio quanto aveva scritto Rousseau nel Contratto Sociale $(11,5)\rangle^{29}$.

Sin embargo, esta interpretación no se puede asumir plenamente: se van a explicar los motivos.

En primer lugar, la posición del Marqués acerca de la pena de muerte como instrumento sancionador para algunas hipótesis delictivas requiere una distinción fundamental que Mereu parece descuidar. Precisamente, en opinión de este Autor, el perímetro, trazado por el pensamiento de Beccaria, en el que puede mantenerse la pena capital, sigue la trayectoria de la doctrina del delito de lesa majestad: las hipótesis relevantes serían los de alta traición, conspiración, complot, pacto con los enemigos del Estado, en fin, aquellos que comportan una perturbación de la forma de gobierno y que, en general, se pueden asociar a la categoría heterogénea de los delitos contra el Estado. En realidad, el elemento fundamental que Mereu no pone en evidencia es que el perímetro trazado por el Marqués no corresponde tout court a la categoría de los delitos contra el Estado. Se trataría, más bien, de delitos ocurridos en una situación de emergencia o en un momento de conspiración política acentuada, es decir, un estado de excepción: el escenario adonde Beccaria

29 «El principio sobre el que se funda la narración del De los delitos y de las penas es el mismo del Contrato social de J.J. Rousseau, que se interpreta dando precedencia a la voluntad general antes que a los derechos individuales [...] ¿Cuáles son, pues, el derecho o los derechos de la sociedad y el derecho o los derechos de los individuos? A esta pregunta Beccaria responde con un sofisma. Ningún individuo ha puesto en las manos de la sociedad el derecho de penarlo con la muerte; pero cuando la sociedad lo considere "útil y necesario" tiene este poder[....] Es decir, cuando los intereses de la sociedad exijan la pena de muerte como "útil y necesaria" (y sería más correcto decir necesaria en cuanto útil, dado que sólo la utilidad es el motor de los asociados), Beccaria no tiene nunguna dificultad teórica en admitirlo. [...] No existe ningún derecho individual imprescriptible, no existe tampoco el valor absoluto de la persona humana. Los únicos criterios de juicio son los intereses del gran Moloch del que se teoriza (la sociedad), y frente a éste el individuo pierde importancia. Es justamente lo que había escrito Rousseau en el Contrato Social $(11,5) »$. 
desenvuelve sus reflexiones aparentaría ser, esencialmente, a la guerra civil. Eso, es preciso notar, disminuye grandemente la extensión del concepto de "enemigo" al que se puede aplicar el suplicio supremo en relación a la teorización de Rousseau: es posible definir a Beccaria como contractualista, pero tal contractualismo encuentra su expresión en el intento delimitador del ámbito de aplicación de la pena capital, según una perspectiva distinta del pensador suizo.

En segundo lugar, como hubo ocasión de afirmar, a todo pensamiento se le debe una contextualización. Mereu siente esta necesidad y, en efecto, concede al Marqués algunos méritos reconociendo que, por ejemplo, «Cesare Beccaria è l'unico intellettuale che, nel 1764, affronta il problema penale, e il suo libro diventa subito un best seller» ${ }^{30}$. Pero, es justamente esta contextualización la que con toda probabilidad juega un papel determinante para confirmar que el mensaje del De los delitos y de las penas se concretizó en un impulso muy innovador. Es cierto, una lectura exclusiva del § XXVIII restituye a un Beccaria algo titubeante, aunque se deba interpretar esta postura a la luz del clima cultural y social en el que él actuaba. Se ha repetido varias veces y el mismo Mereu lo escribe:

«[n]el 1764 la prodigalità dei supplizi e delle pene non è un pleonasmo né un'immagine retorica. [...] La morte viene inflitta senza risparmio e con un apparato pubblicitario che mira a metterla in evidenza. La morte come pena non si discute. Costituisce uno dei baluardi del potere e nessuno osa metterlo in dubbio. L'unica accusa a cui Beccaria reagisce subito - quando pubblica Dei delitti e delle pene - è quella - fatta dal Facchinei - d'essere contro lo ius gladii del principe. Non si fa ripetere due volte l'addebito. Capisce che questo è l'assalto più pericoloso a tutto il libro. [...] Beccaria non poteva negare ai sovrani il diritto d'uccidere perché altrimenti il suo libro non avrebbe circolato. Oltre che all'Indice religioso, sarebbe stato messo all'Indice "laico", con conseguenze ben più gravi. E poi bisogna ricordarsi sempre che Beccaria è un riformista, non un rivoluzionario. È con il potere e non contro. [...] Cesare Beccaria è sempre il marchese Cesare Beccaria. Ed un marchese - nel 1764 - non può essere un "sovversivo", né tantomeno uno che è contro il sistema» ${ }^{31}$.

30 «Beccaria es el único intelectual que, en 1764, se enfrenta al problema penal y su libro se convierte, repentinamente, en un best seller».

31 «[E]n 1764 la prodigalidad de los suplicios y de las penas no es un pleonasmo ni tampoco una imagen retórica. [...] La muerte es infligida sin precaución y con un aparato publicitario que quiere evidenciarla. La muerte como pena no se discute. Constituye uno de los baluartes del poder y nadie se atreve a dudarlo. La única acusación a la que Beccaria responde inmediatamente, tras publicar el De los delitos y de las penas, hecha por Facchinei es la de estar en contra del ius gladii del príncipe. El Marqués no deja que esa acusación se repita, entiende que es el ataque mas peligroso a su obra. [...] Beccaria no podía negar a los soberanos el derecho de matar pues de otra forma su libro no habría circulado. Ademàs del Index religioso, el libro habría sufrido el Index "laico", con 
La situación que se acaba de describir es fundamental para comprender plenamente la posición sobre la pena de muerte expresada en el "libriccino". Tal vez el Marqués no fue un revolucionario pero es innegable que fue un innovador tácticamente prudente. El éxito inmediato que tuvo su obra corrobora esta interpretación. En el entendimiento de Beccaria era importante que ésta se aceptara políticamente, que circularan sus ideas, lo que no se habría verificado si el ensayo se hubiera presentado en franca oposición al poder. Y también el empleo de la pena perpetua, representada en otras páginas como una sanción feroz que transforma al ser humano en «bestia da servigio» ${ }^{32}$, es pues funcional para presentar la obra de forma más atractiva ante el poder. Bajo este enfoque la aparente ruptura entre la dureza de la pena perpetua y el principio de «suavidad de las penas» pregonado en otras partes, aparece menos insanable.

Sobre el asunto de la entidad de las penas, es más, conviene añadir alguna observación a fin de proporcionar una descripción lo más completa posible del pensamiento de Beccaria, pensamiento en el que las categorías de prevención general y especial se utilizan en negativo, con el objetivo de sostener la necesidad, justamente, de que las penas sean moderadas (y, tendencialmente, no contemplen la pena de muerte).

A menudo los estudiosos se han interrogado sobre el bagaje cultural que se puede entrever en la base de ese objetivo. Las matrices del pensamiento de Beccaria son probablemente tres: el utilitarismo, el humanismo cristiano y el proporcionalismo. Ese último aflora en varias partes de la obra, constituyendo uno de los pilares del pensamiento beccariano en el ámbito de las sanciones penales, y no necesita ser profundizado en este artículo. En cambio, las primeras dos matrices merecen que se les dedique algunas palabras.

Por lo que concierne al utilitarismo, obviamente, hay que tener en cuenta cómo éste representa un elemento dotado de potencial peligroso, dado que si se interpreta de manera extensiva podría conducir a resultados horrorosos. A pesar de la reconstrucción hecha por Mereu, a la que se rebate nuevamente, cabe subrayar cómo el Marqués recurra al utilitarismo adoptando un enfoque limitador del ámbito de relevancia penal.

Por último, se señala cómo Mereu sugiere reconocer en el humanismo cristiano el origen de las solicitudes más auténticas en materia de abolición de la pena capi-

consecuencias mucho mas graves. De igual manera es importante recordar que Beccaria es un reformista, no un revolucionario. Él está con el Poder, no en contra. [...] Cesare Beccaria siempre es el Marqués Cesare Beccaria. Y un Marqués, en 1764, no puede ser un "subversivo" ni menos uno en contra del sistema».

32 «Bestia de servicio», sic a disposición (N. del T.). 
tal. Por ejemplo, el mismo Autor opera una contraposición entre Cesare Beccaria y Tomás Moro ${ }^{33}$ :

«Beccaria dirà che la società, quando lo ritiene opportuno, può servirsi della pena di morte. Moro è proprio questo che non ammette. La vita è un bene intoccabile» ${ }^{34}$.

Ahora, puesto que tampoco el humanismo cristiano es completamente extraño a tendencias justificacionistas de la pena de muerte (posiciones que tal vez se substancian en el concepto de la legítima defensa que se podría reconocer a la sociedad), no se puede subestimar la distinta identidad de los dos pensadores y el diferente estatuto epistemológico sobre el que se fundan sus posiciones. En la Utopia (1516) de Moro, de hecho, el argumento parte del supuesto de que si la vida perteneciera al Estado y al individuo particular, no habría elementos ex radice para refutar la previsión de la pena capital. No obstante, Moro acepta el postulado de que la vida pertenece a Dios, lo cual la hace un bien indisponible para el ser humano (individuo, sociedad, Estado) y de la pena de muerte un suplicio que no se puede admitir en ningún caso. A su vez, es importante tener en cuenta que Beccaria propone un discurso laico, lo que no impide encontrar, en algunos de sus razonamientos, elementos de ese humanismo cristiano que ha criticado la sanción capital.

\section{EL DEBATE RECIENTE SOBRE LA PENA DE MUERTE}

Tras haber ofrecido una visión global de la posición beccariana y de su interpretación, como se ha declarado al comienzo de esta contribución, conviene abordar el tema de la pena de muerte en el debate actual y la influencia que ha tenido en éste el pensamiento del Marqués.

Si miramos el panorama italiano, entre los más destacados filósofos del derecho contemporáneos que se han ocupado del presente tema cabe mencionar, sin lugar a dudas, a Luigi Ferrajoli y Norberto Bobbio ${ }^{35}$. El primero opina que el argumento más sólido en contra de la sanción capital es de tipo contractualista: de la protección de la vida humana cual justificación del Estado se deduce, como necesidad lógica, la inadmisibilidad de la pena de muerte. El segundo, por el contrario, analiza la cuestión recurriendo a un argumento moral de origen kantiano: la universalidad de los

33 Mereu, I. op. cit., 63 ss.; el Autor escribe, entre otras cosas: Beccaria «[b]ajo un punto de vista "técnico" no ha dicho nada de nuevo, al revés, se ha quedado mas atrás de otros autores (de Tomás Moro y de Juan Graefe, por ejemplo)» (ivi, 103).

34 «Beccaria dirá que la sociedad, cuando lo considere oportuno, puede recurrir a la pena de muerte. Es precisamente esto lo que Moro no admite. La vida es un bien intangible».

35 Cfr. Ferrajoli, L. «Il fondamento del rifiuto della pena capitale». En Costa, P. (a cura de), Il diritto di uccidere. L'enigma della pena di morte. Milano, 2010, 57 ss.; Bobbio, N. Contro la pena di morte e Il dibattito attuale sulla pena di morte. Ahora en Id., L'età dei diritti. Torino, $7^{\mathrm{a}}$ ed., Torino, 2006, respectivamente 178 ss. y 201 ss. Útil sobre el argumento la lectura de Zolo, D. «Il patibolo e la guerra. La pena di morte come supplizio religioso». En Costa, P. (a cura de), op. cit., 29 ss. 
derechos humanos. Por ende, los dos han intentado fundar su contrariedad absoluta a la pena de muerte bajo premisas filosóficas o iusfilosóficas, aunque adoptando dos perspectivas diferentes.

Manteniéndose en el ámbito de trabajos elaborados en Italia, merece ser mencionado el Documento per l'abolizione universale della pena di morte ${ }^{36}$ de 2009 , preparado con motivo del quinto centenario de la institución de la enseñanza del ius criminale en el seno a la Universidad de Bolonia, firmado por los catedráticos de todas las facultades italianas y difundido en más de ochocientos Ateneos del mundo (incluyendo países donde la pena capital sigue aplicándose).

Las argumentaciones principales empleadas en el Documento para afirmar una contrariedad neta al suplicio capital son esencialmente tres, y en cada una de ellas es posible entrever cierta influencia de las tesis beccarianas.

En primer lugar, se argumenta que la pena de muerte no cumple eficazmente ninguna función preventiva: esta afirmación ha obtenido demostración empírica en varios estudios efectuados en países no abolicionistas y, se recuerda, forma parte del argumentario crítico del Marqués hacia la pena capital. La segunda motivación presentada en el Documento alude al error judicial, siendo natural que una vez ejecutada, la pena capital no permite reconstituir la situación preexistente. A decir verdad, este tema no profundizado debidamente en el "libriccino" del Marqués, aunque él mismo retomó dicha reflexión en el apartado dedicado a la «irreparabilidad ${ }^{37}$, poniéndolo en cierto modo a base de sus razonamientos. Finalmente, el rechazo de la pena de muerte contenido en el Documento surge, esencialmente, de la declinación del discurso de la dignidad, intangibilidad e inviolabilidad de la persona humana y de su vida, en la perspectiva de un jurista laico. El aspecto de la dignidad del ser humano, se apuntó, aparece incluso en el pensamiento de Beccaria: salvo por los casos en los que él propugnó el mantenimiento de la sanción capital y la previsión de la pena perpetua, en los términos, y por las razones, que se han visto, el Marqués afirmó que «[n]on vi è libertà ogni qual volta le leggi permettono che in alcuni eventi l'uomo cessi di essere persona e diventi $\operatorname{cosa}\rangle^{38}$ (y, quizás, se trata de una confirmación de las influencias de tipo humanitarista en sus reflexiones).

A pesar de los argumentos y reflexiones que se han resumido, es interesante destacar cómo las tesis favorables a la pena de muerte reaparecen sin cesar, perpetuando

36 Disponible, por ejemplo, en Criminalia, 2009, 411 ss., y Diritto penale XXI Secolo, 2009, 218 ss., en ambos casos con una Presentazione de S. Canestrari (407 ss. y 215 ss.).

37 Gallarati Scotti, F.; Beccaria, C.; Risi, P. «Voto degli infrascritti individui della Giunta delegata per la riforma del sistema criminale nella Lombardia Austriaca riguardante la pena di morte. 1792». En C. Beccaria, Opere, a cura de S. Romagnoli, II, Firenze, 1958, 739 s.

38 Beccaria, C. Dei delitti e delle pene, cit., $72 \mathrm{~s}$. «No hay libertad cada vez que las leyes permitan que en ciertos acontecimientos el hombre cese de ser una persona y se repute como una cosa». 
la que Ferrajoli define «filosofia patibolare» ${ }^{39}$, de modo que el debate resulta no sólo actual sino ineludible para el penalista ¿Por qué ocurre esto?

Si se quiere dar una respuesta breve y preliminar a esta pregunta, la explicación fundamental podría encontrarse tal vez en el valor simbólico de la sanción capital. Bajo una perspectiva biopolítica, ella representa la idea que la política, el legislador, el Estado, pueden dominar al cuerpo, y lleva consigo, dentro de ciertos límites, la consecuencia lógica de la imposibilidad de frenar el poder del Estado sobre el individuo. Una lectura antropológica del fenómeno contiene, quizás por esa razón, aspectos simbólicos e irracionales: refleja ese temor del «splendore dei supplizi» del que se encuentra, a menudo, un rastro en las reflexiones de Michel Foucault ${ }^{40}$.

A propósito de esto, no se puede dejar de considerar el rol asumido por las élites culturales en el debate: en particular, puede ser útil referirse a la experiencia estadounidens $\mathrm{e}^{41}$. Es importante señalar cómo, en dicho país, la tentativa quizás más sofisticada de legitimación de la pena de muerte nace en las Academias y en las Escuelas de Sicología: en esos ámbitos se verifica, precisamente, una orientación que si por un lado renuncia a utilizar la argumentación de carácter ético-jurídico de la sanción capital como indemnización moral de las víctimas, por otro no renuncia a delinear una victimología esencialmente orientada, en cierto sentido, a una "sicología del profundo" por la que la pena de muerte ayudaría a los familiares de la víctima en la elaboración del luto.

Esta tesis resulta terrible y frágil al mismo tiempo: terrible, ante todo, en cuanto revela un materialismo exasperado; frágil, porque, como demuestran varios estudios que han contado con los familiares de las víctimas, no es cierto que la pena capital garantice satisfacción y, en cierta medida, les permita la elaboración del luto.

Se debe también evidenciar con vigor que se trata de un discurso solapado porque nace al interior de las Academias; y a este aspecto debe prestarse particular atención. Las élites intelectuales y académicas de varios países, en efecto, desempeñan o pueden desempeñar un papel fundamental en general y, por lo que interesa esta contribución, en el debate sobre la pena de muerte.

Eso vale, probablemente aún más, desde una perspectiva abolicionista: no parece ilógico considerar particularmente eficaz, además de una censura política, la promoción de un cambio cultural de un país a través de las relaciones que las élites intelectuales y académicas, que los profesores y los estudiantes mantienen cuando

39 «...filosofía patibular».

40 «...esplendor de los suplicios»: por ejemplo, Foucault, M. Sorvegliare e punire. Nascita della prigione. Torino, $13^{\mathrm{a}}$ ed., Torino, 2006, 35 ss. (orig.: Suveiller et punir. Naissance de la prison, Paris, 1975).

41 Sobre la pena de muerte en EE.UU. se señala el reciente volumen de Garland, D. La pena di morte in America. Un'anomalia nell'era dell'abolizionismo. Milano, 2013 (orig.: Peculiar Institution. America's Death Penalty in an Age of Abolition, Cambridge MA, 2010). 
visitan países donde aún se aplica la pena de muerte y cuando, aquí, se confronten con sus colegas.

Incluso en este sentido, pues, el citado Documento per l'abolizione universale della pena di morte merece una mención, constituyendo un testimonio que ha madurado en el ámbito académico y que se ha introducido de manera, como algunos afirmaron, no solamente simbólica y utópica, en un debate siempre actual en el que el mundo universitario debe de estar presente.

\section{CONCLUSIONES}

Inspirándose en las tesis de Beccaria sobre la pena de muerte e intentando desarrollar sus razonamientos en el contexto actual, estas páginas han querido, en fin, evidenciar cómo la pena de muerte permanece, y debe permanecer en el centro de la atención, tanto en las relaciones con los otros países como en el debate interno.

Aunque en Italia no subsistan hoy en día motivos concretos para temer un regreso de la pena de muerte, la lógica del "enemigo" (con su patrimonio de sentimientos violentos, vindicativos y reaccionarios) resulta, por otro lado, siempre latente. El penalista es llamado a reaccionar decididamente contra esas tendencias sin cometer el error de subestimarlas. No se olvide que, hace pocos años, hubo fuerzas políticas que recogieron firmas de la ciudadanía para proponer la reintroducción de la pena capital, concentrándose en los "enemigos" individuados conformemente a la coyuntura.

Es oportuno terminar la presente contribución volviendo a Beccaria. Se ha visto cómo la interpretación de su posición sobre la pena de muerte no ha sido unívoca: junto a una tradición que lo ha exaltado como promotor de una revolución centrada en el rechazo del suplicio supremo, otros han tratado de reducir grandemente su influencia y rol de innovador, al menos en el ámbito del abolicionismo.

La interpretación que se ha intentado ofrecer sobre el legado beccariano toma partida del entrelazamiento de contractualismo, utilitarismo, humanismo cristiano y proporcionalismo que caracteriza su pensamiento. Pero se ha querido igualmente recordar el contexto social y cultural en el que Beccaria actuó, evidenciando cómo algunas contradicciones aparentes del $\S$ XXVIII del De los delitos y de las penas pueden, en realidad, explicarse en la necesidad política de garantizar la circulación de sus ideas, sin caer bajo la hoz del Índex, religioso o laico.

De esa manera, el Marqués ha logrado importantes resultados prácticos, aspecto nada secundario, ni mucho menos, así como lo demuestra, entre otras cosas, un ejercicio ${ }^{42}$, intitulado Pena di morte, de la Arciconfraternita della Morte e Orazione

42 La Arciconfraternita (Hermandad) escribía diálogos donde se exponía una tesis y se ilustraban los argumentos en favor y en contra. Esto ayudaba en las relaciones de la Arciconfraternita con los condenados a muerte y delincuentes de los que se ocupaba. Estos estudios, llamados ejercicios y orientados cristianamente, profundizaban también el tema de la pena de muerte (N. del T.). 
en Ferrara. En un importante y reciente trabajo de Adriano Prosperi se puede leer un extracto, y con éste queremos terminar:

«Beccaria [...], scosso dall'orrore che gli eccitava l'atrocità di questa pena, se non giunse a provare inconcussamente la mancanza del diritto di vita ai governi, provò peraltro all'evidenza la mancanza di necessità d'applicarla e la possibilità di sostituirle altri equivalenti gastighi [...] E giunse ad ottenerne la sostituzione da varii di quei governi che cominciavano ad aprir l'orecchio alla progrediente filosofia» ${ }^{43}$, la abolicionista, que en el pensamiento de Beccaria encontró una expresión capaz de difundir, aún hoy, su eco.

43 Prosperi, A. Delitto e perdono. La pena di morte nell'orizzonte mentale dell'Europa cristiana. XIV-XVIII secolo. Torino, 2013, 549, se puede consultar incluso para la referencia bibliografica al ejercicio que se ha mencionado (ivi, nt. 27). «Beccaria [...] trastornado por el horror que le suscitaba esta pena, si no logró demostrar inapelablemente la inexistencia del derecho de vida en mano de los gobiernos, intentó demostrar con evidencia la falta de necesidad de aplicarla y la posibilidad de substituirla con otras penas [...] Consiguió que varios gobiernos la substituyeran y prestaran atención a la nueva filosofía que avanzaba». 



\title{
BECCARIA Y EL NACIMIENTO DEL GARANTISMO CONSTITUCIONAL EN EL DERECHO PENAL Y PROCESAL PENAL
}

\author{
JAVIER LLOBET RODRÍGUEZ \\ Catedrático de Derecho Penal y Derecho Procesal Penal \\ Universidad de Costa Rica
}

La publicación por Cesare Beccaria del libro "De los delitos y de las penas" en 1764, es considerada como uno de los hitos jurídicos de más relevancia en la historia del Derecho Penal. Algunos han dicho que Beccaria es el fundador de la ciencia del Derecho Penal. Sin embargo, debe estimarse que en su tiempo ya existía tal ciencia ${ }^{1}$. Otros lo han catalogado como el precursor de la Criminología ${ }^{2}$, en vez de la criminología positivista de Lombroso, Ferri y Garofalo, o la escuela cartográfica de Quetelet. No obstante lo anterior, más bien los aportes de Beccaria deben encontrarse en la Política Criminal',

1 En este sentido: Moreno Castillo, M.A. Estudio del pensamiento de Cesare Beccaria en la evolución del aparato punitivo. En: www.uam.edu.ni/facultades/derecho/jurídico/investigacion/escrito.htm.

2 Cf. Zaffaroni. Criminología. Aproximación desde un margen. Bogotá, Temis, 1993, p. 99-101. En sentido contrario: Kräupl: Die Gesellschaft, der Einzelne und das Verbrechen - Beccarias kriminologisches Verständis. En: Beccaria. Die Anfänge moderner Strafrechtspflege in Europa (Editor: Deimling). Heidelberg, Kriminalistik Verlag, 1989,p. 150, quien indica que Beccaria no puede considerarse fundador de la Criminología en vista de la amplia recepción de la ideología de la teoría social (incluida criminológica) de otras cabezas de la Ilustración, así como la solamente puntual, no sistemática, prosaica y teórica concepción de expresiones de carácter criminológico.

3 Cf. Bustos Ramírez, J. Introducción al Derecho Penal. Bogotá, Temis, 1994, p. 97. Indica Emiliano Borja que los principios político criminales básicos sobre los que se asienta el moderno Derecho Penal, descansan en la propuesta de Beccaria. Cf. Borja Jiménez, E. Ensayos de Derecho Penal 
debido a que promovió una reforma legislativa que introdujera una serie de garantías penales y procesales, que se llegaron posteriormente a incorporar en las constituciones políticas. Por ello es que precisamente se puede hablar de los aportes de Cesare Beccaria al nacimiento del garantismo constitucional en el Derecho Penal y Procesal Penal.

"De los delitos y de las penas" es un pequeño libro, que más que por la originalidad de las ideas, se caracterizó por la fuerza con que Beccaria las defendió, especialmente en lo relativo a la crítica a la tortura y a la pena de muerte. Las principales ideas defendidas del libro eran: a) la crítica a la tortura, b) la crítica a los juicios secretos, c) la defensa del jurado, d) la importancia de la prevención antes que la sanción, e) el principio de legalidad de los delitos y de las penas, f) la diferencia entre delito y pecado, g) la consideración de la dañosidad social al contemplarse los delitos, h) la proporcionalidad de las penas, i) la pena debe ser la menor posible (última ratio y mínima intervención), j) la crítica de la pena de muerte y k) el fin de prevención general de la pena ${ }^{4}$.

El libro debe ser entendido en relación con el Derecho vigente al momento de su publicación, en donde imperaba el sistema inquisitivo, con un quebranto al derecho de defensa y la presunción de inocencia. El aspecto más característico del proceso penal era que la investigación de los delitos descansaba en la práctica de la tortura. Desde la perspectiva del Derecho Penal sustantivo regía la confusión entre delito y pecado, la falta del respeto del principio de legalidad de los delitos, la falta de proporcionalidad de las penas y la amplitud de la aplicación de la pena de muertes.

Era el libro que los enciclopedistas franceses habían estado esperando que se escribiera y por ello lo recibieron con gran entusiasmo. Este júbilo con que fue acogido por los enciclopedistas, hizo que ejerciera en su momento una influencia notable en la declaración francesa de derechos del hombre y del ciudadano de 1789 , por ejemplo en la regulación del principio de legalidad y la del principio de presunción de inocencia ${ }^{6}$.

En el siglo XIX se llegó a incluir en diversas constituciones una enumeración de garantías ante la justicia penal, ello bajo la influencia de la declaración francesa de derechos del hombre de 1789, lo mismo que de la Constitución de los Estados

y Política Criminal. San José, Editorial Jurídica Continental, 2001, p. 233. En el mismo sentido: Zúñiga Rodríguez, L. Política criminal. Madrid, Colex, 2001, p. 76.

4 Cf. Llobet Rodríguez, J. Cesare Beccaria y el Derecho Penal de hoy. Garantías y sistema penal. Saarbrücken, 2011.

5 Cf. Ibid, capítulo I, No. 1.1.

6 Sobre la influencia de Cesare Beccaria sobre la regulación de la presunción de inocencia en la declaración francesa de derechos del hombre y del ciudadano de 1789: Köster, R.-J. Die Rechtsvermutung der Unschuld. Bonn, tesis doctoral, 1979, p. 88, nota al pié 6; Llobet Rodríguez, J. Die Unschuldsvermutung und die materiellen Voraussetzungen der Untersuchungshaft. Freiburg en Brisgovia, Max Planck Institut für ausländisches und internationales Strafrecht, 1995, p. 71, nota al pie 255. 
Unidos de América de 1776 y las enmiendas a la misma de 17917. Sin embargo, no fue hasta después de la Segunda Guerra Mundial y los horrores del Holocausto, que los derechos fundamentales tuvieron un nuevo impulso, a partir de la creación de Tribunales constitucionales en Alemania e Italia, que permiten un control no solamente formal del procedimiento de creación de las leyes, sino además un control substancial, que establece límites al legislador, el que no puede dotar del contenido que quiera a las leyes, sino las mismas deben ser conformes al contenido substancial de los derechos fundamentales, por ejemplo deben respetar el principio de legalidad, el de culpabilidad, el de presunción de inocencia, el derecho de defensa, etc.

Relacionado con ello fue también el desarrollo que se dio del Derecho Internacional de los Derechos Humanos, con la aprobación por la Asamblea General de las Naciones Unidas en 1948 de la Declaración Universal de Derechos Humanos ${ }^{8}$. A la aprobación de esta declaración, siguió luego la de diversas convenciones de derechos humanos.

Como consecuencia de ello, señala Luigi Ferrajoli que se produjo un cambio de paradigma, del que resulta el constitucionalismo, como exigencia no solamente de una legalidad formal, sino de una substancial ${ }^{9}$. Ello corresponde a lo que se ha denominado por Luigi Ferrajoli como el garantismo, que fue desarrollado especialmente como consecuencia de la experiencia negativa vivida en Italia a partir de la legislación de emergencia, aprobada en contra del terrorismo ${ }^{10}$. Se reconoce que el legislador tiene límites no solamente formales, sino también sustanciales, en cuanto al contenido de las leyes, ya que éstas deben ser acordes con los derechos fundamentales que tiene toda

7 Sobre ello: Ferrajoli, L. Derecho y razón (Traducción de Perfecto Andrés Ibáñez y otros). Madrid, Trotta, 1995, p. 356. quien dice: "De la Declaración de derechos de 1789 en adelante, todos los textos constitucionales - de la Constitución italiana a las del resto de los países europeos, de los Estados Unidos a las de la Unión Soviética y el resto de los países socialistas, y hasta las Constituciones de los países del tercer mundo- han incorporado de hecho gran parte de los principios de justicia tradicionalmente expresados por las doctrinas del derecho natural".

8 Señala Norberto Bobbio "Nos sentiríamos tentados a describir el proceso de desarrollo que acaba con la Declaración Universal (...) sirviéndonos de las tradicionales categorías del derecho natural $y$ del derecho positivo: los derechos del hombre nacen como derechos naturales universales, se desarrollan como derechos positivos particulares para hallar luego su plena realización como derechos positivos universales. La Declaración Universal contiene en germen la sintesis de un movimiento dialéctico que comienza con la universalidad abstracta de los derechos naturales, pasa a la particularidad concreta de los derechos positivos nacionales, termina con la universalidad ya no abstracta sino concreta de los derechos positivos universales". Bobbio, N. El problema de la guerra y las vías de la paz. Barcelona, Gedisa, 1992, p. 136. Sobre ello véase también: Bobbio, N. El tercero ausente. Madrid, Ediciones Cátedra, 1997, pp. 154-155.

9 Ferrajoli, L. Derechos y garantías. Madrid, Trotta, 1999, pp. 66-67; Ferrajoli, L. «Filosofía del mal y garantismo». En: Forero, A./Rivera, I./Silveira, H. (Editores). Filosofía del mal y memoria. Barcelona, Anthropos, 2012, pp. 99-122.

10 Cf. Prieto Sánchez, L. Garantismo y Derecho Penal. Madrid, Iustel, 2011, p. 68. Sobre la legislación de emergencia: Ferrajoli, L. Derecho y razón, pp. 478, 486, 508, 548, 610, 699-703, 709, 711, $713,722,727,737-750,752$. 
persona. Igualmente debe el legislador actuar acorde con los derechos establecidos en los Tratados Internacionales de Derechos Humanos y en otras fuentes de acatamiento obligatorio del Derecho Internacional de los Derechos Humanos ${ }^{11}$.

El garantismo penal de Luigi Ferrajoli pretende retomar el ideal ilustrado y profundizarlo. Los autores más citados en el libro "Derecho y razón" son Beccaria y Carrara. Indica Ferrajoli que los principios en que se basa el garantismo: estricta legalidad, materialidad y lesividad de los delitos, la responsabilidad personal, el juicio oral y contradictorio entre las partes, la presunción de inocencia, son parte de la tradición liberal e ilustrada ${ }^{12}$. Agrega que los principios del garantismo tienen su base en buena parte en el pensamiento ilustrado, antes del nacimiento del Estado de Derecho. Cita entre los autores correspondientes a ese pensamiento a Cesare Beccaria ${ }^{13}$. En ese sentido Prieto Sanchis indica que el garantismo es una propuesta de minimización del Derecho Penal a partir de la recuperación de los postulados de la Ilustración jurídica que dieron vida al Derecho Penal liberal ${ }^{14}$. Sobre ello dice Jesús María Silva-Sánchez que algunas interpretaciones del Derecho Penal Mínimo, ligado al garantismo penal, no se encuentran muy lejos de las propuestas que, entre otros, realizara Beccaria, hace dos siglos ${ }^{15}$.

Un aspecto fundamental del constitucionalismo y del garantismo es el sistema de garantías penales. El principio de dignidad de la persona humana es la base del constitucionalismo y del garantismo, ya que los diversos derechos fundamentales,

11 Ello se aplica también a las garantías de carácter social, de modo que así como ninguna mayoría puede decidir la supresión de un inocente la privación de los derechos fundamentales de un individuo o un grupo minoritario, “(...) tampoco puede dejar de decidir las medidas necesarias para que a un ciudadano le sea, asegurada la subsistencia y la supervivencia". Ferrajoli, L. Derecho y razón, p. 865. Acerca del garantismo: Ferrajoli, L. Diritto e ragione. Teoria del garantismo penale. Roma, 1990; Ferrajoli, L. «El Estado Constitucional de Derecho hoy el modelo y su divergencia de la realidad». En: Andrés Ibáñez, Perfecto (Editor). Corrupción y Estado de Derecho. Madrid, Trotta, 1996 pp. 15-29; Ferrajoli, L. Derechos y garantías. La ley del más débil (Traducción: Perfecto Andrés Ibáñez y Andrea Greppi). Madrid, Trotta, 1999 ; Ferrajoli, L. Garantismo. Una discusión entre Derecho y Democracia (Traducción : Andrea Greppi). Madrid, Trotta, 2006; Ferrajoli, L. Principia iuris. Madrid, Trotta, 2 Tomos, 2011; Andrés Ibáñez, P. En torno a la jurisdicción. Buenos Aires, Editores del Puerto, 2007; Carbonell, M. (Coordinador). Neoconstitucionalismo. Madrid, Trotta, 2005; Carbonell, M./Salazar, P. (Coordinadores). Garantismo. Estudios sobre el pensamiento jurídico de Luigi Ferrajoli. Madrid, Trotta, 2005; Gianformaggio, L. (Editora). Las razones del garantismo. Discutiendo con Luigi Ferrajoli. Bogotá, Temis, 2008; Prieto Sánchez, L. op. cit.

12 Ferrajoli, L. Derecho y razón, p. 33. Sobre la pretensión de Ferrajoli de rehabilitar el pensamiento ilustrado: Salas, Minor. Kritik des strafprozessualen Denkens. Múnich, Verlag C. H. Beck, 2005, pp. 181-189.

13 Ferrajoli, L. Derecho y razón, p. 232.

14 Prieto Sánchez, L., op. cit., p. 11.

15 Cf. Silva Sánchez, J.M. La expansión del Derecho Penal. Buenos Aires, B de f, 2006, p. 2. Sobre las ideas de Beccaria y su influencia en los postulados del Derecho Penal Mínimo de acuerdo a la formulación del mismo por Ferrajoli: Asúa, A. «Reivindicación o superación del programa de Beccaria». En: El pensamiento penal de Beccaria. Su actualidad (Coordinadora: Asúa, Adela). Bilbao, Universidad de Deusto, 1990, p. 24. 
contemplados en la Constitución Política, lo mismo que los derechos humanos, previstos en el Derecho Internacional de los Derechos Humanos, tienen su origen en el principio de dignidad de la persona humana ${ }^{16}$. Ello lleva a que deba partirse de una concepción heteropoyética del Derecho y del Estado ${ }^{17}$, que implica que el Estado y el Derecho existen para proteger a los seres humanos y no tienen un fin en sí mismos. Lo anterior conduce que deban ser rechazadas las concepciones de carácter autopoyético, que por ejemplo imperaron en regímenes como el fascismo y el nacionalsocialismo ${ }^{18}$. No puede dejarse de considerar que los regímenes fascista y nacionalsocialista se concebían a sí mismos como enfrentados a la Ilustración y sus ideas.

Indica Luigi Ferrajoli explicando el carácter heteropoyético: "No puede castigarse a un ciudadano sólo porque ello responda al interés de la mayoría. Ninguna mayoría, por más aplastante que sea, puede hacer legitima la condena de un inocente o subsanar un error cometido en perjuicio de un solo ciudadano" 19 . Agrega: "Ni siquiera por unanimidad puede un pueblo decidir (o consentir que se decida) que un hombre muera o sea privado sin culpa de su libertad, que piense o escriba, o no piense o no escriba, de determinada manera, que no reúna o no se asocie con otros, que se case o no se case con cierta persona o permanezca indisolublemente ligado a ella, que tenga o no tenga hijos, que haga o no haga tal trabajo, u otras cosas por el estilo"20.

Desde Foucault se ha criticado a la doctrina ilustrada y dentro de ella a Beccaria, por no perseguir propiamente una ética humanista ${ }^{21}$, sino más bien de carácter utili-

16 Sobre la importancia del principio de dignidad de la persona humana como base de los derechos humanos: Delgado Pinto. «La función de los derechos humanos en un Estado democrático (reflexiones sobre el concepto de derechos humanos)». En: El fundamento de los derechos humanos (Editor: G. Peces-Barba Martínez). Madrid, 1989, p. 138; Schöne. Acerca del orden jurídico penal. San José, Juricentro, 1992, p. 193; Llobet Rodríguez, J. Derechos Humanos y Justicia Penal. San José, Escuela Judicial/Editorial Jurídica Continental, 2008, pp. 79-81.

17 Cf. Ferrajoli, L. Derecho y razón, pp. 880-883.

18 Cf. Llobet Rodríguez, J. Nacionalsocialismo y antigarantismo penal (1933-1945). San José, Editorial Jurídica Continental, 2015.

19 Ferrajoli, L. Derecho y razón, p. 544.

20 Ibid, 859.

21 Foucault, M. Vigilar y castigar. Madrid, Siglo XXI, 1991, p. 98. Comentando lo dicho por Foucault, señala Roberto Fragomeno en Costa Rica: "Foucault tiene razón al sospechar que no son motivos humanitarios los que impulsan a los hombres de la ilustración a terminar con el suplicio, sino que hay un completa causa política en la transformación de la intervención penal. Y esta causa política es la del hombre del contrato, aquel que, según Rouseau, nacía libre y en todas partes estaba encadenado". Indicó además: "Si el suplicio es reemplazado por la prisión es porque la forma de castigar del despotismo absoluto es reemplazada por la forma de la sociedad contractual. De las torturas insoportables y ejemplificadoras se migra a una economía de los derechos suspendidos". Fragomeno, R. Las tribulaciones de la mirada. La lógica del castigo, de los mercaderes, los financistas y los inspectores. San José, Ediciones Perro Azul, 2003, pp. 37-38. Señala Fernando Savater que uno de los adversarios mayores que tiene Foucault es la Ilustración. Esta dice "... es el movimiento promotor de la cultura racional moderna, modernizadora y disciplinariamente humanitaria, 
tarista, de modo que las garantías no son contempladas como una forma de respeto a la dignidad humana, sino porque son útiles para la colectividad. En Alemania esta crítica es desarrollada, por ejemplo, por el profesor Wolfgang Naucke, quien en 1989 impartió una conferencia titulada "La modernización del Derecho Penal a través de Beccaria", ello con motivo del aniversario 225 de la publicación del libro "De los delitos y de las penas" 2 . En dicha conferencia indicó que uno se puede sorprender de lo poco que Beccaria utiliza el argumento humanitario, ya que la argumentación central que emplea es la necesidad política de la pena, no la humanidad. Dijo que la humanidad como un simple argumento de verdad, como límite absoluto de la pena, no se encuentra en Beccaria. Señaló -Naucke- que incluso en lo concerniente a la pena de muerte y a la tortura se acude al argumento de la utilidad, lo mismo que en la teoría de la interpretación, la división de poderes, la proporcionalidad entre el hecho y la pena y la relación entre la policía y el sistema de justicia. La crítica de Wolfgang Naucke ha sido retomada por el profesor Kai Ambos, quien defendió ideas similares en el Congreso sobre el pensamiento de Beccaria realizado en la Universidad Sergio Arboleda el 2 de octubre de $2013^{23}$.

Cesare Beccaria es considerado uno de los principales representantes del utilitarismo. Al señalar los textos que ejercieron una mayor influencia en él, Beccaria destacó el de Helvetius, precursor de las ideas utilitaristas ${ }^{24}$. Conforme a las mismas Cesare

cuyos aspectos panópticos discierne sin complacencias en sus libros más célebres. En una palabra, la Ilustración es la responsable del encierro, la inventora minuciosa e inexorable de la represión articulada de la vida por el poder. Los aspectos tradicionalmente considerados como emancipadores de este movimiento son descartados o, aún peor, mostrados como coartadas para la acentuación represiva del encierro: de ahi que figuras como Pinel o Beccaria aparezcan a pesar de sus méritos del lado infame de la trama. Por supuesto ha habido que forzar un tanto los hechos para obtener este resultado y los más serios contenciosos de los historiadores con Foucault se fundan en este reproche de unilateralidad antagónica. Nada de extraño tiene, pues que Foucault saludase en su día con una reseña entusiástica el libro de André Glucksman Les mâitres penseurs, donde las grandes figuras de la tradición ilustrada aparecen nada menos que como inspiradores teóricos del Gulag y Auschwitz". Savater, Fernando. Ética como amor propio. Barcelona, Mondadori, 1998, p. 279.

22 Cf. Naucke, W. «Die Modernisierung des Strafrechts durch Beccaria». En: Beccaria. Die Anfänge moderner Strafrechtspflege in Europa (Editor: Deimling). Heidelberg, Kriminalistik Verlag, 1989, pp.37-53. Véase además: Naucke, W. «Gesetzlichkeit und Kriminalpolitik». En: Naucke. Gesetzlichkeit und Kriminalpolitik. Fráncfort del Meno, 1999, pp. 225-240; Naucke, W. «Generalprävention und Grundrechte der Person». En: Naucke. Gesetzlichkeit und Kriminalpolitik. Fráncfort del Meno, 1999, pp. 133-153.

23 Cf. Ambos, K. «Del tormento». En: Matus, J.P. (Director). Beccaria. 250 años después. Dei delitti e delle pene. Buenos Aires, B de f, 2011 pp. 155-167.

24 Así dijo: "La segunda obra que completó la revolución en mi espíritu es la de Helvecio. Él es quien me ha impulsado en el camino de la verdad, y el que primero despertó mi atención sobre la ceguera $y$ las desgracias de la humanidad. Debo a la lectura del Espiritu gran parte de mis ideas". En: Beccaria, Cesare. De los delitos y de las penas (Traducción: Francisco Laplaza). Buenos Aires, Ediciones Arayú, 1955, p. 510. Sobre la influencia de Helvecio en Beccaria: Young, D. Introduction 
Beccaria le dio gran relevancia a la búsqueda de la felicidad de la colectividad, como aspecto fundamental que debía ser perseguido a través de la legislación. Dijo: "La felicidad dividida entre el mayor número deberá ser el punto a cuyo centro se dirigiesen las acciones de la muchedumbre" ${ }^{" 25}$. No puede desconocerse además que en los diversos aspectos tratados de su libro, incluso en lo relativo a la pena de muerte y la abolición de la tortura, recurre a argumentos utilitaristas, al lado de humanistas y humanitaristas, lo que hace que no dejara de incurrir en excesos, a partir de su interés en lograr convencer a los gobernantes sin cuestionar su autoridad, de la necesidad de la reforma penal. Estos excesos en que incurrió Beccaria tienen su expresión máxima en la justificación de la pena de esclavitud perpetua, como argumento para la derogatoria de la pena de muerte, por ser una pena más útil ${ }^{26}$. En efecto las consideraciones que hace de la pena de esclavitud perpetua se alejan del humanismo y del humanitarismo, lo que es criticado, con razón, por Naucke y por Ambos.

Debe reconocerse que la lógica del garantismo penal no deja de plantear problemas con el utilitarismo presente en Cesare Beccaria, de modo que el mismo desarrolla sus ideas a partir de ideas humanistas y utilitaristas, sin percatarse del conflicto que podía presentarse al respecto, ya que una lógica humanista tiene la dignidad del ser humano como el aspecto central, mientras una meramente utilitarista parte de la felicidad del mayor número, dejando de lado con ello a los seres humanos individuales, los que podrían ser sacrificados en beneficio de la colectividad. El gran dilema entre el utilitarismo y el sistema de garantías, es que éstas operan con la lógica del imperativo categórico de Kant, no pudiendo ser relativizadas por la mayoría, tal y como lo señala desde el garantismo Luigi Ferrajoli.

Sin embargo, Ferrrajoli llega a distinguir entre dos tipos de utilitarismo. El primero de ellos -indica- es el utilitarismo a medias, que parte de la "máxima felicidad entre el mayor número", de modo que se persigue la máxima utilidad para la mayoría. Indica que de acuerdo con ello el fin de la pena es la prevención de delitos. Advierte que este utilitarismo puede llevar a una auto-legitimación autoritaria, siendo incapaz de suministrar criterios de deslegitimación de sistemas penales concretos ${ }^{27}$. El segundo tipo de utilitarismo, según Ferrajoli, es el utilitarismo garantista, del que parte él mismo. Dice que conforme a éste se trata de buscar no solo el máximo bienestar de los no desviados, sino también de los desviados, resultando que este segundo paráme-

and Notes. Beccaria, Cesare: On Crimes and Punishment (Traductor: Young, David). Indianápolis, Hackett Publishing Company, 1986, p. 88, notas 3 y 4 al capítulo VI.; p. 90, nota 4 al capítulo XIII.; p. 97, nota 5 al capítulo XXVII., p. 103, notas 1, 2 y 5 del capítulo XL y nota 1 del capítulo XLI.

25 Beccaria, C. De los delitos y de las penas (Traducción de Juan Antonio de las Casas). Madrid, Editorial Alianza, 1988, introducción, p. 26. Sobre ello véase: Ferrajoli, L. Derecho y razón, p. 262.

26 Cf. Llobet Rodríguez, J. Beccaria, op. cit., capítulo III, No. 3.14.

27 Ferrajoli, L. Derecho y razón, pp. 263-264, 331. 
tro no tiene relación con la prevención de delitos ${ }^{28}$. El utilitarismo de Ferrajoli parte de que la pena está justificada como un mal menor, en cuanto sea menos aflictiva y menos arbitraria, respecto de otras reacciones no jurídicas que es lógico suponer que se producirían en su ausencia. Agrega que el monopolio estatal de la potestad punitiva está justificado cuantos más bajos sean los costos del Derecho Penal, frente a los costos de la anarquía punitiva ${ }^{29}$. Ferrajoli señala que este utilitarismo no es extraño a la tradición ilustrada ${ }^{30}$. Indica que en las ideologías utilitaristas de Beccaria y Carrara se parte de una concepción de la pena como mínima aflicción necesaria, a diferencia de otras concepciones utilitaristas, que pueden informar concepciones autoritarias y antigarantistas, basadas en la máxima seguridad posible ${ }^{31}$.

Es importante resaltar que como lo indica Maurizio Fioravanti las ideas ilustradas y revolucionarias tuvieron un desarrollo diferente en la misma época en Estados Unidos de América y en la Europa continental. La lucha en los Estados Unidos de América a favor de un sistema de garantías frente al Estado, tenía como un aspecto fundamental la lucha en contra de la ley, la que durante el dominio inglés sobre las colonias norteamericanas, se había revelado como una fuente de arbitrariedad, por ejemplo en la fijación de los impuestos ${ }^{32}$. Por ello no es de sorprender que a principios del siglo XIX se llegara a admitir en los Estados Unidos de América el control de constitucionalidad de las leyes ${ }^{33}$, aspecto que sería conforme a la lógica constitucionalista de Luigi Ferrajoli. En Europa continental, por el contrario, la lucha ilustrada era en gran parte en contra de la arbitrariedad judicial, lo que llevó a confiar en la generalidad de la ley como límite frente a la arbitrariedad. Ello conducía a la defensa del principio de legalidad de los delitos y de las penas, que encontró en Beccaria a uno de sus máximos representantes ${ }^{34}$. Esto podría ser considerado por algunos como contrario al constitucionalismo del garantismo penal, en cuanto el mismo no reclama

\footnotetext{
$28 \quad$ Ibid, pp. 331-332.

$29 \quad$ Ibid, p. 336.

30 Ibid, p. 333.

31 Ibid., p. 33

32 Dice Maurizio Fioravanti refiriéndose a la revolución francesa: "Todas las ideologías que sustentan la revolución llegan a esta conclusión: la convicción de que la ley general y abstracta - más que la jurisprudencia, como en el caso británico - es el instrumento más idóneo para la garantía de los derechos. Se es libre porque se está gobernado de manera no arbitraria, porque en materia de derechos y libertades no vale ya la voluntad de un hombre contra la de otro, porque son abolidas las dominaciones de carácter personal, porque sólo la ley puede disponer de nosotros mismos". Fioravanti. Los Derechos fundamentales (Traducción Manuel Martínez Neira). Madrid, Editorial Trotta, 1996, p. 70. Véase además en particular p. 74 y 83. Véase además: Fioravanti, Maurizio. Constitucionalismo. Experiencias históricas y tendencias actuales (Traducción: Adela Mora Cañada/Martínez Neira, Manuel). Madrid, Trotta, 2014, p. 39.

33 Cf. Fioravanti, M. Constitucionalismo, op. cit., p. 41.

34 Cf. Llobet Rodríguez, J. Cesare Beccaria, op. cit., capítulo III, No. 3.1 y 3.2.
} 
solamente la vigencia del principio de legalidad desde el punto de vista formal, sino también substancial, lo que implica que el legislador tiene límites para legislar. A pesar de lo anterior, no puede desconocerse que en Beccaria no se expresa solamente el principio de legalidad, sino se desarrollan una serie de garantías de carácter substancial, a las que se debe ajustar la ley, por ejemplo la exigencia de que las leyes sean claras, que debe establecerse la distinción entre delito y pecado, que el delito debe basarse en la dañosidad social, que las penas deben ser proporcionadas y que debe actuarse conforme al criterio de la mínima aflicción posible.

El conflicto entre las ideas utilitaristas y las ideas de contención del poder punitivo se encuentra generalmente expresado en la teoría de la pena. Ello encuentra clara expresión en Beccaria. Así en general se reconoce que Cesare Beccaria fue un defensor de la prevención general negativa como fin de la pena, lo que era conforme a las ideas utilitaristas ${ }^{35}$. Sin embargo, a su vez Beccaria hace mención a una serie de garantías que ponen límite a las ideas utilitaristas a medias, según la denominación dada por Luigi Ferrajoli. Por ejemplo reclama la necesidad de proporcionalidad de la pena, pretendiendo evitar con ello penas desproporcionadas. Ello llevó a David Young a afirmar que Beccaria seguía más bien ideas de carácter retributivo y no de utilitaristas. Para ello resaltó la gran preocupación que tenía Beccaria por los derechos humanos del delincuente, en particular al infringírsele una pena y en especial la afirmación de que debe haber proporcionalidad entre los delitos y las penas $^{36}$. Al respecto debe reconocerse la relación que existe entre el principio de proporcionalidad y la concepción retributiva de la pena.

El libro de Beccaria, como se dijo, se debate entre el humanismo y el utilitarismo, sin que pudiera percatarse de los peligros que puede implicar el segundo para el

35 Sobre ello: Ferrajoli, Luigi. Derecho y razón, pp. 275-277.

36 Cf. Young, David. «Cesare Beccaria: utilitarian or retributivist?». En: Journal of Criminal Justice (Estados Unidos de América), 1983, pp. 317-326. Véase también: Young, David. Introduction and Notes. Beccaria, Cesare: On Crimes and Punishment (Traductor: Young, David), pp. xii-xiii y 95. En sentido similar véase: Soto, M. «Fin de las penas». En: Matus, J.P. (Director). Beccaria. 250 años después. Dei delitti e delle pene. Buenos Aires, B de f, 2011 pp. 129-133. Sobre ello dice Adela Asúa: "Recientemente algún autor no ha dudado en calificar a Beccaria como cercano a la perspectiva retribucionista, en base a las referencias al 'merecimiento' de la pena para reponer el depósito del pacto social, la constante alusión a la proporción, a las garantías individuales, frente a las también reconocidas pretensiones preventivas. La adjudicación del calificativo de utilitarista a Beccaria responde más bien a la preocupación clasificadora, de obsesión reduccionista, que al contenido total del mensaje que el milanés ofrece en su obra. Por talante, por hechos, por modelo político y económico Beccaria es un liberal preocupado por acotar el campo estatal de intervención sobre la libertad de los ciudadanos, que encuadra mejor en la caracterización garantista - que los retribucionistas históricos. Efectivamente su posición es clara en cuanto que el fin de las pena no es 'expiar' la culpa o el delito, sino disuadir a los demás hombres, pero la imposición de la pena debe quedar sometida a otra serie de condiciones - proporción, necesidad, prueba de culpabilidad, proceso público y contradictorio - para que no sea injusta”. Asúa, Adela, op. cit., p. 22. 
primero. Sin embargo, sería injusto negarle a Beccaria sus pretensiones humanistas. Incluso Bentham, desde una perspectiva más utilitarista, criticó a Beccaria porque a través de ideas de piedad y generosidad dejaba de tomar en cuenta el interés general de la sociedad ${ }^{37}$. Igualmente Immanuel Kant, defensor de la existencia de un imperativo categórico, opuesto radicalmente a todo utilitarismo en relación con la pena y por ello desde la posición ubicada en el extremo opuesto al utilitarismo de Jeremy Bentham, al criticar la posición de Cesare Beccaria en contra de la pena de muerte, lo hizo atribuyéndole, al igual que Bentham, un humanismo excesivo, indicando que presenta un "sentimentalismo compasivo de un humanitarismo afectado (compassibilitas)" ${ }^{\prime 3}$. Se llega en definitiva en lo atinente a la pena de muerte con Cesare Beccaria, calificado en general como utilitarista, a una posición más respetuosa de la dignidad humana que con respecto a Immanuel Kant, uno de los máximos representantes del antiutilitarismo y considerado a partir del imperativo categórico un defensor del principio de dignidad de la persona humana.

Especialmente en relación con la prohibición de la tortura se expresan claramente los caracteres humanistas y humanitaristas que se encuentran en Beccaria ${ }^{39}$ y que se imponen sobre los utilitaristas, los que son usados por él fundamentalmente como argumentos para convencer de la necesidad de la reforma del sistema penal y en particular de la falta de sentido de la utilización de la tortura, por ser un medio no idóneo para la averiguación de la verdad. Dijo Beccaria tomando en cuenta la necesidad de la abolición de la tortura: "No hay libertad cuando algunas veces permiten las leyes que en ciertos acontecimientos el hombre deje de ser persona y se repute como cosa" ${ }^{\text {"40 }}$. Con dicha expresión Beccaria

37 Bentham, J. Tratado de las pruebas judiciales (Traducción de Manuel Ossorio Forit). Buenos Aires, Valetta Ediciones, T. II, 1971, pp. 122-124.

38 Cf. Kant, I. La metafísica de las costumbres (Traducción: Adela Cortina Corts/Jesús Conill Sancho). Madrid, Tecnos, 1994, No. 335, pp. 171-172; Kant, I. Die Metaphysik der Sitten. Fráncfort del Meno, Reclam, 1990, No. 335.

39 Indica Francisco Tomás y Valiente: "En un sentido amplio (y precisamente el que Sartre rechazaba desde su 'humanismo existencialista') puede ser calificada de humanista toda filosofia que tome al hombre como fin y como valor superior, y en tal forma entendido no sería incorrecto hablar de un humanismo ilustrado. Sin embargo, a los efectos que aqui persigo, esto es, para explicar la reacción frente a la tortura que se produce en la Europa ilustrada a partir, sobre todo, de Beccaria, considero más adecuado el concepto de 'humanitarismo'. Si hay una moral propia de la Ilustración y en ella nuevas virtudes como la tolerancia y la beneficencia, entre ellas hay que situar el humanitarismo, "la compasión de las desgracias ajenas.". Tomás y Valiente, F. La tortura judicial en España. Barcelona, Crítica, 2000, p. 239.

40 Beccaria, C, op. cit., Editorial Alianza, capítulo 20, p. 62. Indica Mondolfo: "Tal afirmación, que en Beccaria se encuentra formulada de pasada y por incidencia, tiene gran importancia filosófica, aun cuando Beccaria no revela darse cuenta de ello en medida adecuada a su trascendencia". Mondolfo, R. Cesare Beccaria y su obra. Buenos Aires, Depalma, 1946, p. 48. En sentido similar al expresado por Beccaria se pronunció Francesco Carrara en 1875, al decir: "No; un delito, por más grave que sea, o una serie de delitos, aun cuando sean repetidos y atroces, no despojan al desgraciado que se manchó con ellos de ninguno de los derechos inherentes a la personalidad humana; no lo transforman en una 
se adelantó a la segunda formulación del imperativo categórico de Kant ${ }^{41}$, conforme al cual el ser humano debe ser tratado como un fin en sí mismo y no solamente como un medio ${ }^{42}$, el que aún hoy es considerado como la mejor conceptualización para determinar el respeto del principio de la dignidad de la persona humana, que es reconocido, como se dijo arriba, como la base de todos los derechos humanos y fundamentales.

Son múltiples las expresiones de Beccaria de carácter humanista. Así dijo: "Me tendré por afortunado aunque no tenga otro mérito más que el de haber presentado el primero en Italia, con alguna mayor evidencia, lo que en otras naciones se han atrevido a escribir y empiezan a practicar. Pero si, sosteniendo los derechos de la humanidad y de la verdad invencible, contribuyese a arrancar de los dolores y angustias de la muerte a alguna víctima infeliz de la tiranía o de la ignorancia, igualmente fatal, las bendiciones y lágrimas de un solo inocente se consolarían del desprecio del resto de los hombres" ${ }^{\prime 4}$.

Escrito con gran sentimiento y humanismo, es el siguiente texto, que revela la fuerza en la defensa de sus ideas por Beccaria y la elocuencia con que las expresó: "Muy pocos han examinado y combatido la crueldad de las penas y la irregularidad de los procedimientos criminales, parte de la legislación tan principal y tan descuidada en casi toda Europa. Poquísimos, subiendo a los principios generales, combatieron los errores acumulados de muchos siglos, sujetando a lo menos con aquella fuerza que tienen las verdades conocidas el demasiado libre ejercicio del poder mal dirigido, que tantos ejemplos de fría atrocidad nos presenta autorizados y repetidos. Y aun los gemidos de los infelices sacrificados a la cruel ignorancia

cosa de la cual la autoridad social pueda hacer, sin medida, un instrumento para servir a sus fines, en la misma forma que lo hacía el civis romanus con sus esclavos". Carrara, F. Opúsculos de Derecho Criminal (Traducción: Ortega Torres/Guerrero). Bogotá, Temis, 1980, Tomo V, p. 20.

${ }_{41}$ En este sentido: Calamandrei, P. «Prefacio y notas». En: Beccaria, Cesare: De los delitos y de las penas (Traducción de Santiago Sentís Melendo y Marino Ayerra Redín). Buenos Aires, Ediciones Jurídicas Europa-América, 1974, p. 69; Mondolfo, R., op. cit., pp. 46-49; Cattaneo, M. Aufklärung und Strafrecht (Traducción de Thomas Vormbaum). Baden Baden. Nomos Verlagsgesellschaft, 1998, pp. 46-47; Agudelo, N. «¿Qué nos dice Beccaria, hoy, a los juristas de Colombia?». En: Cesare Beccaria and Modern Criminal Policy (Editor: Centro Nationale di prevenzione e difesa sociale). Roma, Giuffrè editore, 1990, pp. 402-403; Ferrajoli, L. Derecho y razón, p. 302, nota al pie 110; Ferrajoli, L. Principia iuris, T. I, p. 203; Rivacoba y Rivacoba, M. Función y aplicación de la pena. Buenos Aires, Depalma, 1993, p. 68.

42 Kant, I. Fundamentación de la metafisica de las costumbres, pp. 44-46; Kant, I. Grundlegung zur Metaphysik der Sitten. Fráncfort del Meno, Suhrkamp, 1994, pp. 78-80; Kant, I. Die Metaphysik der Sitten, p. 192; Kant, I. De la conducta moral y politica (Editor: Balladares). San José, Libro Libre, 1988, pp. 110-116. La Iglesia Católica ha también acudido al imperativo categórico kantiano. Así Juan Pablo II en su Carta a las Familias hizo mención a dicha fórmula, al decir: "La persona jamás ha de ser considerada un medio para alcanzar un fin; jamás, sobre todo, un medio de 'placer'. La persona es y debe ser sólo el fin de todo acto. Solamente entonces la acción corresponde a la verdadera dignidad de la persona". Juan Pablo II. Carta a las Familias del Papa. Ciudad de Vaticano, Librería Editrice Vaticana, 1994, pp. 39-40. La doctrina y la jurisprudencia, acuden en general al imperativo categórico kantiano.

43 Beccaria, op. cit, Alianza, capítulo 11, p. 45. 
y a la insensible indolencia, los bárbaros tormentos con pródiga e inútil severidad multiplicados por delitos o no probados o quiméricos, la suciedad y los horrores de una prisión, aumentados por el más cruel verdugo de los miserables que es la incertidumbre de la suerte, debieran mover a esa clase de magistrados que guía las opiniones de los entendimientos humanos" ${ }^{\prime 4}$.

Como ejemplo del espíritu humanitario de Beccaria debe mencionarse además la siguiente cita, referida a la crítica a la tortura: “¿Quién al leer las historias no se llena de horror, contemplando los bárbaros e inútiles tormentos que con ánimo frío fueron inventados y ejecutados por hombres que se llamaban sabios? ¿Quién podrá no sentir un estremecimiento interior y doloroso al ver a millares de infelices, a quienes la miseria (o querida, o tolerada de las leyes que siempre han favorecido a los pocos y abatido a los muchos) obligó y condujo a un retroceso desesperado sobre el primer estado de naturaleza, o a acusados de delitos imposibles y fabricados por la temerosa ignorancia, o a reos sólo de ser fieles a los propios principios, despedazados con supuestas formalidades y pausados tormentos por hombres dotados de los mismos sentidos, y por consiguiente de las mismas pasiones, agradable espectáculo de una muchedumbre fanática?"45.

Debe reconocerse que el pensamiento de Beccaria gira alrededor de dos pensamientos: el humanista y el utilitario, de modo que con frecuencia para reforzar los argumentos humanistas utiliza criterios utilitarios, o bien les trata de dar un fundamento utilitario, como sucede con el principio de proporcionalidad ${ }^{46}$. Igualmente debe admitirse, como se dijo, que Beccaria no reconoció las contradicciones que pueden existir entre los criterios humanistas y los utilitarios, de modo que una ética utilitaria puede llegar a dejar sin efecto los criterios humanistas, todo en contra del principio de dignidad de la persona humana. Sin embargo si se quiere caracterizar la obra de Beccaria habría que hacerlo más por su humanismo y humanitarismo, que por su utilitarismo. El mismo Beccaria al formular la conclusión de su libro dejó fuera las ideas puramente utilitarias, salvo la mención de la necesidad, relacionada indirectamente con éstas, incluyendo más bien ideas de índole humanista. Así dijo: "Para que toda pena no sea violencia de uno o de muchos contra un particular ciudadano, debe esencialmente ser pública, pronta, necesaria, la más pequeña de las posibles en las circunstancias actuales, proporcionada a los delitos, dictada por las leyes" ${ }^{\prime 4}$. Se refleja en dicha expresión la pretensión de contención del poder punitivo, propia del garantismo constitucional.

44 Beccaria, op. cit., Alianza, Introducción, pp. 26-27.

45 Beccaria, op. cit., Alianza, capítulo 27, p. 73.

46 Cf. Llobet Rodríguez, J. Beccaria, op. cit., capítulo III, No. 3.10.

47 Beccaria, op.cit., Alianza, capítulo 47, p. 112. Debe reconocerse que dicha frase no se encontraba en la edición original, sino formó parte de unas segundas adiciones a dicha obra, que se agregaron a las primeras adiciones que le había hecho en ediciones posteriores a la primera. No puedo precisar en qué edición fue que se agregó todo este capítulo 47. Para lo anterior se toma en cuenta lo indicado en: Beccaria, op. cit., Alianza, capítulo 24,. 111-112. 


\title{
EUGENIO MARÍA DE HOSTOS CONTRA LA PENA CAPITAL ${ }^{1}$
}

\author{
CARMELO CAMPOS CRUZ ${ }^{2}$
}

Doctorando en Derecho Internacional y Relaciones Internacionales

Universidad Complutense de Madrid

\section{INTRODUCCIÓN}

Eugenio María de Hostos (1839-1903) es considerado el pensador puertorriqueño más destacado de nuestra historia. Este prócer ha sido reconocido como el Ciudadano de América por su proyección y labor en América Latina. La importancia de la obra de Hostos es tal que ha sido considerado uno de los cincuenta grandes pensadores de la educación a nivel mundial ${ }^{3}$.

Mi interés por el pensamiento de Hostos contra la pena de muerte se remonta a enero de 2008, cuando escribí un comentario de apenas dos páginas respecto a las contundentes y muy poco conocidas expresiones del prócer mayagüezano contra la pena de muerte. Ese contacto inicial con sus escritos coincidió con el proceso de redacción de un texto que titulé Pena de muerte y resistencia en Puerto Rico,

1 Este escrito fue presentado originalmente en una conferencia que se llevó a cabo en el Ateneo Puertorriqueño el 20 de febrero de 2016, evento que fue auspiciado por su Cátedra de Historia y la Coalición Puertorriqueña contra la Pena de Muerte.

2 El autor es abogado y activista de derechos humanos. Es Doctorando en Derecho Internacional y Relaciones Internacionales de la Universidad Complutense de Madrid. Labora como Conferenciante en la Universidad del Sagrado Corazón y el Colegio Universitario de San Juan.

3 Palmer, Joy A. ed. Fifty major thinkers on education, London: Routledge, 2001, pp. 161-168. 
y que fue distribuido por la Coalición Puertorriqueña contra la Pena de Muerte en la conferencia anual del National Coalition to Abolish the Death Penalty que se celebró en San José, California, y donde se otorgó el premio Lighting the Torch al pueblo de Puerto Rico por su oposición histórica a la imposición de la pena capital.

Este escrito consta de cuatro secciones. La primera describe la aplicación de la pena capital en la España en los tiempos de Hostos y las posturas de los estudiosos españoles de entonces respecto a este debate. A continuación examinaremos brevemente las influencias en el pensamiento del prócer y cómo son reflejados en su obra. Una vez realizado ese importante trasfondo, nos adentraremos a los escritos de Hostos que evidencian una firme oposición a la pena de muerte. Finalizaremos con una necesaria reflexión sobre la proyección y pertinencia del pensamiento hostosiano en el movimiento abolicionista puertorriqueño del siglo 21. Agradezco los atinados comentarios y correcciones de las doctoras Lina M. Torres Rivera y Evelyn Vélez Rodríguez a este texto, al igual que los valiosos comentarios del doctor Luis Arroyo Zapatero, de la Red Académica Internacional por la Abolición de la Pena Capital. La responsabilidad por las omisiones, inexactitudes y errores, como es menester, corresponden exclusivamente a este servidor.

La extensa obra hostosiana ha sido destacada en disciplinas como la educación, la sociología, la política o la filosofía, en particular, con aquellos aspectos relacionados con la ética y la moral. Sin embargo, debe recordarse que la formación académica formal de Hostos fue principalmente en el área del derecho. A pesar de que no finalizó la carrera de abogado, cursó estudios de derecho en la Universidad Central de Madrid durante su estadía en esa capital entre 1857 y 1869.

Respecto a su concepción jurídica, José Luis Méndez estima que:

"no se desarrolló de una manera convencional y cerrada en los lindes de sus estudios en derecho, sino como parte de una visión general del mundo en la que la preocupación por la justicia era la piedra angular de toda su lógica, pero estaba entrelazada a un conjunto de ideas estéticas y epistemológicas que se enmarcaban en diversas disciplinas como la sociología, la pedagogía y, sobre todo, la axiología"4.

Una reflexión similar fue hecha por Carmelo Delgado Cintrón, al indicar que "podemos afirmar que la ciencia del Derecho, y la sociología más tarde, es el hilo conductor de su pensamiento y está presente desde el inicio de su vida académica hasta el fin de sus días. Esta vocación por el estudio y la divulgación del saber no

4 Méndez, J.L. Hostos y las ciencias sociales. San Juan, Editorial de la Universidad de Puerto Rico, 2002, p. 160. 
es la de un estudioso gabinete, pues le interesaban los problemas y conflictos de su tiempo y realidad social"s.

Antes de entrar de lleno a las expresiones de Hostos contra la pena de muerte, es imprescindible que analicemos las circunstancias en que se fraguó el pensamiento del Ciudadano de América.

\section{LA PENA DE MUERTE EN LA ESPAÑA DEL HOSTOS ESTUDIANTE}

El debate sobre la aplicación de la pena de muerte en la España de aquella época era uno muy animado. Durante ese periodo estaba vigente en España el Código Penal de 1850 , una edición reformada del código de $1848^{6}$, que dictaba la pena de muerte mediante garrote para un extensísimo catálogo de 24 crímenes por los cuales podía recaer bajo diversas circunstancias ${ }^{7}$.

5 Delgado Cintrón, C. El constitucionalismo de Eugenio María de Hostos. Alicante, Biblioteca Virtual Miguel de Cervantes, 2010, disponible en http://www.cervantesvirtual.com/obra/ el-constitucionalismo-de-eugenio-maria-de-hostos/.

6 Ruiz Funez, M. «Progresión histórica de la pena de muerte en España». En Clásicos españoles sobre la pena de muerte. Cristina Rodríguez Yagüe (ed.), Universidad de Castilla-La Mancha, 2009, pp. 79-82.

7 Esta era la única pena que se disponía para los siguientes delitos de naturaleza política: tentativa para destruir la independencia o integridad del Estado (art. 130), inducir a una potencia extranjera a declarar la guerra a España, si en efecto la guerra llega a declararse (art. 140), matar a un soberano extranjero, residente en España (art. 154), tentativa contra la vida o persona del Rey o inmediato sucesor a la corona (art. 160), rebelión, cometido por autoridades civiles o eclesiásticas, habiendo mediado estragos o combate (art. 168) y parricidio con las circunstancias de premeditación o ensañamiento (art. 323). También se imponía en la ausencia de circunstancias atenuantes para los delitos de ser capitán o patrón de piratas (art. 157), piratería, con las circunstancias de haber hecho fuego, haber apresado al abordaje alguna embarcación, o concurrir homicidio, lesiones graves, atentados contra la honestidad o abandono de personas sin dejarle medios para salvarse (art. 157), entregar a piratas la embarcación a cuyo bordo se fuere, con las mismas circunstancias del delito anterior (art. 158), parricidio, sin premeditación ni ensañamiento, pero también sin circunstancia atenuante (art. 323), homicidio ejecutado con alevosía, por precio o promesa, por medio de inundación, incendio o veneno, con premeditación conocida o con ensañamiento (art. 324), robo con violencia o intimidación en las personas, cuando con motivo u ocasión de él, resulta en homicidio o interviene violación o mutilación causada a propósito (art. 415), robo en cuadrilla y en despoblado, si con motivo u ocasión del mismo delito, resultaren lesiones graves, o fuere detenido bajo rescate, o por más de un día (art. 415), ser jefe de ladrones de cuadrilla armada, total o parcialmente (art. 415), tentativa de robo, con las circunstancias expresadas en los tres casos anteriores (art. 419), incendio en edificio, buque o lugar habitado (art. 456) e incendio en arsenal, astillero, almacén de pólvora, parque de artillería o archivo general del Estado (art. 456). La pena capital también podía ser impuesta para los siguientes delitos, cuando existieran circunstancias agravantes que no fueran compensadas por alguna atenuante: tomar las armas contra la patria bajo banderas enemigas (art. 141), facilitar al enemigo la entrada en el reino, el progreso de sus armas o la toma de una plaza o su tentativa (art. 142), suministrar a las tropas de una potencia enemiga caudales, armas o planos de fortalezas (art. 142), impedir que las tropas nacionales reciban en tiempo de guerra caudales, armas, datos o noticias conducentes a la defensa del país (art. 412), revelar al 
Las ejecuciones eran públicas. El artículo 90 del Código Penal disponía que "el sentenciado á la pena de muerte será conducido al patíbulo con ropa negra, en caballería o carro. El pregonero publicará en alta voz la sentencia en los parajes del tránsito que el Juez señale”. Tras la ejecución, el artículo 92 establecía que: "el cadáver del ejecutado quedará expuesto en el patíbulo hasta una hora antes de atardecer, en la que será sepultado, entregándolo á sus parientes o amigos para ese efecto, si lo solicitaren. El entierro no podrá realizarse con pompa".

En el caso de Puerto Rico, la aplicación de la pena de muerte arreció durante el último siglo del dominio español. Jalil Sued Badillo, en la obra La pena de muerte en Puerto Rico, indica que un $65 \%$ de las sentencias de muerte bajo el régimen español se realizaron en ese periodo; entre los esclavos solamente hubo 105 sentencias y 79 ejecuciones $^{8}$. La pena capital era impuesta por los siguientes crímenes: asesinato, asalto de caminos, bandolerismo, conspiración, parricidio, piratería, insubordinación, deserción, motín, robo y homicidio y agresión agravada. Los métodos utilizados en las ejecuciones variaron dependiendo del crimen cometido y del momento histórico. Por ejemplo, se utilizó el fusilamiento en los casos de conspiración, bandolerismo y piratería, o la horca para las conspiraciones de esclavos 9 . En América Latina siguió utilizándose la pena capital luego de las independencias a principios del siglo $19^{10}$. Sin embargo, desde mediados de ese periodo, algunos países de la región fueron los primeros en eliminarla, como Venezuela en 1864 y Costa Rica en 1877. Eugenio María de Hostos fue estudiante de derecho de 1857 a 1869 . Valga destacar que no existía un rechazo absoluto a la pena capital entre la mayoría de quienes estudiaban el derecho penal en aquella época. Mientras reconocían que la oposición a la pena de muerte avanzaba en otros países europeos, concentraban sus críticas en la publicidad de las ejecuciones, el proceso infamante previo a la ejecución o su aplicación en los delitos de naturaleza política.

Como ejemplo, analicemos los textos de Derecho penal que eran utilizados en la época en que Hostos fue estudiante de derecho en la Universidad Central de

enemigo documentos reservados, de que se tenga noticia por razón de oficio o por algún medio reprobado (art. 144), piratería cometida contra españoles o súbditos de otra nación que no se halle en guerra con España (art. 156) o entregar a piratas la embarcación a cuyo bordo fuere el reo (art. 158). José de Castro y Orozco y D. Manuel Ortiz de Zúñiga. El Código penal explicado. Granada, t. I, Imprenta y Librería de Don Manuel Sanz, 1848, pp. 143-146.

8 Sued-Badillo, J. La pena de muerte en Puerto Rico: retrospectiva histórica para una reflexión contemporánea. San Juan, Publicaciones Gaviota, 2011, pp. 47-49.

$9 \quad$ Ibid, pp. 83-91.

10 Corral, J.L. Historia de la pena de muerte. Madrid, Santillana, 2005, p. 111. 
Madrid. ${ }^{11}$ En Elementos del Derecho civil y penal de España, los doctores Pedro Gómez de La Serna, quien fue uno de los juristas españoles más destacados del siglo 19, y Juan Manuel Montalbán, catedrático de la Universidad Central de Madrid, esbozan una resignada defensa al mantenimiento de la pena capital, cuando argumentaban que:

"Escritores muy célebres han querido proscribir la pena de muerte, y hasta han disputado á la sociedad el derecho a imponerla: adoptaríamos esta opinión si pudiéramos abandonarnos al impulso de nuestros corazones, pero una convicción profunda nos hace creer indispensable en el estado actual de la civilización de los pueblos. Detenernos en esta materia sería salir de nuestro propósito"12.

Los autores limitaban su respaldo a la imposición de la pena capital, al expresar que "si bien estamos convencidos de la necesidad de la pena de muerte, no podemos menos que recomendar que se limite á cierta clase de delitos horrorosos, y de lamentar que con tanta profusión se aplique á otros muchos y especialmente a los políticos"13. Argumentan entonces nuevamente su apoyo al indicar que:

"Además de la humanidad y de los sanos principios del derecho penal, nos mueve á esto la cualidad más ventajosa de la pena de muerte, que es el ser la más ejemplar de todas, esto es, la que produce mayor impresión, porque tanto mas viva es esta cuanto menos frecuente la repetición de su espectáculo.

A la ejemplaridad reúne la pena de muerte las ventajosas circunstancias de destruir el poder de dañar, y la de ser en muchas ocasiones análoga al delito que castiga: mas por otra parte es irreparable y desigual"14.

En cambio, en el libro El Código penal explicado, José de Castro y Orozco y Manuel Ortiz de Zúñiga, evitan adentrarse al debate de la pena capital y despachan este asunto con una escueta pregunta “ ¿A qué hablar de la moralidad ó inmoralidad,

11 Delgado Cintrón, C. «Los escritos jurídicos de Hostos: la etapa española, 1857-1869». En Julio César López, Hostos: sentido y proyección de su obra en América: ponencias presentadas en el Primer Encuentro Internacional sobre el Pensamiento de Eugenio María de Hostos, celebrado en Puerto Rico del 2 al 7 de abril de 1989. San Juan, Editorial de la Universidad de Puerto Rico, 1995, p. 217.

12 Gómez de La Serna, P. y Manuel Montalbán, J. Elementos del Derecho civil y penal de España. T. III, Madrid, Imprenta de D. Vicente de Lalama, 1842, p. 30.

13 Ibid, p. 31.

14 Ibid. 
de la conveniencia ó de la inconveniencia de la pena de muerte, cuestión agotada y discutida hasta la saciedad por casi todos los modernos criminalistas? ${ }^{15 "}$.

En la obra Código penal reformado, comentado novisimamente, José Vicente y Caravantes defiende la pena capital en la forma más salvaje, cuando menciona las ejecuciones mediante ahogamiento en un pantano cerrado por arriba con cañas, que "demuestran los germanos que los grandes crímenes deben expiarse públicamente, y las vergonzosas debilidades y degradaciones deben quedar sepultadas en el misterio" ${ }^{16}$. Este autor realiza una ferviente defensa de la pena capital. Como muestra, leamos la reacción a la crítica a la pena de muerte como ilegítima:

“¿Cómo conciliar esta teoría absoluta con el asentimiento unánime de los pueblos que, en todos los siglos y en todas las épocas, ya de civilización, ya de barbarie, no han vacilado en admitir la pena de muerte, si se han alarmado con su aparato y su ejecución? Este hecho indestructible ha resistido á todas las tempestades políticas, á todas las transformaciones sociales. Ha seguido a los pueblos en sus emigraciones; lo han reconocido todos los cultos sin combatirlo, y no lo han destruido los progresos de la inteligencia, ni el desarrollo moral de la humanidad. La pena de muerte no se ha abolido nunca en el seno de un pueblo, de un modo completo y permanente. ¿Cómo, pues, se acusa á la sociedad en presencia de la historia, de asesinatos jurídicos? ¿Cómo se tacha esta pena de ilegítima, cuando no se oye ni el grito de la conciencia, ni la conmoción de la reprobación pública?"17

Podemos también evidenciar el respaldo a la pena de muerte en otras publicaciones de esa época. Por ejemplo, Joaquín Francisco Pacheco, quien fue uno de los redactores principales del Código penal de $1848^{18}$ y ocupó, entre otras posiciones, la Cátedra de Derecho Penal del Ateneo de Madrid, sintetizó el respaldo de la siguiente forma:

"Si la pena de muerte es necesaria para la expiación de algún crimen cometido, si la pena de muerte es necesaria para el mantenimiento del orden social y la seguridad de un número considerable de ciudadanos, la pena de muerte es completamente legítima con cuanta legitimación puede apetecerse en las obras humanas. Ella en si no es inmoral; y por más que sea terrible, y por más que conmuevan sus efectos, al fin está reducida á adelantar el

15 José de Castro y Orozco y D. Manuel Ortiz de Zúñiga. El Código penal explicado, p. 141.

16 Vicente y Caravantes, J. Código penal reformado, comentado novísimamente. Madrid, Imprenta de Don Alejandro Gómez Fuentenebro, 1851, p. x

17 Ibid, p. 143.

18 Antón Oneca, J. «El Código penal de 1848 y D. Joaquín Francisco Pacheco». En Anuario de derecho penal y ciencias penales, Tomo 18, Fasc/Mes 3, 1965. 
plazo de la naturaleza, y á enviar desde luego ante el tribunal de Dios á los que, condenados por el tribunal de los hombres, parecen incompatibles con la sociedad á la que pertenecen. Si los supuestos de la hipótesis, vuelvo á decir, son exactos, la pena podrá ser dura, y de cierto como dura se escoge y se administra, pero ilegítima también de cierto no lo es"19.

Incluso Concepción Arenal, distinguida feminista y exponente de la reforma penitenciaria en España en el siglo 19, aprobó el uso de la pena capital, aunque criticaba los mecanismos utilizados y proponía la electricidad como alternativa al garrote. Exponía en su obra El reo, el pueblo, y el verdugo o La ejecución pública de la pena de muerte, que:

"No entraremos en la cuestión de derecho, en si la pena de muerte debe abolirse o no; la consideramos como un hecho porque existe en casi todos los pueblos, y de este hecho vamos a partir para investigar si podrían evitarse algunos de los males que consigo lleva. Nuestras ideas parece que deberían ser aceptables, lo mismo a los que la defienden que a los que la combaten"20.

Hemos evidenciado que Hostos recibió su formación como jurista en una comunidad que no rechazaba del todo las ejecuciones realizadas por el Estado. Una muestra de los debates en pro y contra de la pena de muerte que presenció Hostos, fue narrada por Delgado Cintrón:

"En un artículo de prensa suscrito por Francisco de Paula Canalejas se celebra un Congreso de Jurisconsultos los días 27 al 31 de octubre de 1863. Hostos debió sentirse estimulado por el mismo. Canalejas al dirigirse al célebre penalista Pacheco, oponiéndose a la pena de muerte, toma una postura acorde con las corrientes penalistas del Krausismo y especialmente de Roeder. Dice Canalejas:

Pero sí diré, que en mi sentir, sociedad que pide el cadalso y la argolla, como medios de corrección, que acusa a los juzgadores porque no multiplican sangrientos espectáculos, es una sociedad corrompida y viciosa, que no cree en la eficacia de los medios morales y que pide justicia, porque tiene miedo" 21 .

19 Francisco Pacheco, J. Obras jurídicas. T. II, Madrid, Imprenta de M. Tello, 1868, p. 257.

20 Concepción Arenal. El reo, el pueblo, y el verdugo o La ejecución pública de la pena de muerte. 15 de junio de 1867, disponible en http://www.cervantesvirtual.com/obra-visor-din/ el-reo-el-pueblo-y-el-verdugo-o-la-ejecucion-publica-de-la-pena-de-muerte- $0 / \mathrm{html} / \mathrm{fefa} 0640$ 82b1-11df-acc7-002185ce6064_3.html\#I_0

21 Delgado Cintrón, C. «Los escritos jurídicos de Hostos: la etapa española, 1857-1869», cit. p. 203, citas omitidas. 


\section{LAS FUENTES DEL PENSAMIENTO DE HOSTOS}

Examinemos brevemente las corrientes que nutrieron el pensamiento de Hostos y cómo estas influencias afectaron su postura sobre la pena capital. Exponía el insigne hostosiano José Ferrer Canales que los estudiosos del prócer han "encontrado diversas raíces en el pensamiento de Hostos: positivismo, krausismo español de Sanz del Río y Giner, tradición del derecho natural, estoicismo"22. Analicemos primero el krausismo español, descrito por Luis Arroyo Zapatero como:

"Un movimiento liberal filosófico y social español por excelencia, organizado por Julián Sanz del Río a partir del pensamiento jurídico y político de Karl Krause, que fue una excelente solución para superar la dogmática rigidez de Kant y Hegel. Con él se buscaba también satisfacer la necesidad de renovación filosófica y política en la ingenua creencia de poder evitar el enfrentamiento directo con una iglesia católica acostumbrada a dominar por completo la vida espiritual de España, incluida, naturalmente, la vida universitaria y científica"23.

Como indica Carmelo Delgado Cintrón, "puede observarse que mucho de la obra del pensamiento hostosiano se inscribe en estas claves esenciales del krausismo"24.

Según el jurista alemán Peter Landau, estudioso de la obra de Krause:

"El principio utópico-humanitario de la filosofía krausiana del derecho aparece muy clara en su tratamiento del derecho penal. Krause hace una crítica fundamental a toda teoría de vindicación o ajuste de cuentas como base de la pena. La pena en el sentido de un mal que debe aplicarse por haber sido cometido otro mal, es para Krause algo antijurídico, incluso criminal. Las únicas consecuencias legítimas de un delito son la educación del delincuente y la tutela sobre el mismo. En el fondo, el concepto de 'prevención especial' tampoco coincide con la intención de la teoría jurídica de Krause en la cuestión de la pena, pues para este lo primordial al castigar no es la evitación de futuros actos punibles del delincuente, sino lograr un beneficio jurídico para el sujeto del castigo"25.

22 Ferrer Canales, J. Perfil de Hostos, AIH, Actas AIH, 1989, pp. 587-588, disponible en http://cvc. cervantes.es/literatura/aih/pdf/10/aih_10_3_064.pdf.

23 Arroyo Zapatero, L. «Los juristas de la Junta para Ampliación de Estudios». En Traspasar fronteras: un siglo de intercambio científico entre España y Alemania. Madrid, Sandra Rebok (ed.), CSIS, 2010, pp. 269-271.

24 Delgado Cintrón, C. «Los escritos jurídicos de Hostos: la etapa española, 1857-1869», cit., p. 192.

25 Landau, P. La filosofia del Derecho de Karl Christian Friedrich Krause, p. 71, citas omitidas. Citado en Delgado Cintrón, C. «Los escritos jurídicos de Hostos: la etapa española, 1857-1869», cit., p. 193. 
La postura del krausismo en oposición a la pena capital era clara, lo que tuvo influencia directa en el pensamiento de Hostos. En su ensayo El krausismo español, Antonio Heredia Soriano, catedrático de filosofía de la Universidad de Salamanca, expone que:

"Convencido de que el derecho no se reduce a la burda aplicación de la ley del Talión, el krausismo abogó también sin descanso por la abolición de la pena de muerte. Y no sólo en teoría. También adoptaron - unos más y otros menos - una actitud práctica, comprometida, hasta el punto de verse envueltos en más de una ocasión en duras y amargas pruebas: suspensiones de empleo y sueldo, cárcel, destierros... y muchas otras formas de persecuciones" ${ }^{26}$.

Valga mencionar que las influencias del pensamiento abolicionista de Krause trascendieron a España. En Latinoamérica se extendió a figuras como José Batlle y Ordoñez en Uruguay, en cuyas constituciones de 1934, 1942 y 1952 prohibieron pena de muerte ${ }^{27}$, o a José Gálvez Egúsquiza en Perú ${ }^{28}$.

La otra corriente de pensamiento que influye decisivamente a Hostos fue el positivismo. Tomamos la definición del positivismo de Roberto Gutiérrez Laboy en su importante obra Pensar y entender a Hostos, que "los postulados principales del positivismo son que la ciencia es el único conocimiento válido; que la filosofía tiene que usar el mismo método de las ciencias; y que el objetivo de la filosofía debe ser buscar principios a todas las ciencias, usarlos como directrices de la conducta humana y como base de la organización social" ${ }^{29}$. Expuso el profesor Salvador Giner, en una conferencia ofrecida en el Ateneo Puertorriqueño el 2 de mayo de 1963, que:

"Al positivismo, empero, corresponde la mayor parte de la responsabilidad de la formación ideológica de Eugenio María de Hostos. Bastaría con averiguar el hecho de que para él la sociología es la cumbre de la ciencia y que acepta el esquema de la misma, característico de Comte, para reconocerlo así, por lo menos en lo que a la sociología se refiere. Pero su positivismo no será nunca catecismo social, pues esa parte

26 Heredia Soriano, A. "El krausismo español". Cuatro ensayos de historia de España. Madrid, Edicusa, 1975, pp. 75-150. Edición digital autorizada para Proyecto Ensayo Hispánico y preparada por José Luis Gómez-Martínez. Enero 2005, disponible en http:/www.ensayistas.org/critica/generales/krausismo/introd.htm.

27 Dussel, E.; Mendieta E. y Bohórquez, C. El pensamiento filosófico latinoamericano, del Caribe y "latino" (1300-2000): historia, corrientes, temas y filósofos. México, Siglo XXI, 2009, p. 771.

28 Armaza Galdós, J. y Armaza, E.J. Digesto de Derecho Penal Peruano Tomo II: Criminalistas del Siglo XIX. Arequipa, Pangea, 2013, Segunda ed., p. 77.

29 Gutiérrez Laboy, R. Pensar y entender a Hostos. San Juan, SITUM Juan, 2009, p. 109. 
queda en manos de su manera de ser krausista. Hostos es a lo sumo neocomteano"30.

La postura del positivismo, contrario al krausismo, justificaba mayoritariamente la pena capital. Algunos de sus exponentes más reconocidos, específicamente de la escuela positivista italiana, como César Lombroso (1835-1909) y Rafael Garófalo (1851-1934) justificaron el uso de la pena última, mientras que otros, como Enrique Ferri (1859-1929), la repudiaron ${ }^{31}$. Por ejemplo, el médico Lombroso, considerado comúnmente como el padre de la criminología, afirmaba que:

"Esta pena suscita, es verdad, exagerada repulsión; ¡sin embargo, se la aplica en las guerras en proporciones mayores, haciéndola recaer sobre hombres que valen más! Ahora bien, si suprimida la base del derecho divino, no le queda a la justicia humana otra razón que la defensa social, y si esta defensa social no se puede solamente con el secuestro del individuo nocivo, entonces es lícito recurrir a aquella eliminación de los seres más dañosos, que fue el origen del perfeccionamiento, según las leyes de la selección de la lucha por la vida, formuladas por Darwin"32.

\section{HOSTOS CONTRA LA PENA CAPITAL}

Examinar el pensamiento de Hostos supone adentrarnos al estudio de una obra monumental y pluridisciplinaria. Juan Antonio Corretjer lo describió como un océano del pensamiento ${ }^{33}$. Nos enfrentamos ante un agudo intelectual que analizó y dominó múltiples saberes de vital importancia en este tema, como el derecho, la filosofía o la sociología. De igual forma, es posible encontrar claves importantes de su pensamiento en su obra periodística o sus diarios, incluso en la crítica literaria. José Luis Méndez señaló que la visión hostosiana de la facultad del Estado para imponer las penas respondía a:

30 Giner, S. «El pensamiento sociológico de Eugenio María de Hostos». En Manuel MaldonadoDenis, Visiones sobre Hostos. Caracas, Biblioteca Ayacucho, 1988, p. 395.

31 Ferri, E. Criminal Sociology. Boston, Little, Brown \& Company, 1917, p. 528, disponible en https://ia700409.us.archive.org/4/items/cu31924032584629/cu31924032584629.pdf y Wolfgang, M.E. «Pioneers in Criminology: Cesare Lombroso (1825-1909)». En Journal of Criminal Law and Criminology, Vol. 52, No. 4, Winter 1961, p. 386, disponible en http://scholarlycommons.law. northwestern.edu/cgi/viewcontent.cgi? article $=5047 \&$ context $=$ jclc

32 Lombroso, C.; Peset, J.L. y Peset Reig, M. Lombroso y la escuela positivista italiana. Madrid, CSIS, 1975, p. 373.

33 Corretjer, J.A. Hostos y Albizu Campos, p. 3. 
"La desconfianza de Hostos en las instituciones estatales se hace aún mayor cuando se trata de facultar al Estado para castigar al ciudadano. Por eso, el derecho penal de Hostos no es sólo un esfuerzo analítico para estudiar la penología de una manera más moderna, humanista y pluridisciplinaria, sino también un intento para llevar a cabo un sistema de controles para impedir el abuso del Estado y de las personas que se escudan en éste, contra el ciudadano común y en última instancia contra la sociedad" ${ }^{\prime 34}$.

Resulta muy significativo que desde los primeros escritos de naturaleza jurídica de Hostos presenta el tema del poder del Estado para castigar. El 25 de enero de 1867, recién cumplidos los veintiocho años, publicó en la revista Las Antillas de Barcelona un interesantísimo artículo titulado La estadística criminal en Puerto Rico ${ }^{35}$. A pesar de no contener ninguna mención directa al asunto de la pena de muerte, sus argumentos proponen una perspectiva del castigo contraria a la visión punitiva como objetivo de la pena. Hostos expuso su posición sobre la evolución de las penas antes de analizar la situación de la criminalidad en la Isla en 1866 y las características de las personas encarceladas:

"El desenvolvimiento progresivo del espíritu racional, la dilación en espacios, cada vez mas vastos, de la conciencia universal, la moderación creciente de las costumbres por una mejor educación y por más elementos de cultura, las transformaciones sociales y políticas... han determinado en el derecho del castigo y en sus aplicaciones el progreso que observamos, que diferencia esencialmente á la moderna de las antiguas sociedades, y que, dejando de considerar al delincuente como bruto irracional, lo considera hombre perfectible aun después del extravío y el delito"36.

La primera expresión que hemos podido constatar de Hostos donde abordó directamente su repudio a la pena capital la realizó en una carta publicada en el periódico bilbaíno Irurac Bac el 24 de octubre de 1868, a raíz del aumento en la represión política que fue desatada en Puerto Rico como secuela del Grito de Lares. Luego de exponer una enérgica protesta a las medidas que impuso el gobierno metropolitano en la Isla, entre las once peticiones que presenta incluyó " $22^{\circ}$ que, empleando también

34 Méndez, J.L. Hostos y las ciencias sociales, p. 171.

35 De Hostos, E.M. «La estadística criminal de Puerto Rico». En Las Antillas. Barcelona, Núm. 4, 25 de enero de 1867, pp. 97-103, disponible en http://bibliotecadigital.aecid.es/bibliodig/i18n/ consulta/registro.cmd?id=2098. Un fragmento de este escrito se encuentra en De Hostos, E.M. Hombres e ideas. Obras Completas. Vol. XIV. La Habana, Cultural, 1939, pp. 187-197.

$36 \quad$ Ibid, p. 98. 
el telégrafo, ordene la suspensión de los juicios militares, e impida así el derramamiento de sangre" ${ }^{\prime 3}$. Ese derramamiento de sangre no era el otro sino el producido por las ejecuciones impuestas luego de la gesta independentista de septiembre de 1868. De hecho, el gobierno español condenó a muerte a nueve de sus dirigentes, pero recibieron amnistía de sus ejecuciones ${ }^{38}$.

Un rasgo que debe destacarse del repudio de Hostos a la pena de muerte es que no limitaba a la aplicación en Puerto Rico. En el artículo El Luxemburgo y la guerra, resaltó la abolición de la pena de muerte en el ducado de Luxemburgo como parte de los logros de la Asamblea Constituyente de $1848^{39}$. La próxima expresión la produjo en el contexto de una propuesta que fue presentada ante el Congreso del Perú para la abolición constitucional de la pena de muerte. Ante esta iniciativa, el 4 de septiembre de 1872, escribió un artículo desde Valparaíso de Chile para el periódico peruano La Patria, del cual fue fundador. En dicha columna expuso su firme repudio a la pena capital:

"Toda violación, ilegítima o legal, de un derecho, es un acto contra la civilización. El ser humano se civiliza, porque adquiere el conocimiento de sus derechos y de sus deberes, y porque adquiere el convencimiento, ya por experiencia, ya por razonamiento, de que fuera del derecho respetado y del deber cumplido, no hay posibilidad de vida civil. Todo derecho es ilusorio, cuando la sociedad se atribuye el de matar a un hombre; cuando caduca para éste el de vivir. Bajo el punto de vista de los fines individuales y sociales, no hay otra civilización que esa civilización, bajo el punto de vista de los medios es el conjunto de facultades que el individuo y la sociedad aplican armónicamente a la realización de sus fines, y la armonía creciente que entre individuo y sociedad se produce del desarrollo de sus facultades. Va a la civilización, se civiliza, el pueblo que, declarando inviolables y no violando jamás los derechos del individuo y de la sociedad, reprime los males de uno y otro, facilitándose medios de corrección contra ese mal." ${ }^{\text {40 }}$

Las próximas expresiones relevantes de Hostos surgieron a raíz de los fusilamientos de varios oficiales del ejército independentista cubano, quienes estaban a bordo del vapor Virginius luego de que fuera capturado por la Marina Española,

37 De Hostos, E.M. Diario, Vol. I, Obras Completas. Vol. I. San Juan, Editorial Coquí, 1969, pp. 89-97.

38 Sued-Badillo, J. La pena de muerte en Puerto Rico, p. 58.

39 De Hostos, E.M. Hombres e ideas. Obras Completas. Vol. XIV. La Habana, Cultural, 1939, pp. 198-199. No se menciona fecha ni lugar de la publicación original.

40 De Hostos, E.M. «La pena de muerte y el Perú». En La Patria. 4 de septiembre de 1872, disponible en http://www.hostos.cuny.edu/library/Hostos\%20Page/Works_by/Works_by_LA_PATRIA_3.htm 
condenas que fueron ejecutadas el 7 y 8 de noviembre de 1873. Las declaraciones respecto a estas ejecuciones fueron incluidas en una carta que fue publicada en $E l$ Argentino el 9 de diciembre bajo el título de Los fusilamientos en Cuba. La enérgica exposición en esa ocasión giró más en torno a la campaña que desarrollaba Hostos a favor de la independencia cubana en varios países de América del Sur y cómo ese dramático suceso podía beneficiar la gesta libertaria antillana, que sobre el repudio a la pena de muerte. Por ello afirmaba que "ante la conciencia del mundo horrorizada, el fusilamiento de nuestros hermanos es un bien para Cuba y Puerto Rico; el horror de la conciencia humana se convertirá pronto en auxilio decisivo para entrambas islas"41.

La controversia en Buenos Aires sobre estas ejecuciones apenas comenzaba. Narró Antonio S. Pedreira en Hostos, ciudadano de América que:

"El Correo Español, periódico rabiosamente contrario a las ideas de Hostos, empezó con reticencias brutales, para acabar con ataques injuriosos, una campaña de difamación en que trataba de traidores a los cubanos fusilados en esos meses y celebraba las atrocidades cometidas en Cuba, tergiversando los hechos. Con valentía devolvió Hostos aquel ultraje en un artículo, y por respuesta le dedicaron otro llamándole "cobarde, que debían abofetear hasta hacerle salir la lengua". No pudo ya reprimir su dominada cólera y pensó en vengar con un duelo los insultos infames"

Afortunadamente, Hostos desistió de tal idea luego de ser disuadido por los padrinos que había seleccionado para batirse en duelo.

Hostos nos legó las expresiones más elaboradas y doctas cuando fue Catedrático de Derecho Constitucional, Derecho Internacional y Derecho Penal del Instituto Profesional de Santo Domingo, nombre de la universidad dominicana de aquel entonces, entre 1880 y 1888. Los planteamientos contra la pena capital tienen dos vertientes principales: la primera está enmarcada en el concepto del derecho natural, aplicado al derecho individual de la vida, idéntico en su contenido a la defensa del derecho a la vida como un derecho humano que defiende el movimiento abolicionista contemporáneo. La segunda vertiente es de carácter penológico, basada en los requisitos necesarios para la imposición de las penas.

Examinemos las expresiones relacionadas a la pena de muerte como una violación al derecho natural a la vida. Cónsono con las enérgicas condenas a las ejecuciones por motivos políticos, Hostos expuso en las Nociones de Derecho Penal las razones para oponerse a la imposición de la pena capital en los casos de delitos de naturaleza política. La argumentación consistió principalmente en la preeminencia

41 De Hostos, E.M. Cartas. Obras Completas. Vol. IV. San Juan, Editorial Coquí, 1969, p. 47.

42 Pedreira, A.S. Hostos, ciudadano de América, p. 66. 
del derecho natural a la vida. Prestemos atención a esta brillante reflexión, que está a la altura de los grandes opositores de la pena de muerte de la humanidad:

"Pero independientemente de las condiciones esenciales de la pena, la de muerte es particularmente monstruosa cuando se aplica a delitos cometidos por causas políticas. Entonces se plantea más francamente que en ningún otro caso de la misma pena el problema que jamás resolverá a su favor la escuela que sostiene la necesitad del último suplicio. Ese problema es éste: ¿Cuál de dos leyes es primera, la que el hombre da al contribuir a realizar las leyes primarias o naturales de su propio ser, o la ley natural de la vida? Al no dudarlo, antes que cualquier otra ley secundaria, está la ley de la naturaleza en cuya virtud son y por cuya virtud no se puede volver a ser lo que se ha dejado de ser. Si el que combate por el Derecho (que en resumidas cuentas es la querella política de todos los tiempos, y vimos que es la única política verdadera), y en defensa de su idea o en ofensa de la contraria hiere o mata, es indudable que no ha herido o matado por matar ni por herir, ni dando al acto una trascendencia criminal, sino al contrario, una trascendencia generosa, para no asociar la palabra virtuosa a un acto en que la virtud se encuentra con el crimen. No habiendo intención criminal ¿hay crimen? Esa es una de las incógnitas más oscuras de la ciencia penal. Pero habiéndolo o no habiéndolo, el hecho es que no se cometió por cometerlo; y por tanto, aun suponiendo que sea precepto verdadero el de que quien a hierro mata a hierro muere, la aplicación de la pena de muerte a quien no ha privado de la vida a otro sino por motivos lejanos a su propia voluntad, es una pena extraordinariamente excesiva porque entonces, más que nunca, aparece con toda su fuerza la ley natural de la existencia preguntando al legislador, al juez y a la sociedad si puede haber alguna ley humana que sea anterior y superior a la ley natural de vivir y al derecho natural de nuestra vida"43.

La argumentación del derecho a la vida y la pena de muerte fue elaborada también en sus Lecciones de Derecho Constitucional, obra que fue publicada originalmente en Santo Domingo en 1887, de la siguiente forma:

"Si las estadísticas criminales demostraran que los crímenes aumentan en razón directa del respeto que las leyes, orgánicas o constitucionales, manifiestan a la vida del hombre y que la abolición de la

43 De Hostos, E.M. Nociones de Derecho Penal. Lección X. Ensayos Didácticos, Tomo I. Obras Completas. Vol. XVIII. San Juan, Editorial Coquí, 1969, pp. 309-310. 
pena de muerte ha contribuido, en Bélgica, por ejemplo, al aumento de inmoralidad y criminalidad, podría entonces desecharse como un ensueño la inclusión de la inviolabilidad de la vida entre los derechos constitucionales del individuo. Mas cuando acontece, al contrario, que los Estados que más abusan de la pena de muerte son los que más favorecen, aunque inconscientemente, el malsano desarrollo de los crímenes capitales, lógica y derecho penal concurren a presentar como necesaria la consagración de la inviolabilidad de la vida como uno, y el primero, de los derechos absolutos.

Cuanto más absoluto es el derecho, menos derecho es el abuso de él, y más arma en su contra al poder de castigarlo. Matar no es castigar" ${ }^{\prime 4}$.

Finaliza esta brillante argumentación sobre la inviolabilidad del derecho a la vida con una contundente conclusión, tan apropiada para quienes entienden al día de hoy que el rechazo a la pena capital equivale a la aprobación de la conducta criminal: "De ese modo entendido, el derecho de inviolabilidad, lejos de ser un derecho de impunidad, es un reconocimiento del derecho y del poder que el Estado tiene de reprimir los abusos del derecho absoluto de la vida" ${ }^{45}$.

Este argumento a favor del derecho individual a la vida y la pena capital fue abordado nuevamente en sus Nociones de Derecho Constitucional, obra publicada en el 1903, año del fallecimiento del patriota. Esta es la última declaración de Hostos sobre el tema que he podido corroborar, una síntesis poderosa de su pensamiento. Expuso que "el derecho de vida no es completo mientras no se declara la inmunidad de la existencia, aboliendo la pena de muerte. De modo que la consagración del primer derecho individual nos lleva a la abolición de una pena que, además de monstruosa, carece de los requisitos verdaderos de la pena"46.

La segunda vertiente del pensamiento hostosiano sobre la última pena fue expuesta las Nociones de Derecho Penal de 1883. Hostos elaboró su exposición más extensa y minuciosa, esta vez, centrada en los requisitos de las penas. Esta obra inédita fue dictada a viva voz en forma de lecciones a sus discípulos de derecho penal del Instituto Profesional de Santo Domingo. ${ }^{47}$ Hostos también abordó en estas lecciones su visión de la función del sistema penitenciario, aspecto digno de examen a la luz de la situación actual, más por razones de tiempo, no podremos abordar en esta ocasión.

44 De Hostos, E.M. Lecciones de Derecho Constitucional. Lección XXIV. Obras Completas. Vol. XV. San Juan, Editorial Coquí, 1969, pp. 151.

$45 \quad$ Ibid, p. 152.

46 De Hostos, E.M. Nociones de Derecho Constitucional. Lección VIII. Ensayos Didácticos, Tomo I. Obras Completas. Vol. XVIII. San Juan, Editorial Coquí, 1969, p. 388.

47 Pedreira, A.S. Hostos, ciudadano de América, p. 95. 
Antes de discutir la argumentación de carácter penológico relacionada con la pena capital, analicemos brevemente las características y condiciones que, según Hostos, deben poseer las penas, debido a que en esta discusión encontramos las claves de su pensamiento. Algunos fragmentos de su exposición señalan que:

La naturaleza de la pena es de ser social, benévola, correctiva, reparadora, educacional.

Es social, porque como vimos, toca a la sociedad, así en el derecho como en el propósito; de tal modo, que no hay posibilidad de aplicar pena ninguna que, aunque aparentemente solo afecte al individuo sobre quien directamente recae, no afecte también a la sociedad general en cuyo nombre se impone.

...

La pena es benévola, es decir, la pena no es una venganza (vindicta de antiguos y hasta de modernos penalistas), sino un propósito de reforma en el espíritu del que atenta contra el orden social, puesto que lo que a la sociedad importa no es humillar sino rehabilitar, no es privarse sino apoderarse del que por ignorancia, por falsa dirección, por culpa propia o acaso por culpa de la misma sociedad, atenta contra ella, en vez de ser un auxiliar de ella.

La pena es correctiva. Es decir la pena ha de corregir, y el propósito de la pena es que sirva para corregir. Con efecto: es de la naturaleza misma de todo castigo o dolor impuesto por la naturaleza o por los hombres, que ese dolor y castigo sean un correctivo, un escarmiento, no simplemente con el objeto de obligar a abstenerse de la repetición del daño o mal causado al infringir un precepto de la naturaleza o una ley positiva, sino también con el de inducir a realizar el bien contrario al mal antes realizado.

Si la pena, siendo simplemente una venganza de la sociedad, o más bien, del Estado, cayera arbitrariamente sobre el culpable, sin más trascender ni al bien del culpable ni al de las sociedades, ésta no obtendría de la pena otro resultado que el de la eliminación temporal o definitiva del miembro más o menos dañado por esta o es otra causa. En tal caso la pena consumaría un bien o un mal sin trascendencia; bien para la sociedad vengada; mal para la víctima de esa venganza. Pero cuando la sociedad se propone recomponer o reconstruir el miembro enfermo que altera el orden social, la pena es eminentemente trascendente al fin que con ella se ha propuesto el ser social. 
La pena es reparadora. Con esto decimos que uno de los caracteres esenciales o una de las propiedades naturales de la pena es el reparar el mal causado por la infracción penada. Con efecto: el objeto esencial que se propone la pena es el de obtener una reposición de las cosas en el estado en que estaban antes de la infracción. Y aun cuando parezca inaccesible este objeto de la pena, puesto que un mal hecho es un mal irreparable, bastará ligar los dos caracteres anteriores al que ahora examinamos para comprender cómo es posible sin restituir materialmente una cosa maleada o alterada a su estado primitivo, contribuir al orden que se alteró, aumentando en uno a quien se enseña a conocer el orden que antes ignoraba, la cantidad de los que saben cuán esencial es para el bien de la sociedad y asociados, el conocimiento del orden y los medios de hacerlo cada vez más efectivo.

La pena es educadora. Educa o debe educar al individuo que delinque y a la sociedad que lo castiga. Educa al individuo, porque le hace entrar en sí mismo, verse, palparse y conocerse. Educa a la sociedad, porque todos los componentes de ella que presencian el castigo aprenden experimentalmente a reconocer como cosa sagrada el orden preestablecido por la ley y a depurar su propio criterio y a veces su propia conciencia, en el examen de las causas y de los efectos de toda delincuencia ${ }^{48}$.

De igual forma, establecía una serie de condiciones que son esenciales para la imposición de la pena. Estas son justicia, proporcionalidad, reparabilidad, ejemplaridad e inexorabilidad. Las partes que consideramos más relevantes en esta obra para definir tales condiciones son:

Justicia. Con decir que una pena injusta es la más odiosa de las arbitrariedades y puede ser el más espantoso crimen de Estado, definiríamos por contraste lo que ha de ser la justicia de la pena.

Para que la pena sea justa, es necesario que contenga dos elementos constitutivos de la justicia social, que son la legitimidad y la equidad... Para que sea legitima, es necesario que haya sido preestablecida por una ley... Para que sea equitativa, es necesario que la ley, por su parte, y los procedimientos criminales por la suya, rodeen de tales condiciones la pena, que no haya posibilidad de culparla de olvido de alguna de

\footnotetext{
48 De Hostos, E.M. Nociones de Derecho Penal. Lección III, pp. 272-275.
} 
las circunstancias naturales u ocasionales que el legislador debe haber previsto para hacer, en cuanto a él dependa, que la pena iguale al delito.

...

Proporcionalidad. La pena ha de ser proporcional a la culpa: en primer lugar, porque sólo así puede ser efectivamente equitativa; en segundo lugar, porque sólo así puede ser graduada y corresponder a las varias gradaciones del delito.

Si la pena no fuera proporcional, siempre sería monstruosa: cuando fuera excesiva, por exceso; cuando fuera defectiva, por defecto.

...

Reparabilidad. La pena es reparable cuando el penado puede ser rescatado de ella, devuelto al goce de su derecho y su inocencia, indemnizado y rehabilitado. Por lo tanto, esta condición de la reparabilidad de la pena es a propiedad de ser paralizada en sus efectos por el mismo que la impuso.

Como hemos de ver pronto, nada importa tanto a la ley penal y al penalista como asegurar la siempre presunta inocencia de los reos; nada importa tanto a la sociedad y a la ciencia penal como el impedir que la inocencia sea víctima del error o de la maldad. De aquí los esfuerzos hechos para conseguir que, aun en el caso de ser burlada, escarnecida y penada la inocencia, no sufra las consecuencias todas de la pena a que injustamente fué sujeta. Es, por lo tanto, la reparabilidad un reconocimiento de la fabilidad del hombre y de sus instituciones y una necesaria muestra de su disposición a remediar los males que, por falible, haya causado. Si imaginamos, y sin imaginarlo, recordamos que ha habido individuos que han sido condenados a muerte y ejecutados, y cuya inocencia ha brillado después de su muerte, conoceremos la trascendencia de la condición esencial que examinamos, y desde luego empezaremos a prepararnos a considerar como esencialmente inicua, por el mero hecho de ser irreparable, la pena de muerte.

Ejemplaridad. La pena es ejemplar cuando presenta el ejemplo de las consecuencias fatales a que la culpa arrastra al individuo. Si efectivamente es ejemplar, la pena es uno de los más efectivos auxiliares que tiene la moral pública y uno de los frenos más seguros con que retraer el vicio, del crimen y del mal a los ignorantes y los inconcientes.

Inexorabilidad. La pena debe ser inexorable; es decir, no debe dejar en paz al delincuente hasta que le haya devuelto de tal modo la 
conciencia de su delincuencia, que nunca más pueda volver a querer ponerse frente a frente de una culpa.... La pena es inexorable cuando el cumplimiento de la ley es tan estricto que el delincuente, al delinquir, sepa que no ha de sustraer el castigo de su culpa ${ }^{49}$.

Cuando Hostos propuso cuáles eran las penas adecuadas, no solamente descartó la pena capital, sino que abogó por la eliminación de otras, como la degradación civil (que implica la pérdida de los derechos domésticos, civiles y políticos mientras se cumple la pena), las penas infamantes (aquellas que están diseñadas para humillar al penado, como las condiciones que rodeaban la aplicación de la pena capital en aquella época y que detallamos anteriormente, como el uso de determinadas ropas, el transporte del reo por la ciudad o la misma publicidad de la ejecución) o las multas, por considerar que este castigo reduce "a un mero cálculo de las conveniencias o inconveniencias económicas que haya de incurrir o en abstenerse de incurrir" ${ }^{50}$.

$\mathrm{Al}$ descartar la pena de muerte dentro de las posibles alternativas, Hostos expone elocuentemente la condena a este cruel castigo que, por su importancia, es imprescindible citar íntegramente:

Pena de muerte. Omitir de un cuadro de clasificación de penas la de muerte, es tanto como condenarla. No hay que esforzarse mucho para que la condenación sea tan evidente que, lejos de buscar razones para insistir en objetarla, nos maraville que haya habido razones para sostener desacato tan manifiesto de la razón y de conciencia como es la última pena.

Remitiendo a otro momento la condenación doctrinal de este insensato castigo en que, por castigar a otro, la sociedad se castiga a si misma, bástenos ahora aplicar esta idea de la pena de muerte a la ya establecida de las condiciones de la pena y veamos si la pena de muerte reúne las condiciones que toda pena debe reunir para ser lo que en esencia es y lo que se propone.

La pena de muerte no cumple con la condición de inexorabilidad, puesto que la inexorabilidad consiste en que se haya agotado en el penado toda la fuerza de su objeto hasta conseguir la reforma y redención del delincuente.

La pena de muerte no cumple con la condición de ejemplaridad. Lejos de ser ejemplar el espectáculo del último suplicio es una de las más atroces distracciones de la barbarie ante siempre escondida en los repliegues de las multitudes humanas. De tal modo es experimental el

49 De Hostos, E.M. Nociones de Derecho Penal. Lección V, pp. 281-285.

50 De Hostos, E.M. Nociones de Derecho Penal. Lección VIII, pp. 293-295. 
hecho, que el pueblo inclinado por sus instituciones para ser humano, ha suprimido la publicidad de esos espectáculos. Y si se suprimió la publicidad, claro es que queda suprimido el ejemplo. Y si este es tan malo y corruptor cuando es público el espectáculo, claro es que lo malo no es la publicidad, sino el espectáculo mismo.

Por último, la pena de muerte no es reparable. ¿Puede alguien devolver la vida a un muerto? ¿Y si, siendo criminal, no lo era tanto que su crimen aparejara esa tremenda pena? ¿Y si podía corregirse? ¿Y si hubiera podido reformarse? ¿Y si era un demente? ¿Y si era un ignorante, que hasta a si mismo ignoraba? ${ }^{51}$

Luego de exponer un razonamiento tan brillante y vigente en nuestros días, coincido plenamente con el destacado criminólogo venezolano Elio Gómez Grillo, cuando afirmó que "este criterio punitivo sólo puede emanar de un Maestro, de un educador, de un reformador social y de un revolucionario. Únicamente quien posea una sensibilidad superior a la del simple juriscosaurio puede razonar de esta manera" 52 .

Los textos que hemos examinado no son citas esporádicas o fuera de contexto para justificar una posición respecto a este tema, sino una firme trayectoria de varias décadas, que refleja una profunda y meticulosa reflexión en contra de lo que él mismo denominó como una monstruosidad. El pensamiento de Hostos contra la pena capital es una de tantas muestras de su destreza intelectual, acompañada por una estatura moral y jurídica como pocas. Después de estudiar esta faceta de su pensamiento, resulta francamente contradictorio que alguien promulgue seguir el ideario hostosiano y a la vez justifique las ejecuciones realizadas por el Estado.

\section{HOSTOS EN EL MOVIMIENTO ABOLICIONISTA PUERTORRIQUEÑO DEL SIGLO XXI}

Sirva el recuento de este aspecto de la obra de Hostos para contrastarlo con las controversias y retos que ha enfrentado el movimiento abolicionista en Puerto Rico durante las últimas décadas. Es necesario un breve paréntesis para aclarar el uso del término abolicionista, debido a que en la época del patriota era utilizada para denominar el movimiento para la eliminación de la esclavitud, que Hostos también apoyó, a diferencia del abolicionismo actual, que se refiere a quienes favorecemos finalizar con la pena capital. En ese sentido y como hemos expuesto, Hostos fue abolicionista en ambos sentidos.

${ }^{51} \quad$ Ibid, pp. 296-297.

52 Gómez Grillo, E. «Las Nociones de Derecho Penal de don Eugenio María de Hostos». En Manuel Maldonado-Denis, Visiones sobre Hostos, p. 518. 
La oposición del pueblo puertorriqueño ante la monstruosidad de la pena última, primero en los tribunales locales, principalmente hasta su abolición estatutaria en 1929, y más recientemente, en el sistema federal, ha sido extensa y variada. Como ejemplo de los temas que deberían ser investigados y rescatados, está el pensamiento de Manuel Corchado y Juarbe, abolicionista isabelino contemporáneo con Hostos, quién presidió el Ateneo Puertorriqueño en su primera etapa, y dictó una famosa conferencia sobre este tema en el Ateneo Catalán de Barcelona en $1871^{53}$.

El abolicionismo en Puerto Rico se ha enfrentado en los últimos años ante la contumacia de la arrogante fiscalía del gobierno estadounidense de intentar imponernos la barbarie de las ejecuciones, faena cruel que ha fracasado hasta el momento, aunque no conviene bajar la guardia ante tales adversarios. Nadie debe albergar la menor duda de que si Hostos viviese en estos días, sería un tenaz y vocal opositor a los malsanos y anacrónicos esfuerzos del gobierno estadounidense para imponer en Puerto Rico el asesinato legal.

Sin falsos triunfalismos, afirmo que el movimiento abolicionista puertorriqueño ha sido un digno sucesor del pensamiento del patriota. Además de trabajar afanosamente para impedir una sentencia letal en los juicios celebrados en el Tribunal de Distrito Federal, el abolicionismo contemporáneo de Puerto Rico ha comprendido, asumido activamente que nos enfrentamos ante una lucha de carácter mundial. Hostos se opuso a la pena de muerte, fuese impuesta en España, Perú, Cuba o Puerto Rico. De esta misma forma, organizaciones como la Coalición Puertorriqueña contra la Pena de Muerte y el Colegio de Abogados y Abogadas de Puerto Rico se han integrado muy activamente a la campaña abolicionista internacional.

En los pasados años, representantes de estas organizaciones puertorriqueñas han realizado misiones en Bolivia, El Salvador y la República Dominicana, como muestra de la mejor tradición panamericanista hostosiana. En estas misiones han representado al movimiento abolicionista internacional que se agrupa en la Coalición Mundial contra la Pena de Muerte, con el objetivo de que estos países ratifiquen el Segundo Protocolo Facultativo del Pacto Internacional de Derechos Civiles y Políticos, que limita la aplicación de la pena de muerte. Otro ejemplo a destacar, y que bien podemos enmarcar en la visión antillanista de Hostos, ha sido la participación activa del abolicionismo puertorriqueño en la creación del Gran Caribe por la Vida. Esta es una organización no gubernamental constituida en Puerto España, Trinidad el 2 de octubre de 2013 que está formada por individuos y organizaciones opuestas a la pena de muerte de diecisiete países caribeños, lo que la sitúa en este momento como la organización de defensa de derechos humanos más extensa de nuestra

53 Corchado y Juarbe, M. «La pena de muerte». En Obras Completas, Tomo II, Barcelona, Instituto de Cultura Puertorriqueña, 1975, pp. 275-299. 
región. Hostos está presente y vigente en el obrar de quienes continúan levantando como bandera el supremo ideal de la Justicia por el que vivió. 
HACIA UNA TEORÍA DE LA CRUELDAD HUMANA 



\title{
LA CRUELDAD EN EL MUNDO CLÁSICO
}

\author{
CÉSAR CHAPARRO GÓMEZ \\ Catedrático de Filosofía Latina, Universidad de Extremadura, España.
}

\section{CONSIDERACIONES PRELIMINARES}

En primer lugar, doy las gracias al Dr. Luis Arroyo, amigo y compañero en "fatigas y servicios universitarios" desde hace muchos años, por la amable invitación a participar en este Seminario. Seguidamente, he de rogarles que disculpen la necesaria brevedad y puede que 'simplicidad' de mi intervención, debidas principalmente al corto espacio de tiempo del que dispongo. Porque, -bien es sabido por todos-, existen, como en cada uno de los asuntos, muchas formas de encarar, en este caso, el tema de la crueldad en el mundo clásico. Se puede hacer, como lo hace, entre otros, el historiador latino Valerio Máximo en su obra Factorum et dictorum memorabilium ("Hechos y dichos memorables"), quien en el libro IX, capítulo 2 (De crudelitate), aborda el tema de la crueldad haciendo primeramente una reflexión sobre su índole, para a continuación ejemplificar su concreción en comportamientos paradigmáticos de "personajes romanos y extranjeros" (así los presenta Valerio), tales como Lucio Sila, Gayo Mario, Damasipo, Munacio Flaco, por parte romana, o Aníbal, Mitrídates, Ptomomeo el Panzudo, o en general los atenienses, etruscos y "bárbaros". Detrás de cada personaje, hay toda una serie de caprichosas y escogidas muestras de la crueldad más inhumana ${ }^{1}$. Estos son los significativos textos (principio y fin del capítulo) ${ }^{2}$ :

1 Dada la difusión de la obra de Valerio Máximo en la Edad Media y en el Renacimiento, los ejemplos aducidos por él pasaron a ser los "prototipos clásicos" de la crueldad.

2 Crudelitatis uero horridus habitus, truculenta species, uiolenti spiritus, uox terribilis, omnia minis et cruentis imperiis referta. Cui silentium donare crementum est adicere: etenim quem modum 
"La crueldad, por el contrario tiene un aspecto espantoso, una apariencia desagradable, un orgullo intratable, una voz terrible, una boca llena siempre de amenazas y órdenes sanguinarias. No decir nada sobre ella sería algo así como favorecer su difusión. En efecto, ¿qué límites se impondrá a sí misma, si ni siquiera se detiene ante el freno del oprobio? En fin, puesto que ella sabe hacerse temer, sepamos nosotros odiarla"; (al final) "Quejémonos ahora de la naturaleza porque ha querido que estemos expuestos a los muchos y graves inconvenientes de las enfermedades, y soportemos de mal grado el que se haya negado a la condición humana la fuerza y la constitución de los dioses, cuando estamos viendo que el género humano, dócil a los consejos de la crueldad, ha creado contra sí mismo tal cúmulo de torturas".

Podríamos encarar el tema también desde un punto de vista del dolor en general, como se hace en alguna intervención de este Seminario, o circunscribirlo al panorama de las penas y castigos corporales (especialmente en el ámbito de la tortura, tema sobre el que se ha vertido mucha tinta). Sin embargo, como -según creo entenderen el trasfondo de estas reflexiones está la pena o castigo máximo, la muerte, será en este ámbito en el que desarrollaré y sistematizaré algunas ideas, sobre la crueldad a la hora de causar la muerte en el mundo clásico grecolatino. Lo haré de la mano, entre otros, de Eva Cantarella (Los suplicios capitales en Grecia y Roma. Orígenes y funciones de la pena de muerte en la antigüedad clásica) y de su método, consistente en esencia en "estudiar los modos de la respuesta punitiva, reconstruyendo y siguiendo en el transcurso del tiempo las formas de la ejecución capital".

\section{LAS PENAS DE MUERTE EN EL MUNDO CLÁSICO GRECOLATINO}

Los sistemas penales modernos (me refiero a los occidentales), cuando contemplan la pena capital establecen en general para todos los comportamientos sancionados de esta forma un solo tipo de ejecución: la guillotina, la horca, la silla eléctrica, la cámara de gas o la inyección de un fármaco mortal. Pero en el derecho griego y en el romano no existía la pena de muerte sino las penas de muerte. Muchas y variadas ejecuciones, que coexistían en el mismo momento y en el mismo lugar y que desvelan a nuestros ojos un sistema de suplicios que incluye al mismo tiempo actos elementales y horribles por su brutalidad como la decapitación con el hacha (la

sibi ipsa statuet, si ne suggillationis quidem frenis fuerit reuocata? Ad summam, cum penes illam sit timeri, penes, nos sit odisse...; (al final) Queramur nunc cum rerum natura, quod nos multis et asperis aduersae ualetudinis incommodis obnoxios esse uoluerit, habitumque caelestis roboris humanae condicioni denegatum moleste feramus, cum tot cruciatus sibimet ipsa mortalitas inpulsu crudelitatis excogitauerit. 
romana securi percussio); actos no menos expeditivos e impíos (en el sentido actual del término; para los antiguos se trataba, por el contrario y al menos originariamente, de actos de piedad religiosa) como la precipitación al Baratro griego o desde la Roca Tarpeya de Roma; procedimientos más complejos que infligían una muerte lenta y atroz como el de la cremación o la cruz (el tympanon griego y la crux romana); y para terminar, algunos ceremoniales de muerte tan increíblemente complejos que hacen dudar seriamente que se tratase de simples respuestas punitivas: por ejemplo el culleus, la pena prevista por el derecho romano para dar muerte a los parricidas ${ }^{3}$.

Cuanto más nos remontamos en el tiempo y cuanto más nos acercamos a los orígenes de la represión criminal, tanto más la elección de los suplicios ayuda a aclarar aspectos diversos entre sí de la sociedad que los ha practicado y que, ciertamente, no los ha creado de la nada. De hecho, la gran mayoría de las ejecuciones capitales a las que recurrieron los griegos y los romanos en los orígenes de su historia existían antes de la formación de las ciudades griegas y de Roma. Salvo en algunos casos (por lo demás relativos sólo a Roma), las organizaciones políticas nacientes, cuando se dotaron de las primeras reglas, se limitaron a acoger algunos de los variados modos de dar muerte concebidos en un momento antiquísimo, en el que la pluralidad de los suplicios estaba determinada por la diversa función que, en los distintos sectores de la vida social, cada uno de ellos estaba destinado a desempeñar. Cosa que, por otra parte, no puede sorprender excesivamente.

Pero hablar de la crueldad en los suplicios capitales en el mundo clásico no se debe reducir a recapitular (en una especie de arqueología de los horrores) las modalidades con las que se llevaban a término las ejecuciones. Concluir con un elenco de suplicios, entre otras cosas, podría inducir a pensar, de un modo totalmente injustificado y anacrónico, que los griegos y los romanos tenían una especial propensión a la crueldad, que hacían gala de una particular fantasía para desfogar esta propensión, que extraían un placer perverso al infligir sufrimientos gratuitos. Podría además llevar a establecer una especie de clasificación, atribuyendo la palma de la crueldad a uno u otro pueblo (y no hay duda que, en este caso, la victoria correspondería a los romanos).

Partiendo, pues, de unas preguntas como ¿por qué unos tipos de ejecución y no otros? ¿cuál era (si la había) la relación entre el crimen y la ejecución que lo castigaba? y, especialmente ¿por qué en la misma ciudad había varias ejecuciones y no un único suplicio de Estado?, la respuesta en general es que los modos según los

3 Aunque más adelante ahondaremos en su significado, digamos que, como su nombre indica, el instrumento de la poena cullei era un saco, cerrado herméticamente, en el que se introducía al reo, se le cargaba sobre un carro tirado por bueyes negros, se le llevaba a las orillas del Tíber y se le arrojaba al agua. Pero en el culleus, junto con el parricida, también se metía un perro, un gallo, una víbora y un mono. 
cuales se daba muerte a un condenado revelaban las razones que habían inducido a escoger, para él, ese tipo particular de suplicio. En otras palabras, que revelaban las funciones que se atribuían a la pena de muerte: castigar, expiar y vengar; es decir, primeramente, los suplicios dirigidos a castigar a quien no hubiese respetado la voluntad de la autoridad familiar o política; en segundo lugar, los destinados a purificar la colectividad contaminada y puesta en peligro por un comportamiento que, ofendiendo a la divinidad, había provocado o habría podido provocar su ira; y en tercer lugar, las ejecuciones a las que se confiaba la tarea de satisfacer el deseo social y psicológico de venganza de quien había sido víctima de una afrenta.

Sin embargo, llegados a este punto, es necesaria una precisión. En época ciudadana (polis en Grecia, civitas en Roma) las ejecuciones capitales eran la expresión de la voluntad y ejercicio del poder político que, situándose como árbitro y garante de la convivencia civil, se había arrogado el derecho exclusivo a establecer qué comportamientos eran obligatorios, qué comportamientos estaban permitidos y qué comportamientos prohibidos. Además, entre estos últimos había aislado los que tenían que pagarse con la vida. Desde este punto de vista, por lo tanto, en época ciudadana se debe considerar todas las ejecuciones como castigos. Pero esto no impide que en su seno sea posible captar una diferencia de funciones original. En el momento en que nació, la ciudad se encontró con que debía contar con diversas prácticas de muerte. Por un lado tenía frente a sí un poder consolidado (con el que debía pactar) como el de los jefes de los grupos familiares, cuya organización seguía siendo uno de los fundamentos de la ordenada vida social. Por lo demás, tradicionalmente estos jefes ejercían el poder de dar muerte a quien había infringido las reglas de la disciplina doméstica.

En otro orden de cosas, la ciudad no podía ignorar la existencia de antiguas creencias míticas y mágico-religiosas, que no pocas veces suponían la necesidad de eliminar a quien había realizado gestos que contaminaban, que ofendían a la divinidad y provocaban su enemistad. Para terminar, la nueva organización se proponía regular las relaciones interfamiliares, cuyos conflictos, hasta aquel momento, se habían resuelto a través de la venganza privada. Pues bien, cuando se analizan las ejecuciones capitales ciudadanas resulta que no pocas veces son la prolongación de las diferentes formas de dar muerte nacidas en el seno de estos ambientes, de estas dinámicas, de estas lógicas preciudadanas ${ }^{4}$.

4 Hay múltiples pruebas de ello. Por ejemplo, el caso, en Roma, de magistrados como Espurio Casio, el cónsul acusado en el año 485 a. de C. de affectatio regni, que según una de las versiones de su historia fue fustigado hasta la muerte por su padre. O uno de los suplicios previstos por la civitas romana para dar muerte a los culpables de traición, que era la fustigación a muerte (supplicium more maiorum), matarlo a golpes de verga, el arma que imponía la disciplina doméstica. 
Si concretamos algo más, en Grecia (y especialmente en Atenas), el suplicio ciudadano que repetía los rituales del castigo doméstico preciudadano era el apotympanismos, la así llamada crucifixión griega. Se trata de una ejecución cruel que tiene precedentes en los poemas homéricos en donde, de una forma más elemental (que prevé el uso de cuerdas, collares y grilletes), es el que por orden de Ulises se aplica a Melantio, el cabrero infiel ${ }^{5}$. En época preciudadana el suplicio del madero (mazo, garrote o de la clava: tympanon) se revela como la expresión de un poder jerárquico que reafirma su autoridad infligiendo un mal a quien lo ha discutido. Y la polis lo utiliza en la misma perspectiva, para afirmar y hacer efectivo su poder. En resumen, existen penas cuya función siempre ha sido la de afirmar la autoridad: en época preciudadana la autoridad familiar, en época cívica la del nuevo organismo político.

Por el contrario, otros suplicios desarrollaban originalmente otra función, que siguieron desarrollando también en época ciudadana (obviamente junto a la función, común a todos los suplicios, de infligir un castigo para afirmar la autoridad pública). Tomemos el caso de la precipitación, en Atenas en el Barathron (en Roma será desde la roca Tarpeya). En la experiencia preciudadana la precipitación había sido una de las formas por las que se entregaba a los dioses la víctima consagrada. En otras palabras, había sido una forma del sacrificio humano. Posteriormente se había utilizado como ordalía. Se arrojaba desde una altura al sospechoso de haber cometido un crimen religioso de modo que, si era culpable, encontraba la muerte estrellándose contra el suelo o hundiéndose en las aguas. En efecto, los dioses aceptaban tomar su vida sólo si era culpable. Si era inocente lo salvaban, impidiendo que muriese. Como todas las ordalías, la precipitación era al mismo tiempo proceso, condena a muerte y ejecución. Por lo tanto no es casual que en la ciudad se utilizase originariamente como pena de muerte para los delitos religiosos. Pues no era sólo un castigo, tenía también una función expiatoria, salvaba a la colectividad del riesgo de la contaminación que el reo habría difundido inevitablemente en la ciudad caso de no ser eliminado.

Por último había ejecuciones que junto a la función de infligir un castigo tenían también la de dar satisfacción a la víctima de la afrenta. En la organización preciudadana la venganza de sangre era un poderoso y enraizado instrumento de regulación de las relaciones interfamiliares. Quien había sufrido una afrenta no sólo podía, sino que debía responder infligiendo a quien lo había ofendido un mal no menos grave del padecido; si no lo hacía, su honor estaba en juego. Por no hablar, y es un elemento relevante, de la fuerte necesidad psicológica de ver humillado al enemigo directo, necesidad a la que no se sustraían ni el héroe griego ni el hombre romano.

También aparece en el mito en donde, en la versión de Esquilo, es el suplicio escogido por Zeus para castigar a Prometeo, encadenado en los confines del mundo. 
Así pues, en los orígenes de la pena de muerte, tanto en Grecia como en Roma, encontramos una historia compleja, una pluralidad de factores que intervienen en su génesis, una variedad de funciones cuyas raíces se hunden en la vida social precívica. La primera conclusión es la constatación de una continuidad entre la historia preciudadana y la historia ciudadana de los suplicios. Pero junto a las continuidades existen innovaciones. En particular estas innovaciones se encuentran con mayor claridad en la historia romana. En efecto, en Grecia, y más en concreto en Atenas, los dos suplicios utilizados en el momento de la formación de la polis, el apotympanismos (matar al condenado a bastonazos, golpeándolo con un garrote) y la precipitación, tenían ambos una historia preciudadana. El único tipo de ejecución introducido por la ciudad fue la cicuta (koneion): pero nunca fue una pena institucional, fue un privilegio concedido a muy pocos, se puede decir que sólo a los criminales políticos y, entre éstos, sólo a los que tenían la posibilidad de pagar el altísimo precio de una dosis de veneno.

La situación romana era diferente. Quien, tras conocer el sistema de los suplicios griego, decide pasar al romano, aunque esté preparado para el panorama que se presenta ante sus ojos, se ve inevitablemente recorrido por una extraña inquietud. En efecto, los suplicios griegos, aunque crueles, tenían una cierta racionalidad propia. Cada uno de los gestos que los componían poseía una función evidente, una lógica a primera vista clara e inteligible. En otras palabras, revelaban inmediatamente los objetivos de quienes los aplicaban. Por el contrario, los suplicios romanos, o al menos algunos de ellos, no se limitan, como los griegos, a proporcionar una muerte más o menos dolorosa, a prolongar con más o menos crueldad una desgarradora agonía. Se complican con ritos misteriosos, suponen ceremonias complejas e incomprensibles. Bastará por el momento mencionar el ejemplo al que ya tuvimos ocasión de hacer referencia por su absoluta particularidad: la poena cullei, la célebre pena del saco. El deseo de infligir una agonía larga y dolorosa puede explicar alguno de los elementos del rito del culleus, pero no puede explicar las razones de toda la ceremonia. Prescindiendo de la elección de los animales (cuya particular ferocidad sólo es una de sus posibles explicaciones), ¿cómo interpretar la serie heterogénea de gestos que no tienen ni la función de provocar la muerte ni la de hacerla más dolorosa o más infame? Pero lo que sorprende más cuando se contempla el sistema romano de los suplicios no es sólo la complejidad de los ceremoniales previstos, es su variedad: Comparada con otras muertes de Estado la decapitación (securi percussio o decollatio) era una muerte afortunada. ¿Qué decir, en efecto, de la vivicombustión (crematio), de la condena ad bestias, de la crucifixión ( $c r u x)$ o de condenas teóricamente no capitales, pero que no pocas veces tenían tal efecto, como la castración o la tortura, consistente en verter plomo fundido en la garganta del condenado? Etc. Etc. 
Aunque también en Roma el origen de algunos suplicios se remonta a una época en la que todavía no había nacido la ciudad, sin embargo, a diferencia de la polis griega, la civitas romana en el momento de su formación no se limitó a utilizar una serie ya existente de rituales de muerte. La ciudad romana inventó otros nuevos, introduciendo suplicios como la decapitación con el hacha (securi percussio) y la poena cullei. ¿Por qué esta actitud diferente? ¿Por qué los griegos no experimentaron la necesidad de introducir ejecuciones nuevas, a no ser para conceder el beneficio de la cicuta (aunque sólo a unos pocos privilegiados), y los romanos por el contrario experimentaron la necesidad de introducir nuevos suplicios, cruentos como la decapitación con el hacha o crueles como la poena cullei? Es inútil decir que una respuesta que invocase el lugar común de la suavidad de los griegos y de la crueldad de los romanos sería absurda. La respuesta, si admitimos que se puede dar, no se debe buscar evidentemente en un pretendido carácter nacional sino, en todo caso, en las diferentes condiciones en las que nacieron, respectivamente, las ciudades de Atenas y de Roma.

Los atenienses cultivaban el mito de su autoctonía. Un mito que, en todo caso, parece reflejar una situación en cierto modo estable, pues es posible que los grupos que habitaban la zona antes de la formación de la polis viviesen en condiciones, si no de aislamiento, al menos de una cierta tranquilidad, al margen de las incursiones de poblaciones de diversa procedencia. Por el contrario, la prehistoria e historia más antigua de Roma parece haber sido mucho más agitada. A pesar de las dudas e inseguridades que todavía rodean los orígenes de la ciudad, algunos datos pueden darse por adquiridos: en torno al lugar donde nació Roma, en el Lacio y fuera del Lacio, existían ciudades organizadas, ricas y emprendedoras. Como quiera que sea que nació Roma, se crea o no se crea en un acto de fundación de la ciudad, permanece el hecho de que lo hizo en un contexto que hacía compleja su existencia e insegura su posibilidad de supervivencia. La leyenda del gesto fratricida del fundador no puede dejar de tener un sentido, al igual que la del rapto de las sabinas. A todo ello se debe añadir el problema de las relaciones con las ciudades griegas y sobre todo con la potencia etrusca.

En resumen, Roma tenía la necesidad de presentarse ante el exterior con la fuerza de un poder, también militar, que le permitiese defenderse de los muchos peligros y, al mismo tiempo, debía poder controlar una población interna heterogénea, no sólo y no tanto étnicamente cuanto, y sobre todo, socialmente. La codificación de la contraposición patricios/plebeyos, que reproducía en la ciudad antiguos vínculos de subordinación social, planteaba problemas que hacían todavía más necesario un Estado fuerte. Y esta exigencia se expresa también en la previsión de nuevas ejecuciones capitales una de las cuales, no por casualidad, fue la decapitación con el hacha, símbolo del poder militar del magistrado supremo. 
Es diferente, en cambio, el argumento sobre la poena cullei, ceremonia religiosa de tipo expiatorio, que eliminaba a los parricidas considerados como monstruos. ¿Pero por qué decidió la civitas considerar un monstrum a quien había matado al pater? Roma era una "ciudad de padres". Sólo reconocía a los padres la titularidad de los derechos. Según Rose, originariamente sólo los patres tenían el genius, la divinidad protectora individual que en época más avanzada estaba junto a todos, padres e hijos, ya fuesen hombres y mujeres. En una ciudad en la que a los padres correspondía esta posición de absoluto privilegio (por no hablar del poder absoluto sobre sus sometidos) era casi inevitable sancionar la monstruosidad de un gesto como el parricidio. Una vez más, la introducción de un suplicio, que todo parece indicar que no existía en época preciudadana, se remite a la exigencia romana (o, al menos, más romana que griega) de imponer con particular fuerza la propia autoridad.

\section{UN CASO CONCRETO: LA POENA CVLLEI}

Y ya que hemos hablado una y otra vez de la poena cullei, intentaré ahondar (no con toda la profundidad que sería deseable) en su significado y función, sobre todo para ejemplificar una de las tesis expuestas a lo largo de esta intervención: el suplicio administrado tenía que ver con el crimen cometido, en un contexto local y temporal, que hundía sus raíces en creencias míticas y prácticas mágico-religiosas ¿Cuál era el significado de este rito de muerte? Pensar que se trataba sólo del fruto de una elaborada fantasía punitiva es bastante difícil y, al mismo tiempo, un modo de eludir el problema sin resolverlo.

Que la pena del saco (poena cullei), instrumento de ejecución reservada a los parricidas, fuese un rito completamente particular, se hace evidente enseguida, desde el inicio del mismo, y para subrayar su excepcionalidad aparece la previsión de un procedimiento misterioso, que regulaba los modos por medio de los cuales, inmediatamente después de la condena, se llevaba al reo a la cárcel en espera de ejecución. Dicen las fuentes que al parricida se le ponían zuecos de madera y que en torno a su rostro se ataba una capucha de piel de lobo. Se trata de un procedimiento al que no se sometía a ningún otro condenado a muerte, ni en Roma ni en otros lugares. Desde luego, la excepcionalidad no la constituía el encerramiento del criminal en un contenedor (en este caso, un saco); la excepcionalidad la constituye la inserción en el odre de cuatro animales destinados a ser una compañía muchas veces letal para el parricida: sus compañeros de viaje destrozarían su cuerpo haciendo su muerte particularmente atroz. Pero ¿estamos seguros de que era precisamente la búsqueda del desgarramiento del cuerpo del reo la razón que llevó a los romanos a ofrecer al parricida el postrero 'homenaje' de la bestial y letal compañía? O al menos ¿esa fue la única razón? ¿no hay en el heterogéneo grupo de animales otra razón de ser, simbólica según algunos, o ritual, o tal vez mágico-religiosa? 
Excedería en mucho esta intervención la explicación detallada de las características que tenían estos animales y que los hacían especialmente idóneos para acompañar al parricida hacia la muerte. En resumen, la hipótesis más aceptada es que la inclusión en el saco de un perro, un gallo, una víbora y un mono respondería al hecho de que todos ellos eran animales "prodigiosos", es decir, seres monstruosos que era necesario eliminar para evitar que difundiesen la contaminación que llevaban en sí. Eran monstruosos del mismo modo que el parricida. Las características atribuidas a estos animales, ya fuesen verdaderas o falsas, remitían al gesto y al carácter del parricida, encerrado con ellos en el saco. Los peligrosos animales desempeñaban una doble tarea: mientras que el reo estaba vivo lo agredían, lo atormentaban, lo destrozaban con una ferocidad y una inhumanidad pareja a la que él había demostrado cuando había llevado a cabo el más infame de los crímenes. Tras la muerte, ese mismo conjunto de animales confundía sus restos con los del hombre, en un osario promiscuo que tal vez algún día se descubriría en una orilla más o menos lejana. Quien encontrase los miserables despojos comprendería inmediatamente la razón de la ejecución.

Quedarían por explicar en este rito de muerte los zuecos de madera (soleae lignae) con los que se le calzaba, la capucha de piel de lobo con la que se le tapaba la cabeza y las vergas sanguinae ("color de sangre") con las que se le golpeaba. ¿Qué significado y funciones desempeñaban? ¿Quizás el de 'aislar al parricida para que no tuviese contacto con la tierra y así con contaminarla', en el primero de los casos? ¿Tal vez el disfraz lobuno tenía un valor iniciático para el parricida, al ser expulsado de la sociedad civil y condenado a vagar per silvas hasta que alguien lo matase legalmente? ¿Y en el último caso, eran las vergas 'color de sangre' las provenientes de los infelicia ligna, árboles con los que 'conviene quemar los portenta y los malos prodigios'? Como vemos, hipótesis encaminadas a dar razón cumplida del porqué de esta pena capital para una clase concreta de reos.

En resumen, la pena de muerte, en las sociedades griega y romana, respondía a exigencias variadas y desarrollaba funciones diferenciadas: 1) afirmar la autoridad del Estado; 2) alejar el sentido colectivo de la angustia y el peligro que derivaba del temor a que un acto ilegal provocase la contaminación y la venganza divina; 3 ) evitar que las víctimas de una afrenta, al no obtener justicia, se tomasen la justicia por su mano. 



\title{
LA CRUELDAD: SUS MODALIDADES ${ }^{1}$
}

\author{
MARIO PISANI
}

Profesor Emérito de la Università degli Studi di Milano

\section{LA CULTURA Y LA PRÁCTICA DE LA CRUELDAD}

En la voz "tortura" de su Diccionario filosófico, incluida en 1769, Voltaire se mostró crítico. Si bien no exactamente con su teorización, sí con lo que podemos llamar "la cultura de la crueldad", a la que coloca entre los casos más extremos de costumbre e indiferencia social.

Voltaire nos habla del meditabundo juez que, quizá - aventura- haya conquistado con poco dinero su cargo, y con él, el derecho de hacer pasar al prójimo por ciertas experiencias; y que de vuelta chez soi, cuenta a su mujer cómo le ha ido el día. La primera vez, su señora se descompone con el relato. A la segunda, le va cogiendo el gusto (porque "tutte le donne sono curiose"). Después, la primera cosa que la mujer le preguntará al marido nada más volver a casa será: "amor mío (o, mejor: mon petit cœur), ¿hoy no habéis hecho torturar a nadie?”. Es decir: el hábito diluye poco a poco su reacción inicial frente a la crueldad. Pero la cultura de la crueldad puede ser fruto también de una simple pero muy extendida indiferencia. Tras rechazar que Francia, civilizada de siglos, se dejara llevar por viejas costumbres atroces, el mismo Voltaire añade, con amarga ironía, lo que, en definitiva, se piensa en su país: “¿Por qué deberíamos cambiar nuestra jurisprudencia? Al fin y al cabo Europa se sirve de nuestros cocineros, nuestros sastres y nuestros peluqueros, así que -ésta

\footnotetext{
* Traducción de Ana Ruiz Legazpi, Profesora de la Universidad Autónoma de Madrid y Abogada.
} 
debería ser la paradójica conclusión- nuestras leyes son buenas". O sea ¿de qué deberíamos preocuparnos?

A propósito de la jurisprudencia, en efecto, Voltaire había recordado poco antes el célebre caso del suplicio del caballero La Barre: un joven de gran espíritu que, con todo el aturdimiento de su juventud desenfrenada, terminó siendo condenado por los jueces de Abbeville por cantar canciones blasfemas y no quitarse el sombrero al paso de una procesión de capuchinos. Pues bien, aquellos jueces no se conformaron con que se arrancara la lengua al desafortunado, se le cortara la mano y se le quemara el cuerpo a fuego lento: "le sometieron a tortura para saber con precisión cuántas canciones blasfemas había entonado, y cuántas procesiones había presenciado sin osar quitarse el sombrero".

Tampoco ahora estamos ante teoría, sino ante la práctica judicial de la crueldad. Y es sabido que Voltaire escribió su célebre Commentaire (publicado en 1766) a la obra de Cesare Beccaria, precisamente, en medio del encendido sobre el caso La Barre.

\section{LA PENA DE MUERTE: LA "MORT SIMPLE" Y "LES SUPPLICES RECHERCÉS"}

La alusión a Beccaria nos lleva directamente a la cuestión de la pena de muerte. En un Seminario de 1999, Jacques Derrida vino a recodar la consustancial característica de la crueldad de tal pena: que -según dijo- puede ir "desde la más grande brutalidad a las más refinadas perversidades, del suplicio más sanguinario y lacerante a la pena más enmascarada e invisible". El mismo autor no dejó de recordar al Nietszsche de La genealogía de la moral, donde nos invitaba a pensar "antiguas penas alemanas": la lapidación, la tortura de la rueda "¡la invención más característica o la especialidad del genio alemán en el campo de las penas!", el empalamiento, el descuartizamiento por caballos, hervir al reo en aceite o en vino (hasta el S XV), el despellejamiento y otras tantas formas de crueldad. Todo para invitar a la reflexión sobre los largos y difíciles caminos de sangre y horror por los que ha transitado la historia antes de que imperara el reino de la razón.

En este sentido, Montaigne se pronunció ya a mediados del s. XVI en sus Essais sobre la pena de muerte, sin llegar a excluirla, escribiendo (L II, Cap. XI) que, en su opinión, " tout ce qui est au delà de la mort simple, me semble pure cruauté". Quizá sorprenda que Montaige se preocupara de ofrecer un irreverente apoyo a dicha opinión añadiendo, en clave ultraterrenal, que para evitar la "pura crueldad" quien tuviera corazón debía pensar que las almas habían de trascender al más allá en buenas condiciones: lo que ciertamente no puede suceder -decía- si antes se las ha sometido a violencias y llevado hasta la desesperación con tormentos insoportables. Pocas páginas después, Montaige retoma el argumento desde un enfoque bien distinto, al defender que la exclusión de la pena de muerte con crueldad carecía de efectos sobre la prevención de los delitos. 
En el ya mencionado Commentaire, nada más mencionar a Beccaria, Voltaire ( $\S$ II) conjura vivamente "les supplices rechercés, dans lesquuels on voit que l"esprit humain s"est épuisé a rendre la mort affreuse", proclamándolos creaciones de la tiranía más que de la justicia.

La misma idea animó después al mismísimo Beccaria y a sus colegas de la Comisión delegada para la reforma del sistema criminal de la Lombardía austriaca sobre la pena de muerte. Cuando concluyeron, en 1792, que "la pena de muerte debía restringirse a poquísimos delitos" y convenían colegiadamente en la opinión de que "su pura y simple imposición (de la mort simple, se entiende) debía considerarse ya como un suplicio extremo, teniéndose que reputar como "inútiles y atroces" "los agravantes que en los códigos antiguos venían aparejados a la pena de muerte para los delitos más graves".

Voltaire recordaba incluso el caso de Inglaterra, aludiendo a la época en la que se abría el cuerpo del culpable de alta traición para arrancarle el corazón y echarlo luego a la hoguera. Y cómo, con el paso del tiempo, la costumbre se edulcoró ("les moeurs s'adoucirent”), sacándose el corazón solo una vez que el condenado había muerto.

\section{LA EJECUCIÓN Y “LES SUPPLICES NON-RECHERCÉS”}

Más de una vez sucedió que en presencia o no de la intención del suplicio, la ejecución de la pena de muerte degeneró en crueldad ulteriormente, tanto antes como después del uso de la "máquina humanitaria", tal como fue considerada durante mucho tiempo la guillotina. En su Plan de legislación criminal de 1777, el "terrible" Marat recordaba el caso, acontecido veinte años antes, de la pena infligida a Damiens: quien, "habiendo herido levemente a Luis XV con una cuchillada, fue condenado al descuartizamiento como pena prevista para el regicidio". Sucedió que los caballos no lograron desmembrar el cuerpo del condenado, de modo que el verdugo tuvo que mutilarlo con un cuchillo.

Al escribir en 1829 la introducción a la reedición de El último día de un condenado a muerte, Victor Hugo recordó un episodio parecido, sucedido poco tiempo antes con una guillotina en uso en la región del Mediodía francés. Aunque resulte increíble, sucedió que estando el condenado bajo el atenazador filo de la cuchilla, la misma cayó y subió rebotando y golpeando hasta en cinco ocasiones al reo, quien en cada uno de los cinco golpes gritó y movió la cabeza pidiendo clemencia. El pueblo, indignado, cogió piedras y, secundando su sentido de justicia, trató de lapidar al despreciable verdugo. Quien precipitándose bajo la guillotina logró esconderse detrás de los caballos de la policía. Pero no acaba aquí la historia. El implorante condenado, notándose solo en el patíbulo, se había enderezado sobre el cadalso, y desde allí, en pie, asustado, sanguinolento, sujetándose la media cabeza que le colgaba sobre los hombros, pedía con voz débil que alguien lo soltara. Bien 
al contrario, sin embargo, un jovencísimo ayudante de ínclito ejecutor, usó en esa ocasión el cuchillo para terminar la tarea.

A aquellos suplicios que, para distinguirlos de los intencionados, Voltaire habría llamado "non recherchés", y que como tales podían provenir de simples disfuncionalidades del instrumento de la muerte, se les puede equiparar hoy en día (en plena actualidad lo acaecido en los Estados de Oklahoma y Arizona con las llamadas ejecuciones "chapuza" (botched), los suplicios derivados de un error en la dosis de los compuestos químicos usados en las ejecuciones capitales al otro lado del Atlántico. Ciertamente igual de letal que la cicuta de Sócrates pero de acuerdo con la ley.

Sea o no intencionada la adicional crueldad pareja a la ejecución de la pena de muerte, lo cierto es que a muchos nos lleva a sostener, que un paso más, de alguna manera definitivo, en la historia de la humanidad, debería ser considerar la pena capital misma, de por sí, como un tratamiento cruel, y por tanto inhumano y degradante, a abolir de cualquier sistema penal, y ello aunque se concluya sin ningún tipo de incidentes, solo con la mort simple.

\section{PRESUPUESTOS Y PRÁCTICAS DE LA TORTURA JUDICIAL}

Con la alusión a Beccaria se ha hecho referencia implícita al $250^{\circ}$ aniversario de De los delitos y las penas.

Nos viene a la memoria que, todavía cinco años después de su primera publicación, la Constitutio Criminalis Theresiana, o sea, la Constitución criminal, editada en Viena en 1769, y como apunte del $\S$ XVII del artículo XXXVII, titulado, De los motivos e indicios suficientes para la tortura, cuándo, contra quién y cómo ésta ha de aplicarse, contenía un apéndice 4 con el título Designación y declaración de la especie de tormentos y el modo de aplicarlos. Se perfilaban allí cuatro figuras: I "el aplastamiento de pulgares o los llamados silbidos"; II "los relativos a los nudos"; III "el potro, la tortura de la cuerda (es decir, colgar al reo en lo alto por una polea y dejado caer por su peso de forma impetuosa contra el suelo en repetidas ocasiones); IV "el quebranta piernas o bota española", cuyo calificativo proviene de la Constitutio Carolina.

No por casualidad, en Historia del pensamiento jurídico occidental, J. Kelly escribió que en la época de Bach y Mozart los sistemas de justicia penal nos describen todavía "una Europa dominada por escenas de aterradora crueldad". Bajo los dominios de la Casa de los Austria la tortura se abolió en 1776, y ocho años después también en la Lombardía austriaca.

\section{OTRAS PERSISTENTES FORMAS DE CRUELDAD EN LOS SISTEMAS PENALES}

Es verdad que hoy, y hasta donde se sabe, ningún ordenamiento jurídico prevé un elenco de presupuestos, modalidades y técnicas de aplicación de la tortura judicial. 
Ni tampoco ninguno que se inspire en criterios antiguos considerando la pena de cárcel misma como una suerte de tortura o como una medicina del alma. Lo que no quita -digámoslo, aunque sea entre paréntesis-para que, olvidando la distinción beccariana entre pecado y delito, se continúe hablando anacrónicamente ( quia peccatum est!) de penitencia, cuando se habla de penitenciario, de Derecho penitenciario. Pero también es verdad -cerrando el paréntesis- que muchos, demasiados, sistemas penales todavía ofrecen oscuros espacios para la "crueldad objetiva", y por tanto sistemática y sistematizada, evidente $\mathrm{u}$ oculta.

Crueldad evidente, como la que, de hecho, lleva a configurar las cárceles como lugares donde se termina como castigo - una pena que acompaña a la simple privación de libertad misma (diríase, parafraseando a Montaigne, "peine simple")- por castigo: como un sobreañadido negativo constitutivo de tratamientos, no declarados como tales, pero ciertamente inhumanos y degradantes. No nos olvidemos de la "abominable institución" desaprobada por el Marqués de Sade, que, siendo el teórico de la ferocidad, afirmó: la cárcel donde el malhechor es reducido "a la soledad vegetal, a un funesto abandono" fomenta que "sus vicios germinen, su sangre hierva y su cabeza fermente; la imposibilidad de satisfacer sus deseos fortifica la causa criminal, de modo que sólo saldrá de allí más ladrón y peligroso".

Luego está la crueldad rastrera y oculta, a la que Diderot llama, en sus observaciones a Beccaria, "autre atrocité". Tal como la que se producía, y quizá en algún lugar u otro se produce todavía, cuando, tras años de cárcel, el imputado reconocido inocente, pero con la estima, el patrimonio y la salud devastados, se encuentra dejado a su suerte sin poder conseguir una indemnización.

Y todavía hay otra forma de crueldad rastrera y oculta, y que por eso parece menos grave, víctima de la indiferencia o al menos del descuido. Se da con la posición a veces tan trágica de las víctimas, directas o indirectas de los delitos, especialmente los violentos: los cuales no han sido prevenidos por el Estado, a pesar de que se reserva para sí el monopolio de la fuerza física legítima y de que asume el deber de tutelar la seguridad y el orden público.

Son muchas las tipologías de crueldad, que se suman a las multiformes y lacerantes padecidas por los autores de los delitos más graves, y que asolan nuestro mundo de los delitos y las penas. Mas deberá llegar el día -hay quien lo llama utopía, otros prefieren hablar de esperanza de la razón y la racionalidad- el día, decía, en que, de no sé qué metafórica y altísima montaña descenderá un balsámico viento impetuoso, que se llevará una a una todas aquellas residuales manifestaciones crueles, para así liberar la historia y el porvenir de los hombres. 



\title{
LOS TRATOS INHUMANOS EN EL DERECHO PENAL DE LA PROHIBICIÓN DEL TORMENTO Y EL CASTIGO DE LA CRUELDAD DE LOS INDIVIDUOS A LA LLAMADA TORTURA DE NECESIDAD ${ }^{1}$
}

\author{
GONZALO QUINTERO OLIVARES
}

Catedrático de Derecho Penal, Universidad Rovira i Virgili, España.

Resumen. Abordar como penalista el tema de la crueldad es especialmente complejo, pues todo lo que rodea a los castigos, desde la historia más pretérita hasta hoy, está teñido de dolor causado al hombre por el hombre. Son muchos los enfoques posibles del tema. El jurista puede tener presente la valoración antropológico-cultural, la psicológica, la política, pero, sobre todo, ha de ocuparse de la crueldad ante el derecho, $y$, reducido a esa óptica, este pequeños estudio recorrerá algunos aspectos del problema: el movimiento ilustrado hacia la abolición del tormento y la tortura, la prohibición de los tratos inhumanos en el derecho internacional, la respuesta punitiva a la crueldad cuando la ejercen los individuos, y, por último, los intentos de justificar la inevitabilidad del recurso a la tortura en algunas situaciones.

\section{LA PROHIBICIÓN DE LOS TRATOS CRUELES E INHUMANOS: GÉNESIS Y CONTRADICCIONES DE UNA REGLA ESENCIAL}

No hay que engañarse sobre la extensión y abundancia de la crueldad en el mundo "antiguo", aceptada como algo normal, justo y necesario. Tanto que si

1 Contribución al Seminario: Ensayos para una teoría de la crueldad humana, Madrid 13 de octubre de 2014. 
pensamos en los tormentos que aplicaba la Inquisición o bien, siempre sin salir de la historia propia, podemos reconocer comportamientos de extrema crueldad en episodios de nuestro pasado que se presentan con tintes épicos. Por ejemplo, la conquista de América. Como denunciaron en su tiempo Antonio de Montesinos y Bartolomé de las $\mathrm{Casas}^{2}$, y describe, en libro reciente, A. Espino ${ }^{3}$, y es solo un ejemplo, las masacres, asesinatos, amputaciones de manos y pies, heridas curadas con aceite hirviendo, violaciones...fueron lo normal en las batallas que tuvieron lugar durante la conquista de América. Se dirá, y es verdad, que no era mejor lo que aguardaba a los españoles que caían en manos enemigas.

Se dice y se repite que es muy difícil valorar la crueldad con la mentalidad de nuestro tiempo, como si nuestro tiempo pudiera mirar al pasado con la tranquilidad de que ciertas cosas ya no suceden, cuando eso es del todo falso. Los espectáculos de crueldad se prodigan por todo el planeta, y hoy vemos decapitaciones, fusilamientos masivos, lapidaciones, rostros desfigurados con ácidos, seres humanos quemados vivos y podríamos seguir. Se dirá que esas son prácticas perseguidas allí donde se hacen, lo cual en bastantes casos no es verdad, pero lo cierto es que la crueldad está viva y presente en nuestro mundo Teniendo presente, pues, que hay una cierta autocomplacencia en mirar al pasado como algo superado, podemos recordar algunos datos que anteceden a la formal consecución de la abolición del tormento en Europa.

El siglo XVIII marca sin duda un hito en la historia de la humanidad en el camino hacia la racionalidad política y el reconocimiento de los derechos del individuo frente al Poder. En política se registran sucesos transcendentales como la Revolución norteamericana y la Revolución francesa. En la filosofía política y penal aparecen las obras de Montesquieu, Voltaire ${ }^{4}$, Rousseau, Adam Smith, Becaria, Filangieri.

En ese ambiente, y a la vez que se luchaba por los ilustrados en pro de la abolición del tormento, surgieron los penitenciaristas humanistas, que iban a determinar los primeros grandes cambios sobre la concepción de los sistemas penitenciarios, brutales e inhumanos en su tiempo. Su precursor, según se reconoce generalmente, fue el inglés John Howard, a través de su destacada obra "El estado de las prisiones en Inglaterra y Gales" aparecida en 1777. En ella denunciaba las condiciones de

2 La crueldad no fue una deriva exclusiva de los españoles. Como señala Martínez Baracs, con ocasión del comentario crítico a la nueva edición de la obra más importante de De las Casas, “... la sensación que le queda al lector no es de simple condena a los españoles, porque Las Casas nos confronta con el problema de fondo que es el de la crueldad humana, particularmente en las guerras de conquista y depredación de pueblos diferentes. En esto los amerindios no fueron una excepción...”. («Relectura de la crueldad humana». En Letras Libres, enero de 2014, recensión a Fray Bartolomé de las Casas. Brevísima relación de la destruición de las Indias. Edición, estudio y notas de J. M. Martínez Torrejón, Madrid, Real Academia Española, Galaxia Gutenberg, 2013).

3 Espino López, A. La conquista de América: Una revisión crítica. Barcelona, RBA Ediciones, 2014.

4 Es de enorme interés la voz "Suplicio" que escribe Voltaire en su Diccionario Filosófico. 
enfermedad, inmoralidad, miseria y corrupción que había en los presidios ingleses. Y ahí aparecía la primera propuesta de un régimen penitenciario: Howard reclamaba que las cárceles fueran instituciones ordenadas y regidas por responsables honestos y que se clasificara a los delincuentes por grupos y que cada grupo tuvieran un moderado régimen de trabajo.

En realidad, es en esa época cuando nacen las "prisiones" en el sentido que tiene hoy esa palabra. Con ellas se intentaba superar los campos de trabajo, las galeras, los encadenamientos en mazmorras, $\mathrm{y}$, además, desterrar el tormento ${ }^{5}$ y la pena de muerte, que en el Antiguo Régimen eran un siniestro y popular espectáculo que se celebraba en calles y plazas como medio de "terror penal" de segura eficacia. Aquella era una idea de lo "justo" solo compatible con la convicción de que el delincuente era un no-ser, al que se podía descuartizar si se consideraba que eso era lo proporcionado, y viene, como no, a la memoria el suplicio de Robert Damiens en la plaza de la Grève de Paris, recordado por Beccaria.

Una secuela de las ideas de Howard sería el llamado sistema filadélfico ${ }^{6}$, que impulsó un cuáquero ultrareligioso, William Penn, fundador de la colonia Pennsylvania. El régimen consistía en el aislamiento permanente en la celda y el silencio continuado, con la obligación de leer la Biblia y otros libros religiosos, porque de ese modo lograría la reconciliación con Dios. El sistema excluía penas corporales y reducía mucho la pena de muerte. Hay que tener en cuenta que hasta entonces lo normal era que las celdas fueran espacios grandes donde se amontonaban 30 ó 40 presos, y a veces se mezclaban hombres y mujeres. Era normal tanto la homosexualidad como la prostitución. Ahora bien, de eso se pasó al aislamiento celular absoluto de cada condenado, lo cual fue calificado por el gran penitenciarita inglés William Roscoe como la "máxima crueldad con que se puede tratar a un ser humano"7.

La prohibición del tormento y de las penas degradantes se fue imponiendo en Europa, lentamente a partir de comienzos del siglo XIX. En el concreto caso de España todavía en el reinado de Carlos III la tortura era considerada legítima y ade-

5 Para conocer la escalofriante amplitud y variedad de los tormentos aplicados en Europa entre los siglos XVI y XVIII, conviene leer la relación que de las "penas aflictivas" hace Toribio Núñez en "Ciencia social según los principios de Bentham”, Imprenta Real, Madrid, 1835, p.163 y ss.

${ }_{6}$ El nombre del sistema procede de su implantación por la Philadelphia Society for Relieving Distraessed Presioners.

7 A Roscoe lo invoca Charles Lucas. «De l'emprisonnement solitaire». En Revue Encyclopédique, t. XLVI, Paris, 1830, p.23 y ss. En la actualidad el aislamiento es considerado un castigo destructivo, y su frecuente uso como sanción o en cárceles especiales es objeto de atención para diferentes observatorios sobre tortura y tratos inhumanos. Información sobre el tema en Shalev, S. A Sourcebook on Solitary Confinement. London, Mannheim Centre for Criminology, London School of Economics, 2008 . 
cuada a derecho, y, por eso mismo Cuando los ilustrados se oponían y condenaban ${ }^{8}$ el uso del tormento eran tildados de traidores al orden natural y legal ${ }^{9}$. Para muestra de ello basta con la obra que Alfonso de Acevedo escribió sobre el tormento, con el fin de desterrarlo de los tribunales escribió, en 1770, su obra (originariamente en latín) "Ensayo acerca de la tortura o cuestión del tormento; de la absolución de los reos que niegan en el potro los delitos que se les imputan, y de la abolición del uso de la tortura principalmente en los tribunales eclesiásticos". Acevedo defendía la necesidad de suprimir el tormento, texto que provocó un auténtico revuelo en su época, al punto de que fue contestada por Pedro de Castro -Catedrático de Teología en Bolonia y Canónigo de Sevilla- con su "Defensa de la tortura y leyes patrias que la establecieron: e impugnación del tratado que escribió contra ella el doctor d. Alfonso María de Acevedo". Lo peor es que, por muchas razones, ganaron los defensores de la tortura, cuyo uso era tenido como una indisoluble potestad del Estado ${ }^{10}$.

Para admiración de los ilustrados, desde hacía mucho tiempo, en la justicia inglesa se había proscrito el tormento (no la abundancia de la pena de muerte) por ser indigno de la condición humana ${ }^{11}$. En España hubo que esperar más, y la abolición de la tortura legal no llegó hasta las Cortes de Cádiz ${ }^{12}$, y, como consecuencia, la prohibición por Real Cédula de 25 de julio de 1814. En comparación con otros Estados europeos la abolición en España fue tardía. Suecia la abolió en 1722, Prusia en 1754, Dinamarca en 1770, Rusia en 1774, Austria y Polonia en 1776, Francia en 1780, y Holanda en 1798., Noruega en 1819 y Portugal en $1826^{13}$.

8 Forner, J.P. Discurso sobre la tortura, con Estudio preliminar de S. Mollfulleda, Barcelona, Crítica, 1990.

9 Scandellari, S. «La polemica sull'abolizione della tortura nella Spagna della seconda metà del secolo XVIII». En Archivio Storico e Giuridico sardo di Sassari, vol. 1, 1994, p. 103 y ss.

10 A favor de las opiniones de Acevedo se manifestaron personajes de la importancia de Jovellanos, Forner, Sempere y Lardizábal, quien expresamente, en el Discurso sobre las penas, rechazó la obra de Castro.

11 La tortura fue abolida en Inglaterra y Gales en 1641, y en Escocia en 1708.

12 El proceso de abolición comenzó realmente en las Cortes de Cádiz. En esa misma ciudad apareció el 22 de abril de 1811 un Decreto de las Cortes, que abolía la tortura y las prácticas de los "apremios", que eran acciones físicas sobre los reos destinadas a afligirles. Pero al regresar al poder, Fernando VII anuló la Constitución de 1812 y todos los Decretos de las Cortes. Eso suponía la reimplantación teórica de la tortura "legal" (la ilegal tal vez no ha desaparecido nunca) -hasta que se abolió definitivamente por Real Cédula de 25 de julio de 1814. Sobre el proceso penal en España a inicio del XDIX, y lo que eran los apremios, "Tratados de legislación civil y penal, obra extractada de los manuscritos del señor Jeremias Bentham, jurisconsulto inglés, por Esteban Dumont, miembro del Consejo Representativo de Ginebra, y traducida al castellano por Ramón Salas". Madrid, Imprenta de D. Fermin Villalpando), Tomo III, Cap.XX, p.163 y ss.

13 La abolición legal de la tortura no tiene nada que ver con la realidad de la tortura a detenidos y otros excesos crueles. Basta pensar en el período del Terror en Francia, las atrocidades del nazismo, el gulag soviético, el trato a los presos políticos en el Portugal de Oliveira o en la España de Franco, etc. Los datos históricos son solamente eso. 


\section{CONTRADICCIONES: LA PENA DE MUERTE Y LA ESCLAVITUD}

Sabemos que el tormento "legal" desapareció a inicios del s.XIX, mientras que la pena de muerte aun no ha desaparecido ni siquiera en el mundo "desarrollado", y basta citar su abundante aplicación en Estados Unidos, lo cual pone de manifiesto algo que cuando se lee a los protagonistas intelectuales del siglo XVIII queda en la penumbra: la distinta actitud ante el tormento o la tortura legal y la pena de muerte, que es tratada como algo totalmente diferente.

Cuando se mira al pasado sorprende comprobar que la lucha contra la tortura y el uso legal del tormento no conlleva un paralelo rechazo de la pena de muerte, cual si esta no fuera un "suplicio", cuando en la lista de los horrores ocupa el primer lugar, sin entrar, además, en las muy diversas maneras de ejecutar la pena de muerte (con descuartizamiento, emasculación, evisceración, empalamiento, etc.), tantos horrores que se llega a comprender la razón por la que el doctor Guillotin entendía que la máquina que llevaba su nombre suponía una "humanización" del modo de ejecutar la pena de muerte ${ }^{14}$.

Así como respecto del tormento puede decirse que los ilustrados, españoles o extranjeros, lo condenaban unánimemente, no se puede decir lo mismo de la pena de muerte. Entre los precursores de lo que sería el Siglo de las Luces se encuentra, sin duda, John Locke, padre del liberalismo, que escribió, sobre el castigo justo para el asesino: “...debe ser destruido como un león o un tigre, una de esas bestias salvajes, con las cuales los hombres no pueden tener sociedad ni seguridad, y sobre esto está fundada la gran ley de la naturaleza, El que derrame sangre de hombre, por el hombre su sangre será derramada...".

Mucho se ha escrito sobre la historia de la lucha por la abolición de la pena de muerte, e innegablemente muchos personajes representativos del siglo XVIII alzaron claramente su voz contra ella. Así por ejemplo, Becaria, Voltaire, Jean-Paul Marat, en cuyo Plan de législation criminelle, se excluía la pena de muerte, de la que tanto uso haría después la Revolución que él mismo defendió. Pero también muchos ilustrados adoptaron una actitud de reserva o tibieza en relación con la pena de muerte.

14 En realidad el médico Joseph Ignace Guillotin, no fue el inventor, pues reprodujo una máquina que ya se conocía, aunque tal vez la profusión de su uso durante el período del Terror fomentó el "honor" de que se le diera su nombre. Máquinas similares había en Alemania en el siglo XIII, Alemania (Fallbeil), en Inglaterra (Gibbet), Escocia (Maiden) o Italia (la mannaia). La vinculación entre la guillotina y la Revolución francesa es el motivo por el que en su novela El siglo de las luces, Alejo Carpentier hace que el personaje que quiere establecer los principios revolucionarios en el Caribe viaje portando una guillotina en la proa del barco (sobre el tema, Pérez Mink, D. «La guillotina de Alejo Carpentier. En torno a 'El siglo de las luces'». En La llegada de los bárbaros: la recepción de la literatura hispanoamericana en España, 1960-1981, coord. por J. Gracia y J. Marco, Madrid, Edhasa, 2004, p.352 y ss. 
Bentham, y era otra forma de posicionarse, rechazó la pena de muerte, por su inutilidad tanto para el castigo como para la prevención, porque aun con la pena de muerte sigue existiendo criminalidad, lo que denota una postura eventualmente favorable si se probara la utilidad.

Otros ilustrados no asumieron esa postura abolicionista, sino que como máximo aconsejaban un uso "moderado". Karl Hommel, el traductor al alemán de la obra de un abolicionista como Becaria, se mostraba partidario de un uso "limitado" de la pena de muerte. Nuestro Lardizábal se mostró partidario de la pena de muerte, e incluso entró en un análisis de los argumentos abolicionistas de Becaria para rebatirlos ${ }^{15}$.

La emperatriz de Rusia, Catalina la Grande, amiga de Voltaire, y considerada ilustrada, restableció la pena de muerte que había sido abolida en el precedente reinado de Isabel I (1741- 1762). En Inglaterra, que es considerada por muchos la "cuna" de la Ilustración, ni siquiera se planteó la supresión de la pena de muerte y apenas se produjeron reformas penales significativas durante el s. XVIII, a cuyo fin eran más de trescientos los delitos que podían ser castigados con la muerte, situación que no comenzaría a variar, y aun muy lentamente, hasta $1810^{16}$. En cambio, en una Monarquía absoluta como la austríaca la pena de muerte se abolió en 1787, aun cuando fue posteriormente restablecida.

El propio Gaetano Filangieri, que tanto había influido en los ilustrados españoles, aceptaba la pena de muerte, y Jovellanos advertía que era éticamente inaceptable aunque políticamente comprensible, especialmente pensando en los criminales que, según mostraba el delito cometido, habían perdido la condición de persona acercándose a la de bestia ${ }^{17}$. Pero la defensa de la pena de muerte era aun mucho más amplia: Kant y Hegel, los grandes filósofos inspiradores de las teorías absolutas de la pena, y reconocidos patriarcas de la filosofía del derecho, fueron también partidarios de la pena de muerte. El retribucionismo kantiano, que para su autor suponía la única y obligada vía de realizar la justicia, le llevaba a afirmar que la muerte del criminal era un imperativo categórico porque era la única retribución adecuada para quien ha quitado la vida a otro. Y aun más lejos llegó Hegel, para quien la pena de muerte devolvía al delincuente la condición de ser racional, pues "quien ha cometido

15 Una exposición crítica de los argumentos de Lardizábal puede verse en Betegón, J. «Lardizábal: "Discurso sobre las penas" (nota con motivo de su reedición)». En Anuario de Derechos Humanos, núm. 3, Madrid, Universidad Complutense, 1985, p.678 y ss. A los argumentos allí vertidos creo que se puede añadir otro: el temor de Lardizábal a contrariar a la Corona.

16 Vid.: Carbasse, J.M. «La peine de mort». En Que sais-je?, PUF, Paris 2011; Arroyo Zapatero, L. «La experiencia de la abolición de la pena de muerte en Gran Bretaña». En Revista de la Facultad de Derecho de la Universidad Complutense de Madrid, 1981, p.48 y ss.

17 Vid.: Sánchez Corredera, S. Jovellanos y el jovellanismo. Una perspectiva filosófica. Biblioteca de Filosofía en español, Fundación Gustavo Bueno, Oviedo, Pentalfa ediciones, 2004, p. 104. 
un homicidio ha reconocido para sí el homicidio como ley que a él debe aplicársele", a pesar de que el propio Hegel tuviera sus dudas acerca de sus propias tesis ${ }^{18}$.

También hay que recordar que las Cortes de Cádiz no abolieron la pena de muerte en la Constitución de 1812. El Estatuto de Bayona, de 1808, había prohibido la tortura, pero no la pena de muerte, como tampoco lo haría el CP de 1822.

En suma: aunque hubo importantes ilustrados que se pronunciaron contra la pena de muerte, puede afirmarse que la intensidad y generalidad de la oposición al tormento no se dio en modo alguno con la pena de muerte, que habría de llegar con plena vigencia a la segunda mitad del siglo $\mathrm{XX}$.

Otra contradicción (para nosotros) fue la tibieza de muchos ilustrados en relación con el problema de la esclavitud. Es cierto que figuras como Diderot o Rousseau sostuvieron que ningún ser humano puede ser propiedad de otro. Pero también es cierto que muchos ilustrados famosos nada dijeron sobre el tema, o bien incurrían en insalvables contradicciones, como sostener que no se podía esclavizar a un pueblo por el solo hecho de haberle vencido, para luego añadir que en el caso de los negros era justificable por su inferioridad. Voltaire, en los Ensayos sobre las costumbres y el espíritu de las Naciones se manifestó a favor de la esclavitud, pero diciendo que “...se nos reprocha este comercio: un pueblo que trafica sus hijos es aún más condenable que el comprador. Este negocio demuestra nuestra superioridad; lo que nos da una maestría para tenerlos...". Montesquieu, que consideraba impensable la esclavitud en Francia, se manifestaba comprensivo en relación con la necesidad, por razones económicas, de la esclavitud de los negros, a quienes, además, consideraba seres inferiores.

En España, se ha dicho siempre, no hubo un negocio de trata de esclavos comparable al que pudo haber en Inglaterra, Portugal u Holanda. Pero no hay que engañarse: los mismos ilustrados aprobaban esa clase de comercio, comenzando por Campomanes, que tan importante fue para la difusión de la obra de Becaria y de Filangieri, defendía que era imprescindible el libre cambio de esclavos ${ }^{19}$, que se estableció en 1789, y se mantendría hasta finales del siglo XIX.

Los ilustrados españoles, pues, convivieron tranquilamente o sin especiales preocupaciones por el problema de la esclavitud. Ese clima de indiferencia no se alteró hasta que en 1802 Isidoro de Antillón pronunció un profundo discurso ${ }^{20}$ en la Academia Matritense de Derecho Español y Público, en sesión dedicada al problema

18 Mizrahi, E. «La legitimación hegeliana de la pena». En Revista de Filosofía, Vol. 29 Núm. 1, 2004, p. 21.

19 Fernández Durán, R. La corona española y el tráfico de negros: del monopolio al libre comercio. Ecobook, 2011, p. 381 y s.

20 De Antillón y Marzo, I. Disertación sobre el origen de la esclavitud de los negros. Motivos que la han perpetuado. Imp. en Mallorca, Domingo, 1811. 
de la esclavitud, exigiendo la abolición de la esclavitud en los territorios españoles de ultramar el 2 de abril de 1802 en la Real Academia Matritense de Derecho Español y Público. Ese discurso no tuvo consecuencias inmediatas, pero algunos años después, cuando se reunieron las Cortes de Cádiz, en las que el propio Antillón fue también diputado, sus argumentos fueron utilizados por otros diputados abolicionistas, como Guridi, Argüelles y García Herreros, en el debate sobre la necesidad de abolir la esclavitud ${ }^{21}$. Pero de nada sirvió, y la Constitución de Cádiz, fruto tardío del pensamiento ilustrado, mantuvo la esclavitud, a pesar de que Agustín de Argüelles recordó a todos que Inglaterra había abolido la esclavitud en 1807: había demasiados intereses económicos ligados al negocio de esclavos, incluyendo en su defensa, especialmente, a diputados americanos ${ }^{22}$.

\section{LA PROHIBICIÓN INTERNACIONAL DE LOS CASTIGOS CRUELES, INHUMANOS O DEGRADANTES}

\section{III.1. Las proclamas internacionales}

En la cultura penal de nuestro tiempo es lugar común la proscripción de los castigos crueles o inhumanos (lo cual también lo suscriben Estados ${ }^{23}$ que mantienen

21 Forcadell Alvarez, C. «Isidoro de Antillón y Marzo: de provinciano ilustrado a mito de la nación libera». En Revista de Historia Jerónimo Zurita, nº 87, 2012, p. 45.

22 El 8 de febrero de 1815, el Congreso de Viena, celebrado a raíz de la derrota final de Napoleón, decidió también la abolición de la trata de negros. En su virtud los Estados presentes (entre ellos España) se comprometerían a no permitir ni en sus puertos, ni con naves de su pabellón, esa clase de comercio. Pero España se negó invocando los irrenunciables beneficios que ese negocio reportaba. Se acordó compensar económicamente a España a cambio de la promesa de suspender el comercio entre África y América, pese a lo cual España siguió tolerando esa clase de comercio, y así siguió hasta 1837, en que se abolió la esclavitud en la España metropolitana pero permitiéndola en Cuba y Puerto Rico, únicos territorios que España conservaba en América, cuyas oligarquías exigieron la continuidad bajo la amenaza de independizarse o solicitar la anexión a Estados Unidos. En Puerto Rico la abolición no llegaría hasta 1873 y en Cuba, hasta 1880. A su vez, cada una de las Repúblicas americanas tuvo su propio proceso de abolición de la esclavitud, que no siempre fue subsiguiente a la independencia (República Dominicana, 1822, Chile, 1823, Provincias Unidas de Centroamérica, 1824, México, 1825, Bolivia, 1827, Uruguay, 1837, Nicaragua, 1838, Paraguay, 1842, Ecuador, 1851, Colombia, 1852, Argentina, 1853, Perú y Venezuela, 1854, Brasil, 1888).

23 La Convención está firmada por: Afganistán, Albania, Alemania, Antigua y Barbuda, Arabia Saudita, Argelia, Argentina, Armenia, Australia, Austria, Azerbaiyán, Belarus, Bahréin, Bangladesh, Bélgica, Belice, Benín, Bolivia, Bosnia y Herzegovina, Botswana, Brasil, Bulgaria, Burkina Fasso, Burundi, Cabo Verde, Camboya, Camerún, Canadá, Chad, Chile, China, Chipre, Colombia, Corea del Sur, Costa de Marfil, Costa Rica, Croacia, Cuba, Dinamarca, Djibuti, Ecuador, Egipto, El Salvador, Eslovaquia, Eslovenia, España, Estados Unidos, Estonia, Etiopia, Federación de Rusia, Filipinas, Finlandia, Francia, Gabón, Georgia, Ghana, Grecia, Guatemala, Guinea, Guinea Bissau, Guinea Ecuatorial, Guyana, Honduras, Hungría, Indonesia, Irlanda, Islandia, Israel, Italia, Japón, Jordania, Kazajstán, Kenia, Kirguistán, Kuwait, Letonia, Lesoto, Líbano, Libia, Liechtenstein, Lituania, Luxemburgo, Macedonia, Malawi, Mali, Malta, Marruecos, Mauricio, México, Moldava, 
la pena de muerte y cuyos sistemas penitenciarios pisotean sistemáticamente los derechos humanos). En el plano de los documentos esenciales sobre esta cuestión se sitúa, en primer lugar la Convención contra la tortura y otros tratos o penas crueles, inhumanas o degradantes. La Asamblea General de las Naciones Unidas la aprobó el 10 de diciembre de 1984, y está considerada uno de los principales tratados internacionales en materia de derechos humanos. Entró en vigor el 26 de junio de 1987. La Convención contra la Tortura expresamente establece que por "tortura" debe entenderse "todo acto por el cual se inflija intencionadamente a una persona dolores o sufrimientos graves, ya sean físicos o mentales, con el fin de obtener de ella o de un tercero información o una confesión, de castigarla por un acto que haya cometido, o se sospeche que ha cometido, o de intimidar o coaccionar a esa persona o a otras, o por cualquier razón basada en cualquier tipo de discriminación, cuando dichos dolores o sufrimientos sean infligidos por un funcionario público $\mathrm{u}$ otra persona en el ejercicio de funciones públicas, a instigación suya, o con su consentimiento o aquiescencia. No se considerarán torturas los dolores o sufrimientos que sean consecuencia únicamente de sanciones legítimas, o que sean inherentes o incidentales a éstas".

La Convención tuvo sus antecedentes en la Declaración sobre la protección de todas las personas contra la tortura y otros tratos o penas crueles, inhumanos o degradantes que había sido aprobada el 9 de diciembre de 1975 (Resolución 3452 XXX), y su finalidad fue desarrollarla. Dicha Declaración se presentaba como lógico desarrollo del artículo 5 de la Declaración Universal de los derechos humanos de 1948 sobre la tortura ("nadie será sometido a tortura o a tratamientos o castigos crueles, inhumanos o degradantes). A su vez, la Declaración, había sido precedida por el Pacto Internacional de Derechos Civiles y Políticos, aprobado por la Asamblea de ONU el 16 de diciembre de 1966, y que entró en vigor el 25 de marzo de 1976, en el cual se proclamaba que "Nadie será sometido a tortura o a trato o castigo cruel, inhumano o degradante. En particular, nadie será sometido sin su libre consentimiento a experimentación médica o científica".

En el ámbito europeo tenemos el Convenio Europeo para la protección de los derechos y las libertades fundamentales, hecho en Roma el 4 de noviembre de $1950^{24}$, cuyo artículo 3 declara que "nadie podrá ser sometido a tortura ni a penas

Mónaco, Mongolia, Mozambique, Namibia, Nepal, Níger, Nigeria, Noruega, Nueva Zelandia, Países Bajos, Panamá, Paraguay, Perú, Polonia, Portugal, Qatar, Reino Unido, República Checa, República democrática del Congo, Rumania, Santa Sede, San Vicente y las granadinas, Senegal, Seychelles, Sierra leona, Somalia, Sri Lanka, Sudáfrica, Suecia, Suiza, Tayikistán, Togo, Túnez, Turkmenistán, Turquía, Ucrania, Uganda, Uruguay, Uzbekistán, Venezuela, Yemen, Yugoslavia, Zambia.

24 En la actualidad, vid.: Resolución de 5 de abril de 1999, de la Secretaría General Técnica, por la que se hacen públicos los textos refundidos del Convenio para la protección de los derechos y de 
o tratos inhumanos o degradantes"; el Convenio Europeo para la prevención de la tortura y de las penas o tratos inhumanos o degradantes, hecho en el Consejo de Europa, en Estrasburgo el 26 de noviembre de 1987.

El grado de intervención del derecho internacional es, pues, máximo. Pero a pesar de eso quedan zonas oscuras. Concretamente se presentan precisamente cuando se tiene que determinar lo que debe entenderse por "tortura", "trato inhumano", o "degradante". En relación con la tortura las definiciones son aparentemente precisas. La Declaración de $1975^{25}$ precisaba que tortura es "...todo acto por el cual un funcionario público, $u$ otra persona a instigación suya, inflija intencionalmente a una persona penas o sufrimientos graves, ya sean físicos o mentales, con el fin de obtener de ella o de un tercero información o una confesión, de castigarla por un acto que haya cometido o se sospeche que ha cometido, o de intimidar a esa persona o a otras. No se considerarán tortura las penas o sufrimientos que sean consecuencia únicamente de la privación legítima de la libertad, o sean inherentes o incidentales a ésta, en la medida en que estén en consonancia con las Reglas Mínimas para el Tratamiento de los Reclusos..." Se trata pues de una definición (que se repite en la Convención sobre la Tortura) relativamente acotada en cuanto a víctimas (personas privadas de libertad) y responsables (funcionarios o personas que actúen bajo control de ellos), y algo menos en lo que concierne a la acción misma (sufrimientos graves físicos o mentales), lo cual deja abiertos espacios de inconcreción.

Tiene además un punto importante a considerar: la exclusión de componentes subjetivos o de finalidad perseguida en la configuración de la tortura. Con ello se sale al paso de pretendidas exclusiones de la tortura en nombre de que el objetivo no era simplemente causar dolor, sino conseguir una información relevante. Otro punto a tener en cuenta (para cuando más adelante entremos en el tema de llamada tortura de necesidad) es que también se prohíbe a los Estados el derecho a alegar circunstancias excepcionales, tales como estado de guerra o amenaza de guerra, inestabilidad política interna o cualquier otra emergencia pública, como justificación de la tortura $u$ otros tratos o penas crueles, inhumanos o degradantes ${ }^{26}$.

En la interpretación de los conceptos de tortura y trato inhumano o degradante (para el Convenio Europeo antes citado), la Comisión Europea de Derechos Huma-

las libertades fundamentales, hecho en Roma el 4 de noviembre de 1950; el protocolo adicional al Convenio, hecho en París el 20 de marzo de 1952, y el protocolo número 6, relativo a la abolición de la pena de muerte, hecho en Estrasburgo el 28 de abril de 1983.

25 Se repite en el art.1 de la Convención.

26 Esa declaración es importante y coherente con la que hace el art. 4 de la Convención: "Todo Estado Parte velará por que todos los actos de tortura constituyan delitos conforme a su legislación penal. Lo mismo se aplicará a toda tentativa de cometer tortura y a todo acto de cualquier persona que constituya complicidad o participación en la tortura". Pero evidentemente eso no anticipa la extensión que cada jurisdicción nacional quiera dar a la eximente de estado de necesidad. 
nos se pronunció con motivo del caso "Dinamarca, Noruega, Suecia y Los Países Bajos c. Grecia", estableciendo que el grado del sufrimiento que se provoca sobre el individuo distingue a la tortura de los tratos o penas inhumanos y a estos últimos de los tratos o penas degradantes. Para que un acto llegue a ser calificado como tortura "...debe atravesar tres niveles. Primero, debe subsumirse dentro de alguno de los supuestos que definen a un trato degradante. Luego, para ser categorizado como trato inhumano, debe causar un sufrimiento mental o físico severo, aplicarse deliberadamente y carecer de justificación en las circunstancias particulares del caso. Por último, para ser calificado como tortura, el acto debe ser una forma agravada de trato inhumano y perseguir un propósito determinado..."27.

Claro está que esa explicación, en la medida en que abría la puerta a la "justificación de la tortura" había de provocar protestas, pues, aunque no se dijera, la intención era condenar al entonces gobierno de Grecia, pero se quería dejar a salvo la posibilidad de extender la calificación de tortura al tratamiento que en el Reino Unido se daba a los acusados de pertenecer al IRA. Esa influencia se vería claramente poco después, cuando en el caso Irlanda-contra Reino Unido la Corte Europea decidió que las técnicas de interrogatorio usadas en Inglaterra eran tratos inhumanos y degradantes, pero que no provocaron un sufrimiento de tal intensidad y crueldad como para ser considerados como tortura. Ante unos hechos similares, el TEDH, en el caso Chipre c. Turquía entendió que sí había tortura, pues ésta es una situación objetiva, independiente de razones o finalidades ${ }^{28}$.

Desde entonces los criterios del TEDH han ido evolucionando relativamente en sentido ampliatorio, consciente de que las exigencias de que para apreciar tortura el castigo haya de ser deliberado y obedezca al propósito de obtener información o confesiones produce una indudable restricción. Por tal motivo se apreció tortura en un caso de palizas a un detenido sospechoso de traficar con droga, rechazando que la finalidad de obtener informaciones excluyera la tortura ${ }^{29}$.

Hay que añadir que no ha sido esa la posición del Comité de Derechos Humanos de Naciones Unidas, que si bien, por una parte, no ha elaborado una doctrina tan detallada como la del TEDH, no ha abierto la puerta a exclusiones de la tortura en nombre de la justificación o la finalidad perseguida.

27 Alonso de Escamilla, A. «La doctrina penal del Tribunal Europeo de Derechos Humanos: Estudio de casos». En Anuario de derecho penal y ciencias penales, Tomo 43, 1, 1990; en concreta referencia a la tortura y al caso Irlanda c. Reino Unido, p.186 y ss.; Bueno, G. «El concepto de tortura y de otros tratos crueles, inhumanos o degradantes en el derecho internacional de los derechos humanos». En Nueva Doctrina Penal, Editores del Puerto, Buenos Aires, 2003, p. 606.

28 Bueno, G. op.cit., p. 609.

29 Información del caso en «El Tribunal de Estrasburgo condena a Francia por un caso de tortura». En Diario El Pais, 29 de julio de 1999. 
Menos dificultades aparentes ha habido en la concreción de lo que ha de entenderse por tratos inhumanos o degradantes, pues el sistema elegido ha sido el de la exclusión o subsidiariedad, esto es: el trato inhumano o degradante es el que causa dolor físico psíquico, coloca a la víctima en situación de humillación profunda, le hace sentirse en total indefensión y a merced de quien los aplica, tratado cual si fuera un animal, etc., pero no llega a ser tortura. Ciertamente que se puede hablar de inconcreción, pero también hay que aceptar que la relación de actos inhumanos o degradantes podría ser interminable, y, por ello mismo, sería inviable incluirla en una Ley. Ese criterio de subsidiariedad ha sido también el seguido por el TEDH. El artículo 16.1 solo permite entender que la diferencia entre tortura y trato inhumano depende de la intensidad del sufrimiento provocado ${ }^{30}$. Pero hay que notar que en artículo 16.1 no se alude a finalidades que haya de perseguir quien inflige esos tratos.

Por otra parte, y tal vez por eso mismo, la Convención sobre la tortura no aporta grandes precisiones sobre lo que debe entenderse por "dolores graves, físicos o mentales", y por eso mismo el margen de arbitrio que puede haber en su apreciación es significativo, especialmente en lo que se refiere al dolor "mental". Igualmente, la exigencia de una finalidad u objetivo (obtener información) deja en un limbo conceptual los casos en los que el maltrato físico es gratuito, por mero deseo de afirmar el poder o aterrorizar a las personas, con lo cual es teóricamente posible que esa clase de acciones se puedan degradar a la condición de trato inhumano o degradante, en la medida en que, de acuerdo con el artículo 16.1 de la Convención contra la tortura, para la apreciación del trato inhumano no es preciso perseguir objetivo alguno.

En todo caso, la determinación completa de lo que es inhumano o degradante o cruel no puede ser catalogado a priori. Un ejemplo: el aislamiento, con incomunicación, aun disponiendo de medios de alimentación e higiene, puede transformarse en un tormento si se prolonga excesivamente, o bien la observación constante, cual moderna panóptica, que puede resultar degradante al comportar la supresión total de la intimidad. Se trata solo de dos ejemplos, pero ilustrativos, pues tanto valen para el régimen penitenciario como para un delito de secuestro.

30 Convención sobre la tortura, Art. 16 1. "Todo Estado Parte se comprometerá a prohibir en cualquier territorio bajo su jurisdicción otros actos que constituyan tratos o penas crueles, inhumanos o degradantes y que no lleguen a ser tortura tal como se define en el artículo 1, cuando esos actos sean cometidos por un funcionario público $\mathrm{u}$ otra persona que actúe en el ejercicio de funciones oficiales, o por instigación o con el consentimiento o la quiescencia de tal funcionario o persona. Se aplicarán, en particular, las obligaciones enunciadas en los artículos 10,11, 12 y 13, sustituyendo las referencias a la tortura por referencias a otras formas de tratos o penas crueles, inhumanos o degradantes. 


\section{III.2. Derecho español}

El CP español dedica un título (el VII del Libro II) a las torturas y otros delitos contra la integridad moral ${ }^{31}$. No voy a hacer aquí una exposición del análisis doctrinal de estos delitos, pues no es el objetivo de estas páginas. El art. $174^{32}$ define la tortura siguiendo puntualmente la Convención, que España ratificó por Instrumento de 28 abril 1989 entrando en vigor el 1 de septiembre de ese mismo año.

Paralelamente a lo que sucede en el derecho internacional, la distinción entre tortura y trato inhumano se establece en la intensidad. Pero el derecho español complica el tratamiento del problema, pues, a diferencia de lo que puede ver en los instrumentos jurídicos internacionales, amplía la incriminación a cualquier otro atentado a la integridad moral, y trata en otro artículo el sometimiento a trato degradante que menoscabe gravemente la integridad moral, lo cual puede conducir, como señala Tamarit al despropósito de que quepa calificar como torturas supuestos que por carecer de la nota de gravedad no colmarían las exigencias del tipo de trato degradante. En esta misma línea de decisiones legislativas discutibles se puede incluir como que se profundice en el concepto de sufrimiento mental, mencionado expresamente la supresión o disminución de las facultades de conocimiento, discernimiento o decisión. Pero ese paso ampliatorio queda diluido, en cuanto a la amatividad, cuando el precepto incluye, como cierre, cualquier otro atentado a la integridad moral, lo cual además se repite en el artículo 175, que castiga al funcionario que atentare contra la integridad moral sin incurrir en lo dispuesto en el art.174. Todo sumado produce un auténtico caos conceptual.

\section{III.3. Situaciones objetivas inhumanas o degradantes}

En los últimos párrafos hemos examinado someramente las declaraciones internacionales y el derecho español en lo que concierne a la tortura y los tratos inhumanos. Pero hay otra dimensión del problema que también conviene traer a colación:

31 Sobre este Título, vid., por todos, Tamarit Sumalla, J.M. Comentarios al Código penal español. $6^{\mathrm{a}}$ ed., dir. por G. Quintero, vol. I, Thomson Reuters, Cizur Menor, 2011, p.1059 y ss.

32 Art. 174: 1. Comete tortura la autoridad o funcionario público que, abusando de su cargo, y con el fin de obtener una confesión o información de cualquier persona o de castigarla por cualquier hecho que haya cometido o se sospeche que ha cometido, o por cualquier razón basada en algún tipo de discriminación, la sometiere a condiciones o procedimientos que por su naturaleza, duración u otras circunstancias, le supongan sufrimientos físicos o mentales, la supresión o disminución de sus facultades de conocimiento, discernimiento o decisión o que, de cualquier otro modo, atenten contra su integridad moral. El culpable de tortura será castigado con la pena de prisión de dos a seis años si el atentado fuera grave, y de prisión de uno a tres años si no lo es. Además de las penas señaladas se impondrá, en todo caso, la pena de inhabilitación absoluta de ocho a 12 años.

2. En las mismas penas incurrirán, respectivamente, la autoridad o funcionario de instituciones penitenciarias o de centros de protección o corrección de menores que cometiere, respecto de detenidos, internos o presos, los actos a que se refiere el apartado anterior. 
las situaciones inhumanas. Es común referirse a los tratos que unas personas dan a otras directamente, y los podemos calificar como torturas o actos inhumanos, pero no se emplea esa calificación cuando se trata de condiciones objetivas en las que una o muchas personas pueden verse. A esa reflexión se le puede objetar, lógicamente, que requiere establecer con precisión dónde comienza lo cruel o lo inhumano. Que las leyes o las Constituciones recojan esa prohibición, no significa que la realidad penal la contradiga.

En muchos Estados del planeta cuyos sistemas proclaman la prohibición de los malos tratos y el respeto a la dignidad humana, los establecimientos penitenciarios, si es que merecen ese nombre, son en sí mismos una "máquina cruel" de destrozar seres humanos. No hace falta citar países concretos, pero en muchos existen prisiones superpobladas, que están gestionadas desde hace años por los propios reos. El autogobierno sustituye al Estado, y la consecuencia es la corrupción y violencia. El siguiente paso es previsible: cientos de muertes a causa de motines, incendios o luchas internas por el control de los presidios.

En la lista de tragedias puede citarse al incendio de la prisión de Comayagua, donde en 2012 murieron calcinadas 362 personas, pero la lista puede ampliarse terroríficamente. De acuerdo con informaciones aparecidas en enero de $2014^{33}$ se filmó en video, por los propios presos del complejo penitenciario de Pedrinhas, en Maranhão, al norte de Brasil, la escena de tres cuerpos muertos y decapitados, con sus cabezas rodando, a lo que se añadía a unas imágenes que mostraban a un preso descuartizado en un contenedor del mismo presidio.

Algunos gobernantes ya han asumido la calificación que merece la situación: un sistema penitenciario que lance a un ser humano a las fauces de un monstruo en el que va a sufrir extorsiones, palizas y posiblemente la muerte, es inhumano y cruel $^{34}$. La Comisión Interamericana de Derechos Humanos recuerda a los Estados miembros $^{35}$ que la CIDH recuerda que el Estado se encuentra en una posición especial de garante frente a los derechos de las personas privadas de libertad. Esto hace que el acto de reclusión implique un compromiso específico y material del Estado de garantizar la vida e integridad personal de los reclusos. El deber de garantizar implica que éste debe tomar todas las medidas necesarias para prevenir situaciones de riesgo que, como la presente, amenacen gravemente los derechos fundamentales de los reclusos.

33 Vid. diario El Mundo.

34 A raíz de la muerte de 81 reos por un incendio en una cárcel, suceso que conmocionó a Chile, el presidente Piñera declaró que el sistema penitenciario era "inhumano" (cfr. El País, 8 de diciembre de 2010). Fiscal de la Corte Suprema: Sistema penitenciario es "inhumano". La fiscal de la Corte Suprema chilena, Mónica Maldonado, señaló que el sistema penitenciario es "inhumano, degradante y cruel".

35 Comunicado de prensa de 10 de agosto de 2012, a raíz de la muerte de siete internos en una cárcel brasileña. 
En este sentido, los Estados tienen el deber de garantizar que los centros penitenciarios cuenten con estructuras adecuadas y seguras, así como con medios idóneos, planes de acción y personal suficiente y capacitado para mantener la seguridad en los centros penales y hacer frente a este tipo de situaciones de emergencia.

¿Puede afirmarse que eso sucede solo en países que no forman parte de la Unión Europea? No lo creo. En España existen centros penitenciarios, aunque sean la minoría, en donde está garantizado el hacinamiento, la inexistencia de intimidad, las amenazas, todo ello en un clima de violencia que incluye, eventualmente la sodomización violenta. El sistema es, por eso solo, cruel, pues ninguna justificación de la prisión puede acoger eso.

Se dirá, también, que esos ejemplos se circunscriben al mundo penitenciario. Pero tampoco es verdad: son conocidos tratos de humillación y desprecio, o de dolor innecesario, sufridos en la prestación de servicios sanitarios, y no hace falta entrar en la polémica sobre los "límites éticos" de los cuidados paliativos. Y si se quiere ampliar el círculo, podemos entrar en el tema de los desahucios en determinadas circunstancias, sin alternativas, expresamente declarados violaciones de los derechos humanos por el TEDH ${ }^{36}$.

La crueldad y la "inhumanidad" son, pues, una especie de gas invisible que aparece en las más variadas situaciones. De nuevo el Derecho, y en especial el Derecho penal, reconocerán que su capacidad es limitada y que solo puede actuar en situaciones extremas, pero también de eso habría mucho que discutir.

\section{III.4. La crueldad de los individuos y su valoración penal}

La lucha contra los tratos crueles, inhumanos, degradantes, se ha centrado, como es lógico, en la promoción de acuerdos internacionales orientados a su prohibición, y se ha pasmado también en la introducción de preceptos penales que tipifican su práctica. Pero también está presente, y mucho más aún, la crueldad con la que unos individuos tratan a otros. Los criminales "individuales", pueden cometer inimaginables atrocidades.

El CP español, como sabemos, tipifica (art.173 CP) los tratos inhumanos y degradantes que pueda realizar un particular. Además de esa incriminación genérica, tenemos otras disposiciones penales en las que expresa o tácitamente aparece la crueldad, la degradación, el trato inhumano o la humillación.

La agravante de ensañamiento es sin duda la más significativa expresión de la intervención del derecho penal contra la crueldad. Eso quiere decir que reine acuerdo acerca de su contenido jurídico, pues en este tema es fuerte la presión de la "interpre-

36 Plataforma de afectados por la hipoteca (PAH) "El Tribunal Europeo de Derechos Humanos paraliza el desahucio de una madre con dos hijos en el barrio de Vallecas", Mundo Obrero, $14 / 01 / 2013$. 
tación popular", que llega a incluir las puñaladas a un muerto. Es opinión unánime que la brutalidad cruel, el aumento deliberado del dolor, comporta un aumento de la antijuricidad. Que el aumento sea deliberado no significa que haya que probar una «complacencia» del ejecutor, basta con que sea una acción decidida, dolosa, y no consecuencia de un repentino episodio de violencia. Más complicada es la admisión del ensañamiento ejercido por medios morales, como serían las vejaciones no violentas o que no causan por sí mismas dolor físico con las que se acompañará la ejecución del delito. Pero creo que es más prudente, en esos casos, apreciar un concurso de delitos con el de infligir tratos degradantes.

El castigo de la trata de seres humanos ha de tenerse como una decisiva aportación penal a la, lucha contra los tratos inhumanos y degradantes, en ejecución, por supuesto, de un amplio elenco de disposiciones y acuerdos internacionales. Recordemos que se tipifica la esclavitud, la extracción de órganos, los trabajos forzados. Muy cerca de estos delitos se han de incluir los relativos al forzamiento a la prostitución y el tráfico de personas con ese fin.

La propia definición básica de las lesiones (...el que, por cualquier medio o procedimiento, causare a otro una lesión que menoscabe su integridad corporal o su salud física o mental) da entrada a posibles acciones en las que el daño psíquico de las agresiones físicas puede superar a la entidad material de ellas, sin perjuicio de que además esté contemplada la agravación por ensañamiento.

En un plano algo menor, pero sin perder el componente de lucha contra los tratos inhumanos y degradantes, hay que incorporar la crueldad en las agresiones sexuales, por el carácter particularmente degradante o vejatorio de la acción, así como la discriminación racista en el trabajo.

\section{LA LLAMADA TORTURA DE NECESIDAD}

Nuestro tiempo ha conocido nuevas formas de terrorismo, y no voy a entrar ni en ello ni en las especializaciones que el derecho penal, procesal y penitenciario ha registrado a consecuencia de ello. El problema no es solo ese, siendo importante, sino la irrupción de una nueva manera de plantear la lucha contra la criminalidad, comenzando, por supuesto, por el terrorismo, pero sin limitarse a él. En el mundo occidental se habla repetidamente de lo censurable que es la existencia de la prisión especial de Guantánamo, en la que, según Amnistía Internacional, y en nombre de la "guerra global" declarada bajo la presidencia de Bush, EE.UU. utiliza la tortura física y psicológica como práctica rutinaria para "extraer información ${ }^{37}$.

37 En 2012 Amnistía Internacional publicó el informe 'Guantánamo: A Decade of Damage to Human Rights'. Un estudio jurídico, Rodríguez de las Heras, L. «Derecho Internacional Humanitario y lucha contra el terrorismo: El caso Guantanamo». En Eunomía, Revista de Cultura de la Legalidad, $\mathrm{n}^{\mathrm{o}}$ 6, marzo-agosto 2014, p.174 y ss. 
Guantánamo puede ser un ejemplo, pero el problema profundo, y es el que aquí interesa es el de la creciente idea de que en la lucha contra cierta clase de crímenes, especialmente los terroristas, el Estado no ha de tener limitación alguna, pudiendo hacer uso de todos los recursos que tenga a su alcance, incluida la tortura, si con ella se puede conseguir que el detenido diga, por ejemplo, dónde está la persona secuestrada o desactive una bomba de relojería ${ }^{38}$, y ante esa posibilidad reaccionan los que estiman, con razón que el derecho no puede renunciar a sus principios en nombre de la excepcionalidad de la situación ${ }^{39}$ ni puede admitir que los derechos de los detenidos son provisionales.

Esas ideas no gozan del consenso que se pueda suponer en un Estado de Derecho, ya sea la Administración norteamericana o el Estado de Israel en su lucha contra los palestinos ${ }^{40}$. De esas concesiones a la tortura discrepaba, y es una opinión importante por cuanto Alemania produjo una ley que autorizaba el derribo de aviones secuestrados, que fue derogada por el Tribunal Constitucional, cuyo Presidente Hans-Jürgen Papier manifestó, al dar lectura al fallo "...la protección de la dignidad del hombre es estricta y no puede abrirse a limitaciones", así como que "la dignidad humana no es susceptible de ser relativizada, limitada o ponderada con otros intereses públicos o privados" ${ }^{\prime 4}$.

Pese a que esa pueda ser la "postura natural" de un jurista, no han faltado prestigiosas voces discrepantes que opinan lo contrario, $y$, como significativa muestra basta citar por todos a Niklas Luhmann, quien rechaza la idea misma de que hay principios o normas irrenunciables y, por lo tanto, en un caso como el de la bomba de relojería o si se planteara la posibilidad de abatir al avión que se dirige a estre-

38 Sobre este problema se produjo un amplio debate en Alemania. Es de gran interés el artículo de Luis Greco «Las reglas detrás de la excepción.Reflexiones respecto de la tortura en los grupos de casos de las ticking time bombs». En InDret, 4, 2007.

39 Algunos de estos problemas los abordé en mi artículo «Las decisiones extremas ante el derecho penal», en Un derecho penal comprometido. Libro Homenaje al Profesor Dr. Gerardo Landrove Díaz, Valencia, Tirant lo Blanch, 2011. Vid., también Molina, F. «La ponderación de intereses en situaciones de necesidad extrema ¿es justificable la tortura?». En La respuesta del derecho penal ante los nuevos retos: IX jornadas de profesores y estudiantes de derecho penal de las Universidades de Madrid, celebradas en la Universidad Rey Juan Carlos los días 8, 9 y 10 de marzo de 2005, coord. por R. Alcácer Guirao y A. Cuerda Riezu, 2006, p. 265 y ss.

40 Concretamente, el Tribunal Supremo de Israel consideró inconstitucional el recurso a la violencia sobre detenidos, pero exceptuando precisamente el caso de las bombas de relojería, en el cual, siempre que una ley expresamente lo regulara, se podría aceptar. La cuestión se planteaba a propósito de la excepciones que contenían los artículos 8 y 9 de la ley israelí sobre la Dignidad Humana (Basic Law on Human Dignity) de 5 de agosto de 1995. La solución buscada (la específica cobertura legal que legitime la excepción), conduce precisamente a uno de los puntos capitales en este problema: la posibilidad misma de que el derecho regule a priori su propio decaimiento.

${ }^{41}$ Cfr. A propósito de estas declaraciones, J. Luther, "Razonabilidad y dignidad humana", cit. p. 313. 
llarse contra un edificio habitado, pero en cuyo interior viajan personas inocentes, no viene al caso invocar el respeto a la dignidad humana y renunciar a derribar el avión o recurrir a la tortura como solución para encontrar la localización del artefacto ${ }^{42}$.

Luhmann añade, además, y eso es lo más importante para un penalista, que la eventual legitimidad de la tortura en esos casos límite -no sería correcto decir que Luhmann también estaba refiriéndose a Guantánamo, entre otras cosas porque cuando expuso las ideas que comentamos todavía no existía la cárcel de seguridad de Guantánamo, que se creó en 2002-, tendría que estar expresamente acogida en las legislaciones de las democracias modernas, con lo cual no se trata ya de dejar en manos de los Tribunales la apreciación de un eventual estado de necesidad, sino de incluir en la ley un principio general de decaimiento posible de los derechos humanos.

El artículo 2 de la antes citada Convención sobre la Tortura declara que ninguna situación excepcional puede permitir a un Estado justificar la tortura. Doctrinalmente se añade que no es posible argumentar sobre la necesidad de equiparar armas entre quien interroga y el detenido, y ni siquiera se admite que pueda haber una valoración de la vida y de la dignidad humana que conduzca sostener que unas vidas valen menos que otras, o que unos individuos son más o menos dignos que otros ${ }^{43}$.

En este delicadísimo asunto es fundamental el orden del razonamiento: si se tortura a un detenido porque es la única manera de localizar la bomba que puede hacer volar la escuela llena de niños, por ejemplo, el juzgador deberá ponderar los intereses en conflicto. Pero sería un pavoroso salto atrás aprobar a priori la procedencia y justificación de la tortura.

No se puede olvidar que la eximente de estado de necesidad la invoca quien viene acusado de un delito, y por eso mismo todas las situaciones subsumibles en

42 Luhman, N. Gibt es in unsere Gesellschaft noch unverzichtbare Normen?, Heidelberg, C.F. Müller, 1993. En opinión de Luhmann si el terrorista es capturado antes de que la bomba explote, es admisible levantar la "norma irrenunciable" de la dignidad humana en este evento, para obtener la confesión sobre la ubicación de la bomba y la manera de desactivarla. Luhmann sugirió entonces la aplicación de tortura con la vigilancia de jueces internacionales, observación televisada de la escena en Ginebra o Luxemburgo, y dirección a distancia mediante el uso de aparatos de telecomunicación. Para Luhmann, esta no es una solución "satisfactoria", pero "sería peor no hacer nada y ofrendar inocentes al fanatismo de los terroristas". Un importante análisis de esas ideas, y del ulterior debate habido en Europa sobre esa cuestión y la del derribo de aviones, vid. el excelente artículo de Jorg Luther "Razonabilidad y dignidad humana", Revista de Derecho Constitucional Europeo, número 7, Enero-Junio de 2007. En relación con esas ideas vid. también, Juan-Luis Pintos, "Algunas consideraciones sobre los Derechos Humanos en sociedades policontexturales", Santiago de Compostela / Braga, 1999, en Justiça e direitos humanos, Braga, Universidade do Minho, Centro de Estudos Humanísticos, 2001, p. 157-169.

43 Ribotta, S. «Reflexiones sobre la tortura». En Papeles El tiempo de los derechos, Instituto de Derechos Humanos Bartolomé de las Casas, Universidad Carlos III de Madrid, Número: 5, 2011, p.6 y s. 
la eximente son situaciones excepcionales en la que la única salida, según el acusado, ha sido realizar un tipo de delito, por lo tanto, una decisión excepcional pues todo delito es una excepción a la normalidad y no por eso se acepta como regla la exención de responsabilidad ni la atenuación.

Partiendo de ello es imposible regular a priori que la tortura es delictiva salvo que sea precisa, como si se pudiera establecer una analogía e identidad valorativa entre la violencia coactiva y proporcional que ha de aplicarse para practicar una detención justificada y la aplicación de tortura a un detenido con el fin de salvar un bien jurídico. Es por ello incompatible afirmar que se prohíbe la tortura salvo que haga falta, porque eso es lo mismo que renunciar al principio mismo, y ahí entra la conocida tesis de Roxin: la superioridad moral del Estado de Derecho sobre el delincuente proviene de que nunca se vale de los medios que usa el criminal ${ }^{44}$.

La tortura sobre un detenido, porque sabe dónde está la bomba o el niño secuestrado, constituye en todo caso un acto contra su dignidad humana, que no pierde esa condición por el reconocimiento de la dignidad de las personas que pueden perder la vida si la bomba no se desactiva. De ahí extraemos dos conclusiones que a buen seguro a nadie satisfacen, pero que nos ponen en la senda de la renuncia a esperar encontrar una respuesta inequívoca del derecho: que la prohibición de la tortura como trato incompatible con la dignidad del hombre no puede admitir excepciones en nombre de la tesis de que ningún principio es permanente; y que el reconocimiento de la dignidad del agresor no supone olvido de la dignidad de las posibles víctimas.

La antes citada tesis de Luhmann, que se quiera o no aceptar, constituye el epicentro del debate sobre este problema, tiene un "atractivo fatal", en tanto que magnifica las ideas de eficacia y legitimidad de las democracias para defenderse frente a los que las quieren destruir. Pero no es posible caer en tan simplista valoración, sino que es preciso analizarla pues tiene muchos más seguidores de lo que en apariencia se pueda pensar.

Como antes dije, el punto de partida de Luhmann parece fácilmente comprensible: no hay regla sin excepción, y las prohibiciones internacionales de la tortura no pueden ser una excepción a la posibilidad de excepción. A favor de que, efectivamente, la prohibición de la tortura no admite excepciones, se ha pronunciado el TEDH (S.7-7-1989), en la que manifestó que la prohibición de excepciones a la prohibición de la tortura y de los tratos inhumanos y degradantes que hace el art.15.2 de la Convención Europea de Derechos Humanos ( que da base al Título VII del Libro II de nuestro Código penal) no admite excepciones, ni en nombre de la lucha contra el terrorismo ni tampoco contra otros fenómenos criminales graves

44 Roxin, C. ¿Puede llegar a justificarse la Tortura? Trad, J. González Navajas, México DF, Instituto Nacional de Ciencias Penales, Conferencias magistrales, 2010. 
como el tráfico de drogas, que tanto preocupa a los Estados modernos. La posición del TEDH sobre la inderogabilidad de la prohibición de la tortura se concreta en los casos Soering c. Reino Unido, 7 de julio de 1989, Öcalan c.Turquía, de 12 de marzo de 2003 y Jalloh c. Alemania, de 11 de julio de $2006^{45}$, y esa posición es la misma que la del Comité contra la Tortura de Naciones Unidas. Posteriormente, en Sentencia de 11 de julio de 2006 (caso Jalloh contra Alemania ${ }^{46}$ ).

El rechazo a la imposibilidad de admitir excepciones parte de un principio intangible: el respeto a la dignidad humana no decae nunca, y, menos aún, para los funcionarios públicos. Sucede, no obstante, que muchos analistas jurídicos del problema rechazan precisamente ese planteamiento de partida en torno a la dignidad. En síntesis la objeción se presenta del siguiente modo: todos los derechos fundamentales, y, con ellos los que tienen la consideración declarada de derechos humanos, son expresión y consecuencia de la dignidad del hombre, por lo que no es correcto oponer esa dignidad frente a otros intereses como si en esos otros intereses no estuviera también presente la dignidad. Es cierto que despreciar la integridad de los detenidos ofende a su dignidad como personas; pero también se produce el mismo resultado si se desprecia la vida y la dignidad de aquellos a los que se quiere salvar.

Ahora bien, si no se plantea el problema como enfrentamiento entre dos posibles ofensas a la dignidad, sino como conflicto entre la vida de unos y la seguridad de los otros, la conclusión puede ser otra. Si se compara la destrucción directa de dignidad y la integridad del detenido por el propio Estado, como decisión fatal que se toma al servicio del objetivo de salvar la vida de otros, se romperá el pretendido conflicto entre dignidades humanas.

El contra-argumento a lo que acabo de decir es fácil de formular: la muerte de los que están en el objetivo (cuando la bomba explote) puede presentarse como algo absolutamente seguro, y no meramente probable, con lo que la cuestión vuelve a plantearse como opción entre las vidas de unos y la dignidad del detenido y su derecho a no ser torturado. El que tenga que tomar la decisión tendrá que ponderar los vidas y valores enfrentados sin pretender invocar a la dignidad humana como criterio presente solamente en relación con uno u otro sujeto (el detenido y el o los que pueden morir).

En suma, por la vía de la dignidad, entendida como sustrato de todos los derechos fundamentales, no es posible derivar una solución; pero tampoco es posible encontrar una respuesta del derecho dejando a la dignidad del hombre relegada a la

45 De acuerdo con la buena selección que hacen Mieres, J.L; Presno, M.A.; Sarmiento, D. Las sentencias básicas del Tribunal Europeo de Derechos Humanos. Madrid, Civitas, 2007.

46 En el caso se forzó, usando violencia, a un detenido a ingerir eméticos a fin de que expulsara la droga que portaba en su estómago. El Tribunal estimó que el modo en que se ejecutó la acción era inicuo y atentaba contra la dignidad. 
condición de mero principio inspirador y retórico, pues entonces el paso al enfrentamiento entre intereses sería inevitable por voluntad del derecho. La dignidad ha de ser algo más y algo diferente. En problemas como los referentes, y es un ejemplo, a la eutanasia y los cuidados paliativos que pueden acortar la vida, es precisamente la dignidad humana quien marca la extensión del derecho a la vida y del deber de protegerla que otros tienen.

¿Es posible alguna reflexión final? Posiblemente muchas, y a buen seguro lo que el jurista cree que habría que hacer en una situación límite no se corresponderá con lo que opinan legítimamente otros ciudadanos. Las leyes son modestos esfuerzos que han hecho los humanos para poder convivir dominando a los instintos, o a eso tan temible que se designa como justicia popular. Las decisiones o sentencias que en nombre de las leyes se adoptaran en una situación de emergencia serían acusadas, tal vez, de estar desconectadas de la realidad, y de ser meramente simbólicas. De nada serviría aducir que instituciones como el estado de necesidad nacieron precisamente para situaciones extremas, y que es ahí donde se han de ponderar y valorar los intereses y derechos enfrentados. Pero la reacción sería, probablemente, contraria, y primaría la ideología de guerra, frente a la que decae el gobierno de las leyes, lo cual tampoco podría someterse a la objetivación jurídica, habría que confiarlo a la conciencia de los que tengan que decidir. 



\title{
LA CRUELDAD HUMANA EN LA LITERATURA ${ }^{1}$
}

\author{
GABRIO FORTI \\ Profesor de Derecho Penal. Università Cattolica del Sacro Cuore (Milán)
}

\section{UNA «NECESIDAD DIFERENTE»: LA LITERATURA COMO «ATENCIÓN» A LA SINGULARIDAD DE LOS SERES HUMANOS Y SUS HISTORIAS}

Después de haber sido invitado a hablar en la conferencia preparatoria del Congreso Mundial contra la pena de muerte, me siento animado a abordar el tema que ahora voy a discutir - «La crueldad humana en la literatura»- con un significado algo más preciso de aquel que podría evocar el término «crueldad», lo que sugiere al menos dos limitaciones de alcance.

En primer lugar, en esta presentación, consideraré la crueldad humana como aque1la infligida principalmente (o, al menos, de manera más directa) por los Estados, los gobiernos o en general por autoridades y poderes públicos (incluyendo poderes sociales y económicos) sobre los individuos, visto que la pena de muerte (aparte de sus usos metafóricos) es habitualmente entendida como un castigo impuesto por el Estado, por el pueblo o al menos por poderes colectivos. La violencia y la crueldad entre las personas individuales (un tema muy bien tratado en un estudio criminológico publicado recientemente en Italia, con muchas citas bibliográficas y referencias a películas) $)^{2}$, permanecerá en el fondo de mi exposición. Habiendo

1 Traducción del inglés de Agustina Alvarado Urízar, Doctoranda en Ciencias Jurídicas, Università degli Studi di Milano (Italia) y Universidad de Girona (España).

2 Ceretti, A.; Natali, L. Cosmologie violente. Percorsi di vite criminali. Milano, Cortina, 2009. 
dicho esto, de todos modos estoy dudoso sobre si las consideraciones que surgirán de mi discurso, podrían ser eventualmente aplicadas a esta forma tan especial de crueldad del Estado, que implica genocidios y violencia contra pueblos enteros: un tema -que la literatura ha tratado como asesinatos en masa, en primer lugar y principalmente el Holocausto (o, mejor dicho, la Shoah)-merecedora por sí sola al menos de una conferencia exclusivamente para ella ${ }^{3}$, como lo hicimos recientemente en mi Universidad tratando los delitos contra la humanidad y, especialmente, las obras de Primo Levi y sus implicancias para la ley y la Justicia ${ }^{4}$. Tal peculiaridad tal vez dependa, más allá de los rasgos característicos que por ejemplo la literatura atribuye al Shoah, del problema que plantea separar la historia, la literatura y la mitología, los tres relatos arquetípicos, que hace que se requiera una discusión que «ya no reside cómodamente dentro de las antiguas disciplinas» sino que «exige una nueva conciencia y una reevaluación emocional y metodológica» ${ }^{5}$.

En segundo lugar, me aferraré a un significado más bien delimitado del término «crueldad». Uno de los usos actuales de este concepto es «comportamiento que causa dolor o sufrimiento a los demás, en modo especialmente deliberado» ${ }^{6}$. Sin embargo, en el Código Penal italiano, tenemos una circunstancia agravante (art. 61, n. 4) para los delitos cometidos utilizando crueldad contra las personas («...l'aver agito con crudeltà verso le persone») ${ }^{7}$, donde la «crueldad» es comúnmente entendida por los jueces como una violencia deliberada y maliciosa ejercida más allá de lo que se necesita para alcanzar un determinado objetivo ${ }^{8}$. Creo que, además de la idea subjetiva de «crueldad», es precisamente en este exceso de violencia, es decir, en el uso de la violencia más allá de lo que puede ser necesario, razonable o aceptable, en donde podemos encontrar uno de los principales y más relevantes significados del concepto, en el que tengo la intención de centrarme 9 .

3 Sobre el tema general, véase: Schwartz, Y. «Holocaust Literature: Myth, History, and Literature». En Brandes University, International Center for Ethics, Justice and Public Life, Literary Responses to Mass Violence. Brandeis University, 2004, pp. 97-107; Rosen, I. «Literaried Testimonies: Life Histories of Holocaust Survivors of Austro-Hungarian Origin», ibi, pp. 17-34.

4 Conferencia organizada por el «Centro Studi "Federico Stella" sulla Giustizia penale e la Politica criminale: Se questo è un uomo. Narrare la resistenza al disumano, Università Cattolica del Sacro Cuore di Milano», 15 y 16 de Mayo de 2013.

5 Schwartz, Y. op. cit. pp. 98, 106.

6 Oxford Advanced Learner's Dictionary, Oxford University Press, Oxford-New York, 2000.

7 Art. 61, n. 4, Codice penale italiano: «l'avere adoperato sevizie, o l'aver agito con crudeltà verso le persone».

8 Véase entre otros, Corte de Casación, sección I, 88/747; sección I 08/25276.

9 Véase Vocabolario della Lingua Italiana Zingarelli, Zanichelli, Bolonia, 2012, donde «cruel»se define como «algo que causa aflicción, dolor, sufrimiento», es decir, de una persona, sin sentir compasión o remordimiento por los sufrimientos infligidos a otras personas. 
Este es también uno de los significados observados en la Octava Enmienda de la Constitución estadounidense, que prohíbe «castigos crueles e inusuales» ${ }^{10}$ (que fue apropiado por los autores americanos de esta regla a partir de la Declaración de Derechos Inglesa de 1689) ${ }^{11}$. En este punto, no tengo ni la intención de trepar a través de la enorme pila de jurisprudencia sobre esta Enmienda ${ }^{12}$, ni tampoco la intención de profundizar las razones por las que tanto los tribunales estadounidenses federales y de distrito como la Corte Suprema (por ejemplo, en el campo del tratamiento y la disciplina de los presos y condenados), «han alternativamente extendido y circunscrito las condiciones que se consideran humanamente tolerables» ${ }^{13}$. Sin embargo, las palabras que usa la Enmienda y las diferentes maneras en que han sido interpretadas, además de ser muy relevantes para el tema de la pena de muerte, ofrecen una prueba consistente de cuánto resultan movibles los límites entre la violencia proporcionada y excesiva, y cómo dichas sensibilidades pueden diferir en nuestras definiciones de «crueldad» pura. Como señala Richard Posner «la cláusula de la Declaración de Derechos, se añadió con poco debate o discusión, para apaciguar a quienes estaban preocupados de que el gobierno central creado por la Constitución pudiese imitar la práctica británica de usar el castigo penal para intimidar a los oponentes políticos». Por lo tanto, «no se hizo ningún esfuerzo para precisar la prohibición», como ello «hubiera sido una pérdida de tiempo y podría haber desatado la polémica debilitante; era más sencillo ponerse de acuerdo sobre las generalidades que en las particularidades. Los tribunales estarían allí para precisar la prohibición cuando

10 Como generalmente se recuerda, los cuatro principios para decidir si un castigo es o no especialmente cruel e inusual fueron determinados por el juez William Brennan, que, en Furman v. Georgia (408 U.S. 238 (1972), señaló que el «predicado esencial» es «que la pena no debe por su gravedad ser degradante para la dignidad humana», no debe ser impuesta en una «forma arbitraria» en su totalidad, y no debe ser «clara y totalmente rechazada por toda la sociedad»o «manifiestamente innecesaria». Por otra parte, remarcó: «La función de estos principios, después de todo, es simplemente proporcionar medios por los cuales un tribunal puede determinar si el castigo conminado se ajusta a la dignidad humana. Por consiguiente, están relacionados entre sí y, en la mayoría de los casos, será su convergencia la que justifique la conclusión de que un castigo es «cruel e inusual». Por ende, el examen será normalmente acumulativo: si un castigo es inusualmente grave, si hay una fuerte probabilidad de que se inflija de forma arbitraria, si es rechazada sustancialmente por la sociedad contemporánea, y si no hay ninguna razón para creer que sirva a algún fin penal con más eficacia que un castigo menos severo, entonces la respectiva imposición de tal castigo viola el comando de la Cláusula según la cual el Estado no puede imponer penas inhumanas e incivilizadas sobre aquellos condenados por delitos».

11 Posner, R.A. Law and Literature. London, $3^{\mathrm{a}}$ ed., Harvard U.P., Cambridge, Mass.-London, 2009, pp. 300.

12 Para una visión general de la pena de muerte en los Estados Unidos, véase Garland, D. Peculiar Institution: America's Death Penalty in an Age of Abolition. Belknap Press, 2010 (véase también la traducción italiana, La pena di morte in America, ed. por A. Ceretti, Il Saggiatore, Milano, 2013).

13 Sobre este criterio, véase Dayan, C. «The Law is a White Dog». En Princeton University Press, Princeton, NJ, 2011, p. 78. 
fuese necesario». Posner menciona, como otra razón para esta vaguedad del texto y por lo tanto para no definir mejor la prohibición constitucional, el objetivo de mantener «su capacidad de adaptación a los cambios sociales y tecnológicos - cambios en las concepciones de la sociedad sobre la crueldad, de la frecuencia de castigos particulares, y en la gama tecnológicamente posible de métodos de castigo» ${ }^{14}$.

Esta última observación puede ser fácilmente recogida como una buena sugerencia para cualquier debate sobre «la literatura y la crueldad», ya que, obviamente, la literatura no sólo está estrictamente involucrada -como causa y efecto- en los «cambios de las concepciones de la sociedad sobre la crueldad», sino que, aún más importante, a menudo influye en los cambios de las fronteras culturales. Este cambio se debe al peculiar rol social y cultural que juega la literatura, así como a su naturaleza intrínseca, lo que influye (y mejora) la sensibilidad, en primera instancia de los lectores, y luego también del público en general; primero y ante todo, por cuanto respecta a determinar cuándo es «necesaria» la fuerza o la violencia ejercida contra otros seres humanos y, a continuación, en lo relativo a lo que puede ser considerado «cruel» o «no cruel», usual o inusual.

Por el sólo hecho de cuestionarse tal necesidad, creo que la literatura ha jugado y juega hoy en día un papel muy relevante en la divulgación, denuncia y profundización en las raíces culturales más íntimas de la pena de muerte, y de cualquier otro tipo de castigo cruel o inhumano ${ }^{15}$ infligido a seres humanos (y animales también $)^{16}$.

Si siguiendo a Aristóteles ${ }^{17}$ dibujamos la famosa distinción entre historia y poesía, entonces parece que la función de este último no es la relación de «lo que

14 Posner, R.A. Law and Literature, p. $300 \mathrm{f}$.

15 En este sentido es muy destacable la diferente redacción de la Constitución italiana, que (art. 27.3) prohíbe «cualquier castigo que consista en tratamientos contra el sentido de la humanidad» y la de los EE.UU. cuya Octava Enmienda, prohíbe «castigos crueles e inusuales», que en cierto sentido eleva el nivel de tolerancia respecto de comportamientos que causen dolor o sufrimiento a los demás.

16 Véase Nussbaum, M. Frontiers of Justice. Disability, Nationality, Species Membership, The Belkap Press. Cambridge, Mass.-London, 2006 (esp. pp.341 ss. de la edición italiana: Le nuove frontiere della giustizia. Bologna, Il Mulino, 2007).

17 Aristotle, The Poetics, IX (traducido por Ingram Bywater, The Clarendon Press, Oxford, First Published 1920). «Es, además, evidente a partir de lo que se ha dicho, que no es la función del poeta el relacionar lo que ha sucedido, sino lo que puede suceder, -lo que es posible de acuerdo con las leyes de la probabilidad o de la necesidad. El poeta y el historiador no se diferencian por escribir en verso o en prosa. La obra de Heródoto podría ser puesta en verso, y aún así sería una especie de historia, con el contador o sin él. La verdadera diferencia es que mientras una relata lo que ha sucedido, la otra lo que puede suceder. La poesía, por lo tanto, es una forma más filosófica y más elevada que la historia: la poesía tiende a expresar lo universal, la historia lo particular. Por lo universal, me refiero a cómo hablará o actuará una persona de un determinado tipo, de acuerdo con la ley de la probabilidad o necesidad; y es esta universalidad a la que apunta la poesía a través 
ha sucedido, sino en que puede suceder -lo que es posible de acuerdo con la ley de la probabilidad o de necesidad», mientras que la historia simplemente «se refiere lo que ha sucedido».

Me gustaría continuar y decir que el valor agregado que la literatura puede ofrecer, en su diálogo constructivo con la ley y la justicia, se basa propiamente en esta función de relacionar «lo que puede suceder, lo que es posible», aun cuando sea de acuerdo a su propia necesidad, que no es otra que la necesidad de la postura narrativa. Es un tipo tan especial de «necesidad» el que iba a tratar de evocar en los párrafos siguientes, basándome en algunos cuentos y novelas elegidas como paradigmas del discurso literario de la crueldad.

Como primer indicio de tal peculiar «necesidad literaria», me gustaría citar una notable conferencia sostenida por Susan Sontag (que menciono casi todos los años en la conferencia introductoria del curso sobre «Justicia y Literatura» que hemos organizado, desde el año 2009, en la Università Cattolica del Sacro Cuore de Milán) ${ }^{18}$.

Contar una historia es decir: Esta es la historia importante. Es reducir la generalización y la simultaneidad de todo para mostrar algo lineal, un camino. Ser un ser humano moral es estar atento, estar obligado a estar atento, a prestar cierto tipo de atención. Cuando hacemos juicios morales, no sólo estamos diciendo que esto es mejor que eso. Aún más fundamental, estamos diciendo que esto es más importante que eso. Es poner orden a la abrumadora dispersión y a la simultaneidad de todo, al precio de ignorar o dar la espalda a la mayoría de lo que está sucediendo en el mundo. La naturaleza de los juicios morales depende de nuestra capacidad para prestar atención, -una capacidad que, inevitablemente, tiene sus límites, pero cuyos límites se pueden estirar ${ }^{19}$.

Podríamos decir, sobre todo en una época como la nuestra, tan profundamente impulsada por la conveniencia, las actitudes utilitaristas y orientadas al mercado ${ }^{20}$,

de los nombres que ella atribuye a sus personajes. Lo particular es - por ejemplo- lo que Alcibiades hizo o sufrió».

18 Lo que se ha realizado en los dos primeros años del curso (2009-2011) se publica ahora en el libro Giustizia e Letteratura I, Forti, G./Mazzucato, C./Visconti, A. (eds.): Milano, Vita e Pensiero, 2012.

19 Sontag, S. The Truth of Fiction Evokes Our Common Humanity, (también Sontag, S. At the Same Time. The Novelist and Moral Reasoning, text of lectures titled «Nadine Gordimer», Capetown and Johannesburg, Marzo 2004, edición italiana, «Nello stesso tempo: il romanziere e la riflessione morale». En Nello stesso tempo, Milano, Mondadori, 2008, p. 186).

20 Véase Sandel, M. What Money Can't Buy. The Moral Limits of Markets, Farrar, Straus \& Giroux, 2012. 
que la literatura, prestando atención a la singularidad de cada historia única «humana», está llamada a reasumir una de sus funciones originales, como acertadamente destacó Pierre Bourdieu ${ }^{21}$ : habiendo sido creada a partir de la oposición entre valor de cambio y valor estético y distinguiéndose del «campo de la producción cultural a gran escala», da lugar a un tipo de capital cultural en función de una «ideología de mérito no comercial similar a aquella de la esfera de los derechos». De hecho, a finales del siglo XVIII, se ha producido una «aparición simultánea del concepto moderno de "literatura" y del concepto moderno de "derechos" en el discurso popular» que «sugiere una intersección histórica entre la literatura y los derechos humanos $»^{22}$.

Sobre tales premisas, es difícil negar el rol que la literatura juega en la definición de los límites de lo que es la violencia aceptable o «castigos crueles e inusuales», incluso, conceptos que están estrictamente ligados a la idea y al alcance de los derechos humanos, así como al «tipo de atención» que las sociedades y los estados están dispuestos a prestar por la historia de cada ser humano. A partir de este tipo de atención surge la peculiar, un tanto idiosincrática percepción literaria como «exceso» de cierto tipo de castigos, que se hace aguda en un momento en que ninguna conciencia de los derechos humanos es desafiada por las «pesadillas del exceso penal» en las sociedades «obsesionadas con la delincuencia» ${ }^{23}$.

De hecho, existen algunos hitos bien conocidos en la larga historia de decisiones de la Corte Suprema de Estados Unidos sobre el castigo y la pena de muerte, donde los jueces muestran este tipo de atención, es decir, la adhesión a una idea de necesidad, a diferencia de la conveniencia jurídica pura de la ley, junto con un razonamiento emocional sensible, acertadamente citados como importantes ejemplos de la literatura con una posible influencia en el discurso jurídico.

(i) En primer lugar me referiré al caso Woodson v. Carolina del Norte [428 U.S. 280 (1976)], en que la Corte Suprema de Estados Unidos, siguiendo su decisión de Furman v. Georgia (408 U.S. 238), concluyó que una ley de Carolina del Norte en ese momento (1976), había violado las Enmiendas VIII y XIV, porque negaba al jurado, en los casos de asesinato en primer grado, la discrecionalidad ilimitada para elegir si el condenado debía serlo a pena de muerte o a cadena perpetua, haciendo que la pena de muerte fuese obligatoria para tal crimen.

21 Bourdieu, P. The Field of Cultural Production: Essays on Art and Literature, ed. R. Johnson (Cambridge: Polity Press, 1993), citado por Stone Peters, J. «Literature», the «Rights of Man», and Narratives of Atrocity: Historical Backgrounds to the Culture of Testimony». En Yale Journal of Law \& the Humanities, 2013, 17, 2, p. 268.

22 Stone Peters, J. «Literature», the «Rights of Man», and Narratives of Atrocity», pp. 257 ss.

23 «'Excess' and 'obsession', a la que se opone el «excepcionalismo escandinavo». Véase Pratt, J. «Scandinavian exceptionalism in an era of penal excess, Part I: The Nature and Roots of Scandinavian Exceptionalism». En Brit. J. Criminol. (2008) 48, pp. 119-137. 
Me gustaría citar un pasaje de la decisión (pp. 303 y ss.), que se centra en una particular deficiencia constitucional de la ley de Carolina del Norte. Esta deficiencia se identificó en:

Su negativa a permitir una consideración concreta de aspectos relevantes del carácter y de los antecedentes de cada acusado condenado antes de la imposición de una sentencia de muerte en su contra. En Furman, miembros de la Corte reconocieron que no puede justamente negarse -que la muerte, más que una cuestión de grados, es un castigo diferente de todas las otras sanciones [...] Un proceso que acuerda no conceder ninguna importancia a los aspectos pertinentes de carácter y antecedentes de cada delincuente o que por las circunstancias de una particular ofensa excluye la posibilidad de tomar en consideración en la fijación de la pena máxima de muerte la compasión o la mitigación de los factores propios de las diversas debilidades de la especie humana, trata a todas las personas condenadas por un determinado delito no como seres humanos individuales únicos, sino como miembros de una masa anónima, indiferenciadamente sometida a la aplicación ciega de la pena de muerte ${ }^{24}$.

Me parece que este pasaje es una muy buena muestra de la capacidad del juez para entender la «historia» detrás del caso legal y por lo tanto prestar ese «tipo de atención» que es lo que constituye a «un ser humano moral». Muy apropiadamente, la filósofa Martha Nussbaum ha citado esta decisión para ilustrar el rol que las emociones pueden jugar incluso en el derecho ${ }^{25}$. La importancia de las emociones en la ley es especialmente relevante para marcar la distancia entre la idea de ley acariciada por los utilitaristas de aquella apreciada por los pensadores racionalistas y por tanto, para compartir y revivir la crítica tradicional (el denominado «estándar de quejas» como define Richard Posner ${ }^{26}$ en contra de los movimientos de «ley y economía», acusados de distorsionar la realidad humana, haciendo desaparecer las alternativas, un movimiento que toma «la cultura inherente a la retórica que en cierta medida ya está éticamente integrada y la somete a las presiones desintegradoras de la radical teoría de mercado» ${ }^{27}$.

$24 \quad$ El destacado es mío.

25 Nussbaum, M.C. Hiding from Humanity. Disgust, Shame and the Law. Princeton U.P., 2004 (pp. 38 ss. de la edición italiana: Nascondere l'umanità. Il disgusto, la vergogna, la legge. Roma, Carocci, 2005).

26 Véase Posner, R.A. Law and Literature, p. 379, nota 82.

27 Teachout, P.R. «Worlds beyond Theory: Toward an Expression of an Integrative Ethics for Self and Culture», en 83, Michigan Law Review 849, 881 (1985) citado en Posner, R.A. Law and Literature, p. 379 s. 
Sin perjuicio de realizar estas críticas, incluso Richard Posner se ve obligado a reconocer que «si bien la articulación de los principios económicos en modelos matemáticos es indispensable para el análisis de fenómenos complejos y de gran valor para forzar a que los teóricos económicos expliciten sus supuestos, para algunos economistas la matematización se ha convertido en un fin sí mismo».

Por ello, el citado autor estigmatiza la «tendencia a emplear un vocabulario especializado incomprensible para terceros extraños», esto es, una «típica deformación profesional que se ilustra en el uso intensivo que los teóricos hacen en sus estudios literarios de un vocabulario esotérico y pretencioso tomado de los filósofos europeos». Por otra parte, reconoce que en los argumentos de los abogados y en las decisiones de los jueces existe un lugar para hablar de una justicia no científica. «El lenguaje no científico del libre albedrío en el discurso del derecho penal sirve para el propósito ético de la diferenciación de los criminales de otras cosas peligrosas, como los animales y las avalanchas, y al hacerlo, desalientan la invocación de la peligrosidad ocasional como una justificación de castigos severos. Conceptos tales como la dignidad humana son demasiado vagos para los fines científicos de los economistas para tener una función en el juego del lenguaje llamado derecho» ${ }^{28}$.

(ii) La segunda referencia a sentencias del Tribunal Supremo de Estados Unidos (por la que también estoy en deuda con Martha Nussbaum y su análisis para esta cita) se extrae de Hudson vs. Palmer, 468 US 517 (1984), que trata el caso de un preso (el Sr. Palmer) de una institución penal de Virginia, quien afirmó que un funcionario de dicha institución había efectuado una «revisión» injustificada de su celda y de su celular, de la cual había recabado en su contra una acusación falsa, sometida a los procedimientos disciplinarios penitenciarios, relativa a la destrucción de propiedad estatal, exclusivamente para acosarlo. La Corte Suprema rechazó el argumento del preso en orden a que la destrucción de su propiedad personal constituyera una extralimitación en su propiedad en violación de la Cuarta Enmienda ${ }^{29}$, por considerar que la prohibición de registros contenida en la Enmienda no era aplicable a una celda de prisión, y que los funcionarios penitenciarios eran libres de incautar de las celdas cualquier artículo que, en su opinión, perjudicara los intereses institucionales legítimos.

Sin embargo, la opinión disidente del juez Stevens siguió un camino muy diferente y en cierto modo «literario».

28 Posner, R.A. Law and Literature, pp. 382, 385.

29 Cuarta Enmienda: «El derecho de los habitantes a la seguridad en sus personas, domicilios, papeles y efectos, contra incautaciones y cateos arbitrarios, será inviolable, y no se expedirán al efecto las Órdenes correspondientes a menos que exista una causa probable, corroborada mediante Juramento o Declaración solemne, y cuyo contenido describirá con particularidad el lugar a ser registrado y las personas o cosas que serán objeto de detención o embargo». 
Más fundamentalmente, en su afán de adoptar una regla coherente con lo que cree ser una sabia administración penitenciaria, la Corte pasa por alto el propósito de una Constitución escrita y de su declaración de derechos. Por supuesto, su propósito es asegurar que ciertos principios no serán sacrificados a conveniencia; éstos están consagrados como principios fundamentales de derecho más allá del alcance de las autoridades gubernamentales o mayorías legislativas. La Cuarta Enmienda es parte de esa ley fundamental; representa un juicio de valor en orden a que los registros e incautaciones injustificadas ponen en peligro en gran medida la libertad individual, por lo que deben ser condenadas para siempre como una cuestión de principio constitucional. 34 [468 U.S. $517,557]$ Los tribunales, por supuesto, tienen la especial obligación de proteger los derechos de los detenidos. Los prisioneros son verdaderamente los parias de la sociedad. Marginados, despreciados y temidos, a menudo con razón, ocultados lejos de la vista del público, los prisioneros son sin duda una «minoría separada». En este caso, la destrucción de la propiedad de Palmer era una incautación; el poder judicial tenía la obligación constitucional de establecer si la misma estaba justificada. La conclusión final de la Corte en orden a que toda conducta de los guardias penitenciarios se encuentre justificada se basa nada más que en su opinión idiosincrática de los imperativos de la administración penitenciaria - una visión no compartida por los propios administradores de la prisión. Dicha justificación es nada menos que una decisión de sacrificar un principio constitucional a favor de la concepción de oportunidad administrativa de la Corte. Hace más de una década que escribí: «El punto de vista según el cual un preso era un simple esclavo está ahora totalmente rechazado. Las restricciones y el castigo que conlleva una condena penal no coloca al ciudadano más allá de la tradición ética que reconoce el respeto a la dignidad y al valor intrínseco de cada individuo [...] Al decir que ningún aspecto de la individualidad de los prisioneros, desde la foto de un hijo hasta la carta de su mujer, goza del derecho a la protección constitucional, la Corte rompe con la tradición ética que pensé había sido consagrada para siempre en nuestra jurisprudencia ${ }^{30}$.

Según Martha Nussbaum ${ }^{31}$, la opinión disidente del juez Stevens evoca en la mente de los lectores una forma de literatura: la capacidad de imaginar el sentido

30 La cursiva es nuestra.

31 Véase Nussbaum, M.C. Poetic Justice: The Literary Imagination and Public Life. Boston, Beacon Press, 1995 (pp. 147-152 de la edición italiana: Giustizia poetica. Immaginazione letteraria e vita civile. Milano-Udine, Mimesis, 2012). 
que las cosas modestas pueden suponer para un ser humano, aunque sea restringida dentro de las paredes de una prisión, incluso para apoyar y mejorar la expectativa de ser capaz de vivir una vida mejor después de la pena de prisión. El juez Stevens extrae de cada caso concreto una perspectiva general y universal general con respecto a todos los presos y sus sentimientos. Es precisamente a través de la descripción de estas cosas modestas y su significado para el detenido concreto, que el lector de esta descripción «literaria» es inducido a percibir lo verdaderamente injustificado y desproporcionado del curso de la acción seguida por los funcionarios penitenciarios.

\section{LA CRUELDAD COMO EL CONGELAMIENTO DEL FLUJO DE HISTORIAS HUMANAS Y LA IMPOSICIÓN SOBRE EL MISMO DE UNA SOLA NARRATIVA}

La limitación de los objetivos que he tratado de conseguir hasta ahora, todavía nos deja un enorme paisaje literario para explorar y analizar, ya que la violencia «ha sido durante mucho tiempo parte de nuestra tradición literaria» ${ }^{32}$. Cada año, cuando junto con mi grupo de investigación planificamos nuestro curso sobre «Justicia y Literatura» («Giustizia e letteratura»), lamentamos profundamente las limitaciones de tiempo que nos obligan a descartar una gran cantidad de propuestas que fluyen a nosotros de diversas fuentes, no sólo debido al gran océano de novelas, cuentos y poesías que se ocupan de la justicia y el derecho, sino también debido a que las mismas ofrecen perspectivas extraordinarias acerca de importantes cuestiones legales, tanto desde la perspectiva académica como profesional.

Como profesor italiano, podría indicar muchos ejemplos de crueldad en la literatura italiana clásica. Baste mencionar las grandes obras maestras como la Divina Comedia de Dante, Decameron de Giovanni Boccaccio, o El Príncipe de Nicolás Maquiavelo (que no es sólo un ensayo de ciencia política y filosofía, sino también una obra de arte literaria) $)^{33}$, donde la descripción de una completa gama de crueldades privadas y públicas puede ser fácilmente identificada. Sin embargo, preferiría ocuparme de algunas obras maestras literarias que puedan considerarse paradigmáticas o que son, al menos, frecuentemente citadas en muchos estudios $\mathrm{y}$ cursos contemporáneos de «derecho y literatura».

Me gustaría, en particular, prestar atención a unos pocos relatos ejemplares que, aunque tal vez arbitrariamente elegidos, pueden servir a ilustrar el propósito, no tanto sobre cómo la literatura describe directamente la pena de muerte $u$ otras

32 Brown, S.E.; Esbensen, F.A.; Geis, G. Criminology. $5^{\text {a }}$ edición, Matthew Bender \& C., 2004, p. 462.

33 N. Maquiavelo dedica un capítulo entero de su Príncipe a la crueldad, a saber, el Cap. XVII, «Sobre la crueldad y la clemencia, y sobre si es mejor ser amado que temido». 
penas extremas (en que ciertamente tenemos una plétora de tales descripciones) $)^{34}$, sino sobre todo por la forma en que ayudan a centrar nuestra atención en las raíces culturales de los mismos: es decir, sobre las más básicas motivaciones humanas que conducen a las personas y a las instituciones a anteponer sus «necesidades» y con ello a eliminar desde su perspectiva la idea misma de crueldad, rodeándola con un aura de «normalidad».

Como una ayuda para dirigir mi presentación a este punto focal del paisaje literario, me gustaría referirme en primer lugar a los linchamientos como pasado y actual exceso paradigmático de violencia y uso injustificado de la fuerza más allá de lo necesario para lograr un objetivo ${ }^{35}$ : la violencia colectiva como reacción gráfica respecto de actos «percibidos como crímenes de lesa nación, desafiantes del orden social y del código racial del que depende dicho orden $\rangle^{36}:$ «los linchadores actuaron en modos que proclamaban el poder soberano de 'la gente' actuando directamente en nombre propio, vengando a sus parientes víctimas, defendiendo el honor blanco, y demostrando su fuerza colectiva». La transmisión de «un exceso de significado, articulando la destrucción de un delincuente peligroso negro en las diferentes dimensiones de la cultura local y la estructura social» y derivados de diferentes impulsos,

34 La lista sería demasiado larga. Baste mencionar, en la literatura contemporánea, la obra maestra clásica de Truman Capote, A sangre fría (1966) que, aunque principalmente referida al homicidio múltiple, conduce al lector a pensar de forma continua en la pena que espera a los dos delincuentes. En la literatura clásica del siglo XIX, la referencia a Los Miserables de Víctor Hugo no puede ser pasada por alto, ya que en la misma la naturaleza de la pena de muerte se discute de manera explícita, en un pasaje que refleja el punto de vista de Hugo contra la pena de muerte, tal como se expresa en varios otros escritos de ficción y no ficción (Le dernier jour d'un condamné, 1829; Notre-Dame de París de 1831; Claude Gueux de 1834; Affaire Tapner de 1854; etc.) y discursos (La peine de mort est le signe spécial et éternel de la barbarie, Discours à l'Assemblée constituante, 15 septembre 1848; etc.).

Acertadamente, la aversión a la pena de muerte en Los Miserables se describe desde la perspectiva del dispositivo utilizado para ejecutarla: «En efecto, cuando el andamio está ahí, todo montado y preparado, tiene algo que produce alucinación. Uno puede sentir una cierta indiferencia hacia la pena de muerte, uno puede abstenerse de pronunciarse sobre ella, en el sentido de aceptarla o rechazarla, sólo mientras no se haya visto una guillotina con sus propios ojos: si por el contrario, alguien se encuentra entre aquellos que lo han visto, el choque es violento; uno se ve obligado a decidir, y para tomar parte a favor o en contra. Algunos la admiran, como Maistre; otros la execran como Beccaria. La guillotina es la concreción de la ley; llamada venganza; no es neutral ni permite permanecer neutral. Quien la ve se estremece con los más misteriosos escalofríos. Todos los problemas sociales erigen su signo de interrogación en torno a este corta-cuchillo. La tarima es una visión. La tarima no es una pieza de carpintería; la tarima no es una máquina; la terima no es un pieza inerte de un mecanismo construido con madera, hierro y cuerdas» (Les Miserables, Chapter IV: Works corresponding to words, traducción de Isabel F. Hapgood).

35 Recientemente la prensa ha informado y condenado un recrudecimiento de los linchamientos en Bolivia. Véase The New York Times, 7 Junio de 2013; L'Osservatore romano, 12 Junio de 2013, p. 7.

36 Garland, D. «Penal Excess and Surplus Meaning: Public Torture Lynchings in TwentiethCentury America». En Law \& Society Review, Vol. 39, No. 4 (Dic., 2005), pp. 793-833. 
como los intentos de alcanzar la deshonra y la degradación, la justicia expresiva, formación cultural, purificación, terror y control racial, la soberanía y el poder de la policía privada, chivo expiatorio, la solidaridad, el juego de poder, la violencia sexual, etc., resultó inherente a este «exceso de castigo».

Entre todas dichas direcciones, considero el «control del significado» como particularmente relevante para mi análisis sobre la crueldad en la literatura, especialmente «en un escenario que fue muy controvertido y profundamente conflictivo». Citando a David Garland, «el absolutismo en el castigo también está marcado por la ausencia de duda», tal como ocurre en el caso de los linchamientos, «que permiten una sola narrativa, una sola verdad, para ser proclamada públicamente». A diferencia de los procedimientos legales, donde la evidencia y los sistemas de justicia adversarial «podrían romper los estereotipos, disputar los hechos, y humanizar a los acusados, los linchamientos públicos permiten sin obstáculos la proyección de estereotipos raciales puros y contrastes morales rígidos», complaciendo de este modo la avidez de las turbas de masas por afirmar «una sola estructura de significado, sin oposición e incuestionable», prestándose a convertirse en «un mecanismo para evitar la duda (incluyendo la auto-duda) y la supresión de la disidencia» ${ }^{37}$.

El mecanismo de linchamientos representa, de una manera extrema, algunas de las características inherentes al origen mismo de la ley. Aunque los estudiantes de derecho estén acostumbrados a aprender que el derecho surge de hechos (ex facto ius oritur), también podríamos decir, como atinadamente señaló François Ost, que el derecho surge de un conjunto de posibles historias y narraciones de los mismos (ex fabula ius oritur). De toda la gama de posibles historias, desde el mundo de la ficción, la ley opta por una sola historia, asumiéndola como paradigmática, y «normalizándola» a través de una norma jurídica y una sanción. Sin embargo, luego de establecer tales normas, se pone en movimiento un juego de espejos entre la regla y los hechos, norma y ficción, generando los intrincados más complejos ${ }^{38}$. Así, sucede que, a veces, las sociedades, grupos y estados puedan verse tentados e incluso atraídos por miedo u otros sentimientos, a reducir la animada gama de «posibles» historias a una única y "oficial" historia, la más mortal (tanto en un sentido metafórico como real), para ser solemnemente (y, a veces cruelmente) «inscrita» en los cuerpos y/o en las almas de cada uno de los «condenados».

Pertinente a este punto, me parece una breve historia muy conocida de Franz Kafka, En la colonia penitenciaria (Die Strafkolonie), que ofrece una aguda metáfora de las dinámicas y los impulsos culturales de la violencia excesiva. Se trata sobre

37 Garland, D. Penal Excess, p. 822.

38 Fost, F. Raconter la loi. Aux sources de l'imagination juridique. Paris, Odile Jacob, 2004 (p. 25 de la traducción italiana: Mosé, Eschilo, Sofocle. All'origine dell'immaginario giuridico. Bologna, Il Mulino, 2007). 
todo de una descripción de la utilización de un instrumento de tortura y ejecución que esculpe la sentencia del condenado en su piel, antes de dejarlo morir. Hay tres personajes principales de la historia: el oficial, el viajero y el condenado.

«Ciertamente fue él» dijo el Oficial, moviendo la cabeza con una expresión fija y reflexiva. Luego se miró las manos, examinándolas. No le parecieron suficientemente limpias para hacer los diagramas. Así que se fue a la cubeta y las lavó de nuevo. Luego sacó una carpeta de cuero pequeña y dijo: «Nuestra condena no suena grave. La ley violada por un Hombre Condenado debe inscribirse en su cuerpo con una grada. Este Hombre Condenado, por ejemplo» y el Oficial señaló al hombre, «al que se había inscrito en su cuerpo 'Honra a tus superiores'» [...] El Viajero quería hacer varias preguntas, pero después de ver al Hombre Condenado se limitó a preguntar, «¿Conoce él su condena?» «No» dijo el Oficial. Deseaba seguir con su explicación de inmediato, pero le interrumpió el Viajero: «jél no conoce su propia condena?» «No,» dijo el Oficial una vez más. A continuación, hizo una pausa por un momento, como si estuviera pidiéndole al Viajero una razón más detallada de su pregunta, y dijo: «Sería inútil darle esa información. Él la ha experimentado en su propio cuerpo». El Viajero realmente quería guardar silencio en este punto, pero sintió cómo el Hombre Condenado lo miraba — parecía estar preguntándose si aprobaba el proceso que el Oficial había descrito. Así que el Viajero, que hasta ese punto se había inclinado hacia atrás, se inclinó de nuevo hacia delante y continuó con sus preguntas, «Pero, ¿al menos tiene una idea general de que él ha sido condenado?», «Eso tampoco» dijo el Oficial, sonriendo al viajero, como si todavía estuviese esperando de él algunas revelaciones extrañas. «¿No?» dijo el Viajero, secándose la frente, «ientonces el hombre tampoco sabe siquiera cómo se recibió su defensa?» «No tuvo oportunidad de defenderse a sí mismo» dijo el Oficial apartando la vista, como si estuviera hablando consigo mismo y deseando no avergonzar al Viajero con una explicación de cuestiones tan evidentes para él. «Pero él debió haber tenido la oportunidad de defenderse a sí mismo», dijo el Viajero y se levantó de su silla ${ }^{39}$.

Una de las interpretaciones más interesantes de esta historia ha visto acertadamente en ella la descripción de cómo la comprensión de la ley puede depender principalmente o incluso por completo del espectáculo de su sanción, de forma gráfica

39 Traducción de Ian Johnston, Universidad de Malaspina, Nanalmo, BC, Canadá (véase www.kafka. org/index.php?aid=167). 
y cruelmente infligida. Y sobre todo cómo las personas pueden sentirse aliviadas por esta actuación, liberadas de la angustia de las dudas y de la incertidumbre, de la culpa y el remordimiento que pican en la carne y el alma, siempre que no sean conscientes de su existencia o incapaces de comprender su contenido ${ }^{40}$. Esta es una gran enseñanza tanto para estudiantes como para practicantes, que a menudo enfrentan decisiones judiciales donde las sanciones juegan un rol predominante y por tanto desequilibrado por el detrimento de esas reglas, de las que dichas sanciones debiesen ser meros sirvientes, en el sentido de que el poder persuasivo de los preceptos se ha sacrificado por la crueldad fácil - o al menos por un impacto aflictivo- de las penas ${ }^{41}$.

También podríamos decir que en el cuento de Kafka, se desarrolla un mecanismo de «normalización», derivado de una necesidad común de certeza y precisión, y del intento de personas e instituciones de satisfacerlas. No sólo se satisfacen a través de normas legales, que los legisladores realizan en modo claro y fácil de entender, sino que también a través de dinámicas mucho más sutiles, que dibujan la certeza de la sanción en sí misma: se supone que cuanto más dura y gráfica sea la sanción, más transmite la sensación (mejor dicho: la ilusión) de que existen reglas y que éstas están establecidas en modo correcto y claro. Entre sus principales fuerzas impulsoras se encuentra precisamente el «evitar dudas (incluyendo la auto-duda)» y el contar con «una sola estructura de significado, sin oposición e incuestionable», tal como se resume en la triste historia de linchamientos modernas, prácticas donde la crueldad en general, y la crueldad del Estado y el poder público, en particular, se revelan en toda su luz. Entre más modestas e indirectas sean estas prácticas, más amenazas serias se plantean para los derechos humanos, sobre todo en momentos en que los valores morales y legales, son controvertidos y poco claros.

En la actualidad, una de las características más recurrentes de los movimientos de «derecho y literatura» es una crítica explícita o implícita a este tipo de violencia, inherente no sólo en castigos o en el derecho penal, sino en cierto modo propia de la naturaleza esencial de la ley misma. Su naturaleza es tal que podría ser la inminente «violencia original», como se analiza en la famosa Crítica de la violencia de Walter

40 Baioni, G. Kafka. Romanzo e parábola. Milano, Feltrinelli, 1997, p. 145, fn 1.

${ }_{41}$ Este peligro que amenaza a toda decisión judicial y estrictamente relacionado con la llamada distorsión retrospectiva, se ha discutido ampliamente en Italia en diversas áreas del derecho penal y sobre todo después de la promulgación de la ley que desde 2001 castiga a las personas jurídicas como tales, aunque con una especie de sanción administrativa penal cuya verdadera naturaleza es objeto de debate (decreto legislativo n. 231/2001). Especialmente en este tema, es decir, sobre la necesidad de encontrar el equilibrio correcto entre «precepto»y «sanciones» de las leyes, véase nuestro ensayo: Forti, G.: «Uno sguardo ai «Piani Nobili» del d.lgs.n. 231/2001». En Riv.it.dir.proc. pen., 2012, 4, especialmente pp. 1277 y ss. 
Benjamin $^{42}$, donde se argumenta y acertadamente se señala ${ }^{43}$ que, no es posible separar la violencia de la ley, que toda ley es violencia latente y «por tanto es la propia ley la que decide cuál violencia es justificable para determinados fines». Si, como se ha señalado igualmente bien, «el poder establecido por la violencia legislativa amenaza al infractor con la violencia para preservar la ley», tenemos «un ciclo mítico ligado a la repetición sin fin» análoga a la «tautología violenta» descrita en 'La colonia penal' de Kafka. Por tanto, tal vez podríamos decir que el discurso literario es una manera de llegar a un acuerdo con el problema aparentemente insoluble (en la vida social o jurídica real) de la resolución de conflictos, que por sí mismo no requiere el uso de la violencia: la «atención» a la singularidad de los destinos humanos y sus historias que, a través de la literatura, «estamos obligados a prestar», da lugar al dominio de «métodos puros» sin fines, que Benjamín invocó para romper la mítica máquina que era accionada simplemente por una lógica de extremos ${ }^{44}$.

Podemos fácilmente comprender cómo el blanco de tales críticas literarias sobre la violencia (que reproduce su pura crueldad) puede sufrir la misma inestabilidad que los términos de la Octava Enmienda, ya que el discurso literario se ve obligado a enfrentarse al muy variable nivel de violencia aceptable que un Estado puede ejercer contra los ciudadanos, no sólo en función de las normas jurídicas nacionales e internacionales, sino también en función de la prevalencia de ciertas sensibilidades y de la ética. En este sentido, no sólo la pena de muerte, sino que la detención, especialmente en condiciones consideradas inhumanas, pueden ser puestas en duda o incluso criticadas con dureza por sensibilidades actuales. Muy acertadamente, un amplio debate sobre el significado de la Octava Enmienda ha incluido una mención a «las normas morales en evolución que marcan el progreso de una sociedad madura» ${ }^{45}$.

42 Véase Benjamin, W. «Zur Kritik der Gewalt». En Benjamin, W. Gesammelte Schriften, Bd. II.1. Frankfurt / M. 1977, pp 179-203. Para una crítica de la violencia, ver la edición italiana Novus, A. Saggi e frammenti. Torino, Einaudi, 1976, pp. 5-28. En el trabajo de Benjamin, véase Desideri, F.; Baldi, M. Benjamin. Roma, Carocci, 2010, pp 61-68.; Derrida, J. Force de loi (traducción italiana: Forza di legge. Torino, Bollati Boringhieri, 2003, pp. 86 y ss., especialmente pp. 93 y ss.).

43 Auerbach, A. «Remarks on Walter Benjamin's Critique of Violence». Documento presentado en el seminario Después de 1968, dirigido por Katja Diefenbach, Jan van Eyck Academie, 2007.

44 Auerbach, A. «Remarks on Walter Benjamin's Critique of Violence».

45 Las palabras del Presidente de la Corte Suprema Earl Warren en Trop v. Dulles, 356 U.S. 86 (1958). Posteriormente, la Corte de Justicia examinó la evolución de la sociedad, así como en su propio juicio independiente, para determinar cuáles eran esos «estándares morales en evolución». A continuación la Corte aplicó dichos estándares no sólo para determinar qué castigos eran intrínsecamente crueles, sino también para establecer los castigos que si bien no eran intrínsecamente crueles, lo eran por desproporción con el delito en cuestión. Un ejemplo de la idea de «evolución de los estándares» puede verse en Jackson v. Bishop ( $8^{\circ}$ Cir., 1968), una decisión del Octavo Circuito que prohibía el castigo corporal en el sistema penitenciario de Arkansas. El examen de la «evolución de los estándares» no ha estado exento de críticas académicas. Por ejemplo, el profesor John Stinneford afirma que el test sobre la «evolución de los estándares» interpreta erróneamente 
Hay un segundo significado que considero igualmente paradigmático para el presente discurso sobre la crueldad en la literatura, que podemos extraer de 'Colonia penitenciaria' de Kafka. Dicho significado se refiere a lo que ha sido acertadamente definido como la función del proceso judicial «como un ritual de familiarización (una serie de instrucciones verbales, representaciones teatrales y actividades de escritura) que de alguna manera [...] trata de hacer que lo ininteligible o amenazante sea inteligible y dócil $»^{46}$. Del mismo modo en que «la ley que es inscrita con una grada sobre el cuerpo del hombre condenado que la ha violado», este cuerpo (y alma), muy inquieto y misterioso (como el cuerpo de un hombre que se vuelve un extraño y un enemigo por la violencia de la ley) se rindió dócil a través del acto de convertirse en nada más que un vehículo de la norma, siendo desposeído de muchas de las características propias de un ser humano. Este acto, como objeto de inscripción de la ley, sirve a la finalidad de la lectura y escritura de la amenaza desconocida, así le da una «existencia ordenada», la pone «en el control» y proporciona así una «estabilidad psicológica», al mismo tiempo que mantiene una especie de epistemología, al igual que en las primeras acciones legales de Colón, cuando descubrió el nuevo mundo, esto es, «una acción simultánea de limpieza e inscripción» ${ }^{47}$. Por tanto, el otro «tema dentro del discurso» ${ }^{48}$, es que esta «apropiación violenta» evoca la «genealogía foucaultiana del derecho moderno» y la opinión de que «la ley es una manifestación escrita del cuerpo del rey y, por tanto, de su voluntad» ${ }^{49}$. Una inscripción que se exime asimisma de la necesidad de ser comprensible para las personas sometidas a ella, que en realidad son tratados como meros cuerpos, como

la Octava Enmienda: Los autores de la Declaración de Derechos entienden la palabra «inusual» en el sentido de «contrario a los usos de larga data». El reconocimiento del significado original de la palabra invertiría precisamente el examen sobre «la evolución de los estándares de decencia», sugiriendo que la Corte debe comparar los castigos conminados con principios y precedentes de larga data de la common law, en lugar de utilizar nociones movedizas y nebulosas de «consenso social» y de modernos «estándares morales en evolución». Por otra parte, Dennis Baker ha afirmado que el examen de los estándares de decencia en desarrollo concuerda con el propósito moral de la Octava Enmienda y con la intención de los fundadores en el sentido de que el derecho debe ser utilizado para evitar que los ciudadanos estén sometidos a toda forma de castigo injusto y desproporcionado. Como señala el profesor John Bessler, ya el «Ensayo sobre los delitos y las penas», escrito por Cesare Beccaria en la década de 1760, abogaba por castigos proporcionales. Muchos de los padres fundadores, entre ellos Thomas Jefferson y James Madison, habían leído el tratado de Beccaria y fueron influenciados por él.

46 Boire, G. «Symbolic Violence: Law, Literature, Interpretation-An after word». En Ariel, eneroabril 2004, Vol. 35, No. 1-2, pp.231-45.

47 Boire, G. «Symbolic Violence», p. 231.

48 Boire, G. «Symbolic Violence», p. 234, aquí citado de otras fuentes.

49 Boire, G. «Symbolic Violence», p. 240 s., con referencia a Foucault, M. Discipline and Punish: The Birth of the Prison. Traducción de Alan Sheridan. New York, Vintage, 1979, (traducción italiana, Sorvegliare e punire. Nascita della prigione. Torino, Einaudi, 1995). 
carne utilizada para expresar la voluntad del soberano. Me parece que la crueldad inherente a este tipo de mecanismo y, más aún, las fuerzas que lo mueven, son retratadas magistralmente en uno de los grabados del gran pintor Francisco de Goya -el principal mentor artístico para nuestra conferencia- que ha sido acertadamente mencionado por Juan Bordes: No se puede saber por qués0.

Tan «violenta apropiación» también trae como resultado el que «cualquier otro potencial sistema simbólico» ${ }^{51}$ quede (además de colmado de sentido negativo), vaciado de todo significado, ya que en lugar de borrarlos, al instaurar «un orden simbólico que, con el tiempo, se instale inexorablemente como el orden social general», se produce una realineación radical, que los reposiciona consiguiendo que sean prácticamente invisibles ${ }^{52}$.

Otra muestra literaria de un mecanismo de este tipo, donde la crueldad sin embargo es más latente y menos gráfica que en la novela de Kafka (aunque muy similares en sus significados esenciales) y donde se consigue la «apropiación violenta» a través de medios culturales, no directamente por el aparato del Estado, se pueden extraer del libro El hombre invisible, de Ralph Ellison ${ }^{53}$.

La novela, una descripción dramática de la posición de un hombre negro sin nombre en el mundo «blanco», comienza con los que se consideran los párrafos iniciales más memorables de la moderna ficción americana ${ }^{54}$, cuyo contenido anticipa un buen número de aspectos de toda la trama, y que en mi opinión, también ofrecen una visión reveladora de la relación entre la literatura y la crueldad como la que estamos tratando aquí.

Soy un hombre invisible. No, no soy un fantasma como los que perseguía Edgar Allan Poe; ni soy uno de los ectoplasmas de las películas de Hollywood. Soy un hombre de sustancia, de carne y hueso, fibra y líquidos - y hasta podría decir que poseo una mente. Soy invisible simplemente porque la gente se niega a verme. Al igual que las cabezas sin cuerpo que se ven a veces en puestos de feria de circo, es como si me hubiesen rodeado de espejos fijos de vidrio que distorsionan. Cuando se acercan a mí sólo ven lo que me rodea, a sí mismos, o invenciones de su imaginación - de hecho, todo y cualquier cosa, menos yo.

50 Véase también el libro producido exclusivamente para la Conferencia: Francisco de Goya. Contra la crueldad de la pena de muerte, editado por Bordes Cabalero, J.; Arroyo Zapatero, L., 2013, p. 70.

51 Boire, G. «Symbolic Violence», p. 234.

52 Boire, G. «Symbolic Violence», p. 244.

53 Véase Nussbaum, M. Cultivating Humanity (pp. 101 ss. de la edición italiana).

54 Véase Mitgang, H. «'Invisible Man', as Vivid Today as in 1952». En New York Times, $1^{\circ}$ de marzo de 1982. 
No casualmente, uno de los dos epígrafes del libro está tomado de Herman Melville de Benito Cereno: una novela corta donde la crueldad encuentra un lugar destacado y explícito, tal cual es, centrado en un conflicto racial y en la esclavitud, que un crítico ha definido «como la más sobresaliente de las obras: una historia de hombres desesperados en las garras de una furia vengativa que aquellos a quienes odian no pueden empezar a entender» ${ }^{55}$.

«Estás a salvo", gritó el Capitán Delano, cada vez más sorprendido y dolido; «Estás a salvo: ¿Qué te ha arrojado tal sombra sobre ti?»»

Como bien sabemos, aun cuando la esclavitud haya sido abolida después de la guerra civil americana y aunque los hombres negros hayan sido liberados, y tal como relata El hombre invisible, la libertad legal no impidió la persistencia de la invisibilidad social de las personas de raza negra. El «concepto de blackness» continuó asegurando la subordinación racial con la venia del derecho mismo, «produciendo el estigma que determinó su privación $»^{56}$, del mismo modo en que lo hizo la «mítica máquina» de la violencia legal puesta en marcha en contra de todas aquellas personas extrañas, subordinadas y expulsadas de la sociedad, quienes, «una vez hechas importantes discriminaciones de personalidad» veían cómo sus «reivindicaciones se volvían intrascendentes». Melville, en particular, estaba «obsesionado con el hacer y deshacer de materiales humanos, las metamorfosis que se sitúan en la brecha entre las personas y las cosas, así como entre seres humanos y animales $\rangle^{57}$.

De acuerdo con ello (y en lo que respecta a nuestra Conferencia), una de sus novelas más famosas, Billy Budd (una novela que cuenta con una consideración primordial dentro del movimiento de «derecho y literatura» ${ }^{58}$ ), fue compuesta en el periodo (1886 a 1891) en que la atención «nacional e internacional se había centrado en el punto culminante de una larga batalla del siglo contra la pena capital desarrollada precisamente en el mismo lugar donde estaba viviendo Melville - Estado de Nueva York», y de la cual, según se ha indicado, deriva en parte el movimiento

55 Delbanco, A. Melville: His World and Work. New York, Knopf, 2005. Véase también Rosengarten, A. «Citizenship and Invisibility: Ralph Ellison's Invisible Man, Race, and Democratic Prospects». En The University of Chicago Divinity School, 9 de abril de 2010.

56 Dayan, C. «The Law is a White Dog», pp. 52-53.

57 Dayan, C. «The Law is a White Dog», pp. 115-116, quien cita a Benito Cereno, donde al final el Capitán Delano estimula a Don Benito a salir de su penumbra: «Pero el pasado es pasado; ¿Por qué moralizar sobre él? Olvídalo. Mira, tu sol brillante se ha olvidado de todo, y el mar azul y el cielo azul; han entregado nuevas hojas. Benito responde: «Porque no tienen memoria, porque no son humanos».

58 Véase Posner, R.A. Law and Literature, pp. 211-227 con otras referencias. El primer número de los Estudios de Cardozo en Derecho y Literatura (primavera de 1989), dedicado a Billy Budd, fue considerado por Richard H. Weisberg (en su prefacio) como «el texto que ha llegado a 'entender' el Derecho y la Literatura». 
estadounidense contra la pena capital ${ }^{59}$. Como se ha dicho, este trabajo «dramatiza cada uno de los argumentos y conceptos cruciales de ese movimiento», de hecho la esencia de la cuestión y del debate contemporáneo «estructuran la historia»: «¿Qué delitos, si los hay, deberían llevar a la pena de muerte? ¿La pena capital sirve como elemento disuasorio de matar o como un modelo ejemplar para matar? ¿Cuáles son los efectos de las ejecuciones públicas? ¿es alcanzable un método de ejecución apropiado en una sociedad civilizada? ¿El acto de matar, aparentemente razonado con calma, es más o menos censurable que el acto impulsivo de matar de un individuo? ¿La pena de muerte es una manifestación esencial del poder del Estado? ¿Es un ritual de sacrificio? ¿Es un instrumento de opresión de clases? Es un componente clave de la cultura militar?» ${ }^{60}$.

\section{CRUELDAD PERCIBIDA A TRAVÉS DE LA «ATENCIÓN»: LA CRÍTICA DEL SACRIFICIO LEGALISTA DE LA HUMANIDAD INHERENTE A LA CONVENIENCIA DEL DISCURSO LITERARIO}

De acuerdo con la opinión disidente del Juez Stevens en Hudson vs. Palmer previamente citado, la Corte había desatendido el objetivo de una Constitución escrita y de su Declaración de Derechos al «afirmar que ciertos principios no serían sacrificados a conveniencia», olvidándose así de las prescripciones de la Cuarta Enmienda y permitiendo que un funcionario de prisiones, con su conducta vejatoria contra un interno, pueda ejercer este tipo de crueldad.

Creo que un segundo y más sutil nivel de crueldad, que la literatura no describe como tal, pero que nos ayuda a percibir o incluso a materializar en las mentes de los líderes, es el que se desprende de las narrativas donde, acertadamente, la explotación o la conveniencia suprimen el respeto y la dignidad que corresponde a los seres humanos. Quiero decir que en la vida ordinaria (incluida la vida profesional), no seríamos capaces de juzgar ciertos actos y situaciones o incluso percibirlas como crueles o simplemente violentas; en cambio, cuando nos incrustamos en la narrativa literaria, sus personajes despiertan nuestras emociones y muestra simpatía, incluso permitiendo vernos a nosotros mismos, en forma realista, implicados en tales actos o situaciones similares. Me gustaría concebirlo como una «percepción literaria mejorada de la crueldad», a saber, una crueldad que somos capaces de captar sólo gracias a la simpatía y la compasión que la literatura es capaz de suscitar en el público lector.

Hay bibliotecas enteras de novelas y cuentos, que simbolizan la denuncia literaria y la capacidad de la literatura para mejorar nuestra percepción de los actos sin

59 Franklin, H.B. Billy Budd and Capital Punishment: A Tale of Three Centuries in American Literature, 345 (junio 1997).

60 Franklin, H.B. Billy Budd and Capital Punishment. 
escrúpulos, haciendo que los «hechos» aparezcan como pura crueldad aun cuando en sí mismos, en realidad, no revelen esta calidad, o al menos la oculten bajo diversas formas, incluyendo lo que se ha llamado acertadamente "definitional stops», en referencia a las formas comunes de «abusos de definición» ${ }^{61}$. Un ejemplo claro de esta técnica, que hace uso de la experticia y profesionalismo para enmascarar la dura realidad de la privación humana, es precisamente la circunstancia de que los reclusos detenidos en aislamiento se considere como una «medida de precaución administrativa» y no como un ejercicio «disciplinario» o «punitivo», con lo que tal tratamiento queda eximido de una evaluación basada en la Cuarta Enmienda ${ }^{62}$. La crueldad humana encuentra su lugar dentro de la literatura, precisamente cuando sus escondites verbales son desenmascarados, no sólo porque se incrustan en la textura narrativa, sino también porque la buena literatura tiene la capacidad de nombrar las cosas y los hechos correctamente, usando «le mot juste» («la palabra correcta»), como el gran escritor francés Gustave Flaubert recomienda para alcanzar calidad en el arte literario.

La misma Billy Budd de Melville muestra (e implícitamente critica) «la característica más preocupante del utilitarismo - que entroniza el sacrificio deliberado de una persona inocente en aras del interés general $\rangle^{63}$. Este sacrificio toma la forma de la pena capital, para ser infligida a Billy Budd, de acuerdo con el capitán Vere, sobre la base de un argumento bastante similar al efecto disuasorio que es, en general, asumido (y en realidad nunca probado) para acompañar este castigo. Pero de una manera «mucho más cínica»: Vere sustenta su argumento en el supuesto de que el ahorcamiento de Billy ante la tripulación «iba a intimidarlos y a reforzar la

${ }_{61}$ Un «definitional stop», según una expresión acuñada por HART, HLA, es una forma de "abuso de definición", resumida por el argumento del juez Clarence Thomas en orden a que las condiciones de reclusión no son parte de la definición de la pena, porque tal como ha afirmado «son los jueces y jurados, y no carceleros- quienes imponen un castigo». Véase Zaibert, L. «Up rootedness as (Cruel and Unusual) Punishment». En New Criminal Law Review: An International and Interdisciplinary Journal, Vol. 11, No. 3 (Summer 2008), pp. 384-408. Otro ejemplo de abuso de definición es la exclusión de la sanción de expulsión del ámbito del Derecho penal, a pesar de la verdadera naturaleza punitiva de algunas prácticas de la ley de inmigración de Estados Unidos.

62 Dayan, C. «The Law is a White Dog», p. 75.

63 Para otras referencias véase Posner, R.A. Law and Literature, p. 219: «Sin embargo, Vere [...] sostiene una política que -como diría un abogado- hace peligrar un motín. A pesar de que no esté relacionado con legalismo o resentimiento, sino que al contrario con el rechazo del legalismo en favor de la conveniencia, esta es la parte más inquietante del argumento de Vere. Cuando Vere pregunta: "¿Cómo podemos condenar a una muerte sumaria e infame a una criatura inocente delante de Dios, y cómo nos sentimos frente a ello?", pone en la mente del lector las característica más preocupante del utilitarismo, que entroniza el sacrificio deliberado de una persona inocente en aras del bien general. El utilitarismo trata a toda la sociedad como un solo organismo cuyo bienestar debe ser maximizado, lo que hace que sea tan natural matar a una persona por el bien de la sociedad, ya que sería la eliminación de un órgano canceroso». 
«disciplina arbitraria ejercida sobre ellos por los oficiales, mientras que no colgarlo hubiese animado un motín». Un argumento que podría sonar, incluso para los lectores contemporáneos, «tan obviamente engañoso e ilógico como para aparecer casi una parodia de la defensa habitual de la pena capital por el bien de la disuasión» ${ }^{64}$.

Gentleman [Teniente en otras versiones], bajo estas circunstancias, lo que fuera tan claramente legítimo para nosotros, considere las consecuencias de un tal indulto. Las personas (que significa la tripulación del barco), tienen sentido nativo; la mayoría de ellos están familiarizados con nuestro uso naval y la tradición; y ¿cómo lo tomarían? Incluso podría explicárseles lo que nuestra posición oficial prohíbe, ellos más que ser moldeados por una disciplina arbitraria, no tienen ese tipo de reacción inteligente que pueda capacitarlos para comprender y discriminar. No, según la escritura de la gente de gaviero, cualquiera sea el modo en que esté expresado el anuncio, se tratará de un homicidio planeado cometido en un acto flagrante de motín. Ellos saben qué castigos deben seguir. Pero no se siguen ¿Por qué? Ellos rumiarán. Usted sabe lo que son los marineros. ¿Van a volver a la reciente ola del Nore? Ay. Ellos saben que el bien-fundado causa alarma- el pánico golpeó a toda Inglaterra. Ellos darían cuenta pusilánime de su sentencia de indulto. Ellos podrían pensar que nos acobardamos, que tenemos miedo de ellos - miedo de aplicar con rigor la ley exigida singularmente en este momento, para que no pueda provocar nuevos problemas. Qué vergüenza para nosotros tal conjetura de su parte, y lo mortal de su disciplina $^{65}$.

Entre otros ejemplos de los comportamientos que la literatura quiere hacer que percibamos como «crueles» o, al menos, particularmente insensibles, mejorando nuestra empatía hacia los personajes de ficción sacrificados en aras de la conveniencia y el utilitarismo, podría mencionar la novela de Charles Dickens "Tiempos difíciles", como cuidadosamente ha sido analizada por Martha Nussbaum ${ }^{66}$. El personaje principal es Thomas Gradgrind.

Un hombre de realidades. Un hombre de hechos y cálculos. Un hombre que procede sobre la base del principio de que dos y dos son cuatro, y nada más, y que no se puede hablar para permitir nada más. Thomas Gradgrind, señor -perentoriamente Thomas- Thomas Gra-

64 Franklin, H.B. Billy Budd and Capital Punishment.

65 Melville, H. Billy Budd, Capítulo 22.

66 Nussbaum, M. Poetic Justice: The Literary Imagination and Public Life (pp. 49 ss. de la edición italiana). 
dgrind. Con una regla y un par de escalas, y la tabla de multiplicar siempre en el bolsillo, señor, lista para pesar y medir cualquier parcela de la naturaleza humana, y le dirá exactamente lo que se trata. Es una simple cuestión de cifras, un caso de aritmética simple ${ }^{67}$.

Hay (al menos) dos pasajes vivos en la novela, que simbolizan el contraste con lo que el Tribunal Supremo de Estados Unidos declaró en Woodson v. Carolina del Norte como la exigencia legal de tratar a todas las personas (incluidos los condenados) «como seres humanos únicos e individuales», «no como miembros de una anónima e indiferenciada masa», como fenómeno genérico de pura botánica o como simples especímenes de animales.

Ella pasó a la basura con un ligero movimiento de su mano, y concentrando su atención sobre él de nuevo, dijo 'Padre, he pensado a menudo que la vida es muy corta'.- Claramente este fue uno de los temas de que se ocupó.

'Es corta, sin duda, querida. Aún así, está demostrado que la duración media de la vida humana ha aumentado en los últimos años.

Los cálculos de diversas oficinas de seguros de vida y rentas vitalicias, entre otras figuras que no pueden ir mal, han establecido el hecho'.

'Yo hablo de mi propia vida, padre'.

'O ¿en verdad? Todavía', dijo el señor Gradgrind, 'No hace falta que te lo diga, Louisa, que estás gobernada por las leyes que rigen la vida en su conjunto ${ }^{68}$.

'Quiero escucharlo de ti, madre; no de mí mismo'.

¿¿Quieres escucharlo de mí, querida? Eso es algo nuevo, estoy segura, cuando nadie quiere escucharme. No estoy nada de bien, Louisa. Muy débil y mareada'.

‘Sientes dolor, querida madre?'

'Creo que hay dolor en algún lugar de esta habitación', dijo la señora Gradgrind, 'pero no podría afirmar que lo he sentido'.

Después de esta extraña expresión, se tendió en silencio durante algún tiempo. Louisa, sosteniendo su mano, no podía sentir el pulso; pero besándolo, pudo ver un ligero y delgado hilo de vida en movimiento agitándose ${ }^{69}$.

67 Dickens, C. Hard Times. London, Chapman \& Hall, 1905: Capítulo II, «Murdering the innocents».

68 Dickens, C. Hard Times, Capítulo XV, «Father and daughter», el subrayado es nuestro.

69 Dickens, C. Hard Times, Capítulo IX, «Hearing the last of it», el subrayado es nuestro. 
La lectura de estos dos pasajes, y sobre todo el «discurso profundo» de un ser humano desposeído de la conciencia de sus propios sentimientos, precisamente cuando la narración está presentando su historia (de acuerdo con el comentario de Susan Sontag) como «la historia importante», uno se hace consciente de una especie de crueldad en -por lo demás bastante ordinario y sin pretensiones- las actitudes y comportamientos del personaje principal. De este modo, la mágica máquina de contar historias de la literatura puede hacer que percibamos como crueles, lo que en la vida ordinaria podría pasar casi desapercibido o donde el uso de la fuerza parece ser racional y proporcional, sólo porque se nos induce, mediante la lectura, «a prestar cierto tipo de atención».

De hecho, en Furman v. Georgia, entre los principios que según el Juez Brennan "por los cuales podemos determinar si un castigo particular es 'cruel e inusual'», se ha considerado que el «predicado esencial» es que «la pena no debe ser por su gravedad degradante para la dignidad humana». Podríamos decir que mientras nos sensibilizamos, a través de la literatura, sobre la crueldad y el daño que trae, también somos conscientes de una sustancia rica y sutil de la dignidad humana. Tal conciencia «literariamente mejorada» nos hace comprender la dignidad como el debido respeto a la singularidad de cada historia humana y sobre todo como estrictamente entrelazada con la idea de que no puede imponerse ningún fin a dicha historia, cuyo ulterior desarrollo siempre puede mostrar algo nuevo, algún giro inesperado, algo que puede (de acuerdo con la idea de Aristóteles de la literatura) siempre suceder.

Del mismo modo, en Filoctetes ${ }^{70}$ de Sófocles, el lector, sintiendo simpatía con la historia del personaje principal, mordido por una serpiente sagrada, que sufre cruelmente de una herida infectada, llorando terriblemente, se puede percibir que el abandono de Filoctetes por parte de Odiseo -lejos de la "normal" insensibilidad por la vida de otros, dictados por cada uno en la decidida búsqueda del poder- como un mero acto de crueldad dentro de los crueles sufrimientos del «pobre» héroe. En contraste con Ulises, el coro de los guerreros -al igual que el Juez Stevens en su voto particular-es capaz de imaginar tales sufrimientos con simpatía, transmitiendo así al público una comprensión emocional: la capacidad de tener compasión de él-.

\section{Filoctetes}

Te ruego por tu padre, por tu querida madre,

Por todo lo que más quieras en casa:

No me dejes aquí

Viviendo en este dolor, ahora que me has visto,

Y escucha lo que otros te han dicho de mi.

No soy importante para ti.

70 Véase también Nussbaum, M. Cultivating Humanity (pp. 99 ss. de la edición italiana). 
Piensa de todos modos en mí.

Sé que voy a ser una carga problemática para ti,

pero acéptalo.

Para ti y tu noble clase, ser cruel

es una vergüenza; ser decente, honorable.

Si me dejas, será una historia horrible.

Pero si me llevas, tendrás el mejor de los elogios de los hombres,

Eso si vivo para ver los campos de Eta.

CORO

Ten piedad de él, señor.

Él nos ha contado de muchos horribles tormentos.

Es posible que tales problemas no caigan sobre ninguno de mis amigos.

Señor, si tu odias a la terrible Atreides,

Pon su tratamiento a tu ventaja.

Yo lo llevaría, como él lo ha pedido,

Lejos de usted, en su nave de rápida marcha,

huyendo del cruel castigo de los dioses ${ }^{71}$.

Como ha sido recientemente destacado, es sólo a partir de la representación literaria de los sufrimientos espirituales de Filoctetes que se nos induce a percibir la miseria de la condición humana y por lo tanto a sentir compasión hacia él ${ }^{72}$.

Sin lugar a dudas, lo que se espera de la literatura es un enriquecimiento de nuestra imaginación, es decir, de la capacidad de compartir empáticamente el sufrimiento de otras personas y, por tanto, al menos en parte liberarlo de una cuestión de puro acto de propensión, a pensar en posibles desarrollos en sus vidas.

Otra gran representación de la crueldad, de la crueldad racial, es el Mercader de Venecia de William Shakespeare, sin duda, una de las obras más exploradas y discutidas en el ámbito del «Derecho y la Literatura» $»^{73}$. Pero la crueldad aparece en muchas formas diferentes en el drama, no sólo en los «legalismos» de Antonio $^{74}$.

Por lo tanto, el juego de espejos entre la literatura y la ley le muestra una faceta más: la ley nos permite percibir la crueldad justo en su uso conveniente para la ley,

71 Sophokles, Philoktetes.

72 Prete, A. Compassione. Storia di un sentimento. Torino, Bollati Boringhieri, 2013, pp. 41 ss.

73 Para un magistral análisis de este drama, junto al Otello de Shakespeare, especialmente en lo relativo a las crueldades «raciales» que describen allí, véase Cattaneo, A. «Shakespeare alla sbarra. Giustizia e processi nel 'Mercante di Venezia' y en 'Otello'». En Giustizia e Letteratura I, pp. 4-31; D'Alessandro, F. «La discriminazione su base razziale nell'opera di Shakespeare: giudizi e pregiudizi ancora attuali». En Giustizia e Letteratura I, pp. 32-41.

74 Weisberg, R.H. «Antonio's Legalistic Cruelty: Interdisciplinarity and The Merchant of Venice». En Mysiades (ed.): Undisciplining Literature, N.Y.: Peter Lang, 1999, 180, repr. de la literatura universitaria, 25, 1 (1998), pp. 12 - 20, esp. p. 19. 
mientras que la lectura de la historia de Shylock y, la mejora literaria de nuestros poderes imaginativos, podemos sentir empatía por su situación final.

La misma máquina está trabajando en El Proceso (Der Prozess), otra muy famosa novela de Kafka y un gran éxito en las lecturas de «Derecho y Literatura». La novela no describe explícitamente la crueldad, excepto tal vez en la última escena, cuando el personaje principal, Joseph K., es asesinado.

Pero las manos de uno de los caballeros fueron puestas sobre la garganta de K., mientras que el otro empujaba el cuchillo profundamente en su corazón y se lo retorcía allí, dos veces. A medida que su vista fallaba, K. vio a los dos caballeros mejilla a mejilla, cerca frente a su cara, viendo el resultado. «iComo un perro!», dijo, como si su vergüenza debiese sobrevivirlo.

Es más bien la crueldad que se percibe por los lectores en el intento minucioso de Joseph K. para defenderse de una misterioso acusación y del juez («alguien debe haber estado diciendo mentiras sobre Josef K., sabía que no había hecho nada malo, pero, una mañana, fue detenido»), y especialmente por el dolor de estar a lo largo de toda la novela sólo en el papel de parte acusada, por tanto, sin que su entera personalidad fuera objeto de atención, como la que cada ser humano, en la singularidad de su historia, hubiera merecido. Se le trata como un «miembro de una masa sin rostro, sin diferencias, sujeto a la aplicación ciega» de un juicio justo antes que tuviera lugar la ejecución del castigo.

Citando a Garland, tal como destaca en materia de linchamientos públicos, nosotros también podríamos decir que «una sola narrativa, una sola verdad» es impuesta sobre Joseph K., «una sola estructura de significado, sin oposición e incuestionable», que ignora la historia poética de una vida que siempre debe ser un «podría ser» un «lo que es posible», no para ser reducido dentro de los límites deterministas y cuantitativos de «lo que ha sucedido». Es justo lo contrario a «lo que es posible», lo que da lugar a «factores atenuantes o de compasión propios de las diversas debilidades de la especie humana», como se menciona en Woodson v. Carolina del Norte.

Como me aventuré a decir en un seminario sobre Kafka que organizamos en abril en la Università Cattolica del Sacro Cuore de Milán ${ }^{75}$, la descripción de la defensa judicial desesperada de José K. debe leerse conjuntamente con la vida propia de Franz Kafka y especialmente su eterno y agotador intento de defenderse contra su padre. En la novela, Kafka no se limita a actuar fuera de su lucha personal y familiar, sino que somete su lucha a un ineludible veredicto de culpabilidad, que muestra la crueldad, no tanto en el proceso, sino en las condiciones en que un hombre que ha

75 Università Cattolica di Milano, Ciclo seminarial «Giustizia e Letteratura» (Law and Literature) 2012-13, 11 de abril de 2013, «'Davanti alla Legge’. La Giustizia di Franz Kafka». 
sido privado de su propia historia, de una narración abierta a muchos «lo que puede suceder» $\mathrm{y}$, «lo que es posible» que hacen que una vida humana merezca ser vivida $\mathrm{y}$ conservada en su dignidad.

De hecho creo que un poco de inspiración para una tal lectura de El proceso, proviene de un fragmento póstumo por lo general titulado Cada ser humano es peculiar (Jeder Mensch ist eigentümlich), donde Kafka como hijo de sus padres cuenta la profunda angustia de que no le permitieran el placer de leer por la noche. Esta prohibición sufrida por Kafka simplemente como una negación de lo que es peculiar en él. Vemos aquí una especie de crueldad contra un niño que parece paradigmático de cuanto he dicho de la crueldad en general, a saber, que es una expresión de la voluntad de negar a un individuo «lo que es posible» para él, y el rompimiento de la única e infinita narrativa de la vida y de la personalidad que constituye su peculiaridad. Y más aún, ya que el niño Franz Kafka se sintió aplastado por la monstruosa desproporción entre esta prohibición inútil y lo maravilloso, se relevaron ante él infinitas perspectivas de lectura y narración.

En realidad todo era infinito o había desaparecido tanto en lo indefinido que podría compararse al infinito: aquel tiempo era infinito, entonces no podría ser demasiado tarde; mi vista era infinita, entonces yo no podría estropearlo; incluso la noche era infinita ${ }^{76}$.

Parece que el acto de escribir de Franz Kafka en su mayoría se convertirá en una compensación por aquella deliberada negación en que había consistido su peculiaridad, al igual que en El Proceso, en la narración de vidas unidireccionales ( $\mathrm{La}$ metamorfosis, América, El Castillo, etc.), de personas aplastadas por la restricción de un solo camino, privados de la vuelta del «lo que puede pasar», que a la postre drena su alma fuera de ellos.

\section{EL ROL DE LA LITERATURA EN LA EDUCACIÓN MORAL Y LEGAL}

La literatura juega un rol muy relevante en la política y la ley y es un recurso esencial en el desarrollo de la imaginación, en beneficio de la comprensión humana y alimentando así la capacidad de imaginar cómo las cosas podrían suceder, que constituye el pensamiento crítico que se necesita desesperadamente en cualquier democracia $^{77}$. En efecto, el «aprendizaje requiere de la reflexión y la reflexión

76 Kafka, F. «Frammenti da quaderni e fogli sparsi». En Schiovani, G. (ed.): Aforismi e frammenti. Milano, RCS Libri, 2004, pp. 255-259. Para un comentario de este texto, Calasso, R. Adelphi, Milano, 2002, pp. 239-242.

77 Nussbaum, M. Cultivating Humanity. A Classical Defense of Reform in Liberal Education (edición italiana, p. 100), citado desde Aristotle, Poetica. 
requiere distancia. La ficción puede ser superior al hecho como un medio de educación, precisamente porque la ficción es imaginativa o reflectante en lugar de concreta e inmediata. Podemos aprender indirectamente a partir de la reflexión sobre las experiencias de ficción de los demás aquello que no podemos aprender directamente de los acontecimiento en nuestras propias vidas ${ }^{78}$. Como se señalaba acertadamente, un niño comienza a adquirir capacidades morales cuando escucha y se cuenta historias a sí mismo ${ }^{79}$. Todas las historias que se cuentan en las obras literarias que he mencionado, pueden leerse como una denuncia de la incapacidad del ojo «interior» de las personas para ver la realidad humana, para prestar atención suficiente a fin de que sigamos luchando por convertirnos en seres humanos morales, ya que la democracia necesita individuos dotados de tales poderes para observar y realmente ver en otras personas la humanidad común y compartida ${ }^{80} \mathrm{de}$ su individualidad, historias indefinidas.

La compasión surge cuando sentimos nuestra vulnerabilidad y sentimos que compartimos tal condición con cualquier otro ser humano ${ }^{81}$, tal como ha sido expresado en un pasaje de Woodson v. Carolina Del Norte. La crueldad tiene sus raíces en la voluntad de eliminar tales sentimientos compartidos, construyendo una sustitución de una sola narrativa simple en lugar de la narrativa abierta que es la que constituye la vida de las personas y articula el discurso de los derechos humanos.

Por tanto, podemos entender mejor por qué y cómo las historias de la literatura moderna y los derechos modernos están tan entrelazados. Como se ha dicho, «vivir en la literatura, o verse a sí mismo como un portador de derechos [...] era volver a descubrir la propia humanidad, aparte del mundo del comercio y de la política». Por lo tanto, «el lenguaje del 'humano' incrustado en la 'literatura' y «los 'derechos' ayudaron a reforzar este humanismo universalista, así como para distanciar ambos dominios aún más lejos de las nociones mecanicistas de la competencia en las esferas políticas, económicas o culturales» ${ }^{82}$.

78 Zuckert, C.C.H.: «Leadership -Natural and Conventional- in Melville's «Benito Cereno». En Interpretation. A Journal of Political Philosophy, Invierno 1998, Vol. $26 \mathrm{~N}^{\circ}$ 2, p. 252.

79 Nussbaum, M. Cultivating Humanity (p. 103 de la edición italiana).

80 Nussbaum, M. Cultivating Humanity (p. 102 de la edición italiana).

81 Nussbaum, M. Cultivating Humanity (p. 104 de la edición italiana).

82 Como destaca Stone Peters, J. «Literature», the «Rights of Man», (p. 271), «Las Cartas de Schiller sobre la educación estética del hombre son, sin duda, paradigmáticas. Para Schiller, precisamente porque el arte es desinteresado (autónomo del mundo de comprar y gastar), el mismo permite que uno se de cuenta de la conexión entre la humanidad concreta y un nivel más alto y más universal de humanidad que el del mundo cotidiano (comercial). El arte redime el moderno medio-fin del utilitarismo, alivia de la carga de la competencia y la praxis de la vida y la preservación, en sus formas ideales, cosas tales como la alegría, la verdad, la solidaridad y la humanidad. 'El ciudadano que, en la vida cotidiana se ha reducido a una función parcial (actividad medios-fines) puede ser descubierto en el arte como 'ser humano'». 
Obras literarias como Los Miserables o La cabaña del tío Tom han sido consideradas como «el vehículo central para los grandes movimientos humanitarios y de derechos del siglo XIX ${ }^{83}$. Ellos describen ampliamente la crueldad que he llamado como el «modo directo», no sólo en su sentido indirecto, contrastándola con la idea de un ser humano valioso y de dignidad, respeto y a no ser sometido a conveniencias y cómputos. «El humanitarismo fue fundado en nociones sobre la fuerza narrativa del sufrimiento del cuerpo humano como base para una respuesta moral. El discurso de los derechos acompañados por el lenguaje de la obligación moral sirvió como una formulación imperativa de las lecciones de simpatía que enseña la literatura $\rangle^{84}$.

La cuestión que apremia ser investigada por los juristas y profesionales del derecho en vistas de la fruta dulce o amarga que podemos arrancar en la actualidad, es el reciente resurgimiento del «paradigma humanista en que la literatura y los derechos fueron modelados durante los últimos siglos XVIII y XIX», luego de la eclipse efectuada en el siglo XX por un paradigma de la ingeniería social que ha devastado a la humanidad con sus tiranías y totalitarismo y que todavía cierne sobre nuestras vidas en forma de capitalismo financiero.

Nuestros esfuerzos para introducir a los estudiantes de derecho en las experiencias literarias se basan en la idea de una conexión estricta y en el apoyo mutuo entre la literatura, por un lado, y la dosis diaria teórica y práctica en el trabajo de abogados profesionales, legisladores, jueces y fiscales, por el otro. Creemos que en este momento, el discurso literario es una gran fuente de inspiración para varios logros legales importantes y fructíferos, que por lo general se basan en una nueva (o, al menos, ubicada fuera de las principales corrientes actuales o de las recientes perspectivas políticas) aproximación a la justicia criminal y a las respuestas penales.

83 Stone Peters, J. «Literature», the «Rights of Man», pp. 272 ss.: «Escribiendo en 1772, Benjamin Franklin expresaba la idea, en referencia a la «compasión natural por.... Criaturas Semejantes» que provoca «lágrimas ante la visión de un objeto de caridad, que por una relación de sus circunstancias» parece «exigir la asistencia de los que le rodean». «Esta simpática identificación fue concebida para ser sensible a las imágenes, pero aún más a las historias de sufrimiento, es decir, para estímulos visuales, pero aún más a estímulos narrativos («Relación de... las circunstancias»), este tipo de estímulos narrativos fueron producidos en abundancia por la cultura del siglo XVIII: en los informes de la autopsia que se describen en Laqueur (a diferencia de sus predecesores, expandidos en la narrativa pathos de representación); en los cuentos narrativos de no ficción de la época; pero sobre todo en «literatura». Es decir, el humanitarismo era fundamentalmente una ideología narrativa o literaria: Las narrativas sobre el sufrimiento centrales en la literatura enseñan cómo ser un ser humano, y en última instancia a levantarse por encima de las fuerzas deshumanizantes de la modernidad.

84 Stone Peters, J. «Literature», the «Rights of Man», pp. 272 s., quien cita de T.W. Laqueur («Bodies, Details, and the Humanitarian Narrative». En The New Cultural History, ed. Lynn Hunt (Berkeley: U of California P, 1989), pp. 176-204). 
Como se comentó con sensatez, en comisiones y tribunales de la verdad de hoy en día, que en su mayoría tienen que hacer frente a terribles crueldades, encontramos, entre otras muchas cosas, una reiteración de la «creencia en la racionalidad de la esfera pública», de «la idea de que una experiencia traumática privada e individual debe ser traída a la luz pública», de «la opinión que la auténtica voz narrativa de la víctima puede permitir tanto el alivio de la víctima de ser escuchada como la creación de exigencias morales, que, hablando de la compasión natural de la audiencia, puede llevar a cabo una especie de conversión de la sociedad $\rangle^{85}$. Al igual que en el siglo XVIII, la narrativa que fluye de las voces de las víctimas es vista como el «fundamento de la acción de respuesta y de la unión social que puede trascender la alienación de la modernidad y puede devolvernos a lo humano».

También concordamos en que «la proliferación de las comisiones y tribunales de la verdad es una respuesta a un momento de crisis de la ley, producida por una sensación de falta de fundamento de la ley, su radical contingencia, especialmente cuando se traduce en la esfera del súper-Estado, con su autoridad nunca plenamente legitimada».

Y que, en este contexto, «la víctima es responsable de proporcionar una base incuestionable para el ejercicio del poder legal», que «está situado en la ejecución del sufrimiento», que sirve "para autenticar un conjunto de recién creadas y todavía un poco tenues demandas legales en el ámbito de los derechos humanos», y ello a través de la voz humana: «la voz de la víctima ofrece un tipo de verdad que la evidencia documental, los informes, las determinaciones legales, no pueden proporcionar ${ }^{86}$.

Estas expectativas en realidad puede ser bastante problemáticas. Como se ha dicho, la actual «epidemia de la narración» puede ser una que «se limita a exponer la represión histérica de la expresión ritual», «una forma de centrarse en nuestros pequeños dedos a expensas del corpus global (con su triste impersonalidad), o a expensas de abocarse a la complicada tarea técnica de salvar vidas. Puede ser un desplazamiento sentimental y eviscerado de otros tipos de trabajo: la reconstrucción de las ciudades y granjas; la reparación de los cuerpos rotos; la triste actuación policial de una violencia todavía inquietante» ${ }^{87}$.

Sin embargo, no debemos olvidar que el escuchar contar historias sobre la crueldad, especialmente aquellas narradas a través de las voces de las víctimas, es sólo el punto de partida de un viaje difícil, que conlleva una gran responsabilidad para todo el mundo y para las instituciones que participan en tales escuchas, requiriendo la voluntad de contribuir a las políticas y sensibilidades, a una comprensión real y a hacer frente a las condiciones en que han surgido tales crueldades o en que pudieran surgir en el futuro. Por lo tanto, en realidad, el meollo de la cuestión es la forma

85 Stone Peters, J. «Literature», the «Rights of Man», pp. 275 s.

86 Stone Peters, J. «Literature», the «Rights of Man», p. 276.

87 Stone Peters, J. «Literature», the «Rights of Man», pp. 275-283. 
en que este tipo de «epidemia de la narración», sobre todo de la crueldad, puede llegar a orientar las políticas de justicia criminal y penal, así como las posiciones dentro de la judicatura, y no simplemente reducirse a «un mero ofrecimiento de una expresión ritual de una represión histérica» o «un modo de centrarse en nuestros pequeños dedos a expensas del corpus global».

Una manera muy tangible a través de la cual la literatura y los (buenos) relatos pueden encontrar su camino en la justicia penal es en la justicia restaurativa y por tanto, sobre todo, en el diálogo mediado entre delincuente y la víctima ${ }^{88}$.

Esta vasta área de estudios, prácticas y experiencias está estrictamente ligada a la literatura, incluso en el sentido aristotélico, ya que es capaz de transformar tanto el estático marco histórico del delito cometido, de la crueldad infligida y la respuesta penal igualmente estática a la misma, en un proyecto dinámico, en una

88 Especialmente esbozado en el Especially drawing on the already quite conspicuous Italian experiences in the field, I'd limit my references to some essential works: Ceretti, A. «Mediazione penale e giustizia. In-contrare una norma». En AA.VV. Studi in ricordo di Giandomenico Pisapia. Milano, Giuffrè, 2000; Ceretti, A.; Di Ciò, F. «Giustizia riparativa e mediazione penale a Milano. Un'indagine quantitativa e qualitativa». En Rassegna penitenziaria e criminologica, 2003, VI(3), pp. 99 ss.; Ceretti, A.; Mazzucato, C. «Mediazione reo/vittima: le 'istruzioni per l'uso' del Consiglio d'Europa. Un commento alle Guidelines for a Better Implementation of the Existing Recommendation concerning Mediation in Penal Matters». En Nuove Esperienze di Giustizia minorile, Ministero della Giustizia - Dipartimento per la Giustizia minorile, 2008, n. 1, pp. 201 ss. (también disponible en: http://www.giustiziaminorile.it/rsi/pubblicazioni/2008_01.asp); Mannozzi, G. La giustizia senza spada: uno studio comparato su giustizia riparativa e médiazione penale. Milano, Giuffrè, 2003; Mazzucato, C. «Giustizia esemplare. Interlocuzione con il precetto penale e spunti di política criminale». En Bertolino, M.; Forti, G.; Eusebi, L. (eds.): Studi in onore di Mario Romano. Napoli, Jovene, 2011, pp. 407 ss.; id., «Appunti per una teoria 'dignitosa' del diritto penale a partire dalla Restorative Justice». En Dignità e diritto: prospettive interdisciplinari, Quaderni del Dipartimento di Scienze Giuridiche -Università Cattolica del Sacro Cuore (sede di Piacenza) n. 2/2010, Libellula, Tricase, 2010, pp. 99 ss. (también en: http://dipartimenti. unicatt.it/ scienzegiuridiche_dignitadiritto_ebook.pdf); id., «Un umano fare, al posto di un disumano subire. Considerazioni politico-criminali intorno alla giustizia riparativa». En Trecci, P.; Cafiero, M. (eds.): Riparazione e giustizia riparativa. Riflessione di servizio sociale nel sistema penale. Milano, Franco Angeli, 2007, pp. 39 ss.; id., «Un filo rosso unisce mediazione penale e diritti dei bambini. Strategie consensuali e costruttive per la prevenzione dei reati minorili». En UNICEF, Atti del Secondo Incontro Nazionale sulla Giustizia Minorile, Bari 28-29 de abil de 2005, en Mediares, 2006, pp. 267 ss.; id., Consenso alle norme e prevenzione dei reati. Studi sul sistema sanzionatorio penale. Roma, Aracne, 2005; id., «Mediazione e giustizia riparativa in ambito penale. Fondamenti teorici, implicazioni politico-criminali e profili giuridici». En Cosi, G.; Foddai Eds, M.A.: Lo spazio della mediazione. Milano, Giuffrè, Milano, 2003, pp. 151 ss.; id., «L'esperienza dell'Ufficio per la mediazione a Milano». En La mediazione penale in ambito minorile: applicazioni e prospettive, Atti del Seminario di studi a cura dell'Ufficio centrale Giustizia Minorile. Milano, Franco Angeli, 1999, pp. 137 ss.: id., «L'universale necessario della pacificazione: le alternative al diritto e al proceso». En Lombardi Vallauri, L. (ed.): Logos dell'essere, logos della norma. Bari, Adriatica, 1999, pp. 1245 ss.; id., «La mediazione nel sistema penale minorile». En Barbero Avanzini, B. (ed.): Minori, giustizia penale e intervento dei servizi. Milano, Franco Angeli, 1998, pp. 117 ss. 
nueva historia que debe ser vivida y contada, en un nuevo camino abierto a «lo que puede suceder» $y$ «lo que es posible», a ser seguido, posiblemente juntos, por delincuente y víctima ${ }^{89}$. La justicia restaurativa parece reproducir un significado que debe impregnar todo el ámbito de la justicia penal e incluso de la propia ley ${ }^{90}$, a saber, la idea de una alianza entre la sociedad y el delincuente, una alianza que el crimen no ha roto de una vez y para siempre, sino que la respuesta al delito debe incluso, posiblemente, ayudar a restaurar y florecer, en beneficio de la prevención del delito en general, y por tanto, de la protección de la sociedad.

Algunas regulaciones internacionales no parecen particularmente prometedoras, con respecto a la capacidad de apreciar y hacer un buen uso de la justicia restaurativa en la resolución de conflictos y como una alternativa viable a la tradicional «estática» del castigo. En efecto, parecen centrarse estrictamente en las sanciones penales como posibles respuestas a los crímenes y a demostrar una actitud un tanto desconfiada hacia la resolución alternativa de conflictos, incluida la justicia restaurativa y posibles oportunidades para un encuentro directo y al diálogo entre la víctima y el agresor.

Una de estas reglamentaciones es la Directiva 2012/29/UE del Parlamento Europeo y del Consejo, de 25 de octubre de 2012 que «establece normas mínimas sobre los derechos, el apoyo y la protección de las víctimas de delitos», que debería incorporarse a la legislación nacional para el año 2015.

Como acertadamente se señala ${ }^{91}$, el art. $12^{92}$, referido a la justicia restaurativa y aquellas que cuentan con un importante canal para transmitir las voces y relatos

89 Véase Eusebi, L. «La risposta al reato e il ruolo della vittima». En Diritto penale e processo, 5/2013, pp. 527-31.

90 Véase el nuevo sentido de la legislación derivado de las historias del éxodo judío, Ost F., pp. 43 ss.

91 Eusebi, L. «La risposta al reato e il ruolo della vittima», cit., pp. 527-31.

92 Artículo 12 Derecho a garantías en el contexto de los servicios de justicia reparadora 1. Los Estados miembros adoptarán medidas para proteger a la víctima contra la victimización secundaria o reiterada, la intimidación o las represalias, medidas que se aplicarán cuando se faciliten servicios de justicia reparadora. Estas medidas garantizarán que aquellas víctimas que opten por participar en procesos de justicia reparadora tengan acceso a servicios de justicia reparadora seguros y competentes, siempre que se cumplan, como mínimo, las condiciones siguientes: a) que se recurra a los servicios de justicia reparadora si redundan en interés de la víctima, atendiendo a consideraciones de seguridad, y se basan en el consentimiento libre e informado de la víctima; el cual podrá retirarse en cualquier momento; b) antes de que acepte participar en el proceso de justicia reparadora, se ofrecerá a la víctima información exhaustiva e imparcial sobre el mismo y sus posibles resultados, así como sobre los procedimientos para supervisar la aplicación de todo acuerdo; c) el infractor tendrá que haber reconocido los elementos fácticos básicos del caso; d) todo acuerdo deberá ser alcanzado de forma voluntaria y podrá ser tenido en cuenta en cualquier otro proceso penal; e) los debates en los procesos de justicia reparadora que no se desarrollen en público serán confidenciales y no se difundirán posteriormente, salvo con el acuerdo de las partes o si así lo exige el Derecho nacional por razones de interés público superior. 2. Los Estados miembros facilitarán la derivación de casos, si procede, a los servicios de justicia reparadora, incluso mediante el establecimiento de procedimientos $\mathrm{u}$ orientaciones sobre las condiciones de tal derivación. 
de las víctimas a las instituciones de justicia penal, «en los casos que prevé alguna prestación de servicios de justicia reparadora» parece más preocupado por "salvaguardar a la víctima de la victimización secundaria y reiterada», que de reconocer todo su potencial para este tipo de resolución de conflictos como una alternativa a los medios tradicionales de la justicia penal. Por tanto, muestra una actitud más defensiva que proactiva y de promoción hacia los recursos innovadores para hacer frente a la violencia y a las crueldades.

Una actitud similar surge quizá del segundo documento que me gustaría mencionar aquí, a saber, el Convenio del Consejo de Europa sobre la prevención y la lucha contra la violencia contra las mujeres y la violencia doméstica y especialmente el art. 48, que prohíbe expresamente los procesos de resolución alternativa de conflictos o imposición de condenas ${ }^{93}$.

Aunque no podemos dejar de estar de acuerdo con la prohibición de cualquier uso obligatorio de la justicia restaurativa o la participación de la víctima en el mismo, el entero marco de la Convención hace surgir muchas perplejidades, en cuanto Directiva de la UE, parece marcada por un enfoque hacia la justicia restaurativa que en su identificación parece más defensiva y reactiva que proactiva en el posible buen uso de sus muchos valiosos recursos.

93 Artículo 48 - Prohibición de modos alternativos obligatorios de resolución de conflictos o imposición de condenas. 1 Las Partes adoptarán las medidas legislativas o de otro tipo necesarias para prohibir los modos alternativos obligatorios de resolución de conflictos, incluidas la mediación y la conciliación, en lo que respecta a todas las formas de violencia incluidas en el ámbito de aplicación del presente Convenio. 2 Las Partes adoptarán las medidas legislativas o de otro tipo necesarias para que, en el caso de que se condene al pago de una multa, se tenga debidamente en cuenta la capacidad del autor del delito para hacer frente a las obligaciones económicas que tenga contraídas con la víctima. 


\title{
LA PENA DE MUERTE: MORATORIA UNIVERSAL MEDIO SIGLO DESPUÉS DE EL VERDUGO ${ }^{1}$
}

\author{
MIGUEL ABEL SOUTO \\ Catedrático acr. de Derecho penal \\ Universidad de Santiago
}

\section{INTRODUCCIÓN}

A pesar de que en Europa «el abolicionismo ha ganado la partida», la pena de muerte todavía no ha sido erradicada mundialmente y las cifras demuestran que sigue representando «un problema candente y actual» ${ }^{2}$, aunque recientemente se han dado pasos muy importantes para el principio del fin de la pena de muerte, mediante las resoluciones de la Asamblea General de las Naciones Unidas 62/149, de 18 de diciembre de 2007, 63/168, de 18 de diciembre de 2008, 65/206, de 21 de diciembre de 2010 y 67/176, de 20 de diciembre de 2012, sobre moratoria del uso de la pena de muerte ${ }^{3}$, con el objetivo último de su abolición

1 Conferencia pronunciada en la Universidad de Huelva el 28 de noviembre de 2013. Este artículo se integra en el proyecto de innovación docente PID1315013, "Enseñanza del Derecho penal a través de los medios de comunicación y su interrelación con la actual política criminal".

Muñoz Conde, F. «Notas bibliográficas». En Anitua, G.I./Yamamoto, M.V. (comps.), La pena de muerte. Fundamentos teóricos para su abolición. Buenos Aires, Didot, 2011, p. 324.

2 Ibidem.

3 Cfr. Naciones Unidas, Moratoria del uso de la pena de muerte. Resolución aprobada por la Asamblea General el 20 de diciembre de 2012, A/RES/67/176, distr. general 20 de marzo de 2013, p. 1. 
y «la restricción en aquellos países que la mantengan, con el objetivo intermedio de una moratoria universal» $»^{4}$.

La pena de muerte debe ser abolida porque vulnera el «principio de humanidad $»^{5}$ - dada «la brutalidad, la crueldad $»^{6}$, el atentado contra la dignidad y los derechos humanos ${ }^{7}$, carece de justificación tanto desde el punto de vista retributivo como desde la prevención especial o general ${ }^{8}$, pues no hay pruebas de su efecto disuasorio ${ }^{9}$, acaba con la «naturaleza sagrada e inviolable de la vida humana $»^{10}$, resulta anacrónica e ilegítima en una sociedad democrática basada en el modelo del contrato social de Rousseau ${ }^{11}$, constituye una manifestación extrema de «violencia» ${ }^{12}$, impide la reparación de cualquier error judicial ${ }^{13}$, genera frecuentes «enfermedades psiquiátricas en los presos que esperan la ejecución ${ }^{14}$, se aplica de forma discriminatoria y, finalmente, en la medida en que existen penas «menos dañinas y más efectivas» ${ }^{15}$.

Así las cosas, este trabajo aborda dos cuestiones clásicas pero actuales: la pena de muerte y la obra de un director de cine valenciano. He elegido El verdugo porque la película de García Berlanga está de $50^{\circ}$ aniversario, cumple ya medio siglo, pues el año de realización es 1963, y me gustaría rendir con esta contribución un humilde tributo a otro valenciano, el profesor ORTS BERENGUER, ya que precisamente él fue pionero en la coordinación de monografías sobre cine y Derecho penal, en escribir, según sus palabras, «desde una perspectiva que no es la habitual en la profesión docente y doctrinaria ${ }^{16}$, en ofrecernos una necesaria visión «novedosa, atrayente $\mathrm{y}$ hasta divertida» ${ }^{17}$.

\footnotetext{
Arroyo Zapatero, L. «El camino hacia la moratoria universal de la pena de muerte». En Anitua, G.I./YAMAMOTO, M.V., op. cit., p. 43.

5 De la Cuesta Arzamendi, J.L. «The death penalty and drugs». En Arroyo, L./Biglino, P./Shabas, W.A. (eds.), Towards universal abolition of the death penalty. Valencia, Tirant lo Blanch, 2010, $\mathrm{p}$. 367.

6 Muñoz Conde, F., op. cit., p. 323.

$7 \quad C f r$. Naciones Unidas, op. cit., p. 1.

$8 \quad C f r$. De la Cuesta Arzamendi, J.L. «The death penalty...», cit., pp. 376-378.

9 Cfr. Naciones Unidas, op. cit., p. 1.

10 De la Cuesta Arzamendi, J.L. «The death penalty...», cit., p. 377.

11 Ibidem.

12 Arroyo Zapatero, L., op. cit., p. 48.

13 Cfr. Naciones Unidas, op. cit., p. 1.

14 De la Cuesta Arzamendi, J.L. «The death penalty...», cit., p. 377.

15 Ibidem

16 Orts Berenguer, E. «Presentación». En Orts Berenguer, E. (coord.), Prostitución y Derecho en el cine. Valencia, Tirant lo Blanch, 2003, p. 10.

17 Ibidem.
} 


\section{CINE Y TELEVISIÓN COMO RECURSO DIDÁCTICO}

Cualquier manifestación artística, desde la literatura hasta el cine o la televisión puede aportar datos para el análisis jurídico ${ }^{18}$ que siembren la semilla del interés en el alumno ${ }^{19}$ al permitirle, sin esfuerzo, superar, de manera divertida, incluso el cansancio intelectual ${ }^{20}$.

En efecto, el carácter documental e informativo del cine enriquece la enseñanza de cualquier materia, las emociones que produce el séptimo arte pueden despertar el interés del alumno por un tema jurídico, la identificación que genera entre sujeto y objeto potencia el aprendizaje significativo e, igualmente, el cine aporta la baza fundamental para el aprendizaje motivador de enseñar deleitando, reflejada en el aforismo prodesse delectare ${ }^{21}$. Así, $v$. gr., resulta interesante que el alumno reflexione sobre documentales como La corporación o Caso Enron para el aprendizaje del Derecho penal de la empresa mediante tareas vinculadas a aulas virtuale ${ }^{22}$ y la construcción en ellas de «cinetecas» con comentarios de películas que pongan de relieve su conexión con la asignatura ${ }^{23}$. Conviene proyectar obras como Heroína para que los alumnos perciban la incidencia del narcotráfico en Galicia y analicen en grupos la conexión entre el crimen y la drogadicción, si con la actual regulación se protege realmente la salud pública, las propuestas político-criminales de legalización controlada, el atentado contra el principio de legalidad que comportan los tipos abiertos como el artículo 368 del Texto punitivo, la positiva rebaja penológica operada en 2010 para la figura criminológica del traficante-consumidor o las no tan acertadas modificaciones sobre la criminalidad organizada y el tipo de extrema gravedad por uso de embarcaciones ${ }^{24}$. Igualmente, cabe abordar los crímenes contra la

18 Cfr. Quintano Ripollés, A. La Criminología en la literatura universal. Ensayo de propedéutica biológico-criminal sobre fuentes literarias. Barcelona, Bosch, 1951, pp. 10 y 11.

19 Vid. Abel Souto, M. «Desde la literatura, ópera, cine y televisión hasta las ciencias jurídicas y el Derecho penal mediante la nueva técnica pedagógica del aprendizaje basado en problemas». En Dereito, $\mathrm{n}^{\circ}$ 20.2, 2011, pp. 183-205 y Revista Jurídica de Investigación e Innovación Educativa (Rejie), $\mathrm{n}^{\circ}$ 5, 2011, pp. 87-104.

20 Cfr. Del Rosal, J. Crimen y criminal en la novela policiaca. Madrid, Instituto Editorial Reus, 1947, p. 11.

${ }_{21}$ Cfr. De Vicente Martínez, R. Las artes contra la pena de muerte. Valencia, Tirant lo Blanch, 2010, pp. 349 y 350.

$22 C f r$. Ríos Corbacho, J.M. «Innovación docente del Derecho penal de la empresa a través de técnicas colaborativas y entornos virtuales de aprendizaje en el espacio europeo de educación superior». En Rejie, ${ }^{\circ} 3,2011$, p. 75.

23 Cfr. Holgado Sáez, C. «Las nuevas tecnologías en los estudios de Derecho en el marco del EEES: sugerencias didácticas de actividades colaborativas con entornos virtuales». En Rejie, nº 3, 2011, p. 102.

$24 V i d$. Abel Souto, M. «Luces y sombras en la reforma penal sobre drogas de 2010». En La Ley Penal, ${ }^{\circ}$ 83, 2011, pp. 61-86; Lorenzo Salgado, J.M. «Reformas penales y drogas: observaciones críticas. (Especial referencia a la LO 5/2010, de modificación del Código penal)». En Muñoz Conde, F./Lorenzo Salgado, J.M./Ferré Olivé, J.C./Cortés Bechiarelli, E./Núñez Paz, M.A. (dirs.), Un Derecho penal comprometido. Libro homenaje al Prof. Dr. Gerardo Landrove Díaz. Valencia, Tirant lo Blanch, 2011, pp. 631-679. 
humanidad desde ¿Vencedores o vencidos? ${ }^{25}$, las leyes eugenésicas nacionalsocialistas desde Amen y Good $^{26}$, el asesinato desde $A$ sangre fría ${ }^{27}$, las torturas desde Brazill $^{28}$, La pasión de Juana de Arco, Dies irae ${ }^{29}$, El crimen de Cuenca ${ }^{30}$, Estado de sitio $^{31}$, El experimento $^{32} \mathrm{o}$, junto con la violación, el asesinato, la cadena perpetua, la detención ilegal y el abuso de confianza, desde El secreto de sus ojos ${ }^{33}$, las lesiones y la corrupción en el deporte desde Más dura será la caída ${ }^{34}$, los delitos relacionados con la prostitución desde Las noches de Cabiria ${ }^{35}$, Belle de jour ${ }^{36}$, La vida de Oharu ${ }^{37}$, El matrimonio de María Braun ${ }^{38}$, Taxi Driver ${ }^{39}$ o Whore ${ }^{40}$, la deleznable pena de muerte mediante la proyección de más de medio centenar de

25 Vid. Muñoz Conde, F./Muñoz Aunión, M. ¿Vencedores o vencidos? Comentarios jurídicos y cinematográficos a la película de Stanley Kramer El juicio de Nuremberg (1961). Valencia, Tirant lo Blanch, 2003.

26 Vid. Holgado Sáez, C. «El cine como herramienta didáctica para la historia de Alemania: a propósito del programa de eugenesia en el nacionalsocialismo». En Arte y Sociedad. Revista de Investigación, $\mathrm{n}^{\mathrm{o}}$ 4, 2013, pp. 1-19.

27 Vid. De Vicente Martínez, R. A sangre fría. El núcleo duro del Derecho penal. Valencia, Tirant lo Blanch, 2012.

28 Vid. Díaz y García Conlledo, M. «Brazil. Vigilancia, seguridad, tortura». En García Amado, J.A./ Paredes Castañón, J.M. (coords.), Torturas en el cine. Valencia, Tirant lo Blanch, 2005, pp. 99-128.

29 Vid. Paredes Castañón, J.M. «La pasión de Juana de Arco/Dies irae. Las políticas de la tortura». En García Amado, J.A./Paredes Castañón, J.M., op. cit., pp. 47-78.

30 Vid. Doval Pais, A., «El crimen de Cuenca. La tortura de todos: el campo de concentración como metáfora del neofascismo cotidiano». En García Amado, J.A./Paredes Castañón, J.M., op. cit., pp. 143-160.

31 Vid. Barber Burusco, S. «Estado de sitio. Tortura y poder». En García Amado, J.A./Paredes Castañón, J.M., op. cit., pp. 231-244.

32 Vid. Gómez Martín, V. «El experimento. Algunas consideraciones sobre el Stanford Prison Experiment». En García Amado, J.A./Paredes Castañón, J.M., op. cit., pp. 179-199.

33 Vid. Ríos Corbacho, J.M. «El secreto de sus ojos». En http://proyectodecine.wordpress. com/2011/07/01, pp. 1-21.

34 Vid. De Vicente Martínez, R. «Más dura será la caída de Mark Robson. A propósito de deporte en el cine y Derecho». En Revista Aranzadi de Derecho de Deporte y Entretenimiento, n 34, 2012, pp. 427-441.

35 Vid. Orts Berenguer, E. «Las noches de Cabiria. La dignidad de una prostituta». En Orts Berenguer, E. (coord.), op. cit., pp. 93-112.

36 Vid. Quintero Olivares, G. «Belle de jour y la libre opción por la prostitución». En Orts Berenguer, E., op. cit., pp. 113-127.

37 Vid. Mqueda Abreu, M.L. «La vida de Oharu. El comercio sexual de seres humanos: una esclavitud de todos los tiempos». En Orts Berenguer, E., op. cit., pp. 57-72.

38 Vid. Jareño Leal, A. «El matrimonio de María Braun. Abolicionismo o legalización: las opciones legales con respecto a la prostitución». En Orts Berenguer, E., op. cit., pp. 27-55.

39 Vid. Tomás-Valiente Lanuza, C. «Taxi Driver y las posibles razones para reprimir penalmente comportamientos relacionados con la prostitución». En Orts Berenguer, E., op. cit., pp. 129-141.

40 Vid. Cugat Mauri, M. «Whore. El cine contra el cine». En Orts Berenguer, E., op. cit., pp. 13-26. 
películas ${ }^{41}$ así como otras consecuencias jurídicas del delito ${ }^{42}$ y es posible analizar en grupos cómo en Soy un fugitivo ${ }^{43}$, Tres colores: rojo ${ }^{44}$ o La naranja mecánica ${ }^{45}$ se reflejan todas las teorías de la pena ${ }^{46} \mathrm{o}$ esta última obra también puede servir de base para abordar el cambio de posiciones entre criminal y víctima ${ }^{47}$.

De la misma manera la televisión también puede ser una fuente inagotable de recursos didácticos. En este sentido no debemos despreciar el valor de Los Simpson, pues cada episodio representa una inversión de millón y medio de dólares, y aunque nos riamos con estos divertidos personajes, alguien se los toma muy en serio: 300 individuos que destinan 8 meses de trabajo a cada episodio ${ }^{48}$, de los que, según Matt Groening, la mitad se graduaron en Harvard ${ }^{49}$. Se trata de «valernos del interés del público en la serie ${ }^{50}$ para acercarlo al Derecho penal, ya que la ficción puede instruir al provocar respuestas cognitivas y afectivas relevantes con sus personajes, como Homer y Marge, que son caricaturas nuestras, al incidir positivamente sobre la atención del alumno, que se proyecta imaginariamente, aunque al ser dibujos animados no se confunde con ellos, lo que estimula más la reflexión sobre los personajes y las situaciones; además, el humor de Los Simpson contribuye a su valor heurístico, del que siempre disfrutó la comedia como herramienta pedagógica ${ }^{51}$.

41 Vid. De Vicente Martínez, R. «Las artes...», cit., pp. 169-357.

42 Vid. Ríos Corbacho, J.M. «Las consecuencias jurídicas del delito y el cine». En Ciencia Ergo Sum, $\mathrm{n}^{\circ}$ 19.1, 2012, pp. 6-23.

43 Vid. Díaz y García Conlledo, M. «Crimen y castigo. Derecho penal, ¿para qué? A propósito de Soy un fugitivo». En Presno Linera, M.A./Rivaya, B. (coords.), Una introducción cinematográfica al Derecho. Valencia, Tirant lo Blanch, 2006, pp. 77-108.

44 Vid. De Vicente Martínez, R. El color de la justicia. (Tres colores: rojo). Valencia, Tirant lo Blanch, 2003.

45 Vid. Ríos Corbacho, J.M., La naranja mecánica. Problemas de violencia y resocialización en el siglo XXI. Valencia, Tirant lo Blanch, 2009.

46 Vid. Abel Souto, M. Teorías de la pena y límites al "ius puniendi" desde el Estado democrático. Madrid, Dilex, 2006; Ríos Corbacho, J.M. «Los fines de la pena a través del cine». En Anuario da Facultade de Dereito da Coruña, $\mathrm{n}^{\mathrm{0}}$ 15, 2011, pp. 425-456.

47 Vid. Morillas Fernández, D.L./Patró Hernández, R.S./Aguilar Cárceles, M.M. Victimología: un estudio sobre la víctima y los procesos de victimización. Madrid, Dykinson, 2011.

48 Cfr. Irwin, W./Conard, M.T./Skoble, A.J. (eds.), The Simpsons and Philosophy, Open Court, Chicago and La Salle, Illinois, 2001, traducido al castellano por Diana Hernández como Los Simpson y la filosofia. Barcelona, Círculo de lectores, 2009, p. 13.

49 Cfr. Irwin, W./Lombardo, J.R. «Los Simpson y la alusión: 'El peor ensayo de la historia'». En Irwin, W./Conard, M.T./Skoble, A.J., op. cit., p. 101.

50 Skoble, A.J. «Lisa y el antiintelectualismo estadounidense». En Irwin, W./Conard, M.T./Skoble, A.J., op. cit., p. 40, nota 1.

$51 C f r$. Mcmahon, J.L. «La función de la ficción: El valor heurístico de Homer». En Irwin, W./Conard, M.T./Skoble, A.J., op. cit., pp. 263, 269, 271, 272, 280 y 282. 
Los Simpson, con su casi medio millar de episodios divididos en más de 20 temporadas ${ }^{52}$, representan una rica cantera para extraer materiales pedagógicos que sirven para la construcción del aprendizaje en el Derecho penal.

Así, la serie nos ofrece un montón de oportunidades para analizar categorías de la parte general del Derecho penal, v. gr., la comisión por omisión, la posición de garante o la imprudencia respecto al encargado de seguridad en una central nuclear, los estrechísimos márgenes del ius corrigendi como causa de justificación relacionados con las palizas que a Bart le propina Homer y hasta su imputabilidad, la responsabilidad criminal de las personas jurídicas en el entramado empresarial de Burns, la antipedagógica violencia de Rasca y Pica o la hipocresía de una rehabilitación que únicamente aporte una constante sonrisa y complacencia como la de El blues de la Mona Lisa; los numerosos crímenes de Bart pueden servir de base para estudiar la delincuencia de menores, el comportamiento de Nelson y sus colegas permite analizar el mobbing escolar y las bandas juveniles, el episodio Bar, el asesino es útil para abordar características de la criminalidad organizada e incluso el ser más inocente de todos, Maggie, pese a disparar al señor Burns por quitarle su piruleta, plantea cuestiones tan clásicas como la discutible incapacidad de acción en los inimputables o tan novedosas como su silencio, la filosofía del lenguaje de Wittgenstein y la teoría significativa de la acción ${ }^{53}$.

De otro lado, Los Simpson también facilitan abundantes pretextos para estudiar la parte especial del Derecho penal y analizar infracciones como la falta de hurto, $v$. gr. de la hija del reverendo Lovejoy, que sustrae la limosna de la congregación; las estafas inmobiliarias, al contemplar las formas de venta de viviendas en Bocados inmobiliarios, o de seguros, en Boda indemnización, cuando Moe presiona a Homer para que le destroce el vehículo y así poder cobrar el seguro; la utilización fraudulenta de la señal de televisión por cable ajena en Homer contra Lisa y el octavo mandamiento; la corrupción del sistema político de Springfield; la malversación del alcalde Quimby, que se queda con los fondos de la lotería; los constantes cohechos del jefe de policía Wiggum o el del congresista Bob Arnold, que acepta un soborno; la criminalidad económica del señor Burns o sus delitos contra los recursos naturales y el medio ambiente, relativos a la energía nuclear, la protección de la flora, fauna y animales domésticos.

A modo de ejemplo, el episodio Marge encadenada, en el que acaba en prisión por olvidarse de pagar una botella de whisky en el supermercado de Apu, puede servir de base para dividir la clase en grupos que analicen la capacidad de acción,

$52 C f r$. Matheson, C. «Los Simpson, la hiperironía y el sentido de la vida». En Irwin, W./Conard, M.T./ Skoble, A.J., op. cit., p. 150.

53 Vid. Vives Antón, T.S. Fundamentos del sistema penal. Acción significativa y derechos constitucionales. Valencia, Tirant lo Blanch, 2011. 
de la que carecen los dibujos animados, los elementos subjetivos del injusto y su incompatibilidad con la comisión imprudente, la falta de hurto, la crisis de las penas cortas privativas de libertad, las alternativas a la prisión, nuestra tasa de criminalidad en comparación con la de otros países y las estadísticas penitenciarias españolas, europeas y estadounidenses. La puesta en común de todos los grupos permitiría extraer interesantes conclusiones sobre nuestro sistema penal, que no es ninguna broma, que cualquiera por un descuido puede acabar en prisión, como le sucedió al ser más íntegro de Springfield, que en España, con uno de los mayores porcentajes de encarcelamientos en la Unión europea pese a poseer una de las menores tasas de criminalidad, se abusa de la prisión y que cada vez nos alejamos más de Europa con figuras como la conversión de tres faltas de hurto en un delito, introducida por la reforma penal de 2010 — para acercarnos a lo más salvaje del oeste americano, el cual, de momento, con el séptuplo de nuestra tasa de encierros, mantiene el récord mundial de encarcelamientos ${ }^{54}$.

\section{LA PENA DE MUERTE Y EL VERDUGO}

La pena de muerte repugna a la más mínima sensibilidad jurídica y humana, pese a que se mantenga en algún país, y no me refiero precisamente en repúblicas bananeras, sino en naciones que pretenden ser las abanderadas del desarrollo y la civilización mundial.

Por extensión la repugnancia que provoca esta pena se traslada a su ejecutor, el verdugo, como puede comprobarse en la película de GARCÍA BERLANGa, que cuenta con famosos actores españoles, como José Isbert (Amadeo), José Luis López Vázquez (Antonio) o Alfredo Landa (el sacristán), y se plantea si es posible comprender con ternura al ejecutor de un semejante ${ }^{55}$.

Respecto al argumento, Carmen, la hija del verdugo Amadeo, que no conseguía encontrar novio por culpa de la profesión de su padre, se casa con José Luis, empleado de una funeraria, al quedarse embarazada, pero para que la familia pueda mantener el piso el yerno tiene que heredar la profesión del suegro, lo que hace pensando en que dimitirá si se viese obligado a ejecutar a alguien. La profesión lo reclama, su suegro lo tranquiliza con la esperanza de que el reo será indultado, mientras aguardan como turistas en Mallorca, el lugar de ejecución, «pero el indulto no llega $»^{56}$.

$54 C f r$. Abel Souto, M. «Alternativas necesarias frente al punitivismo: probation, suspensión y sustitución de la pena de prisión en el Código penal español, reformado por la Ley orgánica 5/2010, de 22 de junio». En Gaceta Penal \& Procesal Penal, n² 23, 2011, pp. 386 y 387.

55 Cfr. Ruíz Sanz, M. El verdugo: un retrato satírico del asesino legal. Valencia, Tirant lo Blanch, 2003, p. 15.

56 Ruíz Sanz, M., op. cit., p. 19. 
Resulta paradójico que las esperanzas de José Luis se depositen en otra institución tan anacrónica como la pena de muerte: el indulto, fuente de escándalos constantes, como los de un consejero delegado del Santander, condenado por acusación y denuncia falsa, mossos d'esquadra torturadores o un conductor kamikaze que mató a un joven, por citar los más recientes ${ }^{57}$.

La visión de la muerte en la película es sarcástica y esperpéntica, a través de empleados de pompas fúnebres, ejecutores, el garrote, cortejos funerarios ${ }^{58} \ldots$

Según la resolución del IV foro internacional sobre crimen y Derecho penal en la era global ${ }^{59}$ la abolición de la pena de muerte resulta inevitable porque «es un castigo inhumano, atroz y brutal que elimina la vida humana, base fundamental de todos los derechos humanos y de la existencia del individuo» ${ }^{60}$. Esta proclamación posee un especial interés dado que se aprobó en Pekín en diciembre de 2012 y China ejecuta a más personas que el resto de los países juntos: durante el año 2012 en 21 estados hubo 682 ejecuciones, sin embargo en China ese mismo año, aunque el gobierno no suministra datos oficiales, los ejecutados se cuentan por miles ${ }^{61}$.

En España la pena de muerte fue abolida por el Código penal republicano de 1932, se restableció poco después, en 1934, y se mantuvo hasta la Constitución de 1978. Era ejecutada mediante el garrote vil, ya usado desde el siglo XV para sustituir a la hoguera, cuando los condenados se confesaban o arrepentían de sus pecados, como «medida piados» ${ }^{62}$.

Amadeo es un gran defensor del garrote vil, aunque sus argumentos provocan risa en el espectador, de modo que con «humor negro» ${ }^{63}$ García Berlanga «condena la pena de muerte a través de su defensa $\aleph^{64}$, habida cuenta de que para Amadeo el garrote resulta mucho más humano que la guillotina, pues estéticamente al ajusticiado no le quedaba separada la cabeza del tronco ni se vertía sangre a borbotones, y que la silla eléctrica, como le intenta demostrar a José Luis cuando pretende

57 Vid. Abel Souto, M. «El indulto: una propuesta para incluir en el Código penal su regulación adaptada a principios constitucionales básicos y al estado democrático de derecho». En ReCrim, 2013, http://www.uv.es/recrim, pp. 2-5.

58 Cfr. Sojo, K. El verdugo. Madrid, Notorious ediciones, 2010, p. 43.

59 Vid. Fourth Session of the International Forum on Crime and Criminal Law in the Global Era, Beijing, 2012.

${ }^{60}$ Núñez Paz, M.A. «La pena de muerte en el International Forum on Crime and Criminal Law in the Global Era». En Revista Penal, nº 32, 2013, p. 336.

${ }_{61}$ Amnistía Internacional. Condenas a muerte y ejecuciones 2012. Madrid, Edai, 2013, p. 6, en http:// www.amnesty.org.

62 Ruíz Sanz, M., op. cit., p. 21.

63 Maroto Laviada, R. «El verdugo. Escenas sombrías de una España reciente». En Rivaya, B. (coord.), Cine y pena de muerte. Valencia, Tirant lo Blanch, 2003, p. 133.

${ }^{64}$ Ibidem. 
introducirle la mano en la lámpara de casa para que vea lo que duele una descarga eléctrica ${ }^{65}$.

El garrote consistía en una soga, colocada alrededor del cuello, con un nudo corredizo que se apretaba mediante un palo el cual funcionaba como torniquete, de manera que los reos morían asfixiados, o estrangulados, pero fue evolucionando hasta convertirse en un collar de hierro, a modo de corbatín, que se juntaba con un tornillo o manivela hasta la estrangulación. Una rápida vuelta de manivela podía quebrar el espinazo a la altura de la cuarta vértebra cervical. Si se conseguía aplastar el bulbo raquídeo o romper la cervical con un corte medular se producía un coma cerebral instantáneo, pero no siempre sucedía así, pues a veces la ejecución duraba 20, 25 o hasta 30 minutos agónicos ${ }^{66}$.

Desde los años 50 los tres últimos verdugos españoles ejecutaron a 50 personas, muy pocas si se comparan con las cifras chinas más recientes - país en el que se viene hablando de unas 5.000 ejecuciones anuales ${ }^{67}$, pese al «secreto de estado» ${ }^{68}$, y más recientemente de unas $2.000^{69}$ - aunque demasiadas si se tiene en cuenta la intolerable lesión de derechos humanos que la pena de muerte implica. El oficio era esporádico e implicaba una lacra social por lo que las necesidades económicas, como las de José Luis, motivaban las solicitudes. Según la orden de 29 de septiembre de 1948 cobraban 6.000 pesetas, como un peón de albañil, no tenían derecho a sindicarse ni a pensión y su nombramiento se mantenía en secreto ${ }^{70}$, de lo cual se alegra José Luis al decirle a su amigo que «el cajero tampoco lo sabe».

En el año de rodaje de la película, 1963, se ejecutaron a tres personas: Julián Grimau, Francisco Granados y Joaquín Delgado ${ }^{71}$. El primero era el responsable de organización interior del partido comunista y los otros dos fueron miembros de las juventudes libertarias, acusados de haber colocado bombas que no produjeron muertos, mas en su domicilio se encontraron armas y explosivos destinados a matar a Franco. Los verdaderos responsables reconocieron la autoría en 1994 desde su exilio en París ${ }^{72}$.

El verdugo está basada en los hechos reales que le contó a García BerLANGa un abogado, amigo suyo ${ }^{73}$, el cual asistió a la «terrible» ${ }^{74}$ ejecución en Valencia, el 19

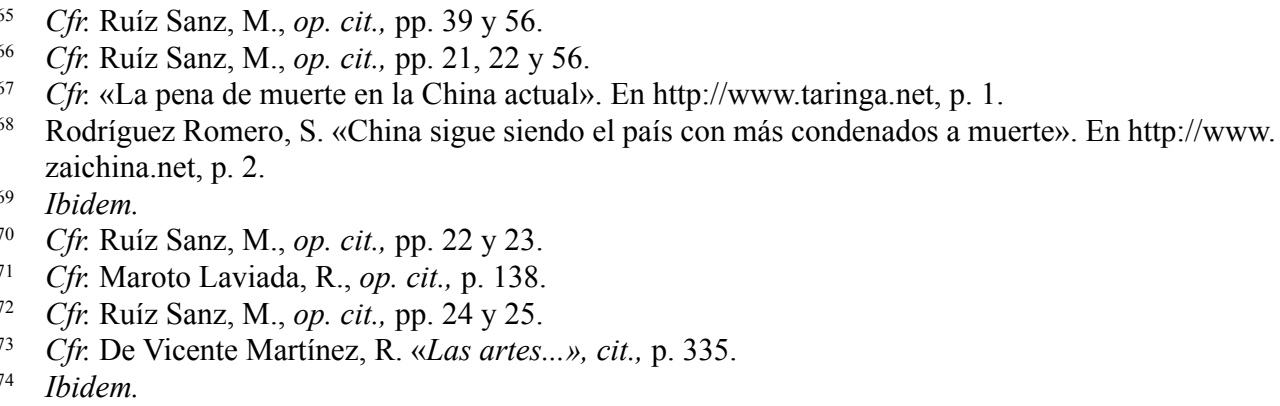


de mayo de 1959, de Pilar Pradas, una cocinera que envenenó a las compañeras para servir a su señora en exclusiva, ajusticiamiento, el último de una mujer en España seguramente debido a lo que pasó ${ }^{75}$, en el que el verdugo, Florencio Fuentes, estaba tan nervioso que parecía el condenado, por lo que fue necesario inyectarle un tranquilizante y arrastrarlo hasta el lugar de ejecución. Este titular de la audiencia de Valladolid, hombre bueno y tímido, casado y con 11 hijos, trabajó mucho en los años 40 y a principios de los 50, pero acabó acobardado, temblaba cuando tenía que ejecutar y siempre pedía a la guardia civil que lo escoltase, como ocurre en la película con José Luis. Despreciado por los vecinos, distanciado de la familia, terminó mendigando y se ahorcó. Curiosamente hasta la norma ignora al verdugo, pues el reglamento de servicio de prisiones de 1956, aunque cita a 11 personas que deben asistir a la ejecución, se olvida de mencionar al verdugo ${ }^{76}$.

De otro lado, volviendo a la película, fue censurada por el franquismo, ya que se acusó a García Berlanga de ser «un títere de los comunistas, un anarquista desubicado, un compañero de viaje de los rojos $\rangle^{77}$ e incluso el dictador llegó a llamarlo «mal español» ${ }^{78}$ y se cortaron hasta cuatro minutos y medio de la cinta ${ }^{79}$, se suprimió la escena del funcionario que instruía en el patio de la prisión al nuevo verdugo, colocándole las anillas metálicas o el ruido de los hierros del maletín al transportarlo y también fueron cortadas otras escenas menos importantes, le costó la cartera al ministro de información y turismo, Manuel Fraga Iribarne, por liberalizador, ganó el premio de la crítica en 1963 en el festival de Venecia amén de otros muchos galardones y ha sido considerada no solo la mejor película de la historia del cine español sino también una de las más destacables de la cinematografía universal ${ }^{80}$.

\section{OTROS ASPECTOS PENALES Y FÍLMICOS DE EL VERDUGO}

Además de la pena de muerte en la película se advierten otros interesantes aspectos penales, como la corrupción, por ejemplo en la escena en que suegro y yerno acuden a solicitar el trabajo de verdugo y les dicen, tras superar todos los inconvenientes del papeleo burocrático, que «hace el número 37 », que «tiene 36 por delante» $\mathrm{y}$ «como no tenga una buena recomendación no hay nada que hacer», ante lo que Amadeo produce con los labios el cómplice y tradicional sonido para pedir silencio, dando a entender que todo está arreglado, o en la escena en que José Luis va con su compañero a una oficina, después de un entierro, y el funcionario le dice

\footnotetext{
75 Cfr. Maroto Laviada, R., op. cit., pp. 137 y 138.

76 Cfr. Ruíz Sanz, M., op. cit., pp. 26 y 27.

77 Sojo, K., op. cit., p. 24.

78 Ibidem.

79 Cfr. Maroto Laviada, R., op. cit., p. 139.

80 Cfr. Ruíz Sanz, M., op. cit., pp. 29, 30, 32 y 33.
} 
que está cerrado, pero el problema se soluciona regalándole un purito, corrupción que sigue siendo «uno de los grandes problemas de nuestro tiempo» ${ }^{81}$, como ya puso de relieve FERRÉ OLIVÉ en el encuentro ítalo-hispano-luso-polaco sobre blanqueo de dinero y corrupción en el sistema bancario, celebrado en Lisboa del 18 al 21 de abril de 2002, tanto en el mundo, de hecho fue el tema que se trató en el V foro internacional sobre crimen y Derecho penal en la era global también celebrado en Pekín ${ }^{82}$, hace un mes, como en España, la cual estaba situada en percepción de la corrupción, según Transparencia Internacional, durante el año 2012 en el puesto 30 de 176 países $^{83}$ y retrocedió en 2013 a la posición 40 de $177^{84}$.

Realmente España posee una regulación penal razonable contra la corrupción ${ }^{85}$, pero existen serios problemas de falta de recursos ${ }^{86}$. Pese a las necesidades de medios materiales y humanos ${ }^{87}$, las sentencias por delitos relativos a la corrupción en nuestro país se incrementaron en un $151 \%$ durante los años 2010, 2011 y $2012^{88}$. El verdugo, con su costumbrismo y sarcasmo, entronca con la literatura picaresca de nuestro siglo de oro y refleja plenamente la sociedad española del momento, no solo sus problemas con la pena de muerte y la corrupción, sino también la burocracia, la religión, el noviazgo represivo, el "pseudoacademicismo", la explosión del turismo, el trapicheo para sobrevivir, el machismo ${ }^{89} \mathrm{y}$ «la anulación de la voluntad individual $\rangle^{90}$, de la $\ll$ libertad personal $\rangle^{91}$.

81 Ferré Olivé, J.C. «Corrupción, crimen organizado y «blanqueo» de capitales en el mercado financiero». En Ferré Olivé, J.C. (ed.), Blanqueo de dinero y corrupción en el sistema bancario. Delitos financieros, fraude y corrupción en Europa. Salamanca, Ediciones Universidad de Salamanca, Salamanca, 2002, vol. II., p. 20.

82 Vid. Fifth Session of the International Forum on Crime and Criminal Law in the Global Era, Beijing, 2013.

83 Vid. Transparency International. Corruption Perceptions Index 2012. En http://www.transparency.org.

${ }^{84}$ Vid. Transparency International. The 2013 Corruption Perceptions Index. En http://cpi.transparency.org.

85 Vid. Arias Rodríguez, J.M. «Algunas reflexiones sobre la política anticorrupción de la Unión Europea». En Diario La Ley, $\mathrm{n}^{\circ}$ 7989, 2012, pp. 8-11; Blanco Cordero, I. «La reforma de los delitos de corrupción mediante la Ley orgánica 5/2010: nuevos delitos y aumento de penas». En Diario La Ley, $\mathrm{n}^{\circ} 7534,2010$, pp. 1-11; De la Cuesta Arzamendi, J.L. «La corrupción ante el Derecho y la Justicia». En Diario La Ley, no 8153, 2013, pp. 7-9.

86 Cfr. Grupo de Estudios de Política Criminal. Comunicado a la opinión pública sobre corrupción, 2013. En http://www.gepc.es.

87 Cfr. Abel Souto, M. «Anti-corruption strategy in the global era and money laundering». En Fifth Session of the International Forum..., cit., p. 1.

88 Cfr. Torres-Dulce Lifante, E. Memoria elevada al gobierno de S.M. presentada al inicio del año judicial por el Fiscal General del Estado Excmo. Sr. D. Eduardo Torres-Dulce Lifante. Madrid, Centro de Estudios Jurídicos, Ministerio de Justicia, 2013, vol. I., p. 655.

89 Cfr. Ruíz Sanz, M., op. cit., p. 35.

90 Maroto Laviada, R., op. cit., p. 131.

91 Ibidem. 
Por lo que concierne al tratamiento cinematográfico, toda la estructura de la película se construye alrededor de una violencia que lleva a la frustración, como la ejercida sobre José Luis, obligado a ser verdugo, renunciando a su sueño de emigrar a Alemania para convertirse en mecánico. La violencia modifica el previsible rumbo de los planos y la agresión suele proceder de un elemento que no está en el campo al comenzar el plano, sino que bruscamente es introducido en el encuadre y en la acción ${ }^{92}$.

Efectivamente, cada plano crea una expectativa que se verá frustrada. Así, cuando José Luis y Carmen pretenden «estrenar» el colchón llega la carta para el «estreno» como verdugo; cuando bailan en el campo el dueño del transistor se marcha exclamando «isi quieren bailar, que se traigan la música!»; cuando continúan danzando amorosamente con los silbidos de José Luis y parece que la vida se abre camino el futuro verdugo desconcierta a Carmen diciendo «bonito paisaje, ¿a ti donde te gustaría morir?»; cuando están de visita turística en las Cuevas del Drac el encanto se rompe con la irrupción de los guardias civiles en un bote que llaman al joven verdugo para que cumpla con la muerte, emulando la mítica barca de Caronte $^{93}$, que cruzaba la Laguna Estigia para dirigirse al Hades en el último trayecto ${ }^{94}$; cuando parece que no están solos y que cuentan con el apoyo familiar, pues el hermano de José Luis, Antonio, y su mujer asisten a la boda, ella le retira la flor que se ha puesto en la solapa y él no quiere firmar como testigo; cuando Carmen tiene un antojo de embarazada y pide a José Luis que le compre un helado el recién casado sale corriendo en busca de su hermano y ni se da cuenta de que un carro de helados cruza la escena; cuando Amadeo y José Luis van a la feria del libro para obtener la recomendación del académico y escritor Corcuera, autor de una monografía sobre el garrote de la que Amadeo guarda celosamente un ejemplar dedicado, pues se siente orgulloso de haber colaborado, por su experiencia, con el académico, rápidamente se critica a los «pseudointelectuales» franquistas, ya que al preguntar dos ancianas si está el señor Pemán para dedicarles un libro y responder el librero «no, hoy es el señor Corcuera», les da igual, al preguntar dos jóvenes si tienen algo sobre Bergman o Antonioni, consagrados directores de cine, el académico confunde a la actriz sueca con el director del mismo país y al preguntar Amadeo a los jóvenes si el que firma y con el que han estado hablando es el señor Corcuera, pues tienen que conocerlo, le contestan que no lo saben; cuando bajan del barco en Mallorca unas misses para competir en un concurso de belleza se ve el maletín del verdugo, que viene a matar, y a dos guardias civiles para escoltarlo, como Florencio Fuentes siempre pedía; cuando aparece la comitiva de coches que lleva a las concursantes,

92 Cfr. Ruíz Sanz, M., op. cit., p. 37.

93 Cfr. Ruíz Sanz, M., op. cit., pp. 38, 40 y 41.

94 Vid. Sojo, K., op. cit., p. 28. 
termina con el vehículo de la guardia civil que traslada a José Luis como si fuera un preso; cuando parece que el verdugo va a disfrutar de unas vacaciones en Mallorca con su traje claro y sombrero de turista se le introduce en el ambiente lúgubre de la prisión; cuando José Luis se «confiesa» con el director del establecimiento penitenciario como si fuera el reo - de hecho le sirven el champán que han traído para el condenado y en vez de contemplarse el encuentro de los familiares con el que va a ser ejecutado el funcionario de prisiones comunica «la visita del ejecutor»- y parece que el compresivo responsable de la cárcel le liberará de su destino, el director manda que le pongan una corbata a José Luis, que se convierte en víctima y verdugo del estado al cumplir con el deber de colocarle, poco después, el corbatín del garrote al condenado; finalmente, cuando se espera que el que debería acudir a la cita con la muerte por la fuerza o desfallecido es el que va a ser ejecutado, gran parte de la comitiva que acompaña al reo lo abandona para atender al verdugo ${ }^{95}$, cuya flaqueza de piernas «se convierte en uno de los mejores alegatos contra la pena de muerte» ${ }^{96}$.

Llega a tal la repugnancia de GARCíA BERLANGa hacia la pena de muerte que, a diferencia de lo que ocurre en la mayoría de las películas sobre esta materia ${ }^{97}$, que tienden a recrearse en la ejecución, no muestra el ajusticiamiento ${ }^{98}$.

Concluye la película con un espectacular contraste surrealista: parece mentira que en un ambiente colorido, veraniego y festivo, como el de Mallorca, se llevasen a cabo ejecuciones ${ }^{99}$, aunque hubo que esperar hasta 1974 para asistir en España a las dos últimas ejecuciones con garrote, año en el que no se produjo la postrera muerte legal en nuestro país, pues el 25 de septiembre de 1975 se fusilaron a cinco terroristas ${ }^{100}$.

La penúltima escena de la película es desconsoladora, ya que tras exclamar José Luis «¡no lo haré más!» se oye a Amadeo aseverar «eso mismo dije yo la primera vez» mientras sostiene en brazos a su nieto, al que parece aguardarle el funesto destino de perpetuar la dinastía de verdugos, comprendidos por nuestra literatura y hacia los que mostró compasión, como la de José de Espronceda, el cual dejó escrito que «...la herencia/ que legue al hijo,/ el que maldijo/ la sociedad» ${ }^{101}$ no es más «que nuestra vergüenza común» ${ }^{102}$ que cae sobre él.

\footnotetext{
95 Cfr. Ruíz Sanz, M., op. cit., pp. 45 y 49.

96 De Vicente Martínez, R., Las artes..., cit., p. 337.

97 Vid. Maroto Laviada, R., op. cit., pp. 128-130.

98 Cfr. Ruíz Sanz, M., op. cit., p. 49.

99 Vid. Sojo, K., op. cit., pp. 3 у 9.

100 Cfr. Ruíz Sanz, M., op. cit., pp. 62 у 63.

101 De Espronceda, J., El verdugo, 1835, versos 13-16.

102 De Espronceda, J., op. cit., verso 9.
} 
Por fortuna la Constitución de 1978 liberó al vástago del verdugo de su funesto destino y a todos nos queda la esperanza de la escena final de la película, la alegre imagen de unos jóvenes bailando el twist en un yate que se aleja del puerto, la esperanza de que pronto sea abolida universalmente la pena de muerte y mientras tanto nos sumamos a la acogida con beneplácito de la decisión adoptada por un «número creciente» ${ }^{103}$ de naciones «de aplicar una moratoria de las ejecuciones, seguida en muchos casos por la abolición» ${ }^{104}$.

103 Naciones Unidas, op. cit., p. 2.

104 Ibidem. 


\section{PENA DE MUERTE EN EL DERECHO INTERNACIONAL}





\title{
ACTORES, FACTORES Y PROCESOS EN EL CAMINO DE LA ABOLICIÓN UNIVERSAL DE LA PENA DE MUERTE ${ }^{1}$
}

\author{
LUIS ARROYO ZAPATERO \\ Prof. Dr. Dr. h. c. mult. \\ Presidente de la International Society of Social Defence y Catedrático de \\ la Universidad de Castilla-La Mancha. Ciudad Real. España.
}

\section{INTRODUCCIÓN}

En el año 2015 se revisó el grado de cumplimiento de dos relevantes iniciativas de las Naciones Unidas, la de los objetivos del milenio, establecidos por la declaración de la Asamblea General del año 2000 y el de la resolución 62/149, de 2007, que reclamó una moratoria universal en la aplicación de la pena de muerte. Son dos asuntos diferentes pero muy relacionados. Los objetivos del milenio pretenden que los Estados y la comunidad internacional eviten dejar morir a millones de personas por hambrunas y epidemias de enfermedades curables. En la segunda iniciativa la mayoría de los miembros de la Asamblea General reclamaba que los Estados dejen de matar como pena de su sistema de justicia, ni siquiera en un pro-

1 El texto tiene su origen en la conferencia pronunciada en la Jornada organizada por la École Normal Supérieure en octubre de 2013, "Vers l'interdiction absolue de la peine de mort. Perspectives philosophiques et juridiques", organizadas por Marc Crépon, Jean Luis Halpérin y Stefano Manacorda del Collége de France, que acaba de ser publicados con el título: La peine de mort. ¿vers l'abolition absolue?, La Une, Paris 2016 y publicado con variaciones en el libro editado por el autor La pasión de la crueldad/the passion of cruelty, UCLM, Cuenca 2016. 
ceso legal. Se trata en ambos casos de ideas de las Naciones Unidas, producto de los trabajos políticos y académicos de quienes protagonizan la vida de las Naciones Unidas como diplomáticos, funcionarios, expertos y miembros de organizaciones no gubernamentales que construyen un patrimonio cultural y político de la humanidad ${ }^{2}$. Será necesario construir los argumentos ahora para vincular también la causa de la abolición con el progreso de los derechos humanos prevista en el objetivo 16 de la nueva Agenda 2015 para el Desarrollo Sostenible.

La cuestión de la abolición de la pena de muerte no se planteó en los primeros momentos de la vida de la organización. La paz se simbolizó precisamente con las ejecuciones de los criminales de guerra en Nuremberg y Tokio. El debate sólo dio comienzo en el curso de la elaboración de la Declaración universal de los derechos humanos en 1948, pero no se alcanzó ningún consenso y se prefirió no hacer mención al asunto al proclamar el derecho a la vida, carencia de consenso que se reprodujo en la elaboración del Pacto internacional de derechos civiles y políticos, en 1966, en cuyo artículo 6 se llegaría a consagrar la legitimidad de la pena capital, aún cuando se formuló de tal manera que quedó sometida a ciertas restricciones y controles para los países que mantengan dicha pena en vigor, lo que ha permitido un notable control por parte de los diferentes instancias de las Naciones Unidas, hoy, especialmente, por parte del Consejo de Derechos Humanos.

En el momento de la adopción de la Declaración universal de derechos humanos en 1948 no más de una docena de países habían abolido la pena de muerte. En diciembre de 2014 son más de 106 los que lo han hecho, y no pocos son los países -39- que aún cuando la mantienen en sus leyes, no la ejecutan, pero en la actualidad todavía retienen y ejecutan la pena capital un grupo relevante de países, algunos de ellos tan relevantes en todos los órdenes como Estados Unidos, China y Japón ${ }^{3}$. El estudio de los datos sobre la abolición en los diferentes países se debe completar con un estudio de las razones y factores que han impulsado la decisión en favor de la abolición legal o de facto de la pena capital.

Una cartografía tradicional sobre la pena de muerte en el mundo es un instrumento de gran utilidad y puede trazar la transformación de los países de retencionistas en abolicionistas desde finales de los años 50. Pero la evolución de los colores del mapa político no transmitirá por sí solo suficiente información para comprender las

2 Sobre este asunto, con referencias, Arroyo Zapatero, L.; Biglino, P.; Schabas, W. (Edit.), Hacia la abolición universal de la pena capital. Valencia. Ed. Tirant Lo Blanch. 2010. Vid. Informe del Secretario General sobre la Moratoria 15 de Agosto 2016, A/6971/332 y Simonovic (Editor) Moving away from the death penalty, Human Rights Office of the High Commissioner, Nueva York 2014.

3 Ver últimos datos en Hood, R./Hoyle, C., The death penalty. A worldwide perspective. 5th. Oxford University Press 2015, p. 16. Una edición en español será publicada por Tirant lo Blanch en este 2016. 
razones y motivos de la evolución y las tendencias y obstáculos para la abolición. No será fácil obtener conocimientos para comprender mejor y orientar con eficacia esa armonización internacional del derecho penal que comporta la abolición de la pena de muerte en todo el mundo. Una cartografia moderna como la que desarrollan Jean-Luis Halperin y Stefano Manacorda en el equipo formado por ambos entre el Collège de France y la Ecole Normal Superieur de Paris -y que acaba de ser objeto de publicación- pretende ser precisamente un instrumento de conocimiento y comprensión, capaz de producir una guía para la acción. Esos caminos de la armonización son también el modelo de interpretación de la evolución de los hechos jurídicos, especialmente los penales, que a modo de una teoría general ha elaborado en los últimos años Mireille Delmas-Marty, liderando un notable grupo de investigadores ${ }^{4}$.

Mireille Delmas-Marty ha desarrollado un modelo de interpretación y construcción técnica de los procesos de armonización jurídica internacional y que conocemos por el nombre de "Les chemins de l'harmonisation". A mi modo de ver un complemento imprescindible de los métodos tradicionales del Derecho comparado. La metodología de los Chemins puede proyectarse a numerosas asuntos concretos como lo que hoy se armonizan, construyendo nuevas realidades jurídicas: terrorismo, Derecho internacional penal, trata de personas, lavado de dinero, corrupción, etc., pero también a cuestiones que se desarmonizan o se "armonizan al revés", como es el fenómeno de la abolición universal de la pena de muerte, que parte de una situación de vigencia universal hace poco más de 60 años.

Se trata pues aquí de analizar en todo el contexto internacional el movimiento hacia la abolición de la pena de muerte en los países que lo han llevado a cabo, en los que la mantienen sin aplicarla y en los que la retienen:

a) Los procesos singulares de abolición ensayando una clasificación sistemática de los mismos;

b) Los actores que intervienen en los procesos, tanto públicos como particulares;

c) Los factores que desencadenan la abolición y, en su caso, la moratoria. Todo ello se examinará en los procesos ya realizados como en los que la cuestión está viva. Del mismo modo se examinarán los procesos de los países que mantienen encarnizadamente la pena capital.

El objetivo es obtener referencias de utilidad para el proyecto cartográfico de la abolición. A la organización del análisis nos ayudan los procesos de mayor impacto de la abolición en la era contemporánea que pueden sintetizarse en tres modelos.

$4 \quad$ La peine de mort. ¿vers l'abolition absolue?, La Une, Paris 2016.

5 Delmas-Marty, M./ Pieht, M./Sieber, U., Les chemins de l'harmonisation pénale. Harmonising criminal law, Société de Législation Comparée, Paris 2008 ; edición española de Tirant, Los caminos de la armonización, Valencia 2009. 


\section{PROCESOS DE TRANSICIÓN, DE EVOLUCIÓN Y DE INTEGRACIÓN}

A la altura de la elaboración de la Declaración Universal de Derechos Humanos, apenas media docena de países había adoptado la abolición ${ }^{6}$. Sin embargo es en los procesos constituyentes tras la segunda Guerra Mundial cuando se producen las aboliciones inicialmente más representativas: Alemania e Italia. En ambos países la abolición representa una reacción frente a los excesos homicidas del nazismo y del fascismo, una reacción cerrada porque repugna totalmente la muerte arbitraria y cruel infligida por el Estado. Otro momento relevante sin salir de Europa es el de la salida de algunos países de los viejos regímenes autoritarios, como el de España y Grecia, que comparten el rechazo a las numerosas ejecuciones capitales en su historia inmediata, especialmente en el caso de España. En Portugal no tuvo lugar este fenómeno, pues la dictadura había mantenido la temprana abolición del siglo XIX y a la hora de hacer desaparecer a sus enemigos se valió de la ejecución extrajudicial y solo en contadas ocasiones?

También se advierten procesos de abolición en sistemas democráticos estables como es el caso de Gran Bretaña y Francia. En el primero de ellos la abolición es un proceso al que se llega con dos factores desencadenantes: los trabajos de la Comisión Real sobre la pena de muerte y el descubrimiento público de que la que resultó ser la última ejecución en la persona de Evans ${ }^{8}$ había sido fruto de un trágico error judicial, pues el autor de los crímenes por los que fue ejecutado el primero confesó su autoría y el de otros tantos crímenes más. Fue el impacto en la opinión

6 Ancel, M., The death penalty Part I: Evolution until 1960 and Part II: Evolution from 1961 to 1965. Department of Economic and Social Affairs New York, United Nations. 1968. Para el contexto europeo vid. Ancel, M. La peine de mort dans les pays européens. Rapport. Conseil de l'Europe. 1962.

7 Sobre la singular historia del primer país abolicionista del mundo Braga da Cruz, G. «O movimento abolicionista e a aboliçao da pena de morte em Portugal: Resenha histórica». En AAVV, Pena de Morte. "Coloquio Internacional comemorativo do Centenário da aboliçao da pena de morte em Portugal". Edit. Faculdade de Direito da Universidade de Coimbra, 1967, 3 vols. II, p. 423-557: Miranda Rodrigues, A., «Portugal como país pionero en la abolición de la pena de muerte en Europa». En Arroyo, L./Nieto, A./ Schabas, W. Pena de muerte: Una pena cruel e inhumana y no especialmente disuasoria, Cord. García Moreno, Beatriz. UCLM \& Tirant lo Blanch, Cuenca 2014. p. $79-84$.

8 Un apasionante relato puede verse en el capítulo 10 de las Adventures in Criminology de Sir Leon Radzinowicz, p. 245 y sigs. Con todo detalle, el mismo con Hood, R. A History of English Criminal Law. Vol 5, The emergence of penal policy, 1986, p. 661 y sigs. Hood, R./Hoyle, C. The death penalty. A worldwide perspective. $4^{\mathrm{a}}$ ed. Oxford University Press 2008, p. 40 y sigs. Una presentación en español en Arroyo Zapatero, L. «La experiencia de la abolición de la pena de muerte en Gran Bretaña». En Revista de la Facultad de Derecho de la Universidad Complutense de Madrid, 62, Madrid 1981, p. 47-66, ahora en Clásicos españoles sobre la pena de muerte, Cristina Rodríguez Yagüe, edit., UCLM, Ciudad Real 2013,p. 471 y ss. 
pública el que inclinó la balanza política de la Comisión Real, pues esta misma no ofrecía conclusión concreta sobre el retencionismo o la abolición.

El caso francés es un prototipo de la decisión política contra la pena de muerte, inclusive con una opinión pública mayoritariamente a favor de la misma. Se trata del factor Badinter, un abolicionista compacto, en el que se conjuga el profesor "savant" y el abogado penalista especializado en casos capitales en los que ha puesto de manifiesto ante los jurados y la opinión pública los déficits de personalidad de origen familiar de la mayor parte de los casos capitales que impiden castigar con la pena máxima por adolecer los acusados de falta de culpabilidad plena.

De entre los procesos políticos de origen internacional son interesantes los de Turquía, Polonia y Letonia. El primero, como país significativo de la Convención Europea de Derechos Humanos, se vio siendo sometida a la presión reduccionista de la Pena de Muerte por obra del Tribunal de Estrasburgo y en un momento posterior, en su anhelo de integración en la Unión Europea, optó legislativamente por la abolición. Polonia, en los momentos previos a la plena integración en la UE experimentó reacciones contrarias a la orientación comunitaria, como el caso de la pena de muerte que fueron neutralizados por la previa gran decisión en favor de la integración y, posteriormente por el Tratado de Lisboa.

\section{LOS ACTORES}

En los procesos nacionales de abolición el protagonismo suele ser responsabilidad del Gobierno y de las mayorías parlamentarias. En ocasiones no destaca ningún actor especial en el proceso. Así, por ejemplo, en los casos de Alemania, Italia, España y Francia.

En ocasiones el protagonismo principal lo tiene un órgano judicial, como fue en Sudáfrica su Corte Suprema, que declaró la pena de muerte como una pena inhumana y degradante. Con mayor frecuencia se ha tratado de Tribunales regionales, tanto en Europa con el Tribunal de Estrasburgo, como en el caso de América Latina con la Corte Interamericana de Derechos Humanos. La jurisprudencia establece en sus jurisdicciones una especie de cerco a la pena capital que sin hacer una declaración directa de vulneración convencional sí la proclama de modo indirecto, en especial como pena cruel, inhumana y degradante. Así fueron los casos de Soering y de O'Calan. Su eficacia en relación a Turquía fue muy relevante. Aún más relevante ha resultado en los países abolicionistas, por ejemplo, en Chile y en Perú, en los que la Convención internacional proscribe la reintroducción una vez ha sido abolida. La moratoria en la República Rusa está en directa relación con el proceso de su incorporación al Consejo de Europa. El único país encarnizadamente retencionista, Bielorrusia, evita por esta y por otras razones-su incorporación a la Convención Europea. 


\section{LOS ORGANISMOS INTERNACIONALES}

Los organismos internacionales han cumplido, y cada vez más, un papel estelar en el elenco de actores del proceso de abolición. El primer gran paso adelante lo dio la Comisión para la Prevención del Delito y el Tratamiento del Delincuente de las Naciones Unidas, en especial en el Crime Congress de 1980 en Caracas, en el que se adoptó por una parte una propuesta de abolición y todo el aparato que conocemos como salvaguardias, que se incorporaron al artículo 6 del Pacto Internacional de Derecho Civiles y Políticos de 1966 en los años sucesivos al mencionado Congreso y especialmente en 1989. De todos modos, ya anteriormente el Secretario General en su informe había manifestado que desde los años de fundación y el tiempo de la Declaración las Naciones Unidas habían pasado de ser observadores preocupados a partidarios de la abolición?.

El propio Consejo de Europa siguió un proceso similar pero más completo y cerró la cuestión con la adopción del equivalente al $2^{\circ}$ protocolo facultativo del PIDPyS (ICCPR), con el protocolo ${ }^{\circ} 6$ al Convenio Europeo de Derechos Humanos, hoy ratificado por todos salvo por Bielorrusia. La cláusula de cierre ha sido el Tratado de Lisboa y su abolición expresa ${ }^{10}$.

El proceso concluyó provisionalmente con la adopción del $2^{\circ}$ Protocolo facultativo al Pacto Internacional que establece la abolición salvo en tiempos de guerra, bien es cierto que en el año del optimismo global de 1989. Pero con posterioridad se ha visto refrendado con fuerza normativa y simbólica extraordinaria en las tres resoluciones del Consejo de Seguridad y la Asamblea General al renunciar a la pena de muerte como castigo de los delitos más graves - contra la humanidad y de guerra- en los Tribunales ad hoc de los años 90. La corona ha sido su reiteración en el Estatuto de Roma. Sus efectos sobre la legislación nacional se manifestaron especialmente en la abolición en Ruanda, pero sus efectos se despliegan desde entonces por todo África.

\section{ACADÉMICOS Y ABOGADOS}

Un grupo de actores con un rol significativo ha sido el de los "académicos", tanto en la propia esfera universitaria como en su participación en órganos de orden político representativo. Como ejemplo de lo primero merece recuerdo, en el caso de España, mi Maestro Marino Barbero. Su lección magistral del curso académico

9 Halvorsen, En Scherdin, Lill (Edit.) Capital punishment. A hazard to a sustainable criminal justice system. Ashgate, 2014, p. 297.

10 About safeguards s. Bernaz, N.: Le droit international et la peine de mort. La documentation Française. Paris, 2008. Para su reforma v. Penal Reform International, Strengthening death penalty standards, London 2015. Yorke, Jon. The right to life and abolition of the death penalty in the Council of Europe, European Law Review. (2009), p.205-229. 
1963-1964 sobre la pena de muerte, clamando por su abolición y a meses de las ejecuciones del dirigente comunista Julián Grimau, que fue el último ejecutado del genocidio franquista. Fue el cierre del primer y segundo franquismo que dio paso a la versión "solamente" autoritaria del Régimen y dejó profundo recuerdo en la vida española. Todavía la máxima autoridad académica, el Rector de la Universidad de Murcia, vestía bajo su traje académico el uniforme del Partido del Movimiento. Se estremeció seguro cuando clamó Marino Barbero que si tras tantas razones en contra de la pena capital se empeñaban en mantenerla por su gran importancia, que fuera el propio Jefe del Estado quien la ejecutara con sus propias manos ${ }^{11}$.

Otro académico que dedicó con éxito buena parte de su vida a la abolición fue el Presidente de la Société, Marc Ancel. Sus informes para la Asamblea General de Naciones Unidas y luego para el Consejo de Europa han sido las piedras sillares del pensamiento abolicionista. Son de señalar también los académicos en quienes ha recaído en los últimos veinte años la responsabilidad del informe quinquenal para el Secretario General: Roger Hood y William Schabas. A caballo entre la academia y la política se sitúa sin duda Robert Badinter. En los últimos años de la modernización de China el mayor impulso a la reducción y abolición de la pena de muerte proviene de los más cualificados profesores contemporáneos: Gao Mingxuan y Zao Bingzhi ${ }^{12}$.

Los abogados penalistas y los Colegios de Abogados han sido siempre grandes impulsores de la denuncia de la pena de muerte y del impulso de la abolición. Citaré un caso más lejano, representativo del abogado sistemático ante jurados de tiempos difíciles. Muy posiblemente el abogado más singular contra la pena de muerte en los Estados Unidos de los años entre las dos guerras mundiales fuera Clarence Darrow, muy activo abogados de los sindicatos y en procesos sobre derechos civiles como el juicio sobre la enseñanza del determinismo, el "juicio de los monos". Sus defensas de acusados con petición de pena de muerte crearon opinión, que además

11 Barbero Santos, S. Pena de muerte. El ocaso de un mito, Depalma, Buenos Aires 1985 El texto de 1964 puede verse en Clásicos españoles contra la pena de muerte, Cristina Rodriguez (Edit.). UCLM, Ciudad Real 2013, p. 111 y ss. De la siguiente generación destaca el profesor y abogado ante el Tribunal de Orden Público Carlos García Valdés, autor de un llamativo librito en las postrimerías del franquismo, con la pena de muerte bien viva, 1973, ampliado en, No a la pena de muerte. 1975, Madrid, Editorial Cuadernos para el Diálogo.

12 Gao Mingxuan/Wang Junping, "The Death Penalty upon Larceny should be Abolished in China: A Global Perspective", en Zhao Bingzhi (ed.), Chinese Practice of Death Penalty Reform, China Legal Publishing House, 2010, and Zhao Bingzhi/Wang Shuiming, "Development Trend of Death Penalty in contemporary Era and Its Inspiration for China", en Zhao Bingzhi (ed.), Chinese Practice, op. cit.. Ver también Sizu Wang, en Arroyo Zapatero, L. Biglino, P./Schabas, W. (Edit.): Towards universal abolition of the death penalty. Valencia. Ed. Tirant Lo Blanch. 2010, p. 309 y sigs., 
se sustentada en escritos criminológicos notables ${ }^{13}$ Sobre la capital labor en España de los abogados baste la cita al más insigne, Carlos García Valdés, abogado de perseguidos políticos bajo la dictadura y con la democracia colaborador directo del constituyente en la fórmula adoptada para la abolición en el texto constitucional, más tarde en 1978, y director general de prisiones al ser asesinado su antecesor por los terroristas. En lo institucional baste recordar que fue el congreso general de la Abogacía, en León en 1970, una instancia entonces oficial, acordó en medio de grandes debates el acuerdo por la abolición total en plena dictadura ${ }^{14}$.

Las ONGs se incorporan tardíamente al elenco de actores contra la pena capital pero cuando lo hicieron, en las vísperas de la globalización, su voz se escuchó en todas partes. Su campaña se tituló "cuando el Estado es el que mata" y desencadenó un movimiento que asumido monográficamente por Ensemble contre le pene de mort, dio lugar al fenómeno de la World Coalition against the death penalty, movimiento movilizador que junto con otros fenómenos ha dado lugar a la creación de la organización intergubernamental de la Comisión Internacional contra la pena de muerte en 2010 y que preside Federico Mayor Zaragoza en buenas compañías ${ }^{15}$. En el momento del informe de Amnistía Internacional se indicaba que 70 países habían abolido por ley o de facto la pena capital mientras que 100 la conservaban.

\section{LOS HECHOS DESENCADENANTES DE LOS PROCESOS DE ABOLICIÓN}

En los procesos de abolición destacan hechos desencadenantes que tienden a ella, aunque hay otros que tienen el efecto contrario.

Entre los hechos desencadenantes de la abolición destacan los errores judiciales. Ya se ha mencionado el caso Evans, que condujo a la abolición en Gran Bretaña. Los numerosos casos de errores judiciales manifestados en Estados Unidos especialmente -pero no sólo- a partir fundamentalmente de la disponibilidad de pruebas de ADN y que hoy es reconocido y bien sistematizado en el Death Penalty Proyect es el hecho que más ha hecho progresar la abolición en USA. Más de 30 condenados a penas de

13 Farrel, J., Clarence Darrow, Attorney for the Damned, Penguin Randowm House 2012. De carácter autobiográfico: Darrow, C. The story of my life, 1939 en www.gutemberg. Net.au (1.5.2015), también del autor Crime. Its cause and treatment, Crowell. Co. Nueva York, especialmente su opinión sobre la pena de muerte en las p. 166 y ss. Disponible en línea.

14 No a la pena de muerte. 1975, Madrid, Editorial Cuadernos para el Diálogo. Vid. También Zaragoza, A. Abogacía y política, Cuadernos para el Diálogo, Madrid 1974.

15 Una presentación puede verse en Mayor Zaragoza, F. «La abolición de la pena de muerte». En Arroyo, L./Bordes, J. Francisco de Goya. Contra la crueldad de la pena de muerte/Against the cruelty of capital punishment, Universidad de Castilla-La Mancha y Real Academia de Bellas Artes, Madrid 2013. En línea en http://www.inacipe.gob.mx/stories/publicaciones/novedades/ Goya.pdf. 
muerte declarados inocentes hicieron tambalear a Gobernadores como el de Ilinois E. Ryan, que narró Scott Turow. A continuación, con moratoria como esta o sin ella, siete Estados de Norte América han abolido la pena de muerte como reacción al horror de la ejecución de inocentes en los últimos seis años ${ }^{16}$.

El fenómeno de general aversión social a la pena de muerte se debe fundamentalmente a la conciencia del riesgo de error y a la repugnancia de la crueldad en la ejecución, especialmente en los caso denominados ejecuciones "chapuza", con producción de dolor constitutivo de tortura ${ }^{17}$. Pero en 2014 en el laboratorio norteamericano acaba de surgir un nuevo factor desencadenante que ha estado a punto de hacer triunfar la abolición por referéndum en California: el coste económico para el Estado de los procesos penales con petición de pena capital. El due process, extremado en garantías en los casos capitales, multiplica los costes procesales, lo que replicado en miles de casos produce un rechazo en los que se preocupan del déficit público, lo que genera aliados extraños para la abolición.

Además de las guerras, de sus horrores, de las masacres, etc. Otro factor relevante en la época contemporánea ha sido la disolución de los bloques militares. Sus frutos más directos, vinculados al optimismo de 1989, son los ya citados de la Convención internacional de Derechos del Niño que ha llegado a excluir a éstos de los candidatos a la ejecución en países reacios a ello inclusive por la repugnancia a captar fuentes de valor jurídico en instancias internacionales como los Estados Unidos. También a ejecutantes encarnecidos como Arabia Saudí y China. La aprobación de las salvaguardias pertenece al mismo proceso.

También se pueden identificar hechos que desencadenan procesos sociales inversos, favorables al mantenimiento de la pena capital o su reintroducción, lo que incluye el recurso a la ejecución en los países abolicionistas de facto.

Crímenes horribles son los que han provocado el caso del abolicionismo de facto en Gambia. Son las numerosas violaciones despiadadas con o sin asesinato realizadas, o por vez primera conocidas, en la India lo que ha reforzado la repercusión social institucional de la pena capital en un país que sólo la había ejecutado una vez en los últimos años y solo por el atentado terrorista de Mumbay que produjo más de 70 asesinatos. Fue el terrorismo el hecho que desencadenó el intento de reintroducción de la pena capital en Perú ${ }^{18}$.

16 Sobre los efectos de los errores judiciales vid. Hood, R./Hoyle, C.: The Death Penalty, a worldwide perspective. $5^{\mathrm{a}}$ Ed. Oxford 2015, p. 323 y ss.

17 Radelet, M., Examples of Post-Furman Botched Executions, 24 de julio 2014, http://www.deathpenaltyinfo.org/some-examples-post-furman-botched-executions

18 Hurtado Pozo, J. «Attempts to reinstate the death penalty in Peru». E Arroyo Zapatero, L./Biglino, P./ Schabas, W. (Edit.). Hacia la abolición universal de la pena capital. Valencia. Ed. Tirant Lo Blanch. 2010, p 283 y ss. 
Quizá podrían ser incluidos entre los hechos más que desencadenantes de la vigencia de la pena capital el fenómeno religioso, de determinadas religiones, y el espíritu del talión, aunque éste no requiere de las letras del Libro para ser eficaz en la vida social. El talión es también un hecho sociológico atípico que opera por sí mismo, especialmente en la sociedad de los medios de comunicación de masas irresponsables. Habrá que abordarlo en otro momento.

\section{CONSIDERACIONES PROVISIONALES}

Todo lo expuesto muestra una grille de procesos, hechos y autores relevantes en la evolución del proceso de abolición. Completados con los muchos años que pueden aportar otros colegas más competentes que nos acompañan puede servir para la construcción de una cartografía de la pena de muerte.

Lo que impulsa los procesos de abolición no es solo la idea positiva de lo que denominamos derecho a la vida sino, sobre todo, la idea y sentimiento de rechazo al trato cruel, a la causación de daño a otro. Se trata del sentimiento de rechazo a la tortura, al tratamiento cruel, al matar a sangre fría. El rechazo a la pena de muerte puede bien formar parte de una contemporánea "ética cosmopolita", que rechaza radicalmente todo matar a otro ${ }^{19}$.

La cuestión más compleja radica en cómo definir y trasmitir el rechazo de la pena de muerte y el fundamento de su proscripción. Una vez más, parece como si fueran las artes plásticas, incluida la fotografía y la literatura los medios más aptos para definir la emoción del rechazo a la muerte a sangre fría que comete el Estado con la pena capital y la solidaridad con el que se ve sometido a ella. Francisco de Goya es el primer debelador de las penas crueles e inhumanas, así como de las crueldades de la guerra. El rechazo de la pena de muerte resulta en él manifiesto ${ }^{20}$. Para encontrar manifestaciones de valor semejante hay que esperar a las modernas vanguardias y, muy especialmente, a los expresionistas alemanes de los años 20, bien recuperador en el centenario de la Primera Guerra Mundial, inspirados como Goya en los "desastres de la guerra".

No son pocos quienes hoy están a la búsqueda de una guía para la acción humana fundada en la búsqueda del bien común, en la solidaridad y en el rechazo de la crueldad con pretensión de búsqueda científica, más allá del universalismo ético kantiano y del pensamiento moral cristiano, incluido el programa de la "ética mun-

19 Held, D. Cosmopolitanism: Ideals, Realities, and Deficits. Cambridge: Polity Press 2010; Charvet, J., «The possibility of a cosmopolitan ethical order based on the idea of universal human rights». En Millennium - Journal of International Studies, vol. 27, 3, 1998, pp. 523-541.

20 Blas, J./Matilla, J.M. El libro de los Desastres de la Guerra, 2 vol. Museo Nacional del Prado, 2000. También Arroyo, 1./Bordes, J. Francisco de Goya. Against the cruelty of capital punishment, op. cit. 
dial" de Hans Kung ${ }^{21}$. Dos orientaciones merecen ser destacadas: la aportación de Richard Rorty en su "contingencia, ironía y solidaridad" y la de Von Trotha ${ }^{22}$, la primera primordialmente sobre la solidaridad y la segunda sobre la crueldad. Así mismo resulta bien pertinente el argumentario contra el "consentimiento homicida" desarrollado por Marc Crépon ${ }^{23}$.

También la literatura es un medio idóneo para trasmitir sentimientos además de ideas. En unos casos son las obras literarias, en otros es el pensamiento de sus autores, los intelectuales. Valga citar por todos a los que reúnen ambas condiciones tal y como lo propone Robert Badinter: Víctor Hugo y Albert Camus. Son hoy numerosos quienes buscan orientaciones para guiar su acción en la búsqueda del bien común, en lo que tiene un lugar primordial el respeto por los derechos humanos y entre ellos el de no ser privado de la vida ni por la acción de particulares ni por el Estado en su práctica de la justicia. Es una tarea a la que se han dedicado lo mejor de las generaciones que han construido y desarrollado las ideas de las Naciones Unidas.

\section{Y UN NUEVO Y PODEROSO ACTOR SE SUMA AL PROCESO: LA IRRUPCIÓN DEL PAPA FRANCISCO EN LOS TRABAJOS POR LA ABOLICIÓN}

El panorama contemporáneo de la pena de muerte en el derecho y el pensamiento oficial católico era de restricción de la misma, pero sin excluirla. Sin embargo, el Papa Francisco ha levantado de la abolición una bandera universal y tanto para los católicos como para todos los demás, a los que suele llamar "hombres y mujeres de buena voluntad", para dirigirse más allá de los creyentes.

Los primeros indicios de que el nuevo Papa traía un aire muy renovador se manifestaron en su primera Pascua, el 28 de marzo de 2013, cuando realizó el tradicional lavado de pies a los 12 apóstoles, que en esta ocasión en vez de ser obispos y cardenales en su Iglesia de Roma, lo hizo en una cárcel de menores a diez varones y a dos mujeres, una de ellas musulmana, incluyendo pues a éstas en el valor simbólico de los doce apóstoles, matiz doblemente significativo. A este sencillo acto siguió un documento doctrinal de alto nivel - exhortación apostólica-, en el que además de asuntos de naturaleza puramente religiosa se incluyó un amplio manifiesto crítico del neoliberalismo económico y sus terribles efectos sociales en buena parte del mundo [ Exhortación apostólica Evangelii Gaudium, 24 noviembre 2013, párrafos 52 a 75 y 186 a 237]. En 2015 publicó una Encíclica sobre la cuestión del medio ambiente, de gran relevancia, Laudato sí.

21 Kung, H. A Global Ethic for Global Politics and Economics. Oxford University Press, New York 1998.

22 Trotha, Trutz von y Rösel, Jakob, On cruelty, Sur la Cruauté, Über Grausamkeit, R. Köppe: Cologne 2011.

23 Crépon, M. Le consentement meurtrier, Cerf: Paris 2012. 
Una posición radical de la Iglesia Católica solo se había producido, hasta ahora, en espacios nacionales. Puede considerarse muy relevante la declaración contra la pena capital del episcopado francés, en pleno debate sobre la abolición, cuando Robert Badinter se afanaba por alcanzar la abolición y la oposición pública seguía siendo mayoritariamente retencionista. En países como Filipinas se considera que la abolición llevada a cabo por la Presidenta Gloria Macapagal Arroyo estuvo muy vinculada a la posición de la iglesia católica filipina.

En los últimos decenios el Vaticano había dado pasos para restringir severamente la legitimidad de la pena de muerte, pero sin excluirla. El artículo 2266 del Catecismo de la Iglesia Católica (1992) reconoce -y sigue en vigor- la legitimidad de la pena de muerte y en el párrafo siguiente expone como circunstancia habilitante de su aplicación el que las demás penas no cruentas "no basten para defender del agresor injusto". En la Encíclica Evagelium Vitae de Juan Pablo II en su parágrafo 56 , segundo inciso, establece que "hoy, sin embargo, gracias a la organización cada vez más adecuada de la institución penal, estos casos son ya muy raros, por no decir prácticamente inexistentes". Pero la propia Encíclica recuerda a continuación que sigue en vigor el precepto enumerado anterior, por el que se proscripción de la pena de muerte sólo la proclama respecto de las personas inocentes $\left(\mathrm{n}^{\circ} 57\right)$.

Todo seguía así hasta que el Papa Francisco hizo su primera declaración en la materia en la audiencia a los Presidentes de las Sociedades científicas internacionales de la cuestión penal, el 23 de octubre de 2014 en el Vaticano. La declaración del Papa se refería a variadas cuestiones penales, presidida por el rechazo a lo que se ha denominado "populismo punitivo". Tras una intervención al respecto el Papa proclamó la primacía de la vida y de la dignidad de la persona humana y sale directamente al paso de lo que era la reserva de espacio para la pena de muerte en la doctrina hasta ahora vigente, e indicaba que hoy es imposible imaginar que los Estados no puedan disponer de otro medio que no sea la pena capital para defender a las personas de la agresión injusta. A continuación el Papa continua: "los argumentos contrarios a la pena de muerte son muchos y bien conocidos, la Iglesia oportunamente destaca algunos de ellos, como la posibilidad de la existencia de error judicial y el uso que hacen de ella los regímenes autoritarios que la utilizan como instrumento de supresión de la disidencia política o de persecución de las minorías religiosas y culturales... “. El Papa denunció también las ejecuciones extrajudiciales, así como la prisión perpetua, a la que calificó como pena de muerte oculta, las condiciones miserables de las prisiones, el elevado número de presos sin condena, la tortura $\mathrm{y}$ otras medidas y penas crueles, inhumanas y degradantes".

Pero la intensidad de las condenas se incrementó en la carta al Presidente de la Comisión contra la pena de muerte que es objeto de publicación en este libro. En su argumentario destaca la inadmisibilidad de la pena sea cual sea el delito cometido, 
su calificación de violación de la vida y la dignidad de la persona, su condición de fomentar la venganza, la selectividad y discriminación social, racial o religiosa en su aplicación, la susceptibilidad al irreparable error judicial y a modo de síntesis, "la pena de muerte es contraria al sentido de la humanitas y a la misericordia divina... Implica un trato cruel, inhumano y degradante", que se manifiesta también en "la angustia previa al momento de la ejecución y la terrible espera entre el dictado de la sentencia y la aplicación de la pena, una "tortura" que, en nombre del debido proceso, suele durar muchos años y que en la antesala de la muerte no pocas veces lleva a la enfermedad y la locura".

A la reunión de Federico Mayor Zaragoza con el Papa Francisco le acompañamos el Secretario general de la Asociación Latinoamericana de Derecho penal y criminología, el argentino Roberto Carlés, el que suscribe, como Presidente de la Sociedad Internacional de Defensa Social, fundadora con las otras de la Red Académica Internacional contra la pena de muerte y la secretaria general de la Comisión Internacional, Asunta Vivó. Fue una agradable sorpresa que ya en el primer momento el Papa nos entregara la carta, para así poder dedicar el tiempo de la Audiencia a hablar. Y añadió: y "no se preocupen ustedes, yo me voy a ocupar de esto". La conversación fue verdaderamente jugosa, incluida la referencia a los próximos viajes a Estados Unidos de América y a su propósito de invitar a la abolición en el Congreso. En el inmediato "viernes santo" de dichas fechas durante el "vía crucis" reclamó la abolición de la pena de muerte y desde entonces no ha dejado de hacerlo de modo sistemático. Así, precisamente en el discurso ante el Congreso y el Senado de los Estados Unidos el 24 de septiembre de 2015, con la asistencia en primera fila de varios Jueces del Tribunal Supremo, en el décimo tercer párrafo, se refería a la certeza de que tratar a los demás con la misma pasión y compasión con la que queremos ser tratados es la regla de oro de la vida y es lo que "me ha llevado desde el principio de mi ministerio, a trabajar en diferentes niveles para solicitar la abolición mundial de la pena de muerte. Estoy convencido que este es el mejor camino, porque cada vida es sagrada, cada persona humana está dotada de una dignidad inalienable y la sociedad sólo puede beneficiarse en la rehabilitación de aquellos que han cometido algún delito. Recientemente, mis hermanos Obispos aquí, en los Estados Unidos, han renovado el llamamiento para la abolición de la pena capital. No sólo me uno con mi apoyo, sino que animo y aliento a cuantos están convencidos de que una pena justa y necesaria nunca debe excluir la dimensión de la esperanza y el objetivo de la rehabilitación".

En la referencia se advierte que no solo el Papa "se ocupa" de la pena de muerte en sus palabras, sino como movimiento y organización. El manifiesto de los Obispos Católicos de Estados Unidos previa al viaje del Papa en 16 de junio de 2015 es fruto de la combinación de ideas y de acción, que se eleva a un nivel superior cuando se integra 
en un programa de acción y comunicación como en el Año Santo de la Misericordia, que concentra la actividad de los católicos del mundo de modo permanente durante septiembre de 2015. Baste recordar los llamamientos, primero en el Ángelus del 21 de febrero de 2016, el 21 de marzo de 2016 al dirigirse al Congreso Internacional de Ministerios de Justicia en Roma, cuando en un llamamiento a la comunidad internacional para que se acuerde la abolición definitiva instó a que no se produzca ningúna ejecución en el mundo durante este año de la Misericordia. Otras declaraciones al respecto se han producido el 4 de mayo y 3 de junio de 2016. Prácticamente una al mes.

Sin duda un nuevo actor se ha unido con fuerza y convicción al proceso de impulsar la abolición universal, lo que representa un serio respaldo a los que se reúnen en Oslo en el congreso mundial contra la pena de muerte. Tendrá sin duda consecuencias. 


\title{
LA PENA DE MUERTE Y EL DERECHO CONSUETUDINARIO INTERNACIONAL
}

\author{
ANA MANERO SALVADOR \\ Profesora Titular de Derecho Internacional Público y Relaciones Internacionales \\ Universidad Carlos III de Madrid
}

\section{INTRODUCCIÓN}

Si bien es cierto que el actual panorama iusinternacionalista no establece la prohibición de la pena de muerte, sí que es cierto que existe una clara tendencia abolicionista, derivada tanto de la evolución de los textos convencionales como de las normas consuetudinarias. En este sentido, es pertinente aludir en primer lugar al contexto convencional con el objeto de situar el objeto de nuestro trabajo, para a continuación argumentar la doble naturaleza de la prohibición.

$\mathrm{Y}$ es que al hablar de las fuentes del derecho internacional hay que aludir a aquellas de carácter convencional pero también a las consuetudinarias. La costumbre internacional se compone de dos elementos esenciales, la práctica o elemento material y la opinio iuris o elemento subjetivo. Si bien no cabe duda de la naturaleza convencional de la obligación que prohíbe la pena de muerte para aquellos Estados que se han obligado por ella, dada la tendencia existente es posible apuntar también a la naturaleza consuetudinaria de esta obligación.

\section{LA PENA DE MUERTE EN EL MARCO CONVENCIONAL}

El texto convencional de referencia al aludir a derechos civiles y políticos es el Pacto Internacional de Derechos Civiles y Políticos de $1966^{1}$, que no prohíbe de

En vigor desde el 23 de marzo de 1976, actualmente cuenta con 168 Estados parte. 
forma específica la pena de muerte, lo que sí hace su Segundo Protocolo adicional de $1989^{2}$, así como otros instrumentos de ámbito regional, como son el Protocolo a la Convención americana sobre derechos humanos relativo a la abolición de la pena de muerte de $1990^{3}$, el Protocolo 6 al Convenio para la protección de los derechos humanos y de las libertades fundamentales relativo a la abolición de la pena de muerte de $1983^{4}$ y el Protocolo 13 al Convenio para la protección de los Derechos Humanos y las Libertades Fundamentales, relativo a la abolición de la pena de muerte en todas las circunstancias de $2002^{5}$.

Claramente se manifiesta una tendencia convencional hacia la prohibición de la pena de muerte, dado el número creciente de Estados que se obligan por estos instrumentos. Es más, se puede afirmar que esta evolución ha sido muy rápida dado que en el momento en el que el Pacto Internacional de Derechos Civiles y Políticos fue redactado, sólo 10 Estados habían abolido la pena de muerte ${ }^{6}$, y hoy son muchos los Estados de la Comunidad Internacional los que han asumido este compromiso. Pero, ¿en qué consiste esta obligación? Para aquellos Estados que han consentido en obligarse por los instrumentos que establecen la prohibición total, está claro que rechazan la existencia de esta pena. Ahora bien, los Estados que no han asumido este compromiso no pueden aplicar esta sanción si no es con claras limitaciones derivadas de su especial gravedad. Estas limitaciones ya se prevén en el texto de referencia en materia de derechos de primera generación, el Pacto Internacional de Derechos Civiles y Políticos.

El artículo 6 del Pacto -derecho a la vida- establece que "en los países que no hayan abolido la pena capital sólo podrá imponerse [...] por los más graves delitos y de conformidad con las leyes que estén en vigor en el momento de cometerse el delito y que no sean contrarias a las disposiciones del presente Pacto ni a la Convención para la Prevención y la Sanción del Delito de Genocidio." Además "esta pena sólo podrá imponerse en cumplimiento de sentencia definitiva de un tribunal competente". La pena de muerte se prohíbe para los menores de 18 años, así como para las mujeres embarazadas. En esta primera aproximación se establecen, pues, limitaciones con una clara visión restrictiva, que marcan la tendencia de la evolución de esta prohibición. Es más, estas condiciones pueden considerarse como normas imperativas de derecho internacional.

\footnotetext{
En vigor desde el 11 de julio de 1991, actualmente cuenta con 81 Estados partes.

En vigor desde el 28 de agosto de 1991, actualmente cuenta con 11 Estados partes.

En vigor desde el 1 de marzo de 1985, actualmente cuenta con 46 Estados partes.

En vigor desde el 1 de julio de 2003, actualmente cuenta con 44 Estados partes.

International Bar Association, The Death Penalty under International Law: A Background Paper on the IBAHRI Resolution on the Abolition of the Death Penalty, May 2008.
} 
Pero ¿la pena de muerte afecta únicamente al derecho a la vida? Desde la perspectiva de las normas consuetudinarias es posible afirmar que también se infringen otras obligaciones, como la prohibición de ser sometido a tortura o a otros tratos y penas inhumanas, crueles o degradantes.

\section{LA PENA DE MUERTE EN EL ÁMBITO CONSUETUDINARIO}

Dada la extraordinaria gravedad de esta sanción, se considera que no va a afectar únicamente al derecho a la vida, violación ya de por sí de gran gravedad, sino también a otros derechos humanos, como el derecho a no ser sometido a tortura ni a otros tratos o penas crueles, inhumanas o degradantes, el derecho a la igualdad y a la no discriminación y a la dignidad humana.

El Derecho Internacional es un ámbito en constante evolución, sobre todo en el marco relativo a la protección de los derechos humanos. En este sentido, desde la relatoría especial sobre la tortura y otros tratos o penas crueles, inhumanas o degradantes se han realizado avances muy importantes en la tendencia abolicionista, analizando en profundidad la naturaleza normativa de la prohibición de la pena de muerte, teniendo en cuenta la labor realizada tanto en el marco de organizaciones internacionales como por la práctica desarrollada por los Estados.

Esta labor es especialmente valiosa, dado que el derecho a no ser sometido a tortura forma parte del núcleo duro del Derecho Internacional, esto es, de las normas imperativas, también llamadas de ius cogens, inderogables sin excepción.

Ya en 2009 desde la relatoría se dudaba de la compatibilidad de la pena de muerte con la prohibición de ser sometido a tortura y con la evolución del derecho internacional $^{7}$. En este sentido, determinadas prácticas relacionadas con esta pena son claramente contrarias al derecho internacional en tanto que si "se acepta en general que los castigos corporales constituyen al menos un trato cruel, inhumano o degradante, no pueden considerarse una sanción legal y, por consiguiente, pueden ser categorizados como tortura"8, sobre cuya práctica existe una prohibición absoluta en el Derecho Internacional. En este sentido, fenómenos como el corredor de la muerte ${ }^{9} \mathrm{o}$ los métodos de ejecución pueden ser considerados como tales. La lapidación ${ }^{10} \mathrm{o}$ la asfixia con gas $^{11}$ infringen por sí mismos la prohibición, el ahorcamiento ${ }^{12}$, la inyección letal ${ }^{13} \mathrm{o}$

\footnotetext{
$\mathrm{A} / \mathrm{HRC} / 10 / 44$

A/67/279, párr. 28

Id. párr. 42 y ss.

Véase el caso Jabari vs. Turquía del Tribunal Europeo de Derechos Humanos. Id. párr. 31

Véase el caso Ng vs. Canadá del Comité de Derechos Humanos. Id.

Véanse, entre otros, los casos Mwamba vs. Zambia del Comité de Derechos Humanos y Al-Saadoon \& Mufdhi vs. Reino Unido del Tribunal Europeo de Derechos Humanos. Id. párr. 34 y ss.

13 A/67/279, párr. 37 y ss.
} 
el pelotón de fusilamiento ${ }^{14}$ podrían infringir dicha prohibición. Y es que el concepto de tortura es un concepto viviente, que poco a poco va ampliando su paraguas de protección a través de una evolución interpretativa expansiva.

Así pues, poco a poco el Derecho Internacional ha impuesto limitaciones cada vez más firmes a la pena de muerte, y asimismo la prohíbe en determinadas circunstancias. Estos aspectos, vistos en el análisis del marco convencional, nos sirven de prueba a la hora de establecer la existencia de una norma consuetudinaria que prohíbe la pena de muerte en tanto que supone una violación de la prohibición de la tortura. El Relator ha indicado que "hay pruebas de reiteradas prácticas estatales en todo el mundo que reflejan la opinión de que la imposición y la puesta en práctica de la pena de muerte [...] infringe en sí misma, la prohibición de la tortura y otros tratos crueles, inhumanos o degradantes. Esta conclusión se origina en el hecho de que el derecho internacional no atribuye diferente valor al derecho a la vida cuando se trata de diferentes grupos de seres humanos, como menores, personas con discapacidad mental, embarazadas o personas sentenciadas después de un proceso judicial viciado, sino que considera que la imposición y puesta en práctica de la pena de muerte en esos casos es particularmente cruel, inhumana y degradante e infringe el artículo 7 del Pacto y los artículos 1 y 16 de la Convención contra la Tortura"15.

En consecuencia, para realizar esta afirmación es clave indicar que no se retrocede, esto es, no hay Estados que procedan a la reinstauración de la pena de muerte ${ }^{16}$, sino que la tendencia es la contraria ${ }^{17}$. Esta tendencia es una clara prueba de la opinio iuris de los Estados, esto es, de su convicción de que estamos ante una práctica que viola derechos humanos y por tanto las obligaciones asumidas en el marco internacional. Y, además, constituyen prueba de la práctica repetida ${ }^{18}$.

En este sentido, se puede decir con certeza que existen regiones libres de pena de muerte, por lo que la existencia de una costumbre regional es una evidencia. ${ }^{19}$

\footnotetext{
Id. párr. 40

Id. párr. 58

E/2015/49 párr. 8

17 Sobre la evolución abolicionista, véase A/67/279 párr. 70 y ss., donde se alude a las decisiones judiciales y a las decisiones de gobiernos en esta línea.

Asimismo, el Secretario General afirma que en "2013 había 101 países abolicionistas respecto de todos los delitos". E/2015/49 párr. 6

18 El relator llega a realizar la siguiente afirmación: "mientras va surgiendo una norma consuetudinaria según la cual la pena de muerte infringe per se la prohibición de la tortura y otros tratos o penas crueles, inhumanos o degradantes, las condiciones en que mayormente se aplica la pena de muerte en la práctica equivalen a la tortura. También cuando se la aplica en muchas otras condiciones menos severas, sigue constituyendo un trato cruel, inhumano y degradante." A/67/279 párr. 75

19 E/2015/49 párr. 43 y ss.
} 
Estaríamos ante una costumbre en Europa ${ }^{20}$ e Iberoamérica ${ }^{21}$, y la tendencia va a en el sentido en otras regiones. Así hay que aludir a la labor del Grupo de Trabajo sobre la Pena de Muerte y las Ejecuciones Extrajudiciales Sumarias o Arbitrarias en África, establecido por la Comisión Africana que promueve la abolición ${ }^{22}$. Asia es un continente que se encuentra aún en una posición retrasada, aunque la tendencia hacia la restricción es clara ${ }^{23}$. Y si bien existen Estados que aún pueden ser calificados como objetores persistentes, no es menos cierto que se encuentren dentro de la tendencia restrictiva atendiendo a las salvaguardias de humanización.

\section{CONCLUSIONES}

El Derecho Internacional de los derechos humanos se encuentra realizando una intensa labor hacia la abolición de la pena de muerte. El hecho de que este marco jurídico considere que viola determinados derechos, más allá del derecho a la vida, y que afecte específicamente a normas imperativas como el derecho a no ser sometido a torturas ni a tratos y penas inhumanas, crueles o degradantes, conduce a ampliar el marco de protección contra esta atroz práctica.

Como es sabido, existen textos convencionales que limitan o prohíben la pena de muerte, pero también esta prohibición está adquiriendo carácter consuetudinario. Ya existen regiones libres de la pena de muerte, como es Europa e Iberoamérica, y la tendencia normativa es la de la existencia de una costumbre universal que prohíbe la pena de muerte, dada la corriente cada vez más restrictiva incluso abolicionista existente en la Comunidad Internacional.

20 Sólo un Estado europeo sigue contemplando la pena de muerte en su ordenamiento jurídico: Belarús. El Consejo de Europa ha instado a su abolición en la Resolución 1857 (2012)

${ }^{21} \mathrm{E} / 2015 / 49$ párr. 55 y 56

22 Véase la Declaración de Cotonou de la Conferencia Continental sobre la Abolición de la Pena de Muerte en África de 8 de julio de 2014

23 Véase $\mathrm{E} / 2015 / 49$ 



\section{LAS SALVAGUARDIAS PARA PROTEGER LOS DERECHOS DE LAS PERSONAS CONDENADAS A MUERTE Y SU RELACIÓN CON EL IUS COGENS}

FLORABEL QUISPE REMÓN

Universidad Carlos III de Madrid

\section{ANTECEDENTES: EL COMPROMISO DE LOS ESTADOS CON LOS DERECHOS HUMANOS}

Desde 1945 los diversos Estados del mundo han incidido en la preocupación por el reconocimiento y protección de los derechos humanos. Ésta se ha visto plasmada en los diversos instrumentos internacionales que nacen a partir de 1948, año en el que se adopta el primer instrumento de reconocimiento internacional de los derechos humanos como es la Declaración Universal de los Derechos Humanos (DUDH). Posteriormente, también en el ámbito universal nace en 1966 el Pacto Internacional de Derechos Civiles y Políticos (PIDCP). Lo mismo sucede a nivel regional; en el ámbito americano en 1948 con el nacimiento de la Declaración Americana de Derechos y Deberes del Hombre (DADH) y en 1969 la Convención Americana de Derechos Humanos (CADH); en el ámbito europeo en 1950 con el nacimiento del Convenio Para la Protección de los Derechos Humanos y de las Libertades Fundamentales (CEDH); y finalmente en el ámbito africano, en 1981 con la Carta Africana de los Derechos Humanos y de los Pueblos. Con posterioridad se han adoptado instrumentos de carácter temático como la Convención sobre los derechos del niño o la Convención sobre la prohibición de la tortura. 
Todos estos instrumentos reconocen derechos humanos y a su vez establecen los órganos de protección de los mismos. El encargado de interpretar y vigilar el PIDCP es el Comité de Derechos Humanos (CDH); por su parte, en el ámbito americano, la Comisión y la Corte Interamericana de derechos humanos; en el europeo el Tribunal europeo de derechos humanos (TEDH); y en el africano, la Comisión y la Corte. No debe olvidarse la existencia de otros órganos no convencionales.

Tanto de los propios instrumentos como de la jurisprudencia, de la doctrina y de las decisiones y/o resoluciones de los órganos no judiciales de protección de los derechos humanos, se advierte que algunos de los derechos reconocidos reciben especial atención, como el hecho de ser considerados inderogables -no ser suspendidos bajo ninguna circunstancia- por ser indispensables para la existencia misma de dichos derechos. A éstos se les conoce como el núcleo duro de los derechos humanos.

Entre ellos tenemos el derecho a la vida; la prohibición de la tortura, penas o tratos inhumanos o degradantes; y las garantías judiciales conocido también como debido proceso.

En cualquier caso, solo este núcleo duro formaría parte de las normas imperativas de Derecho Internacional, conocido como normas de ius cogens y por ende serían obligaciones erga omnes.

El presente trabajo tiene por objeto determinar si las Salvaguardias para garantizar la protección de los derechos de los condenados a la pena de muerte (Salvaguardias) aprobadas por el Consejo Económico y Social de Naciones Unidas en 1984 forman parte de este núcleo duro de derechos humanos y si alcanzarían la naturaleza de ius cogens.

\section{EL NÚCLEO DURO DE LOS DERECHOS HUMANOS: EL PACTO INTERNACIONAL DE DERECHOS CIVILES Y POLÍTICOS Y LA INTERPRETACIÓN DEL COMITÉ DE DERECHO HUMANOS}

El PIDCP en el artículo 4 señala taxativamente algunos derechos que no son derogables ${ }^{1}$. Entre ellos, encontramos, el artículo 6 que incluye: el derecho a la vida (6.1); en los países en que aún haya pena capital sólo podrá imponerse la pena de muerte por los más graves delitos y de conformidad con las leyes que estén

\footnotetext{
Lo mismo sucede en el ámbito americano en el artículo 27 de la CADH y en el artículo 15 del $\mathrm{CEDH}$ en el ámbito europeo. El artículo 27 de la CADH recoge como derechos inderogables, entre otros, el derecho a la vida, el principio de legalidad y de retroactividad, y las garantías judiciales. Garantías judiciales reconocidas en el artículo 8 de la CADH que incluye el derecho a la presunción de inocencia, el derecho a un juez independiente, e imparcial, el derecho a otorgar medios necesarios para una defensa adecuada, el derecho a un juicio imparcial, a la asistencia letrada, al intérprete si no conoce el idioma, y el derecho a la doble instancia, entre otros. Este artículo es el equivalente al artículo 14 del PIDCP y al artículo 6 del CEDH.
} 
en vigor en el momento de cometerse el delito (6.2); el derecho de toda persona condenada a muerte de solicitar el indulto o la conmutación de la pena de muerte. La amnistía, el indulto o la conmutación de la pena capital podrán ser concedidos en todos los casos (6.4); y no se impondrá la pena de muerte por delitos cometidos por personas menores de 18 años de edad, ni se la aplicará a las mujeres en estado de gravidez (6.5); el artículo 7 que se refiere a la prohibición de la tortura, penas o tratos crueles, inhumanos y degradantes ${ }^{2}$; y el artículo 15 que recoge el derecho a no ser condenado por actos $\mathrm{u}$ omisiones que en el momento de cometerse no fueran delictivos según el derecho nacional o internacional. Tampoco se impondrá pena más grave que la aplicable en el momento de la comisión del delito. Si con posterioridad a la comisión del delito la ley dispone la imposición de una pena más leve, el delincuente se beneficiará de ello.

De modo uniforme los instrumentos internacionales marco de protección de los derechos humanos reconocen el derecho a la vida como un derecho inderogable $^{3}$. El derecho a la vida, es fundamental para todos los derechos humanos ${ }^{4}$. El $\mathrm{CDH}$ destaca que se trata de un derecho supremo respecto del cual no se autoriza suspensión alguna, ni siquiera en situaciones excepcionales que pongan en peligro la vida de la nación y su protección exige la adopción de medidas positivas por parte del Estado. No debe interpretarse en un sentido restrictivo ${ }^{5}$. Respecto al artículo 6.2 reitera la obligación de los Estados a restringir la aplicación de la pena de muerte a los delitos más graves y debe interpretarse de forma restrictiva en el sentido de que la pena de muerte debe constituir una medida excepcional. Ésta solo puede imponerse de conformidad con el derecho vigente en el momento

2 Recogida en dos Convenciones, la de Naciones Unidas de 1984, y la interamericana de 1985. El carácter imperativo de esta prohibición ha sido confirmado por decisiones de órganos internacionales. Cfr. El Tribunal Penal Internacional ad hoc para la Ex -Yugoslavia (Trial Chamber II), en el caso A. Furundzija, No IT-95-17/1, sentencia de 10 de diciembre de 1998. Voto razonado del juez Cançado Trindade en la Opinión Consultiva $N^{\circ} 18$ de la Corte Interamericana de Derechos Humanos, párr.69. También recogido por el Grupo de Trabajo de la CDI en Fragmentación del derecho internacional: Dificultades derivadas de la diversificación y expansión del derecho internacional, A/CN.4/L.682, del 13 de abril de 2006, párr. 374.

3 Lo mismo sucede a nivel jurisprudencial. A modo de ejemplo señalamos el caso Bámaca Velásquez contra Guatemala (2000) donde la Corte Interamericana señaló que hay equivalencia entre el contenido del artículo 3, común en los Convenios de Ginebra y el de las disposiciones de la Convención Americana, y de otros instrumentos internacionales acerca de los derechos humanos inderogables (tales como el derecho a la vida y el derecho a no ser sometido a torturas ni tratos crueles, inhumanos o degradantes) (párr.209). En su voto razonado el ex juez de la Corte Interamericana hoy juez de la Corte Internacional de justicia Cançado Trindade sitúa al derecho a la vida en el dominio del ius cogens.

4 Comité de Derechos Humanos, Observación General No 14 , El derecho a la vida, $23^{\circ}$ periodo de sesiones (1984), párr.1.

5 Comité de Derechos Humanos, Observación General No 6 , El derecho a la vida, $16^{\circ}$ periodo de sesiones, 1982, párr.1. 
en que se haya cometido el delito y que no sea contrario al Pacto. Deja establecido que deben observarse las garantías de procedimiento que establece el PIDCP en el que se incluye el derecho de la persona a ser oída públicamente por un tribunal independiente, a que se presuma su inocencia y a gozar de las garantías mínimas en cuanto a su defensa y al derecho de apelación ante un tribunal superior. Aclara que estos derechos son aplicables sin perjuicio del derecho de solicitar un indulto o la conmutación de la pena ${ }^{6}$.

En igual sentido al pronunciarse sobre la prohibición de la tortura $u$ otros tratos o penas crueles, inhumanos y degradantes (artículo 7) ha reiterado que tampoco es posible su suspensión bajo ninguna circunstancia por cuanto su finalidad es proteger la dignidad y la integridad física y mental de la persona, mediante medidas legislativas y de otra índole. Según el $\mathrm{CDH}$, esta prohibición se completa con el párrafo 1 del artículo 10 según el cual "toda persona privada de libertad será tratada humanamente y con el respeto debido a la dignidad inherente al ser humano"7. La prohibición no solo abarca los actos que causan dolor físico a la víctima, sino también a los que causan sufrimiento moral. Deja dicho el Comité que si un Estado Parte aplica la pena de muerte a los delitos más graves, la pena no solo debe estar limitada estrictamente según lo dispuesto en el artículo 6 del Pacto, sino que deberá ser ejecutada de manera que cause los menores sufrimientos físicos o morales posibles.

Si bien el PIDCP no reconoce las garantías judiciales como un derecho inderogable, el CDH -órgano encargado de su interpretación-, dada la importancia de este derecho se ha pronunciado en diversas ocasiones en sus Observaciones Generales?

En relación con estas garantías reconocidas en el artículo 14 del $\mathrm{PIDCP}^{10}$, el Comité señaló que los Estados Partes las deben respetar independientemente de su

\footnotetext{
Ídem, párrs. 6 y 7.

7 Comité de Derechos Humanos, Observación General No 20. «Prohibición de la tortura u otros

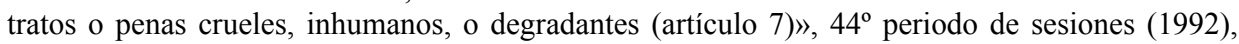
sustituye a la Observación General No 17 (1982), párr.2.

8 Ídem, párr.6.

9 Lo mismo hizo sobre el derecho a la vida y la prohibición de la tortura incidiendo en su importancia e inderogabilidad. El Comité de Derechos Humanos ha emitido varias Observaciones Generales vinculadas con el derecho a la vida, la prohibición de la tortura y el debido proceso. De los cuales se advierte una amplia y detallada interpretación de los mismos. La Observación General $\mathrm{N}^{\mathrm{o}} 6$ (1982) y Observación General N ${ }^{\circ} 14$ (1984) sobre el derecho a la vida; la Observación General $\mathrm{N}^{\mathrm{o}} 7$ sobre la prohibición de la tortura, sustituida por la Observación General № 20 (1992); y las Observaciones Generales Nos 13 (1984) y 32 (2007) sobre el debido proceso y la 24 (1994) sobre las reservas a tratados de derechos humanos.

10 Un amplio estudio sobre las garantías judiciales en los sistemas de protección de los derechos humanos véase en Quispe Remón, F. El derecho al debido proceso en el derecho internacional y en el sistema interamericano. Tirant Lo Blanch, 2010, $650 \mathrm{pp}$.
} 
tradición jurídica y de su derecho interno ${ }^{11}$. Respecto a la inderogabilidad manifestó que "las garantías procesales nunca podrán ser objeto de medidas derogatorias que soslayen la protección de derechos que no son susceptibles de suspensión". Todo juicio debe contar con los requisitos del artículo 14 incluso en los estados de excepción. En ningún caso debe desviarse de los principios fundamentales del juicio imparcial, incluida la presunción de inocencia ${ }^{12}$. "Las garantías relacionadas con la institución de la suspensión, según se definen en el artículo 4 del Pacto, se basan en los principios de legalidad y del Estado de derecho inherentes al Pacto en su conjunto. Como ciertos elementos del derecho a un juicio imparcial están explícitamente garantizados por el derecho internacional humanitario en tiempo de conflicto armado, el Comité no encuentra ninguna justificación para suspender dichas garantías durante cualquier otra situación de excepción". A juicio del Comité, los principios de legalidad y del Estado de derecho exigen que los requisitos fundamentales del derecho a un juicio imparcial se respeten durante un estado de excepción. Sólo un tribunal de derecho puede enjuiciar y condenar a una persona por un delito respetando la presunción inocencia ${ }^{13}$.

Así, al pronunciarse sobre las reservas a los tratados de derechos humanos también se refirió a las garantías judiciales del al artículo 14. Manifestó que si bien se pueden aceptar reservas a cláusulas concretas de este artículo, no cabría una reserva general al derecho a un juicio imparcial, a un juicio con las debidas garantías ${ }^{14}$. Dice el Comité, un Estado no puede reservarse el derecho de torturar, de someter a personas a tratos o castigos crueles, inhumanos y degradantes, de privar arbitrariamente de la vida a las personas, de presumir que una persona es culpable hasta que se demuestre su inocencia, de ejecutar a mujeres embarazadas o a niños. ${ }^{15} \mathrm{En}$ palabras del Comité las disposiciones del Pacto que son de derecho internacional consuetudinario y que tienen el carácter de normas perentorias no pueden ser objeto de reservas y las reservas contrarias a normas perentorias no serían compatibles con el objeto y fin del Pacto.

11 Comité de Derechos Humanos, Observación General № 32. «El derecho a un juicio imparcial y a la igualdad ante los tribunales y cortes de justicia», $90^{\circ}$ periodo de sesiones (2007), sustituye a la Observación General No 13 , párr.4

12 Ídem, párr.6. Anteriormente, al pronunciarse sobre la suspensión de obligaciones en un estado de excepción, el CDH ya se había pronunciado en este sentido. Cfr. Observación General № 29 (2001) «Suspensión de obligaciones durante un estado de excepción», párr.15

13 Observación General No 29, ob. cit. párr.16.

14 Comité de Derechos Humanos, Observación General No 24, $52^{\circ}$ periodo de sesiones, «Cuestiones relacionadas con las reservas formuladas con ocasión de la ratificación del Pacto o de sus Protocolos Facultativos, o de adhesión a ellos, o en relación con las declaraciones hechas de conformidad con el artículo 41 del pacto» (1994), párr.8.

15 Ibídem. 
Para el CDH las disposiciones cuya aplicación no puede suspenderse guardan relación con la cuestión de si ciertas obligaciones en materia de derechos humanos tienen el carácter de normas imperativas de derecho internacional. Así el hecho de que existan derechos en el artículo 4.2 del PIDCP que no pueden suspenderse debe considerarse en parte como el reconocimiento del carácter de norma imperativa de ciertos derechos garantizados por el Pacto ${ }^{16}$. No obstante reconoce que la categoría de normas imperativas va más allá de dicha lista. "Los Estados Partes no pueden invocar el artículo 4 como justificación de actos que violen el derecho humanitario o normas imperativas de derecho internacional, por ejemplo (...) la inobservancia de los principios fundamentales de un juicio imparcial, en particular la presunción de inocencia"17. Otro elemento que a juicio del Comité no puede ser objeto de suspensión legítima conforme al artículo 4 es, entre otros que toda persona privada de libertad debe ser tratada humanamente y con el debido respeto a la dignidad inherente al ser humano ${ }^{18}$. Así, el Comité amplía el catálogo que establece el artículo 4.2 del PIDCP e incluye dentro de aquellos derechos que no pueden ser objeto de suspensión legítima.

Desde luego, la existencia de una normativa jurídica internacional que establezca ciertos derechos que deben ser protegidos de modo especial es compatible con los planteamientos de la doctrina sobre la existencia de un núcleo duro de los derechos humanos.

Si bien los Estados que han ratificado el PIDCP están en la obligación de brindar de manera efectiva cada una de las garantías que recoge el Art. 14 a todas las personas al margen de la gravedad de los delitos que hayan cometido, en los delitos cuya condena es la pena capital estas garantías adquieren mayor trascendencia porque una aplicación ineficaz constituye una violación del derecho a la vida, una violación de una norma de ius cogens. Justamente por ello el CDH en sus observaciones generales incide en la importancia de respetar estos derechos cuando se trata de casos de la pena de muerte. Destaca la importancia de la asistencia letrada en el proceso penal y señala que ésta puede ser obligatoria cuando una persona condenada a muerte desee obtener la revisión constitucional de irregularidades cometidas en un juicio penal y no tenga medios suficientes para interponer dicho recurso ${ }^{19}$. Es importante, dice el Comité, que los acusados dispongan del tiempo y medios adecuados para la preparación de su defensa y de la comunicación con su defensor de su elección, por cuanto se trata de un elemento importante de la garantía de un juicio justo.

\footnotetext{
16 Comité de Derechos Humanos, Observación General No 29 (2001). «Suspensión de obligaciones durante un estado de excepción», párr.11.

17 Ibídem.

18 Ídem, párr.13

19 Observación General N 32, ob. cit., párr.10
} 
Así, el derecho de apelar adquiere especial importancia en los casos de pena de muerte. En palabras del Comité, la denegación de asistencia letrada a una persona indigente por un tribunal que revise una condena a muerte constituye una violación no solo del derecho a un abogado defensor sino también del derecho a que el fallo sea revisado por otro tribunal, por cuanto en estos casos la denegación de asistencia jurídica para apelar impide de hecho una revisión efectiva del fallo condenatorio y de la pena por un tribunal superior ${ }^{20}$. Deja claramente establecido que en juicios que conducen a la imposición de la pena de muerte, es particularmente importante el respeto escrupuloso de las garantías de un juicio imparcial ${ }^{21}$.

No queda duda, de la interpretación realizada por el $\mathrm{CDH}$, del carácter inderogable del art. 14 del PIDCP, así como la importancia que tiene la adecuada aplicación del derecho al debido proceso en todos los procesos penales, especialmente en aquellos cuya condena es la pena capital, y su carácter inderogable incluso en las situaciones excepcionales.

En este contexto, es de señalar que 168 Estados han ratificado el PIDCP; 25 la CADH; 47 el CEDH, y 53 la Carta Africana. Con ello se han obligado de manera unilateral y voluntaria, a nivel universal y regional, a reconocer y garantizar el ejercicio efectivo de los derechos reconocidos en dichos instrumentos y en su caso también a reconocer toda la interpretación que de ellos hacen los órganos de protección de estos instrumentos, a todas las personas, por el solo hecho de serlo, sin ningún tipo de distinción. A ello sumamos que existe cierto consenso de la gran mayoría de los Estados respecto de los principios fundamentales de la Carta de las Naciones Unidas, desarrollados por la Resolución 2625 de 1970 que deja dicho que todo Estado tiene el deber de promover, mediante acción conjunta o individual, el respeto universal a los derechos humanos y a las libertades fundamentales y la efectividad de tales derechos y libertades de conformidad con la Carta de las Naciones Unidas. No hay constancia de oposición respecto al contenido de esta resolución por parte de ningún Estado a lo largo de estos cuarenta y cinco años.

\section{LAS SALVAGUARDIAS PARA GARANTIZAR LA PROTECCIÓN DE LOS DERECHOS DE LOS CONDENADOS A LA PENA DE MUERTE Y SU RELACIÓN CON LOS DERECHOS INDEROGABLES.}

No obstante a estos instrumentos marco de protección de los derechos humanos en el mundo y las interpretaciones realizadas por sus órganos sobre el alcance y

20 Ídem, párr. 51. También en diversos casos el CDH ha manifestado la importancia del abogado defensor. En la comunicación núm. 1096/2002: Kurbanov c. Tayikistán, señaló "es axiomático que el acusado sea asistido efectivamente por un abogado en todas las etapas del proceso". Cfr. CCPR/C/79/D/1096/2002, 12 de noviembre de 2003, párr. 6.5.

21 Ídem, Observación General No 32, párr.59. 
contenido de los mismos, se tienen otros instrumentos, documentos y resoluciones emanadas de otros órganos principales y/o subsidiarios de las Naciones Unidas con el fin de otorgar cada vez más una mejor protección al ser humano. La ONU cuenta, por un lado, con órganos principales como el Consejo Económico y Social (ECOSOC) y, por otro, con órganos subsidiarios como el Consejo de Derechos Humanos, la Comisión de Derecho Internacional, el Alto Comisionado para los Derechos Humanos, además de un importante número de relatores, grupos y comisionados creados con el objetivo de promover los derechos humanos en el ámbito internacional.

El ECOSOC, que dentro de sus funciones tiene el de fomentar el respeto y la observancia a los derechos humanos y libertades fundamentales, en 1973 mediante Resolución 1745 (LIV) invitó al Secretario General de Naciones Unidas a presentar quinquenalmente informes periódicos actualizados y analíticos sobre la pena de muerte. Informes que se vienen presentando desde 1975 hasta la fecha.

Es en este marco que en 1984, a través de la Resolución 1984/5022 aprueba nueve SALVAGUARDIAS PARA GARANTIZAR LA PROTECCIÓN DE LOS DERECHOS DE LOS CONDENADOS A LA PENA DE MUERTE, las que incluyen disposiciones relativas a los tipos de delitos a los que se puede aplicar la pena de muerte, las personas a las que no se debe aplicar, y las garantías sobre un juicio justo para quienes puedan ser condenados a muerte. Ha sido refrendada en la Resolución 39/118 de la Asamblea General de 14 de diciembre de 1984.

La primera salvaguardia se refiere a la imposición de la pena de muerte solo a los delitos más graves; la segunda al principio de legalidad, solo podrá imponerse por un delito para el que la ley estipulara la pena de muerte en el momento en que fue cometido, y quedando entendido que si con posterioridad a la comisión del delito, la ley estableciera una pena menor, el delincuente se beneficiará del cambio; la tercera, a no condenar a muerte a menores que en el momento de cometer el delito tenían menos de 18 años, a mujeres embarazadas o que hayan dado a luz recientemente, a personas de edad, a personas con discapacidad mental o intelectual; la cuarta, a la presunción de inocencia; la quinta a las garantías de un juicio imparcial, es decir, solo podrá ejecutarse la pena capital de conformidad con una sentencia definitiva dictada por un tribunal competente, tras un proceso jurídico que ofrezca todas las garantías posibles para asegurar un juicio justo, equiparables como mínimo a las

22 En Resoluciones posteriores se pronuncia sobre su importancia y su aplicación: En la Resolución 1989/64 (sobre La aplicación de las salvaguardias para garantizar la protección de los derechos de los condenados a la pena de muerte), 1990/51, 1995/57, 1996/15, y con su Decisión 2005/247 mediante la cual el ECOSOC solicitó al Secretario General (SG) que siga recogiendo datos relevantes e información sobre la pena capital y las salvaguardias a través de los distintos sectores, además de preparar informes adicionales a los quinquenales. 
que figuren en el art. 14 del PIDCP, incluido el derecho de todo sospechoso o acusado de un delito sancionables con la pena capital a la asistencia letrada adecuada en todas las etapas del proceso; la sexta, referida al derecho a la apelación ante un tribunal de jurisdicción superior y a la adopción de medidas para garantizar que esas apelaciones sean obligatorias; la séptima, al derecho de toda persona condenada a muerte a solicitar el indulto o la conmutación de la pena; los mismos que se podrán conceder en todos los casos de pena capital; la octava, a la suspensión de la pena de muerte mientras hayan recursos pendientes sea apelación $u$ otros procedimientos de recurso o relacionados con el indulto o la conmutación de la pena; y la novena, a causar el menor sufrimiento posible cuando se ejecute la pena capital.

Dada la importancia de las salvaguardias y la verificación de su cumplimiento, el ECOSOC en la Resolución 1989/64 del 24 de mayo, recomendó al Secretario General incluir en el informe quinquenal sobre la pena de muerte, la aplicación de las salvaguardias ${ }^{23}$. Así desde el quinto informe en adelante en el punto VI encontramos un informe detallado sobre el cumplimiento y obstáculos de las salvaguardias en todos aquellos Estados que aún mantienen la pena capital. En todos ellos se advierte la colaboración de un gran número de Estados Miembro (EEMM) proporcionando información sobre la aplicación de las salvaguardias al Secretario General. Si bien estos informes muestran los problemas en la implementación de las salvaguardias también muestran la colaboración cada vez más mayor por parte de los Estados en brindar información y en dar cumplimiento en aras de una mejor protección al ser humano que se encuentra imputado por un delito sancionado con la pena capital.

De ellos se advierten recomendaciones a los EEMM para tomar medidas necesarias para aplicar las salvaguardias y reforzar la protección de los derechos de los condenados a la pena de muerte, facilitándoles el tiempo y los medios para la preparación de su defensa, incluida la asistencia letrada apropiada en todas las fases del procedimiento, por encima y más allá de la protección prestada en casos no capitales; señala la obligatoriedad de la apelación o revisión en todos los casos de pena capital; asimismo se pronuncia sobre el establecimiento de un límite de edad después del cuál nadie podrá ser condenado a muerte ni ejecutado.

23 Informes del Secretario General sobre la Cadena Perpetua: primer informe correspondiente a los años 1969-1973; segundo informe correspondiente a los años 1974-1978; tercer informe correspondiente a los años 1979-1983; cuarto informe correspondiente a los años 1984-1988. Informes del Secretario General sobre la Cadena Perpetua que incluye informe sobre las Salvaguardias para garantizar la protección de los derechos de los condenados a la pena de muerte: quinto informe correspondiente a los años 1989-1993; sexto informe correspondiente a los años 19941998; séptimo informe correspondiente a los años 1999-2003; octavo informe correspondiente a los años 2004-2008 y el noveno y último informe correspondiente a los años 2009-2013. Además existen otros informes "suplemento anual" complementarios al informe quinquenal. 
También se refiere a la eliminación de la pena de muerte para las personas que sufren de retraso mental o con capacidad mental sumamente limitada, ya sea en la etapa de sentencia o ejecución ${ }^{24}$.

Se invoca a los Estados a dar cumplimiento pleno al Art. 14 del PIDCP brindando garantías para asegurar un juicio justo a cada acusado que enfrenta una posible sentencia de muerte. Asimismo establece que los Estados deben tener en cuenta los Principios básicos relativos a la independencia de la judicatura, los Principios básicos sobre la función de los Abogados, las Directrices sobre la función de los Fiscales, el Conjunto de Principios para la protección de todas las personas sometidas a cualquier forma de detención o prisión, y las Reglas mínimas para el tratamiento de los reclusos.

Exhorta a los EEMM que los funcionarios involucrados en las decisiones para llevar a cabo una ejecución estén plenamente informados de la situación de las apelaciones y peticiones de indulto del preso en cuestión. Insta a los EEMM para aplicar efectivamente las Reglas mínimas para el tratamiento de los reclusos, con el fin de reducir al mínimo el sufrimiento de los presos condenados a muerte y para evitar cualquier exacerbación de tal sufrimiento.

Así, advertimos desde inicios de los años noventa el statu quo de las salvaguardias en los diversos Estados. Estos informes se desarrollan con la colaboración y conocimiento de los EEMM de las Naciones Unidas y teniendo en cuenta informes y/o resoluciones de otros órganos de protección de derechos humanos a nivel regional como universal. Es el caso del Consejo de Derechos Humanos y/o el Relator Especial sobre ejecuciones extrajudiciales, sumarias o arbitrarias, la Alta Comisionada de Naciones Unidas para los Derechos Humanos ${ }^{25}$. En los últimos años con

24 ECOSOC, Resolución 1989/64 de 24 de mayo, en la misma línea en la Resolución 1996/15 del 23 de julio.

25 De las conclusiones y recomendaciones del último informe anual del Alto Comisionado de las Naciones Unidas para los Derechos Humanos e informes de la oficina del Alto Comisionado y del Secretario General se advierte la necesidad de que los Estados que aún aplican la pena de muerte cumplan las disposiciones internacionales en materia de derechos humanos conforme al artículo 6 del PIDCP. Inciden en que la pena capital solo puede imponerse por los delitos más graves; en que los Estados deben respetar las garantías de un juicio imparcial; en que la concesión de gracia, el indulto y la conmutación de pena son medidas esenciales hacia la abolición de la pena de muerte; que los Jefes de Estado y de Gobierno y otras autoridades estatales responsables deberían ejercer su competencia constitucional o legal para conceder una amnistía o indultar a los condenados a muerte, o conmutar sus penas en todos los casos. A/HRC/30/18, 16 de julio de 2015, párr.59. En la misma línea el Comité contra la Tortura insta a los Estados Parte a que garantice que los condenados a muerte gocen de todas las garantías legales y de protección previstas en la Convención contra la Tortura las mismas que están vinculadas con las salvaguardias. Es el caso de: la garantía de asistencia efectiva por un abogado de los condenados a muerte en todas las etapas del proceso; poner a disposición de las autoridades el indulto, la conmutación y el aplazamiento en la práctica para los condenados a muerte; la introducción de un sistema obligatorio de revisión en casos de pena capital, con efectos suspensivos después de una condena pena de muerte en primera instancia. Cfr. CAT/C/JPN/CO/2, párr. 15, c,d,e. 
referencias a estudios e informes de organizaciones y organismos internacionales. No hay constancia de un pronunciamiento por parte de ningún Estado sobre la oposición a una, varias o todas las salvaguardias. Es más, desde 1984 muchos órganos de las Naciones Unidas se han pronunciado sobre las mismas a través de diversas resoluciones e informes reafirmando su importancia e invocando a los Estados a dar cumplimiento a las mismas. Han transcurrido más de tres décadas desde la aprobación por parte del ECOSOC de las salvaguardias y más de veinte años desde su incorporación en los informes quinquenales de donde se advierten una mayor colaboración y toma de conciencia de la importancia de éstas por parte de los Estados, incluido uno de los países con mayor población en el mundo como es China.

Los informes quinquenales dejan claro que las salvaguardias son normas mínimas reconocidas internacionalmente que deben aplicar los países que aún mantienen la pena capital en su legislación, que afortunadamente son cada vez menos (ver Tabla 1 y Figura 1). Dejan dicho que es indiscutible que éstas son vinculantes incluso para los Estados que no hayan ratificado ningún tratado. De los dos últimos informes se advierte la importancia que en esta línea tiene el Examen Periódico Universal (EPU) por cuanto, la aplicación de este mecanismo del Consejo de Derechos Humanos confirma que las salvaguardias pueden considerarse normas generales de derecho aplicable en materia de pena capital, incluso para los Estados que no hayan contraído ninguna obligación respecto a los tratados que impongan la pena capital. Destaca el informe que bajo este mecanismo los EEMM informan sobre el cumplimiento de las normas internacionales de derechos humanos, incluidas las salvaguardias aunque no estén sujetos a obligaciones convencionales vinculados a la pena capital ${ }^{26}$. Así, como consecuencia del EPU, el último informe ha sido desarrollado teniendo en cuenta la información de casi todos EEMM de la ONU.

Si bien en 1984 el ECOSOC recoge nueve salvaguardias exclusivamente para garantizar la protección de los derechos de quienes se enfrentan a la pena de muerte, gran parte de ellas ya habían sido recogidas en la DUDH (Art. 3, 5, 10 y 11), más tarde en los Art. 6, 7 y 14 del PIDCP, y en los instrumentos regionales aplicables para todas las personas sin ningún tipo de distinción. Es más, la primera, segunda, tercera y séptima salvaguardia ya en 1966 habían sido recogidas como derechos inderogables en el artículo 4 (que declara inderogables los artículos, entre otros, 6, 7 y 15 del PIDCP vinculados con el derecho a la vida, la prohibición de la tortura y al principio de legalidad); la cuarta, quinta y sexta reconocidas también con posterioridad como inderogables por el Comité de Derechos Humanos a través de sus Observaciones Generales en el marco del debido

26 Cfr. Noveno y último informe quinquenal del Secretario General al ECOSOC, «La pena capital y la aplicación de las salvaguardias para garantizar la protección de los derechos de los condenados a la pena de muerte $(\mathrm{E} / 2015 / 49) »$, párr. 60 y 61. 
proceso recogido en el artículo $14^{27}$. La octava y novena si bien no han sido taxativamente reconocidas como inderogables, la práctica reiterada y aceptada las ha consolidado como esenciales para la protección de la persona y su dignidad. Nadie duda hoy en día que la última salvaguardia está además protegida bajo el paraguas del Art. 7 del PIDCP que prohíbe la tortura, penas o tratos crueles, inhumanos y degradantes ${ }^{28}$ (ver Tabla 2). Los órganos de Naciones Unidas en reiteradas ocasiones han manifestado que muchos métodos que se utilizan en la pena de muerte constituyen tratos inhumanos. Además el $\mathrm{CDH}$ ha considerado en su Observación General 24 como no susceptible de suspensión, entre otros, que toda persona privada de libertad debe ser tratada humanamente y con el debido respeto a la dignidad inherente al ser humano.

Además de los instrumentos marco y la interpretación que de ellos hacen los órganos de protección se han adoptado muchos instrumentos a nivel universal como regional que fortalecen las garantías inderogables y de los que la gran parte de los Estados forman parte. A modo de ejemplo podemos señalar la Convención sobre los derechos del niño (1989), que ha sido ratificado por casi todos los Estados del mundo, el mismo que ha contribuido a la universalizado de la prohibición de aplicación de la pena de muerte a menores de 18 años $^{29}$, y la Convención contra la tortura y otros tratos o penas crueles, inhumanos y degradantes (1984).

Dada la importancia de los derechos recogidos en las salvaguardias, éstos han sido objeto de reiterados pronunciamientos por los distintos órganos judiciales y no judiciales de derechos humanos cuya conclusión no es otra que su inderogabilidad y su carácter indispensable para aquellos cuyos delitos se sancionan con la pena capital. Es así que las salvaguardias forman parte de ese núcleo duro de los derechos humanos que son inderogables tal y como han sido reconocidos en los propios instrumentos internacionales de protección de los derechos humanos y por los órganos de protección.

Lo que hizo la Resolución del ECOSOC de 1984 es incidir en su protección y respeto con especial énfasis para aquellas personas condenadas a la pena capital. Para entonces ya eran garantías conocidas y aceptadas por la comunidad interna-

27 El artículo 27 de la CADH reconoce todas las salvaguardias como inderogables a diferencia del PIDCP. Un análisis del debido proceso y su consideración como norma de ius cogens puede verse en Quispe Remón, F. El derecho al debido proceso en el derecho internacional..., ob. cit., pp. 449-581.

28 Véase: $\mathrm{CDH}$, Observación General No 20, párr.6, ob. cit.

29 A modo de ejemplo podemos señalar, en el ámbito americano el pronunciamiento de la Comisión Interamericana de Derechos Humanos en reiteradas ocasiones sobre la prohibición de la ejecución de niños menores de 18 años por ser una norma de ius cogens. Véase Caso Roach y Pinkerton contra Estados Unidos (Informe Anual 3/87), en la misma línea en el caso Michael Domínguez también contra Estados Unidos (Informe Anual 62/02) y en el caso 11.193 Fondo, Gary T. Gram, conocido como Shaka Sankofa contra Estados Unidos (Informe Anual 97/03). 
cional en su conjunto como inderogables, y la aprobación por parte del ECOSOC ha consolidado ese reconocimiento y focalizado la importancia de su aplicación para garantizar la protección de los derechos de quienes se enfrentan a la pena de muerte. Su reconocimiento y aplicación ha sido y viene siendo cada vez mayor y sin oposición de ninguna naturaleza. Hay un consenso por parte de la comunidad internacional de su carácter esencial por los intereses que protege.

\section{LAS SALVAGUARDIAS COMO PARTE DEL NÚCLEO DURO DE LOS DERECHOS HUMANOS Y SU CONSIDERACIÓN COMO NORMAS DE IUS COGENS}

En el Derecho Internacional Público existen normas dispositivas y normas imperativas- conocidas como ius cogens. Gran parte de ellas forman parte de las primeras y los Estados, si lo consideran, pueden no reconocer, no ratificar un tratado, ni incorporar en su derecho interno y por ende no cumplirlas; sin embargo con el pequeño puñado de normas que forman parte de las segundas esto no puede suceder, ya que al ser imperativas los Estados están obligados a cumplirlas, al margen de haberlas o no reconocido, ratificado y/o incorporado en su derecho interno, por la naturaleza especial del objeto que protegen y por ende se torna en una exigencia en el mundo. Van más allá de la voluntad de los Estados ${ }^{30}$.

Las normas imperativas han sido reconocidas en el artículo 53 de la Convención de Viena de 1969 sobre el Derecho de los Tratados (CV69) al señalar:

"Es nulo todo tratado que, en el momento de su celebración está en oposición con una norma imperativa de derecho internacional general. Para los efectos de la presente Convención, una norma imperativa de derecho internacional general es una norma aceptada y reconocida por la comunidad internacional de Estados en su conjunto como norma que no admite acuerdo en contrario y que sólo puede ser modificada por una norma ulterior de derecho internacional general que tenga el mismo carácter".

Son normas que no admiten acuerdo en contrario salvo que exista otra norma de la misma naturaleza. "Si algo claro define a la norma de ius cogens es el estar relacionada con obligaciones que son esenciales para la salvaguardia de los intereses fundamentales de la comunidad internacional"31. Su valor es superior a las

30 Cfr. Quispe Remón, F. «Las normas de ius cogens: Ausencia de catálogo». En Anuario Español de Derecho Internacional $\mathrm{N}^{\circ}$ 28, Universidad de Navarra, 2012, pp. 143-183.

31 Casado Raigón, R. y Vásquez Gómez, E. «La impronta del ius cogens en el Proyecto de artículos de la Comisión de Derechos Internacional sobre la responsabilidad del Estado por hechos internacionalmente ilícitos». En Soberanía del Estado y Derecho Internacional, Homenaje al profesor Juan Antonio Carrillo Salcedo, Universidad de Córdoba, Universidad de Sevilla y Universidad de Málaga, 2005, p. 348. En igual sentido Acosta Estévez, J. B. «Normas de ius cogens, efecto erga omnes, crimen internacional y la teoría de los círculos concéntricos». En Anuario de Derecho Internacional, 1995, pp. 5-21. 
demás porque recogen los valores esenciales de la comunidad internacional que está fundamentado en la idea de humanidad. Se trata, "de necesidades de orden moral, económico, político, etc., indispensables para la existencia misma de la sociedad internacional y, por consiguiente, imperiosas y absolutas; el Derecho internacional no puede desconocerlas, pues acaban por imponerse o desaparece la sociedad internacional; representan el mínimo jurídico que la comunidad internacional, en un momento dado, considera esencial para su existencia y constituyen por ello el más fuerte límite que el medio colectivo en que los Estados viven imponen al relativismo del Derecho internacional, al voluntarismo y subjetivismo de los Estados soberanos" ${ }^{\prime 2}$. Sin duda, se trata de normas cuya importancia y trascendencia es imprescindible para la existencia misma de la sociedad y el respeto de los valores humanos esenciales. Su respeto redundará en la mayor y mejor protección del ser humano.

En 1970, la Corte Internacional de Justicia en el caso Barcelona Traction, señaló: "En particular, debe hacerse una distinción esencial entre las obligaciones de los Estados respecto a la comunidad internacional en su conjunto y las que nacen respecto a otro Estado dentro del marco de la protección diplomática. Por su naturaleza misma, las primeras conciernen a todos los Estados. Dada la importancia de los Derechos en cuestión, todos los Estados tienen un interés jurídico de protegerlos, las obligaciones en cuestión son obligaciones erga omnes". Tales obligaciones se derivan, por ejemplo, en el Derecho Internacional Contemporáneo, de la prohibición de los actos de agresión y de genocidio, pero también de los principios y normas relativos a los Derechos Fundamentales de la persona humana, incluida la protección contra la práctica de la esclavitud y la discriminación racial"33.

De esta forma, por vez primera la jurisprudencia deja clara la obligación de los Estados hacia la comunidad internacional en su conjunto, obligaciones denominadas erga omnes, teniendo en cuenta la importancia de los derechos. Incluye dentro de estas obligaciones, los principios y reglas relativas a los derechos fundamentales de la persona humana.

No hay duda de la existencia en el Derecho internacional de normas superiores a la voluntad de los Estados, indispensables para la vida internacional y profunda-

32 El documento completo donde Antonio de Luna hizo dicho comentario puede verse en: A/CN.4/ SR.684 de 21 de mayo de 1963. Yearbook of the International Law Commission, 1963, vol. I, párrs. 58-66, en http://untreaty.un.org/ilc/documentation/english/a_cn4_sr684.pdf.

33 I.C.J., Barcelona Traction, Light and Power Company, Limited (Belgium v. Spain) Judgment of 5 February 1970, párrs. 33 y 34. No obstante, hay que señalar que la CIJ de una manera implícita ya vinculaba a la prohibición del genocidio con la obligación erga omnes (Opinión Consultiva sobre Reservas a la Convención para la prevención y sanción del delito de genocidio del 28/05/1951). Otra decisión en la que se advierte esta posición es en el Caso sobre la Aplicación de la Convención para la prevención y sanción del delito de genocidio (Objeciones Preliminares) de 11 de julio de 1996, párr. 31. 
mente arraigadas en la conciencia internacional, que se refieren a los intereses de la comunidad internacional, a los de toda la humanidad, y que, por ello, tiene carácter imperativo ${ }^{34}$. De hecho no considerar ciertas normas de derechos humanos como normas imperativas con carácter de ius cogens sería ignorar los evidentes efectos legales de ciertos instrumentos y el carácter fundamental de varios principios que la comunidad internacional no pone en duda ${ }^{35}$.

$\mathrm{Su}$ ámbito de aplicación traspasa el derecho de los tratados y se extiende a cualquier acto jurídico de derecho internacional general. Son normas de derecho internacional general en tanto que también tienen naturaleza consuetudinaria. Entre estos encontramos el derecho a la vida, la prohibición de la tortura y las garantías del debido proceso ${ }^{36}$.

De los informes del Secretario General sobre las salvaguardias advertimos que éstas forman parte de esas normas, cuyo respeto y cumplimiento, van más allá de la voluntad de los Estados. Es la propia naturaleza de estas garantías que hace que se apliquen cada vez más y sin restricción alguna. Hay un consenso de los Estados sobre los valores esenciales de la comunidad internacional que limitan el poder del Estado.

Una exigencia básica para otorgar tal naturaleza es el reconocimiento por parte de los Estados de la comunidad internacional en su conjunto. De lo mencionado líneas arriba se entiende que las salvaguardias, que protege valores esenciales e inherentes a la dignidad humana, han sido y vienen siendo aceptadas por prácticamente todos los Estados del mundo, incluido los Estados que aún mantienen la pena capital en su derecho interno como es el caso, entre otros, de China y Estados Unidos. Ambos han mostrado su interés por colaborar con los informes de los que se advierte, en lo que a reconocimiento se refiere, un gran avance aunque de la práctica se observe otra cosa. Lo mismo sucede con los Estados que forman parte del Consejo de Europa (47), la Unión Europea (28) y la Organización de los Estados Americanos (35). Se exige un consenso general de Estados, no de todos los Estados, para otorgar dicha naturaleza. Es más, ningún Estado tiene veto y la oposición aislada, de ser el caso, de un Estado no impide el reconocimiento de la condición imperativa ${ }^{37}$. Al ser normas de Derecho Internacional General, la repercusión internacional juega un papel importante en su reconocimiento.

34 Miaja de la Muela, A. «'Ius cogens’ y ‘ius dispositivum’ en Derecho Internacional Público». En Estudios Jurídicos Sociales. Homenaje al profesor Luis Lagaz Lacambra, vol. II, Santiago de Compostela, 1960, pp. 1121 y ss.

35 Marks, S. P. «Principios y normas de derechos humanos aplicables en situaciones de emergencia: subdesarrollo, catástrofes y conflictos armados». En Las Dimensiones Internacionales de los Derechos Humanos, Vasak, K., editor general. España, editorial Serbal, 1984, volumen I, II y III, p. 301.

36 Respecto a este último véase las sentencias de la Corte Interamericana en el Caso Goiburú c. Paraguay (2006) y la Cantuta c. Perú (2006) y Opinión Consultiva No 18 (2003).

37 Véase la Conferencia de Naciones Unidas sobre derecho de los tratados, $1^{\circ}$ sesión, 1968, p. 513 y 514. 
Las salvaguardias cuentan con fundamentos sólidos para formar parte de las normas imperativas de derecho internacional general y cumplen cada una de las exigencias del Art. 53 CV69 por cuanto se trata de garantías básicas y esenciales que son inherentes al respeto de la dignidad humana y por ende aplicables a todos y en todas partes.

Forman parte del núcleo duro de los derechos humanos como inderogables y han sido aceptados por la comunidad internacional en su conjunto como normas imperativas de Derecho internacional por la importancia del valor que protege: la vida. Ningún Estado puede considerarse con poderes ilimitados ni exento en su cumplimiento.

Teniendo en cuenta que la finalidad de las normas de ius cogens está directamente relacionada con la existencia misma de la sociedad y el respeto del ser humano, la relación entre las salvaguardias y el ius cogens es directa. Ambas protegen intereses y valores esenciales cuyo objetivo es la protección del ser humano y su dignidad. Así, las salvaguardias pasan a formar parte de ese grupo minoritario de derechos, que consagran los valores esenciales de la comunidad internacional. Son estos valores básicos que sobrepasan el consentimiento de los Estados, que en el derecho internacional condicionan la validez de las normas.

Siendo ello así, el reconocimiento de las salvaguardias como normas de ius cogens implicaría: En primer lugar el cumplimiento obligatorio en todos sus extremos al margen de haber o no haber ratificado un instrumento internacional que recoja estos derechos. Una obligación erga omnes ${ }^{38}$. En segundo lugar deja sin efecto cualquier norma que esté en contradicción con las normas de ius cogens, es decir, deja sin efecto cualquier norma de derecho interno que vulnere o atente contra una, varias o todas las salvaguardias.

38 Más aun considerando que en el 2001, la Comisión de Derecho Internacional adoptó el Proyecto de Responsabilidad del Estado por hechos internacionalmente ilícitos que por vez primera, establece la responsabilidad internacional del Estado por la violación grave de una obligación que emane de una norma imperativa de derecho internacional general. Se individualiza la responsabilidad del Estado por la violación de una norma de ius cogens, yendo su aplicación más allá del contexto de los tratados que establece la CV69. El Art. 48 de este Proyecto establece que el Estado que infringe una de estas obligaciones compromete su responsabilidad, no sólo frente al Estado que la sufre directamente, sino también frente a los otros miembros de la comunidad internacional, lo que legitimaría a cualquiera de ellos para exigirla. 
Tabla 1. Estadísticas Informes Quinquenales

\begin{tabular}{|c|c|c|c|c|c|c|c|c|c|c|c|c|}
\hline $\begin{array}{l}\stackrel{\Xi}{\Xi} \\
\stackrel{0}{0} \\
\Xi\end{array}$ & 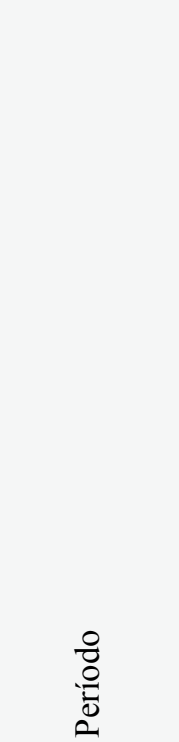 & 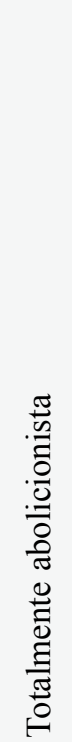 & 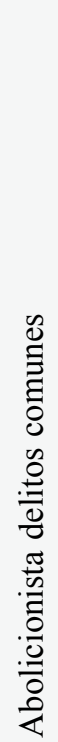 & 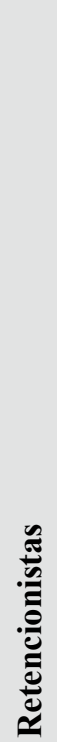 & 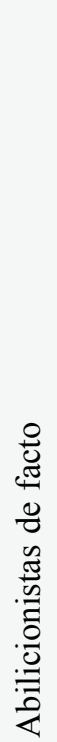 & 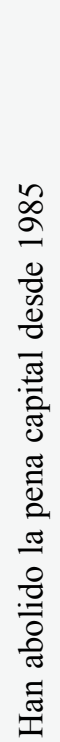 & 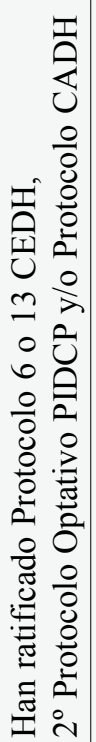 & 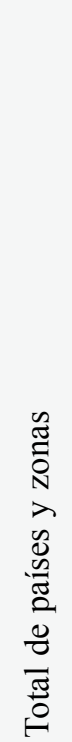 & 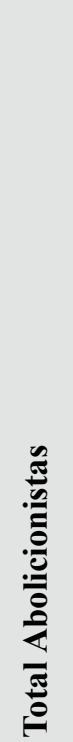 & 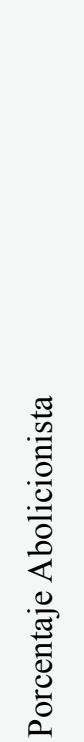 & 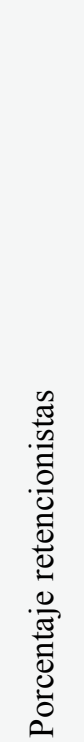 & 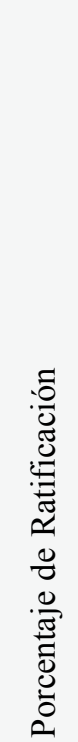 \\
\hline 6 & 1994-1998 & 76 & 11 & 71 & 36 & 46 & 64 & 194 & 123 & $63 \%$ & $37 \%$ & $33 \%$ \\
\hline 7 & 1999-2003 & 80 & 12 & 62 & 41 & & 70 & 195 & 133 & $68 \%$ & $32 \%$ & $36 \%$ \\
\hline 8 & 2004-2008 & 95 & 8 & 47 & 46 & & 83 & 198 & 149 & $75 \%$ & $24 \%$ & $42 \%$ \\
\hline 9 & $2009-2013$ & 101 & 7 & 39 & 51 & & 89 & 198 & 159 & $80 \%$ & $20 \%$ & $45 \%$ \\
\hline
\end{tabular}

Fuente: Elaboración propia (septiembre de 2015) 
Figura 1. Gráfica de estadísticas de los Informes Quinquenales

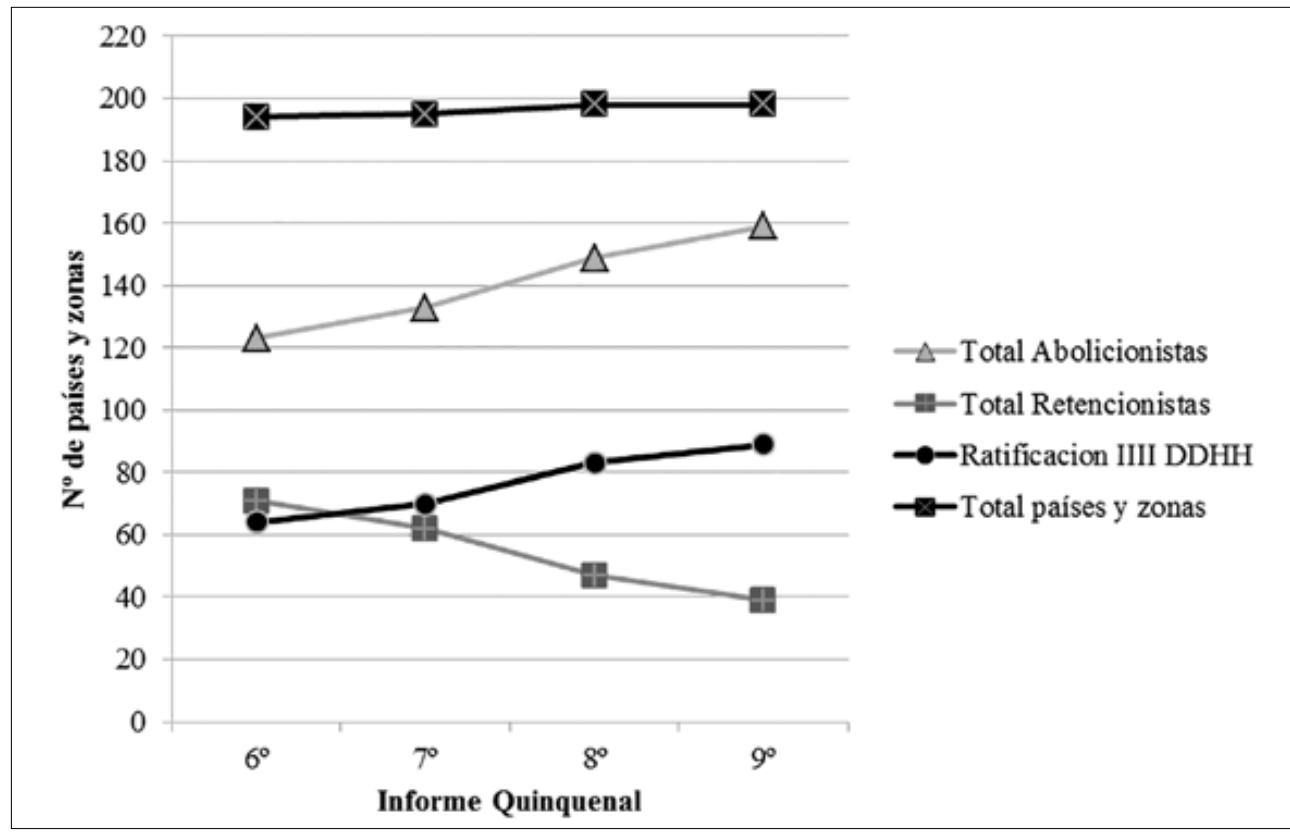

Fuente: Elaboración propia (septiembre de 2015)

Tabla 2. Reconocimiento e Inderogabilidad de las Salvaguardias en Instrumentos de Derechos Humanos

\begin{tabular}{|l|c|c|c|c|c|c|c|c|}
\cline { 2 - 10 } \multicolumn{1}{c|}{} & \multicolumn{4}{c|}{ RECONOCIMIENTO } & \multicolumn{4}{c|}{ INDEROGABILIDAD } \\
\cline { 2 - 11 } \multicolumn{1}{c|}{} & \multicolumn{3}{c|}{ Normativa } & \multicolumn{3}{c|}{ Normativa } & Interpretación \\
\hline Salvaguardia & PIDC & CADH & CEDH & Africana & PIDC & CADH & CEDH & CDH \\
\hline Delitos más graves & 6.2 & 4.2 & & & 4.2 & 27.2 & & \\
\hline Principio legalidad & 15 & 9 & 7 & 7.2 & 4.2 & 27.2 & 15.2 & \\
\hline Menores 18 años & 6.5 & 4.5 & & 5.3 & 4.2 & 27.2 & & \\
\hline Presunción de inocencia & 14.2 & 8 & 6 & $7.1 . \mathrm{b}$ & & 27.2 & & OG29 \\
\hline Garantía juicio imparcial & 14.3 & 8 & 6 & $7.1 . \mathrm{c}$ & & 27.2 & & OG32 \\
\hline Derecho a la apelación & 14.5 & 8 & & $7.1 . \mathrm{a}$ & & 27.2 & & OG32 \\
\hline Derecho a solicitar indulto & 6.4 & 4.6 & & & 4.2 & 27.2 & & \\
\hline Suspensión PdM por rrpp & & 4.6 & & & & 27.2 & & \\
\hline Causar menor sufrimiento & $7 ;$ & 5.1 & 3 & 5 & & 27.2 & 15.2 & OG29 \\
\hline
\end{tabular}

Fuente: Elaboración propia (septiembre de 2015). 


\title{
EL INCIERTO CAMINO DE LA PENA DE MUERTE EN ASIA. LA NECESIDAD DE DISEÑAR NUEVAS ESTRATEGIAS PARA SU ABOLICIÓN
}

\author{
ANTONIO MUÑOZ AUNIÓN \\ Catedrático de Derecho Internacional Universidad autónoma de \\ Chile - REPECAP - Academicsforabolition.net
}

\section{REFLEXIONES PREVIAS}

El título del artículo indica que no son buenas las nuevas para los defensores del abolicionismo, y si hasta la fecha la historia de la pena de muerte en el área podía describirse como una historia de dos ciudades parafraseando la obra clásica de Dickens ${ }^{1}$, en la actualidad los países abolicionistas de la zona se encuentran en minoría frente a un renovado ímpetu por aplicar una de las penas más crueles e indignas que el ser humano ha podido diseñar para los enemigos de la sociedad y esta inflexión se ha producido en un período de tiempo muy breve, dado que en 2015 Naciones Unidas patrocinó un estudio que se tituló "Abandonando la pena de muerte. Lecciones en el Sudeste Asiático" que ofrecía una lectura positiva del proce-

1 Las 30 jurisdicciones asiáticas se dividen en 14 en las que la ley contempla la pena de muerte y ha habido al menos una ejecución en los últimos diez años, y 16 donde existe una abolición formal o de facto. La división prácticamente en dos mitades iguales no refleja el equilibrio real ya que prácticamente todos los centros principales de población son retencionistas, en más detalle, Johnson, T-D.; Zimring, E-F. «Death Penalty Lessons from Asia». En The Asia-Pacific Journal Japan Focus, vol. 7, s. 39, núm.1 septiembre 2009, p. 2 http://apjjf.org/-Franklin-E-Zimring-David-TJohnson/3228/article.pdf, última consulta 11 de octubre 2016. 
so de abolición ${ }^{2}$. En el continente asiático la recuperación de la pena de muerte o de formas afines, las ejecuciones sumarias y extrajudiciales, o los asesinatos selectivos, se encuentra en expansión quebrando las esperanzas que las últimas resoluciones de la Asamblea General sobre la moratoria de esta pena habían traído con un número creciente de países adherentes ${ }^{3}$ y los compromisos internacionales firmados en los últimos años. La realidad, al día de hoy, es distinta y el Sexto Congreso mundial contra la pena de muerte que se celebró en Oslo el pasado mes de junio tuvo entre sus principales preocupaciones enviar un mensaje a los países asiáticos para no iniciar un descenso a los infiernos en la guerra contra el terrorismo o el narcotráfico ${ }^{4}$. Esta cuestión no es baladí dado que Asia alberga al $60 \%$ de la población mundial y es responsable de más del $90 \%$ de las ejecuciones mundiales.

La época de las luces del proceso abolicionista se ha visto alterada por el populismo penal que proclama que la pena capital es el mejor remedio para la lucha contra la criminalidad organizada, posición liderada por Singapur, corroborado por las recientes noticias de Filipinas, las sempiternas de Indonesia con regulares ejecuciones de presos extranjeros ${ }^{5}$, el discreto retencionismo de Japón ${ }^{6}$, la ruptura de la moratoria de facto que existía en Pakistán

2 Moving Away from the Death penalty. Lessons in South - East Asia http://bangkok.ohchr.org/files/ Moving\%20away\%20from\%20the\%20Death\%20Penalty-English\%20for\%20Website.pdf

3 La reciente aprobación del proyecto de Sexta Resolución sobre moratoria en el uso de la pena de muerte, discutida en la sesión plenaria n. 65 de la Asamblea General el 19 de diciembre de 2016, es prueba de esta agridulce etapa en la campaña abolicionista donde si bien la proporción en votos es similar al de la resolución de 2014, con 117 votos a favor, 40 en contra, y 31 abstenciones, por cuanto al continente asiático se han producido modificaciones relevantes, a saber, Filipinas y las Islas Seychelles dejaron de apoyar la abolición para abstenerse y Maldivas paso de la abstención a votar en contra, véase, Naciones Unidas A/71/484/Add.2 Draft resolution II Moratorium on the use of the death penalty

4 Véase, texto declaración final (en inglés) http://congres.abolition.fr/wp-content/uploads/2016/06/FinalDeclaration-of-the-6th-World-Congress-Against-the-Death-Penalty.pdf (última consulta, 12 de octubre 2016).

5 El 17 de enero de 2015 el ciudadano brasileño Marco Archer Cardoso Moreira fue ejecutado y se reinició una política retencionista por parte de Indonesia tras una moratoria no oficial de 4 años, a la que siguió la ejecución de Rodrigo Gularte en mayo de 2015, a pesar de las fuertes protestas de la Cancillería brasileña.

6 Al tiempo que se escribía este artículo, el Center for Prisoners Rights en Japón anunciaba la ejecución de Kenichi Tajuri en la cárcel de Fukuoka sin que se hubiera pronunciado el Tribunal Supremo al retirarse el recurso y por el veredicto de jueces legos, ambos puntos severamente criticados por las instituciones internacionales. http://www.cpr.jca.apc.org/archive/report_en (Consulta, 12 de noviembre 2016.) Sobre la excepcionalidad en Japón, se debe señalar que, primero, la Asociación de Colegios de Abogados de Japón ha indicado que una de las principales razones de que se mantuviera la pena capital en el país se debía al extraordinario secretismo que rodeaba el sistema de pena capital y la falta de información para discutir la abolición, y segundo, se debe celebrar que la citada Asociación haya situado por primera vez en su historia la abolición de la pena de muerte como línea principal de trabajo a fin de cumplir con la resocialización del delincuente con independencia de la gravedad del delito, Véase, en https://adpan.org. Fecha de consulta 27 de septiembre de 2016. Sobre la situación en Japón, véase, Johnson, David T. «The death penalty in Japan: Secrecy, silence, and salience». En Austin Sarat y Christian Boulanger (eds) The cultural lives of capital punishment: Comparative 
y la India, la ampliación de la Sharia en Brunei-Darussalam7, y para mayor befa, las voces de defección en las Islas Maldivas. Todo lo anterior hace difícil compensar los tímidos avances producidos en la República popular $\mathrm{China}^{8}$, en la adopción de una moratoria por el Presidente de Mongolia ${ }^{9}$, el proceso de autodeterminación en Timor Oriental tutelado por Naciones Unidas que dejó atrás la pena capital en 1999, la abolición en Bután ${ }^{10}$, o los recientes cambios legislativos en Vietnam, siendo en este último los logros muy reseñables.

Sin embargo, estas páginas explicarán cuales serían las estrategias para el activismo con las que poder replicar y al menos reescribir una historia de dos ciudades que se convierten en una, sobre un terreno abierto al diálogo y no a la confrontación ni a la falta de trasparencia de fríos y sesgados datos gubernamentales, para incluir la agenda abolicionista como anexo de los Objetivos del Milenio con más sectores de la población empoderados y conscientes de la debilidad de la vida en un mundo complejo e interconectado, y alcanzar al mismo tiempo la reducción de la crueldad y la consecución de un mundo más humanizado a fin de generalizar el sentimiento que expresara tan lúcidamente el poeta clásico inglés del siglo XVII John Donne "la muerte de cualquiera me afecta, porque me encuentro unido a toda la humanidad"

Es cierto que al igual que ocurriese en Europa, la opinión pública en este continente es tibiamente favorecedora de la pena capital ${ }^{12}$, y es por ello por lo que resulta necesario que las elites tomen el liderazgo de la vanguardia y se explique el desarme del sistema de la pena capital en un proceso de "arriba- abajo"13. Esta tarea según Hood y Hoyle es fundamental y corresponde a los sistemas de justicia penal ser responsables ante los ciudadanos en cuya representación aplican la ley. Por ello han de ser realmente transparentes máxime cuando se trata de una pena sin remedio como es la pena de muerte y la vida de seres humanos corre el riesgo de

perspectives, p. 251-73. Stanford, CA: Stanford University Press.2005 Johnson, David T. «Where the state kills in secret: Capital punishment in Japan». En Punishment \& Society 8 (3), 251-8, 2006.

7 Este Código amplía el número de delitos para los que la pena capital es aplicable e introduce la lapidación como método de ejecución.

8 Hong, L. «China's Death Penalty: Reforms on Capital Punishment». En EAI Background Brief No. 4125 de noviembre de 2008.

9 El proceso se inició en 1992 tras la adopción de la nueva Constitución, el empleo de la pena de muerte se limitó a los crímenes más graves, y en 2010 el Presidente Tsakhia Elbegdorj anunció una moratoria y presentó una ley al Parlamento para la ratificación del Segundo Protocolo Opcional al Pacto Internacional de Derechos Civiles y Políticos.

10 Dorji, K."Bhutan: Capital punishment abolished“ Kuensel News, abril 13, 2004, http://www.thinkcentre.org/article.cfm?ArticleID=2357

11 Meditaciones en tiempos de crisis n. XVII, Ariel 2012 Trad. Ascensión Cuesta, cit.

12 Por ejemplo, respecto de Japón, cfr.; Japan Times, «Public support for death penalty not overwhelming, researchers say», 16 septiembre 2015, http://www.japantimes.co.jp/news/2015/09/16/ national/public-support-death-penalty-not-overwhelming-researchers-say/\#.VgvzdBNVikr.

13 Cfr.; Comisión Internacional contra la Pena de Muerte. Cómo los Estados abolen la pena capital, Oslo 2013, en http://issuu.com/icdp/docs/report_english 
una aplicación errada de la ley por parte de los organismos de justicia penal y de errores judiciales ${ }^{14}$, palabras que sin duda son extensibles a otros poderes del Estado.

\section{LA SITUACIÓN EN LA REPÚBLICA SOCIALISTA DE VIETNAM: UN FUTURO PROMISORIO}

En la actualidad la pena de muerte se aplica a 18 delitos entre los que se encuentran el narcotráfico, la violación de menores, la fabricación de medicamentos falsos, y delitos económicos como corrupción y malversación de fondos, también se aplica a delitos políticos que son considerados como amenazas para la seguridad nacional. Todo esto llevó a que el Comisionado de Derechos Humanos en 2013 lamentara que Vietnam no reconociera el umbral mínimo de gravedad de delitos para los cuales la pena de muerte puede verse legitimada ${ }^{15}$. No obstante, existe una tendencia positiva en la reducción de crímenes afectados por la pena capital desde los cuarenta y cuatro en 1999, y las limitaciones a la misma aplicando el modelo de las salvaguardias de Naciones Unidas que se constató en 2015 con la reforma del Código Penal que eliminó otros siete delitos de la pena capital que entró en vigor en julio de 2016. Lo más significativo por el área geográfica y la excepción que plantea es la eliminación de la pena capital para actos de narcotráfico, particularmente por cuanto países vecinos llevan una campaña feroz antinarcóticos basada en la aplicación sin misericordia de la pena capital, como Indonesia o Malasia donde la presión internacional de los países abolicionistas, Australia, Brasil, o la propia Unión Europea poco han podido hacer, a excepción de fuertes protestas diplomáticas. Asimismo, la reforma procedimental para hacer más humana la forma de ejecución sustituyó el pelotón de fusilamiento por la inyección letal que desde 2012 sufre un retraso en la fabricación y entrega de los componentes debido a la presión internacional y la concienciación de las propias empresas farmacéuticas lo que llevó a una suspensión de las ejecuciones y a una reanudación plagada de críticas y malfuncionamiento ${ }^{16}$, por lo que todo indica que pronto Vietnam alcanzará el estatus de país en moratoria de facto, una ganancia marginal en otros lugares del mundo pero un paso de gigante referencia para la comunidad asiática marcada por un excepcionalísimo cultural muy acentuado.

Un ejemplo de que los tiempos estaban cambiando lo mostró la abstención del país con ocasión de la aprobación de la Resolución de la Asamblea General de Naciones Unidas de 2007 que hacía el llamado a alcanzar una moratoria universal de la pena de muerte previa a su abolición, y que se ha vuelto a repetir en 2016.

14 En general, Capital Punishment. A hazard to a sustainable criminal justice system? (ed) Scherdin, L.; Routledge 2014

15 Véase, https://www.fidh.org/IMG/pdf/2016__report_on_death_penalty_in_vietnam.pdf, p. 3

16 Por cuenta de acudir al mercado ilegal para adquirir drogas de dudosa eficacia lo que incrementa el sufrimiento del condenado, de lo que existe numerosas evidencias en Estados Unidos, cfr., Alper, T. «The United States Execution Drug Shortage: A Consequence of our values» 21 Brown J. World Aff. 27 (2014), en http://scholarship.law.berkeley.edu/facpubs/2471 última consulta, 25 de octubre 2016 


\section{EL FACTOR TERRORISTA COMO CRIMEN EXTRAORDINARIO EN LA REANUDACIÓN DE EJECUCIONES EN PAKISTÁN Y LA INDIA}

En ambos países, sus tribunales superiores habían utilizado un argumento judicial irreprochable pero también trasnochado y proclive a arbitrariedad ${ }^{17}$, como método para demorar la ejecución de sentencias de muerte, éstas quedaban arrinconadas a castigar aquellos actos más reprochables, oprobiosos y extraordinarios ${ }^{18}$, lo que llevó a varios años sin ejecuciones y a que se considerara que morir ejecutado en el subcontinente indio era tan improbable como fallecer por la caída de un meteorito, sobre todo tomando en consideración el tamaño de sus poblaciones. Sin embargo, la amenaza terrorista ha pasado a formar parte de la ecuación y en 2014 Paquistán levantó la moratoria que estaba en vigor desde 2008 con la intención de ejecutar a terroristas, si bien sólo un año después la amplió, por lo que hoy son alrededor de 30 delitos los que pueden llevar a esta pena en este estado islámico, a saber, asesinato, violación, blasfemia, adulterio, apostasía o los delitos relacionados con drogas, en procesos penales que están colmados de anomalías y se infringen las salvaguardias de Naciones Unidas ${ }^{19}$, principalmente en lo que respecta a la no ejecución de menores de edad por falta de procesos fiables de determinación de la edad ${ }^{20}$.

Por cuanto a la India, este país también aplicó una moratoria de facto entre 2004 y 2012 cuando se ejecutaron a dos personas condenadas por la participación en ataques terroristas en Bombay en noviembre de $2012^{21}$, pero aún le corresponde el dudoso honor de tener el índice más bajo de ejecuciones del mundo que ha llevado a denominar la cuestión de la ejecución de la pena capital en el país como propia de una mayúscula lotería legal, 1 por 1170 millones de habitantes ${ }^{22}$. Según la oficina de estadísticas del Buró Nacional de Archivos de Crímenes, entre 2001 y 2011 un

17 Cfr. Blackshield, R-A. «Capital punishment in India». En Journal of the Indian Law Institute, 137, 1979.

18 El Tribunal Supremo de la India en el contexto de la pena de muerte utiliza las siguientes expresiones a la hora de autorizar la aplicación de la pena capital justificándola en "actos excepcionalmente depravados y crueles que representan una grave amenaza para el conjunto de la población”, Bachan Singh c. Estado de Punjab AIRSC 898 en p. 936, 1980.

19 Cfr. último Informe Anual del Consejo de Derechos Humanos 30 sesión, Capital Punishment and the Implementation of the safeguards guaranteeing protection of the rights of those facing the death penalty $\mathrm{A} / \mathrm{HRC} / 30 / 1816$ de julio de 2015 .

20 Cfr. «The Death Penalty in relation to juveline offenders», U.N Doc. E/CN.4/Sub.2/RES/2000/17.

21 «Mumbai attack Gunman Ajmal Qasab Executed». En BBC News, 21 de noviembre de 2012, también Zimring, F- E y Johnson, D-T. «Executing Kasab: A new beginning or the beginning of the end of India's Death Penalty». En Economic Political Weekly, 29 de diciembre 2012, p. 10.

22 Cfr, Batra, B-J. «Lethal Lottery: The Death Penalty in India: A Study of Supreme Court Judgments in Death Penalty Cases, 1950-2006». En Amnistía Internacional y la Unión popular de libertades civiles, Nueva Delhi, 2006. En general sobre privación arbitraria de la vida, véase, Boyle, K. 
promedio de 132 sentencias de muerte, eran dictadas por año si bien el Tribunal Supremo confirma a lo sumo 3 o 4 anuales, y eso se constata en el último informe de la Comisión Jurídica de la India donde se deja manifiesta la existencia de cadenas de conmutaciones por el Tribunal Supremo en base a múltiples deficiencias ${ }^{23}$.

No obstante, la situación de la India no es absolutamente diáfana por su inflexible posición en la Asamblea General donde vota en contra de las Resoluciones que de forma periódica nos recuerdan la necesidad de alcanzar una moratoria universal, su cambio de opinión tendría un efecto de atracción para otros países con los que India tiene estrechas relaciones que se verían forzados o liberados para votar de forma favorable. Asimismo, un paso fundamental sería avanzar más allá de la recomendación que se hiciera a este país de disminuir progresivamente la pena capital para los delitos de sangre para entrar en un reducido grupo de países que la aplican como mecanismo excepcional para los crímenes contra el Estado que amenazan la integridad de la nación ${ }^{24}$.

En conclusión, la práctica de ambos países atestigua la existencia de dudas profundas en el sistema de ejecución de la pena capital lo que despierta esperanzas de un inminente abandono de la misma ${ }^{25}$.

\section{INDONESIA Y SUS REPLICADOS EFECTOS EN FILIPINAS}

El puño de hierro que se ha venido utilizando en Indonesia en la lucha contra el narcotráfico con ejecuciones de ciudadanos de terceros países ha tenido un excelente alumno en la Presidencia de Filipinas donde el llamado a una guerra contra el narcotráfico ha llevado a un frenesí de crueldad que dilapida los esfuerzos de sus anteriores Ejecutivos ${ }^{26} \mathrm{y}$ asimismo supone una violación de normas internacionales recientemente suscritas como el Segundo Protocolo Opcional al Pacto Internacional

«The Concept of Arbitrary Deprivation of Life». En Ramcharan, B-G.(ed). The Rigth to Life in International Law, Martinus Nijhoff Pub, 1985.

23 En, http://lawcommissionofindia.nic.in/reports/report262.pdf (última consulta, 20 de octubre 2016). En concreto, punto 7.1.6 “... La administración de justicia se encuentra en una grave crisis... la pena de muerte opera en este contexto y por tanto sufre de los mismos defectos estructurales y sistémicos...”.

24 Un pequeño grupo cada vez más menguante, en la actualidad de 7 países tras el abandono de Letonia, que incluye a Brasil, Chile, El Salvador, Fiji, Israel, Kazajstán y Perú.

25 Indian Express Editorial, "Justice more humane?," Enero 22, 2014, en http://indianexpress.com/ article/opinion/editorials/justice-more-humane/; Hindustan Times Editorial, SC ruling on death penalty a step closer to its abolition?, Enero 22, 2014.

26 En dos ocasiones se abolió la pena de muerte en Filipinas, en 1987 con la adopción de la nueva Constitución y en 2006. En la actualidad, la antigua Presidenta Gloria Macapagal Arroyo es miembro de la Comisión Internacional contra la pena de muerte junto a otros ilustres políticos y representantes de la sociedad civil internacional. 
de Derechos Civiles y Políticos ${ }^{27}$. Además, ambos países se unen a un grupo retencionista entre los que destaca Irán que realiza un activismo constante en la Oficina de Naciones Unidas para la Prevención del Crimen y la Justicia Penal (UNDOC) con sede en Viena, y en sus respuestas al Examen Periódico Universal, (EPU) para demostrar que sus éxitos en la reducción del tráfico de drogas con destino a los países occidentales se deben principalmente a sus medidas draconianas e inclusive solicitan la liberación de recursos financieros para seguir con estas políticas de rigor ${ }^{28}$.

Resulta paradójico como Vietnam que tradicionalmente se encuentra en el triángulo dorado de las rutas de heroína ha dejado de considerar el narcotráfico como un delito de extrema gravedad que requiere de la más cruel de todas las penas, donde además no existen datos de que haya existido un aumento del tráfico debido a la imposición de penas menos lesivas, y sin embargo, el repunte haya sido una constante según el discurso político de los partidos oficialistas en Indonesia, Malasia y Filipinas, y es por ello que desde las instancias de derechos humanos se debe hacer participar a los representantes políticos del país para explicar en foros como ASEAN (Asociación de Naciones del Sudeste asiático ${ }^{29}$ los beneficios de esa política más humana en la lucha contra el tráfico de $\operatorname{drogas}^{30}$, sin incidir de manera frontal en el principio de no injerencia en los asuntos internos. Desgraciadamente, el proceso en Asia descansa más en proyectos nacionales dado el déficit de organismos internacionales regionales ${ }^{31}$.

27 En el asunto Damjanovic c. Federación de Bosnia y Herzegovina, Sala de Derechos Humanos de BYH, 5 de septiembre de 1997, CH96/30 en referencia al artículo 2 del Protocolo Segundo Opcional consideró que el término "aplicación" de la pena de muerte cubría tanto su imposición como la ejecución de la misma. par. 36.

28 En oposición con la Resolución de la Asamblea General de Naciones Unidas, A/RES/67/193, de 23 de abril de 2013, párrafo 2. Cfr.; Hlinomaz, O. Sheeran, S. Bevilacqua, C. "The Death penalty for drugs crimes in Iran: Analysis of Iran's International Human Rights Obligations”, marzo 2014, Human Rights in Iran Unit. Universidad de Essex, Legal Research Studies p. 35.

29 Organización que dispone de una Comisión intergubernamental de Derechos Humanos, y que ha permitido el establecimiento de una Coalición para la abolición de la pena de muerte (CADPA) y en cuya Declaración de Derechos Humanos su artículo 11 declara que "toda persona tiene el derecho inherente a la vida que será protegido por ley, y que ninguna persona será privada de la vida salvo de conformidad con la ley".

30 Revirtiendo por la fuerza de los hechos la decisión del Consejo Privado colonial de 35 años atrás que considero legítima la aplicación de la pena de muerte obligatoria a los condenados por tráfico de drogas en un asunto referido por Singapur Ong Ah Chuan v. P.P (1980-81) Sing, L-R (1981) A. C 648 y que en el contexto del Caribe fuera revertida afirmando que en general toda sentencia a muerte obligatoria era inconstitucional e infringe la dignidad inherente del individuo por cuanto se le priva del derecho a que un tribunal tome en consideración las circunstancias atenuantes a la hora de emitir el fallo. Véase, Reyes v. The Queen (2002) 2 A. C 235. En más detalle, véase, Hor, M. "The death penalty in Singapore and International Law" Singapore Yearbook of International Law and Contributors, p. 105-117, 2004.

31 En contraste con el escenario europeo donde todos los nuevos miembros del Consejo de Europa como requisito previo a la admisión están obligados a ratificar el Protocolo n. 6 del Convenio para la protección de los derechos humanos y las libertades fundamentales relativo a la abolición de la pena de muerte en tiempos de paz. 


\section{V. ¿LA ÚLTIMA FICHA DEL DOMINÓ O EL PRINCIPIO DEL OCASO DE LA PENA CAPITAL? EL CASO DE MALDIVAS}

La excepcionalidad de Maldivas en el área en razón de que no se llevan a cabo ejecuciones desde la década de los cincuenta $^{32}$ bien podría acabar pronto ${ }^{33}$, al menos por cuanto a los aspectos funcionales, pues en 2016 en el presupuesto anual se contempla la construcción de una cámara de ejecuciones ${ }^{34}$. Si bien la población del país no supera las 400,000 personas resulta evidente que la perspectiva de ejecuciones vaya a superar el insignificante promedio en países como India, Pakistán o Bangladesh con un tamaño poblacional infinitamente superior, y que nos lleva a recordar el triste record de Singapur donde la ratio de ejecuciones por habitante era ridículamente astronómica en comparación a otros países retencionistas ${ }^{35}$ y que inclusive la llevó a modificar su legislación desde 2010 a fín de revertir la progresión, y dejar de ser percibida como un espacio de gatillo fácil para las ejecuciones ${ }^{36}$. Asimismo, rompe con la tradición existente en otras pequeñas ínsulas de tamaño similar desperdigadas a lo largo de los océanos Índico, p. ej, Comoras, Seychelles, y Mauricio; y Pacífico, p. ej, Nauru, Tonga, Fiji, Islas Cook, Islas Marshall, Kiribati, Micronesia, Niue, Papúa- Nueva Guinea, Palao, Samoa, Tuvalu, y Vanuatu que han abolido la pena de muerte para todos los delitos.

\section{ESTRATEGIAS DE ACCIÓN PARA REVERTIR LA TENDENCIA}

Este análisis nos deja una sensación agridulce por los sobresaltos en la dinámica abolicionista, pero esto se debe a que el modelo asiático tiene una sinergia específica como indicara el estudio de Zimring y Johnson de 2008 "Law, Society and Capital Punishment in Asia "que detectase las rápidas fluctuaciones que se producen en el continente. Por lo tanto, el desencanto que rodea al lector puede verse rápidamente sustituido por alegría en el devenir próximo. En cualquier caso, las noticias de Cam-

32 Según los datos de Amnistía Internacional, la última ejecución se produjo en 1954.

33 Ya el rumbo se torció cuando en 2012 el Parlamento introdujo por segunda vez una enmienda al artículo 21 de la Ley de Clemencia para impedir que el Presidente pudiera firmar clemencias cuando el Tribunal Supremo había decidido mantener una sentencia a muerte o la emitía. Cfr., Hood, R. Briefing Paper, Enhancing EU Action on the Death Penalty in Asia, EXPO/B/ DROI/2011/22 octubre 2012 p. 12

34 Haveeru, "Maldives reintroducing death penalty biggest mistake', says UN rapporteur", 13 December 2015. Available at: http://www.haveeru.com.mv/news/64766.

35 Que llevó a su denominación como la capital mundial de las ejecuciones.

36 La ciudad - estado tuvo el segundo lugar en proporción de ejecuciones por habitante del mundo entre 1994 y 1998, según Naciones Unidas, 13, 83 ejecuciones anuales por millón de habitantes, sólo superado por Turkmenistán un país hoy abolicionista que llegó a tener un promedio de 14,92. En parte se explica por el cambio de la legislación procesal que modificó el panel de 2 jueces criminales por uno, por tanto, el espacio para la duda razonable se limitó. 
boya, Tailandia ${ }^{37}$, Laos, Myanmar ${ }^{38}$, y las recientes de Vietnam en la península de Indochina deben contemplarse como una pieza más de un puzle imaginario de entidades políticas gradualmente libres de pena de muerte, como lo fuera Mongolia en Asia, o Sudáfrica en el continente africano, que replican el gran espacio europeo-americano que ha convertido el desuso de la pena de muerte en una costumbre regional en vía de materialización como ius cogens ${ }^{39}$ y un testimonio de cómo cada vez más naciones soberanas van progresivamente adaptándose a las limitaciones a la pena capital que aparecieron en forma de Salvaguardias en 1984 revisadas en 1989, y reiteradas por la Comisión de Derechos Humanos en $2005^{40}$ hacia su erradicación absoluta.

Como se ha apuntado en la doctrina, el proceso abolicionista se compone de actores, factores, y circunstancias ${ }^{41}$ de ahí que se propongan un conjunto de medidas heterogéneas, entre las que se encuentran:

Primero, los pequeños avances en el continente asiático deben ser objeto de publicidad y visualización en las Cumbres internacionales y modelo de presentaciones en las reuniones de los organismos de derechos humanos en Ginebra, Nueva York y Viena como una referencia en la dinámica de abolición de la pena capital con respeto de tradiciones, valores y la soberanía de los Estados, y sostén para los grupos de activistas que trabajan de forma aislada ${ }^{42}$. Hasta recientemente, era impensable que la cuestión de la pena capital fuera objeto de debate, ejemplo de esto, lo encontramos en las palabras de un parlamentario de Singapur en noviembre de 2012, "toda vida humana es valiosa... no sólo en relación a nuestro sistema

37 Este país incluyó la abolición de la pena de muerte en su Plan de Acción de Derechos Humanos en 2009 si bien no ha tenido una verdadera continuidad es un indicio claro de que los tiempos están cambiando en el país.

38 Este país en su último informe universal ante el Consejo de Derechos Humanos en 2011 indicó que no se llevan a cabo ejecuciones en el país desde 1988, y si bien las cortes inferiores siguen emitiendo veredictos de muerte, desde el 2014 son conmutadas por la Corte Suprema. UN News Centre "UN Rights Office praises Myammar for commuting all death sentences "10 enero 2014, http://www.un.org /apps/news/story.asp?NewsID=46904\#.VBeVji65zeY.

39 Sawyer, G. «Death penalty is Dead wrong: Ius cogens Norms and the Evolving Standard of Decency». En Penn State International Law Review, vol. 22 No. 3, article 9, 2004, por ejemplo, argumenta que "una prohibición contra la pena de muerte está lentamente madurando en una norma general de Derecho Internacional" p. 459; también Ohlin, J-D. «Applying the death penalty to Crimes of Genocide». En Cornell Law Faculty Pub, p. 748, 2005.

40 Resolución ECOSOC 1984/50, 25 de mayo de 1984 adoptada por Resolución de la Asamblea General 1984/50 sin votación el 14 de diciembre de 1984, Resolución ECOSOC 1989/64 de 24 de mayo de 1989; y Resolución de la Comisión de Derechos Humanos 2005/59 de 20 de abril de 2005.

${ }_{41}$ Arroyo Zapatero, L. "Actors, factors and processes on the road to the abolition of the death penalty». En http://www.academicsforabolition.net/repositorio/ficheros/506_286.pdf. Última consulta, 25 de octubre 2016.

42 En detalle, Capital Punishment in Asia. Human Rights, Politics, and Public Opinion (ed) Hood, R. \& Deva, S. Oxford University Press 2013. 
de justicia criminal... sino sobre el modelo de sociedad que anhelamos construir, una sociedad que valora a toda persona y toda vida humana, y que no abandona a sus congéneres. "Esta declaración sólo fue posible una vez que cristalizó lo que se conoce como una democracia de consenso ${ }^{43}$. De hecho, la caída o advenimiento de gobiernos totalitarios tiene una consecuencia directa en el número de ejecuciones.

Segundo, en el plano interno, la principal medida es la disponibilidad de información, así Alston, Ph.; indicó como Relator especial de Naciones Unidas para las ejecuciones extrajudiciales, sumarias y arbitrarias, que el no ofrecimiento de información veraz y actual sobre la aplicación de las penas por parte de las Autoridades era equivalente a una violación de los estándares de derechos humanos ${ }^{44}$. La trasparencia es un deber del Estado que no depende de petición por parte del interesado ${ }^{45}$, en este sentido, los Estados indicados podrían resaltar sus compromisos según la Carta Asiática de Derechos Humanos cuyo artículo 3.7 es un recordatorio del ideal de alcanzar la pronta abolición y de cumplir entretanto estrictamente con las salvaguardias de Naciones Unidas.

Tercero, en el plano de la cooperación internacional en auge constante en razón de la interconexión global ${ }^{46}$, un elemento clásico en la reducción de la criminalidad ha sido la extradición ${ }^{47}$, y existen tanto pronunciamientos judiciales nacionales e

43 Utilizando el término que popularizara, McGann, A. Sandholtz, W. «Patterns of Death Penalty Abolition, 1960-2005: Domestic and International Factors». En 56 International Studies Quarterly, 275-89, 2012 como medio más versátil a la hora de alcanzar la abolición de la pena capital por sus representantes políticos. Como ejemplo de prácticas secretistas contrarias, con incidencia en los Estados Unidos, véase, Alper, T. «Anesthizing the Public Conscience: Lethal Injection and Animal Euthenasia». En Fordham Law Urban Law Journal 11, no. 46, p. 817-55; 2008. Campbell, A. «Identities of Execution Drug Pharmacists Should be Shielded: Prosecutors». En Huffington Post, 2 de octubre de 2014; The Guardian, «Ohio Prosecutors Demand Immunity for Execution Drugs Makers», 4 de octubre 2014; Huggins, W-A. «Legislative proposal would shield source of Ohio lethal injection drugs, protect experts». En Associated Press, 20 de noviembre de 2014. Una posición retencionista favorable a la transparencia de los protocolos para una articulación efectiva de la responsabilidad, en Denno, W-D. «The Lethal Injection Quandary: How Medicine has dismantled the death penalty». En 76 Fordham L Rev. 49, $2007 \mathrm{en} \mathrm{http://ir.lawnet.fordham.edu/flr/vol76/iss1/3,} \mathrm{última} \mathrm{consulta} 10$ octubre 2016.

44 Informe del Relator a la Comisión de Derechos Humanos 62 sesión E/CN.4/2006/53/Add.3 24 de marzo de 2006 Transparencia e Imposición de la pena de muerte p.5-6.

45 Comunicación del Comité de Derechos Humanos n. 215 (1986) Van Meurs c. Holanda CCPR/ C/39/D/215/1986 párrafo 6.1 En el asunto Toktakunov v. Kyrgyzstan, el Comité de Derechos Humanos encontró que la información sobre la utilización por el Estado de la pena de muerte era de interés público. Comunicación No. 1470/2006 28 de marzo de 2011.

46 Entendiendo que la Globalización jurídica avanza a un ritmo más pausado, como sostiene Remiro Brotons, A. «Crisis global y respuesta mundial». En Anuario de la Facultad de Derecho de la Universidad autónoma de Madrid, n. 14, 2010, p. 23-40.

47 Schabas, W. «Indirect Abolition: Capital Punishment 's Role in Extradition Law and Practice». En 25 Loy. L.A Int'L \& Comp. L. Rev. 2003, p. 581. En el mismo sentido, Roecks, R-C. «Extradition, Human Rights and the Death penalty: When Nations must refuse to extradite a person charged with a capital crime». En $25 \mathrm{Ca}$ W. Int'l lL. J, 189, 1996, p. 193. 
internacionales, así como normas y declaraciones internacionales que prohíben o desautorizan la extradición a países donde exista la pena capital lo que Schabas ha denominado proceso de abolición indirecto ${ }^{48}$. De los primeros, recordar el fallo del Tribunal Supremo de Canadá en el Asunto Estados Unidos c. Burns de 2001 cuya decisión fue “... que el Gobierno debía exigir garantías,... de que no se aplicaría la pena de muerte antes de extraditar a una persona a un Estado requirente (...) 49 “"y por cuanto al espacio internacional, el art. 19.2 de la Carta Europea de Derechos Fundamentales que prohíbe la extradición a un Estado donde exista el riesgo de quedar sujeto a la pena capital ${ }^{50}$, y la Comunicación del Comité de Derechos Humanos en el asunto Charles Chitat Ng c. Canadá n. 469/1991 ${ }^{51}$.

La negativa de entrega a países retencionistas en el área, así como la no cooperación en temas de seguridad, o colaboración en la lucha contra el terrorismo, o el establecimiento de medidas comerciales que restrinjan la comercialización de útiles para la muerte ${ }^{52}$, serán elementos eficaces de persuasión y presión para

48 Ya desde el inicio de los noventa, por ejemplo, el modelo de Tratado de extradición adoptado por la Asamblea General de Naciones Unidas, en cuyo artículo 4(d) se dispone: "la extradición podrá ser rechazada si el delito para el que se solicita la extradición conlleva la pena capital según la legislación penal del Estado requirente, a excepción de que este Estado se comprometa a que la pena de muerte no será impuesta, o en su caso no será ejecutada, y que el Estado requerido lo considere como una declaración vinculante", y que hoy día no se discute como norma aceptada de orden público. Véase, también, Yorke, J.(ed) Against the death penalty: International Initiatives and Implications. University of Surrey: Ashgate Publishing Company, 2008. Esta facultad de no cooperación se extiende no solo al ámbito penal sino también al tema migratorio, por cuanto a las deportaciones, a partir del asunto Bader y otros c. Suecia, appl. No. 13284/04 46 Eur H. R Rep. 13 (2005) e inclusive a la jurisdicción militar, asunto Al- Saadoon y Mufdhi c. Reino Unido, appl. No. 61498/08 Eur. Ct. H. R 282 (2010).

49 Las cursivas son del autor para resaltar que éstas deben ser efectivas y objeto de sanción en caso de incumplimiento, 2001 SCC 7, [2001] S.C.J. No 8. Consúltese, en https://scc-csc.lexum.com/ scc-csc/scc-csc/en/item/1842/index.do.

50 Un texto de gran complejidad jurídica y política, y que se adoptó para que el ciudadano europeo confiara en la excelencia del sistema de normas europeas, en detalle, véase, Fernández Tomás, A. La Carta de Derechos Fundamentales de la Unión Europea. Tirant lo Blanch, 2002.

51 Texto en Oficina del Acto Comisionario de las Naciones Unidas para los derechos humanos, Pacto Internacional de Derechos Civiles y Políticos. Selección de Decisiones del Comité de Derechos Humanos adoptadas con arreglo al protocolo facultativo vol. 5 (período de sesiones 47 a 55) Naciones Unidas 2005. En más detalle, véase, Conte, A.\&Burchill, R. Defining Civil and Political Rights. The Jurisprudence of the United Nations Human Rights Committee 2 ed. Routledge, 2016.

52 En primera instancia por el Reglamento (CE) del Consejo No. 1236/2005 relativo al comercio de ciertos productos que pueden ser utilizados para la pena capital, tortura y otros tratos o penas crueles, inhumanas o degradantes de 27 de junio de 2005 DOCE L. 200 1. (2005) revisado por Reglamento del Consejo No. 1226/2010 de la Comisión de 20 de diciembre de 2010 (DOUEL-2010-82375) y Reglamento No. 1352/2011 de la Comisión, recientemente modificado por $\boldsymbol{e l}$ Reglamento (UE) 2016/2134 del Parlamento Europeo y del Consejo de 23 de noviembre de 2016 (D.O. de 13 de diciembre de 2016). Instrumentos inéditos y de gran utilidad basándose en mecanismos comerciales para la consolidación de los derechos humanos, por parte de una Organizaciones 
alcanzar cierto grado de aislacionismo ${ }^{53}$ que no se corresponde con la necesidad de integración debido al proceso de Globalización, y que no necesariamente tiene que provenir de los valores de las democracias occidentales sino mediante un proceso desde dentro del continente, que marque un ritmo adecuado a sus necesidades. Muy relevantes han sido los cambios profundos en el plano económico, social y político. En este sentido, Johnson, D y Zimring, F. derriban el mito de los "valores asiáticos" encontrando que el principal obstáculo para acabar con las ejecuciones en Asia es la política, no la cultura o la tradición ${ }^{54}$.

Cuarto, en el plano de la diplomacia se ha demostrado, con la excepción de Indonesia ${ }^{55}$, que la presión unilateral ${ }^{56}$ o concertada de los Ministerios de asuntos exteriores de países abolicionistas a la hora de proteger a los extranjeros condenados a muerte, una vía útil que ha conseguido la disminución del número de ejecutados y un proceso de clemencia diferenciado, lo que en el medio plazo repercutirá en beneficio de los nacionales en base a un principio de no discriminación y de beneficios análogos para todos los condenados sobre la base del principio de reciprocidad.

Quinto, un elemento importante en la transformación de la visión sobre la pena capital lo constituye la formación de parlamentarios, jueces y abogados con la participación de $\mathrm{ONG}^{\prime}$ s, por ejemplo, Unidos contra la pena de muerte, a través

regional y que puede servir de ejemplo para otras. Por ejemplo, en el continente americano, la Comisión Interamericana de Derechos Humanos admitió que la inyección letal implicaba el riesgo inaceptable de causar un dolor y sufrimiento incalculable para el condenado, IACHR Report 63/12, Comunicación 1762/11, Virgilio Maldonado Rodríguez c. Estados Unidos, marzo 2012, lo que pudiera llevar a la prohibición de comercialización por parte de los organismos del área.

53 Sobre el caso particular de Estados Unidos. Véase, Warren, M. «Death, Dissent, and Diplomacy: The U.S. Death Penalty as an Obstacle to Foreign Relations». En 13 Wm. \& Mary Bill Rts. J. 309, 2004, p. 335.

54 «The Next Frontier: National Developmet, Politcal Change, and the Death Penalty in Asia». En New York: Oxford University Press, 2009.

55 Paradójicamente este país actúa de igual forma que el resto, creando un Grupo de trabajo para interceder y en última instancia, solicitar clemencia en beneficio de sus nacionales, principalmente en Malasia y Arabia Saudita donde tienen mayor proporción de trabajadores migrantes, y también invocan, en este caso, Irán la efectividad de las salvaguardias de Naciones Unidas, que niegan en el ámbito interno, lo que indica que incluso países retencionistas no se encuentran cómodos con la perspectiva de la aplicación de la pena de muerte por otras jurisdicciones a sus nacionales. Shetty, S. «The value of International Standards in the Campaign for abolition of the death penalty». En Brown Journal of World Affairs, otoño/invierno, vol. XXI, núm.1, 2014, p. 12. Un ejemplo de funcionamiento anómalo de sistemas penales, es el de Arabia Saudita donde se han ejecutado prisioneros que desconocían que habían sido condenados a muerte. Cfr.; http://www.irinnews.org/news/2005/04/08/saudi-beheading-somalis-grossly-unfair-\%E2\%80\%93-amnesty-says. Última consulta, 10 octubre 2016.

56 En este sentido la creación de una Estrategia para la abolición de la pena de muerte sobre la base de la experiencia británica puede ser un modelo adecuado para los países vecinos abolicionistas de iure o de facto, con objeto de disponer de informes de última hora y centralizar la acción de los distintos Ministerios, que confluya en la creación de un Consejo de Sabios con alto reconocimiento. 
de procesos de capacitación e intercambio de ideas patrocinado y financiados por organismos internacionales ${ }^{57}$, como las actividades de la Comisión Internacional contra la Pena de muerte y de oficinas similares. En este contexto es relevante la acción de la Red Asiática contra la pena de muerte (ADPAN) ${ }^{58}$ con sede en Malasia, la Alianza Taiwanesa para abolir la pena capital (TAEDP) ${ }^{59}$ y en el ámbito académico, el flujo de pensamiento entre Universidades ${ }^{60}$.

\section{CONCLUSIONES}

En conclusión, si se comparan las cifras de ejecuciones en estos países en la actualidad con las ocurridas hace décadas se constará la existencia de un retroceso inexorable que cierra toda posibilidad de pesimismo, y si bien no se alcance la abolición total para el 2025 como había pronosticado con exceso de optimismo, entre otros, el experto William Schabas ${ }^{61}$, el grado de vertebración de la Comunidad internacional y la desaparición gradual de las fronteras tanto visibles como ocultas $^{62}$ permiten contemplar el futuro de la vida humana con optimismo, y comparto las palabras de Robert Badinter, antiguo Ministro de Justicia de Francia, de que el mayor obstáculo para la abolición de la pena capital lo representan determinados países islámicos fundamentalistas extremistas, y no las naciones de Asia, al igual que en el continente americano, la pena de muerte como una institución peculiar de Estados Unidos utilizando los términos de David Garland es sólo en parte cierto, ya que son muy escasas las jurisdicciones locales que aplican este castigo, en realidad, sólo 9, y no todas igual de activas, de las 51 jurisdicciones, (50 estatales y la federal $)^{63}$ y su pervivencia en Estados Unidos en la cuarta década desde su reinstauración por el Tribunal Supremo en 1976 no supone más que el estertor de una pena que no encuentra acomodo en las páginas de la Historia mundial contemporánea.

57 En general sobre actores no estatales y su participación en la promoción de los derechos humanos, véase, Alston Ph.(ed) Non- State actors and Human Rights. Oxford University Press 2005. Sobre la acción de la Unión Europea, en particular, véase, Yorke, J.\& Berhmann, C. «The European Union and the abolition of the Death penalty». En 4 Pace Int'L. Rev. núm.1, 2013, p.72-76,http://digitalcommons.pace.edu/pilronline/39/.

58 Vid. http://adpan.org

59 Vid. http://taedp.org.tw.

60 Por ejemplo, iniciativas como la Red Académica contra la Pena de Muerte Academicsforabolition. net con sede en la Universidad de Castilla - La Mancha (España), o la red Universidades contra la Pena de Muerte impulsada por la Universidad de Oslo (Noruega).

${ }_{61}$ Sobre la base de un modelo cuantitativo en regresión desde la década de los cincuenta. Schabas, W. «Accelerating world trend to abolish capital punishment». En Oxford University Press, Blog, 11 October 2013. Disponible en http://blog.oup.com/2013/10/world-day-against-the-death-penalty-pil/

62 Véase, Hood, R. Hoyle, C. «Abolishing the Death penalty worldwide. The impact of a "new dynamic"». En Crime and Justice, vol. 38 n. 1, 2009, p.55-56.

63 Sobre esta última habría que señalar que la vida del terrorista de Boston Tsarnaev no corre peligro inminente al ser uno de los 60 presos federales en el corredor de la muerte cuya jurisdicción sólo ha llevado a cabo tres ejecuciones en el último medio siglo. 



\title{
PERSPECTIVAS DE ABOLICIÓN INTERNACIONAL DE LA PENA DE MUERTE
}

\author{
AGUSTINA ALVARADO URÍZAR \\ Doctoranda Universidad de Milano y Universidad de Girona
}

Conferencia internacional, Toledo 8 y 9 de septiembre 2015, Facultad de Ciencias Jurídicas y Sociales, Convento de San Pedro Mártir, coordinado por el Instituto de Derecho Penal Europeo e Internacional de la Universidad Castilla-La Mancha, Société Internationale de Défense Sociale y la Red Académica Internacional contra la Pena de Muerte.

El 8 y 9 de septiembre 2015 tiene lugar en Toledo, en la Sala de Música de la Facultad de Ciencias Jurídicas y Sociales, Convento de San Pedro Mártir, la Conferencia Internacional sobre Perspectivas de abolición internacional de la pena de muerte. Luego de los saludos de inauguración institucional, a cargo de la Dra. Ágata María Sanz Hermida, Vicedecana de Relaciones Internacionales, Gestión y Administración Pública de la Facultad de Ciencias Jurídicas y Sociales de Toledo, y de la Dra. Marta Vilardell, Embajadora para Asuntos Humanitarios y contra la Pena de Muerte del Ministerio de Asuntos Exteriores, el inicio de los trabajos fue precedido por las relaciones introductorias sobre el contexto coyuntural de la pena de muerte, a través de las intervenciones del Presidente de Gobierno (periodo 2004-2011), señor José Luis Rodríguez Zapatero y del Presidente de la Comisión Internacional contra la Pena de Muerte, señor Federico Mayor Zaragoza. El Presidente de la Société Internationale de Défense Sociale, Director del Instituto de Derecho Penal Europeo e Internacional, Catedrático de Derecho Penal y Rector Honorario de la Universidad 
Castilla-La Mancha, Dr. Luis Arroyo Zapatero distinguió a las autoridades recién mencionadas, así como al señor Adán Nieto Martín y al señor Eduardo Demetrio Crespo, ambos Catedráticos de Derecho Penal de la Universidad Castilla-La Mancha, con la entrega de los retratos elaborados por la Periodista Gráfica Sofía Moro, en señal de reconocimiento al trabajo y compromiso desplegado en materia de abolición de la pena de muerte.

I. - El profesor Eduardo Demetrio Crespo presidió la primera sesión del seminario, dedicada a la «Actualidad de la abolición de la pena de muerte»: el objetivo del encuentro consistió en efectuar una aproximación a la pena de muerte desde la perspectiva de la universalidad de los derechos fundamentales del individuo, deteniéndose en el rol que debe ser desplegado por los diversos actores del sistema social en su conjunto (Universidades/academia, Iglesia y Gobiernos), planteando una reflexión en orden a los avances alcanzados y en torno a los retos por superar.

La primera relación estuvo a cargo de la profesora Lill Scherdin (Catedrática de Criminología y Delegada del Rector de la Universidad de Oslo para la Declaración de las Universidades contra la Pena de Muerte), quien hizo énfasis en los daños colaterales asociados a la pena de muerte, transversales al complejo social en su conjunto y particularmente conectados a los aspectos éticos de la discusión. En este contexto, la profesora Scherdin destaca cómo es que estos daños colaterales escapan al sistema procesal penal ordinario y afectan al entero sistema político. En efecto, se subraya la incidencia de la existencia de la pena de muerte respecto al principio de proporcionalidad de las penas, como factor de distorsión y desproporción de las decisiones políticas. En este sentido, la relatora atribuye a la academia universitaria la esencial función de configurar la fuerza compensadora de esta tendencia.

La relación del profesor Roberto Carlés (Universidad de Buenos Aires y Coordinador de la Reforma penal argentina) titulada «La declaración del Papa Francisco contra la pena de muerte. Evolución de la Iglesia Católica sobre la cuestión», efectuó una fundamental aclaración de cuestiones teológicas contenidas en el catecismo católico en relación a los aspectos morales puestos a fundamento de la pena de la muerte a partir de la conceptualización de la legítima defensa social. Históricamente, la Iglesia habría aceptado la pena de muerte en base a la legítima defensa social, siempre que fuese el único camino posible para defender eficazmente las vidas humanas del injusto agresor. Es de destacar, por ende, el que el fundamento de la pena de muerte no se halle ni en la mayor culpabilidad del autor ni en la mayor intensidad de la agresión. Sin embargo, la Iglesia ha modificado sustancialmente su posición a partir de dos cartas y un discurso del Papa Francisco, que no sólo dicen relación con la pena de muerte en particular sino que con el rol del ejercicio del poder punitivo del Estado en general. Así, a partir de la carta de fecha 30 de mayo de 2014, dirigida a la 
$19^{\mathrm{a}}$ Convención de la Asociación Internacional de Derecho Penal y $3^{\mathrm{a}}$ de la Asociación Latinoamericana de Derecho Penal y Criminología; el discurso de 23 de octubre de 2014; y la carta de fecha 20 de marzo de 2015 dirigida a la Comisión internacional de Zaragoza, es posible identificar un cambio en la posición institucional de la Iglesia que preside Federico Mayor Zaragoza decantándose por un completo y total rechazo de la pena de muerte, excluyendo toda hipótesis excepcional de aplicación, negando que los presupuestos de la legítima defensa sean susceptibles de trasladarse a la protección del medio social, dejando por ende atrás la posición planteada por la Encíclica Evangelius Vita, del Papa Juan Pablo II.

La sesión matutina continuó con la intervención de la Secretaria General de la Comisión Internacional contra la Pena de Muerte, señora Asunta Vivó, con la relación del título «Cinco años de trabajo de la Comisión Internacional contra la pena de muerte». La exposición dio cuenta de la actividad de la Comisión, explicando detalladamente aspectos organizativos, funcionales, y logísticos de su quehacer, así como la necesidad de actuar en base a planes estratégicos ad hoc para la situación social, cultural y política de cada Estado en que se pretende intervenir. En este sentido, se hizo especial mención a los exitosos resultados obtenidos en Mongolia y Surinam, y a los desafíos pendientes en países como Estados Unidos y China.

La sesión matutina se concluyó con el desarrollo de una ronda de preguntas en que tuvieron la posibilidad de participar e interactuar público presente y relatores.

II. - La sesión vespertina abocada al «Análisis de la pena de muerte desde la perspectiva del Derecho Internacional», fue presidida por el profesor Adán Nieto Martín (Universidad Castilla-La Mancha), quien evidenció el valioso aporte que dicha disciplina puede ofrecer a la tendencia abolicionista de la pena de muerte.

La primera relación, titulada «LLas salvaguardias contra la pena de muerte como Derecho consuetudinario internacional»), fue sostenida por el profesor William Schabas (Catedrático de Derecho Internacional y de Derechos Humanos, Midelsex University y Presidente de la Red Académica contra la pena de muerte), que ha analizado la particular tendencia abolicionista que han asumido aquellos Estados, que sin asumir un compromiso formalmente convencional en tal sentido, han trabajado sobre la base del principio de reciprocidad en cuanto práctica simpatizante con la detención de su aplicación.

Con la relación del título «La pena de muerte y el derecho consuetudinario internacional», la profesora Ana Manero (Profesora de Derecho Internacional Públicode la Universidad Carlos III) ha presentado los interesantes avances relativos a la prohibición de la pena de muerte, y que van más allá de la perspectiva del derecho a la vida, fundamentándose en el debido cumplimiento de las normas de derecho consuetudinario contra la tortura y otros castigos crueles, inhumanos y degradantes. 
En efecto, dentro del fenómeno relativo a la pena de muerte es posible identificar una serie de situaciones que calzan con la tortura, como es cuanto ocurre con el llamado corredor de la muerte y con los métodos de ejecución desarrollados para su verificación. A las normas contra la tortura les es generalmente reconocido el carácter de ius cogens, siendo por ende inderogables y al subsumir estas hipótesis dentro de la conceptualización de la tortura, resulta entonces posible sostener la violación de estas últimas y por ende el incumplimiento de las obligaciones internacionales contraídas a partir del art. 6 del Pacto Internacional de Derechos Civiles y Políticos, por parte de todos aquellos Estados que prevean la pena de muerte. Según la profesora Manero, el razonamiento expuesto, ha conducido a la generación de una fuerte opinio iuris de los Estados contrarios a la pena de muerte, es decir, la convicción de los Estados sobre la existencia de una norma consuetudinaria en este sentido, que ha contribuido positivamente en una marcada tendencia abolicionista tanto a nivel regional como local.

El seminario continuó con la relación de la profesora Florabel Quispe Remón (Profesora Titular Acreditada de Derecho Internacional Público de la Universidad Carlos III), sobre el tema «Salvaguardias para proteger los derechos de las personas condenadas a muerte y su relación con el ius cogens». La relación comienza por efectuar una aclaración de conceptos claves para el análisis de la cuestión. En este sentido, en primer lugar, pone de manifiesto que las normas de ius cogens constituyen normas imperativas del derecho internacional de carácter obligatorio para todos los Estados, que opera con efecto erga omnes, independientemente que se haya procedido o no a su adhesión convencional a través de un tratado como forma unilateral voluntaria de adhesión, ya que las mismas se refieren a sentimientos universalmente compartidos por la comunidad internacional. En segundo término, indica que el Derecho internacional de los derechos humanos (doctrina y jurisprudencia internacional) ha identificado en estos últimos la existencia de un "núcleo duro" del cual se predica el carácter de ius cogens. En este núcleo duro es que se ubican una serie de salvaguardias procesales y sustanciales establecidas en torno a la regulación de la pena de muerte, a partir de la interpretación armónica del art. 4 en relación con los arts. 6, 7, 8 (párr. 1 y 2), 11, 15, 16 y 18 del Pacto Internacional de Derechos Civiles y Políticos, y de la interpretación efectuada por la Comisión Interamericana de Derechos Humanos a través de sus Observaciones generales. Ellas son: 1) la previsión de la pena de muerte sólo para los casos de delitos más graves; 2) el respeto del principio de legalidad en su previsión; 3) imposibilidad de aplicación de la pena de muerte respecto de menores de 18 años; 4) imposibilidad de aplicación de la pena de muerte respecto de mujeres embarazadas o en periodo de primera lactancia; 5) imposibilidad de aplicación de la pena de muerte respecto de personas discapacitadas; 6) que en su imposición se respeten las garantías asociadas a un juicio imparcial y al debido proceso en general; 7) el derecho del condenado a 
acceder al indulto; 8) que la ejecución de la misma sea suspendida mientras existan recursos pendientes; 9) que se cause el menor sufrimiento posible en su ejecución. El atribuir a este núcleo duro el carácter de ius cogens es de extrema importancia toda vez que el ius cogens, a diferencia de lo que ocurre con las normas consuetudinarias, no puede ser objeto de refracciones persistentes. Según la relatora, este paradigma ha aumentado la conciencia en la comunidad internacional sobre la necesidad de abolir la pena de muerte y ha contribuido a obtener la observancia de este núcleo duro por parte de los países que prevén este tipo de pena, en especial respecto de Estados Unidos, a través de su participación en el sistema americano constituido por la Convención americana.

La segunda parte de la jornada vespertina, fue dirigida por el profesor Jacobo Dopico Gómez-Aller (Profesor Titular de Derecho Penal de la Universidad Carlos III). El curso de los trabajos sucesivos se refirió al tema «Inocentes condenados a muerte o a penas largas de prisión». En este contexto, el profesor Julio Fontanet (Decano de la Facultad de Derecho de la Universidad Interamericana de Puerto Rico) expuso la ponencia titulada «El proyecto inocente en Norteamérica y Puerto Rico. Origen y trascendencia», a través de la cual inicia el análisis de las causas estructurales asociadas al modelo adversarial así como de las causas trasversales y comunes a todo sistema de persecución penal. Dentro de estas últimas, identifica: i) el indebido ejercicio de presiones para lograr la confesión o autoincriminación del imputado; ii) el uso de prueba pericial de baja calidad o, en todo caso, poco confiable; iii) el uso de testimonios de testigos que voluntaria o involuntariamente incriminan a una persona inocente; iv) la inadecuada o ineficiente representación legal de la defensa técnica que asistió al imputado; y v) la deficiente regulación de los reconocimientos oculares que sirven de fundamento principal de la imputación, enmarcada en un contexto de inadecuado comportamiento de los operadores del sistema. A continuación el profesor Fontanet, efectúa una interesante referencia a casos reales sometidos al examen del Proyecto Inocentes (tanto en Estados Unidos como en Puerto Rico) y ofrece una descripción comparativa del modo en que ha operado dicho proyecto en ambos sistemas normativos, haciendo hincapié en la necesidad de que el mismo cuente con el apoyo de la labor Universitaria en coordinación con una institución estatal que se ocupe seriamente de la situación de los inocentes condenados.

En esta constelación de ideas, el Seminario recibe el aporte multidisciplinario ofrecido por la intervención del Periodista de El País, señor Álvaro Corcuera, con la relación titulada "Inocentes condenados en el mundo. Tres grandes experiencias" y con la participación del periodista y escritor Braulio García Jaén, con la ponencia del título "Condenados por la Cara". Ambas exposiciones tienen el mérito de tratar y dar a conocer historias reales de inocentes condenados, mostrando la faz humanitaria concreta existente tras las cifras y sistemas. 
Para concluir la jornada, se contó con la intervención de la profesora Ágata Ruiz Hermida, quien presentó la ponencia del título "La reciente reforma del recurso de revisión para condenados inocentes". En dicha exposición se efectuó un análisis crítico de la actual redacción de las causales previstas para el recurso de revisión en España, poniendo en evidencia el escaso impacto práctico que el mismo representa como solución material de condenas injustas.

La jornada se concluyó con una exposición e interpretación musical en el concierto temático titulado «Recuerdo y nostalgia de Miguel de Cervantes y de Juan Ramón Jiménez en la capilla de Garcilaso de la Vega». El evento tuvo lugar en el Paraninfo de San Pedro Mártir y contó con la participación de las intérpretes Silvia Nogales a la guitarra y de Esther Acevedo a la narración.

A continuación, tuvo lugar la Reunión de la Red Académica contra la pena de muerte, preparatoria del próximo día mundial, dirigida por el profesor titular de la Universidad Autónoma de Madrid, señor Mario Maraver.

III.- En la mañana del día miércoles 9 de septiembre de 2015, se desarrolló la tercera sesión del Seminario sobre el tema «Pena de muerte en perspectiva mundial hoy»), presentada por Beatriz García Moreno (Investigadora del Instituto de Derecho Penal Europeo e Internacional) y coordinada por Antonio Muñoz Aunión (Profesor de Derecho Internacional de la Universidad Autónoma de Chile), dirigida a la exposición de los trabajos de traducción de la obra "Death penalty. Worldwide perspective", de los autores Roger G. Hood y Carolyn Hoyle.

La introducción de los trabajos estuvo a cargo de Marta Muñoz de Morales (Universidad Castilla-La Mancha). A continuación se dio la palabra a los participantes de la traducción de cada uno de los capítulos en el siguiente orden y con las siguientes ponencias: David Carpio (Universidad de Barcelona) sobre «El movimiento abolicionista. Progresos y perspectivas»; Javier de León y Beatriz López Lorca (Universidad Castilla-La Mancha) sobre "La vanguardia de la abolición»; Alejandro de Pablo (Universidad de Valladolid) sobre «Los paises y regiones en los que se mantiene la pena capital»; Miren Odriozola (Instituto de Criminología de la Universidad del País Vasco) sobre «La proyección de la pena de muerte en las leyes»; Isabel Germán (Instituto de Criminología de la Universidad del País Vasco) con la ponencia «El proceso de ejecución y el corredor de la muerte»; Silvia Mendoza (Universidad Pablo Olavide de Sevilla) con el tema «Librar de la pena de muerte a las personas vulnerables»; Jordi Gimeno (Universidad Castilla-La Mancha) sobre «La protección de los derechos de los acusados de delitos con pena de muerte y debido proceso»; Beatriz García Moreno (Universidad Castilla-La Mancha) con la relación del título «Decidiendo quién ha de morir: problemas de desigualdad, arbitrariedad y discriminación»; Alfonso Galán (Universidad Pablo 
Olavide de Sevilla) sobre «La cuestión del efecto disuasorio de la pena de muerte»; Víctor Macías (Universidad de Huelva) en la relación del tema "Una cuestión de opinión o de principios»; finalmente, la última intervención titulada "Alternativas adecuadas para sustituir a la pena de muerte» estuvo a cargo de Cristina Rodríguez Yagüe (Universidad Castilla-La Mancha).

IV.- La cuarta y última sesión matutina del Seminario se dedicó al tema relativo a la «Prisión perpetua en el mundo», presidida por el profesor Manuel Maoto (Profesor Ayudante, Doctor de Derecho Penal de la Universidad Castilla-La Mancha).

La primera relación estuvo confiada al profesor Emilio Viano (Presidente de la International Society of Criminology y profesor de la Universidad Americana de Washington). El profesor Viano efectúa un breve análisis histórico sobre el origen de la regulación legislativa de la pena de prisión perpetua en los Estados Unidos y su relación con la política conocida como three strikes and you're out. Indica además que uno de los factores que incidió en esta política de dura represión de los delitos estuvo constituido por una atención desmedida de las condiciones y necesidades de las víctimas y testigos como parte de una inclinación relacionada con los movimientos políticos de derecha, que triunfó en las ciudades más emblemáticas del país. Se trata de una versión de la pena de muerte, que en los hechos resulta aún más terrible e indigna que la misma, ya que se basa en la consideración de la imposible rehabilitación de ciertos sujetos, incluidos menores de edad. Se advierte que el éxito de la abolición de la pena de muerte en los Estados que se han sumado a esta tendencia, lo han hecho en el sentido de satisfacer la potestad punitiva en pro de la seguridad a través del establecimiento de la cadena perpetua. Este tipo de pena ha terminado por establecerse tanto para delitos violentos y no violentos, sobre todo en materia de tráfico de drogas y sustancias estupefacientes, motivo por el cual ha influenciado negativamente en el aumento excesivo de la población carcelaria de los países que la prevén en estos términos. Otros aspectos negativos -no tenidos en cuenta por esta política- dicen relación con el gasto público y financiero destinado a la mantención de las cárceles, en que subsisten por una parte, los intereses privados de los inversores en las cárceles concesionadas, y el mercado laboral que favorece a los intereses del Estado y que se crea en torno del incremento de construcciones destinadas a este fin. Tampoco se considera la incidencia que una pena de este tipo puede tener en el desarrollo familiar del reo. En efecto, el sistema de aislamiento e incomunicación al que están sometidos los reclusos impide toda posibilidad de rehabilitación e reinserción tanto en el medio familiar como en su eventual reinstalación laboral, ya que las indignas condiciones generales de espacio, y la separación e incomunicación respecto del medio social generan una serie de disfunciones mentales que obstaculizan toda posibilidad de obtener la salida al medio libre. En 
términos conclusivos, el profesor Viano efectúa una lapidaria crítica a la situación existente en los Estados Unidos, resaltando el hecho que una vez que se obtiene una sentencia condenatoria a cadena perpetua en ese país, resulta extremamente dificultoso obtener la libertad del sujeto con todos los daños colaterales a nivel de abandono familiar, emocional y económico que ello implica y a nivel de los costos asociados a la mantención del recluso.

El profesor José Luis de la Cuesta (Presidente Honorario de la Asociation International de Droit Pénal, Catedrático de Derecho Penal y Director del Instituto de Criminología de la Universidad del País Vasco) se refirió al tema de «El principio de humanidad y la prisión perpetua〉. La intervención comienza por reivindicar el principio de humanidad en materia de pena de muerte, como concepto relativo que permite equilibrar los principios de culpabilidad y de necesidad con la debida atención puesta en el autor y en la víctima. Por otra parte, la relación llama a colación la observancia del principio de legalidad en relación al respeto de la prohibición de prever penas crueles, inhumanas y degradantes, sobre todo si se considera que en materia internacional es extremadamente dificil identificar una norma (por ejemplo del Pacto Internacional de Derechos Civiles y Políticos) que proscriba la pena de muerte. En efecto, lo mismo ocurre en materia de cadena perpetua, que paradojamente es utilizada en el ámbito internacional para manifestar la voluntad duramente represiva de los delitos de lesa humanidad. Hoy la cadena perpetua ocupa el lugar de la pena de muerte como reacción punitiva, y por ello corresponde interrogarse sobre la legitimidad de que una persona sea privada de su vida en libertad y que muera privada de libertad. Obviamente esta idea no es compatible con la orientación de la función de rehabilitación de la pena, sobre todo si se tiene presente que las penas corporales en general ya han demostrado en sí mismas la deshumanización del ser humano. El listado de argumentos a favor de la pena perpetua como pena inhumana es muy extensa en un debate no reciente, que basándose en la ciencia evolutiva ha intentado establecer una pena temporal determinada y limitada. Esta ha sido la posición de la Corte Europea de Derechos Humanos, pronunciándose en el mismo sentido del Tribunal Constitucional alemán al rechazar la previsión de una pena perpetua no susceptible de revisión, es decir, establece la "revisabilidad" como elemento humanizador de la pena. Sin embargo, el relator destaca que ello no hace variar el carácter injusto de la sanción, de modo que en su opinión, se requiere volver atrás en la argumentación y tener en cuenta que la supuesta rehabilitación en términos positivos mientras el detenido se encuentra en prisión, poco o nada influye en la futura comisión de nuevos delitos, ya que los factores influyentes no se reducen a la sola tendencia criminógena del sujeto, de modo que la discusión debe reenfocarse y evitar mezclar criterios sustanciales y adjetivos. Así, desde una perspectiva retribucionista 
no absoluta de la pena, debe considerarse que la comisión del primer delito debe determinar el límite de intervención del Estado, cuya superación implica el inicio del exceso de intervención: la pena debe ser limitada temporalmente de acuerdo a la culpabilidad del sujeto pero su extensión debe ser fijada en consideración a los estudios criminológicos de la conducta en modo que en su imposición se respete el principio de responsabilidad por el hecho.

El profesor LUIS ARROYo ZAPATERo pone fin al encuentro con algunas reflexiones que servirán de base a futuros proyectos en la materia y agradeciendo la presencia y el compromiso para continuar con la obligación moral relativa a la abolición de la pena de muerte en el mundo. 

